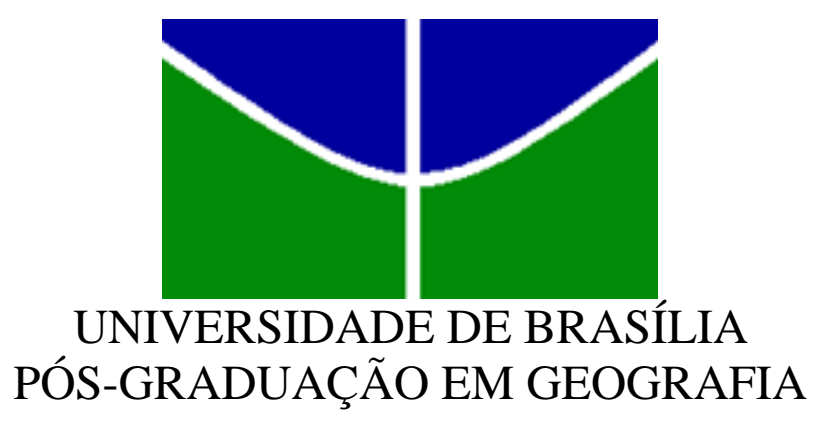

PAISAGEM CULTURAL DO RECÔNCAVO BAIANO: UMA NARRATIVA ESPACIAL REGIONAL A PARTIR DA ANÁLISE DO PATRIMÔNIO URBANO

Luís Cláudio Requião da Silva Tese de Doutorado 
UNIVERSIDADE DE BRASÍLIA

DEPARTAMENTO DE GEOGRAFIA

\section{PAISAGEM CULTURAL DO RECÔNCAVO BAIANO: \\ UMA NARRATIVA ESPACIAL REGIONAL A PARTIR DA ANÁLISE DO PATRIMÔNIO URBANO}

Luís Cláudio Requião da Silva

Orientador: Prof. Dr. Neio Lúcio de Oliveira Campos

Tese de Doutorado submetida ao Departamento de Geografia da Universidade de Brasília, como parte dos requisitos necessários para a obtenção do Grau de Doutor em Geografia, área de concentração Gestão Ambiental e Territorial, linha de pesquisa Produção do Espaço e Território Nacional. 


\title{
PAISAGEM CULTURAL DO RECÔNCAVO BAIANO: UMA NARRATIVA ESPACIAL REGIONAL A PARTIR DA ANÁLISE DO PATRIMÔNIO URBANO
}

\author{
Luís Cláudio Requião da Silva
}

Tese de Doutorado submetida ao Departamento de Geografia da Universidade de Brasília, como parte dos requisitos necessários para a obtenção do Grau de Doutor em Geografia, área de concentração Gestão Ambiental e Territorial, linha de pesquisa Produção do Espaço e Território Nacional.

Aprovado por:

Prof. Dr. Neio Lúcio de Oliveira Campos Instituição: GEA - UnB - Brasília - DF (orientador)

Prof. Dr. Cristovão Cássio de A. Brito Instituição: POSGEO/UFBA - Salvador - BA

Prof $^{a}$. Dr ${ }^{a}$. Ana Elizabete Medeiros Instituição: FAU/UnB - Brasília - DF
Prof. Dr. Rafael Sanzio A. dos Anjos Instituição: GEA - UnB - Brasília - DF (Suplente)

Prof. Dr. Fernando Araújo Sobrinho Instituição: GEA - UnB - Brasília - DF

Prof. Dr. Everaldo Batista da Costa Instituição: GEA - UnB - Brasília - DF

de de 2015

Brasília - DF 


\section{SILVA, LUÍS CLÁUDIO REQUIÃO DA}

Paisagem cultural do Recôncavo Baiano: Uma narrativa espacial regional a partir da análise do patrimônio urbano, 272 p., 297 mm, (UnB-CDS, Doutor, Gestão Ambiental e Territorial, 2015).

Tese de Doutorado - Universidade de Brasília. Instituto de Ciências Humanas. Departamento de Geografia. Programa de Pós-Graduação em Geografia.

1. Geografia

3. Território usado

5. Narrativa espacial regional

I. UnB-CDS.
2. Paisagem cultural

4. Patrimônio urbano/edificado

II. Paisagem cultural do Recôncavo

Baiano: Uma narrativa espacial regional a partir da análise do patrimônio urbano

É concedida à Universidade de Brasília permissão para reproduzir cópias desta tese e emprestar ou vender tais cópias somente para propósitos acadêmicos e científicos. O autor reserva outros direitos de publicação e nenhuma parte desta tese de doutorado pode ser reproduzida sem a autorização por escrito do autor. 
Dedico este estudo ao povo da Bahia e seus ancestrais de matriz indígena, africana $e$ europeia que no Recôncavo Baiano, com a força da sua resistência, batalhas, trabalho, suor, lágrimas, sofrimento, fé e alegria deram início a uma parcela fundamental da cultura e civilização brasileira, nas suas dimensões material $e$ imaterial, formando a excepcional paisagem cultural baiana. 


\section{AGRADECIMENTOS}

Agradeço as forças infinitas do Universo nas suas mais diversas formas de manifestação e intervenção sobre minha trajetória, especialmente nesta etapa da minha vida, a qual demandou muito equilíbrio de energia e matéria, transformada na materialização deste trabalho.

A comunidade acadêmica da Universidade de Brasília, especialmente a meu orientador Prof. Dr. Neio Lúcio de Oliveira Campos pela sabedoria e competência no processo de orientação, além de grande incentivador. Hoje, mais um amigo!

Ao Prof. Dr. Cristóvão Brito, por aceitar participar da Banca (membro externo).

Aos professores Dr. Rafael Sanzio Araújo dos Anjos, Fernando Araújo Sobrinho, Dra . Ana Elisabete de Almeida Medeiros (FAU/UnB), e Dr. Everaldo Batista da Costa, por aceitarem o convite para participar da Banca.

A Prof ${ }^{a}$. Dr ${ }^{\mathrm{a}}$. Lucia Cony, pelas orientações iniciais.

A Prof ${ }^{a}$. Dr ${ }^{a}$. Marília Peluso, pelas sugestões no exame de qualificação.

Um agradecimento especial ao colega Marcus Fábio, pelos "papos" e ajuda na confecção das plantas dos centros históricos das cidades pesquisadas.

Aos funcionários da Secretaria da Pós Graduação, nas pessoas de Simoni e Jorge, sempre solícitos para atender às minhas necessidades.

A comunidade acadêmica da Universidade do Estado da Bahia - UNEB (meus exalunos, colegas e funcionários) pelo apoio em todos os sentidos, para que eu continuasse a caminhada... Além do incentivo desta Universidade com a bolsa de estudos e liberação em tempo hábil para minha estada em Brasília. Agradecimento especial ao colega, Prof. Dr. James Amorim Araújo, pela leitura do projeto original.

Agradeço ao meu pai, Deraldo Almeida da Silva, homem do centro histórico de Salvador, aquele que primeiro me mostrou os horizontes, dentre eles, a Baía de Todos os Santos e o seu Recôncavo. Um cidadão da velha "cidade da Bahia", ainda presente entre nós no auge dos seus 88 anos. A ele, dedico de forma especial este trabalho.

A minha mãe, Acidália Requião da Silva, mulher guerreira, oriunda da Saubara, interior da Baía de Todos os Santos, que no auge dos seus 87 anos ainda me orientou, me aconselhou e me consolou nos momentos mais difíceis dessa etapa da minha vida.

A todos os meus irmãos e irmãs, pela força, tolerância, incentivo e amor, fundamentais para realização deste trabalho.

A minha filha Catarina, por tudo, especialmente o companheirismo e o amor incondicional.

A minha esposa Liane pela paciência, tolerância e companheirismo, além de cuidar das nossas meninas Sophia e Sarah, ao longo das minhas ausências. A elas também agradeço o amor incondicional e dedico este esforço.

Agradeço a Adalberto Sales, ex-aluno, amigo e agora colega, pelo apoio na etapa final de minha estada em Brasília.

Ao amigo Cláudio Lemos, ex-vizinho e restaurador de obras sacras. Um homem de alma barroca! Gratidão pela sua inestimável colaboração, através do empréstimo dos dois volumes do Inventário de Proteção do Acervo Cultural; monumentos e sítios do Recôncavo IPAC - BA, desde o início da pesquisa.

Finalmente, agradeço a todos os autores aqui citados e referenciados, pela inspiração e companhia onipresente na elaboração do texto. 


\section{RESUMO}

Esta tese situa-se no âmbito da Geografia Histórica Urbana com a emergência de uma narrativa espacial regional a partir da análise da paisagem cultural e urbana de sete cidades históricas portuárias do Recôncavo Baiano, região situada no entorno da Baía de Todos os Santos, estado da Bahia, Brasil. Neste sentido, levantamos a hipótese, segundo a qual, existiu uma produção simultânea dos territórios urbanos no processo de produção e organização espacial das cidades de Jaguaripe, Cachoeira, São Francisco do Conde, Maragogipe, Santo Amaro, Nazaré e São Felix, detectado pela similaridade de padrões estéticos e estruturais de seus conjuntos arquitetônicos e urbanísticos e pela concomitância temporal na ereção dos mesmos, materializadas no patrimônio urbano, culminando no que denominamos de narrativa espacial regional. Busca a compreensão dessa narrativa, foco do trabalho, nas escalas local e regional, articulada à socioeconomia, à história e à produção do urbano. $\mathrm{O}$ patrimônio edificado é reconhecido como elemento principal que caracteriza a cultural de natureza material, cuja expressão simbólica suscita numa narrativa espacial multiescalar (local e regional), expressa nas paisagens urbanas das referidas cidades. A descrição, investigação e análise do patrimônio edificado visa detectar a produção simultânea dos territórios no processo de ereção dos conjuntos urbanísticos e monumentos isolados, demonstrado pela similaridade de formas, estilos arquitetônicos e concomitância temporal na produção e organização espacial das mesmas. Paisagem (cultural/urbana), território (território usado) e patrimônio (urbano/edificado) são as categorias de análise. O recorte temporal situa-se no período entre 1823 a 1889. A pesquisa bibliográfica e documental; a análise de fotografias de época e atuais e a iconografia de maneira geral, foram os procedimentos de pesquisa utilizados. As paisagens dessas cidades nos revelaram uma narrativa espacial comum às mesmas, caracterizada por uma paisagem cultural bastante peculiar e simbólica. Fato que corrobora para o sentido de identidade territorial regional. Ao descobrirmos essa narrativa, que está na história do território, discutimos o sentido do patrimônio no presente. Concluímos que a referida narrativa espacial existiu no período estudado e ainda permanece no território na dimensão local e regional. Nesse sentido, recomenda-se a intervenção urgente por parte do poder público, no sentido da salvaguarda da região e das cidades em tela.

Palavras-chave: Paisagem cultural. Território usado. Patrimônio urbano/edificado. Narrativa espacial regional. Recôncavo Baiano. 


\begin{abstract}
This thesis is located within the Historical Urban Geography with the emergence of a regional spatial narrative for to analysis of one cultural landscape from seven historic port cities in the Recôncavo Baiano, a region situated in the vicinity of the Bay of All Saints, the state of Bahia, Brazil. To understand this narrative, the research articulates the dimensions socio economics, historical and of production of the urban. Cultural landscap, territory used and cultural heritage this categorys of the thesis. The time frame is between the years 1823-1889. The description, investigation and analysis of urban heritage/buildings the cities of Jaguaripe, Cachoeira, São Francisco do Conde, Maragogipe, Santo Amaro, Nazaré and São Felix aims to detect what we call the simultaneous special production in the erection of process of urban sets and isolated monuments, shown by the similarity of shapes, architectural styles and temporal concurrence in production and spatial organization was the same. We assume that the set of socioeconomic events, cultural and political produced throughout history resulted in similar landscapes in the territories of these cities, especially in their historical centers, whose heritage buildings is the most visible cultural expression, especially in the XIX century, with significant continuities until today. The bibliographical and documentary research, as also photographical and iconography analysis were the research procedures used. The landscapes in these cities revealed a common spatial narrative to them. Therefore, a regional spatial narrative is characterized by a cultural landscape rather peculiar that confirms the sense of regional territorial identity. To discover this narrative, which is the history of the territory, aid us to discuss the meaning of patrimonial heritage in the present. We conclude that spatial narrative that existed during the study period and remains in the landscape studied. In this sense, it is recommended the urgent intervention by the Government, towards safeguarding the region and the screen in cities.
\end{abstract}

Keywords: Cultural landscape. Used Territory. Urban heritage. Regional spatial narrative. Recôncavo Baiano. 


\section{SUMÁRIO}

\section{LISTA DE FIGURAS}

LISTA DE ABREVIATURAS E SIGLAS

\section{INTRODUÇÃO}

2 SITUANDO A GEOGRAFIA HISTÓRICA E O ESPAÇO GEOGRÁFICO..........25

2.1 O ESPAÇO GEOGRÁFICO NA GEOGRAFIA CLÁSSICA........................................30

2.2 ESPAÇO GEOGRÁFICO, A NOVA GEOGRAFIA E A GEOGRAFIA

HISTÓRICA

2.3 A VISÃO MARXISTA DO ESPAÇO GEOGRÁFICO: A GEOGRAFIA CRÍTICA....38

2.4 A ANÁLISE DO ESPAÇO GEOGRÁFICO NA ATUALIDADE.

3 OS CONCEITOS ESTRUTURANTES E MEDIADORES

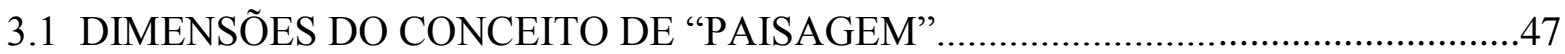

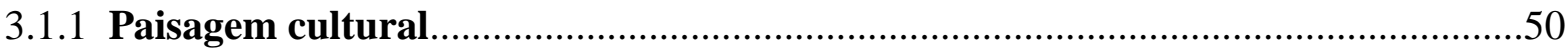

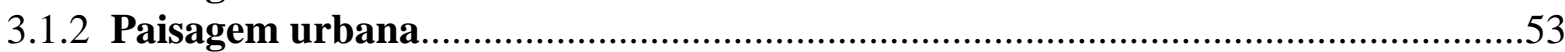

3.2 DIMENSÕES DO CONCEITO DE PATRIMÔNIO CULTURAL E URBANO...........58

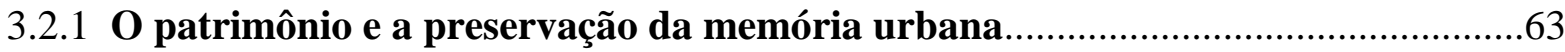

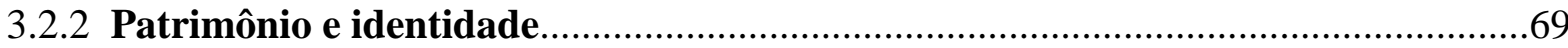

3.3 O USO DO TERRITÓRIO: A TERCEIRA CATEGORIA ANALÍTICA......................74

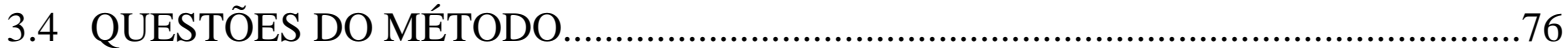

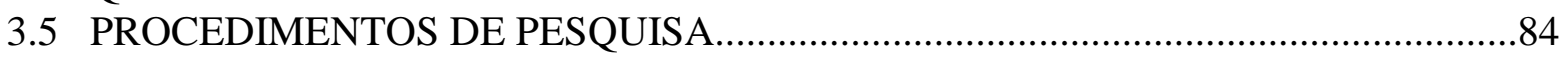

4 O RECÔNCAVO BAIANO NO CONTEXTO GEOHISTÓRICO DA FORMAÇÃO TERRITORIAL E POLÍTICA DO BRASIL ..............................................................8

4.1 O RECÔNCAVO BAIANO E A QUESTÃO REGIONAL ..........................................94

4.2 A DINÂMICA SOCIOECONÔMICA E ESPACIAL DO RECÔNCAVO BAIANO

ENTRE O SÉCULO XVI E MEADOS DO SÉCULO XIX

\section{A RELAÇÃO ENTRE SALVADOR E AS CIDADES HISTÓRICAS} PORTUÁRIAS DO RECÔNCAVO BAIANO

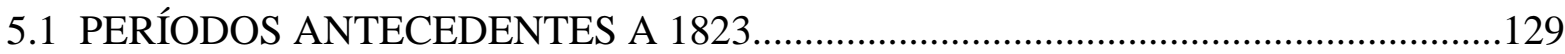

$5.1 .1 \mathrm{O}$ período entre 1549 e 1650 ( $\mathbf{1}^{\mathbf{0}}$ período de Vasconcelos $)$....................................129

5.1 .2 O período entre 1650 e 1763 ( ${ }^{\mathbf{o}}$ período de Vasconcelos $)$....................................130

$5.1 .3 \mathrm{O}$ período entre 1763 e 1823 (30 período de Vasconcelos) ......................................135

5.2 O PERÍODO ENTRE 1823 E 1849 (4º PERÍODO DE VASCONCELOS).................137

5.2.1 A interação entre a cidade de Salvador e as vilas portuárias do Recôncavo Baiano, na consolidação da independência do Brasil na Bahia, e o patrimônio edificado como testemunho

5.3 O PERÍODO ENTRE 1850 E 1889 (5 PERÍODO DE VASCONCELOS).................154

5.4 BREVES CONSIDERAÇÕES SOBRE O PERÍODO ENTRE 1889 E MEADOS DO SÉCULO XX. 
6 A CONCEPÇÃO DE URBANISMO E O PATRIMÔNIO DAS CIDADES PORTUÁRIAS DO RECÔNCAVO BAIANO: A NARRATIVA ESPACIAL

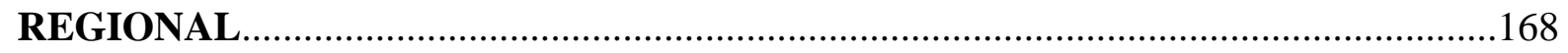

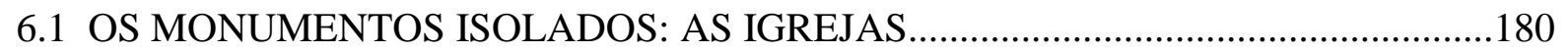

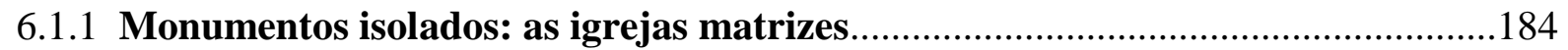

6.1.2 Monumentos isolados: as casas de câmara e cadeia...........................................196

6.2 A CONSTITUIÇÃO DO FATO URBANO: A narrativa espacial regional....................205

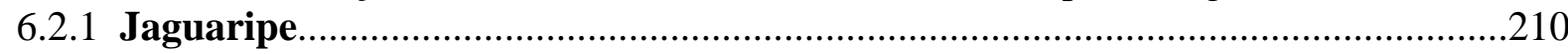

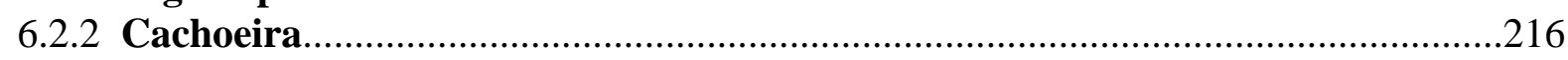

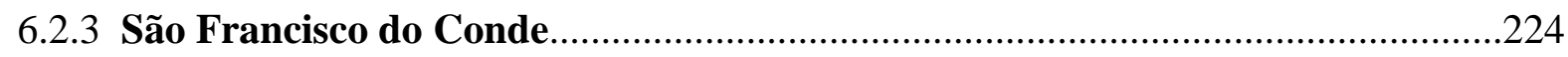

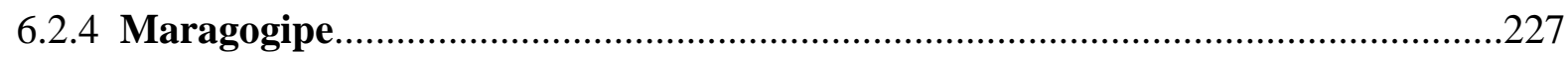

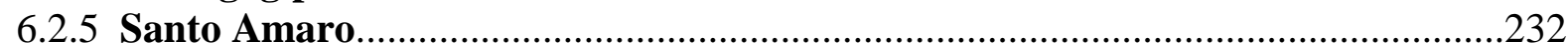

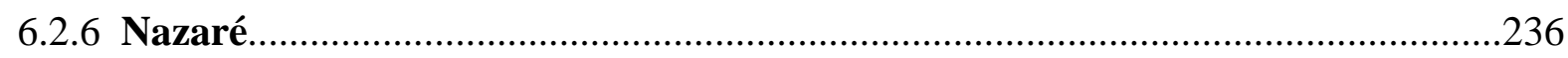

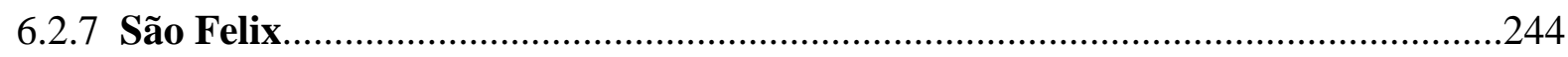

7 CONCLUSÃO

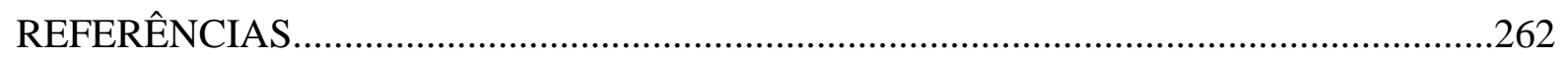

ANEXOS 


\section{LISTA DE FIGURAS}

\section{Capítulo 4:}

\section{Seção 4.1}

FIGURA 4.1.1 - Recôncavo Baiano em meados do século XVIII. .99

FIGURA 4.1.2 - Caminhos hierárquicos da Rede urbana do Recôncavo Baiano ao final do século XVIII. 100

FIGURA 4.1.3 - Região do Recôncavo Baiano segundo Milton Santos (1960).....................101

FIGURA 4.1.4 - Recôncavo Sul (Governo da Bahia)..........................................................101

FIGURA 4.1.5 - Mesoregião Metropolitana de Salvador....................................................102 FIGURA 4.1.6 - Recorte onde podem ser visualizadas as áreas: "Território de Identidade Recôncavo", "Metropolitana de Salvador" e parte do "Baixo Sul".

FIGURA 4.1.7 - Recôncavo Baiano segundo o IPAC, com delimitação da área inventariada.

FIGURA 4.1.8 - Recôncavo Baiano segundo o IPAC, com delimitação de área inventariada.

\section{Seção 4.2}

FIGURA 4.2.1 - Núcleos primitivos de povoamento na capitania da Bahia no século XVI. 106

FIGURA 4.2.2 - Caminhos do povoamento no século XVI..................................................107

FIGURA 4.2.3 - Principais vilas e caminhos do povoamento no século XVII.....................109

FIGURA 4.2.4 - Capitania da Bahia: Situação das vilas no século XVIII..............................112

FIGURA 4.2.5 - Engenho Pedra Branca no Recôncavo Baiano............................................117

\section{Capítulo 5:}

\section{Seção 5.1.2}

FIGURA 5.1.2.1 - Igreja de São Domingos de Gusmão, praça do Terreiro de Jesus.

FIGURA 5.1.2.2 - Reclame informativo do IPHAN sobre a história da Igreja de São

Domingos de Gusmão, centro histórico de Salvador - BA

FIGURA 5.1.2.3 - Igreja de São Pedro dos Clérigos, praça do Terreiro de Jesus, centro histórico de Salvador - BA.

FIGURA 5.1.2.4 - Características da igreja de São Pedro dos Clérigos, praça do Terreiro de Jesus, centro histórico de Salvador - BA.

\section{Seção 5.1.3}

FIGURA 5.1.3.1 - Vista da cidade do Salvador a partir da Baía de Todos os Santos no século XIX.

\section{Seção 5.2.1}

FIGURA 5.2.1.1 - Exposição Rota da Independência, centro histórico de Salvador - BA...143 FIGURA 5.2.1.2 - Cidade de Santo Amaro - BA e arredores na exposição Rota da 
FIGURA 5.2.1.3 - Cidade de Cachoeira - BA na exposição Rota da Independência.

FIGURA 5.2.1.4 - Cidade de Maragogipe - BA e arredores na exposição Rota da

Independência.

FIGURA 5.2.1.5 - Cidade de São Francisco do Conde - BA e arredores na exposição Rota da Independência.

FIGURA 5.2.1.6 - Cidade de São Felix - BA e arredores na exposição Rota da

Independência.

\section{Seção 5.3}

FIGURA 5.3.1 - Vista panorâmica da cidade baixa em Salvador - BA 156

\section{Seção 5.4}

FIGURA 5.4.1 - Ambiente da rampa do mercado em Salvador - BA na coleção "As sete portas da Bahia"

FIGURA 5.4.2 - Desenho retratando a Feira de Água de Meninos em Salvador - BA na coleção "As sete portas da Bahia"

FIGURA 5.4.3 - Ônibus de linha especial para turistas na cidade de Salvador, trafegando entre a cidade alta e baixa, com foto da igreja e do cruzeiro de São Francisco.

\section{Capítulo 6:}

FIGURA 6.1 - Tela retratando a atual praça municipal de Salvador - BA no século XIX, prospecto da Exposição Diógenes Rebouças 1914-2014

FIGURA 6.2 - Centro da cidade de Braga, Portugal, vendo-se ao fundo a catedral da cidade, década de 1990

FIGURA 6.3 - Largo de São Francisco em Salvador - BA.

FIGURA 6.4 - Vista panorâmica do centro antigo da cidade de Salvador - BA na atualidade, onde vê a área do Pelourinho ao centro

FIGURA 6.5 - Esquema de localização do núcleo de ocupação histórica de cinco vilas do Recôncavo Baiano.

\section{Seção 6.1}

FIGURA 6.1.1 - Centro da cidade de Salvador - BA no século XIX.

\section{Seção 6.1.1}

FIGURA 6.1.1.1 - Igreja Nossa Senhora da Ajuda em Jaguaripe - BA, no alto, ao fundo, a partir do rio Jaguaripe

FIGURA 6.1.1.2 - Igreja matriz de Nossa Senhora do Rosário em Cachoeira - BA.............186

FIGURA 6.1.1.3 - Lápide localizada na parede da igreja matriz de Cachoeira - BA...........188

FIGURA 6.1.1.4 - Igreja matriz de São Gonçalo em São Francisco do Conde - BA...........189

FIGURA 6.1.1.5 - Igreja matriz de São Bartolomeu em Maragogipe - BA..........................190

FIGURA 6.1.1.6 - Igreja matriz de Nossa Senhora da Purificação em Santo Amaro - BA..192

FIGURA 6.1.1.7 - Igreja matriz de Nossa Senhora em Nazaré - BA. 


\section{Seção 6.1.2}

FIGURA 6.1.2.1 - Casa de Câmara e Cadeia de Jaguaripe - BA..........................................196

FIGURA 6.1.2.2 - Casa de Câmara e Cadeia de São Francisco do Conde.............................197

FIGURA 6.1.2.3 - Casa de Câmara e Cadeia de Maragogipe - BA......................................199

FIGURA 6.1.2.4 - Casa de Câmara e Cadeia de Cachoeira - BA...........................................200

FIGURA 6.1.2.5 - Casa de Câmara e Cadeia de Santo Amaro - BA.....................................201

FIGURA 6.1.2.6 - Paço Municipal de Nazaré - BA................................................................201

FIGURA 6.1.2.7 - Paço Municipal de São Felix - BA........................................................203

\section{Seção 6.2.1}

FIGURA 6.2.1.1 - Painel fotográfico da cidade de Jaguaripe...............................................212

FIGURA 6.2.1.2 - Centro histórico da cidade de Jaguaripe - BA.......................................213

FIGURA 6.2.1.3 - Vista da cidade de Jaguaripe - BA a partir do rio do mesmo nome........215

\section{Seção 6.2.2}

FIGURA 6.2.2.1 - Ilustração da vila de Cachoeira - BA na primeira metade do século XIX

FIGURA 6.2.2.2 - Centro histórico da cidade de Cachoeira - BA.........................................222

FIGURA 6.2.2.3 - Cidade de Cachoeira - BA, década de 1970..........................................223

FIGURA 6.2.2.4 - Vista panorâmica da cidade de Cachoeira - BA na atualidade, exposição

"Quem ama a Bahia" - Salvador e o Recôncavo Baiano......................................................224

\section{Seção 6.2.3}

FIGURA 6.2.3.1 - Centro histórico da cidade de São Francisco do Conde - BA.................225

FIGURA 6.2.3.2 - Cidade de São Francisco do Conde - BA, década de 1970.....................226

\section{Seção 6.2.4}

FIGURA 6.2.4.1 - Cidade de Maragogipe - BA, década de 1970.......................................227

FIGURA 6.2.4.2 - Ruina da fábrica da Suerdieck, Maragogipe - BA..................................229

FIGURA 6.2.4.3 - Centro histórico da cidade de Maragogipe - BA.....................................230

FIGURA 6.2.4.4 - Casario no centro histórico de Maragogipe - BA....................................231

\section{Seção 6.2.5}

FIGURA 6.2.5.1 - Cidade de Santo Amaro - BA, década de 1970......................................233

FIGURA 6.2.5.2 - Centro histórico da cidade de Santo Amaro - BA....................................2234

FIGURA 6.2.5.3 - Vista panorâmica da cidade de Santo Amaro - BA na atualidade............235

\section{Seção 6.2.6}

FIGURA 6.2.6.1 - Cidade de Nazaré - BA, década de 1970..............................................238

FIGURA 6.2.6.2 - Saveiros atracados no porto de Nazaré - BA, 1860...............................239 
FIGURA 6.2.6.3 - Prédio onde funcionou a Santa Casa de Misericórdia de Nazaré - BA, atual Hospital Gonçalves Martins

FIGURA 6.2.6.4 - Centro histórico da cidade de Nazaré - BA............................................244

\section{Seção 6.2.7}

FIGURA 6.2.7.1 - Centro histórico da cidade de São Felix - BA........................................245

FIGURA 6.2.7.2 - Cidade de São Felix - BA, década de 1970........................................247

FIGURA 6.2.7.3 - Vista panorâmica de São Felix na exposição "Quem ama a Bahia” -

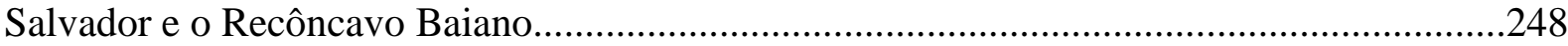




\section{LISTA DE ABREVIATURAS E SIGLAS}

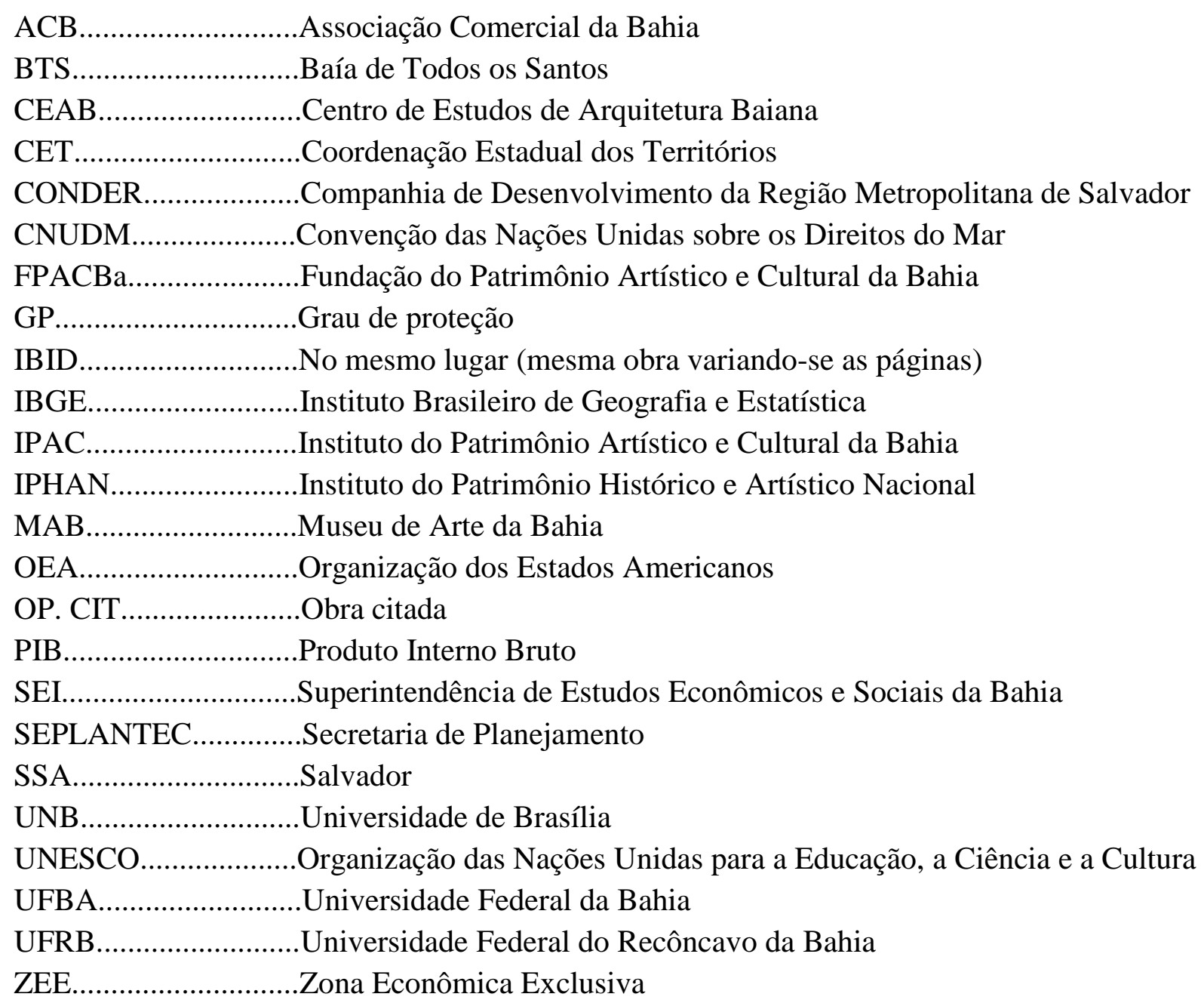




\section{1 - INTRODUÇÃO}

Nas últimas décadas nota-se que as abordagens e debates sobre a dimensão urbana do patrimônio se ampliaram, tanto no âmbito acadêmico, quanto nas diferentes esferas políticoadministrativas de governo, especialmente no que tange às políticas de preservação, em escala global, nacional, regional e local. Nota-se também o crescimento do número de pesquisas sobre este tema na Arquitetura, Geografia Urbana e História.

O presente estudo propõe compreender, sob perspectiva do campo disciplinar da Geografia Histórica Urbana, a expressão das paisagens de sete cidades históricas portuárias do Recôncavo Baiano (Jaguaripe, Cachoeira, São Francisco do Conde, Maragogipe, Santo Amaro, São Felix e Nazaré). Ou seja, trata-se de uma leitura analítica da paisagem cultural/urbana dos centros históricos das referidas cidades, com foco no patrimônio edificado ao longo do processo de produção e organização espacial das mesmas, tendo como recorte temporal o período entre 1823 e 1889.

O referido recorte espaço-temporal vai do início da consolidação da Independência do Brasil, na Bahia, até a proclamação da República. Isto é, o período do Brasil Império. Entretanto, admitimos que a dimensão temporal da pesquisa num dado período não pode estar dissociada de outro, principalmente, aos períodos anteriores, assim como são referências para o entendimento de períodos posteriores.

Neste sentido, se fez necessário dialogarmos com períodos anteriores ao recorte temporal proposto. Por isso, em alguns momentos da pesquisa retrocedemos aos antecedentes da formação urbana do período, para entender a sua formação. Em outros momentos, fomos um pouco mais além, dando indicações de períodos posteriores, meados do século XX e a atualidade. Tal procedimento em relação ao período posterior tem a ver com o nosso interesse em registrar os momentos da institucionalização oficial do processo de salvaguarda do patrimônio urbano, a partir de 1937, com a criação do atual Instituto do Patrimônio Histórico e Artístico Nacional (IPHAN). Além de registrar que a relação em rede entre Salvador e as cidades históricas portuárias do Recôncavo Baiano, mantiveram-se além do nosso recorte temporal, possibilitando as discussões e propostas na atualidade. Entretanto, ressaltamos o nosso foco principal no século XIX, no período anteriormente mencionado. 
Partimos do pressuposto, segundo o qual, o conjunto de eventos socioeconômicos, culturais e políticos produzidos ao longo da história resultou em paisagens semelhantes nos territórios das referidas cidades, especialmente em seus centros históricos, cujo patrimônio edificado é a expressão cultural mais visível, reflexo do conteúdo socioespacial que a constituiu em épocas pretéritas. Portanto, a leitura e interpretação dessas paisagens urbanas, constituída da materialidade produzida no território, podem nos revelar uma ou mais narrativas espaciais comuns às mesmas. Ou seja, uma narrativa espacial regional, tendo como referência empírica o Recôncavo Baiano e suas cidades históricas portuárias, para destacar a produção simultânea dos territórios, a partir da paisagem urbana. Portanto, ao descobrir essa narrativa, que está na história do território, discutimos o sentido do patrimônio no presente, como perspectiva.

É óbvio que essa leitura é feita não apenas com base na interpretação pura e simples das formas, mas também, e necessariamente, a partir dos conteúdos históricos que elas traduzem. O conhecimento histórico dos conjuntos urbanísticos e dos monumentos isolados no contexto da cidade, de sua vida urbana, é preponderante para o aprofundamento das questões que o mesmo suscita por si só.

Buscamos analisar e interpretar as referidas cidades que, vistas como um "livro", nos oferecem pistas para encontrarmos os traços da cultura material da região como um todo, registrados nas suas formas urbanas. Formas estas que também expressam o seu conteúdo socioespacial, através do seu patrimônio edificado. Esse processo resulta no que denominamos de narrativa espacial regional.

A análise prioriza uma perspectiva de abrangência do conjunto urbano, o que não impede eventuais análises de monumentos isolados, resultado da produção e organização do espaço, analisado no sentido da busca do seu significado e simbologia em escala local e regional, a partir das cidades em tela.

Estamos considerando que a narrativa espacial se apoia em imagens. A iconografia nos ajuda, no sentido do reforço da mensagem do conteúdo histórico, inclusive nas suas mais variadas linguagens artísticas. Ou seja, o texto está apoiado em pesquisa bibliográfica e iconográfica, que permitem narrar os fatos na região e suas cidades, através de fotografias de exposições sobre o tema e imagens em telas de pintores que retratam a região e seu cotidiano. Além da literatura de ficção. Todos funcionando como apelo à memória e à identidade regional. 
O Recôncavo Baiano é uma região do entorno da Baía de Todos os Santos, localizada no estado da Bahia. Congrega uma rede de cidades históricas portuárias em pontos estratégicos, às margens dos principais rios da região e no interior da referida baía. Nelas ainda é possível encontrar referências do patrimônio histórico edificado dos séculos XVII, XVIII, XIX e primeiras décadas do XX.

Estudar as cidades históricas portuárias do Recôncavo Baiano sem se remeter à cidade do Salvador e à Baía de todos os Santos constitui uma imprecisão. Por isso, estaremos sempre nos reportando a Salvador e sua relação com a região pesquisada. Entretanto, o papel da Baía de Todos os Santos já está intrínseco na imbricada relação entre os núcleos urbanos pesquisados e a capital, pois desde os primórdios da colonização, toda a relação entre a primeira capital do Brasil e os primeiros núcleos urbanos portuários, tinha a navegação pela referida baía como via de comunicação, transporte de pessoas e mercadorias.

As cidades históricas portuárias da região do Recôncavo Baiano foram importantes entrepostos comerciais ao longo da história do Brasil, desde a colônia até a segunda metade do século XX. Tal importância vem sendo retomada aos poucos na atualidade, inclusive no sentido do enaltecimento de sua simbologia para a história e a identidade do povo baiano, além da dinâmica econômica.

Os núcleos de povoamento ali estabelecidos ao longo das diversas fases da história brasileira formaram uma rede de cidades, cujo patrimônio histórico edificado é uma das expressões mais significativas da cultura material da sociedade que nelas viveram. A maioria desses núcleos que posteriormente passaram da condição de povoados e vilas, elevando à categoria de cidades, exerceu papel preponderante como vias de escoamento da produção agrícola regional. Tal dinâmica se deu através de seus portos fluviais e marítimos, que funcionavam como entrepostos comerciais entre o sertão, o Recôncavo e a cidade do Salvador e sua função portuária e administrativa ligando a Bahia as outras capitais e ao "mundo".

O Recôncavo Baiano está incluído nos estudos de rede urbana regional e foi estudado nessa perspectiva - de rede urbana - primeiramente por Santos (1959), que o analisou numa perspectiva temporal, abrangendo vários períodos históricos. Mais recentemente, Andrade (2013), demonstrou através de profunda pesquisa bibliográfica e em fontes primárias (documental, cartográfica e iconográfica histórica) no Brasil e em Portugal, a existência de uma incipiente rede, desde o século XVIII. Estes são dentre outros estudos, dois trabalhos de fundamental importância para o entendimento daquele espaço em tempos distintos. 
Consideramos que jamais poderíamos estudar as cidades em tela, sem fazer referências à estrutura de rede por elas formada.

Estamos considerando a partir de estudos exploratórios que a rede urbana do Recôncavo Baiano, além de se constituir na primeira rede urbana do Brasil, também se constituiu desde o século XVIII como a mais densa, dinâmica e com maior número de núcleos urbanos, num perímetro territorial de grandes dimensões, guardadas as devidas proporções de distância entre seus pontos nodais para a época. Entretanto, foi provado que já existiam precárias vias terrestres de ligações entre os povoados, freguesias e vilas, desde o século XVIII (ANDRADE, 2013), muito embora o grande fluxo de pessoas e mercadorias se desse por via marítima e fluvial.

O grande volume de estudos sobre essa região é indicativo de sua importância no contexto da formação territorial, econômica, política, social e cultural do Brasil, especialmente da Bahia. Diversos estudos sobre o Recôncavo Baiano, além dos dois citados acima, tais como o de Costa Pinto (1958), Mattoso (1992), Brandão (1997), Barickman (2003), Pedrão (2007), Brito (2008), dentre tantos outros, são de fundamental importância para o entendimento desta região, sob a perspectiva histórica, social e econômica, em seus imprecisos limites regionais.

Da mesma forma que não poderíamos compreender o papel das cidades portuárias do Recôncavo Baiano sem entendê-las numa perspectiva de rede, também não poderíamos compreender a referida rede sem associá-la à história da cidade do Salvador (pensando a capital como a "cabeça" da rede).

A compreensão dessa rede nos dá o suporte para o entendimento do sentido do diálogo entre as referidas cidades, juntamente com Salvador, para daí, metaforicamente falando, interpretarmos o seu "texto", considerando o seu patrimônio edificado como palavras e o conjunto de suas paisagens urbanas como texto. Tudo isto entendido como se cada uma das cidades fosse um volume de uma coleção de obras literárias sobre um mesmo tema, escrita por vários autores, com diferentes enfoques e personagens, entretanto, numa mesma temporalidade. A região seria o conjunto de toda a obra, a expressão cultural de tudo isso.

O recorte temporal (1823-1889) coincide com o período de consolidação dos territórios de primeira e segunda geração de vilas da região, oriundas dos primeiros núcleos de povoamento e colonização do Brasil. Por outro lado, ocorreram também nessa época grandes rupturas na dinâmica socioeconômica e política no Brasil que afetaram diretamente o Recôncavo Baiano. Além disso, foi nesse período também que foram erigidos a maioria do 
patrimônio edificado, especialmente os prédios (sobrados) de função residencial e comercial, oriundos da cultura e da economia açucareira, do fumo e da mandioca.

É nesse período que todas as vilas se emanciparam, passando para a condição de cidade. No caso de São Felix, apenas um ano depois, em 1890. O período é marcado também pelo declínio da economia açucareira na Bahia e pela produção de um intenso e dinâmico mercado interno regional e local de mantimentos para alimentar a força de trabalho escrava dos engenhos e da população de Salvador.

Ocorreu também neste período (1823-1889) uma grande mudança nas relações de trabalho devido à proibição do tráfico de escravos para o Brasil (1850) e de todo o processo de recomposição e reorganização produtiva, a partir da mão-de-obra livre e assalariada. Neste período também se deu o apogeu da cultura fumageira na região. Todo esse processo deixou marcas indeléveis no território, até hoje presentes na paisagem das cidades que compõem a rede urbana da referida região.

A este estudo interessa a porção material e simbólica das paisagens, associadas ao processo socioeconômico e socioespacial de sua formação, suas permanências, como marco histórico do uso do território no espaço geográfico, com a emergência de uma narrativa espacial regional, comum a todas elas, oriundas do que também estamos denominando de produção simultânea dos territórios urbanos.

Estamos considerando que são duas narrativas que se interpenetram: a primeira origina-se e está posta no próprio território; a segunda é gerada pela análise e interpretação das ações dos sujeitos históricos que produziram as paisagens e buscam compreendê-la.

Com base no que foi exposto, buscamos responder a seguinte questão de pesquisa: como a análise das permanências do patrimônio edificado, produzido ao longo da história e, especialmente entre 1823 e 1889, pode ser reveladora da dimensão socioespacial da paisagem urbana das cidades históricas portuárias do Recôncavo Baiano, possibilitando identificar, na atualidade várias narrativas que, lidas numa perspectiva de abrangência regional, culminam numa única narrativa espacial que denota uma identidade territorial regional?

Portanto, o objetivo geral é compreender como as paisagens urbanas das cidades históricas portuárias do Recôncavo Baiano podem ser reveladoras de uma narrativa espacial regional, comum entre elas, que denote uma identidade territorial e produção simultânea dos seus territórios urbanos.

No intuito de alcançar o objetivo geral acima proposto, traçamos os seguintes objetivos específicos: 
1 - Identificar o patrimônio edificado (conjuntos urbanísticos e arquitetônicos e/ou monumentos isolados) das cidades históricas portuárias do Recôncavo Baiano - Cachoeira, São Felix, São Francisco do Conde, Santo Amaro, Nazaré, Maragogipe e Jaguaripe - erigidos entre 1823 e 1889 e outros de relevância histórica que antecederam o período, para melhor compreensão da gênese dos sítios urbanos;

2 - Detectar no repertório construtivo do patrimônio edificado das cidades em tela, elementos visuais simbólicos e demais informações de base documental que caracterizem suas similaridades e concomitância temporal no período em que foram construídos;

3 - Decodificar o patrimônio edificado das cidades em foco, produzido entre 1823 e 1889, a partir da leitura e interpretação dos conjuntos arquitetônicos urbanos e monumentos isolados.

Neste sentido, levantamos a hipótese, segundo a qual, existiu uma produção simultânea dos territórios urbanos no processo de produção e organização espacial das referidas cidades históricas portuárias do Recôncavo Baiano, detectado pela similaridade de padrões estéticos e estruturais (arquitetura e estilo dos seus edifícios como conjuntos urbanísticos e monumentos isolados) e pela concomitância temporal na ereção dos mesmos, materializadas como patrimônio urbano, culminando no que denominamos de narrativa espacial regional.

É importante salientar que todas as cidades pesquisadas apresentam bens culturais de natureza arquitetônica e/ou urbanística, reconhecidos como patrimônio no âmbito do Governo do Estado e do Governo Federal. Entretanto, cabe também ressaltar que, quando falamos em analisar o patrimônio das cidades no recorte proposto, não significa afirmar que os bens construídos no período já nasceram como patrimônio. Ou seja, não se trata de monumentos intencionais, pensados para a eternidade quando construídos, mas não intencionais, cujo reconhecimento, por meio de atribuição de valores se deu bem depois.

O presente estudo busca contribuir para a continuação do processo de preservação da memória do patrimônio urbano/edificado e para o fortalecimento da identidade das cidades em tela, enquanto um conjunto peculiar, formador de uma rede urbana histórica pioneira no território brasileiro, sob o olhar da Geografia Histórica Urbana. A dimensão e o número de cidades envolvidas, com forte apelo simbólico, caracteriza o sentido de territorialidade regional de expressão diferenciada no Brasil.

O termo paisagem é utilizado como conceito estruturante e categoria dominante de análise, numa perspectiva mais abrangente, no sentido de um olhar panorâmico, numa escala 
regional para o conjunto das cidades em foco. O conceito de paisagem cultural é utilizado como um conceito e categoria mediadora, derivado do primeiro, no sentido de um olhar para os conjuntos arquitetônicos e urbanísticos de cada cidade analisada, numa perspectiva local. O conceito de paisagem urbana é utilizado também como categoria mediadora de análise da tessitura urbana em caráter mais específico sobre o patrimônio urbano/edificado. Ou seja, como já apontado, o patrimônio cultural é visto como elemento da narrativa.

O patrimônio cultural é também concebido como uma categoria de análise, em sua dimensão urbana/edificada A terceira categoria de análise utilizada é a de "território usado", também vista como método na perspectiva miltoniana. Ou seja, a paisagem urbana como a narrativa do uso do território.

Associamos a produção e organização do espaço geográfico regional do Recôncavo Baiano na escala local à escala nacional e internacional, na dimensão do processo histórico de uso do território em cada cidade estudada. Realizamos a análise das cidades em foco, separadamente e associando-as à rede que formaram no conjunto da região. Ou seja, a expressão, a "fala" e o uso do território regional é também a expressão do seu patrimônio edificado, nas suas formas comuns, originadas num mesmo período histórico em cada uma delas.

Como falamos em narrativa espacial regional, resultante da análise e interpretação da dimensão urbana do patrimônio de natureza material (patrimônio edificado) e sua simbologia no processo de produção do espaço das cidades portuárias do Recôncavo Baiano, dois caminhos foram trilhados: o primeiro, através de uma análise geohistórica da produção do espaço urbano e regional; o segundo, a partir das categorias de análise "paisagem urbana" e "paisagem cultural", possibilitando a leitura do repertório construtivo do patrimônio edificado. Ou seja, através da investigação, descrição, análise e interpretação no processo do uso do território. Ambos os caminhos na perspectiva da dimensão mais abrangente da categoria da tese: a análise socioespacial.

A análise do Recôncavo Baiano em sua totalidade com vistas à interpretação do seu patrimônio edificado só se faz possível vinculando à escala nacional, tendo em vista a sua dinâmica socioeconômica ao longo de sua história. Autores afirmam que "[...] a história do território brasileiro é, a um só tempo, una e diversa, pois é também a soma e a síntese das histórias de suas regiões" (SANTOS; SILVEIRA, 2001, p. 23).

Como procedimento de pesquisa analisamos as imagens in locu e através da interpretação da iconografia de época e atual, principalmente dos conjuntos urbanísticos e 
também de monumentos isolados, buscando compreender, através da simbologia do patrimônio edificado, o sentido das paisagens.

É imprescindível estarmos atentos para a questão relacionada aos cuidados que o pesquisador deve ter quando do procedimento de análise de um objeto de pesquisa baseada em fonte iconográfica. Trata-se de um método que exige cautela sobre o que se apresenta na imagem e a realidade do contexto em tela. Principalmente quando se trata de pesquisa em Geografia Histórica Urbana, onde se faz necessário compreender a relação entre o espaço e tempo, de forma sistematizada, com uma definição clara do recorte temporal e de possíveis periodizações, principalmente quando de um tempo de longa duração.

As permanências do patrimônio cultural urbano de natureza material das cidades portuárias do Recôncavo Baiano, na forma de seus conjuntos urbanos e monumentos isolados nos dão pistas da dimensão de suas funções e da dinâmica socioeconômica, relacionadas ao seu universo regional. Entretanto, estamos cientes de que, nem tudo que aparece nas suas paisagens urbanas, especialmente quando "congeladas" pelo olhar do momento (imagem fotográfica), possível realidade do cotidiano vivido. Contudo, algo de importante sempre pode ser revelado.

Complementamos o nosso estudo através de pesquisa comparada entre as imagens da paisagem urbana destas cidades. Buscamos demonstrar a simultaneidade e a similaridade na construção do seu tecido urbano, caracterizando uma peculiaridade na produção e organização do espaço regional, no qual formou uma rede de conexão intensa, sendo o seu patrimônio edificado a maior expressão de sua narrativa espacial.

No que tange à pesquisa documental, o Inventário de Proteção do Acervo Cultural da Bahia (BAHIA, 1982a; 1982b) é a fonte de apoio principal da nossa pesquisa empírica. A referida obra, produzida entre meados da década de 1970 e início da década de 1980, é de fundamental importância e a principal fonte de dados para o nosso objeto de pesquisa.

A referida fonte é um documento precioso que consiste num estudo detalhado dos monumentos que foram inventariados à época nas sete cidades pesquisadas. Extraímos do mesmo as informações ${ }^{1}$ inerentes ao patrimônio, coletadas em campo na época, que tem maior relevância para a nossa pesquisa.

\footnotetext{
${ }^{1}$ As informações mencionadas são as seguintes: a localização dos monumentos e sítios urbanos; análise das fotografias; denominação; localização; situação e ambiência; época de construção, descrição arquitetônica; utilização; dados tipológicos; dados cronológicos; histórico arquitetônico e dados jurídicos no período das pesquisas realizadas pela equipe na época (IPAC, BAHIA, 1982). No capítulo três descrevemos mais detalhadamente sobre a metodologia e as características gerais do referido documento.
} 
A obra acima citada serviu de parâmetro para analisarmos e compararmos os dados entre as cidades pesquisadas, buscando encontrar as similaridades das formas e concomitâncias temporais na produção do patrimônio edificado, e daí apontarmos o que há de comum entre elas.

Outro procedimento foi a observação direta e o uso de fotografias dos conjuntos urbanos e monumentos isolados da época (1823-1889), registrados na atualidade, com observação detalhada, no intuito de detectar elementos significativos que confirmem uma possibilidade de uma narrativa espacial comum na tessitura urbana das cidades pesquisadas.

Os capítulos da tese estão estruturados da seguinte forma: No segundo capítulo, situamos o leitor quanto ao objeto da Geografia - o espaço geográfico - ao longo da história do pensamento desta ciência. Situamos também a subárea que pretendemos trabalhar: a Geografia Histórica.

O terceiro capítulo trata mais especificamente dos conceitos estruturantes e mediadores da pesquisa, buscando alinhá-los de forma lógica para permitir a devida compreensão do objeto de pesquisa, indicando o estado da arte a que propomos como base teórica e metodológica do estudo.

No quarto capítulo fizemos um estudo de contextualização geohistórica do Recôncavo Baiano, junto à formação territorial e política do Brasil, alinhando à produção e organização do espaço regional e o papel da dinâmica socioeconômica na formação da paisagem urbana e da dinâmica cultural na formação do seu patrimônio edificado.

No quinto capítulo tratamos da relação entre Salvador e as cidades históricas portuárias do recôncavo baiano, com o intuito de entendermos a imbricada relação de rede e de fluxos e refluxos no processo de formação socioeconômica, política e cultural entre a capital, o Recôncavo e suas cidades históricas portuárias, com destaque para o evento da Independência do Brasil, na Bahia, e a relação entre elas no processo de articulação e uso do território naquele momento ímpar da nossa história.

No sexto capítulo, como resultado da pesquisa, apresentamos uma contextualização das sete cidades estudadas, sua origem, produção e organização espacial e suas características urbanísticas, com o intuito de detectar a produção simultânea dos territórios, apontando as similaridades e concomitâncias temporais, expressas nas formas e estilos arquitetônicos dos monumentos e conjuntos urbanísticos de relevância na paisagem urbana das mesmas, tendo como base documental as fotos atuais e o inventário feito pelo Instituto do Patrimônio Artístico e Cultural da Bahia (IPAC) (BAHIA, 1982a; 1982b), além de outras fontes. 
Posteriormente apresentamos as nossas conclusões e indicações de propostas de ações de preservação para a região. 


\section{2 - SITUANDO A GEOGRAFIA HISTÓRICA E O ESPAÇO GEOGRÁFICO}

Em se tratando do movimento de renovação da Geografia enquanto ciência é importante salientar o que Pires (2008) nos coloca sobre as abordagens da maioria dos livros sobre a história do pensamento geográfico. Segundo ele tais abordagens trataram deste movimento com tendência a colocar apenas a corrente da Nova Geografia ou Geografia Quantitativa como único movimento de oposição à Geografia Moderna no século XX. Mas não foi bem assim.

Para o autor acima referido,

[...] Isso talvez tenha ocorrido porque o movimento que culminou com a crítica efetuada pela Nova Geografia tenha merecido mais destaque e seja mais conhecido que o movimento pela consolidação da Geografia Histórica. Mas, a história do pensamento geográfico no século XX conheceu três grandes movimentos de renovação: o primeiro fundou a Geografia Histórica e Cultural; o segundo criou a Nova Geografia ou Geografia Quantitativa; o terceiro erigiu a Geografia Radical ou Crítica. Estes movimentos emergiram, em oposição à Geografia Moderna, os dois primeiros, simultaneamente, no mesmo contexto histórico e o último no início dos anos 70 (PIRES, 2008, p. 2).

A assertiva acima é de fundamental importância, pois nos ajuda a situar os novos paradigmas da Geografia Histórica no processo de evolução desta ciência, que não teve o devido destaque na historiografia do pensamento geográfico.

Pires (2008) enaltece o importante papel da Geografia Histórica no contexto da evolução do pensamento geográfico, afirmando que os grandes representantes daquela corrente "[...] introduziram novas metodologias, estudaram os mais diferenciados campos do saber humano" (PIRES, 2008, p. 14). E que a Geografia Histórica estabeleceu uma relação concreta e coerente entre o tempo e o espaço na formação do território, no seu processo histórico e no presente. Segundo o referido autor, "[...] ela engendra, a partir de modelos, a observação da relação espaço-temporal das sociedades e analisa a influência ou determinação do espaço como meio e sujeito na organização e no desenvolvimento das sociedades" (PIRES, 2008, p. 14). Em síntese, pode-se afirmar, ainda segundo ele, que a “[...] Geografia Histórica 
estuda as características e evolução dos espaços históricos, sua morfologia, paisagem e organização territorial assim como sua formação social” (PIRES, 2008, p. 10).

A Geografia Histórica tem grande influência de paradigmas, cujas teorias são baseadas no historicismo e vai influenciar sobremaneira a Geografia Cultural, oriunda da França. Para Vasconcelos (2015, p. 1) a “[...] definição de geografia histórica vai depender da época em que foi elaborada, dos paradigmas dominantes, levando também em consideração as visões globais da própria disciplina".

O referido autor, em artigo inédito, menciona vários temas da Geografia Histórica, baseado nos estudos de grandes autores especialistas neste subcampo da geografia. Alguns destacam dentre outros temas as análises regional, cultural e da percepção, além das paisagens industriais e urbanas. Outros destacam também dentre outros temas, a análise da paisagem (VASCONCELOS, 2015). O artigo cita um grande número de autores estrangeiros e ainda segundo Vasconcelos $(2015$, p. 3) “[...] a maior parte dos estudos da geografia histórica é voltada para o estudo das paisagens e morfologias, assim como para as questões agrárias e rurais".

Nos Estados Unidos, Karl Sauer (1889-1975) foi um dos disseminadores dessa corrente nos países de cultura anglo-saxônica nas primeiras décadas do século XX. Ele integrou a famosa escola americana (estadunidense) de Berkeley. Propôs o desenvolvimento de uma teoria geográfica da "morfologia da paisagem" e da "história cultural" (PIRES, 2008).

Segundo Pires (2008), a crítica efetuada pela Nova Geografia ou Geografia Quantitativa à geografia clássica ficou mais destacada e conhecida na historiografia do pensamento geográfico do que o movimento pela consolidação da Geografia Histórica. Ainda segundo este autor, a Geografia Histórica e a Geografia Cultural nascem, simultaneamente, no mesmo contexto histórico (anos vinte do século XX), com o primeiro movimento de oposição à Geografia Moderna.

O nosso trabalho é permeado por uma narrativa que busca o diálogo entre a Geografia e a História. Ou seja, é uma pesquisa na qual, a história por si só, além de alguns elementos do urbanismo, se complementam numa perspectiva geográfica. Trata-se de uma análise cuja tônica se revela mais proeminentemente pelo processo de formação espacial dos territórios de sete cidades portuárias que formaram uma rede de densa conexão no âmbito da região na qual estão inseridas. Portanto, as discussões se ancoram no campo disciplinar da Geografia Histórica Urbana, através de uma abordagem interpretativa com forte apelo retrospectivo, no qual o espaço geográfico é o objeto principal da investigação. 
O conceito de narrativa espacial não é utilizado como uma simples descrição do objeto de pesquisa. Ou seja, não se trata de narração pura, como algo que é posto de maneira inquestionável, mesmo porque é essa narrativa que traz o fio condutor da análise histórica com suas contradições. Estamos considerando várias narrativas, inclusive a que culmina na nossa proposta.

A ideia de narrativa espacial que propomos se alia com a compreensão de Da Guia (2010), para o qual, quando os acervos são apropriados pela população, existirão conexões entre gerações. Ou seja, o diálogo entre a sociedade de hoje e as histórias de seus antecessores pode ser intermediada através de narrativa espacial de estimado valor cultural. Alguns exemplos tais como o potencial para a compreensão das lutas de defesa do território, a exemplo das suas fortificações espalhadas pelo país.

No caso do Recôncavo Baiano, podemos citar o caso das batalhas pela Independência do Brasil, na Bahia, entre 1822 e 1823, quando foram utilizados edifícios residenciais (sobrados) e administrativos (Casas de Câmara e Cadeia), como pontos de reuniões de líderes locais para deliberar as estratégias de logística de guerra contra as tropas portuguesas, assim como o uso de algumas igrejas católicas para assistência à população e aos combatentes. Alguns desses prédios permanecem na atualidade e são referências para a memória da população dessas localidades.

Outro exemplo são as formas de governo observados nos diversos exemplares de monumentos (a arquitetura institucional de um determinado governo); no idealismo religioso cristão, mais preponderante na cultura brasileira. A narrativa espacial se expressa nas igrejas, conjuntos monásticos, Casas de Misericórdia, Seminários entre outros. Pontes, arquedutos, arrimos, chafarizes, fontes, estações de transporte ferroviário e rodoviário etc. são vestígios da infraestrutura e da engenharia urbana que são testemunhos do processo de ocupação do território com suas marcas registradas na paisagem, como uma narrativa simbólica do espaço vivido (DA GUIA, 2010). Ou seja, a "fala” do território através da paisagem, cujo conteúdo é o patrimônio urbano/edificado nela contida.

Como já foi dito na introdução, o recorte temporal escolhido foi o período do Brasil Império, século XIX, a partir de 1823 até 1889. Entretanto, cabe ressaltar que, quando necessário, lançamos um olhar que ultrapassa os limites temporais propostos. Especialmente no que se refere à análise de monumentos isolados erigidos anteriormente ao período estabelecido, que fazem parte do acervo do tecido urbano das referidas cidades e são fundamentais para o entendimento da organização espacial das mesmas e ajudam na 
compreensão da origem dos sítios urbanos pesquisados. É o caso das Casas de Câmara e Cadeia e Paços Municipais, além de igrejas (matrizes) que compõem a paisagem daquelas localidades.

A escolha do período se deve ao fato de que se incluem dois subperíodos na história da cidade do Salvador que tem reverberação direta na história das cidades do Recôncavo Baiano e vice-versa, especialmente aquelas que são foco desta pesquisa. Um dos exemplos mais contundentes deste fato é a consolidação da Independência do Brasil, na Bahia em julho de 1823.

Tomamos como base, portanto, a periodização de Vasconcelos (2002) para o qual neste recorte se incluem dois períodos marcantes: 1 - Salvador no Império: instabilidade e africanização (1823/1849); 2 - Salvador no Império: estabilidade e infra estrutura (1850/1889).

Estes subperíodos, embora relacionados à cidade do Salvador, são referência para o esclarecimento de questões que suscitem uma dimensão mais reduzida na escala temporal, associadas aos eventos neles contidos e à produção do espaço das cidades pesquisadas, no sentido de uma contextualização espaço temporal. Entretanto, o olhar analítico de referência é o período como um todo. Quando necessário, também buscamos um olhar para períodos anteriores a 1823 .

Dentro destes períodos se destaca o ano de 1850 como exemplo específico de início de um "período denso" da história de Salvador, na concepção de Vasconcelos (2009), considerado por este autor como um momento de ruptura. Este ano que deu início a um período daqueles “[...] que saem da rotina, e nos quais ocorreram eventos mais significativos, que ocasionam modificações na sociedade urbana, assim como nas funções, nas estruturas e nas formas espaciais" (VASCONCELOS, 2009, p. 148). Considerando que as cidades históricas do Recôncavo Baiano formavam uma rede urbana em conexão direta com a capital desde o século XVIII, fica evidente a possibilidade de que todas elas sofreriam também os impactos no período. Entretanto dado o grau de quase "autarquia" destas cidades, consideramos a possibilidade de transformações originais, assim como a fusão entre originalidade e imitação de ideias; organização política e ideológica; arte e cultura de uma maneira geral.

Apesar da necessária existência de um recorte temporal e espacial para contemplarmos nossos objetivos junto ao objeto de pesquisa, não podemos restringir nossa análise a esses limites espaciotemporais. Entretanto, sabemos que cada período histórico deixa a sua marca, 
seja ela em forma de ideias ou ideologias (VASCONCELOS, 2009); ou na forma pura, concreta, da materialidade produzida no território. Como considerou Santos (1988), o espaço como uma acumulação desigual dos tempos. Daí a necessidade de uma periodização, pois estas nos oferecem um tempo externo e um tempo interno a cada subespaço (SANTOS, 1996).

Dentre as questões apontadas pelo referido autor em relação às questões metodológicas na Geografia Histórica Urbana, nos interstícios de nossa análise, caminhamos na direção onde:

[...] o aparecimento de novas ideias e ideologias, que podem modificar as maneiras de pensar e transformar os valores da sociedade urbana em exame, como, por exemplo, as ideias da Contra Reforma ou as da Revolução Francesa etc., assim como as influências do estilo artístico de cada período (Renascimento, Barroco, Clássico etc.) (VASCONCELOS, 2009, p. 151).

É o caso da possibilidade de identificação de um ou mais estilos de época, revelados nos conjuntos urbanísticos e monumentos das cidades pesquisadas, a partir do exame dos "[...] frontispícios ou perfis das cidades, nos quais podem ser observados inclusive as transformações da arquitetura e da paisagem urbana” (VASCONCELOS, 2009, p. 148).

Devem-se incluir nesse exame a observação da organização espacial das estruturas funcionais diversas, geradoras de formas diferenciadas que, por sua vez se originam e se transformam, dependendo da conjuntura histórica e da consequente evolução urbana que as cidades foram submetidas.

Corroboramos, portanto, com a visão de Pires (2008, p. 9), segundo a qual o estudo do espaço “[...] requer obrigatoriamente a reconstituição de seus elementos históricos, da história de sua produção. Isso requer, inevitavelmente, que o geógrafo reconheça a noção de tempo como um elemento fundamental para os estudos geográficos".

No caso da História, especificamente da História Cultural, por exemplo, o que se percebe na contemporaneidade é fruto do que já havia sido plantado nas concepções do pensamento das ciências sociais no século XIX e início do século XX, a exemplo da visão do mundo por uma dimensão da representação simbólica.

Corroboramos com a ideia de Pesavento (2008) segundo a qual é imprescindível a noção da cidade real lida por meio de suas representações, enquanto parte da realidade, não apenas como geradoras de práticas sociais, mas ainda porque nelas, nas imagens metafóricas 
da cidade que se sobrepõem à realidade (fotografias, textos ficcionais, iconografia em geral), evidencia-se o esforço do jogo entre revelação e ocultamento. A autora acima referida defende a cidade como espaço por excelência da construção de significados que se expressam, entre outros, em seus bens culturais, da mesma maneira que a ideia de imaginário social como um sistema de representação que os homens, em todas as épocas, construíram para si, dando sentido ao mundo. Tais noções são cruciais para o nosso estudo.

Alinhamo-nos com a perspectiva acima apontada e a explicitaremos mais pormenorizadamente, quando tratamos da narrativa do episódio da Independência do Brasil na Bahia (tópico 5.2.1), que estaria "escrita” em pedra e cal, nos edifícios históricos das cidades estudadas, a exemplo das igrejas e casas de câmara e cadeia. Ou em lápides comemorativas ao centenário do referido evento em todas as cidades que participaram mais efetivamente do mesmo.

Buscando compreender um pouco mais sobre as referidas mudanças de paradigmas e concepções sobre o "espaço geográfico", serão revistas aqui de forma sucinta, os três momentos da evolução do pensamento da Geografia enquanto disciplina acadêmica, como um passo introdutório para darmos continuidade à discussão das questões conceituais e metodológicas da nossa pesquisa. Para isso, referenciamos epistemologicamente os paradigmas que nortearam o percurso desta ciência nos referidos períodos, para demonstrar que muitas das suas concepções, guardadas as devidas proporções para época, ainda são atuais. É o que veremos a seguir.

\subsection{O ESPAÇO GEOGRÁFICO NA GEOGRAFIA CLÁSSICA ${ }^{2}$}

Para falar do espaço geográfico na Geografia Clássica, se faz necessário um esforço de revisão histórica na qual deveremos incluir, principalmente, uma contextualização da conjuntura socioeconômica e política do que se considera como época clássica da Geografia enquanto ciência institucionalizada. Portanto, consideraremos para esse fim, o período entre a segunda metade do século XIX e o final da Segunda Guerra Mundial em 1945. Nesse período,

\footnotetext{
${ }^{2}$ Partes dos escritos desse tópico e dos demais adiante, referentes a este capítulo, são oriundos de anotações de aulas da disciplina Teoria do Espaço Geográfico (2011.2), ministrada pelos professores Dr. Neio Campos e Dr ${ }^{\mathrm{a}}$. Ignez Costa, do curso de Doutorado em Geografia da Universidade de Brasília - UnB.
} 
incluem-se alguns movimentos nas primeiras décadas do século $\mathrm{XX}$, que deram origem à Geografia Histórica e Cultural, mas ainda dentro do que se convencionou chamar de Geografia Moderna.

Apesar de ter uma história longa desde os gregos na Antiguidade Clássica, a Geografia somente passou a ter o status de ciência, ensinada e praticada nas universidades a partir de meados do século XIX. Foi na Alemanha onde primeiro se formou uma corrente de pensamento no seio desta ciência, que ficou conhecida como "escola alemã". Sua característica central era ser iminentemente determinista e naturalista. Seus maiores expositores foram os alemães A. Von Humbolt, C. Ritter e F. Ratzel (CAMARGO; REIS JUNIOR, 2005, p. 83).

Pensar e analisar a conjuntura nesse período é constatar que a Geografia enquanto ciência existiu para subsidiar Estados-Nação de formação recente, oriundos de impérios europeus, contribuindo enquanto ciência de informação, de cunho descritivo. Tal contribuição é essencialmente relativa ao domínio do território, sob a concepção de que o espaço era vital para a sobrevivência do Estado. Nesta perspectiva o espaço geográfico é sinônimo de poder e de sobrevivência, porém sem ser visto como o objeto propriamente dito da Geografia e nem sob a ótica que o entendemos atualmente.

A Geografia foi fundamental no processo de conhecimento dos espaços, onde se produziram territórios circunscritos, sob o domínio político e ideológico de nações tecnicamente mais poderosas. Para tanto, a sobreposição dessas ideologias e culturas dominantes, sob a forma inicial de acesso e domínio territorial e, posteriormente, sob a forma de dominação ideológica e cultural, acontecia na maioria das vezes de forma coercitiva. A colonização brasileira é um exemplo típico deste processo, fato que permanece em vários aspectos da nossa cultura material e imaterial.

É nesse contexto que a Geografia Clássica compreende o espaço geográfico ainda sob uma perspectiva do determinismo geográfico, onde a natureza era capaz de determinar a essência das culturas, sendo o homem um mero paciente e não um agente da transformação na relação sociedade/natureza. Ou seja, o homem passivo na produção do espaço geográfico.

Cabia à Geografia, portanto, dentro do contexto das ciências da natureza, um lugar de ciência de síntese e de informação no processo de transição entre o Determinismo de Ratzel e o Possibilismo de La Blache. Esse último, responsável por levar essa ciência a um nível mais experimental para a época, dando a oportunidade de encará-la como uma Ciência Humana, social, pois o homem passaria da condição de mero paciente das ações e influências da 
natureza, para a condição de agente interveniente dos processos de produção e organização do Espaço Geográfico.

La Blache propunha uma Geografia Humana para melhor compreensão do espaço, onde o homem seria o agente principal dessa nova abordagem, sem, porém, desconsiderar as prerrogativas das ciências naturais, base da Geografia Determinista da época. Isso se deve à evolução técnica dos processos de domínio da natureza, assim como da necessidade política de afirmação da Geografia enquanto ciência autônoma.

Com La Blache, a Geografia passa a ter um caráter de ciência preocupada também em descrever compartimentações do espaço, sob a forma de caracterização dos lugares, entendidos como partes de um todo, com suas heranças geohistóricas, fruto de uma combinação entre sociedade e natureza, quando ambos passam a interagir como causa e efeito no processo de produção do espaço. Contudo, a dificuldade de fazer uma discussão direta sobre o objeto da geografia - o espaço geográfico - na Geografia Clássica é exatamente dela não ter concebido um objeto claro, mas vários, a exemplo da paisagem, região etc. Portanto se tornava fragilizada perante as outras ciências sociais.

O homem para La Blache era resultado de sua história e não completamente de sua independência intelectual, o homem apolítico, ainda subalterno, apesar do desenvolvimento técnico da época. A Geografia nesse contexto passa por um momento de crise, sem uma identidade, sem autonomia, uma "ciência de síntese", aglomerado de outras ciências.

$\mathrm{Na}$ busca de um destaque mais contundente para a Geografia nas relações com outras ciências da época, La Blache concebia a ideia de lugar, entendido segundo o mesmo, como uma parte do todo (terra), cabendo à Geografia se deter no estudo das partes desse todo. O que vai gerar um "gênero de vida", ou seja, o lugar será o resultado da ação do homem. Apesar disso, o estudo da região era fundamental, já que interessava ao Estado centralizador as informações advindas dos levantamentos da pesquisa. Entretanto, ainda permanecia uma mera descrição dos lugares. Uma espécie de naturalização entre pessoas e lugares.

O "gênero de vida" de La Blache não se explica apenas pela ação do homem, mas também pela ação da natureza, que é a origem da ciência geográfica, enquanto ciência da natureza nos seus primórdios. Entretanto, à época da afirmação das concepções deste geógrafo, as possibilidades técnicas de ação do homem sobre a natureza vão gerar uma nova concepção, dessa vez menos deterministas nas relações homem/natureza, sociedade/espaço.

Nesse processo o homem adapta as condições do meio às suas necessidades e daí por diante não cabe mais uma análise dicotômica do espaço geográfico sob uma perspectiva 
científica, unilateral, unicamente física ou humana. Talvez tenha sido essa a grande contribuição de La Blache no processo de evolução da Geografia Clássica. É ele próprio quem preconiza as mudanças de enfoque na Geografia. Em seu texto publicado originalmente na Revue de Synthèse Historique, escreveu que:

Tanto nos procedimentos quanto nos resultados, a obra geográfica do homem é, essencialmente, biológica. Frequentemente, velhos hábitos de linguagem fazem com que consideremos a natureza e o homem como dois termos opostos, dois adversários em duelo. Entretanto, o homem não é "como um império dentro de um império"; ele faz parte da criação vivente, é seu colaborador mais ativo. Ele não age sobre a natureza senão nela e por seu intermédio. É entrando na disputa da concorrência dos seres, tomando partido, que ela assegura seus propósitos (LA BLACHE, 2012, p. 102-103).

Diante do exposto percebe-se que o espaço geográfico na Geografia Clássica, a partir de La Blache, começa a ser percebido como um ente de possibilidades de novos métodos. Neste sentido, o autor escreveu o seguinte em relação à Geografia Humana daquela época:

[...] Portanto, a Geografia humana merece esse nome porque estuda a fisionomia terrestre modificada pelo homem; nisso ela é geografia. Ela não considera os fatos humanos senão em sua relação com a superfície onde se desenvolve o variado drama da concorrência dos seres vivos [...] (LA BLACHE, 2012, p. 103)

Segundo La Blache (2012), a Geografia Humana ainda apresentava restrições quanto à abordagem, continuando carente de um método, especialmente naquela época, quando se iniciava com a Anthropogeographie de Ratzel. Em sintonia com as mudanças de conjuntura da época, relacionadas dentre outras coisas com a influência das "poderosas civilizações contemporâneas" no contato com as regiões da zona tropical.

Entretanto, para os historiadores, Vidal de La Blache e seus seguidores deram grandes contribuições para a questão da problematização do recorte regional. Segundo Graça Filho (2009, p. 17), “[...] aqui, as discussões sobre a parte e o todo se tornam aplicações para a análise de um espaço geográfico e humano, que precisa ser especificado em sua natureza única". Portanto, em relação à questão espacial, o todo e as partes não podem estar desassociados "[...] das dimensões históricas da ação humana em um determinado meio geográfico" (GRAÇA FILHO, 2009, p. 17).

Segundo Berdoulay (2012, p. 105), “[...] devemos a Paul Vidal de La Blache e a seus primeiros discípulos a formulação de uma teoria geral das relações humanas sobre o meio 
ambiente, normalmente chamada de possibilismo [...]". Para o referido autor, o possibilismo privilegiou “[...] o estudo dos gêneros de vida e das organizações regionais, como mediações, que fornecem a abordagem mais sutil em matéria de relações entre o homem e o meio ambiente [...]" (BERDOULAY, 2012, p. 105). Portanto, tais mediações são as paisagens, as regiões, os gêneros de vida etc., “[...] concebidos como um conjunto de interações com modificações recíprocas das culturas e de seus meios [...]" (BERDOULAY, 2012, p. 105).

Assim concebemos o objeto da nossa pesquisa, o Recôncavo Baiano e suas cidades portuárias, no sentido de compreender a expressão cultural de suas paisagens, numa perspectiva histórica e de totalidade nas mais variadas escalas geográficas, principalmente a local e regional.

Nessa fase da evolução da Geografia, as contribuições de La Blache e seus seguidores foram fundamentais, pois acrescentaram a dimensão da dinâmica histórica no processo de compreensão do meio geográfico, quando alterado pela ação do homem. Para Graça Filho (2009, p. 18) “[...] o reconhecimento da historicidade da geografia aproximou-os dos historiadores, em particular dos fundadores da Escola dos Annales, [...] com grande destaque, na geo-história de longa duração de Fernando Braudel".

Diante de um contexto de desenvolvimento técnico e científico nunca antes visto no processo de evolução da humanidade, especialmente entre o final do século XIX e meados do século XX, o objeto da Geografia - o espaço geográfico - tornou-se cada vez mais complexo e difícil de ser analisado, diante de uma mudança abrupta na conjuntura do conhecimento científico e técnico, dando subsídio às ações políticas. Ou seja, as ideologias políticas e tensões sociais estavam caminhando juntas numa sociedade voltada para expansão comercial capitalista, que se materializava na conquista de territórios e na expansão das escalas de ações políticas para esse fim.

A questão do método na Geografia Clássica, à medida que se aproximava do meado do século XX era cada vez mais criticada por geógrafos que naquele momento buscavam dar a esta ciência um caráter mais de unicidade científica, quanto ao objeto, teoria e modelos de análise, que posteriormente viria caracterizar a Geografia Quantitativa.

Tendo em vista o exposto, reafirmamos a nossa convicção sobre a questão da readaptação de métodos e teorias clássicas que se mantém atuais e fundamentais para o entendimento da realidade socioespacial ao longo do desenvolvimento da ciência, especialmente a Geografia. 
Quanto à construção de uma abordagem sociocultural, por exemplo, para o conceito de região em Geografia, Serpa (2015, p. 11) assevera que o pressuposto de partida para tal abordagem, "[...] advém do fato da íntima interligação dos fatos econômicos com os sistemas de valor, tradições e organização social, em suma, com os fatos sociais e culturais, em qualquer recorte, inclusive no recorte regional”. E o referido autor adverte para o fato de que esse entendimento remonta à antiguidade clássica.

Entretanto, é necessário estar atento também para as mudanças ocorridas ao longo da história da humanidade e perceber que no contexto da Geografia Clássica, como afirma Serpa $(2015$, p. 12) “[...] a produção do conhecimento geográfico ainda estava muito atrelada a uma visão positivista, base de um determinismo geográfico injustificável para uma abordagem sociocultural do conceito de região [...]”. Ainda segundo Serpa (2015), em termos de método, a proposta de Vidal de La Blache não rompeu com as formulações de Ratzel, foi antes um prosseguimento destas. Vidal era, entretanto, mais relativista, negando a ideia de causalidade e determinação de Ratzel.

Portanto, nesta revisão histórica, de meados dos oitocentos até o fim da Segunda Guerra Mundial, buscamos esclarecer, sobretudo para o leitor que não pertence ao campo da Geografia, fatos importantes para o entendimento do contexto em que esta ciência se estabeleceu no mundo acadêmico.

Destacamos entre Estado-Nacional e a Geografia enquanto ciência e o entendimento, nesta relação, do espaço geográfico como sinônimo de poder e sobrevivência deste mesmo Estado, ainda que ao homem seja atribuído, neste momento, um papel passivo na produção do espaço. Papel este que apenas se altera, assumindo um protagonismo ativo, na Geografia Humana.

Além do papel do homem, trouxemos à tona também a questão das escalas geográficas, aproximando-se do recorte regional, bem como da dimensão da história para o entendimento do processo de produção do espaço geográfico.

Mais adiante, no quarto capítulo, a questão da abordagem do conceito de região será retomada, desta vez na contemporaneidade e especialmente para a Região do Recôncavo Baiano, quando tratamos das diversas conceituações sobre essa região, culminando no mais recente processo de implantação das políticas de desenvolvimento territorial e regionalização da Bahia, executado pelo Governo do estado a partir de 2007.

A seguir veremos as contribuições da Geografia Neopositivista para o pensamento geográfico da época. 


\subsection{O ESPAÇO GEOGRÁFICO, A NOVA GEOGRAFIA E A GEOGRAFIA HISTÓRICA}

O pensamento científico proveniente da Geografia Quantitativa/Neopositivista, que começou a se formar logo após a Segunda Guerra Mundial, foi estruturado primeiramente sob a ótica da abstração inicial na abordagem do fenômeno e não apenas como uma técnica que antecede a teoria. Essa corrente teve maior preocupação com os casos isolados do que com as generalizações.

Não se pode negar que a visão neopositivista contribuiu no processo de análise do espaço geográfico à época, já que estava havendo uma necessidade de distinguir o papel da Geografia perante outras ciências e a base filosófica, para essa distinção estaria nos fundamentos da filosofia positivista. Segundo Camargo; Reis Junior (2005) a vertente científica do Positivismo

[...] assume o papel de valorizar o conhecimento racionalizado, que era considerado útil, técnico, objetivo, baseados nos fatos concretos existentes no mundo real e que podiam ser apreendidos pelo sujeito do conhecimento. Percebe-se, assim, o quanto a filosofia dá importância ao que se verifica pela via empírica, a ponto de considerar a observação e a experimentação os únicos critérios para atestar a veracidade, a única base possível para se atingir o conhecimento de fato (positivo, verdadeiro) (CAMARGO; REIS JUNIOR, 2005, p. 84).

No processo da afirmação da "Nova Geografia", o neopositivismo ganha importância, porque a ciência estava chamada a pré-dizer sobre o conhecimento de uma nova realidade. $\mathrm{O}$ espaço geográfico na Geografia Quantitativa, portanto, passa a ser uma categoria, o escopo da quantificação de seus elementos, trazendo consigo o estigma neopositivista que, além do rigor da linguagem matemática, trouxera também a noção de fisicalismo, leitura física dos fatos, a exemplo do estudo da difusão espacial dos fenômenos, levando em consideração aspectos teóricos precedentes.

A leitura termodinâmica de Christofolete sobre o espaço urbano é um exemplo de fisicalismo, ou seja, a utilização do rigor da física na análise dos fenômenos do espaço geográfico. Entretanto, não podemos esquecer o fisicalismo presente em algumas análises, permitindo uma abordagem mais fenomenológica dos fatos.

A dificuldade de fazer uma discussão sobre o objeto da geografia - o espaço geográfico - na geografia clássica, por exemplo, era de que ela não teria concebido um objeto 
claro, mas vários, a exemplo da paisagem, região etc.. Portanto se tornava fragilizada perante as outras ciências sociais. Pode-se afirmar que a Geografia Clássica era positivista em certos aspectos, mas em outros não. As políticas, por exemplo, não podem ser elaboradas levando-se em consideração o espaço como algo acabado. São trajetórias, as histórias em tempos diferentes. Traços antigos que permanecem. Que se transformam.

$\mathrm{Na}$ Geografia Quantitativa, por outro lado, a renovação era muito mais metodológica do que teórica. Criaram-se novas ferramentas metodológicas. A visão sistêmica. Isto é, trabalhar com interações, ignorando muitas vezes a conjuntura. O espaço ficou neutralizado. Ou seja, passou-se a ter uma visão mais reducionista, mais compartimentada do espaço geográfico. Ou seja, ainda não predominava uma visão de totalidade do espaço geográfico. Isto é, uma visão mais holística.

O rigor linguístico foi fundamental como peculiaridade da Nova Geografia, a possibilidade de instaurar modelos de aplicação universal a exemplo de um estudo de metrópoles, incluindo São Paulo e Nova e York num estudo mais ampliado.

Na Geografia Quantitativa a unicidade do método é o seu diferencial maior. Ou seja, não há diferença entre o que se estuda sobre a perspectiva do humano e da natureza por exemplo. O objeto deve ser pensado, primeiramente, sob a ótica da abstração inicial na abordagem do fenômeno e não apenas como uma técnica que antecede a teoria. Por isso, muitas vezes se confunde, nas análises sobre o método. A quantificação, por exemplo, muitas vezes é necessária para o entendimento de certos aspectos da pesquisa em Geografia, apoiada pela matemática/estatística. Daí o surgimento de modelos teóricos que se traduzem em previsões precisas, muitas vezes engessadas em padrões de análises espacialmente restritas e compartimentadas, baseados na teoria sistêmica.

Aqui, o texto passou por um segundo recorte temoporal que sucede ao primeiro, após o término da Segunda Guerrra Mundial e buscou elucidar o papel da filosofia positivista, do empirismo na afirmação de uma Nova Geografia apoiada, entre outros, no fisicalismo entendido como a leitura física dos fatos, ou na Geografia Quantitativa e sua neutralização do espaço por meio de um processo de renovação muito mais metodológica que teórica, apoiada em modelos de aplicação universal.

Do ponto de vista desta pesquisa veremos que o espaço geográfico não é neutro. Assumimos que existe uma dialética entre a ação do homem sobre o espaço transformando-o e a ação do espaço, que fica, que permanece no tempo, atuando na mudança do próprio homem. 
Tendo em vista o exposto, pensamos que apesar das restrições de alguns modelos criados no bojo da Geografia Quantitativa, não se pode descartá-los de forma definitiva, pois as análises atuais do espaço geográfico perpassam descrições que, necessariamente embutem alguns desses modelos.

No próximo tópico analisaremos sucintamente o Espaço Geográfico na Geografia Crítica.

\subsection{A VISÃO MARXISTA DO ESPAÇO GEOGRÁFICO: A GEOGRAFIA CRÍTICA}

Parte-se da percepção de que o conceito neopositivista influenciado pela racionalidade e "neutralidade" científica, baseados na matematização das análises geográficas, gerou padronizações na construção do objeto da Geografia, típicos da corrente quantitativista. Novos caminhos analíticos passam a dominar o pensamento geográfico após os anos de 1960. A análise das relações entre a sociedade e a natureza, principalmente com uma tendência a desprezar a materialidade histórica dos fatos, levou a uma reformulação de pesquisas que restringiam a visão de totalidade do espaço nas mais diversas escalas. Tornou-se necessária então uma revisão da análise do espaço geográfico.

No início dos anos de 1970 havia um grande movimento acadêmico em torno do marxismo, ensejado por uma conjuntura na qual grandes eventos de ordem social aconteciam pelo mundo. Na visão de Harvey (2004, p. 15), era um momento em que alguns professores das universidades americanas, especialmente uma minoria mais radical, “[...] tentavam encontrar uma base teórica, uma maneira de entender todo o caos e toda a disrupção política evidentes no mundo". Harvey (2004) se referia aos levantes urbanos que se seguiram ao assassinato do líder negro Martin Luther King nos Estados Unidos; a crescente guerra imperialista no Vietnã; os movimentos estudantis de massa de 1968, que abalaram o mundo em todos os continentes, de "Paris à cidade do México, de Berkeley e Berlim a Bancoc"; a "Primavera" de Praga e a sua reverberação após a repressão soviética; a "Guerra dos Sete Dias" no Oriente Médio; os dramáticos eventos ocorridos na Convenção Nacional Democrata em Chicago.

É nesse contexto que surge a visão marxista do espaço geográfico, pois o método da “Geografia Quantitativa” não mais dava conta como modelo único de entendimento das 
relações socioespaciais e seus rebatimentos no processo de produção e organização do espaço. Ou seja, na produção e reprodução capitalista do espaço.

O espaço geográfico à luz do marxismo é visto sob a égide da lógica dialética, que se torna método no processo de análise. O modo capitalista de produção gera contradições e desigualdades espaciais, gerando a necessidade de novos enfoques científicos para análise do objeto da Geografia. Para Corrêa (1986, p. 21), “[...] a Geografia Crítica descobre o Estado e os demais agentes da organização espacial [...] herdada basicamente da nova geografia". Tratava-se de ir além da descrição de padrões espaciais, buscando enxergar "[...] as relações dialéticas entre formas espaciais e os processos históricos que modelam os grupos sociais" (CORRÊA, 1986, p. 21).

O resgate da filosofia marxista no âmago do pensamento científico da Geografia entre as décadas de 1970 e 1980 tentou demonstrar, por exemplo, que Marx não deixou de considerar o espaço geográfico em suas análises sob o modo capitalista de produção, a partir dos estudos sobre o capital.

David Harvey ao longo de seus estudos e pesquisas observou e compreendeu que o espaço geográfico em Marx é considerado no processo de mobilidade da força de trabalho e na circulação da mercadoria, fatores fundamentais no processo de acumulação. O espaço, portanto, passa a ser visto como condição, meio e produto no processo de relação sociedadenatureza.

No nosso caso, por exemplo, entendemos que se imbricam as especificidades teóricometodológicas da Geografia Clássica, no sentido dos conceitos/categorias utilizados nas mediações da relação entre o homem e a natureza (paisagem, região); da Geografia Histórica e Cultural, na mediação tempo/espaço e os agentes sociais na relação sociedade/espaço, especialmente no contexto urbano; da Nova Geografia, e a necessária leitura física dos fatos, assim como a necessária dimensão estatística em algumas abordagens; assim como da Geografia Crítica, que perpassa uma perspectiva histórica materialista e crítica do espaço geográfico na atualidade. Segundo Harvey (2004, p. 27) “[...] Apartar-nos de Marx é cortar nosso nariz investigativo a fim de satisfazer à face superficial da moda intelectual contemporânea".

Como foi visto neste subtópico, a partir de 1960 predominou uma visão marxista de um espaço geográfico produzido e reproduzido pelo capital, revelando um espaço desigual, contraditório, onde o poder do Estado aparece exigindo análises dialéticas entre formas espaciais e processos históricos, na relação sociedade-natureza. 
No próximo tópico analisamos o espaço geográfico na atualidade.

\subsection{A ANÁLISE DO ESPAÇO GEOGRÁFICO NA ATUALIDADE}

Desde o final da década de 1970 a Geografia vem passando por um novo processo de maturação em relação a sua trajetória teórico/metodológica, principalmente a partir das obras de Santos (1978, 1980, 1988, 1996), Harvey (2003, 2004), Lefebvre (2001) e, mais recentemente, Massey (2009).

Esse processo é contínuo, inclusive em obras que resgatam os clássicos, como fez Haesbert (et. al., 2012), trazendo o pensamento de La Blache (1908) para a atualidade e que Serpa (2015) identifica e faz uma crítica do seu uso no processo da nova regionalização pelo Governo do estado da Bahia, implementado pelo Governo do estado da Bahia desde 2007, quando afirma que:

Vidal de La Blache definiu o objeto da Geografia como a relação homemnatureza sob a perspectiva da paisagem, pressupondo a adaptação do homem ao meio através de técnicas, hábitos, usos e costumes, que se exprimiram em gêneros de vida singulares, com extensão territorial (MORAES, 1981). O maior problema é que o mundo que La Blache analisou, na virada do século XIX para o XX, era um universo essencialmente rural, anterior à Revolução Industrial, e não incluía as cidades e o modo de vida urbanos. O que mais interessava a Vidal eram as permanências e continuidades e, no campo, as mudanças eram bem mais lentas que nas cidades, permitindo a "revelação" de regiões de caráter essencialmente agrário, a partir da identificação de paisagens culturais e de gêneros de vida "típicos" para cada unidade regional (HAESBAERT et. al., 2012). Uma situação similar parece ocorrer na regionalização institucional do estado da Bahia, já que o processo de "revelação dos territórios" vai ser aplicado, em um primeiro momento, naquelas regiões onde predomina a agricultura familiar (MORAES, 1981; HAESBAERT et. al., 2012 apud SERPA, 2015, p. 21).

A citação acima nos revela que a aplicabilidade de conceitos e pensamentos clássicos da Geografia continuam a permear a atualidade do pensamento desta ciência, muito embora com outras roupagens e com a inferência da crítica, no sentido de readaptá-los à realidade atual.

Moreira, no conjunto de sua obra (2006, 2009, 2010a, 2010b), faz uma discussão importantíssima da produção do pensamento geográfico brasileiro, tratando da sua 
"epistemologia crítica"; de suas "matrizes de renovação"; das suas "matrizes clássicas originárias" e, finalmente, das "matrizes brasileiras".

Na produção literária internacional, destacamos a obra de Massey (2009), a qual busca uma nova dimensão sobre o entendimento do espaço. Entretanto, entendemos que Santos (1996) já o tinha feito, potencializando-o também na sua dimensão social e política. Por isso a destacamos aqui, tendo em vista enaltecer a maturidade do pensamento geográfico produzido no Brasil.

A relação que a referida autora busca fazer entre tempo e espaço, numa dimensão cujo debate parte da "[...] proposição de que o espaço é uma multiplicidade discreta, cujos elementos, porém, estão, eles próprios, impregnados de temporalidades” (MASSEY, 2009, p. 89). Santos (2008b) já dizia de outra forma, considerando o espaço como sistemas de objetos e sistemas de ações, funcionando em conjunto e de forma indissociável. Entendemos que estas ações estão impregnadas nos territórios de acordo com o seu uso e das políticas de ação sobre os mesmos, inclusive com o uso político e econômico da cultura local e regional, no processo de ações de agentes do sistema capitalista de reprodução do capital.

No caso das cidades históricas portuárias do Recôncavo Baiano, acreditamos que existiu uma temporalidade que aconteceu de forma simultânea nos diferentes lugares, cada um conservando suas peculiaridades. Acreditamos, entretanto, como diz Massey (2009), não numa "temporalidade estática", mas numa "simultaneidade dinâmica" que, no nosso caso, é bastante reveladora dentro de um contexto regional, no qual estão inseridas as cidades em tela.

Sobre a questão do espaço como produto de inter-relações, Massey (2009) entende que as políticas não podem ser construídas levando-se em consideração o espaço como algo acabado. Ela fala de trajetórias, as histórias em tempos diferentes, traços antigos que permanecem ou que se transformam (MASSEY, 2009, p. 29-36). Adiante, veremos que Santos $(1978 ; 1996)$, também já apontava para tal.

Para essa autora, a questão da representação do espaço, a representação estática, com a cartografia, enaltece mais ainda a importância da representação, como diferencial sobre o pensamento. Para ela, uma representação fixa das coisas tira a possibilidade de uma mudança coletânea. A representação fixa do espaço influencia no pensamento sobre o mesmo. Essa representação induz a um olhar para o espaço como algo fixo, imutável, tirando a possibilidade de imaginarmos as diferenciações simultâneas de diferentes atores e agentes sociais e suas inserções políticas e ideológicas (MASSEY, 2009, p. 53). 
Serpa (2015, p. 300), assinala que a Geografia tem muito a colaborar e a dizer sobre a questão da articulação de escalas e recortes espaciais, "[...] fazendo pensar em questões como a distribuição espacial dos programas, planos e projetos no território nacional e as desigualdades regionais advindas da formulação e da implementação das políticas públicas no Brasill”. O autor cita o trabalho de Santos (1994), quando este último já afirmava as diferenças de grau de intencionalidades e abrangência de atuação entre as políticas públicas elaboradas na escola no nível federal e suas discrepâncias nos governos estaduais e municipais.

Ainda sobre a questão da escala, Serpa (2015, p. 300) chama a atenção para a discussão sobre “[...] o papel das representações espaciais como norteadoras de políticas públicas [...]”. Tal discussão nos remete ao que Massey (2009), havia comentado anteriormente, no sentido de estarmos atentos para a questão da representação fixa do espaço, dando a ideia de algo imutável. Esses dois autores, vão ao encontro do que postulam Rancine; Raffestain; Ruff (1983), citados por Serpa (2015), para os quais as relações políticas e de poder, ainda tendem a ser incutidas nas representações espaciais e depender dos mais diversos interesses a da voz dos diversos agentes envolvidos.

Eis aqui uma questão cuja discussão tem muito a ver com a representação cartográfica dos limites da região do Recôncavo Baiano, cujas imprecisões de sua delimitação apontam a dificuldade de se estabelecer limites precisos ao longo de diferentes conjunturas históricas. Nesse processo, diversas pesquisas suscitaram novas representações cartográficas, devido a grande dificuldade em estabelecer um limite único para a mesma, tendo em vista a incorporação de novos territórios, como consequência da ação de novos agentes sociais e novas políticas que se inserem no espaço geográfico.

Para Massey (2009, p. 94), “[...] conceber o espaço como um recorte estático através do tempo, como representação, como um sistema fechado, e assim por diante, são todos modos de subjuga-lo". Segundo a mesma é ignorar a sua própria e verdadeira relevância.

Quanto à relação tempo e espaço, a referida autora afirma o seguinte:

Se o tempo deve ser aberto para um futuro do novo, então o espaço não pode ser equiparado com os fechamentos e horizontalidades da representação. De um modo mais geral, se o tempo deve ser aberto, então o espaço tem de ser aberto também. Conceituar o espaço como aberto, múltiplo e relacional, não acabado e sempre em devir, é um pré-requisito para que a história seja aberta e, assim, um pré-requisito. Também, para a possibilidade da política (MASSEY, 2009, p. 94-95). 
$\mathrm{Na}$ representação estática com variáveis discretas, o espaço passa a ser a representação, não correspondendo à realidade. Mesmo no zoneamento técnico, informacional, pois mesmo estes estão embutidos de critérios diferenciados, com inferências ideológicas e políticas, muitas vezes para atender a diferenciadas legislações. As contingências são muitas, há que se pensar nas distorções das representações gráficas (MASSEY, 2009). Exemplo disso são alguns critérios de regionalização empreendidas pelo Estado utilizando variáveis tais como produção da agricultura familiar, a partir do potencial agrícola de um determinado território. A divisão do estado da Bahia em "Territórios de Identidade" desde 2007, exclui municípios e inclui outros, cuja identidade e aspectos relacionados à economia estão representados na cartografia, alheios a verdadeira identificação de sua sociedade. É o caso da cidade de Jaguaripe e da cidade de São Gonçalo, que sempre foram incluídos em outras regionalizações como pertencentes ao Recôncavo Baiano e na última regionalização, anteriormente mencionada, vigente até então, estão fora de sua representação cartográfica.

Outra questão abordada por Massey (2009, p. 46), caminha no sentido da espacialidade e espacialização. A espacialidade é a percepção no espaço, a colocação do fenômeno no espaço, enquanto que a espacialização é a trajetória que se estabelece no espaço. Todo fenômeno está em algum lugar. A espacialização está relacionada mais às ciências que estão mais preocupadas com o espaço, com o ato de se relacionar com espaço.

Coadunamos com Massey (2009), para quem a história se faz com relações espaciais. A história está representada no espaço, que está se transformando. Apesar de serem distintos, espaço e tempo são indissociáveis. A implicação disso na análise do espaço está na consideração dessa temporalidade, sendo o espaço formado por trajetórias temporais diversas, portanto tem que ser considerado. Por isso a crítica à teoria geral dos sistemas, que só acontece num tempo determinado, não demonstra outras projeções possíveis. Essa foi também a grande crítica à Geografia Radical.

O que se percebe é que esta autora trata com profundidade filosófica a questão do espaço e de sua historicidade, concebendo-o como uma dimensão em processo, aliada ao tempo.

Para Tonet (2013, p. 10), o conhecimento “[...] deve ser tratado sempre em sua articulação íntima com o conjunto do processo histórico e social, permitindo, assim, compreender a sua vinculação, mesmo que indireta, com determinados interesses sociais". 
Na nossa compreensão sobre o caso dos paradigmas do pensamento geográfico, eles não se desconstruíram completamente ao longo de sua evolução. O que se percebe é que a estruturação de um pensamento científico gerador de um método ou teoria, não necessariamente exclui o antecessor. As correntes do pensamento geográfico e paradigmas, resultantes das mais diversas escolas ao longo da história da ciência geográfica, não têm sido completamente descartados nas obras atuais de reflexão sobre a Geografia.

A historiografia recente sobre o tema não descarta completamente nenhuma corrente de pensamento geográfico. Autores como Gomes (1996), Moreira (2006; 2009; 2010), anteriormente citados, ao analisarem as obras de grandes geógrafos como David Harvey e Milton Santos, por exemplo, mostram que os mesmos transitaram por diferentes correntes da Geografia. Recentemente, em obra de Haesbaert (2012) o clássico pensamento de Vidal de La blache sobre a paisagem como categoria de análise do espaço geográfico, foi retomado, como já foi visto anteriormente.

Na obra de Serpa (2015), também anteriormente citada, tratando da cidadania, regionalização e políticas culturais nos territórios da Bahia, numa abordagem sobre as políticas públicas, o referido autor faz uma revisão das várias teorias e modelos de localização e de desenvolvimento, mostrando a que aplicação destas no Brasil,

[...] se consolidou no âmbito da produção do conhecimento, especialmente na Nova Geografia, como uma possibilidade de operacionalização de uma perspectiva geográfico-econômica para a formulação de políticas públicas de desenvolvimento territorial (SERPA, 2015, p. 301).

Serpa (2015), por outro lado, também nos chama a atenção para um possível esgotamento ou superação parcial, se não total, de modelos e teorias e surgimento de novas abordagens em Geografia, nas últimas décadas, afirmando o seguinte:

Fala-se aqui de teorias de localização industrial, do modelo dos polos de crescimento, das teorias das localidades centrais e centro-periferia, de modelos como aquele do Estado isolado (para explicar a localização das atividades agrícolas) ou do desenvolvimento regional induzido, ou ainda da teoria da propagação das ondas de inovação. Se tais modelos e teorias não foram totalmente superados no âmbito da produção do conhecimento geográfico, deve-se reconhecer que foram bastante questionados no âmbito da disciplina nas últimas décadas. Tais questionamentos fizeram surgir abordagens culturais e dialéticas [...] São essas abordagens que abrem novas perspectivas para a Geografia como conhecimento básico e fundamental para a formulação e a implementação de políticas públicas nos mais variados recortes do território nacional (SERPA, 2015, p. 302). 
No início do século XX a incorporação da dimensão cultural à agenda de pesquisas sobre a dinâmica da população e do território na Geografia foram as tendências mais destacadas dos estudos geográficos e das ciências humanas em geral. Assim como na Geografia, a História também estava numa espécie de efervescência de paradigmas em relação a esses novos olhares sobre o mundo. A questão das representações, introduzida por Marcel Mauss e Émile Durkheim, e a aproximação da História com a Antropologia Cultural é outro exemplo do processo anteriormente citado (PESAVENTO, 2008).

Concluimos esse tópico com a noção de que a crítica ao pensamento clássico não o invalida, mas segue muito mais na direção de adaptá-lo à realidade atual. Neste sentido buscamos estabelecer um diálogo entre as obras de Milton Santos e Dorren Massey, convergentes quando se trata de afirmar a temporalidade do espaçoque o tarna dinâmico e em constante processo de transformação.

Por isso é importante frizar que, apesar de falarmos de "cidades históricas", entendemos que toda a cidade assim o seja. Isto é, toda a cidade é histórica. Portanto, fica clara a nossa adesão à ideia da relação indissociável entre espaço e tempo na necessidade do entendimento do espaço geográfico como uma dimensão em processo que exige considerar as marcas deixadas por temporalidades distintas.

Adiante, no capítulo três, veremos os conceitos e as categorias de análise que subsidiam nossa pesquisa e que subsidiarão o que estamos denominando de narrativa espacial regional do Recôncavo Baiano. Chamamos a atenção no sentido de que, apesar de discutirmos os conceitos em subtópicos, a nossa intenção é a de contemplá-los de forma articulada, dentro da perspectiva da Geografia Histórica e numa dimensão holística do conhecimento, como já apontado anteriormente. 


\section{3 - OS CONCEITOS ESTRUTURANTES E MEDIADORES}

A articulação teórica desta pesquisa perpassa pela dimensão de três conceitos que estamos denominando de conceitos estruturantes e suas derivações como conceitos mediadores. Aqui entendidos também como categorias de análise, tendo em vista que toda categoria é um conceito, mas nem todo conceito é uma categoria.

O primeiro conceito estruturante é o de "paisagem" e suas derivações mediadoras nas categorias de paisagem cultural e urbana. O segundo conceito estruturante é o conceito de patrimônio cultural, cujas categorias mediadoras derivadas são o patrimônio urbano/edificado. O terceiro conceito estruturante é o de território, aqui desenvolvido como categoria analítica mediadora de "território usado". Este último, também utilizado na concepção miltoniana como "o uso do território", no sentido de uma noção que norteará a pesquisa também como um método (SANTOS; SILVEIRA, 2001). Daí por diante a ideia é demonstrar que, no âmbito da pesquisa teórica e empírica, os conceitos e categorias analíticas utilizadas para subsidiar nosso trabalho se articulam e se complementam e funcionam como mediadores no processo de análise.

Entendemos que a leitura e análise da paisagem nas suas dimensões cultural e urbana culminam numa narrativa espacial, que expressa uma identidade territorial regional. É através da interpretação do seu patrimônio cultural na sua dimensão edificada, a partir da identificação do seu repertório construtivo e de seus símbolos, que é possível identificar as similaridades e concomitância temporal da produção do espaço na escala regional do Recôncavo Baiano e na escala local de suas cidades históricas portuárias. Esse entendimento é que nos leva à ideia de uma produção simultânea dos seus territórios urbanos, especialmente de seus núcleos de povoamento, atualmente considerados a partir de seus centros históricos.

Iniciamos pelos conceitos que consideramos mais abrangentes, tais como "paisagem" e suas ramificações (paisagem cultural e urbana); passando pelas dimensões do "patrimônio cultural", na sua dimensão urbana/material/edificada. O conceito de "território usado" subsidia nossa análise nas escalas regional e local, esta última relacionada ao espaço urbano das cidades pesquisadas.

No que concerne ao conceito de "patrimônio cultural", este nos servirá de subsídio para análise da sua dimensão material, edificada. O patrimônio urbano. Neste caso utilizamos 
como base para a análise numa escala bem mais restrita do que os anteriores. Isto é, uma análise na dimensão dos conjuntos urbanísticos e monumentos isolados do centro histórico de cada cidade em tela. Em suma, o patrimônio urbano de cada uma delas.

Além disso, alguns desses conceitos devem ser encarados como tal e também como categorias de análise, como é o caso do conceito do "território", aqui também visto como "território usado", na perspectiva de uma visão das transformações e permanências da materialidade construída e percebida na paisagem urbana regional. Mais adiante, o referido conceito é também discutido enquanto método de análise.

O conceito de região está sempre presente ao longo das discussões, tendo em vista que o arranjo espacial formado pelas cidades em tela se constituiu ao longo da história numa rede urbana de intensa coesão, configurando uma identidade cultural peculiar do ponto de vista paisagístico, numa escala de dimensões regionais.

\subsection{DIMENSÕES DO CONCEITO "PAISAGEM"}

Sobre o conceito de paisagem geográfica, Yázigi (2002), descreve-o em duas fases: a primeira, com a escola da geografia regional da França, no início do século XX, quando ainda existia coincidência entre os limites da paisagem e a região administrativa em que se encontrava. Em meados do século XX, situa-se a segunda fase. Nesse período histórico o mundo conheceu um forte desenvolvimento dos meios de transportes e comunicação, gerando grande circulação de mercadorias e capitais, fazendo com que as paisagens perdessem seus fundamentos locais para refletir as relações das redes de economia e sua simbologia “universalizante”. Segundo este mesmo autor, a partir daí, já não era mais possível entender o lugar por inteiro sem recorrer ao conhecimento das redes que o ultrapassam - sem entender as "complexificações" que culminariam no que hoje denominamos globalização (YÁZIGI, 2002, p. 19). A rede de cidades que compõem o Recôncavo Baiano é um exemplo típico deste processo.

Voltamos a Vidal de La Blache, que no início do século XX dizia que:

Desde que a Geografia pedagógica saiu do gabinete onde frequentemente se fechava e pôs-se a observar diretamente a natureza, a interpretação das 
paisagens tornou-se um de seus principais temas. É uma arte delicada [...] Nela, a análise e a síntese têm, cada uma, seu papel. A análise esforça-se por distinguir os aspectos heterogêneos que integram a composição de uma paisagem e, como as causas passadas e presentes se misturam nas formas do relevo, esse gênero de interpretação guarda um pouco de exegese (sic). No entanto, por outro lado, essa paisagem forma um todo, cujos elementos se encadeiam e se coordenam; sua interpretação exige uma percepção lógica da síntese plena da vida que ela lança sob nossos olhos (LA BLACHE, 2012, p. 125)

$\mathrm{Na}$ assertiva de La Blache percebe-se que seu foco é direcionado às paisagens naturais, quando fala para as formas de relevo. Entretanto, também menciona a paisagem como o resultado de um encadeamento de elementos, formando um todo. Guardadas as devidas proporções entre o olhar para as paisagens naturais daquela época e as paisagens urbanas na atualidade, as palavras de La Blache nos trazem a sensação de um olhar sob uma dimensão mais abrangente de conteúdo das paisagens e não só de sua forma pura. Mais adiante, no mesmo texto - exposto no Congresso Internacional de Geografia, ocorrido em Genebra, Suiça, em 1908 - o autor afirma que:

Por suas obras e pela influência que exerce sobre si mesmo e o mundo vivente, o homem é parte integrante da paisagem. Ele a humaniza e a modifica de algum modo. Por isso, o estudo de seus estabelecimentos fixos é particularmente sugestivo, visto que é de acordo com eles que se ordenam cultivos, jardins, vias de comunicação; eles são o ponto de apoio das alterações que o homem produz sobre a terra (LA BLACHE, 2012, p. 129).

Nas assertivas de La Blache acima mencionadas percebemos que as mesmas continuam predominantes nos processos de pesquisas atuais. A questão da análise e da síntese, por exemplo, presentes na obra de Santos; Silveira (2001), quando fizeram um esforço de análise e de síntese do território brasileiro a partir do uso do território. Percebemos também a iminência do conceito de "fixos", utilizado por Milton Santos muitos anos depois, além de estar vinculado ao mundo urbano, quando o autor fala em vias de comunicação, que naquela época seriam os caminhos e estradas para passagem de animais e carruagens. No nosso caso o caminho dos tropeiros entre as vilas. Nesse sentido La Blache continua no mesmo texto, inferindo que:

[...] Limitemo-nos a observar que os estabelecimentos humanos introduzem um elemento de fixidez nas relações geográficas. O próprio fato de existirem é uma prova de sobrevivência, pois representam um depósito que as gerações anteriores deixaram às seguintes [...] Ademais, a rede de estradas e 
a formação de relações que lhes assegura, em muitos casos, novas razões de existência. É uma planta que estende suas raízes; contudo, pode, também, definhar e morrer. No entanto é raro que, em nossos países de construções sólidas, desapareçam sem deixar traços [...] Como dizia Ratzel, há uma geografia das ruínas, e sua persistência nas áreas [contrées] de pedra e areia é, por si só, um fato geográfico (LA BLACHE, 2012, p. 129).

No trecho acima, ainda da mesma conferência sobre a interpretação geográfica das paisagens, La Blache já nos traz a ideia de rede; de vida de relações; de herança patrimonial, através dos monumentos e ruinas de paisagens pretéritas, que muito nos subsidia, quando falamos em paisagem urbana nas cidades históricas do Recôncavo Baiano.

A metáfora que o autor utiliza para falar de uso e desuso das redes de estradas, se reportando a uma planta, cujas raízes podem se alastrar ou simplesmente "definhar e morrer", nos remete àquelas cidades, a exemplo de Jaguaripe, que quase parou no tempo; de Salvador e de Cachoeira que ressurgiram no contexto do Recôncavo Baiano e do mundo, através de sua consagração como patrimônios nacional e mundial da humanidade. Além de outras espalhadas pelo planeta. Podemos perceber também a questão das rugosidades dos territórios reinterpretadas por Milton Santos em várias de suas obras.

Segundo Oseki; Pellegrino (2004), as paisagens são representações inventadas no século IV, na China. Posteriormente, a palavra e a noção correspondente surgiram na Europa, no Renascimento, incorporando-se, nas línguas latinas o sufixo agem (ação sobre) à palavra país, que significava cantão, região ou província. Podemos inferir que paisagem é processo, portanto, podendo estar em contínua transformação na forma ou no conteúdo. Exemplo disso são as antigas cidades que se reinventam no seu processo de evolução histórica, preservando o patrimônio de suas paisagens e os reutilizando para funções diferenciadas das que lhes deram origem.

Na concepção ocidental, a paisagem corresponde a uma dimensão teórica (pensar) e prática (fazer), ou seja, ao mesmo tempo uma representação e uma construção, correspondendo também a um "despedaçamento da natureza" (OSEKI; PELLEGRINO, 2004). Esses autores baseiam-se em Auguste Berque, para o qual

[...] "a paisagem é a expressão sensível de uma mediância”, pois revela o sentido da relação de uma sociedade com o seu meio ambiente. As paisagens são tanto maneiras de ser (produtos e projetos) como maneiras de ver (percepções sobre) os espaços produzidos (isto é, as cidades e os campos historicamente formados) (OSEKI; PELLEGRINO, 2004, p. 488). 
Esses mesmos autores observam que, uma das decorrências que estão surgindo dentro do novo paradigma do planejamento ambiental, por exemplo, (também conhecido como planejamento da paisagem), é a arquitetura da paisagem.

Aqui chamamos a atenção para o entrecruzamento entre duas dimensões escalares de observação e investigação que muito nos interessa nesses dois conceitos ("paisagem" e "patrimônio"), especialmente no que tange ao processo de planejamento urbano e da preservação do patrimônio edificado.

A primeira delas diz respeito a uma escala mais abrangente, panorâmica, do conjunto da paisagem urbana e cultural das cidades, no sentido dos conjuntos urbanísticos. A segunda, diz respeito ao conteúdo desta paisagem numa escala menos abrangente, mas não menos importante, que é o patrimônio na forma de seus monumentos, mesmo de forma isolada.

As derivações do conceito de paisagem tais como "paisagem cultural" e "paisagem urbana", por exemplo, se complementam na análise da cidade na perspectiva do seu patrimônio cultural/edificado. É o que veremos a seguir.

\subsubsection{Paisagem cultural}

O entendimento de "paisagem cultural" é concebido como um dos conceitos mediadores da nossa análise, oriundo de um conceito mais abrangente. O conceito de paisagem. Este último, por sua vez, funciona como um conceito estruturante e uma categoria dominante e articuladora entre a descrição e a análise do objeto de pesquisa. Portanto, os conceitos aqui citados também funcionam como categorias de análise.

O uso da categoria "paisagem" funciona como articuladora da relação teórico/empírica, por considerarmos que é na paisagem onde se encontram os resultados dos processos da relação entre sociedade e espaço no âmbito do objeto da pesquisa, concebido enquanto forma-objeto, a qual revela conteúdos sociais pretéritos.

Ou seja, estamos considerando que a paisagem é a matriz de uma possível narrativa espacial que é interativa sob o ponto de vista local e regional. No caso do nosso objeto de pesquisa, as escalas locais e regionais alinham-se numa dimensão de análise da totalidade desde a formação do fato urbano ao fato regional na consolidação da rede urbana, nas suas 
peculiaridades, similaridades de formas e conteúdos; concomitância temporal e complementaridade nas suas funções.

Em sintonia com a perspectiva acima apontada é que analisamos a paisagem das cidades pesquisadas. Nela se incluem os elementos que darão subsídios ao estudo, como por exemplo, os bens culturais, aí incluídos o patrimônio edificado.

A paisagem cultural para Almeida (2013) pode contemplar símbolos, significados e tornar-se patrimônio, chegando até a institucionalizar-se. Para essa autora, analisando o sentido da paisagem na Constituição Brasileira de 1988, quando trata no seu artigo 216, define-se o patrimônio cultural brasileiro e, no inciso V, são definidos "os conjuntos urbanos e sítios de valor histórico, paisagístico, artístico, arqueológico”, revela que:

[...] a paisagem é percebida como um dos elementos centrais na cultura; um conjunto ordenado de objetos passível de ser interpretado, repetimos, como um texto e que atua como uma criadora de signos pelos quais um sistema social é transmitido, reproduzido, vivenciado e explorado (ALMEIDA, 2013, p. 189).

Para nós está evidente na assertiva acima que os conceitos de cultura, paisagem e patrimônio estão intimamente imbricados e quase que se fundem, quando da perspectiva de uma análise geohistórica da paisagem urbana, com foco na materialidade construída no território.

Para essa autora,

O patrimônio e o território têm, assim, o duplo papel de mediadores interpessoais e de cimentos identitários na sociedade. Os elementos materiais como construções, vegetação, propriedades, por exemplo, e os bens imateriais como imagens, cultura, símbolos, etc. são valores patrimoniais (ALMEIDA, 2013, p. 190).

Para Almeida (2013, p. 188), “[...] o fato de a paisagem cultural ser uma maneira de demonstrar a identidade territorial evidencia outro viés de como 'ler' a paisagem". Neste sentido entendemos que a leitura do território pelo território é feita pela mediação da imagem concreta nele instalada.

Estamos concebendo o território, metaforicamente, como um "corpo" que fala, através da paisagem cultural nele inserida. Seus "gestos", suas "vestes", sua "dança”, sua simbologia instalada na materialidade, expressão e reflexo da sociedade que o produziu e o organizou, 
através do trabalho, do lazer, da religião, da filosofia de vida e da arte. Enfim, da dialética da existência, produzindo cultura em forma de patrimônio material e imaterial. Finalmente, produzindo cultura e identidades.

No sentido apontado anteriormente, corroboramos com o que afirma Costa (2014), para o qual:

A paisagem enquanto suporte material das lembranças assenta afetividades e efetiva acontecimentos, grupos sociais e saberes-fazeres, guarda as marcas do tempo, o movimento da história. Identidade é enraizamento, é sobreposição de objetos e ações e identificação com estes mesmos elementos; a paisagem-memória cumpre esse papel de enraizar para afagar a alma humana [...] Por um lado, se a paisagem é material, por outro, sua função é a de alimentar o subjetivo. Ela indica as correntezas das relações do passado e preserva as tradições técnicas no presente para, sobretudo, dar corpo a um imaginário sobre objetos, lugares e grupos a serem mantidas nas lembranças do futuro [...] (COSTA, 2014, p. 82).

A assertiva acima indica a polissemia do conceito de paisagem, ainda mais quando o associamos à identidade e à cultura, no processo histórico de produção e organização do espaço geográfico, suas territorialidades e memórias. Nesse sentido, para Brito (2008):

[...] a territorialidade humana e seu substrato material, com todas as características naturais e as socialmente criadas são termos que encerram uma única assertiva - resultam de relações sociais desenvolvidas entre os diferentes agentes, mediadas pelo poder e projetadas numa dada porção do espaço geográfico que se torna território (BRITO, 2008, p. 20).

Entendemos que a paisagem também é reveladora de relações de poder. Neste sentido podemos perceber a imbricada e complexa relação inerente ao conceito de paisagem cultural e território, quando se busca compreender a diversidade das relações entre sociedade e espaço. Especialmente quando se trata de pesquisa cujo objeto analisado encontra-se na escala do lugar e da região, simultaneamente, como é o caso das cidades históricas portuárias do Recôncavo Baiano, como veremos mais adiante.

Nas duas assertivas acima citadas, entendemos que duas possibilidades filosóficas de entendimento do espaço geográfico e suas categorias se fundem: a fenomenologia da paisagem e o materialismo histórico. Tal fusão só enriquece as análises aqui propostas e a tese propriamente dita.

A abordagem sobre o patrimônio cultural pede um recorte espacial. O conceito de paisagem cultural tem sido uma ferramenta importante nos processos de tombamento, haja 
vista o Rio de Janeiro em $2012^{3}$. Já o Instituto do Patrimônio Histórico e Artístico Nacional (IPHAN), mesmo ao inventariar patrimônios imateriais, vai selecionar seus territórios, ou seja, é no espaço que se materializa a ideia do tombamento. E a geografia, que lida com esses conceitos espaciais, não pode ficar fora do processo (PAES, 2010).

Percebe-se na assertiva acima que o conceito de paisagem remete ao estudo do território na perspectiva das políticas de preservação, que por sua vez se incluem nas políticas de planejamento urbano e regional. Ou seja, espaço, território e paisagem se complementam no processo de análise.

A seguir tratamos do conceito de "paisagem urbana", aqui também utilizado no âmbito dos conceitos mediadores.

\subsubsection{Paisagem urbana}

Estamos considerando a paisagem urbana como um desdobramento da paisagem cultural. Entretanto é também concebido um segundo conceito mediador, derivado da categoria "paisagem", que também é um dos nossos conceitos estruturantes. Todos aqui concebidos como categorias de análise.

A paisagem urbana pode expressar as diversas formas como os indivíduos habitam a cidade, caracterizando suas peculiaridades e modos de vida. Dessa forma, essa categoria pode oferecer pistas que contribuam para a compreensão das características dos grupos sociais que ali residem ou residiam, além da possibilidade de expressar a dinâmica socioeconômica de uma localidade ou região, a partir do conhecimento geohistórico de sua produção e organização espacial.

\footnotetext{
${ }^{3}$ O IPHAN trabalhou na candidatura do Rio de Janeiro como Paisagem Cultural, em parceria com o Governo do Estado e a Prefeitura do Rio de Janeiro, a Fundação Roberto Marinho e a Associação de Empreendedores Amigos da UNESCO. Em setembro de 2009, o IPHAN entregou à UNESCO o dossiê completo da candidatura, justificando seu valor universal pela interação da sua beleza natural com a intervenção humana.

O conceito de paisagem cultural foi adotado pela UNESCO em 1992 e incorporado como uma nova tipologia de reconhecimento dos bens culturais, conforme a Convenção de 1972 que instituiu a Lista do Patrimônio Mundial. Até o momento, os sítios reconhecidos mundialmente como paisagem cultural relacionam-se a áreas rurais, a sistemas agrícolas tradicionais, a jardins históricos e a outros locais de cunho simbólico, religioso e afetivo. O reconhecimento do Rio de Janeiro culminará em uma nova visão e abordagem sobre os bens culturais inscritos na Lista do Patrimônio Mundial. Disponível em: <http://portal.iphan.gov.br>
} 
La Blache em 1908, no mesmo texto anteriormente referido, propunha examinar traços das obras do homem, perceptíveis em certas paisagens, afirmando o seguinte:

\begin{abstract}
Sem cair num excesso de determinismo que não seria menos falacioso que o inverso, podemos afirmar que agrupamentos, cultivos, movimentos e relações humanas não escapam em nada a essa rede de causas e efeitos. Ainda que nem sempre o fizessem, os geógrafos do passado se preocupavam em explicar a posição das cidades mais importantes - embora não imaginassem voltar suas atenções às aldeias ou aos modos de agrupamentos mais simples. Entretanto, são as formas mais elementares as que melhor revelam os motivos pelos quais o homem teve de escolher tal lugar, em detrimento de outro, para nele criar condições seguras de existência [...] (LA BLACHE, 2012, p. 127).
\end{abstract}

A cidade nesta perspectiva constitui-se como o resultado da acumulação das diversas ações sociais ao longo do tempo. Conforme argumenta Oliveira; Silva (2008, p. 2-3) “[...] é, portanto, a cidade, a materialidade social acumulada no tempo, tendo em seu patrimônio histórico as memórias coletivas e urbanas acumuladas”. Esse caráter confere a diferenciação entre as paisagens urbanas, isto porque, cada grupo social confere um atributo distinto aos espaços em que vivem.

O conceito de "paisagem urbana" está associado ao conceito de patrimônio cultural urbano, na sua dimensão mais específica, relacionada ao patrimônio edificado, o qual é o foco empírico da pesquisa.

A análise do patrimônio edificado das cidades históricas portuárias do Recôncavo se faz sob a perspectiva, segundo a qual, sua produção espacial é o conjunto de objetos e ações, como resultado da ação humana, funcionando de forma indissociável (SANTOS, 1996), e sua organização espacial traduz a forma como o espaço foi estruturado ou é reordenado para o desenvolvimento das atividades humanas (CORIOLANO; SILVA, 2005). Ou seja, como território.

Portanto, associou-se aqui aos conceitos de produção e organização espacial, a categoria de paisagem urbana, que para Carlos (1994) constitui-se,

[...] como forma de manifestação do urbano que tende a revelar uma dimensão necessária da produção espacial, o que implica ir além da aparência; nesse contexto, a análise já introduziria os elementos da discussão do urbano considerado como processo. A paisagem de hoje guarda momentos diversos do processo de produção espacial, remetendo-nos ao modo pelo qual foi produzida (CARLOS, 1994, p. 43). 
A perspectiva segundo a qual "[...] da observação da paisagem urbana depreendem-se dois elementos fundamentais; o primeiro dizendo respeito ao espaço construído; o imobilizado nas construções, e o segundo ao movimento da vida" (CARLOS, 1994, p. 50), são aqui também utilizados como parâmetro de análise. Dessa forma, a produção e organização do espaço do patrimônio edificado serão discutidas como elemento principal no contexto da paisagem, originados da ação dos agentes sociais, individuais e coletivos (VASCONCELOS, 2002).

$\mathrm{Na}$ mesma perspectiva apontada anteriormente, Santos (2004) entende a paisagem como resultante do processo de mudança da sociedade, gerando por sua vez mudanças na economia, nas relações sociais e políticas, em ritmos e intensidades variados, nada tendo de fixo ou imóvel. Ou seja, as heranças são expressas pelo conjunto de forma, que num dado momento representam as relações localizadas entre homem e natureza sucessivamente (SANTOS, 1996).

A paisagem urbana como categoria da Geografia, ajuda a revelar, através das formas materializadas no espaço geográfico, os processos históricos da relação sociedade/natureza, submetida a constantes processos de transformação. Para Santos (1988, p. 75), a paisagem não é total, é parcial e, em relação à configuração territorial "[...] é necessário compreendê-la dentro e em função da totalidade das coisas que a formam".

Os objetos e infraestruturas implantadas pelos agentes em determinados momentos históricos, tais como o poder público e a iniciativa privada, resultam em novas formas urbanas e paisagens.

O conceito "paisagem" está relacionado ao conjunto de fatores históricos que a produziram, através de formas estáticas, também produzidas ao longo do tempo. Tais formas aparecem, transformam-se, permanecem ou desaparecem, mudando o contexto da paisagem que pode ter diferentes interpretações para quem a observa. Ou seja, a ideia de estático diz respeito às formas tangíveis, enquanto que a ideia de movimento refere-se ao intangível. Isto é, àquilo que diz respeito à produção e organização do espaço geográfico, gerando formas que compõem o conjunto das paisagens.

Para Yázigi,

A paisagem dos geógrafos é um termo e uma noção de uso fundamentalmente pedagógico. Para o turista ou para o cidadão comum, ela é objeto de contemplação e dos mais diversos significados. Oportuno ainda lembrar que a natureza (assim como o meio) não é paisagem: a primeira 
existe em si, enquanto a segunda só existe em relação ao homem e segundo a sua forma de percebê-la. O fato de a paisagem ser patrimônio cultural, coletivamente percebido com memória e imaginário, não deixa de ser também uma porção do espaço que determina um envelope e um conteúdo de todas as representações paisagísticas desta porção do espaço (YÁZIGI, 2001, p. 34).

No sentido apontado por Yázigi percebe-se uma aproximação ao que Santos (2001) concebe como o território. Isto é, o território não apenas como palco, mas, sobretudo, como uma espécie de mediador da dinâmica social. Ou seja, o território também é sujeito na dinâmica socioespacial.

A investigação da produção associado ao espaço do patrimônio histórico edificado das cidades em tela pode ser revelador do processo de transformação no campo das diferenciações e das similaridades de uso dos espaços das mesmas. Para Lefebvre, as análises do "urbano", da vida urbana, incluindo aí a sociedade urbana, “[...] não podem dispensar uma base prático sensível, uma morfologia" (LEFEBVRE, 2001). Nessa perspectiva, o patrimônio edificado é a base material desta pesquisa, para daí compreender o seu papel no processo de evolução urbana da cidade e, consequentemente, de sua paisagem.

Um bom exemplo das diferenciações, acima mencionadas, está na interferência do poder público em centros históricos, enquanto conjunto ou em monumentos isolados mudando as funções. Para isso são utilizados incentivos fiscais na restauração de equipamentos urbanos que viabilizem a multimodalidade de seus usos, mantendo-se as formas e mudando as funções de alguns equipamentos, como é o caso dos conventos e mosteiros em vários países do mundo. Muitos destes passaram a exercer a função de hotéis e pousadas de alto luxo. Este fato revela de forma contundente a mudança nos modos de uso do patrimônio edificado público e privado em várias cidades do mundo.

No âmbito das investigações dos processos espaciais formadores das dinâmicas territoriais urbanas, a ciência geográfica tem grande parcela de contribuição, pois analisa a evolução espacial, através da história da construção material no processo do uso do território. Isto é, o uso do território pode ser definido pela implantação do que Santos; Silveira (2001) denominam de sistemas de engenharias. Ou seja, as novas funções do espaço geográfico são configuradas a partir da implantação de infraestruturas, mas também pelo dinamismo da economia e da sociedade. Concorda-se que, 
São os movimentos da população, a distribuição da agricultura, da indústria e dos serviços, o arcabouço normativo, incluídas a legislação civil, fiscal e financeira, que, juntamente com o alcance e extensão da cidadania, configuram as funções do novo espaço geográfico (SANTOS; SILVEIRA, 2001, p. 21).

Isto se aplica na produção e na organização do espaço dos serviços urbanos, determinados para atender novas funções em cidades que ampliaram sua escala geográfica de relações, incluindo-se aí o fenômeno do turismo e, consequentemente, as infraestruturas necessárias ao seu desenvolvimento. Apesar de que é importante considerar que o espaço está em constante renovação. Isto é, o novo na verdade é o espaço que se transforma constantemente.

Segundo Santos (1988, p. 21), “[...] Os novos conhecimentos 'científicos' apontam para o reino do possível, enquanto sua realização concreta pertence mais ao domínio das condições econômicas, culturais e políticas". Percebe-se na afirmação deste autor que, entre o domínio das ideias, da ciência e das ações existe uma lacuna que é balizada pelas forças do capital e da política.

Silva (2003, p. 21) afirma que “[...] atualmente, economistas, sociólogos, geógrafos e muitos outros profissionais destacam a relevância da integração local/global, com suas escalas intermediárias". Trata-se de um fenômeno ligado cada vez mais a toda estrutura interna das regiões em diferentes escalas e sua capacidade de absorver as interferências da globalização econômica e sociocultural.

Entendemos a paisagem urbana como reflexo da produção do espaço pela sociedade, sendo este organizado pela estrutura social e técnica implantada por agentes sociais que produziram elementos fixos, materializados na forma tangível, modificando-se, por sua vez, no processo de transformação de suas funções no contexto urbano. Nesse sentido, coaduna-se com Rodrigues (2003, p. 108), que, com base em Santos (1985), afirma que “[...] embora pareça paradoxal, os fixos, expressos pelos objetos, compõem a paisagem dos núcleos receptores, que é essencialmente dinâmica, cuja leitura pode ser feita através do estudo da forma".

Quanto à questão da produção do espaço, Carlos (2002, p. 48), considera que esta “[...] se realiza enquanto consequência do desenvolvimento do mundo da mercadoria, que, num determinado momento da história, produz o espaço enquanto valor de troca”, e continua afirmando que “[...] nesse sentido, o turismo e o lazer entram neste momento histórico como 
momento de realização da reprodução do capital, enquanto momento da reprodução do espaço - suscitadas pela extensão do capitalismo".

Nesta perspectiva de análise, portanto, a leitura do patrimônio pode viabilizar e revelar parte importante da interação da cidade com sua região de influência, com o espaço nacional e com o espaço global, como equipamento de apoio ao comércio, indústria, assim como no processo da vida de relações da cidade.

É neste sentido que partiremos para a nossa segunda categoria analítica, concebida também como o segundo conceito estruturante no processo de descrição e análise do objeto de pesquisa.

\subsection{DIMENSÕES DO CONCEITO DE PATRIMÔNIO CULTURAL E URBANO}

A análise do nosso objeto de estudo se alinha à perspectiva de Santos (1988, p. 10), o qual argumenta que: “[...] falar sobre espaço é muito pouco, se não buscamos defini-lo à luz da história concreta. Falar simplesmente do espaço, sem oferecer categorias de análise é também insuficiente”. Nesse sentido, afirma que a totalidade supõe um movimento comum da estrutura, da função, da forma e do processo (SANTOS, 1988).

No caso em tela trata-se de uma pesquisa na qual os conceitos e categorias tais como paisagem e patrimônio, analisados na perspectiva do uso do território, dão o suporte teórico/metodológico para a consolidação do estudo, pois se trata da geografia histórica das cidades como patrimônio cultural urbano no conjunto regional. Uma análise sob um viés de herança cultural, produzida no processo histórico de formação regional, aliada ao contexto nacional, materializado na paisagem cultural/urbana, nas escalas regional e local.

O patrimônio cultural é concebido como o nosso segundo conceito estruturante e também como categoria analítica, na sua derivação como patrimônio urbano/edificado. Se faz necessário eleucidar, entretanto, que o conceito de patrimônio em uma pesquisa com viés geográfico é indissociável das noções de cultura e paisagem, quando na arquitetura se coloca de maneira diversa: fato arquitetônico, natural e, mais recentemente, até social isolado.

São muitas as categorias e desdobramentos conceituais contidos no conceito de patrimônio cultural, especialmente na análise sob a perspectiva da Geografia Histórica Urbana. Dentre estes podemos citar: patrimônio histórico, patrimônio artístico e arquitetônico, 
patrimônio urbano, patrimônio ambiental, patrimônio material e imaterial, patrimônio arqueológico, patrimônio vernacular, patrimônio edificado etc.. Nesse sentido concordamos com Scarlato; Costa (2013), quando insistem na necessidade de deixar claro quais os princípios teóricos deverão estar associados ao termo "patrimônio", numa pesquisa com viés geográfico.

Para nós, "patrimônio", não pode estar dissociado de cultura e paisagem, por exemplo, quando da análise da materialidade histórica do urbano e da cidade em conexão direta na formação dos territórios regionais. Por isso, concordamos que essa discussão em Geografia “[...] parece estar alinhavada à ideia de herança espacial, quando o conjunto de bens materiais ou imateriais sintetiza um legado na dialética do processo histórico que se expressa nas paisagens e no próprio território [...]" (SCARLATO; COSTA, 2013, p. 371).

$\mathrm{O}$ estudo do patrimônio edificado no contexto da paisagem urbana das cidades históricas portuárias do Recôncavo Baiano pode ser revelador de processos inerentes à complexa rede de relações econômicas da qual essa região participou em períodos históricos distintos. Significa buscar pistas, através de equipamentos fixos e, a partir daí compreender a relação destes elementos no espaço geográfico. Sua produção e organização espacial, associada à complexa engrenagem que produz a totalidade das cidades que compõem o referido espaço regional.

A análise do patrimônio edificado das cidades históricas portuárias no Recôncavo Baiano nos remete à noção de cidade como um produto cultural. No nosso caso, cidades que expressam uma linguagem material similar numa determinada época. Portanto, direcionamos nossa análise do patrimônio no seu desdobramento material, edificado, sem perder de vista que a mesma está inserida numa concepção mais abrangente de patrimônio urbano que está em ininterrupto processo de materialização e ressignificação (SCARLATO; COSTA, 2013).

Outra derivação do conceito de patrimônio é abordada por Yázigi (2003), o qual reflete sobre a noção de patrimônio ambiental urbano, que persegue uma percepção dos valores embutidos neste conceito. Este autor corrobora com as ideias de Choay (2006), para quem a ideia de conjunto é fundamental. Portanto, segundo Yázigi (2003),

Academicamente, a ideia de patrimônio ambiental urbano se representa por quatro vertentes: a) conjuntos arquitetônicos e urbanísticos, com ou sem monumentos; b) espaço público com seus equipamentos e mobiliário; c) espaços naturais integrados a esse meio, aí se incluindo até formas de relevo; d) quaisquer adereços ou obra de arte urbanos. $\mathrm{O}$ traço de união de tudo isso 
só poderia estar num contexto de relações dado pelo homem (YÁZIGI, 2003, p. 58).

A assertiva acima nos remete à questão do conjunto arquitetônico urbano das cidades históricas do Recôncavo Baiano numa escala local e regional, que ainda mantem traços de uma época revelados em suas paisagens urbanas. Daí o nosso foco no patrimônio edificado. Acreditamos também que as vertentes cultural e ambiental urbano do patrimônio não devem ser segmentados.

Yázigi (2003) assevera que:

[...] o patrimônio ambiental urbano pode ser reconhecido sob várias formas geométricas: enquanto zona, linear ou pontualmente, podendo ocorrer eventuais interrupções desconformes, pois nas condições históricas da urbanização brasileira, raros conjuntos conseguiram se manter em grandes extensões homogêneas ou com todos os elementos iniciais. Depreende-se então que a ideia de conjunto é fundamental (YÁZIGI, 2003, p. 58).

Corroboramos com a concepção deste autor, quando o mesmo aponta que a noção de ambiente inserida na ideia de "patrimônio ambiental urbano" se "identifica com o lugar, mas não é coisa física, é relação" (YÁZIGI, 2003, p. 59). Portanto, é cultural e político também.

Nesse sentido, entendemos que Castriota (2009), caminha nessa mesma direção e complementa a afirmação acima, quando considera que:

[...] Pensar a cidade como um 'patrimônio ambiental' é pensar, antes de mais nada, no sentido histórico e cultural que tem a paisagem urbana em seu conjunto, valorizando o processo vital que informa a cidade e não apenas monumentos 'excepcionais' isolados.

Assim, não há, de fato, que se pensar apenas na edificação, no monumento isolado, testemunho de um momento singular do passado, mas é preciso, antes de mais nada, perceber as relações que os bens naturais e culturais apresentam entre si, e como o meio ambiente urbano é fruto dessas relações (CASTRIOTA, 2009, p. 89).

Nesse mesmo caminho, Pelegrini (2006) discute sobre a relação entre patrimônio e memória, faz uma revisão do conceito de patrimônio e identidade cultural. No caso do conceito de patrimônio a autora faz uma revisão do significado do termo a partir do latim, demonstrando que a acepção da palavra se engaja na concepção de herança paterna, citando Pedro Paulo Funari, para o qual o conceito de patrimônio faz alusão ao moneo, que em latim significa "levar a pensar". Portanto está vinculado às noções de lembrança e memória. 
O conceito de cultura também é explicitado, principalmente no âmbito de sua relação com o patrimônio e memória, demonstrando a amplitude deste conceito quando vinculado à noção de diferenciação de formas e relações das diferentes sociedades e sua relação com as paisagens naturais e as socialmente construídas.

Para essa autora,

[...] atualmente embora a definição de patrimônio cultural busque contemplar as mais diversas formas de expressão dos bens da humanidade, tradicionalmente o referido conceito continua sendo apresentado de maneira fragmentada, associado às distintas áreas do conhecimento científico que o definem como patrimônio cultural, natural, paisagístico, arqueológico e assim por diante. Contudo, nos últimos anos do século XX e início do século XXI, já se depreende que essas áreas se inter-relacionam e que, independentemente das suas respectivas categorias, todo o patrimônio se configura e se engendra mediante suas relações com a cultura e o meio. Sem dúvida, hoje se reconhece que a cultura é construída historicamente, de forma dinâmica e ininterrupta, alterando-se e ampliando seu cabedal de geração em geração, a partir do contato com saberes ou grupos distintos (PELEGRINI, 2006, p. 117-118).

Portanto, a interpretação do patrimônio cultural não pode ser desvinculada das noções de territorialidade, já que esta é também uma expressão material e simbólica da cultura de um povo, de uma nação ou de um Estado-nação. Ou seja, é a expressão da relação sociedade natureza e, segundo a autora, “[...] não pode ser abstraída dialeticamente das ações historicamente responsáveis por sua construção, nem tampouco do sentido de pertencimento" (PELEGRINI, 2006, p. 121).

Para Pelegrini (2006), a degradação do meio ambiente e dos bens culturais, a especulação do solo urbano e a privatização, entre outros problemas como a pobreza, as péssimas condições de existência e trabalho, as privações que corroboram com a crescente agressão à natureza e a descaracterização do patrimônio, são questões comuns das áreas preservadas e dos centros históricos dos países latino-americanos a despeito da sua heterogeneidade em relação às condições políticas, sociais e econômicas.

Na concepção de Luchiari (2005), a questão da apropriação capitalista do patrimônio cultural em cidades históricas com apelo turístico, incluído a questão da economia da cultura que transforma o patrimônio cultural em mercadoria, demostra que a paisagem pode ser deliberadamente construída para tornar-se simbólica. Portanto, a mesma é utilizada como artefato no processo de reprodução capitalista, através da refuncionalização, servindo agora, segundo esta autora “[...] à ideologia do consumo e não mais às práticas culturais 
representativas do sentimento de pertencimento das culturas e populações locais" (LUCHIARI, 2005, p. 2). O enfoque é dado principalmente ao patrimônio de natureza material, ou seja, o patrimônio arquitetônico.

Para Luchiari (2005), as práticas de preservação do patrimônio cultural, seja este de natureza material, cultural ou ambiental, são oriundas de processos históricos seletivos de atribuição de valores às formas e às práticas culturais que produzem intervenções balizadas por projetos políticos que a sociedade local de cada tempo produz. Isto é, na maioria das vezes, são produto das classes dominantes ou a que a estas interessam. Por isso, os bens culturais tombados representam, algo criado pelos grupos sociais hegemônicos.

No que diz respeito à associação entre a urbanização, mercantilização, indústria cultural e turismo, Luchiari (2005) mostra como estes fenômenos estão inseridos no patrimônio de toda natureza. Discute também a questão do hibridismo cultural dos nossos tempos e seus reflexos no processo de revalorização do patrimônio. Além disso, traz no bojo das discussões o papel dos agentes envolvidos no processo de organização e reorganização socioterritorial, tais como o Estado, as empresas e a sociedade civil, na implantação das práticas preservacionistas de toda a ordem.

A preocupação central desta autora diz respeito às condições de exploração social em que se produzem a espetacularização da natureza, da cultura e de suas formas na atualidade. Ela ainda traz à tona a questão das intencionalidades, ideologias e propósitos no processo de apropriação dos territórios inseridos nas ações de políticas de preservação. Para tanto é mencionada a questão da organização socioterritorial do espaço, fundamentada nas categorias geográficas como "forma" e "função" que, engendradas pelo conteúdo social, reanimam as paisagens.

No sentido apontado acima, interessa considerar o espaço das permanências, como expressão materializada do uso da terra urbana, através da ação dos agentes sociais envolvidos no processo de organização espacial, definindo áreas de intervenção pública e privada, caracterizadas em formas espaciais para a implantação de novos usos e funções possíveis. Neste sentido, segundo Corrêa (2004),

[...] a complexidade da ação dos agentes sociais inclui práticas que levam a um constante processo de reorganização espacial que se faz via incorporação de novas áreas ao espaço urbano, densificação do uso do solo, deterioração de certas áreas, renovação urbana, relocação diferenciada da infraestrutura e mudança, coercitiva ou não, do conteúdo social e econômico de determinadas áreas da cidade. (CORRÊA, 2004, p. 11). 
$\mathrm{Na}$ atualidade nas cidades de Salvador e Cachoeira a requalificação do centro histórico ilustra perfeitamente o texto de Corrêa. Ou seja, a produção do espaço e sua organização em função do comércio, do turismo e do lazer a partir da transformação no sentido da reconfiguração dos seus conteúdos sociais. Processo este imposto pela ação de agentes públicos no processo de requalificação e restauração de algumas áreas e implantação de novas infraestruturas noutras, atendendo a demanda de novas funções relacionadas à prestação de serviços. Ainda conforme este mesmo autor, o espaço urbano se mantém simultaneamente fragmentado e articulado a cada transformação, reflexo e condicionante social, ainda que as formas espaciais e suas funções tenham mudado (CORRÊA, 2004).

Diante do exposto até aqui nos parece evidente que nas discussões sobre o conceito de paisagem, de uma maneira geral, nas diversas visões dos autores aqui referenciados, duas vertentes filosóficas afloram e caminham imbricadas. Por um lado, uma visão de cunho marxista, quando a paisagem é tratada como possibilidade de se tornar mercadoria, no sentido da reprodução do capital, utilizando os lugares como apelo de atrativo turístico e cultural rentável, numa visão economicista de transformação intencional das referidas paisagens e do patrimônio nelas inserido. Por outro lado, percebemos também um viés fenomenológico da análise, quando a paisagem também é tratada levando-se em consideração a percepção do sujeito, no sentido de que o patrimônio nela contido é percebido sob a perspectiva das representações sociais, interferindo de forma simbólica em suas memórias e identidades.

Assim, as questões da espetacularização da cultura e de suas formas no contexto das paisagens também estão incutidas nos projetos e políticas de preservação do patrimônio que foram surgindo ao longo do tempo, cujas práticas também estão carregadas de ideologias.

\subsubsection{O patrimônio e a preservação da memória urbana}

A questão da preservação do patrimônio é tratada adiante na perspectiva de contextualizarmos e exaltarmos a relevância dessa discussão, no sentido de valorizar o conhecimento dessa temática que, ao fim, dá sentido à pesquisa em tela. Ou seja, buscar através do conhecimento científico, sem, contudo, desprezar totalmente o senso comum, opções de preservação do nosso patrimônio material e daí resguardar a nossa memória e identidade. 
A origem das práticas de preservação do patrimônio cultural no mundo moderno está associada aos processos de formação dos Estados nacionais. Modelo que se ampliou globalmente, consagrando a institucionalização do monumento histórico, dando a este um estatuto temporal diferente. A intensidade da presença concreta e a instalação do monumento num "passado" definitivo e irrevogável são as marcas daquele momento histórico que "[...] foi construído pelo trabalho conjunto da historiografia e da (tomada de) consciência historial das mutações impostas pela Revolução Industrial às habilidades dos seres humanos" (CHOAY, 2006, p. 206).

A noção de patrimônio urbano histórico, no sentido do conjunto, e não apenas do monumento isolado, acompanhada de um projeto de conservação nasceu na Grã-Bretanha, sob os auspícios de Ruskin, em meados do século XIX, na mesma época das grandes reformas urbanas de Paris, capitaneadas por Haussmann. Entretanto, pesquisas revelam que foi na França onde se deu o advento de uma administração assumida pelo Estado, através de um modelo jurídico, administrativo e técnico, o qual foi oferecido à Europa (CHOAY, 2006).

No século XX, no final da década de 1960, especialmente na Europa e nos Estados Unidos surge a preocupação com a restauração de centros históricos degradados, permitindo a expressão "cidade museu". Esta ação se propagou por diversos países, enquanto empreendimento visando preservar o legado patrimonial e a herança cultural das paisagens urbanas.

Em vários países a existência de cidades históricas representa fontes de valorização do passado e possibilidade de diferentes leituras do presente, especialmente a partir do seu patrimônio edificado. A literatura mostra diferentes tipos de tratamento da questão.

A preservação e requalificação de conjuntos urbanos através do uso do patrimônio edificado, restaurado para as mais diversas funções, são as iniciativas mais visíveis nas cidades históricas espalhadas pelo planeta. As novas funções administrativas, educativas, comerciais, residenciais ou de entretenimento, inseridas ao patrimônio para preservar sua forma estão sendo utilizadas como maneira de manter parte do legado cultural e indentitário da sociedade.

Tal fato se deve, por um lado, ao despertar para a necessidade de conservação da memória material e da tentativa de resgate da identidade dos lugares. Por outro lado, se deve a uma possibilidade de utilização da paisagem urbana como forma de reprodução do capital por parte dos agentes estatais hegemônicos e da iniciativa privada, muitas vezes a serviço do 
grande capital nacional e/ou internacional. $\mathrm{Na}$ atualidade o fenômeno do turismo, por exemplo, favorece a esta segunda possibilidade.

No Brasil, a existência de cidades históricas representou a partir dos anos de 1930 um suporte para a questão da construção da identidade nacional, quando foram construídas inúmeras legislações de proteção do patrimônio histórico edificado. No entanto, a realidade atual nos permite inferir que as políticas públicas de preservação foram insuficientes para atender a todas as necessidades regionais, especialmente num país de dimensões continentais.

Importante observar, aqui, que a noção de cidades históricas neste momento não está associada à preservação de conjuntos urbanos, mas à soma de arquiteturas isoladas em si, mesmo que de forma ainda não institucionalizada.

Portanto, deu-se especial atenção e prioridade a alguns edifícios e menos aos conjuntos urbanos. Assim como o direcionamento das políticas de salvaguarda em determinadas regiões em detrimento de outras que, naquela época, afastados dos centros de decisão do poder vigente ficaram à margem das intervenções do Governo Nacional. Como consequência ocorreu um estado de degradação do patrimônio histórico edificado de conjuntos urbanos de significativa relevância nas cidades históricas do país, inclusive no Nordeste e, em especial, no Recôncavo Baiano.

Na visão de Costa; Scarlato (2012, p. 105), a questão da preservação e da conservação patrimonial passa por contradições que exigem uma "[...] leitura da concretude do ordenamento do território e da refuncionalização da paisagem". Segundo os autores, a dimensão política para consagração de determinados territórios como patrimônio mundial, por exemplo, está vinculado ao que ele considera como “[...] uma Geografia que é o retrato concreto de uma história político-patrimonial universal e da ideologia dominante de Estadosnações, fundamentados em objetos e territórios singulares".

Dessa mesma forma, entendemos que países como o Brasil, também absorveram essa mesma ideologia, quando da eleição dos conjuntos patrimoniais urbanos a serem tombados em nível nacional e/ou consagrados como patrimônio mundial. É o caso, por exemplo, das cidades de Ouro Preto em Minas Gerais; Salvador, na Bahia. As duas eleitas e consagradas como Patrimônios da Humanidade pela UNESCO, em 1980 e 1985, respectivamente.

Acerca do Recôncavo Baiano, sua importância e não reconhecimento em relação a Ouro Preto, por exemplo, deve-se considerar o "eixo" Rio-Minas e seu significado político no processo de institucionalização da prática preservacionista cujos maiores nomes, Lucio Costa e Rodrigo Melo Franco de Andrade tinham relação com Minas Gerais. Além disso, é 
importante atentar, ainda, para o fato das peculiaridades da arquitetura e do urbanismo modernos no Brasil, associada à questão da memória, de uma identidade nacional que vai enxergar em Aleijadinho o "artista" local.

Sobre a questão das políticas de preservação do patrimônio cultural, Rodrigues (2005, p. 21) afirma que "[...] até a década de 1960, poucas leis aprovadas no país tratavam da preservação de bens culturais". Isto é, para esta pesquisadora, até então só o tombamento prevalecia, mas sem ampliar "as formas legais de proteção adotadas". Concordarmos com a autora, pois segundo a mesma, “[...] o tombamento continua a ser a forma predominante, embora muitas vezes, não atenda a dinâmica necessária à manutenção do ambiente, em especial nas áreas urbanas".

Percebemos que, apesar da existência do Instituto do Patrimônio Histórico e Artístico Nacional (IPHAN), desde 1937, permanece o paradoxo entre as políticas de planejamento urbano, relacionadas à preservação, inclusive no que tange à ação de refuncionalização de áreas tombadas.

Paes (2010) afirma que:

\begin{abstract}
Muitos autores, urbanistas, e mesmo o poder público em seu discurso oficial, utilizam os termos requalificação e reabilitação, considerando que estes não se limitam a restauração das formas, como ocorreria na revitalização, mas abrangem uma intervenção em áreas urbanas degradadas de interesse histórico ou social, aliando modernização à manutenção dos valores tradicionais, sejam arquitetônicos, funcionais ou culturais. Contudo, tais termos tem se apresentado transitórios em seu uso, contraditórios em sua concepção, ou já foram devidamente criticados por inúmeros autores, portanto, adotamos a concepção geral de refuncionalização, entendendo que, tanto teoricamente, em relação ao método geográfico, quanto em termos operacionais, este processo está presente em todas estas formas de intervenção urbana citadas (PAES, 2010, p. 14-15).
\end{abstract}

Corroboramos com a concepção teórico-metodológica da autora acima, por considerarmos que, em se tratando de uma análise geográfica, categorias como estrutura, forma, função e processo caminham juntas, sendo o conceito de refuncionalização o que atinge maior alcance e contempla uma análise da totalidade do processo de intervenção no espaço, a partir do planejamento urbano.

Segundo Carvalho (2009), o planejamento urbano

[...] teve grande impulso na Europa e nos Estados Unidos, no período posterior a Segunda Guerra Mundial, em face da necessidade de 
reconstrução de cidades ou de suas áreas destruídas durante o conflito. $\mathrm{Na}$ esteira das ações de recuperação, as intervenções urbanas expandiram-se com forte acento de renovação urbana - para áreas centrais das cidades, visando à reposição de grandes áreas do tecido urbano [...] que eram consideradas 'deterioradas' ou em 'decadência (DEL RIO apud CARVALHO, 2009, p. 28).

Em 1933 foi escrita a "Carta de Atenas", cuja meta era propor uma cidade que funcionasse adequadamente. Neste sentido, a "cidade funcional" deveria ser organizada para atender quatro necessidades humanas básicas: habitação, lazer, trabalho e circulação. Por sugestão da delegação italiana, introduziu-se uma seção destinada ao "patrimônio histórico" das cidades (SILVA, 2003, p. 52).

Posteriormente à Carta de Atenas foi elaborado outro documento de referência mundial, oriundo do II Congresso Internacional de Arquitetos e Técnicos de Monumentos Históricos, realizado na cidade de Veneza em 1964, que resultou na conhecida "Carta de Veneza" (SILVA, 2003).

Segundo Silva (2003, p. 53), a primeira contribuição dada pela Carta de Veneza é a afirmação de um interesse universal pela conservação das obras de interesse histórico. Ainda segundo este autor, “[...] o preâmbulo da Carta de Veneza evoca a responsabilidade da humanidade em relação à salvaguarda das 'obras monumentais' que integram seu 'patrimônio comum' para as 'futuras gerações".

Podemos inferir daí que, estavam lançadas as primeiras sementes para o fértil campo da possível sustentabilidade do patrimônio urbano, englobando os monumentos mais significativos para a memória das sociedades urbanas.

A Carta de Veneza, ainda segundo Silva (2003), surgiu em razão da crescente preocupação com a deterioração dos monumentos históricos, sobretudo daqueles destruídos durante a Segunda Guerra Mundial. Ela retomou a preocupação da Carta de Atenas em relação à proteção do patrimônio histórico.

No Brasil, segundo Rodrigues (2005), só a partir de 1964 é que houve um aumento da intervenção do Estado na cultura e, nesta mesma década, o Brasil participou de um encontro promovido pelo Departamento de Assuntos Culturais da Organização dos Estados Americanos (OEA) que aconteceu no Equador, resultando num documento conhecido como a "Carta de Quito", o qual o Brasil é signatário.

Neste documento recomendava-se que 
[...] os projetos de valorização do patrimônio fizessem parte dos planos de desenvolvimento nacional e fossem realizados simultaneamente com o equipamento turístico das regiões envolvidas. Recomendava-se ainda, a cooperação dos interesses privados e o respaldo da opinião pública para o desenvolvimento desses projetos [...] (RODRIGUES, 2005, p. 18-19).

Com base nisso, o turismo cultural tem induzido um apelo conservacionista às cidades, utilizando o patrimônio como atrativo e, consequentemente, transformando o conjunto das paisagens em produto. Neste processo, o espaço da cidade é produzido e organizado numa relação dialética sob o modo de produção vigente, associado às ações e mecanismos de diferentes agentes e em diversas escalas.

Ainda em relação à questão do turismo como um fenômeno produtor e consumidor de paisagens, Almeida (2010) acrescenta a questão da temporalidade, afirmando que:

Contemporaneamente o turismo caracteriza-se por uma procura não somente de paisagens distintas por parte do turista, como de tempos diversos. O ambiente físico, enquanto uma encarnação do tempo possibilita uma leitura e vivência do entrelaçamento entre passado e presente, do qual deriva a preocupação de que sua conservação é pré-requisito de uma continuidade [...] (ALMEIDA, In: PAES; OLIVEIRA, 2010, p. 7).

Segundo Soares $(2003$, p. 21) “[...] a preservação do patrimônio cultural e material, que constitui habitat do ser humano, decorre dos deveres de resguardar aquilo que não se pode reconstruir, uma vez destruído". Nesse sentido, admite-se que o fenômeno do turismo pode tornar-se uma ameaça ou uma esperança, no processo de sustentabilidade do patrimônio urbano.

É sabido que as práticas preservacionistas, oriundas do planejamento urbano, a exemplo do tombamento, podem ter implicações diversas no cotidiano das cidades e nas áreas patrimoniais e consiste em tarefa complexa. Henrique (2009) nos alerta que:

[...] os processos de produção do espaço implicam em mudanças e movimentos constantes tanto no plano das formas (morfologia) quanto dos conteúdos (funções) e, portanto, o tombamento, apesar da necessidade de preservação e conservação dos patrimônios urbanos, podem retirar das cidades ou áreas tombadas os movimentos da vida cotidiana que preenchem e animam as formas, que permanecerão na cidade, mas esvaziadas de conteúdos, em uma cenarificação do espaço (HENRIQUE, 2009, p. 187).

A questão levantada por Henrique (2009) é pertinente e deve pautar o rol de preocupações inerentes aos projetos de planejamento e gestão dos territórios sob intervenção, 
observando-se as peculiaridades regionais e locais, refuncionalizando o patrimônio e incorporando-o ao cotidiano local, de forma que contemple a dialética da existência local. Como se viu anteriormente, uma reorganização do espaço em função do turismo, por exemplo, sem a preocupação primordial com a população local, tende a cair no risco de uma espetacularização das paisagens, relegadas apenas aos olhares passageiros dos turistas.

Para Yázigi (2003), apesar da existência do IPHAN desde 1937, salienta-se que:

[...] constantes lamentos dos amantes da preservação, poucos espaços de interesse se mantiveram em pé. Algumas políticas urbanas estaduais, geradas a partir do II PND, conheceram um breve período de vagas preservacionistas, seguidas de falência quase total. Foi nesse contexto do último quartel do século XX que surgiu entre nós a primeira formalização do interesse pelo patrimônio ambiental urbano. Era a reafirmação da necessidade de um quadro de vida, uma denúncia contra a negligência do Estado e da sociedade perante a história (YÁZIGI, 2003, p. 64-65).

Assim, no Brasil, atualmente ainda assistimos a uma contínua degradação e destruição do patrimônio histórico cultural urbano, salvo algumas exceções, onde o tombamento foi capaz de reestruturar a dinâmica da vida de algumas cidades. As cidades históricas do Recôncavo Baiano são exemplo do processo acima referido, onde o resgate da memória através da simbologia do patrimônio pode resgatar a representação social da comunidade.

No próximo tópico discutimos a relação entre patrimônio e identidade, revelado no contexto da relação das sociedades e as paisagens que a rodeiam.

\subsubsection{Patrimônio e identidade}

Sobre a discussão do conceito de identidade, Magnavita (2010, p. 68) nos chama a atenção para o cuidado que devemos ter quanto ao uso recorrente da referida palavra, pois segundo ele, é um “[...] conceito válido apenas no mundo da representação”. Nossa pesquisa trata da análise de um objeto cuja expressão maior está em sua exterioridade. Isto é, a representatividade do patrimônio urbano através de seu uso.

Essa representatividade é entendida aqui como uma narrativa genuína do lugar, que é expressa pelos elementos de sua paisagem. A materialidade construída e usada do/no 
território. Neste caso, a paisagem cultural urbana de um conjunto de cidades que, a princípio, supomos ter uma identidade comum que reforça o sentido de um espaço geográfico de caráter regional.

Ora, Magnavita (2010) nos traz outra dimensão da perspectiva do conceito de identidade que é pouco percebida e é preocupante para esse autor, pois vai além da visão puramente clássica deste conceito. Ele argumenta o seguinte:

Filosoficamente, enquanto conceito (um virtual), identidade tem o sentido de mesmo, idêntico, ou seja, afirma a permanência de algo, de uma "coisa em si”, de uma essência. Vale salientar que diferentes vertentes do pensamento contemporâneo criticam o essencialismo, pois a vida, a existência se afirma como processo transformacional, onde tudo se transforma, nada permanece o mesmo. Não existem coisas em si, pois as coisas são relações, multiplicidade de elementos resultantes de imprevisíveis conexões processuais. Trata-se, portanto, sempre de um devir - outro da existência. Justamente por isso, é preciso ter o devido cuidado, ao se usar o conceito de identidade, pois ele expressa apenas a exterioridade das coisas, como mero reconhecimento de algo, de alguém, de um grupo social, de um país e que, todavia, se encontra em contínuo processo de transformação, de diferenciação, de mudança, e não são essências, coisas em si, que permanecem (MAGNAVITA, 2010, p. 70).

Para Massey (2009, p. 30) o "[...] espaço não existe antes de identidades/entidades e de suas relações". Ela argumenta que identidades/entidades e as relações entre elas gera uma espacialidade que faz parte desta relação construtiva. Essa autora coaduna com a ideia de que "[...] identidades especificamente (lugares, nações) podem, igualmente, ser reconceitualizados em termos relacionais" (MASSEY, 2009, p.31).

A autora acima referida afirma o seguinte sobre a questão da relação lugar/identidade e política dessas relações de construção:

[...] Se nenhum lugar/espaço é uma autenticidade coerente e contínua, então uma questão que é levantada é a de sua negociação interna. Se as identidades, tanto as especificamente espaciais quanto as outras, são, de fato, construídas relacionalmente, então isto coloca a questão da geografia dessas relações de construção. Levanta a questão da política dessas geografias e de nosso relacionamento e responsabilidade com elas, e faz surgirem, de modo contrário e, talvez, de maneira menos esperada, as geografias potenciais de nossa responsabilidade social (MASSEY, 2009, p. 31).

As assertivas acima, grosso modo, são de fundamental importância, pois nos alertam para o fato de que, as semelhanças nas exterioridades nem sempre pressupõe semelhança nos conteúdos. Ou seja, no caso da análise geográfica, por exemplo, as formas até podem 
permanecer, mas os processos de sua existência determinam diferentes estruturas e funções, assim como a dimensão política do espaço, que deve ser conceituado, segundo Massey (2009, p. 95), como “[...] aberto, múltiplo e relacional, não acabado e sempre em devir". Concordamos, portanto, com esse ponto de vista, pois, como afirma a própria autora: “[...] é um pré-requisito para que a história seja aberta e, assim, um pré-requisito, também, para a possibilidade da política".

É isso que nos parece estar claro quando tratamos do nosso objeto de pesquisa numa dimensão galgada na Geografia Histórica Urbana, pois a ideia de rever o passado por intermédio de sua materialidade construída num recorte temporal pretérito, não congela as possibilidades de encarar o espaço geográfico na sua dimensão atual, tendo em vista, numa dimensão miltoniana, suas rugosidades, seus fixos e seus novos fluxos. Tudo isso sempre teve implicações políticas, até mesmo no processo de salvaguarda dos bens patrimoniais como Patrimônios da Humanidade.

Chamamos a atenção de que, no caso da nossa pesquisa, são os significados das exterioridades que nos interessam. As permanências em forma de patrimônio urbano na sua essência material. Portanto, como se trata de uma análise que busca detectar a narrativa espacial comum entre sete cidades de uma mesma região, a identidade da essência do patrimônio urbano em sua exterioridade aparente, que nos interessa. Ou seja, se trata, aqui, da própria arquitetura percebida como representação em pedra e cal, de uma dada identidade. Uma concomitância temporal e uma similaridade de formas e, portanto, identidade regional baseada num "fazer" regional.

Entretanto devemos estar atentos para o que afirma Magnavita (2010) quanto ao uso do termo "identidade" na atualidade. Segundo o autor:

Hoje, o termo mais empregado do ponto de vista filosófico, não é o de identidade, mas o de diferença, pois se as coisas mudam, via de regra, elas se repetem, diferenciando-se, ou seja, ocorrem diferenças, que podem ser tanto diferenças de grau e/ou de nível, ou mesmo, diferenças de natureza, e isto, quando ocorrem atos criativos, evidenciando a mobilidade processual da existência. É sempre a diferença e não a identidade que se afirma. Pois identidade é um conceito conservador, herdado da antiguidade, e que integra o repertório conceitual da lógica clássica aristotélica, reciclada pela modernidade, e que pretende assegurar a permanência de uma essência que se pressupõe existir. Entretanto, o que de fato ocorre é a permanente mudança, transformação que evidencia a diferença, ou seja, uma descontinuidade (ruptura), um acontecimento, uma criação, um devir-outro da existência (MAGNAVITA, 2010, p. 70). 
Entretanto, estamos cientes e concordamos que o espaço é um produto de relações, assim como diz Massey (2009) e Santos (2006), quando concordam que é "um conjunto indissociável entre objetos e ações". Tais proposições se coadunam com o que Magnavita (2010) pressupõe para o conceito menos essencialista de identidade e espaço. Ou seja, como afirma Massey:

[...] um espaço jamais poderá ser essa simultaneidade completa, na qual todas as interconexões já tenham sido estabelecidas e todos os lugares já estão ligados a todos os outros. Um espaço, então, que não é nem um recipiente para identidades sempre já constituídas nem um holismo completamente fechado. É um espaço de resultados imprevisíveis e de ligações ausentes. Para que o futuro seja aberto, o espaço também deve sê-lo (MASSEY, 2009, p. 32)

Seguindo as sugestões de Magnavita (2010) e Massey (2009) nos apoiaremos em Gil Filho (2005, p. 57-58) com a abordagem das representações sociais na geografia que vem ser “[...] uma geografia do conhecimento simbólico, que assume as representações sociais como ponto de partida para uma Geografia Cultural do mundo banal, da cultura cotidiana, universo consensual impactado pelo universo reificado da ciência e da política". Neste sentido, tais pressupostos nos remete, segundo este mesmo autor, a duas linhas de argumentação as quais corroboramos para identificar e analisar a relação entre a percepção da paisagem e sua representação para a população, num processo de observação relacionada ao senso comum, e posteriormente, interpretada pela ciência.

As argumentações são as seguintes, segundo Gil Filho (2005):

I) A primeira é relacionada às identidades sociais como resultado da imposição dos universos reificados sobre os consensuais das representações.

II) A segunda é uma Geografia do Conhecimento banal que cada comunidade produz a partir da representação que cada grupo faz de si mesmo. Uma Geografia Cultural do mundo banal, da cultura cotidiana, do universo consensual impactada pelo universo reificado da ciência e da política (GIL FILHO, 2005, p. 56).

Ainda para Gil Filho (2005),

[...] existe uma identidade comum ao grupo, livre e de certo modo igualitária. Dois mundos coexistem: um consensual, próprio das representações sociais, e outro reificado, próprio das ciências e da política. Enquanto o segundo surge fora de nós de modo coercitivo e é aquele ao 
qual devemos ser submetidos na forma de um espaço de relações de poder, o primeiro é a consciência coletiva que restabelece uma harmonia convencional na explicação das coisas e dos fatos do cotidiano em um espaço banal. A análise das representações sociais nos coloca diante da necessidade de decodificar este mundo próprio do universo banal, o do ser no espaço para o ser enquanto espaço (GIL FILHO, 2005, p. 57-58).

Afinal como afirma Torres (2008), analisando as cidades como expressão cultural em suas paisagens e objetos ali contidos,

[...] as instituições culturais - aquelas que reúnem um conjunto de práticas, técnicas, símbolos e valores capazes de garantir a reprodução de um estado de coexistência social e ainda, de sentidos de pertinência social, ainda que atravessados por discursos múltiplos e imaginários - inscrevem-se na paisagem das cidades como lugares relevantes para a re-apresentação da memória desta mesma paisagem, constituindo-se estruturas dinâmicas no tecido urbano. Portanto, a paisagem à qual estamos nos referindo é a acumulação, no tempo e no espaço, de práticas, técnicas, valores e símbolos culturalmente constituídos (TORRES, 2008, p. 40).

Para Torres (2008) a cidade é o lugar da representação da cultura, e afirma que:

[...] A noção de patrimônio se torna fundamental para a compreensão da cidade como lugar de re-apresentação da memória e da cultura. Cidade como representação da cultura e patrimônio, portanto, fundamentam o trabalho da memória. Uma memória que se escreve no singular, mas que se afirma e se estrutura como plural e tensa. Sem o trabalho da memória, a ossatura da cidade ficaria exposta de uma outra maneira e nos distanciariam da "alma da cidade" (TORRES, 2008, p. 40).

$\mathrm{Na}$ assertiva acima se percebe a fusão dialética entre os conceitos de paisagem, patrimônio, cultura, memória e representação social, todos imbricados na atmosfera urbana das cidades e que serão refletidos na identidade com o lugar.

Neste sentido, Gonçalves (2013) afirma que:

A discussão da dimensão urbana do patrimônio é uma agenda muito oportuna no contexto brasileiro, onde está em curso um redirecionamento das políticas culturais no sentido da integração dos sítios históricos nos seus propósitos de salvaguarda. Esta oportunidade se estende a outros contextos geográficos e sociopolíticos, como é o caso dos países do sul europeu cujas políticas de ordenamento do território tendem a dar menos valor às dinâmicas de expansão urbana e a valorizar cada vez mais as operações que tem o prefixo re no seu nome: regeneração, revitalização, renovação, reabilitação e várias outras [...] Porém, se por um lado é importante e necessário debater as políticas e as metodologias de 
salvaguarda e gestão do patrimônio de dimensão urbana, também não deixa de ser verdade que esse debate não encerra grandes novidades ou, pelo menos não encerra novidades em termos absolutos. Há muito que se sabe que a salvaguarda deve ser integrada no desenvolvimento. Porém essa não é a prática corrente [...] (GONÇALVES, 2013, p. 29).

A assertiva apresentada por Gonçalves (2013) se aplica em parte à realidade do Recôncavo Baiano, no sentido de que algumas intervenções de conservação do patrimônio urbano, no caso deste estudo, o patrimônio edificado, já foram realizadas na cidade de Cachoeira de forma mais intensa, numa articulação mais imbricada entre esferas políticoadministrativas do país (União, Estado e Município). Entretanto, ainda há muito por fazer nas outras cidades da região, especialmente naquelas que são o foco da nossa pesquisa.

\subsection{O USO DO TERRITÓRIO: A TERCEIRA CATEGORIA ANALÍTICA}

O terceiro conceito articulador, também concebido como categoria analítica é o "território".

O conceito de "território" como sinônimo de "espaço geográfico", por exemplo, descrito por Santos (2001), é outra dimensão de análise que nos traz a possibilidade de uma visão histórica da materialidade construída e da dimensão múltipla e holística de frações do "espaço geográfico". Na nossa compreensão isso facilita o processo de pesquisa e nos dá subsídios para o estudo de novos objetos e novas ações que se desencadeiam na relação sociedade e espaço.

Concordamos com a ideia segundo a qual o espaço é sempre histórico e que sua historicidade deriva da conjunção entre as características das ações e as características da materialidade territorial (SANTOS, 2001, p. 248). Ou seja, a noção de "uso do território" constitui-se o alicerce da abordagem.

Santos (2001) propõe “apresentar a sucessão de meios geográficos no Brasil", interpretado por intermédio da análise das suas técnicas diversas ao longo de períodos históricos determinados e da sua aplicação nos lugares. Ou seja, contar a história do território a partir do uso que sociedade faz dele. 
Da mesma forma que Santos (2001) considera o território como a fala privilegiada da nação, assim o fez Celso Furtado a partir da economia; Darcy Ribeiro a partir da cultura e Florestan Fernandes a partir do povo. Santos (2001) propõe uma teoria do Brasil a partir do território, uma tentativa de explicar a sociedade brasileira, “[...] tomando como pano de fundo o próprio espaço geográfico" (SANTOS, 2001, p. 15).

Em sua obra, Santos; Silveira (2001) oferecem uma visão de conjunto do espaço geográfico brasileiro, da Geografia do Brasil, interpretando-o no processo de globalização, utilizando o conceito de território como teoria e método para esse fim. Este conceito é utilizado como um dos aspectos integradores da realidade brasileira e também como o subsídio científico (teórico e empírico) fundamental para o entendimento da realidade socioespacial do Brasil.

Como afirmam Santos; Silveira (2001, p. 12), “[...] um retrato das novas quantidades e, sobretudo das novas qualidades do território que, vistas de maneira dinâmica, oferecem, ao mesmo tempo, fundamentos para vislumbrar tendências". Nessas tendências se incluem o planejamento regional, a gestão dos territórios, as políticas públicas etc.. Para os autores,

O território já usado pela sociedade ganha usos atuais, que se superpõem e permitem ler as descontinuidades nas feições regionais. Certas regiões são, num dado momento histórico, mais utilizadas e, em outro, o são menos. Por isso cada região não acolhe igualmente as modernizações nem seus atores dinâmicos, cristalizando usos antigos e aguardando novas racionalidades (SANTOS; SILVEIRA, 2001, p. 12-13).

No nosso entendimento a afirmação acima contempla a realidade do Recôncavo Baiano e das suas cidades históricas portuárias, haja vista a dinâmica socioeconômica e os processos socioespaciais a ela inerentes na produção e organização do espaço geográfico regional e local.

É neste sentido que pretendemos interpretar a narrativa espacial do Recôncavo Baiano, produzida por sua dinâmica socioeconômica e cultural, através da compreensão do seu patrimônio edificado, descrevendo-o e explicando-o. Sem perder de vista, entretanto, que uma narrativa histórica jamais alcançará a verdade plena dos fatos e dos eventos, porém podem sugerir pistas que muito nos aproximam dela e nos ajudam a compreender a narrativa espacial das cidades na atualidade.

Portanto, o conceito de "território", que funcionará também como método para a nossa pesquisa é aqui concebido de maneira similar ao proposto por Santos; Silveira (2001), no 
esforço de análise e síntese para o território brasileiro e suas regiões. No nosso caso, adaptado para universo regional onde se incluem as sete cidades portuárias em tela.

\subsection{QUESTÕES DE MÉTODO}

Alguns cientistas já admitem não mais medir ou representar a evolução dos paradigmas de forma unilateral, como uma sucessão engessada dentro das ciências. Já existem críticas relacionadas ao método científico moderno como sinônimo de caminho único e adequado de produzir conhecimento verdadeiro (TONET, 2013).

Pesavento (2008), fala-nos de:

[...] insights e posturas, surgidas ao longo do tempo, sem linhagem direta, espécie de longo caminho, nem sempre sequente, com muitas lacunas, sem diálogo obrigatório entre aqueles que intuíam novas formas de pensar. Falamos, sobretudo, de uma espécie de novas formas de pensar. São como que sintomas esparsos, ao longo do tempo, de posturas distintas que se foram insinuando, tais como as reflexões filosóficas de Hegel, a propósito do pensamento fazer parte do real e com ele se confundir [...].

Há que ter em conta que tais indícios se manifestam em um mundo dominado pelo progressivo avanço das ciências que, desde o racionalismo cartesiano do século XVII, passando pelo Iluminismo para chegar ao cientificismo novecentista e ao materialismo do século XX, consolidava uma outra ordem: a da pureza e da racionalidade dos conceitos e da capacidade da ciência de produzir verdades sobre o mundo. Tal modo de conhecimento racional do mundo oferecia certezas, o que se colocava em contraste com uma certa indefinição ou fluidez de outras formas de apreensão do real, mais apoiadas na sensibilidade e nos sentimentos (PESAVENTO, 2008, p. 21).

No que diz respeito à História Cultural, a autora demonstra que a fusão de paradigmas desse campo da História, na contemporaneidade, tinha se plantado nas Ciências Sociais ainda no século XIX e início do século XX, a exemplo da visão do mundo por uma dimensão de representação simbólica.

O que existe na atualidade é uma grande fusão do pensamento. Para Vasconcelos (2015, p. 9), “[...] a geografia histórica vem se ampliando, sobretudo diante da busca de novos paradigmas e da queda das grandes teorias". As ciências humanas, especialmente, se tornaram muito mais fluidas, menos segmentadas ao longo da evolução técnica e científica da humanidade, apesar de suas especificidades e da intensa especialização. As abordagens e 
concepções sobre o objeto da Geografia é um grande exemplo disso, como já vimos anteriormente.

Em relação ao espaço geográfico - objeto da Geografia - Santos (2008, p. 61) afirma que é necessário o domínio do método. Segundo o autor, “[...] Falar em objeto sem falar em método pode ser apenas o anúncio de um problema, sem, todavia, enunciá-lo”. Para ele “[...] É indispensável uma preocupação ontológica, um esforço interpretativo de dentro, o que tanto contribui para identificar a natureza do espaço, como para encontrar as categorias de estudo que permitam corretamente analisa-los” (SANTOS, 2008, p. 61).

Corroboramos com a concepção de Camargo; Reis Filho (2005), segundo a qual,

\begin{abstract}
A busca de novos caminhos e metodologias analíticas (detalhe que acaba enriquecendo o acervo do pensamento geográfico) não é uma novidade e tudo indica que tal detalhe deverá ainda prosseguir. Daí, então, a necessidade de os geógrafos terem conhecimento das referidas "escolas" epistemológicas e a consequente opção/apoio a uma ou outra corrente mais aproveitável em suas respectivas áreas de trabalho (CAMARGO; REIS FILHO, 2005, p. 84).
\end{abstract}

Nossa ideia é mostrar que alguns desses paradigmas permanecem nas pesquisas científicas atuais, inclusive nesta. Eles se fundem e se moldam na perspectiva de atender as novas conjunturas que se apresentam. Principalmente quando se trata de pesquisa em Geografia Histórica Urbana, como é o caso em tela.

Santos (1988), quando analisa o presente e a totalidade do espaço em relação à análise geográfica, afirma o seguinte:

A Geografia deve preocupar-se com as relações presididas pela história
corrente. O geógrafo torna-se um empiricista, e está condenado a errar em
suas análises, se somente considera o lugar, como se ele tudo explicasse por
si mesmo, e não a história das relações, dos objetos sobre os quais se dão as
ações humanas, já que objetos e ações mantêm relações dialéticas, onde o
objeto acolhe as relações sociais, e estas impactam os objetos. O geógrafo
seria um funcionalista se levasse em conta apenas a função; estruturalista se
apenas indicasse as estruturas, sem reconhecer o seu movimento histórico ou
relação social sem o conhecimento do que a produziu. Impõe-se na análise,
apreender objetos e relações como um todo, e só assim estaremos perto de
ser holistas, isto é, gente preocupada com a totalidade (SANTOS, 1988, p.
57).

Vasconcelos (2002) ao tratar de questões metodológicas empreendidas para a sua pesquisa sobre Salvador, levanta uma questão e ao mesmo tempo assevera, com base em Santos (1996), que: 
Como uma combinação de eventos e processos, ao longo do tempo, conduz à formação de uma sociedade e de um espaço com características próprias. $\mathrm{O}$ lugar é, neste caso, o resultado de uma acumulação de formas sobreviventes de diversos períodos, ao mesmo tempo que concentra uma estrutura social que adquiriu características próprias e, embora articulada a uma sociedade global, apresenta certas combinações que permitem o aparecimento de uma cultura única (SANTOS, 1996 apud VASCONCELOS, 2002, p. 18).

Entretanto, é importante ponderar que esta "cultura única" é sempre híbrida, não podendo ser considerada como totalmente excepcional.

As duas assertivas acima contemplam a nossa perspectiva de análise, quando tratamos das cidades históricas portuárias do Recôncavo Baiano, no sentido de que não seria possível fazê-lo sob numa só direção teórico/metodológica.

Neste sentido Luchiari (2001, p. 9) indica que a "[...] razão simbólica, constitutiva do processo de construção da paisagem, desnaturaliza seu significado e revela sua dimensão cultural". Assim é possível perceber nas palavras de Rubens Alves, citado por esta mesma autora que: “[...] O que está em jogo não são os olhos, mas os acordos institucionais que fazem com que vejamos ou não vejamos" (LUCHIARI, 2001, p. 9).

Percebe-se que ambas afirmativas vão ao encontro do que Santos preconizou acima sobre a noção de espaço como um conjunto indissociável de sistemas de objetos e sistemas de ações, podendo-se reconhecer suas categorias analíticas internas. Entre elas, a categoria paisagem.

O espaço é condição, meio e produto. O espaço é condição, meio e produto. Os sistemas técnicos - objetos e formas de fazer - “[...] permitem explicar como, onde, por quem, por que e para que" esse território é usado (SANTOS; SILVEIRA, 2001). Como dizem os autores,

[...] torna-se necessário elaborar uma teoria menor do país e uma teoria menor do lugar, a serem situadas no plano empírico-teórico (portanto, um propósito maior de sugerir uma 'teoria das mediações', na qual a escolha dos fatos e relações relevantes possa estar apoiada. Essa teoria é apoiada pelo uso da "categoria de formação socioespacial" (SANTOS; SILVEIRA, 2001, p. 12).

Entendemos que assim o fez Santos (2008) ao longo do conjunto de sua obra, na sua busca por um método para entender o espaço, sem desvinculá-lo do tempo, gerando um “[...] sistema descritivo e um sistema interpretativo da geografia" (SANTOS, 2008, p. 18), aliando os eventos ao tempo e ao espaço de forma indissociável (SANTOS, 2008). É nesse sentido 
que buscamos compreender o que estamos chamando de "produção simultânea dos territórios". Ou seja, mesmo numa escala previamente definida, não podemos desassociá-la de outras mais abrangentes. É o caso da produção e organização dos territórios das cidades históricas portuárias do Recôncavo Baiano, circunscritas para descrição, análise e explicação na escala local e regional, aliadas à escala nacional e global.

Portanto, coadunamos com a ideia de Santos (2008), quando trata da relação entre o tempo, os eventos e o espaço. Ele admite que:

Se consideramos o mundo como um conjunto de possibilidades, o evento é um veículo de uma ou algumas dessas possibilidades existentes no mundo. Mas o evento também pode ser o vetor das possibilidades existentes numa formação social, isto é, num país, ou numa região, ou num lugar, considerados esse país, essa região, esse lugar como um conjunto circunscrito e mais limitado que o mundo.

O lugar é o depositário final, obrigatório, do evento [...] (SANTOS, 2008, p. 144).

Estamos considerando que "o mundo" na dimensão da assertiva acima é o mesmo considerado na concepção de Tonet (2013, p. 22), que por sua vez, o considera como “[...] um conjunto de partes, articuladas, em constante processo de efetivação e reciprocamente determinadas. Em especial, uma destas partes se destaca como sendo o momento fundante desta totalidade". Para o referido autor, o trabalho é aquela categoria que "[...] ao produzir os bens materiais necessários à existência humana, dá origem ao mundo social [...]” (TONET, 2013, p. 22). Deste modo, ainda segundo Tonet (2013):

[...] mundo significa, em primeiro e fundamental lugar, o intercâmbio dos homens com a natureza, ou seja, as operações necessárias à transformação da natureza para produzir os bens materiais necessários à existência humana. Isto implica um determinado desenvolvimento das forças produtivas - dos instrumentos de produção e dos próprios indivíduos - e determinadas relações sociais que se estabelecem no processo de trabalho. Da natureza do trabalho se segue que ele não só produz os bens materiais, isto é, a realidade objetiva, mas também os próprios seres humanos, isto é a realidade subjetiva. Ao transformar a natureza, os homens também se transformam a si mesmos. Evidentemente, o mundo não é constituído apenas pelo trabalho, mas também por muitas outras dimensões. Todas elas, porém, embora tenham uma especificidade própria e uma autonomia - relativa - tem sua raiz no trabalho (TONET, 2013, p. 22).

A concepção de "mundo" acima, no nosso entendimento, vai ao encontro do que Santos $(2008$, p. 22) busca para analisar e compreender a realidade do meio, “[...] com seus 
diversos conteúdos em artifício e a complementaridade entre uma tecnosfera e uma psicosfera". A divisão social e territorial do trabalho, expressa na materialidade produzida e reproduzida nos territórios em diferentes partes do planeta, talvez seja o exemplo mais eloquente dos processos anteriormente descritos.

Tendo em vista o exposto e considerando os objetivos da nossa pesquisa, buscamos definir no amplo universo teórico/metodológico da ciência geográfica caminhos que, no nosso entendimento, conseguem concatenar as dimensões metodológicas vistas anteriormente, aliados à dimensão da Geografia Histórica Urbana.

Como já dissemos, o conceito de território é aqui visto na perspectiva miltoniana, no sentido da percepção de como os agentes sociais usaram o território em diferentes momentos históricos. Coadunamos com a ideia segundo a qual “[...] certas regiões são, num dado momento histórico, mais utilizadas e, em outro, o são menos. Por isso cada região não acolhe igualmente as modernizações nem seus atores dinâmicos, cristalizando usos antigos e aguardando novas racionalidades" (SANTOS, 2001, p. 13). Entendemos que esta perspectiva se aplica na escala regional do Recôncavo Baiano quando a referenciamos em relação à escala nacional e também nas escalas inter-regional e intra-regional.

Portanto, os conceitos de região e de rede urbana também norteiam a pesquisa. No caso da região, estamos considerando na perspectiva de Graça Filho (2009), como parte ou unidade de um todo ou conjunto coerente, cuja delimitação abrigará uma unidade específica, que poderá estar na intersecção de conjuntos diferentes ou não. Ou seja, caminhamos no sentido clássico da definição de uma região como uma parte de um todo, com uma especificidade que a distingue do espaço contíguo. Assim, ainda segundo este o autor, “[...] os elementos que tornam uma região exclusiva podem estar abrigados em conjuntos diversos, conforme a temática a ser estudada" (GRAÇA FILHO, 2009, p. 11). No nosso caso, uma das características que distingue o Recôncavo das demais regiões da Bahia, é o patrimônio edificado, com suas similaridades de estilos arquitetônicos e concomitância temporal no processo de criação/construção de seus edifícios.

No caso da rede urbana, estamos a considerando na perspectiva de (ANDRADE, 2013), como um conjunto de cidades que se constituíram em nós de uma rede articulada desde o século XVIII, cujas características principais são: "a gênese dos núcleos urbanos", principalmente a das cinco primeiras vilas criadas entre o final do século XVII (1693/1697 Jaguaripe, Cachoeira, São Francisco do Conde) e a primeira metade do século XVIII (Maragogipe - 1724 e Santo Amaro - 1727); as funções comuns que desempenhavam, 
conferindo-lhes uma centralidade regional (político-administrativa, judiciária, comercial e religiosa); "a dependência de determinados produtos", tanto para a exportação, como para o consumo interno; "o sítio urbano" das cinco primeiras vilas criadas na região, que guardavam similaridades devido à aproximação funcional dos antigos povoados que lhes deram origem; "a paisagem urbana", cujas características comuns são marcadas pela predominância do urbanismo colonial português; "a ampliação do número de centros de rede", como foi o caso do crescimento de outros núcleos de povoamento, como as sedes de freguesias e pousos com centros comerciais, a exemplo de Nazaré e São Felix (elevadas à condição de vila no século XIX), entretanto, com características urbanas similares às cinco primeiras; "o padrão espacial de rede", cujo padrão dendrítico era predominante, mas não exclusivo na região, com domínio de Salvador sobre o território regional; "o papel dos diferentes agentes sociais no processo produtivo", com a identificação, principalmente, de dois grupos pela constituição e dinâmica da rede urbana: os funcionários da Coroa, a Igreja e os grandes produtores rurais (agentes hegemônicos) e os comerciantes, mascates, roceiros, escravos, prestadores de serviços diversos etc. (agentes secundários, mas com uma ação mais pulverizada e de maior abrangência regional); e "as articulações com os espaços exteriores à rede" (ANDRADE, 2013, p. 279-281).

O espaço aqui é visto como resultado da interação das práticas sociais, no qual fica registrado parte da cultura material e simbólica da sociedade que com ele interagiu, transformando-o ou conservando-o como elo de sua evolução, memória e identidade. Portanto, corroboramos com a ideia de Gomes (1996), segundo a qual a Geografia se preocupa com as razões que explicam a disposição das coisas no espaço e as significações e consequências dessa ordem espacial.

Contudo, não podemos esquecer que, a interação entre sociedade e espaço acontece num tempo histórico. Assim, para efeito de análise tanto do geógrafo como do historiador, há a necessidade de um recorte espacial e temporal ou de uma periodização. Corroboramos com a ideia segundo a qual a variável "tempo" é fundamental para o geógrafo, assim como a variável "espaço" é para o historiador. Cada um determinando o espaço e o tempo de sua narrativa (CERTAU, 1982).

Nesse sentido Pires (2008) nos informa sobre a importância da perspectiva teóricometodológica braudeliana, cujas temporalidades histórico-sociais são classificadas em três escalas hierárquicas, onde tempo o histórico e o processo histórico são concebidos sob vários ângulos e temporalidades imbricadas: 
1. Tempo de curta duração ou dos acontecimentos, geralmente vinculado aos ritmos consuetudinários (do cotidiano), temporalidade da qual se ocupa o jornalista, o cronista ou advogado, trata-se do tempo das estruturas do cotidiano; 2. Tempo de média duração ou das estruturas econômicas, constitui a temporalidade das condições conjunturais a que se submetem as relações econômicas, sociais (tempo das gerações humanas), políticas e culturais, também chamadas de condições objetivas; 3 . Tempo de longa duração ou da geografia, também chamada de temporalidades lentas, centenárias, as que estruturam a história das civilizações, ou as que se submetem à escala geológica dos acontecimentos (PIRES, 2008, p. 12).

Dentro desta perspectiva braudeliana, Vasconcelos (2009) examina as cidades na "longa duração", “centenárias". Propõe dois conceitos para tal: o de "períodos densos" e o de "hiatos temporais". O nosso caso se enquadra no que este autor compreende como período denso. Segundo o mesmo

Uma das maiores dificuldades no exame das transformações espaciais, numa opção pela longa duração, é a relação entre os longos períodos, nos quais predominam as questões do cotidiano, e os momentos ou períodos que saem da rotina, e nos quais ocorrem eventos mais significativos, que ocasionam transformações na sociedade urbana, assim como nas funções, nas estruturas e nas formas especiais.

Esses períodos, embora possam ser de curta duração, eu proponho que sejam chamados de "períodos densos", porque representam momentos de grande intensidade, de importantes transformações que extrapolam o cotidiano, mas que não seriam ainda momentos de ruptura, que colocam a sociedade urbana (ou a mais ampla) diante de uma nova realidade ou de uma nova ordem" (VASCONCELOS, 2009, p. 148).

Podemos citar como exemplo de período denso, na concepção do autor acima referido, as batalhas para expulsão das tropas portuguesas no Recôncavo Baiano, no processo de consolidação da Independência do Brasil, na Bahia, no ano de 1823. Ainda dentro do período do nosso recorte temporal ocorreram grandes mudanças de ordem social e tecnológica - nos anos de 1823, 1850, 1888, 1889, que influenciaram sobremaneira o conjunto do funcionamento da sociedade urbana (funções, estruturas e formas) nos moldes do que Vasconcelos (2009, p. 148) considerou acima, mas não chegou a colocar essa mesma sociedade diante de uma nova realidade ou de uma nova ordem.

Entretanto, para Vasconcelos (2002), alguns cuidados devem ser observados:

[...] em primeiro lugar, num trabalho de longa duração a quantidade de eventos é enorme, e tanto o geógrafo como o historiador precisam fazer escolhas: daí a importância do que é fundamental, do que é original, do que é estruturante, do que transforma a cidade. Tanto são mais importantes alguns 
momentos, quanto determinados espaços em que ocorreram os eventos e as transformações (VASCONCELOS, 2002, p. 20).

É nesse sentido que nossa pesquisa caminha, pois estamos trabalhando com descrição, análise e explicação dos elementos da paisagem urbana de várias cidades numa escala local/regional, num período definido. Associamos tempo e espaço ao processo socioeconômico de formação da região, que por sua vez, está associada à formação do país e deste ao mundo.

O resultado de tudo isso, derivou na escolha do patrimônio urbano/edificado, suas similaridades e especificidades; a concomitância temporal no processo de sua construção, tanto do ponto de vista da escala local dos centros históricos das sete cidades pesquisadas, assim como do ponto de vista em escala regional, sob a perspectiva da compreensão do conjunto sobre as referidas cidades; suas permanências e as transformações sofridas na atualidade.

Neste tópico fizemos um apanhado teórico-conceitual e metodológico buscando uma coerência lógica entre os conceitos e categorias de análise que mais se adequam ao método proposto e se imbricam no processo de pesquisa do objeto, tendo em vista a dialética entre teoria e empiria.

Portanto, o conceito de paisagem com suas categorias derivadas de paisagem urbana e paisagem cultural; o conceito de patrimônio, na sua dimensão material na categoria de patrimônio urbano/edificado e o conceito de território, na sua categoria de território usado, são basilares para que, através da investigação e análise histórica numa perspectiva de uma Geografia contemporânea de base teórica oriunda de autores nacionais, consigamos investigar, analisar e interpretar o objeto de pesquisa, numa espécie de fusão dialética entre métodos que perpassam por diferentes correntes filosóficas de entendimento do espaço, sem, contudo, nos determos numa direção única.

Como se trata de um trabalho na área da Geografia Histórica Urbana, que discute a questão do uso do território em escala local e regional, onde categorias como a paisagem e o patrimônio é o pano de fundo da análise, não poderíamos deixar de "beber da fonte" do urbanismo e da história urbana e buscar nessa interdisciplinaridade uma maior consistência para a nossa pesquisa. Portanto, o embasamento sobre o urbanismo lusitano, no que se refere a forma da cidade de origem portuguesa foi fundamental para o entendimento das cidades 
pesquisadas. Assim como a história urbana das mesmas, suas nuanças no contexto da formação da rede urbana regional e seu patrimônio cultural.

No próximo tópico discutimos os procedimentos de pesquisa que permearam o processo de análise do objeto.

\subsection{PROCEDIMENTOS DE PESQUISA}

A descrição, análise e interpretação do nosso objeto de pesquisa se realizam com base na pesquisa bibliográfica, iconográfica e, especialmente, através da observação de fotografias dos conjuntos urbanísticos, assim como da observação direta dos monumentos isolados em trabalho de campo e extraídas do Inventário ${ }^{4}$ do IPAC de 1982, anteriormente referido, além de outras fontes.

Trata-se de imagens que reúnem um painel com fotos panorâmicas dos centros históricos das referidas cidades, além de fotos de monumentos isolados. Nossa intenção é a de reuni-las com o objetivo de observarmos de forma conjunta e daí detectarmos as similaridades de padrões arquitetônicos e concomitância temporal, fatores que subsidiarão nossa tese. $\mathrm{Na}$ página eletrônica do IPAC encontramos informações ${ }^{5}$ importantes sobre o referido documento ${ }^{6}$.

\footnotetext{
${ }^{4} \mathrm{O}$ inventário acima referido foi realizado com apoio financeiro do Governo Federal, através do Programa das Cidades Históricas do Nordeste e com apoio também da Companhia de Desenvolvimento da Região Metropolitana de Salvador (CONDER). A execução ficou a cargo do Instituto do Patrimônio Artístico e Cultural da Bahia (IPAC), com a colaboração do Instituto do Patrimônio Histórico e Artístico Nacional (IPHAN); da Fundação do Patrimônio Artístico e Cultural da Bahia (FPACBa); do Centro de Estudos de Arquitetura Baiana $(\mathrm{CEAB})$ e do Instituto Brasileiro de Geografia e Estatística (IBGE). Como se vê, trata-se de um importantíssimo estudo, que teve vários agentes estatais envolvidos, especialmente em nível federal e estadual.

${ }^{5}$ O Inventário de Proteção do Acervo Cultural da Bahia, também conhecido como IPAC/SIC, foi executado na década de setenta do século XX, sob coordenação do arquiteto Paulo Ormindo de Azevedo, através da Secretaria da Indústria e Comércio/Coordenação de Fomento ao Turismo, Governo do Estado da Bahia. Constituiu-se como iniciativa pioneira no Brasil, utilizando como base o sistema desenvolvido pelo Conselho de Cooperação Cultural da Europa para o fichamento de monumentos, o qual era usado por várias nações. O Inventário baiano aprimorou o método do referido Conselho, definindo sua própria metodologia de levantamento e avaliação dos bens culturais. Trata-se de um inventário sistemático que inclui não apenas os bens tombados, mas também monumentos que à época não eram reconhecidos como tal, mas já eram considerados como ameaçados. No IPAC/SIC, os monumentos foram agrupados segundo grandes categorias:
}

1. Arquitetura religiosa assistencial ou funerária;

2. Arquitetura militar;

3. Arquitetura civil de função pública;

4. Arquitetura civil de função privada; 
Bertrand (2014) assevera o seguinte sobre a relação entre o Geógrafo pesquisador e o uso da fotografia como procedimento de pesquisa:

Em Geografia, assim como em Fotografia, há de início o olhar. Mais precisamente olhares múltiplos, cruzados, que varrem e exploram o visível, e o interrogam no anseio de tudo abraçar. O real torna-se uma paisagem. Em seguida vem o momento do ato fotográfico. Ele é uma escolha. Escolha do melhor ângulo de visão, que irá relatar, se não a realidade, pelo menos a nossa percepção num dado momento. De modo mais ou menos explícito, relatará aquilo que queremos demonstrar. E mediante uma dupla objetiva primeiramente a do olho do pesquisador; depois, a do aparelho fotográfico. A fotografia capta, enquadra e fixa uma imagem. Ela jamais é neutra (BERTRAND, 2014, p. 6).

Concordamos com assertiva acima, pois por trás de uma imagem fixa, existem várias categorias basilares para a interpretação em Geografia, tais como a forma, o processo, a estrutura e a função, embutida numa paisagem, que jamais seria possível apreendê-la apenas pela fotografia. Entretanto, por outro lado concordamos que a imagem, quando analisada e precedida por uma análise geohistórica bem estruturada do ponto de vista científico, pode nos oferecer pistas importantíssimas na interpretação das paisagens.

Neste sentido, corroboramos com a visão de Costa (2014), para quem,

[...] "Consciência, imagem, imaginário e imaginação perfazem o domínio dos sentidos, da significação e da percepção das coisas do mundo" [...] Então, a paisagem, enquanto expressão concreta da estrutura social, produz e é produzida por estes sentidos que também forjam imagens e imaginários da memória (COSTA, 2014, p. 86).

\footnotetext{
5. Arquitetura industrial ou agrícola.

Lançado o primeiro volume em 1975, o Inventário passou a ser um instrumento técnico-administrativo de referência para a valorização e preservação do patrimônio cultural baiano, destinado a facilitar a tarefa de preservação no Estado. Sete volumes compõe o Inventário de Proteção do Acervo Cultural da Bahia:

Volume I - Monumentos do Município do Salvador;

Volume II - Monumentos e Sítios do Recôncavo, I Parte;

Volume III - Monumentos e Sítios do Recôncavo, II Parte;

Volume IV - Monumentos e Sítios da Serra Geral e ChapadaDiamantina;

Volume V - Monumentos e Sítios do Litoral Sul;

Volume VI - Monumentos e Sítios das Mesorregiões Nordeste, Vale SanFranciscano e Extremo Oeste Baianos; Volume VII - Monumentos da Região Pastoril Disponível em: <http://patrimonio.ipac.ba.gov.br/documentacaoe-memoria/ipac-sic/ >. Acesso em 05/09/2014, grifo nosso).
}

\footnotetext{
${ }^{6}$ Os volumes impressos do Inventário de proteção do acervo cultural; monumentos e sítios do Recôncavo (I parte. $2^{\text {a }}$ ed, v.2, de 1982; II parte. $1^{\text {a }}$ ed. v. 3), também de 1982; foram utilizados como referência teórica e empírica em todo o processo de pesquisa.
} 
A assertiva acima vai ao encontro do que preconiza Bertrand (2014, p. 6), quando afirma que "[...] fotografar é um ato de criação e a imagem fotográfica é um artefato - detalhe que costumamos esquecer, ou minimizamos, quando utilizando-a como documento, desejamos comenta-la”. O referido autor nos indica que a fotografia deve ser usada com "espírito crítico" e "preocupação", pois se trata de um documento complexo, fruto do olhar e não apenas "a imagem de um objeto; é também o espelho do fotógrafo". Ou seja, da percepção do sujeito em relação ao objeto.

Nesse sentido, em nosso procedimento de pesquisa a iconografia - fotografias de época e atuais, além de imagens pictóricas - foram usadas como elementos fundamentais de apoio ao texto. Porém, com o cuidado de não extrapolar nas interpretações das mesmas, principalmente, as fotografias por nós elaboradas. No caso das fotos e imagens utilizadas como fontes secundárias, especialmente àquelas oriundas do Inventário do IPAC, as descrições foram basicamente reproduzidas do referido documento, seguidas de análise crítica, contextualizadas com os objetivos de pesquisa. Escolhemos aquelas fotos que para nós, melhor representaram a narrativa espacial e o uso do espaço urbano e regional. Daí partimos para a nossa narrativa.

Para Loizos (2008, p. 138) a imagem “[...] oferece um registro restrito, mais poderoso das ações temporais e dos acontecimentos reais - concretos, materiais". Considera que a pesquisa social, que contempla complexas questões teóricas e abstratas pode empregar a informação visual como dado primário, embora os registros fotográficos não possuam a tridimensionalidade da realidade. Eles são bidimensionais, pois se apresentam de forma simplificada, dependente, reduzida das realidades que os originaram. É uma escala secundária de análise, por isso os problemas aparecem, já que nada mais são “[...] que representações, ou traços, de um complexo maior de ações passadas" (LOIZOS, 2008, p. 138).

Escolhemos duas dimensões de análise iconográfica para o patrimônio edificado nas cidades pesquisadas: os monumentos isolados e os conjuntos urbanísticos. A primeira dimensão se constitui de duas categorias de edifícios: os de função pública e administrativa (Casas de Câmara e Cadeia e Paços Municipais); e os edifícios de função religiosa (Igrejas Matrizes). Esses edifícios se destacam na paisagem urbana e foram erigidos antes do período estipulado do nosso recorte temporal. A segunda dimensão de análise inclui os conjuntos de edifícios e arruamentos residenciais erguidos entre 1823 e 1889.

O nosso trabalho de campo serviu de base para obtermos uma ideia da atual situação dos sítios e monumentos pesquisados, - muito embora este não seja o objetivo principal da 
pesquisa, mas torna-se de fundamental importância para o que propomos como produto da mesma, - no que tange ao estado de conservação -, suas transformações e permanências.

Como a pesquisa tem como foco o patrimônio urbano, aqueles edifícios que representaram a materialidade da cultura e da economia açucareira que se situam ou situavamse na zona rural, ficaram de fora da nossa análise. É o caso de muitos edifícios de "casas grandes" de antigos engenhos espalhadas por fazendas em todo o Recôncavo.

Feitas as devidas premissas teórico-metodológicas anteriormente vistas, no capítulo dois e três, no próximo capítulo tratamos da formação territorial e política do Recôncavo Baiano no contexto de sua formação socioespacial, que é a categoria da tese e que se dá na escala nacional. Guardadas as devidas proporções da formação socioespacial e socioeconômica na dimensão escalar das regiões, no processo de consolidação do território brasileiro. Portanto, para compreender a produção do espaço das cidades históricas portuárias do Recôncavo Baiano, se faz necessária a compreensão inicial do contexto geohistórico no qual se formaram, em sua totalidade. É o que veremos a seguir. 


\section{4 - O RECÔNCAVO BAIANO NO CONTEXTO GEOHISTÓRICO DA FORMAÇÃO TERRITORIAL E POLÍTICA DO BRASIL}

Para compreendermos a importância do Recôncavo Baiano no contexto nacional, se faz necessário um entendimento sobre os princípios e as bases da formação territorial e política do Brasil. Nesse sentido é importante estarmos atentos aos agentes sociais que interviram na produção do espaço nacional e de suas regiões.

A história do Recôncavo Baiano não pode ser desvinculada da história econômica mundial. A relação do seu conjunto de cidades, capitaneadas por Salvador, em escala nacional e internacional, não pode ser desvinculada da história do Brasil. Por isso se faz necessário falar dessa região, relacionando-a à formação do território nacional.

A produção espacial do mundo urbano, na dimensão de sua cultura material, especialmente do patrimônio edificado nas cidades coloniais do Recôncavo Baiano, está atrelada à sua relação de rede em várias escalas, que se deu em concomitância e complementaridade ao longo de sua estruturação.

Os primeiros pontos nodais da rede surgiram a partir de fixos erigidos nos núcleos de povoamento (engenhos, capelas, freguesias, povoados) no século XVI, estruturando-se, ainda que de forma incipiente, entre o final dos seiscentos e as três primeiras décadas do século XVIII. Neste período foram fundadas/erigidas as cinco primeiras vilas da região entre 1697 e 1727.

O processo de colonização do Brasil tem a princípio um caráter privado, administrado de longe pela Coroa portuguesa que só posteriormente viria a intervir de maneira mais direta através de seus representantes com a implantação de sua representação política e administrativa na própria colônia, adquirindo a Capitania que foi doada a um particular, para ser a sede do Governo Geral na cidade do Salvador (SEI, 2001, p. 24).

$\mathrm{O}$ fato é que as capitanias eram doadas às pessoas de confiança do rei e que as cartas de doação eram muito semelhantes e, dentre as numerosas atribuições, constava da licença de criação de vilas (SEI, 2001, p. 25). Nessas vilas iriam se formar os núcleos de poder local e, posteriormente regional, das áreas que formariam os territórios das cidades mais importantes na formação econômica e político-administrativa do país. 
A ocupação do Brasil ocorreu em caráter de urgência, pois a Coroa portuguesa necessitava defender a colônia da ameaça de outras nações, administrando-a junto a todos os agentes participantes do processo, tais como governantes, bandeirantes, religiosos, aventureiros, boiadeiros, garimpeiros e agricultores, dentre outros. Criou-se então uma estrutura administrativa que impediria os abusos que ocorriam nas capitanias e ao mesmo tempo propiciasse rendimentos à Coroa (SEI, 2001).

Assim, para cumprir o objetivo de estabelecer rotas marítimas e explorar monopólios comerciais, o projeto colonial português conquistou novas áreas e necessitou assegurar o controle das mesmas, através da implantação de feitorias, de fortes, de portos em pontos estratégicos da costa brasileira a partir do século XVI. Daí ser construída uma rede de cidades, na sua maioria “[...] junto ao mar, em baías abrigadas ou na embocadura ou margens de rios navegáveis, com fáceis comunicações para o interior” (TEIXEIRA, 2012, p. 8). Como foi o caso da Baía de Todos os Santos e sua região de entorno, inclusive Salvador, região esta que posteriormente viria ser chamada de Recôncavo Baiano.

A criação de vilas foi a medida adotada para o fim a que se propunha a Coroa portuguesa, que ocorreu paulatinamente até o século XIX. Após a proclamação da Independência do Brasil, com a outorga da Constituição brasileira de 1824, o quadro mudou à medida que era facultado às províncias subdividirem seus territórios, o que antes dependia do poder central. Na antiga Capitania da Bahia, por exemplo, foram criadas 63 vilas entre 1827 e 1889, número superior ao somatório daquelas criadas nos séculos XVI, XVII e XVIII (SEI, 2001).

No final do século XVI, a América Portuguesa já apresentava 18 vilas e quatro áreas de adensamento da colonização: a do Recôncavo Baiano, tendo por centro a cidade de Salvador, sede do governo geral; da capitania de Pernambuco e adjacências, polarizada pela vila de Olinda; as imediações do Rio de Janeiro, onde haviam sido expulsos os agentes de um fluxo colonizador francês; e um conjunto de núcleos meridionais da chamada "ocupação vicentina", a qual apresentava a peculiaridade de uma singular expansão para o interior (expressa na fundação da vila de São Paulo) (MORAIS, 2011).

Morais (2011) quando discute a emancipação dos Estados nacionais no processo de descolonização, chama a atenção para o entendimento sobre a criação dos aparelhos de Estado na era colonial. Segundo ele, a expansão dos impérios europeus resultou em demarcações territoriais que serviram de referência para afirmação de nacionalidades, destacando, neste sentido, o caso paradigmático do Brasil. Daí, segundo o referido autor, 
O Estado territorial gerado no processo de emancipação política não se constituiu como uma dominação em qualquer identidade do tipo étnico ou em outra característica cultural. Interesses eminentemente políticos e econômicos presidiram um processo que não foge do controle de uma elite pouco expressiva em termos populacionais, que construiu um sentido "nacional" a partir do Estado. [...] vale aqui salientar a discrepância entre a pretensão de domínio territorial (o espaço de soberania legítima reivindicado pelo novo Estado) e a porção deste território efetivamente incorporada pelo processo colonizador português (o "território usado", nos termos de Milton Santos) (MORAIS, 2011, p. 52).

A discussão de Morais (2011), acima referida, nos é pertinente numa perspectiva de análise indicada pelo próprio autor sobre a importância de se pensar a geografia histórica do Brasil. Pois a área de jurisdição formal de controle estatal excedia em muito o espaço econômico articulado à economia-mundo, incluindo grandes extensões de fundos territoriais com limites ainda imprecisos (MORAIS, 2011).

Desenvolveu-se daí todo um arcabouço de circunscrições diretamente ligadas à associação entre poder local, regional e metropolitano, que continuaria no Império na relação das lideranças no interior das Províncias e entre estas e o poder centralizador, representado na figura do Imperador. No Brasil republicano o processo ocorreria dessa vez com um pacto federativo extremamente complexo e de difícil gestão das políticas administrativas entre União, Regiões, Estados e Municípios. Teixeira; Andrade (1984) afirmam que,

[...] o maior problema para a compreensão do funcionamento da máquina administrativa colonial brasileira, acontecia em razão da coincidência frequente entre os limites geográficos e as atribuições dessas mesmas divisões. Observe-se ainda que a mesma imprecisão transferiu-se para o período posterior à independência, ficando o Império brasileiro organizado de forma semelhante, salvo algumas modificações (TEIXEIRA; ANDRADE, 1984, p. 28).

Nas palavras de Morais (2011), as elites regionais ciosas da manutenção do domínio de suas áreas imediatas de expansão sustentaram a pretensão de soberania estabelecida no movimento de independência, apoiando o projeto monárquico de manutenção das pretensões territoriais metropolitanas defendidas nos tratados de Madri, Santo Idelfonso e Badajós (MORAIS, 2011).

Portanto, segundo Morais (2011):

[...] Apesar de algumas secessões em âmbitos regionais nas primeiras décadas do novo país, a afirmação do poder estatal caminhou no sentido de 
construção de redes de solidariedade e identidade políticas de alcance nacional que integravam as estruturas e práticas dos poderes locais e regionais então vigentes (MORAIS, 2011, p. 121-122).

Lencione (2003) na obra intitulada "Região e Geografia" menciona o professor Candido Mendes de Almeida que elaborou o Atlas do Império do Brasil, no ano de 1868, destinado à instrução pública no Império, onde

[...] o Brasil aparece dividido, segundo expressão, sob quatro pontos de vista. $\mathrm{O}$ primeiro dizendo respeito ao aspecto administrativo, apresentando as províncias do Império, que por sua vez são organizadas em quatro classes: Setentrionais, Meridionais, Orientais e Ocidentais. O segundo relativo ao poder eclesiástico, com a divisão territorial segundo as dioceses. O terceiro corresponde ao poder judiciário (comarcas); e, por último, segundo os distritos eleitorais. Esses 'quatro pontos de vista' indicam que as divisões concebidas se constituem em esferas do poder sobre o território brasileiro. Do Império e da Igreja. Nesse sentido, as divisões do Império não tem nada de novo, pois a divisão do Brasil desde os tempos do descobrimento fundouse no poder metropolitano - capitanias hereditárias e governos gerais - e no poder eclesiástico (LENCIONE, 2003, p. 98-99).

Percebe-se pelo exposto que desde sempre, no processo de ocupação do espaço geográfico nacional, a sua produção e organização espacial foi sempre acompanhada por uma complexa relação administrativa e de poder político entre os agentes sociais produtores do território brasileiro.

A hierarquia aristocrática, a relação entre os membros da Coroa portuguesa e o consequente favorecimento aos mais afortunados no processo de posse da terra brasileira, geraria uma complexa política oligárquica na formação das primeiras unidades políticoadministrativas da Colônia no interior das Capitanias Hereditárias.

Segundo Santos (2001), mesmo sendo marcantes os fatos históricos ocorridos no Brasil, como a instalação do governo geral em Salvador em 1549; o vice-reinado no Rio de Janeiro, com a transferência da cabeça do Império português em 1808 e a Independência em 1822, tais eventos não foram capazes de criar, no domínio da economia, fluxos verdadeiramente nacionais. Segundo este mesmo autor:

[...] a máquina de Estado servia para preservar e ampliar as fronteiras, manter o regime e a ordem, assegurar a coleta de impostos e, com ajuda da Igreja, unificar a língua. A unidade política e linguística se dava ao mesmo tempo em que as diversas regiões, produzindo para o mercado externo, a este se ligavam praticamente sem intermediário, de modo que sua evolução 
espacial e econômica era ditada por relações quase diretas. Daí a imagem de um vasto arquipélago formado na verdade, por um conjunto de 'penísulas' da Europa (SANTOS, 2001, p. 32).

A cidade do Salvador e o Recôncavo era uma das "penínsulas" acima citadas, considerada por Santos (2001, p. 41) "[...] como a primeira rede urbana estruturada nas Américas".

Um processo de transformação iniciava-se na segunda metade do século XIX, com a mecanização da produção do açúcar, com a instalação de usinas e a mecanização do território, com a instalação da navegação a vapor e, posteriormente com as estradas de ferro, que trouxeram uma maior, mas ainda incipiente integração entre as regiões brasileiras. Segundo Santos (2001, p. 35) “[...] Ás técnicas da máquina circunscritas à produção sucedem as técnicas das máquinas incluídas no território".

Com o desenvolvimento do capitalismo no século XIX a terra passou a ser revalidada no Brasil, sendo criada a Lei das Terras de 1850, com o objetivo de tentar legitimar e regulamentar as propriedades, pois durante o período colonial a terra era doada pela Coroa ou seus representantes, com a exigência de que os beneficiados tivessem capital para explorá-la (TEIXEIRA; ANDRADE, 1984). Tal fato explica a atual situação de desequilíbrio fundiário do país, pois naquele momento muitos proprietários de pequenas e médias áreas de terras, não tiveram condições financeiras para oficializar suas supostas propriedades, já que muitas delas era fruto da audácia aventureira dos que não tinham o que herdar. Portanto foram conquistadas na base da invasão de terras devolutas, adentrando o território em direção ao seu interior, ao "Sertão".

No Brasil colônia, a terra equivalia a prestígio social e poder econômico. Mais adiante, no século XIX, “[...] a terra passou a significar basicamente poder econômico, e em sua decorrência vinha o prestígio social” (TEIXEIRA; ANDRADE, 1984 p. 43).

O processo descrito anteriormente nos fornece algumas pistas para o entendimento sobre a organização fundiária brasileira, demonstrando que até os nossos dias, permanecem ainda reminiscências das relações políticas entre os grandes proprietários rurais e suas representações político-partidárias.

Ainda segundo as autoras supracitadas,

[...] é possível que temas como autonomia provincial, federalismo, centralização e autoritarismo não fossem plenamente compreendidos pelos homens que ocupavam certos cargos administrativos e muito menos pela 
população em geral, pois grande parte dela era composta de escravos e pequenos lavradores. Para essa população, o comportamento mais usual era o que a ligava à posição dos chefes políticos, homens de destaque por suas posses, laços de família e cargos que ocupavam (TEIXEIRA; ANDRADE, 1984, p. 37).

É nessa mesma perspectiva de visão da política e da administração pública brasileira e seus rebatimentos regionais, relacionada ao processo histórico de formação das classes sociais no Brasil, que Brandão vai ao encontro da assertiva acima, afirmando que:

Torna-se difícil mensurar a correlação de forças políticas postas no bloco então no poder, de natureza oligárquico-mercantilista, tendo "camadas baixas" difusas, deserdadas e com fratura orgânica na falta de propriedade e de direitos. De maneira totalmente diversa sujeitos/protagonistas da elite, na situação de subdesenvolvimento, as massas subalternas, recorrentemente se tornando apenas "objeto dos eventos históricos". Nesse contexto de apatia e desorganização política dos de baixo, uma massa informe, torna-se cristalizada a reprodução de um certo tipo de dominação interna, com desigualdades estruturadas, sistemáticas e reprodutíveis de poder. Deve-se ficar claro que não se trata apenas de privilégios, mas da própria forma estrutural em que se constituíram e reproduziram as classes na situação de hegemonia em um ambiente de atraso estrutural e subdesenvolvimento (BRANDÃO; PEDRÃO, 2007, p. 86).

Esse processo revela o nível das relações sociais e a origem da política oligárquica rural brasileira, que muito influenciou na configuração do território nacional, nas mais variadas escalas espaciais de suas circunscrições. A origem e desenvolvimento dessas circunscrições têm a ver com espaços de delimitação política e administrativa do território, oriundos das relações políticas locais e regionais, baseado na posse da terra e do poder dela advindo. No período republicano, por exemplo, as antigas províncias foram elevadas à categoria de estado. Também nesse período foi abolida a categoria de freguesia, contudo o complexo processo administrativo do país continuaria no interior do seu território.

O exercício da administração pública muitas vezes tornou-se difícil no complexo uso de suas atribuições, principalmente num país onde a influência estatal, eclesiástica e jurídica sempre acompanhou o processo de gênese e desenvolvimento de suas unidades político/administrativas. Esse fato repercutiu de forma direta na implantação das instituições, especialmente no mundo urbano que se expandia no país.

Masi (2014) comenta sobre a dinâmica da relação entre cidade e campo no Brasil. Segundo o referido autor: 
Foi apenas com as profundas mudanças determinadas pela chegada da corte no Rio de Janeiro (1808) e, sobretudo, pela abolição da escravidão (1888) e pela consequente chegada dos imigrantes, que as instituições burocráticas, as profissões livres e as organizações políticas começaram a reclamar para si um espaço autônomo em relação ao modelo familiarista, ao mesmo tempo em que o peso da cidade começava a prevalecer sobre o do campo em termos demográficos, administrativos e de consumo (MASI, 2014, p. 658).

O processo de sobreposição da vida urbana sobre o campo no Brasil entre meados do século XIX e meados do século XX, foi atribuído, principalmente a alguns fatores, mas, principalmente, à abolição oficial do trabalho forçado (escravidão) e a consequente substituição pelo trabalho assalariado dos imigrantes, que competia com o escravista, mas depois o superou. Nessa época também prevaleceram a hegemonia política e econômica do centro e do sul do país sobre o norte; a cidade sobre o campo; a produção do café sobre a do açúcar; a influência dos intelectuais sobre os políticos; dos bancos sobre os agiotas; as sociedades anônimas sobre as empresas familiares (MASI, 2014, p. 658).

No próximo tópico tratamos da questão regional, no sentido de entendê-la na perspectiva das dimensões territoriais do Recôncavo Baiano ao longo de sua história, que está relacionada à questão da formação de seus primeiros núcleos de povoamento e a gênese dos primeiros núcleos urbanos.

\subsection{O RECÔNCAVO BAIANO E A QUESTÃO REGIONAL}

Buscamos o entendimento de parte da expressão cultural de uma sociedade numa escala local e regional, através da sua dimensão urbana, expressa no seu patrimônio edificado. Portanto, a região aqui é vista como um conceito intelectualmente produzido (CORRÊA, 1986), discutida num sentido mais abrangente que ultrapassa uma delimitação territorial de base estritamente política e fisiográfica. Ela é concebida também por sua territorialidade cultural, sua abrangência simbólica e suas similaridades materiais no âmbito da totalidade do espaço geográfico.

A questão da definição de um limite regional preciso para o Recôncavo Baiano é bastante complexa. São várias as discussões a respeito de uma delimitação e de uma definição do seu espaço regional. Sua abrangência territorial; o grau de influência inter e intraregional e 
interurbano de suas cidades; suas sub-regiões; sua contiguidade espacial e cultural etc.. Enfim, são muitas e diversificadas as variáveis que o diferenciam de outras regiões, entretanto, é difícil circunscrevê-la devido à abrangência simbólica que exerce sobre diversas áreas dos municípios circunvizinhos.

Existe uma dificuldade histórica em estabelecer um viés de recorte regional para o Recôncavo Baiano. É necessário relativizar este conceito (o de região) para esta área, pois que não é tarefa fácil definir os limites da região, apesar da pretensa unidade regional. Andrade (2013, p. 49) entende o conceito, com base em Roberto Lobato Corrêa, como um “[...] recorte espacial com relativa homogeneidade interna que a diferencia do entorno, produzindo uma identidade interior [...]", tenha um sentido relativo para o Recôncavo Baiano. Concordamos com o referido autor, quando afirma que “[...] esses recortes rígidos atendem apenas aos domínios da geopolítica e do planejamento territorial”. Entretanto, para uma pesquisa de cunho geohistórico, esses limites tornam-se bem mais difíceis de delimitá-los.

Para Santos (1959):

O Recôncavo foi sempre mais um conceito histórico que mesmo uma unidade fisiográfica. [...] A unidade do Recôncavo provinha e provém das relações mantidas de longa data entre suas várias porções com vocação e atividade diferentes (Recôncavo canavieiro, Recôncavo fumageiro, Recôncavo mandioqueiro e da cerâmica, sem falar nas zonas pesqueiras beirando mais proximamente o litoral, e do Recôncavo ao norte da cidade, servindo-a de lenha e carvão vegetal) (SANTOS, 1959, p. 62-65).

Nessa definição de Santos podemos perceber as várias sub-regiões oriundas de diversas atividades agropastoris. A cidade a que o autor se refere acima é Salvador. Ele considerou que a capital presidia e coordenava as funções diretoras do espaço no Recôncavo. Devido ao alargamento das relações da cidade com toda essa área, permitiu incluí-la na região, "pois o conteúdo se alargava" (SANTOS, 1959).

As diferentes atividades contribuíam para um relacionamento interregional mais amplo, de complementariedade com outras regiões do estado.

Mattoso (1992), numa visão mais fisiográfica definiu o Recôncavo da seguinte forma:

Recôncavo significa fundo de baía. Mas o Recôncavo baiano abrange todas as terras adjacentes, ilhas e ilhotas, bem para além das praias, vales, várzeas e planaltos próximos ao mar: uma orla de quase trezentos quilômetros torna bastante fácil a circulação, ainda mais porque numerosos rios se juntam na baía por amplos braços navegáveis. [...] O Recôncavo é, assim, antes de 
tudo, uma terra oceânica: suas áreas agrícolas encontram-se em estreita dependência das águas salgadas e dos rios marinhos (MATTOSO, 1992, p. $51-54)$.

Nesta proposição a autora se limita aos aspectos naturais que, embora limitadores da abrangência cultural da região foram fundamentais para o entendimento da importância da sua geografia física, aspecto crucial no processo da relação sociedade/natureza daquela área.

O quadro natural dentro do que Pedrão (2007) assinala como limites administrativos do Recôncavo Baiano entre os séculos XVIII e XIX podem ser resumidos em duas dimensões, no que tange aos seus aspectos estruturais geológicos e geomorfológicos. Ou seja, as dimensões que,

[...] encobrem uma complexa realidade histórica, que sugere distinguir uma parte norte, que compreende municípios que se confundem com a região do Agreste e que estão ao norte da falha geológica da bacia do Rio Jacuípe; e uma parte sul, que compõe a meia lua em torno da Baía de Todos os Santos e cuja ponta sul é o estuário do Rio Jaguaribe. Além disso, é uma região em quatro patamares de altura: os manguezais, a planície de Santo Amaro e Cachoeira e a "mata fina", que são os "tabuleiros" que vão da parte alta dos municípios que estão entre as bacias dos rios Paraguaçu, Subaé e Jacuípe (PEDRÃO, 2007, p. 2).

Brandão articulou os aspectos naturais ao humano definindo a área da seguinte maneira:

O Recôncavo nunca fora, seja quanto ao substrato ambiental, ou a ocupação econômica, uma área uniforme, mas antes um complexo de sub-áreas especializadas. A produção do açúcar jamais subsistiu só, mas integrada a um complexo de atividades espacialmente diferenciadas (BRANDÃO, 1997, p. 30).

$\mathrm{Na}$ assertiva acima percebemos que a visão de Brandão é complementar à de Santos no sentido de que a região do Recôncavo é um complexo de várias sub-regiões que se complementam e se articulam, principalmente no que concerne às atividades de suporte da cadeia produtiva regional.

Barickmam (2003) considerou em sua obra a região a partir do que o governo estadual considerava na época (1990), ou seja, uma área de cerca de $10.400 \mathrm{Km}^{2}$ em torno da Bahia de Todos os Santos. 
O Recôncavo Baiano é reconhecido na historiografia sobre as regiões brasileiras como aquela que exerceu papel fundamental no Império colonial português, pois nela se formou uma importante rede de cidades, percussoras do movimento de interiorização da colônia. Essa rede de cidades, além de outras funções, articulava os fluxos de pessoas e mercadorias entre a capital da colônia - Salvador - e os sertões do Brasil. Todo esse processo exerceu forte influência econômica, política e cultural na formação da identidade do estado da Bahia desde os tempos do Brasil colônia. Passou por períodos dinâmicos e de ostracismo econômico ao longo da sua história, formando a primeira e mais importante rede urbana do Brasil (SANTOS, 1959).

O único município por nós estudado que não pertence ao Recôncavo Baiano na última regionalização proposta pelo Governo do estado da Bahia em 2007, através da Secretaria de Planejamento (SEPLANTEC), que adota o critério de Territórios de Identidade, é Jaguaripe, considerado atualmente pertencente ao Território de Identidade Baixo Sul. Os demais são incluídos no Território de Identidade Recôncavo. Entretanto, em outras regionalizações, o município de Jaguaripe já foi considerado pertencente a essa região.

Concordamos como a assertiva de Serpa (2015, p. 11), segundo a qual, a construção de uma abordagem sociocultural para o conceito de região em Geografia, tem como pressuposto de partida para justifica-la, o "[...] fato da íntima interligação dos fatos econômicos com os sistemas de valor, tradições e organização social, em suma, com os fatos sociais e culturais, em qualquer recorte, inclusive no regional".

Neste sentido e tendo em vista o exposto até aqui, consideramos o Recôncavo como um grande "caldeirão cultural" que se destaca no território baiano pela sua geografia e pela sua história no processo de formação de sua identidade regional. Especialmente na sua "vida de relações" e dinâmica espacial de complementaridade entre suas cidades portuárias, marcada por sua peculiar paisagem urbana, as similaridades do seu patrimônio edificado, tendo no conjunto arquitetônico uma de suas marcas mais visíveis e contundentes.

Ainda segundo Serpa (2015):

A questão das identidades regionais, enquanto manifestações específicas de certo tipo de identidades territoriais, mantém-se insuficientemente exploradas na Geografia. No entanto, parece consensual que identidades se constroem sempre a partir do reconhecimento de uma alteridade. Isso, no entanto, só pode acontecer onde há interações, transações, relações ou contatos entre grupos (SERPA, 2015, p. 15). 
Corroboramos com a assertiva acima, pois, no nosso caso, a região do Recôncavo Baiano, atualmente denominada Território de Identidade Recôncavo, desde a formação dos seus primeiros núcleos de povoamento, sempre esteve em conexão com outras regiões em várias escalas, já que de certa forma complementava e mediava espacialmente a relação entre Salvador e o interior da colônia. O sertão.

Como já mencionado anteriormente, se faz necessário enfatizar que quando falamos da história da dinâmica regional do Recôncavo, não podemos esquecer que a configuração espacial da mesma compreendia outros municípios e se estandia até Salvador.

Com a regionalização do estado da Bahia em territórios de identidade (2007), o Recôncavo passa a abranger um novo conjunto de municípios, aproximando-se da sua regionalização histórica, mas sem contemplá-la efetivamente no sentido de seus laços de identidade imateriais e territoriais. No entanto, entendemos que historicamente esssas regionalizações sempre oscilaram na metodologia para a circunscrição de seus territórios. É o que veremos aseguir, a partir de uma sequência de mapas que ilustram muito bem nossa assertiva acima.

Na Figura 4.1.1, a seguir, podemos visualizar um fragmento de mapa do Recôncavo Baiano do século XVIII (1758), segundo pesquisa documental de Andrade (2013), no qual são referenciadas as áreas onde se encontram as atuais cidades de Salvador (denominada na época Cidade da Bahia), São Francisco do Conde, Santo Amaro, Cachoeira, Maragogipe e Jaguaripe. 


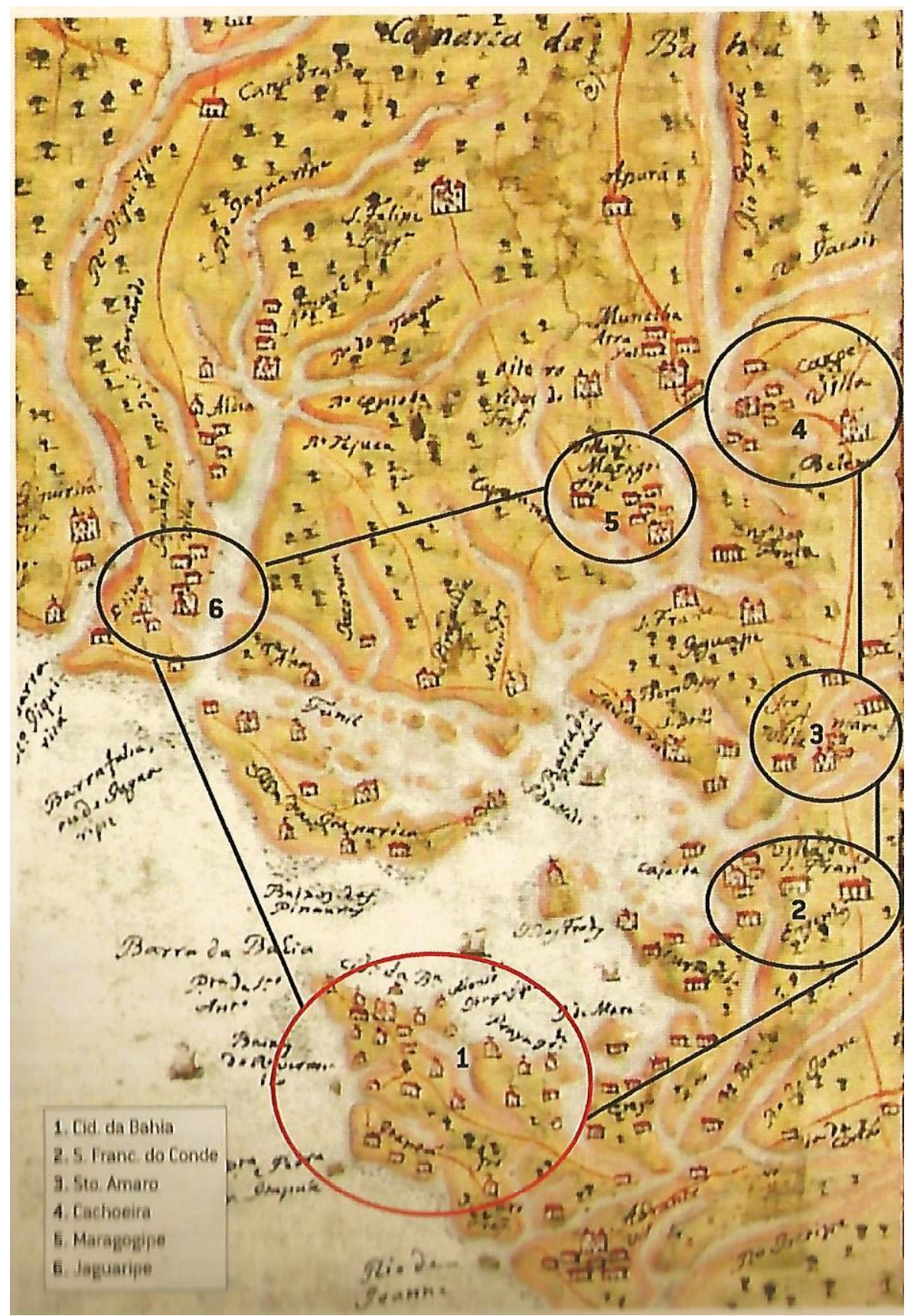

Figura 4.1.1- Recôncavo Baiano em meados do século XVIII (ANDRADE, 2013, p. 243)

A Figura 4.1.1 acima referencia os caminhos hierárquicos da Rede urbana do Recôncavo Baiano ao final deste mesmo século (XVIII), que iriam culminar nas diversas regionalizações para a região. Salientamos, entretanto, que nosso objetivo principal não é o de analisar a formação da rede urbana do Recôncavo, nem tão pouco analisar suas diversas regionalizações, mas trazer essas duas importantes questões para um melhor entendimento da 
produção e organização espacial da região em estudo e assim dar um maior supote metodológico para compreensão do nosso objeto de estudo.

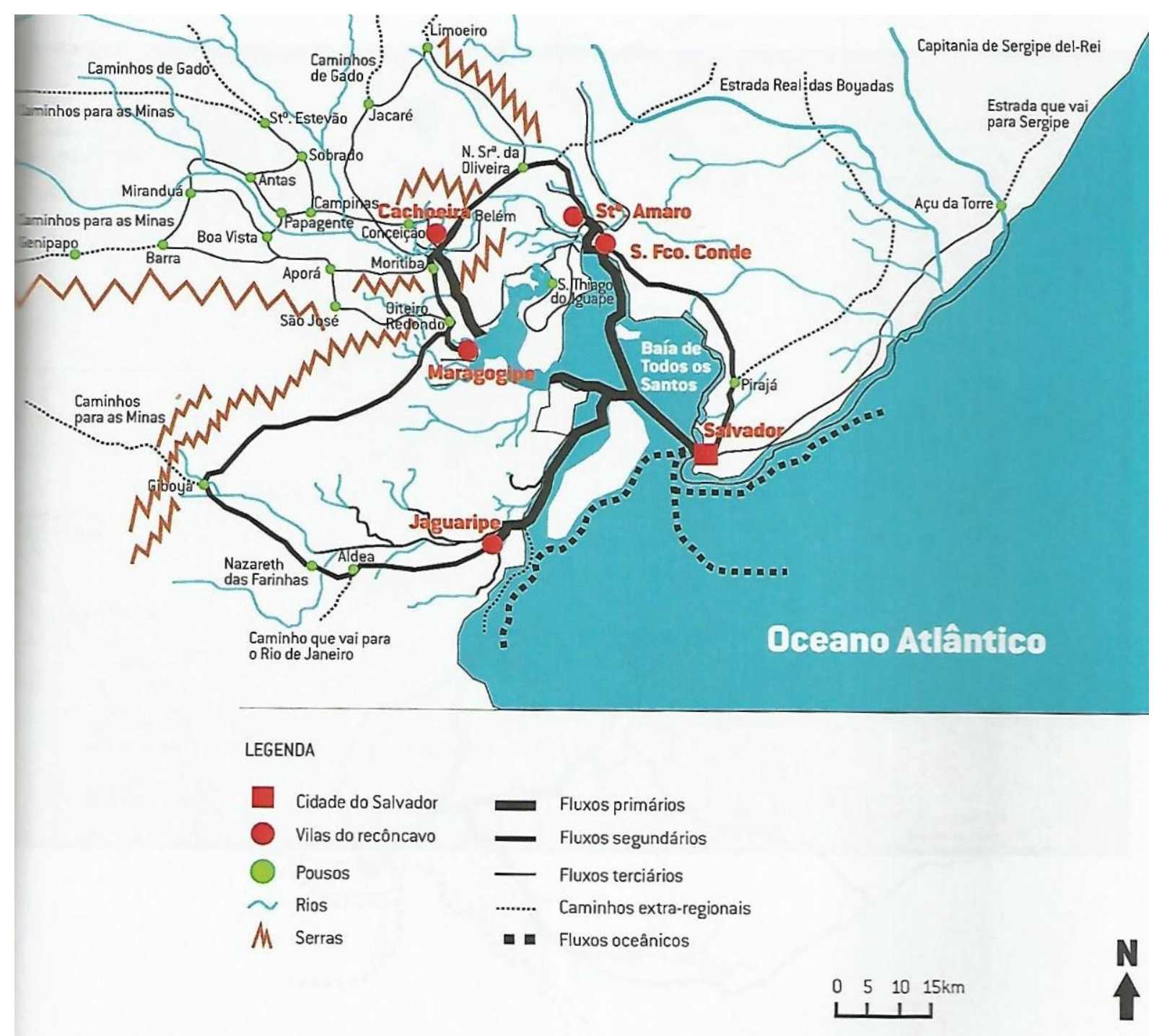

Figura 4.1.2 - Caminhos hierárquicos da Rede urbana do Recôncavo Baiano ao final do século XVIII (ANDRADE, 2013, p. 249)

Em seguida vê-se na sequencia das Figuras 4.1.3, 4.1.4 e 4.1.5 as regionalizações mais atualizadas a partir do século XX até os nossos dias, iniciando pelo estudo de Santos (1960), que serviu de referência para outras regionalizações oficiais em nível estadual (Governo da Bahia) e federal (IBGE). 


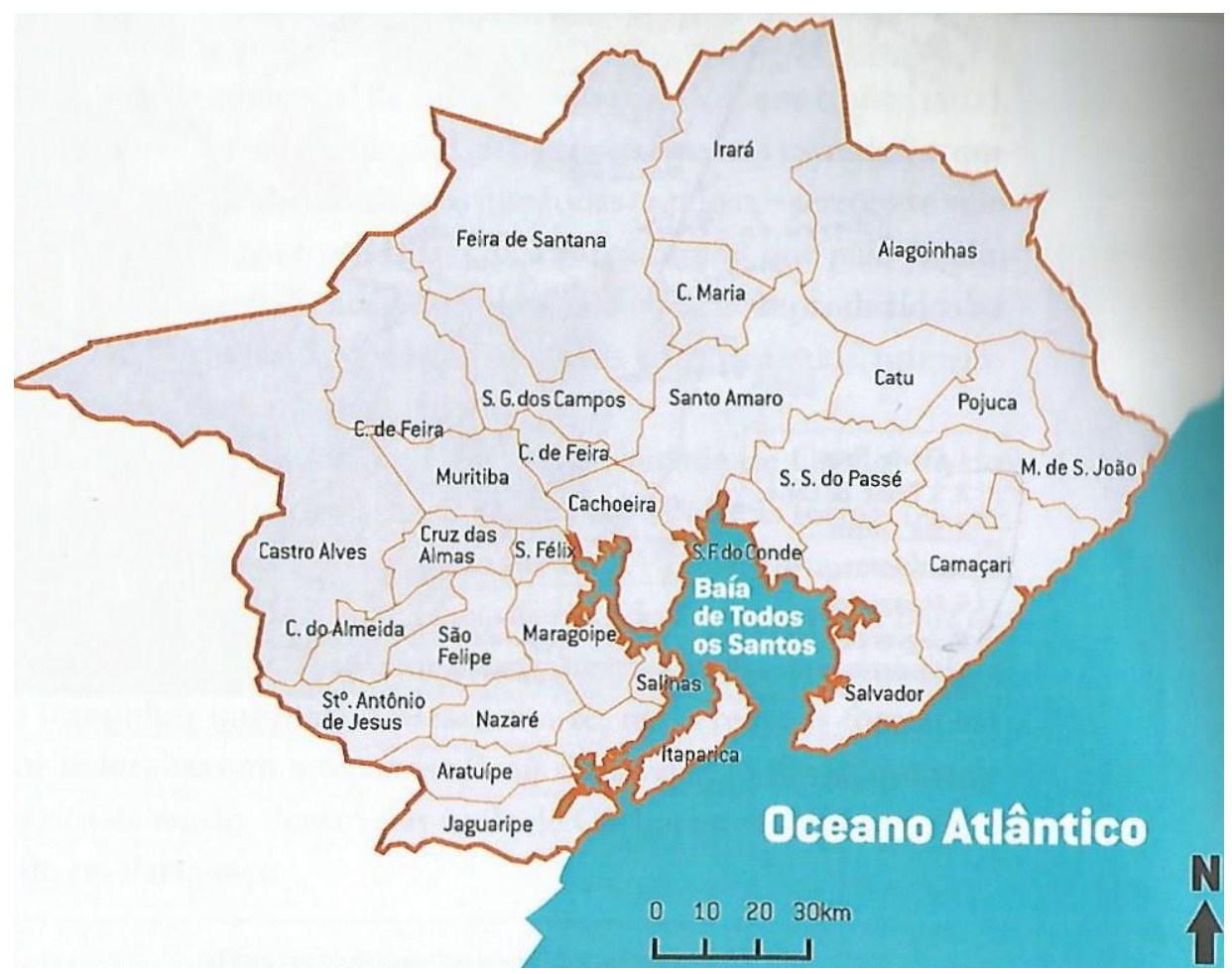

Figura 4.1.3 - Região do Recôncavo Baiano segundo Milton Santos (1960) (ANDRADE, 2013, p. 244)

Segundo Andrade (2013, p. 346), o mapa da Figura 4.1.3 acima revela "[...] um amplo recorte espacial que cobre todo o entorno da Baía de Todos os Santos e vai a áreas interiores, destacando as novas centralidades da região".

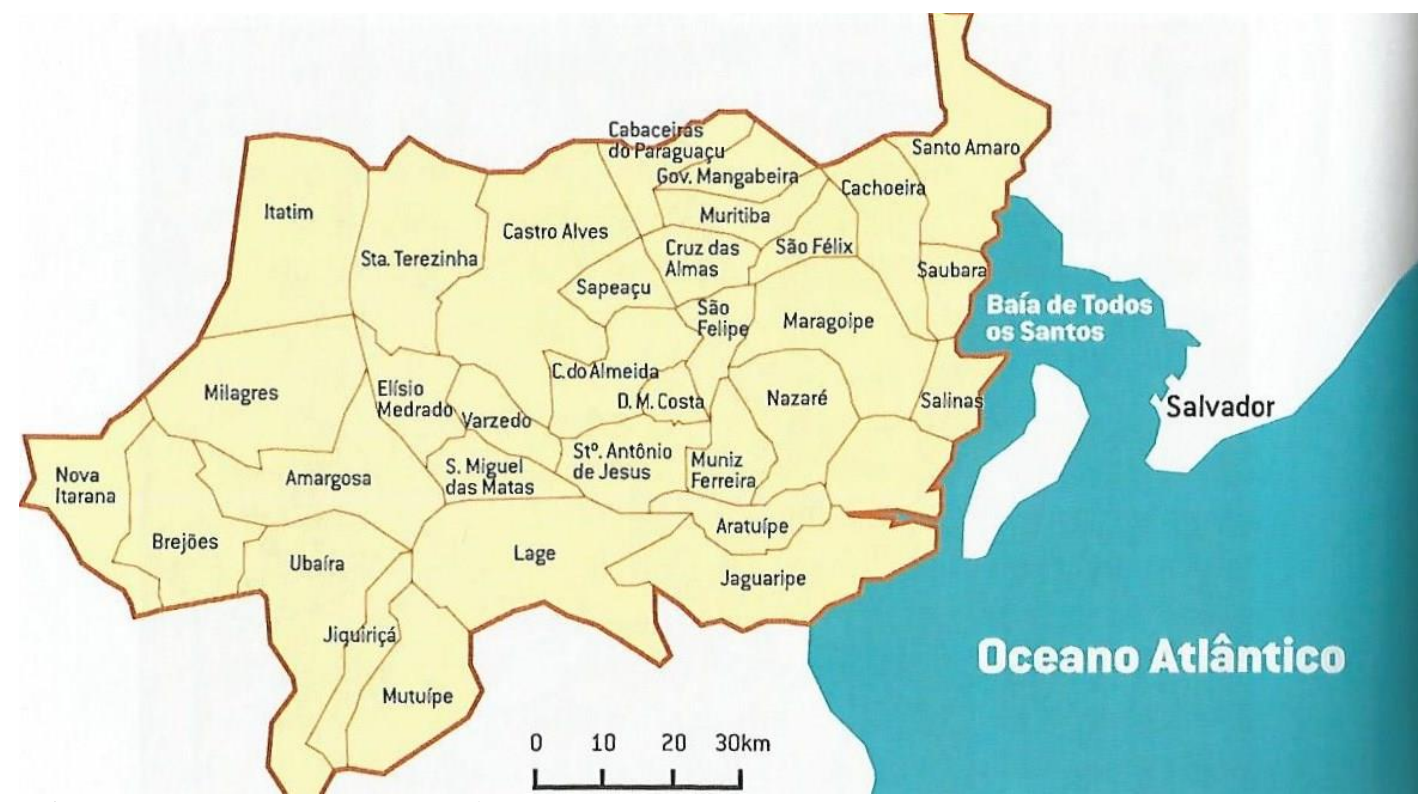

Figura 4.1.4 - Recôncavo Sul

(ANDRADE, 2013, p. 244) 
Segundo Andrade (2013), o "recorte" espacial proposto para a regionalização apresentada na Figura 4.1.4, destaca as cidades de Amargosa, Santo Antônio de Jesus, Nazaré, Cachoeira e Cruz das Almas, “[...] o que revela novas centralidades em relação ao Recôncavo do Período Colonial” (ANDRADE, 2013, p. 347).

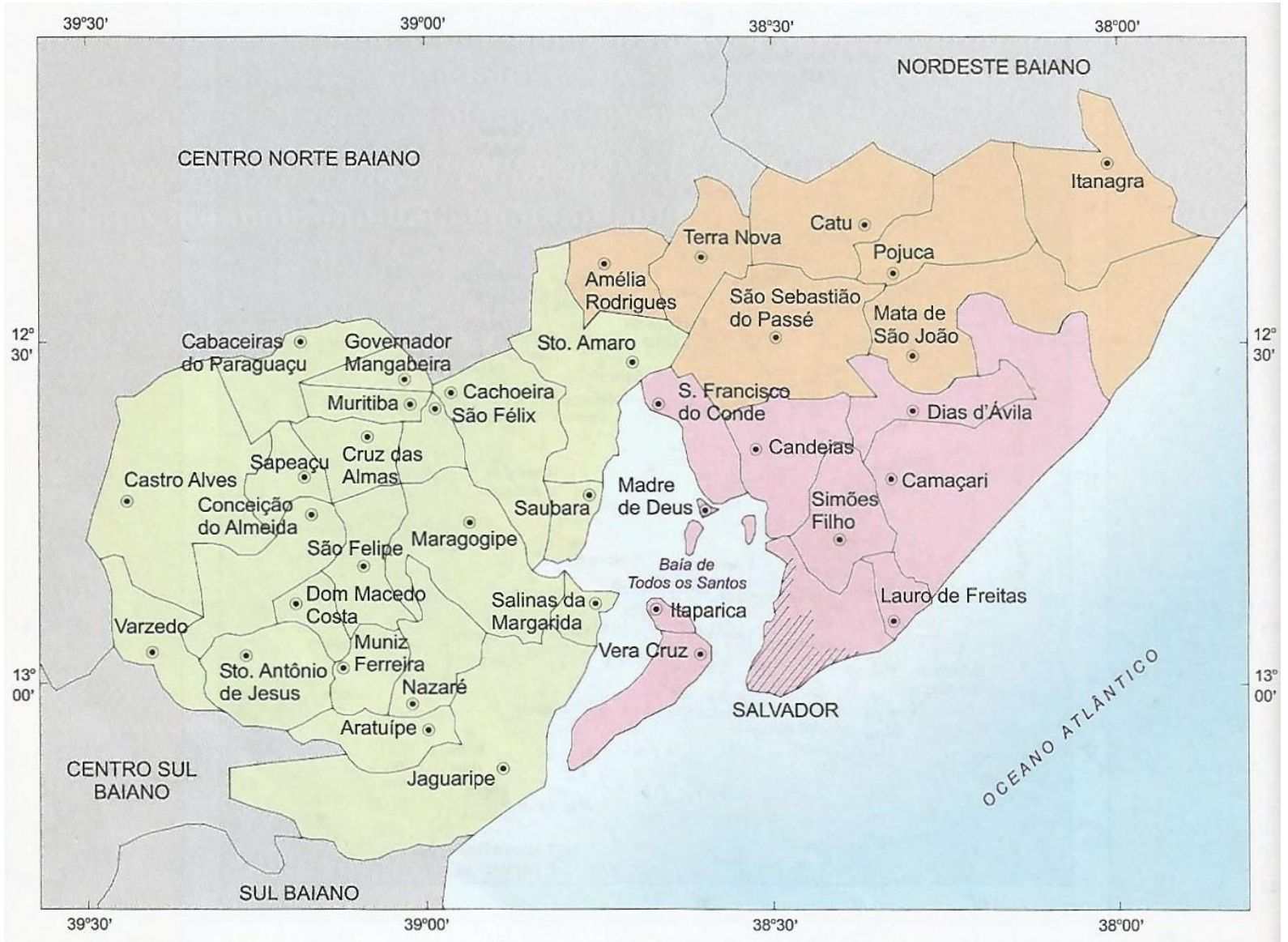

Figura 4.1.5 - Mesoregião Metropolitana de Salvador

(SILVA, 2004, p. 32)

A Mesorregião Metropolitana de Salvador, Figura 4.1.5 acima, engloba três Microrregiões Geográficas: Catu, Santo Antônio de Jesus e Salvador. Trata-se de um recorte espacial proposto pelo IBGE e utilizado no "Atlas Escolar da Bahia", referenciado na figura mencionada. Segundo Andrade (2013), três microrregiões que ampliaram o entendimento da região em relação a outras propostas de regionalização contemporâneas.

Na Figura 4.1.6 a seguir, podemos visualizar a última regionalização do Governo da Bahia, institucionalizada desde 2007, onde podemos visualizar a localização dos dois “Territórios de Identidade", onde localizam-se as cidades pesquisadas: Cachoeira, São 
Francisco do Conde, Maragogipe, Santo Amaro, Nazaré e São Felix (Recôncavo); Jaguaripe (Baixo Sul); mais Salvador (Metropolitana de Salvador). É importante ressaltar que o município de Jaguaripe está fora da área que delimita o Território de Identidade Recôncavo, assim como Salvador, mas estamos considerando sua identificação histórica com o mesmo, como foi visto nos mapas acima.

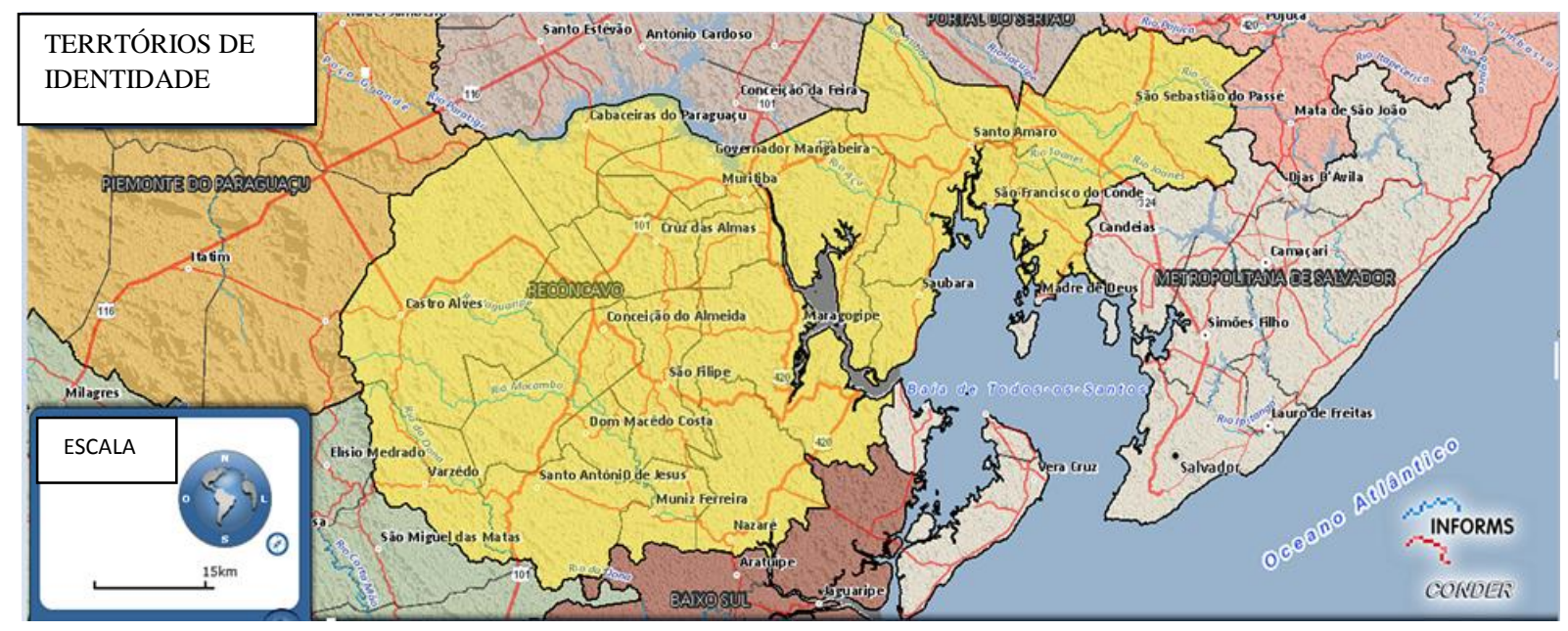

Figura 4.1.6 - Recorte onde podem ser visualizadas as áreas: "Território de Identidade Recôncavo", "Metropolitana de Salvador" e parte do "Baixo Sul" (SEI, 2001)

Quanto à delimitação elaborada pelo IPAC entre 1978 e 1982, foco da nossa pesquisa, foram englobados dois mapas, Figuras 4.1 .7 e 4.1 .8 a seguir, os quais incorporaram um maior número de municípios, considerados pertencentes ao Recôncavo Baiano à época. Tal delimitação difere da atual (Territórios de Identidade). Inclusive o Município de Jaguaripe, onde a cidade sede faz parte da nossa pesquisa, atualmente pertence à região do Território de Identidade Baixo Sul, como pode ser visto na figura 4.1.7, a seguir. 


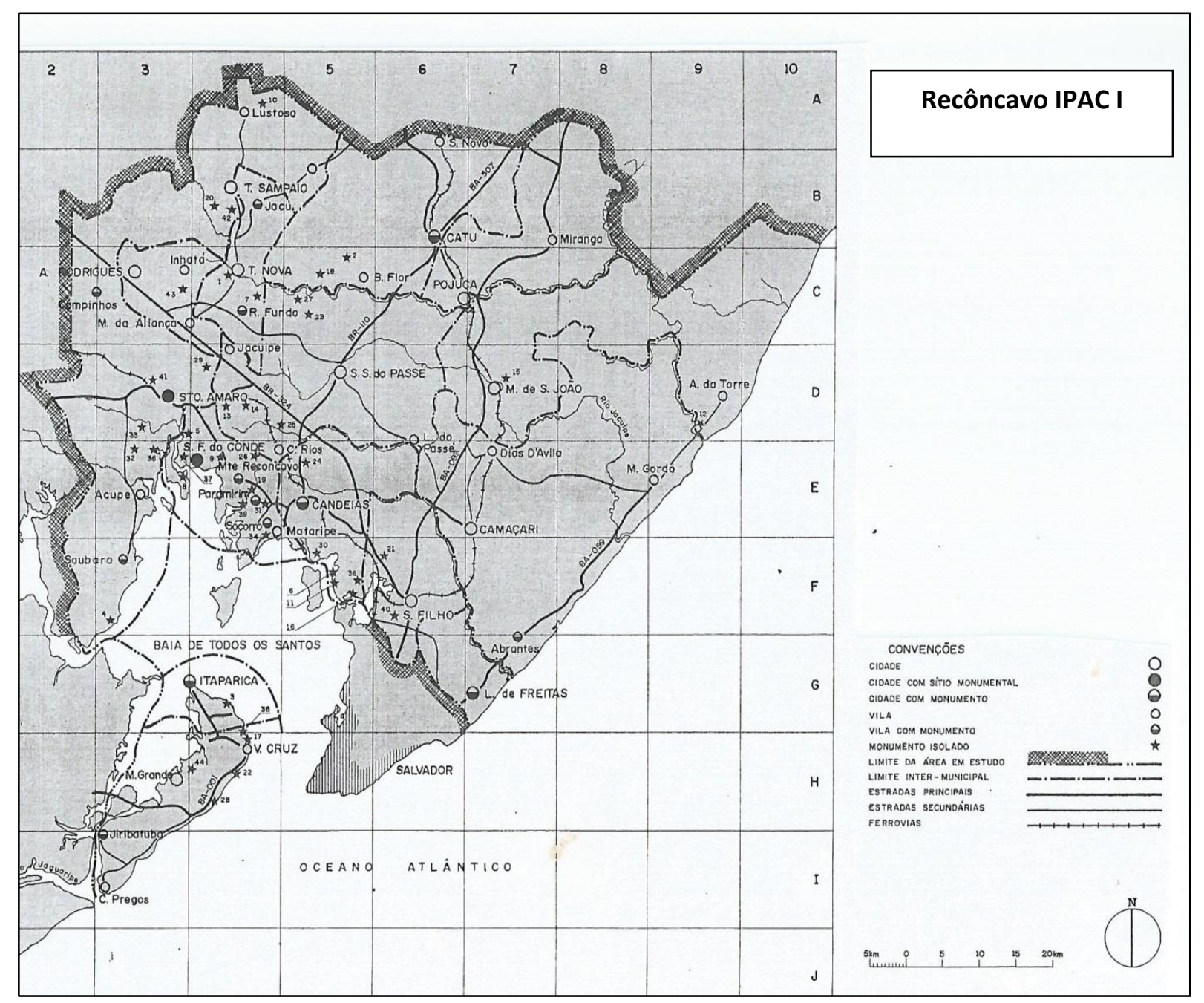

Figura 4.1.7 - Recôncavo Baiano segundo o IPAC, com delimitação da área inventariada (BAHIA, 1982a)

Vários municípios que constam deste mapa, Figura 4.1.7 acima, que denominamos de IPAC I, não mais constam da delimitação da atual regionalização do estado da Bahia, em Territórios de Identidade, instituída desde 2007, como já mencionada anteriormente.

Em relação à delimitação da nossa área de trabalho, esclarecemos que, tendo em vista o exposto sobre a questão regional do Recôncavo Baiano e toda a história do município de Jaguaripe, estamos considerando que, para efeito desta pesquisa, o referido município e sua cidade se incluem na região pesquisada. 


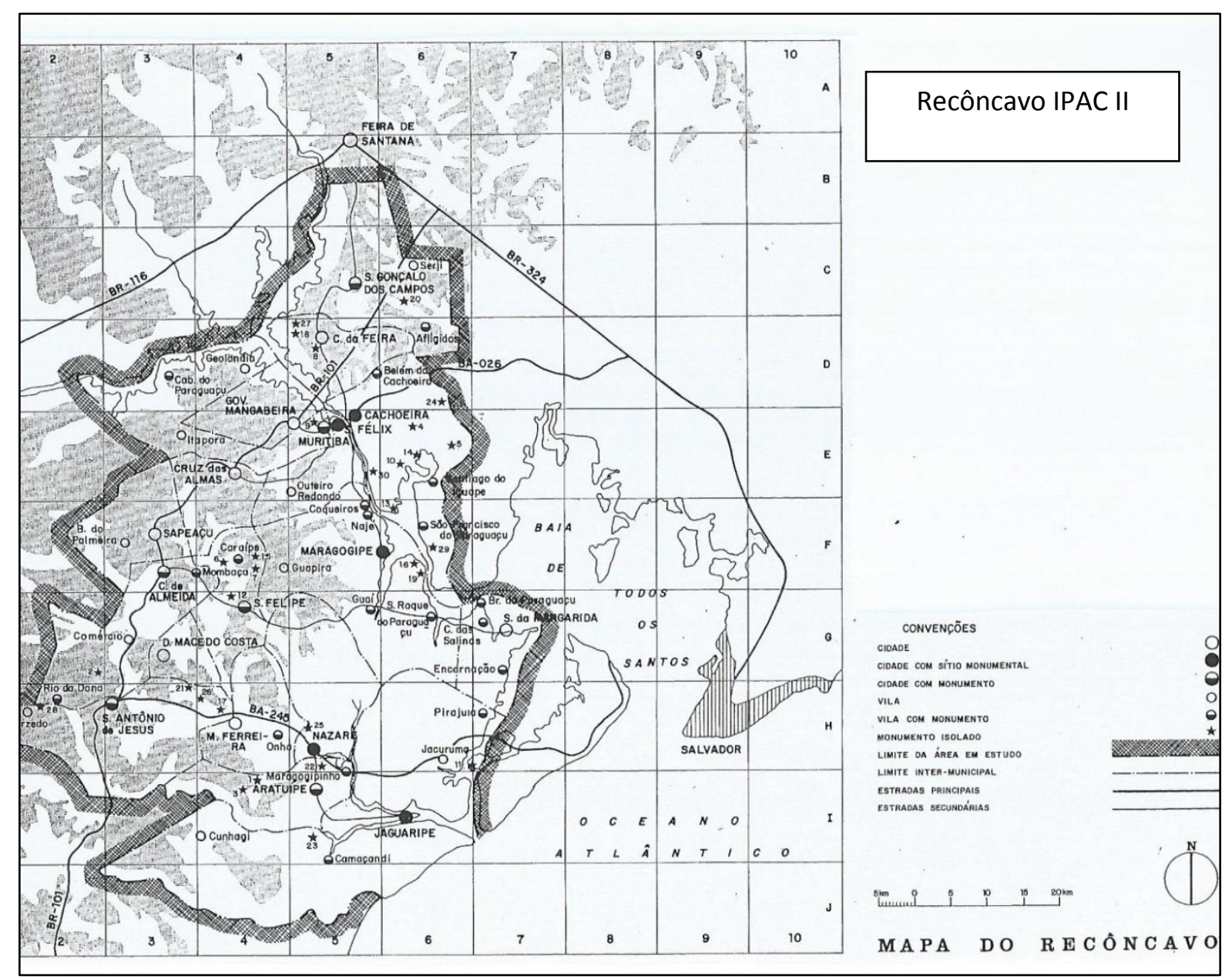

Figura 4.1.8 - Recôncavo Baiano segundo o IPAC, com delimitação de área inventariada (BAHIA, 1982b)

Em uma busca histórica a próxima seção trata da dinâmica dos sistemas produtivos para o mercado interno e externo e seus reflexos na paisagem urbana da região. Portanto, houve a necessidade de retrocedermos ao período entre 1823 e 1889, para melhor compreensão e contextualização do mesmo.

\subsection{A DINÂMICA SOCIOECONÔMICA E ESPACIAL DO RECÔNCAVO BAIANO ENTRE O SÉCULO XVI E MEADOS DO SÉCULO XIX}

A ocupação da Bahia pelo colonizador ainda era incipiente em meados do século XVI, restrita basicamente às sedes das capitanias. Com o decorrer do tempo, o baixo curso dos rios 
do entorno da Baía de Todos os Santos foram alcançados à medida que também se proliferava a cultura da cana de açúcar, que era beneficiada nos engenhos. A partir dali surgiram os núcleos de povoamento primitivos, localizados em Águas de Meninos, Pirajá, Paripe, Praia Grande, Passé, Matoim, Aratu, Iguape, Itaparica, Jaguaripe e Tinharé (SEI, 2001).

Podemos visualizar na Figura 4.2.1 a seguir, os referidos núcleos primitivos de povoamento da Capitania da Bahia de Todos os Santos, no século XVI, e ter uma noção da configuração espacial da ocupação do Recôncavo baiano, com destaque para Salvador, fundada em 1549, como primeira capital do Brasil. Portanto, sede do poder político, administrativo e eclesiástico da época, abrigando o primeiro Bispo do Brasil e, consequentemente, a primeira residência arquiepiscopal do Brasil, fato que lhe conferia a característica de cidade. Para além da capital, apenas Jaguaripe aparece como a vila mais distante da capital, nos limites da Capitania da Baía de Todos os Santos.

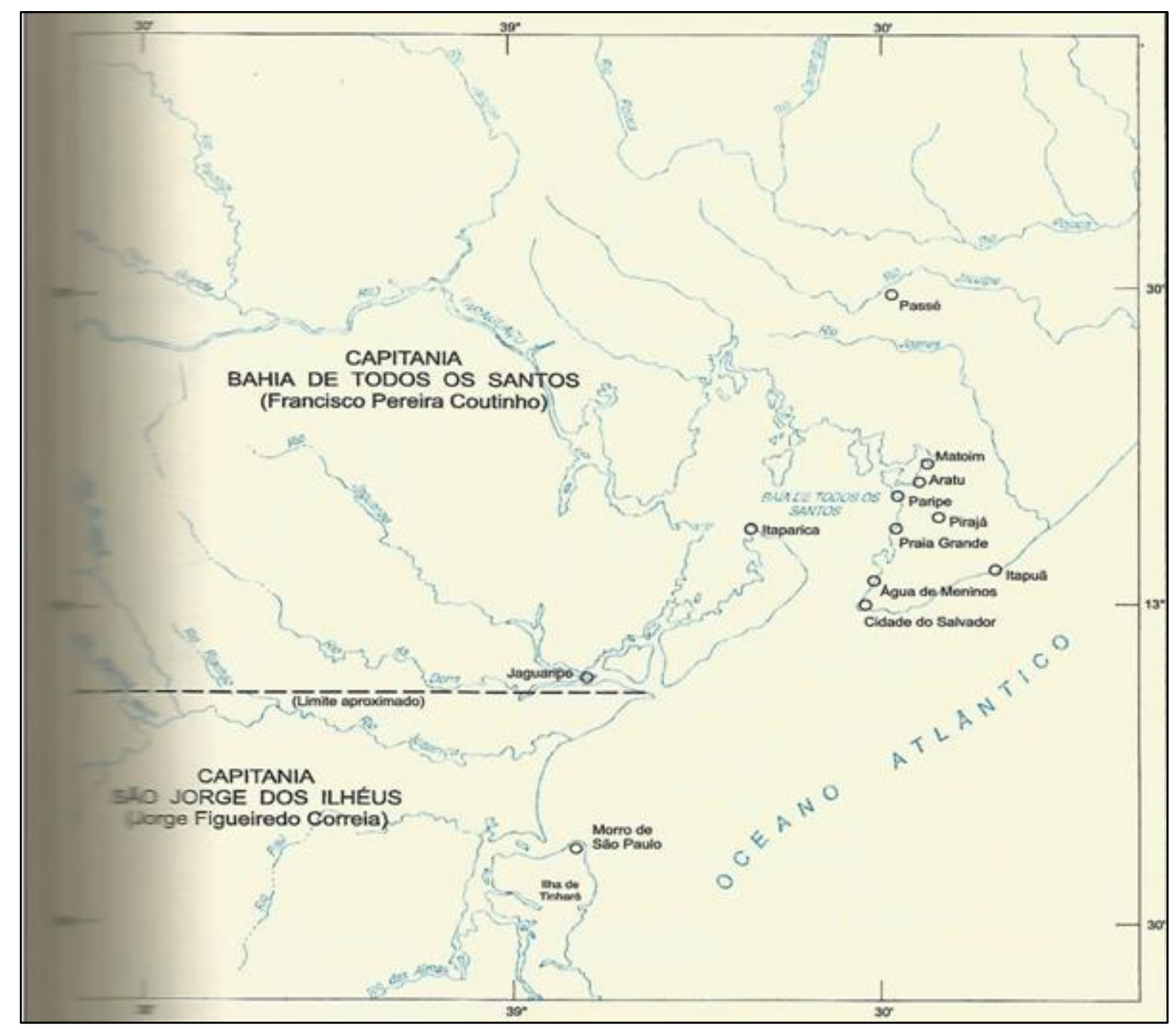

Figura 4.2.1 - Núcleos primitivos de povoamento na capitania da Bahia no século XVI (SEI, 2001, p. 37) 
No decorrer da segunda metade do século XVI, as trajetórias de povoamento avançaram na direção norte, até o rio Real, e ao sul, alcançaram o rio Jaguaripe, onde se originaria a vila do mesmo nome em 1697. A direção dos caminhos de povoamento e das vilas mais importantes até o final do século XVI pode ser vista na Figura 4.2.2 abaixo.

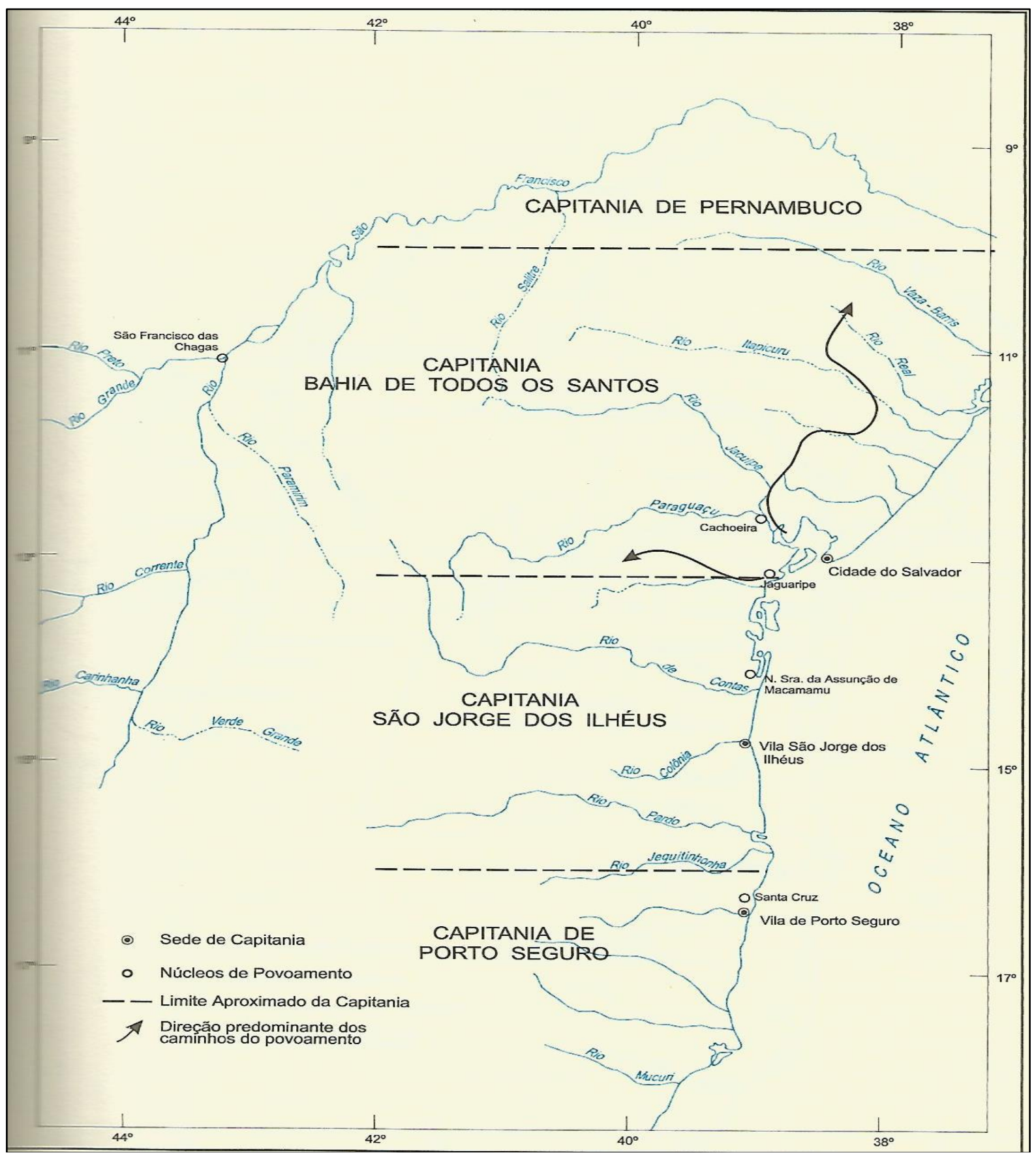

Figura 4.2.2 - Caminhos do povoamento no século XVI

(SEI, 2001, p. 39) 
Na Figura 4.2.2 é possível perceber que no século XVI, dois importantes núcleos de povoamento já existiam e seriam os mesmos que iniciariam a formação da rede urbana do Recôncavo Baiano. São eles: Jaguaripe e Cachoeira. Ambos estrategicamente situados às margens de dois importantes rios da região. O Rio Jaguaripe e o Rio Paraguaçú, respectivamente. Ambos de suma importância para a constituição da referida rede de vilas, que no século XVII começavam e se estruturar em função do fluxo de mercadorias provenientes daquela região em direção a Salvador e vice-versa por via fluvial e marítima.

Ainda neste mesmo século, a participação efetiva da Coroa portuguesa consolidou a ocupação do território brasileiro, assumindo novas direções para o sertão e para o sul. Neste sentido foram criadas importantes vilas. Na Bahia, o Recôncavo tornou-se a região mais promissora devido a sua própria geografia: localização estratégica, clima, relevo, hidrografia e solos propícios para o cultivo de cana de açúcar, tabaco e mandioca. Culturas que iriam dinamizar a economia daquela região nos dois séculos seguintes.

Segundo um estudo da SEI (2001) sobre o histórico da evolução territorial e administrativa do estado da Bahia, a Coroa portuguesa fez grande esforço para ocupar o território. Em relação à criação das primeiras vilas na capitania da Baía de Todos os Santos, o referido estudo afirma o seguinte:

Buscando atender as necessidades de povoamento da capitania da Baía de
Todos os Santos, D. João de Lencastro, o trigésimo segundo governador, em
carta régia datada de 1693 , ordenou a criação de vilas e povoados. Como
consequência dessa medida foram criadas três vilas. A primeira, em abril de
1697, é a de Nossa Senhora da Ajuda de Jaguaripe, oriunda da mais antiga
sesmaria de que se tem notícia, datada de 1563 . A segunda é a Vila de Nossa
Senhora do Rosário do Porto de Cachoeira, criada em janeiro de 1698 e que
tinha por termo uma grande área que ia do Rio Subaúma ao Rio Inhambupe,
cortando direto pela praia e daí até intestar com o Rio Real. A terceira, São
Francisco da Barra do Rio Sergipe do Conde, foi criada em fevereiro de
1698. Esta vila disputava com Cachoeira a primazia de ser a mais antiga do
Recôncavo, ignorando Jaguaripe, naturalmente (SEI, 2001, p. 35).

Outras vilas também foram criadas ao longo do século XVII nas três capitanias que formavam o atual estado da Bahia, porém no Recôncavo, elas se situavam relativamente próximas umas das outras e também da capital da colônia, guardadas as devidas proporções de distância e de meios necessários para percorrê-las naquela época. Fato que lhes conferiu um maior desenvolvimento, além de sofrerem uma influência cultural e simbólica quase que 
direta da cidade do Salvador. A Figura 4.2.3, nos dá uma ideia desta distância e das direções predominantes dos caminhos do povoamento ainda no século XVII.

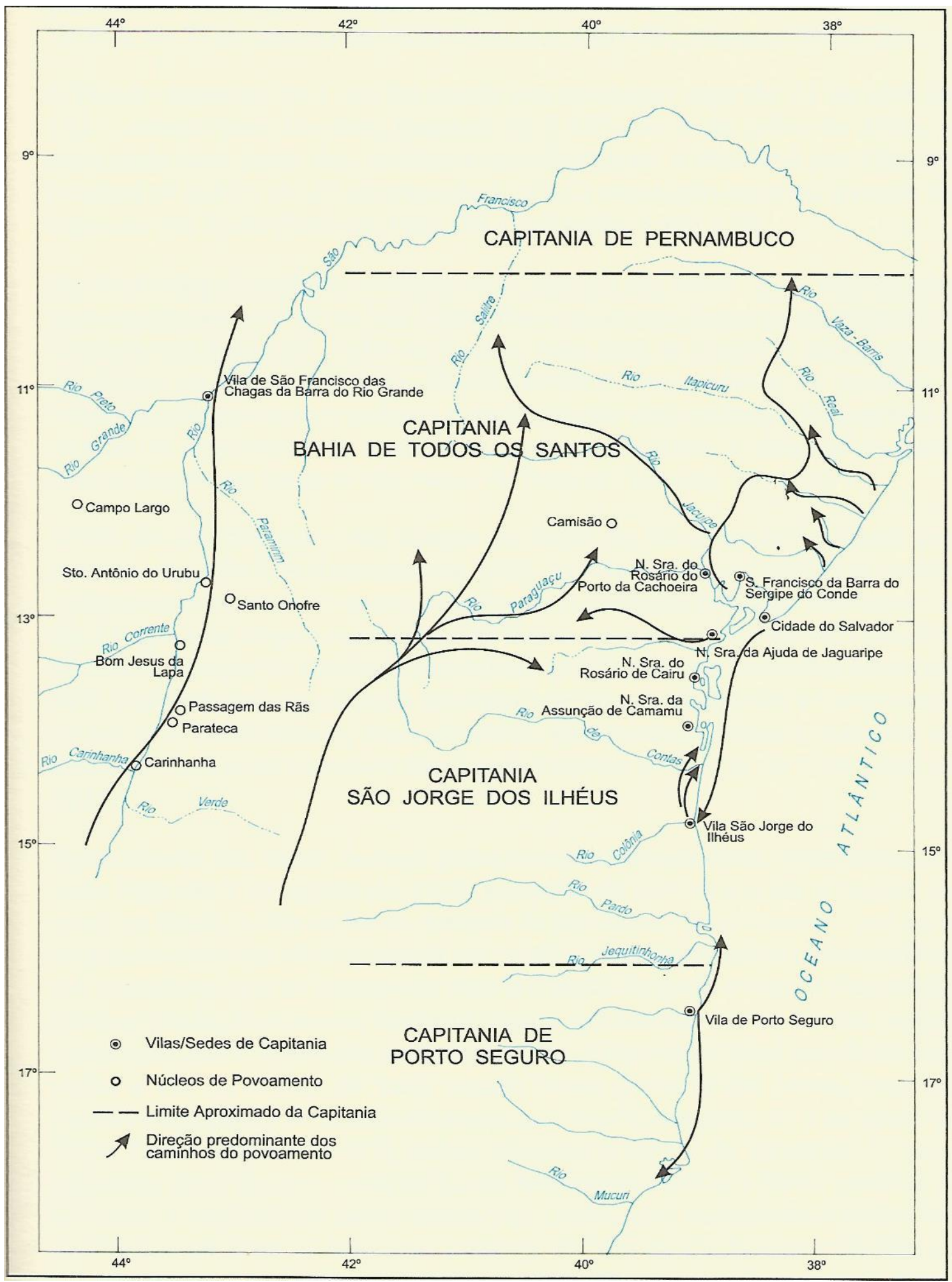

Figura 4.2.3 - Principais vilas e caminhos do povoamento no século XVII (SEI, 2001, p. 45) 
Segundo Andrade (2013),

Os rios e os caminhos terrestres eram continuidades urbanas junto às pequenas vilas interiores da rede. Eles tanto orientavam o crescimento como articulavam o povoamento com a região. A escolha do sítio e a importância do ajuntamento humano estavam diretamente relacionadas à sua posição junto às estruturas fixas que cruzavam em rede o Recôncavo. A própria existência dos caminhos terrestres e fluviomarítimos já pressupunha uma série de ligações e fluxos que passavam por essas formações urbanas (ANDRADE, 2013, p. 286).

É notório na afirmativa acima que no século XVIII já se podia apontar a formação de uma incipiente, porém significativa, rede urbana regional no Recôncavo Baiano, formada principalmente por um grupo de vilas que se articulavam em duas vertentes. Uma interior, inter-regional e a outra com a sede da Colônia, Salvador. Segundo Andrade (2011) essas Vilas

[...] se articulavam entre si, com a cidade capital do outro lado da baía de Todos os Santos e com diversas outras nodalidades interiores (sedes de freguesias, pousos, engenhos etc.). A segunda vertente ligava a região com outras áreas do mundo colonial português, dentro do Brasil (demais capitanias do litoral norte e sul, sertões e minas) ou fora dele (África, Ásia e África) (ANDRADE, 2011, p. 2).

Os nós da rede e toda a vida de relações entre as vilas, o campo e a capital da Baía de Todos os Santos, se faziam estruturada por um tripé que se articulava em torno dos engenhos de açúcar, mão de obra escrava e o transporte fluviomarítimo, através de embarcações artesanais (saveiros), responsáveis pelo fluxo de transporte dos produtos oriundos da região. Andrade afirma que,

As vilas, localizadas estrategicamente em áreas de escoamento junto a rios navegáveis, mesmo antes de serem erguidas à sede de formações urbanas, já se constituíam em centros interiores (engenhos, povoados, sedes de freguesias etc.). Nelas havia além da centralidade político-administrativa, uma mínima infraestrutura em portos fluviais (cais, armazéns/trapiches, mercados) que viabilizava o escoamento dos produtos do entorno (ANDRADE, 2011, p. 8).

Tais produtos eram encaminhados dos portos fluviais das vilas para o porto de Salvador e daí, em embarcações de maior porte, transportados para os portos europeus, africanos e asiáticos. 
Suas cidades originaram-se dos primeiros núcleos de povoamento do território baiano e estruturaram-se como centros urbanos dinâmicos. Formaram uma conexão comercial e cultural importantíssima que gerou uma região formada por um conjunto ímpar de cidades, constituindo uma de suas características mais peculiar. Ou seja, uma hinterland em conexão com o mundo, via Salvador.

No século XVIII, esse movimento de fluxos de mercadorias (principalmente o açúcar, o fumo e a farinha de mandioca), de pessoas e de intercâmbio cultural, guardadas as devidas proporções para a época, consolidou uma economia próspera e dinâmica em nível regional. Neste século nasce a segunda geração de vilas no Recôncavo Baiano e outras são criadas no interior da Capitania, intensificando o intercâmbio com o sertão, configurando um total de 36 (vilas), como pode ser visto na Figura 4.2.4, a seguir. 


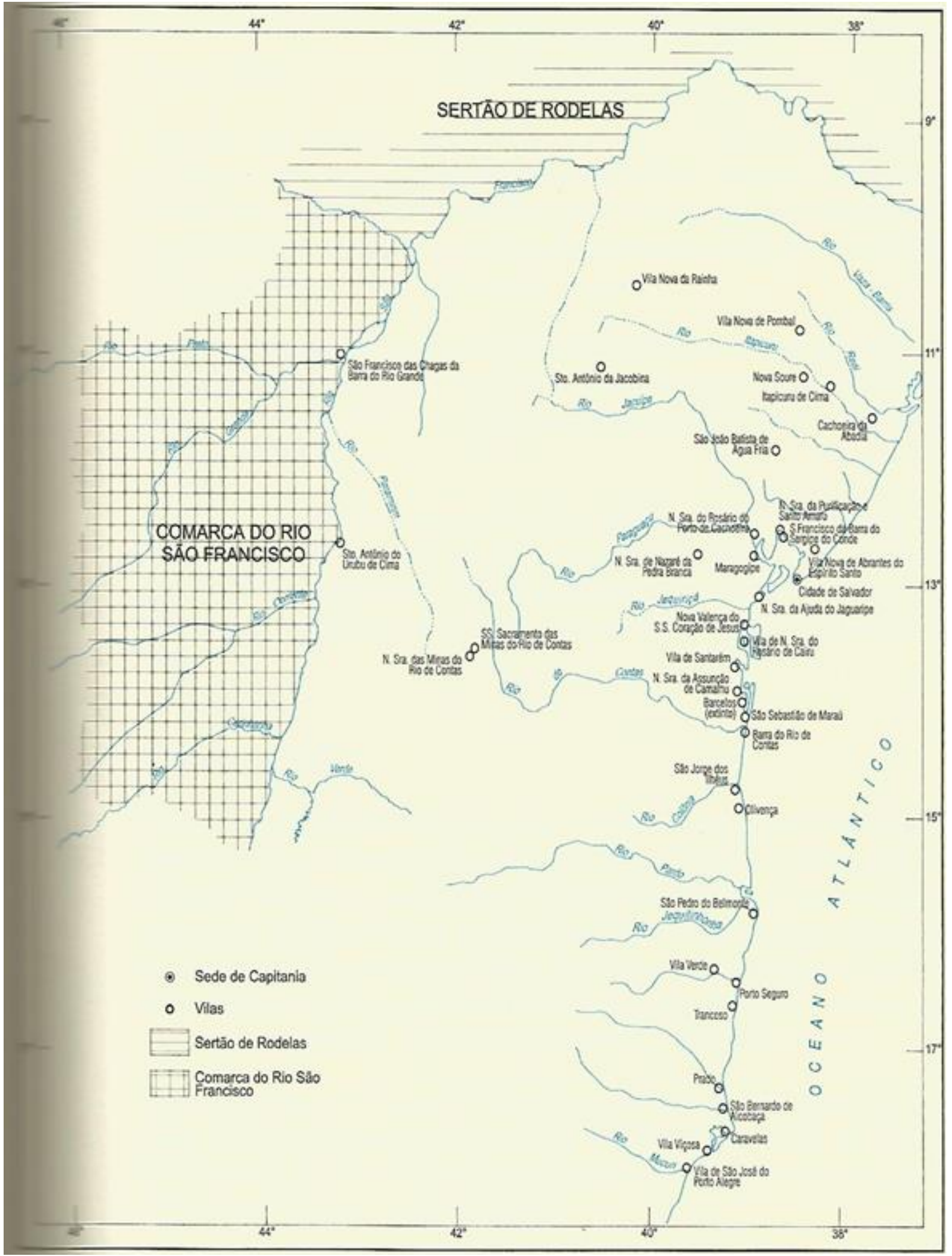

Figura 4.2.4 - Capitania da Bahia: Situação das vilas no século XVIII (SEI, 2001, p. 41) 
Schwarts (1988), fundamentado em fontes primárias, com base em cartógrafos e eclesiásticos da era colonial, nos fala da organização espacial do Recôncavo a partir da cidade do Salvador. O referido pesquisador nos dá uma ideia dos critérios utilizados na época, alertando que, tais critérios de medição da ocupação do Recôncavo não se baseavam apenas em termos de crescimento populacional, mas também na localização dos engenhos e das paróquias. Segundo ele:

A partir da base em Salvador, os santos e os engenhos caracterizaram a colonização da capitania. [...] Quando, na década de 1560, povoados começaram a se desenvolver no Recôncavo, com uma população fixa instalada nas imediações dos engenhos, a Igreja reconheceu essa realidade através da criação de paróquias distintas [...].

As paróquias instituídas pela Igreja estabeleceram a forma básica de organização no Recôncavo por duzentos anos; entretanto em fins do século XVII um sistema de organização secular, baseado em municipalidades, também começou a formar-se. Em 1698, criaram-se no Recôncavo as vilas de São Francisco do Conde, Cachoeira e Jaguaripe; Santo Amaro foi estabelecida em 1727. Jaguaripe foi subdividido em 1724, com a criação da vila de Maragogipe, não sem o costumeiro protesto da municipalidade original (SCHWARTS, 1988, p. 81).

Ainda se referindo às localidades do Recôncavo na fase inicial de seu povoamento até o início do século XIX, Schwarts (1988) afirma que:

[...] Essas localidades eram pequenas. Na década de 1720, Santo Amaro possuía apenas quatrocentos residentes livres do sexo masculino. As vilas secundárias do Recôncavo limitavam-se a proporcionar um esqueleto administrativo, instalações portuárias e serviços às terras agrícolas onde se estabeleciam. Nelas o governo não era rigoroso e, muitas vezes, informal. Até princípios do século XIX, a câmara de Santo Amaro não se reunia regularmente, sendo convocada apenas à chegada de correspondência importante de Salvador. Não obstante, essas vilas propiciavam um arcabouço de governo (SCHWARTS, 1988, p. 81).

Não é difícil imaginar que, para a Metrópole portuguesa, todo o processo de gestão e planejamento do território tem nos proprietários de terras e no clero, os seus fiéis representantes até a consolidação de um sistema administrativo local, a partir do surgimento das instituições normativas e reguladoras da vida nacional, especialmente após a independência do país.

A dinâmica da economia regional do Recôncavo entre os séculos XVIII e XIX girava em torno da produção de açúcar, tabaco e mandioca, principalmente e, secundariamente, da 
produção de couro, carne e algodão. Todos esses sistemas produtivos estavam atrelados ao consumo de mão-de-obra escrava, suporte imprescindível das atividades agropastoris, que também movimentava o comércio local e regional, ao longo do processo de formação de suas primeiras vilas.

Em comentário sobre a movimentação de produtos e pessoas que circulavam em diferentes tipos de embarcações que transitavam entre as cidades do Recôncavo, Salvador e vice-versa, no século XIX, Sampaio (2005) afirma o seguinte:

Entre a grande variedade de embarcações que cortam as águas mansas da baía, os saveiros [...] Chegam a todas as vilas e cidades do Recôncavo, levando para Salvador os mais diversos gêneros alimentícios, frutas, peixes, azeite de baleia de Itaparica, farinha de Nazaré, tigelas, potes de barro, tijolos e cerâmica variada de Maragogipe e produtos sem conta, para atender ao mercado doméstico. Trazem de volta tudo aquilo de que as populações ribeirinhas precisam. Destinados ao comércio de exportação, transportam sacas de açúcar e muito fumo, sustentáculos da economia da Província, secundados pelo diamante, café, couros e outros itens menores (SAMPAIO, 2005, p. 17).

Podemos perceber pela assertiva acima que a produção de alimentos e criação de animais para o abastecimento da população local gerou um comércio interno bastante dinâmico entre as vilas e destas com Salvador. Só para termos uma ideia, entre 1780 e 1860, segundo Grahan (2013, p. 138), os municípios de Jaguaripe e Nazaré forneciam $43 \%$ da farinha de mandioca consumida em Salvador. Ainda segundo o mesmo autor na cidade comercial de Nazaré, cerca de 10 a 12 mil alqueires de mandioca eram vendidos aos sábados.

A fumicultura, cujo produto era utilizado inicialmente no tráfico negreiro e depois se consolidou como lavoura comercial de alto rendimento nos mercados europeus, também fazia parte do ativo comércio regional entre os municípios produtores, que escoavam sua produção através de suas vilas e cidades portuárias.

Nardi (2013) nos informa sobre o panorama geral do mercado externo e sobre as diversas fases da produção fumageira na Bahia, com destaque para o Recôncavo Baiano, demonstrando que o comércio externo foi a principal motivação dessa cultura. $\mathrm{O}$ referido autor delimita quatro fases da dinâmica comercial deste produto após o sistema colonial, descrevendo-as da seguinte forma:

Na fase preliminar, sob domínio português, o fumo é expedido para Lisboa de onde, além de ser útil à indústria e o consumo interno da metrópole, ele é 
reexportado para outras nações da Europa. Saindo diretamente de Salvador, também serve de moeda para a compra de escravos na África, em particular, a Costa da Mina (Benim).

Terminado o sistema colonial, o fumo passa por quatro fases. Entre $1821 \mathrm{e}$ 1850 (Fase A), as exportações conhecem uma queda de $43 \%$ passando de, aproximadamente, 7 mil para 4 mil toneladas. É uma fase de reestruturação em que se estabelecem as relações diretas com os países da Europa enquanto, até 1854, continua o tráfico negreiro. Depois disso, o fumo entra numa fase de crescimento constante $(+700 \%)$ que termina em 1910; as exportações sobem para $30 \mathrm{mil}$ toneladas (Fase B). Segue a fase de estagnação até 1950, com algumas oscilações, como em 1940, devido a duas guerras mundiais (Fase C). Após 1950 começa a fase designada como decadência (Fase D) [...] (NARDI, 2013, p. 63 - 64).

A periodização de Nardi (2013) nos interessa, pois se enquadra no recorte temporal da nossa pesquisa, especialmente as fases de crescimento (1854 - 1910) e de estagnação (1910 1950). Nesse período verificamos que houve grande produção do patrimônio urbano das cidades em tela, principalmente daquelas que tiveram maior envolvimento com a cultura do fumo, a exemplo de Cachoeira, Maragogipe e São Felix.

No que concerne aos aspectos sociais do Recôncavo Baiano no período em tela, Pedrão chama a atenção para o papel dominante do capital mercantil na região, afirmando que:

Essa região foi criada pelos interesses do capital mercantil já internacionalizado em busca de meios materiais para expandir-se, que se instalou em Salvador. A prosperidade do açúcar criou uma classe subalterna rica - os senhores de engenho - que se tornou um poder ambivalente, extraindo sua identidade do Recôncavo, mas fazendo-se representar no contexto político de Salvador (PEDRÃO, 2007, p. 9).

Ainda segundo Pedrão (2007),

Não se deve ignorar que o império valeu-se de um estrato de administradores que transitaram entre os diversos pontos de concentração de interesses do sistema, dando lugar a vínculos com a metrópole, que também funcionaram como atrativos para esses pequenos grupos de oligarcas com pretensões de ascensão nobiliárquica (PEDRÃO, 2007, p. 9).

A análise acima nos revela um quadro social de extremos, onde a diferenciação de extratos sociais é relevante e demonstra a origem do caráter concentrador de riqueza e prestígio social do grupo de proprietários de terras e membros da nobreza representativa da metrópole portuguesa. 
Essa estrutura social é também expressa na opulência da forma em que foi materializada a estrutura urbana das cidades, revelando na sua monumentalidade o poder e a riqueza de uma classe oligárquica.

Para termos uma ideia da notoriedade social, política e econômica do recôncavo, se faz necessário ter a dimensão de sua opulência atrelada à cidade do Salvador que, segundo Mattoso (1997), junto com as cidades do Rio de Janeiro e de Recife, formava a tríade de capitais portuárias que difundem a modernidade oitocentista no Império.

Podemos daí inferir que toda a regulação e planejamento do território tinha uma base eclesiástica (capela, freguesia, paróquia) e uma municipalidade nos moldes portugueses que, por sua vez tem sua origem na concepção romana de município.

O estabelecimento das cidades no Recôncavo Baiano neste período se deu principalmente em função da cultura da cana de açúcar, que por sua vez incrementou toda uma dinâmica relacionada à sua cadeia produtiva. O engenho é o maior exemplo desse processo, especialmente no que se refere ao aparelhamento técnico a eles incorporado e ao arcabouço de infraestruturas associadas à produção e distribuição deste produto.

Caio Prado Junior (2008) em sua obra clássica sobre a história econômica do Brasil fez uma descrição interessante e completa, seguida de uma análise sobre a propriedade canavieira que dispunha de engenho próprio. Ele diz o seguinte:

A razão por que nem todas as propriedades dispõem de engenho próprio são as proporções e os custos das instalações necessárias. O engenho é um estabelecimento complexo, compreendendo numerosas construções e aparelhos mecânicos: moenda (onde a cana é espremida); caldeira, que fornece o calor necessário ao processo de purificação do caldo, casa de purgar, onde se completa essa purificação. Além de outras, o que todas as propriedades possuem é, em regra, a casa grande, a habitação do senhor; a senzala dos escravos; e instalações acessórias ou sumárias: oficinas, estrebarias etc. Suas terras, além dos canaviais, são reservadas para outros fins: pastagens para animais de trabalho; culturas alimentares para o pessoal numeroso; matas para o fornecimento de lenhas e madeira de construção. A grande propriedade açucareira é um verdadeiro mundo em miniatura em que se concentra e resume a vida toda de uma pequena parcela da humanidade (PRADO JUNIOR, 2008, p. 38).

Na Figura 4.2.5, a seguir, podemos ter uma ideia panorâmica do "complexo" que forma a dinâmica de um engenho como descrito acima. 


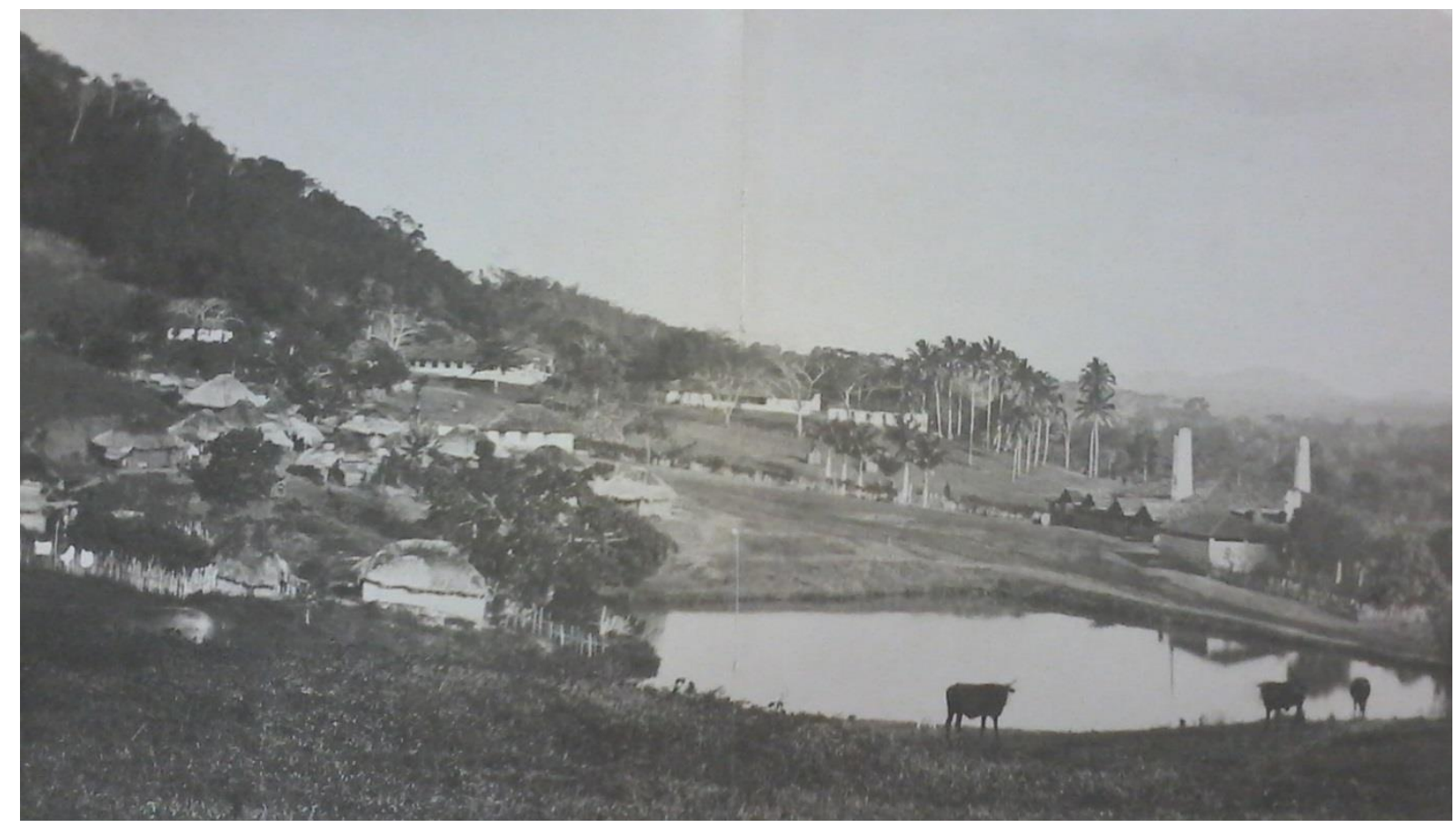

Figura 4.2.5 - Engenho Pedra Branca no Recôncavo Baiano (FERREZ, 1998)

Muitas das cidades do Recôncavo Baiano, portanto, se originaram dos engenhos de açúcar, onde se estabeleceram as primeiras estruturas materiais para formação do que viria a ser uma vila e posteriormente cidade. Ou seja, dos engenhos surgiram as vilas operárias das usinas canavieiras dos últimos anos do século XIX e início do século XX, compostas com os primeiros aparelhos urbanos, tais como vendas, alojamentos para os trabalhadores etc., e demais estruturas necessárias à cadeia produtiva da cultura da cana de açúcar.

Para entender cada etapa da construção da estrutura socioeconômica brasileira, sempre será necessário retrocedermos ao período analisado, como já o fizemos anteriormente. Portanto, para avançar na compreensão do período entre a segunda metade do século XIX e a primeira do século $\mathrm{XX}$, voltaremos mais uma vez ao final dos oitocentos e ao início dos novecentos.

O século XIX foi um período de profundas transformações mundiais, especialmente do ponto de vista técnico, ocasionado pelo desenvolvimento da ciência em países avançados do continente europeu, especialmente a Inglaterra. Uma ação internacional que influenciou diretamente o contexto nacional brasileiro em suas escalas regionais e locais, foi a pressão exercida por este país contra o tráfico de escravos. Naquele momento aquele país era o líder político e tecnológico mundial e influenciou diretamente as mudanças internas ocorridas no 
Brasil, especialmente no que se referiu às relações de trabalho. Este fato reverberaria na dinâmica econômica e territorial brasileira, principalmente a partir da segunda metade desta centúria.

Segundo Prado Junior (2008) o renascimento agrícola iniciado em fins do século XVIII e fortemente impulsionado após a abertura dos portos em 1808 e a emancipação política do país, favoreceu, sobretudo, de início, as regiões agrárias mais antigas do Norte. Aí incluímos o Recôncavo Baiano. Segundo o referido autor, essas regiões “[...] voltam a ocupar posição dominante desfrutada no passado e que tinham parcialmente perdido em favor das minas. Mas esse novo surto do Norte brasileiro não durará muito" (PRADO JUNIOR, 2008, p. 157).

Prado Junior (2008) aponta dois fatos inter-relacionados que explicam as transformações que ocorreram no século XIX:

[...] um de natureza geográfica: é o deslocamento da primazia econômica das velhas regiões agrícolas do Norte para as mais recentes do Centro-sul (o Rio de Janeiro e partes limítrofes de Minas Gerais e São Paulo). Outro é a decadência das lavouras tradicionais do Brasil - da cana de açúcar, do algodão e do tabaco -, e o desenvolvimento paralelo e considerável da produção de um gênero até então de pequena importância: o café, que acabará por figurar quase isolado na balança econômica brasileira (PRADO JUNIOR, 2008, p. 157).

Para o autor acima referido, nada modificou tanto a fisionomia do país como a "verdadeira revolução" que se operou na distribuição das atividades produtivas brasileiras, em função do deslocamento do eixo econômico, a partir da cultura do café, para a região sudeste do país (PRADO JUNIOR, 2008).

Apesar da primeira metade do século XIX ter sido uma etapa de transição política, com a independência do país, Furtado (1968), afirma que o Brasil de meados do século XIX, no que se refere a sua estrutura econômica, não era muito diferente do que tinha sido nos três séculos anteriores, pois sua economia continuava alicerçada principalmente no trabalho escravo, mantendo-se inalterada nas "etapas de expansão e decadência" até o final do século. Tratava-se de um país totalmente carente de base técnica.

Para o autor referido acima, o estancamento das exportações foi a causa principal do atraso relativo da economia brasileira na primeira metade do século XIX. O Brasil entrou muito tarde para a lista dos grandes produtores, ocupando posição muito modesta no início dos dezenove, afirma Prado Junior (2008). 
Para Furtado (1968),

[...] As atividades não ligadas ao comércio exterior são, via de regra, indústrias e serviços localizados nas zonas urbanas. Não existe, entretanto, nenhuma indicação de que a urbanização do país se haja acelerado nesse período. O que houve, muito provavelmente, foi um aumento relativo do setor de subsistência [...] (FURTADO, 1968, p. 117).

Por outro lado, Barickman (2005), critica a "visão plantacionista" da maioria dos intelectuais que pesquisaram a história da economia rural brasileira, incluindo Celso Furtado e Caio Prado Junior, ressaltando que,

[...] Os historiadores que lançaram seu olhar além dos limites da plantation demonstraram que a agricultura de exportação não dominava todo o Brasil rural e que as maiores cidades brasileiras possuíam vigorosa vida social e econômica. Extensas redes de comércio abasteciam essas cidades de provisões essenciais, tecidos e outras manufaturas, tudo produzido no Brasil (BARICKMAN, 2005, p. 27-28).

Para Barickman (2003), a historiografia do Recôncavo, por exemplo, não deu a devida importância à dinâmica e ao peso do mercado interno de gêneros de primeira necessidade, a partir da escravidão e da agricultura de exportação. Furtado (1968) apenas nos dá pistas que vão ao encontro do que afirma Barickman (2003) no que concerne a um crescente mercado interno, no qual o setor de subsistência tem papel fundamental no suprimento de gêneros alimentícios para o abastecimento interno. Segundo este pesquisador,

[...] o uso generalizado do trabalho escravo não impediu que surgisse no Recôncavo um mercado urbano e rural bem desenvolvido para víveres básicos. Pelo contrário, a expansão da economia de exportação promoveu, e até exigiu, o crescimento de um mercado interno. As centenas de pequenos lavradores que abasteciam este mercado utilizavam regularmente mão-deobra escrava para produzir excedentes substanciais de farinha de mandioca (BARICKMAN, 2003, p. 30).

Percebemos que o autor acima citado, chama a atenção para o fato de que o Recôncavo Baiano produziu entre 1780 e 1860 grandes quantidades de açúcar e fumo para o mercado mundial. $\mathrm{O}$ autor nos mostra as relações de dependência mútua entre a produção para a exportação e o necessário desenvolvimento do mercado interno nas principais vilas do Recôncavo. Especialmente centros portuários como Cachoeira, São Francisco do Conde, Jaguaripe, Santo Amaro, Maragogipe e Nazaré. 
Barickman (2003) aponta para a densa rede de relações que, na Bahia, ligavam a vida cotidiana de senhores de engenhos, consumidores urbanos, roceiros, escravos rurais e lavradores de fumo a mercados externos e também locais.

Entre 1780 e 1860 vai haver uma retomada da economia de exportação, o reestabelecimento da agricultura da cana de açúcar e do tabaco, que, na primeira metade do século XVIII passaram por muitas oscilações, principalmente em relação a competitividade desses produtos, oriundos de outras áreas da América, como o açúcar das Antilhas produzido pelas colônias britânicas, francesas e holandesas.

O naturalista francês Alcide Dessalines D’Orbigny (1802 - 1875), chegou ao Brasil na primeira metade do século XIX e descreveu a dinâmica do comércio entre a cidade do Salvador, o Recôncavo, o interior da Província da Bahia e outras localidades, como a Província de Pernambuco. O referido naturalista assim descreve a província da Bahia e sua capital:

O comércio da Bahia, importante e rico, esteve concentrado, durante muito tempo, nas mãos de algumas casas inglesas, poderosas por seus capitais e por seu crédito. Hoje a concorrência derrubou essa espécie de monopólio.

O principal artigo de exportação é o açúcar, do qual saem por ano cerca de oitenta mil caixas, de quarenta arrobas cada uma. [...] O melhor açúcar da Bahia vem do Recôncavo, sendo ele de duas espécies: o da cana colhida em torno da baía, no interior o açúcar mais claro, proveniente de cana colhida além da baía e ao longo da costa.

O tabaco é outro artigo de boa qualidade que se embarca nos navios estrangeiros que tocam no porto. No interior o monopólio pesa sobre esse artigo, que só é livre para a exportação. $\mathrm{O}$ tabaco chega aos mercados da Bahia de janeiro a março, por intermédio das cidades de Cachoeira e Santo Amaro. É armazenado por entrepostos do governo, onde se torna objeto da mais rigorosa vigilância. $\mathrm{O}$ algodão é outro produto do interior que vai se trocar na Bahia por artigos manufaturados da Europa. [...] a maior e a melhor parte do que se vende na Bahia procede da parte meridional da província de Pernambuco. $\mathrm{O}$ algodão de fora é preferível ao do interior [...] A maior parte desse último vem de Vila Nova do Príncipe, na Comarca de Jacobina, de onde é mandado a Cachoeira, em mulas e cavalos. Grandes barcos o transportam dali à Bahia. $\mathrm{O}$ arroz, os couros secos e curtidos, as madeiras de tintura, o melaço, o óleo de peixe, o café, diversas drogas e um pouco de cachaça fazem parte, ainda, das exportações principais.

A Bahia não é, apenas, um dos mais ricos e mais movimentados mercados da América Meridional - com uma residência salubre e temperada - que não conhece nenhuma das endemias que assolam a zona intertropical, cercada de uma atmosfera purificada pelas brisas da terra e do mar [...]

[...] Nada se iguala à animação do porto da Bahia, sobretudo nas vésperas de dias de festa. Vêem-se, então milhares de barcos que acorrem de vinte a trinta léguas de distância. É divertido observar o movimento do cais, ouvir o canto dos negros que carregam fardos cadenciadamente, apreciar a multidão 
que se espalha pelo cais pela Rua da Praia e por seus vastos entrepostos (ORBIGNY, 1976, p. 106).

Várias são as impressões que podemos obter a partir do relato de Orbinigy (1976). A primeira delas é a denominação atribuída à cidade do Salvador, que era chamada de "Bahia", ou "São Salvador". Bahia, provavelmente, numa alusão entre a sua importância no contexto regional e ao acidente geográfico de seu entorno - a Baía de Todos os Santos - e o seu Recôncavo, com suas cidades intermediárias, complementando a ligação entre a capital e as demais regiões da Bahia e do Brasil. Essas cidades, capitaneadas por Salvador formavam uma rede dinâmica, especialmente entre aqueles centros que funcionavam como entrepostos comerciais dos produtos oriundos da própria região, como também daqueles vindos dos sertões, num intenso fluxo de pessoas e mercadorias nos dois sentidos.

Outro aspecto importante de ressaltar era a intensa relação desta cidade com sua região nas escalas regional, nacional e internacional. Esse fato já foi apontado anteriormente, quando da análise no período dos setecentos. Fica claro na descrição acima, a hegemonia da Inglaterra no comércio com o Brasil, desde a chegada da corte portuguesa e a abertura dos portos às "nações amigas" de Portugal, mas naquele momento, Orbigny assinalava o fim daquela hegemonia e a intensa concorrência com a participação de outras nações.

Orbigny (1976), dentre outras observações, faz alusão aos principais produtos de exportação naquela época e também aos produtos secundários. $\mathrm{O}$ açúcar e o tabaco provenientes do Recôncavo Baiano lideravam as exportações na primeira metade do século XIX e eram intermediados no seu transporte para a capital pelos portos de Cachoeira e de Santo Amaro. Esse fato nos dá a dimensão da importância daquelas cidades no contexto regional.

Como já foi dito anteriormente, no Recôncavo se formou uma das mais vigorosas redes de cidades ao longo da história do Brasil. Barickmam (2005) afirma que não menos de 80\% da farinha preparada nas roças de Jaguaripe, Nazaré e Maragogipe na década de 1780 já se destinava ao mercado interno. Ainda segundo ele a demanda rural e urbana de farinha incentivou centenas de roceiros no sul do Recôncavo e ao longo de todo o litoral baiano a cultivar mandioca. Para Barickman (2005), não se pode desprezar os pequenos lavradores, que além dos grandes senhores proprietários de terras, também possuíam escravos e os usavam para produzir excedentes consideráveis de farinha para o mercado interno. 
Toda a argumentação acima nos serve de referência para refletirmos sob outro ponto de vista, mencionado anteriormente, relacionado à fruição da vida cotidiana entre o campo e a cidade, o contexto interurbano e intra-urbano.

A cadeia produtiva de farinha de mandioca no contexto regional do Recôncavo Baiano dinamizou de forma frenética o mercado consumidor interno deste produto. Municípios como Jaguaripe, Maragogipe e Nazaré foram alguns dos mais movimentados da região, que entre 1780 e 1860, além da mandioca, produziam também a cana de açúcar, o fumo e o café (BARICKMAM, 2005, p. 302). É importante chamar a atenção para o fato de que, a localização geográfica dessas localidades, permitiu que, naturalmente, se tornassem importantes pontos de escoamento e recepção da produção agrícola local e regional, através de seus atracadouros e portos, pois se situam às margens de importantes rios.

Em suas pesquisas, Barickmam (2005), comprova através de análise de inventários post-mortem que,

[...] entre meados da década de 1820 e 1860 , mais de $75 \%$ dos lavradores de Maragogipe e Nazaré tinham casas de farinha. Portanto, a expansão do fumo e do café no sul do Recôncavo resultou não na difusão da monocultura de exportação, mas na diversificação da produção em fazendas e sítios de porte médio e pequeno (BARICKMAN, 2005, p. 302).

O dado acima nos permite apontar para uma dinâmica econômica inter-regional de grande envergadura, notadamente no que se refere à cadeia produtiva de alimentos e produtos de consumo interno entre as cidades da região. Nos dá também dimensão das relações sociais do Recôncavo Baiano, que sempre foi fundamentada diretamente entre os proprietários de terra, que por sua vez tornavam-se representantes da política local e regional. E a classe trabalhadora, na sua maioria escrava.

Além disso, indica a divisão inter-regional do trabalho no Recôncavo neste período. Pois, isso não era feito na área da cana de açúcar.

Como se vê, foram mudanças estruturais importantes do ponto de vista técnico, de larga influência espacial, a partir da escala global, passando pelas escalas nacional, regional e local, que foram rebatidas nas cidades além de Salvador.

Podemos citar como exemplo da influência inglesa no contexto das grandes mudanças estruturais na conjuntura do século XIX, especialmente após 1850, na escala regional do Recôncavo Baiano, a construção da Imperial Ponte D. Pedro II, inaugurada em 1885, ligando 
a cidade de Cachoeira à cidade de São Felix. Essa obra foi considerada como uma das mais importantes da época na Bahia.

Segundo o inventário do IPAC,

A construção da Estrada de Ferro Central da Bahia, que tinha como finalidade facilitar o escoamento da produção mineral da Chapada Diamantina. A rigor, bastaria chegar ao Porto de São Felix, mas Cachoeira, a segunda cidade do Estado (Província), pressionou para que nessa oportunidade se concretizasse o seu velho sonho de cruzar o Paraguaçu, incorporando o Distrito de São Felix à cidade e garantindo o seu acesso à região das lavras [...] com apenas quatro vãos e $100 \mathrm{~m}$ de comprimento, lançou mão da tecnologia mais avançada da época. Em sua construção foram utilizados os mais novos equipamentos disponíveis, como bombas centrífugas, guindastes móveis acionados a vapor e rebitadores hidráulicos. As treliças vieram em grande parte prontas da Inglaterra (3). Esta estrutura foi, com justa razão, considerada a mais importante ponte ferroviária realizada na América do Sul até então e constitui um dos mais relevantes marcos históricos da engenharia brasileira (BAHIA, 1982).

É importante salientar que, apesar de o documento do IPAC informar que a construção da referida ponte se trata de "um dos mais relevantes marcos históricos da engenharia brasileira", o primeiro projeto foi apresentado pela 'Paraguassu Steam Tramroad Company' e assinado pelo Eng. E. B. Webb (BAHIA, 1982). Entretanto, esse primeiro projeto não foi executado. É notório, portanto, a influência da tecnologia inglesa em vários aspectos da estruturação técnica das cidades na época, principalmente no que se tratava de engenharia e montagem de estruturas de ferro fundido para construção de pontes, ferrovias e estações ferroviárias.

Tendo em vista o exposto, entendemos que essas narrativas são muito ricas de informações, o que nos ajuda a compreender o contexto socioeconômico, político e cultural da época, desde o final do século XVIII até meados do século XIX.

No território essas mudanças ficaram nítidas nas paisagens urbanas das cidades brasileiras que foram oriundas dos primeiros núcleos de povoamento. No Brasil Colônia, Império e no Brasil da Primeira República floresceram cidades associadas principalmente à economia canavieira e fumageira e, posteriormente, ao ciclo do ouro, borracha e café, respectivamente. Entretanto é sabido que os ciclos não datas exatas de extinção ou decadência, muitas vezes permanecendo em diferentes territórios de forma simultânea e em menores dimensões. 
Ribeiro (2010, p. 103) afirma que no período colonial produzimos muito mais riqueza de exportação do que a América do Norte e "[...] edificamos cidades majestosas como o Rio, a Bahia, Recife, Olinda, Ouro Preto [...]”. Acrescentamos nessa lista as cidades portuárias do Recôncavo Baiano, que descreveremos no próximo capítulo. 


\section{5 - A RELAÇÃo ENTRE SALVADOR E AS CIDADES HISTÓRICAS PORTUÁRIAS DO RECÔNCAVO BAIANO}

Tratar da dinâmica socioeconômica do Recôncavo Baiano edificado de sua paisagem e do seu patrimônio, com base nas permanências do seu patrimônio em suas cidades, vai além da sua esfera eminentemente urbana. Tratam-se, sobretudo, de um esforço de visão ampla das relações entre o campo - aí incluídas todas as atividades de suporte e infraestrutura agropastoris inter-relacionadas à vida urbana; bem como as relações sociais daí advindas - e

as cidades. Essas últimas, locus das atividades inerentes à administração da vida regional. É compreender que uma coisa está intimamente relacionada à outra. Isto é, a formação dos seus primeiros núcleos de povoamento perpassa por um ordenamento territorial regional, onde o urbano passou a ter maior destaque e visibilidade na paisagem geográfica.

Segundo Teixeira (2012), além da língua portuguesa, falada hoje por mais de 220 milhões de pessoas espalhadas por países e regiões na Europa, Américas, África e Ásia, o patrimônio urbano e arquitetônico é outra expressão da cultura portuguesa mais visível nas áreas onde esta cultura prosperou. Afirma também que "[...] mesmo nos locais em que a cultura portuguesa não sobreviveu por meio da língua, ela permanece no urbanismo, na arquitetura e nos modos de fazer e de construir que resultaram desse multifacetado encontro civilizatório, e do qual são testemunhos” (TEIXEIRA, 2012, p. 7).

Neste sentido Risério (2006) afirma que:

De um modo geral as cidades do velho mundo foram uma criação do campo e do tempo. Formaram-se pelo ajuntamento gradual de pessoas num determinado sítio, quase sempre á volta de um mercado. No novo mundo, ao contrário, as cidades nasceram de uma decisão Real, em função de um plano colonizador. A cidade de São Salvador da Baía de Todos os Santos, primeira capital do Brasil, é um exemplo disso. Uma cidade que nasceu não como um produto do passado, mas como um projeto de um futuro. Nas colônias americanas de língua espanhola, as cidades foram planejadas de acordo com o novo modelo urbanístico do Renascimento, um traçado geométrico abstrato, um tabuleiro de xadrez. No Brasil não. Os portugueses transplantaram para as nossas latitudes tropicais, a localização e o desenho da cidade medieval lusitana. Salvador foi pensada e construída como uma cidade lusa no ultramar. Uma cidade que aceita os caprichos do relevo, que se estende sinuosamente à beira mar, a cavaleiro do Atlântico, com suas igrejas e sobrados distribuindo-se por dois andares e a Cidade Baixa, 
também chamada Bairro da Praia ou Comércio, pelo fato de ali terem se concentrado nossas atividades mercantis (RISÉRIO, 2006, s/p.).

Assim como frisou o autor antes referido, sobre a questão da cidade do Salvador aceitar os "caprichos do relevo", Teixeira (2012, p. 7) nos alerta para a questão da especificidade local de cada uma das realidades urbanas e arquitetônicas portuguesas espalhadas pelo mundo "[...] que devem ser entendidas em suas múltiplas raízes europeias, africanas, índias e orientais" Entretanto, chama a atenção para o fato de que o elemento comum que as une é a sua matriz portuguesa.

Neste sentido, Andrade (2013) após um estudo sobre a rede urbana do Recôncavo no século XVIII, afirma que,

O desenho urbano das vilas coloniais, ainda que seguissem as práticas do urbanismo português, estavam determinantemente atrelados à dinâmica espacial vivida. Assim, para além da base comum (praça central, relativa regularidade, respeito à topografia etc.), a forma que o espaço urbano tomava acabava sendo uma derivação das funções primordiais assumidas pela vila (defesa, entreposto, porto fluvial ou marítimo, centro de base agrária), o que orientava, inclusive, a construção do conjunto edificado (ANDRADE, 2013, p. 286).

A rede de núcleos acima mencionada foi o embrião do que Andrade (2013) chamou de uma incipiente rede urbana que se formava no início do século XVIII e que se tornou bem articulada no final deste mesmo século, formando o que viria a se tornar a rede urbana do Recôncavo Baiano nos séculos posteriores. Esse conjunto de vilas e povoações se articulava, tendo Salvador como cabeça dessa rede e por onde era escoada a produção da região.

No caso da análise das cidades portuárias do Recôncavo Baiano, todo o processo de produção do espaço urbano é fruto de uma intencionalidade política e ideológica, cujos traços aparecem nos territórios. Essa rede tem a cidade do Salvador como "cabeça", o que a tornou referência para as outras cidades da região em diversos aspectos, especialmente na forma urbana. Por isso não poderíamos falar sobre elas, sem antes ter uma ideia do papel exercido pela referida cidade no conjunto da província da Bahia e de sua região.

Como também já foi apontado anteriormente o recorte temporal da nossa pesquisa situa-se no século XIX (1823 a 1889). Considerarmos este período como o mais significativo no que tange às permanências das formas urbanas nas cidades históricas portuárias do Recôncavo Baiano. Portanto, faz-se necessário, ainda que de forma resumida, apontar os 
contextos temporais anteriores ao período, para que possamos ter uma noção do papel dos principais agentes que contribuíram na produção e organização do espaço urbano das referidas cidades.

Fazer alusão às cidades portuárias do Recôncavo Baiano perpassa por uma contextualização junto a Salvador. Essa última não se enquadra no nosso objeto, porém está intimamente associada à vida de relações de todas as outras sete cidades por nós pesquisadas.

Assim, é natural que retomemos a história da capital da Colônia; da Sede da Capitania Real da Bahia; da primeira capital da colônia; capital da Província da Bahia e da atual Capital de estado Bahia. Nesse sentido buscamos apreender o sentido da relação entre a cidade do Salvador e as demais cidades da região em foco, retrocedendo nossa análise a períodos históricos anteriores ao proposto para esse estudo.

Salvador foi desde 1549 até 1763 a primeira capital do Brasil e a segunda maior cidade do Império Português, ficando atrás apenas de Lisboa, que em 1820 tinha 210.000 habitantes; a cidade do Porto, no início do século XIX, tinha aproximadamente 55.000 habitantes e estima-se que Salvador, em 1818 tinha 115.000 habitantes (VASCONCELOS, 2002, p. 12).

No contexto do Recôncavo Baiano estima-se que Cachoeira, a mais importante vila e o maior nó de rede urbana daquela região no início do século XIX, tinha aproximadamente 10.000 habitantes (ORBIGNY, 1976). Esse dado nos dá uma ideia da dimensão do significativo aglomerado urbano desta vila do interior da capitania, se compararmos a uma cidade europeia como o Porto, em Portugal, na mesma época.

Pelos dados acima apontados, podemos imaginar o potencial da vida de relações no âmbito regional, guardadas as devidas proporções para a época (século XIX), da cidade de Salvador com as demais vilas/cidades do Recôncavo Baiano, capitaneadas principalmente por Cachoeira, tendo em vista serem locais de concentração demográfica; de atividades econômicas; de núcleo de controle social e territorial; como pela difusão de inovações, como palco de conflitos sociais diversos, dentre outras características, definidas por Abreu (2002) para o estudo das cidades.

Destacaríamos as seguintes características acima apontadas para Salvador, como as mais eloquentes para o nosso estudo: 1- como polo difusor de inovações, desde o pensamento filosófico de uma época, passando pela influência religiosa e com ela a organização do território, até as características da arquitetura a ela inerentes; 2 - as ideologias, que incitam os movimentos sociais e suas articulações na escala local e regional; 3 - as ideias; 4 - a difusão 
da ciência, através dos centros de formação (Liceu de artes e ofícios); 5 - a difusão da técnica aplicada na produção dos territórios e de seus respectivos equipamentos urbanos; 6 - da arte, nas suas mais diversas expressões, principalmente na pintura e na escultura barroca dos edifícios, no interior e no exterior das sedes de templos religiosos. Enfim, a cultura de uma maneira geral, que se difunde nas mais diversas dimensões e escalas.

A cidade do Salvador, portanto, funcionava como uma espécie de "magnetismo", fundamental para o entendimento das demais cidades do Recôncavo Baiano, pois estas giram em torno de sua "órbita" de influência.

Vale lembrar que o aspecto para o qual focamos nossa pesquisa é o patrimônio cultural de natureza material, na sua dimensão urbana/edificada, a partir da análise dos conjuntos urbanísticos e monumentos isolados, com destaque para aquilo que foi construído entre 1823 e 1889.

Como também já dissemos anteriormente, a análise acima referida não pode ser feita sem o devido conhecimento sobre a dinâmica socioeconômica e socioespacial das cidades em foco, nas suas múltiplas relações escalares. Por isso se faz necessário o reconhecimento da cidade do Salvador como base desse entendimento.

É com esse intuito que faremos um breve resumo sobre o papel dos agentes sociais que tiveram participação efetiva na produção e organização espacial da cidade do Salvador em diferentes períodos de sua história, com base na periodização de Vasconcelos (2002), que estudou profundamente as transformações e permanências da referida cidade entre 1549 e 1999. Reportar-nos-emos aos períodos denominados pelo referido autor até o limite que mais nos interessa, buscando, quando possível, associá-los ao universo de nossa pesquisa. Dentre os períodos estipulados por Vasconcelos (2002), destacamos os seguintes:

1. Implantação da "Cabeça de Ponte": Capital Colonial Defensiva (1549/1650);

2. A idade do ouro de Salvador: riqueza e religiosidade (1650/1763);

3. Capital de capitania: hegemonia mercantil (1763/1823);

4. Salvador no Império: instabilidade e africanização (1823/1849);

5. Salvador no Império: estabilidade e infraestruturação (1850/1889);

6. Salvador $(1889-1930)$

Algumas questões da referida periodização, como o fim do tráfico, são bastante gerais e podem servir para uma visão numa escala mais ampliada como a do Recôncavo. Por outro lado, as "reformas urbanas" foram específicas de Salvador, mas o período inicial (1889) coincide com a república, o que é bastante geral também. 
Os três primeiros períodos anteriores ao estipulado para nossa pesquisa (1823/1889) nos servirão de expiação, para o entendimento do contexto da cidade e da região por ela polarizada, na medida do possível para esta associação. Entretanto, o quarto, e o quinto períodos são os que mais se aproximam do nosso recorte temporal e foco principal da análise. O sexto período é importante no sentido de termos uma visão de uma época posterior e assim percebermos o diálogo possível, às transformações e permanências entre um período e outro da história.

Adiante faremos um breve resumo dos referidos períodos, contextualizando os acontecimentos mais importantes ocorridos em cada um deles na escala local da cidade de Salvador e, na medida do possível, associando à escala regional e no contexto das cidades históricas portuárias do Recôncavo Baiano.

\subsection{PERÍODOS ANTECEDENTES A 1823}

\subsubsection{O período entre 1549 e 1650 ( $1^{\circ}$ período de Vasconcelos)}

Segundo Vasconcelos (2002, p. 39), no primeiro período (1549/1650), “[...] os principais 'Agentes Econômicos' eram os senhores de engenho, que exerciam suas atividades em áreas rurais, Recôncavo, embora participassem da vida da cidade". Aqui já podemos ressaltar a relação direta entre o Recôncavo ainda rural e a capital da colônia. Os comerciantes e artesãos eram outros agentes que também faziam parte do universo da cidade naquela época, embora com menos importância social. Os africanos, aos poucos substituíram os indígenas no trabalho escravo (VASCONCELOS, 2002).

No que diz respeito à morfologia urbana, produção e organização espacial, Salvador foi planejada. Na parte alta implantaram a sede do poder civil e religioso. Na parte baixa, no nível do mar, implantaram-se as atividades marítimas e de comércio.

Segundo Sena (2015), no período entre os séculos XVI e XVIII, os pilares de sustentação em Salvador eram três: defesa, implantação da fé cristã e o estabelecimento do comércio para lucros. Como a cidade já nasceu com a peculiar função de capital, tornou-se importante internacionalmente, assim como o seu porto, que se expandiu a ponto de ser, no 
século XVIII, o maior do Atlântico Sul. Salvador foi a cidade mais populosa do hemisfério sul no século XVIII, afirma o referido autor, arquiteto e professor da Universidade Federal da Bahia, em entrevista ao jornal A TARDE de 29/03/2015 (p. 3). Data em que a referida cidade completou 466 anos.

Ainda segundo Sena (2015) a arquitetura da época ainda pode ser percebida até os dias de hoje, especialmente as da fase monumental de suas igrejas, do auge do barroco no Brasil, que vai do final do século XVII a meados do século XVIII. Também nesse período vão surgir os grandes sobrados e conjuntos urbanos de grandes dimensões, que marcam a paisagem urbana do século XIX, e que marcam o atual centro antigo da cidade. É que continuaremos a ver a seguir.

\subsubsection{O período entre 1650 e 1763 ( $2^{\circ}$ período de Vasconcelos)}

No segundo período (1650/1763), Vasconcelos (2002) aponta que a Colônia era a parte mais importante do Império Português. Daqui saíram donativos para o casamento do príncipe português em 1728. Da capitania da Bahia saíram contribuições vultosas para a reconstrução de Lisboa, após o terremoto de 1755, durante um período de trinta anos, com grande soma do total enviado por Salvador (VASONCELOS, 2002). É evidente que nessa época toda a riqueza desta cidade era proveniente de sua zona de influência direta, principalmente relacionada à cultura canavieira e fumageira do Recôncavo Baiano.

Segundo Vasconcelos (2002), nesse segundo período a Igreja Católica foi o principal agente no processo de produção e organização do espaço urbano de Salvador, quando foram construídos os principais edifícios religiosos da capital. Também o Estado teve papel fundamental para o desenvolvimento da cidade, à medida que consolidou o sistema de fortificações, permitindo uma certa segurança para a mesma. Ainda segundo o referido autor, os agentes econômicos (senhores de engenho e comerciantes), “[...] ainda profundamente impregnados pela mentalidade religiosa, e com a circulação de bens ampliada com a descoberta de ouro nas minas, também participaram dessas transformações urbanas nesse período ‘áureo’ de Salvador” (VASONCELOS, 2002, p. 75).

Nesse período surgiram as igrejas de porte monumental e de grande densidade na decoração interna de seus templos, com altares de retábulos follheados a ouro, que 
influenciariam suas congêneres nas principais vilas do Recôncavo Baiano. Segundo o autor supracitado, “[...] o período entre 1650 e 1763, é um dos mais importantes para Salvador, na medida em que foram implantados os principais edifícios do conjunto arquitetônico e urbanístico de caráter monumental" (VASCONCELOS, 2002, p. 92). Nas Figuras 5.1.2.1 e 5.1.2.2, a seguir, podemos ter uma ideia e uma visualização da assertiva acima.

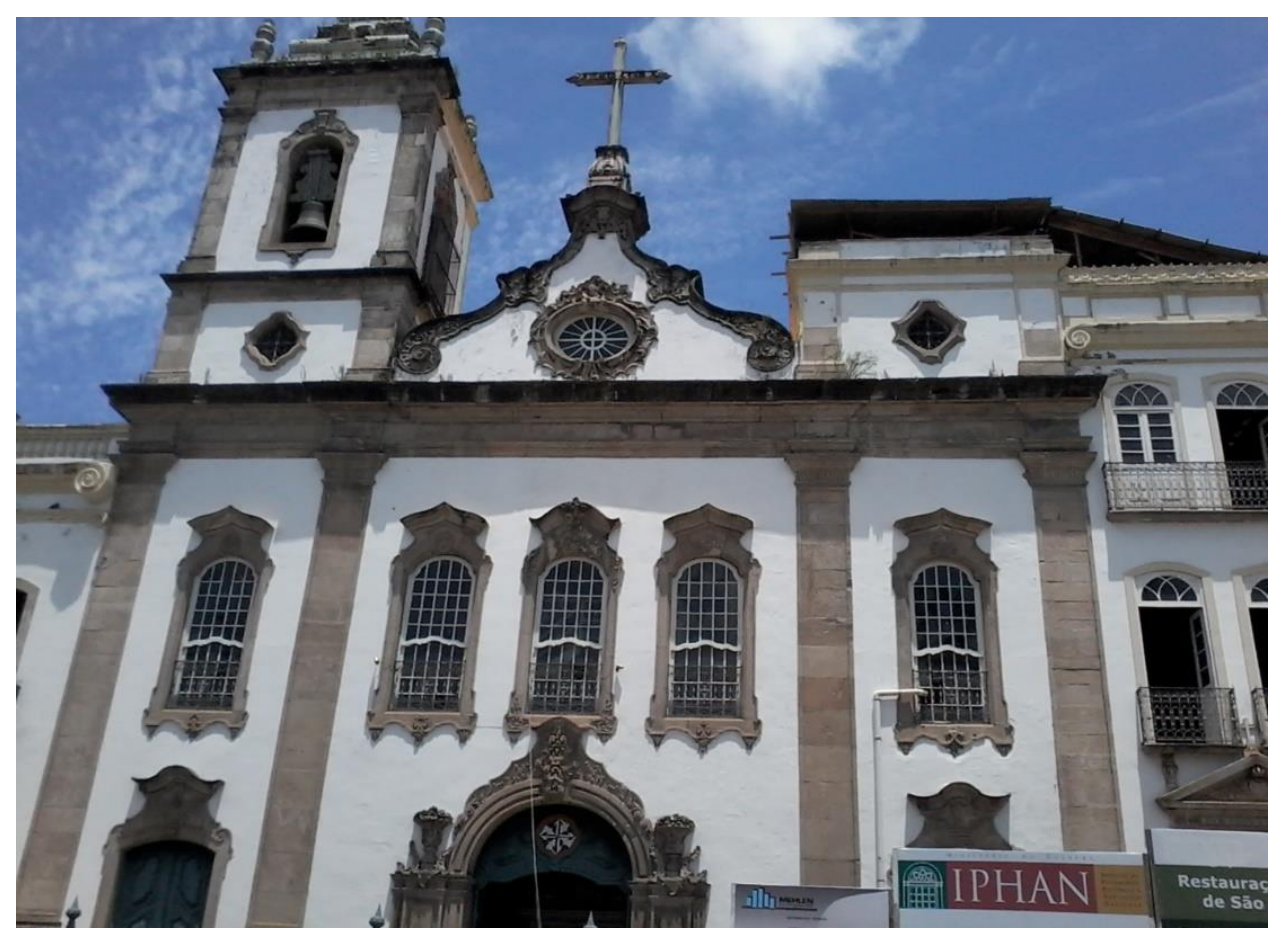

Figura 5.1.2.1 - Igreja de São Domingos de Gusmão, praça do Terreiro de Jesus (Imagem do autor em trabalho de campo, 2014)

Na Figura 5.1.2.2, a seguir, temos as características da igreja acima, em placa do IPHAN, que na ocasião da execução da fotografia, estava em processo de intervenção e restauro da área externa e interna da referida igreja. 


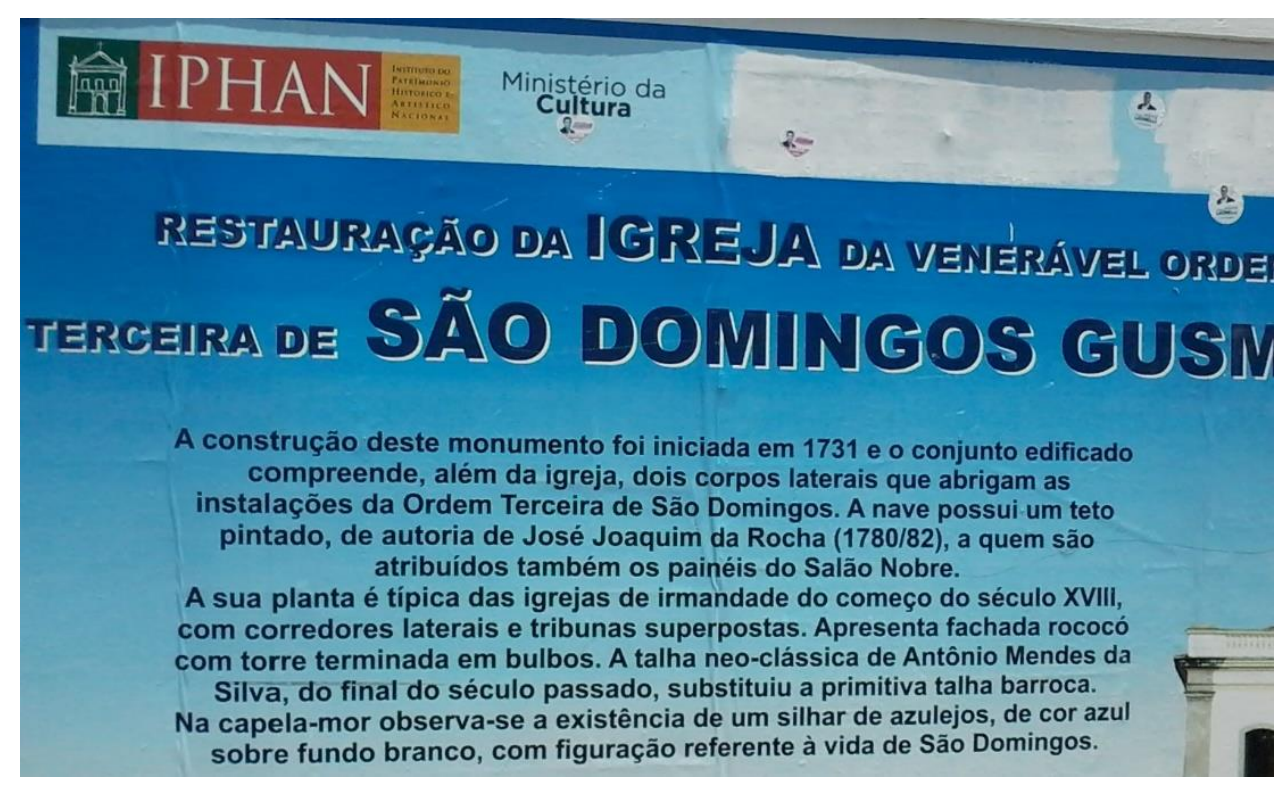

Figura 5.1.2.2 - Reclame informativo do IPHAN sobre a história da Igreja de São Domingos de Gusmão, centro histórico de Salvador - BA (Imagem do autor em trabalho de campo, 2014)

Ainda tratando sobre a monumentalidade desses templos católicos erigidos na cidade do Salvador no século XVIII, as Figuras 5.1.2.3 e 5.1.2.4 nos dão uma dimensão da riqueza e da concentração desses prédios numa única praça, O Terreiro de Jesus. Ali foram erigidos o Colégio dos Jesuítas, a Catedral Basílica e a igreja de São Pedro dos Clérigos Figura 5.1.2.3 todas de caráter monumental. Além dessas, em praças que se interligavam, ainda temos a igreja de São Francisco, em Praça do Cruzeiro do mesmo nome e na Praça da Sé, onde se localiza o primeiro prédio da residência Arquiepiscopal do Brasil. Todos desse período. 


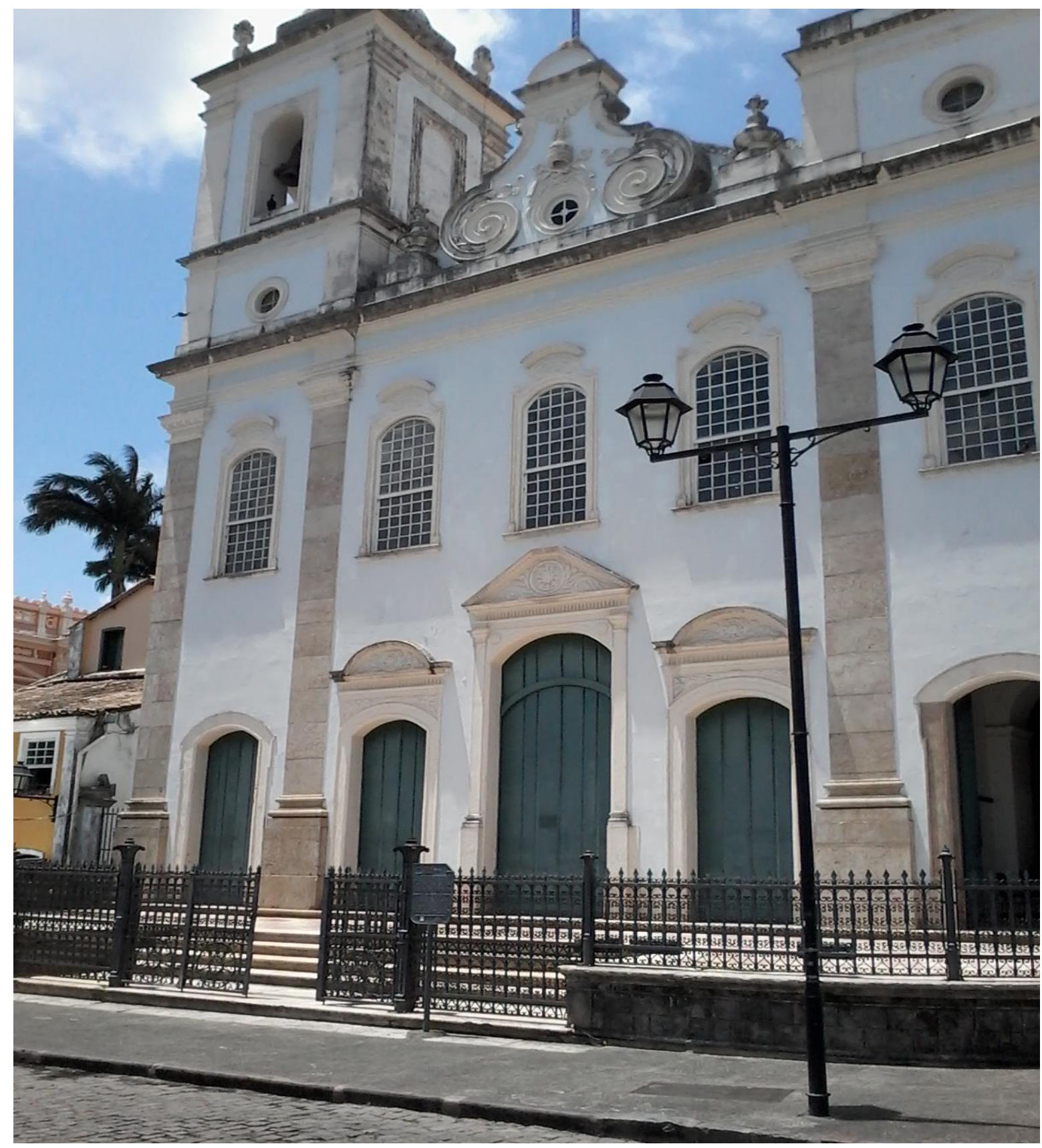

Figura 5.1.2.3 - Igreja de São Pedro dos Clérigos, praça do Terreiro de Jesus, centro histórico de Salvador - BA

(Imagem do autor em trabalho de campo, 2014)

Na figura 5.1.2.4, a seguir, temos uma placa com a descrição das características da Igreja acima, que foi construída ao longo do século XVIII e início do século XIX, por isso apresenta maior diversidade de estilos no seu interior. 


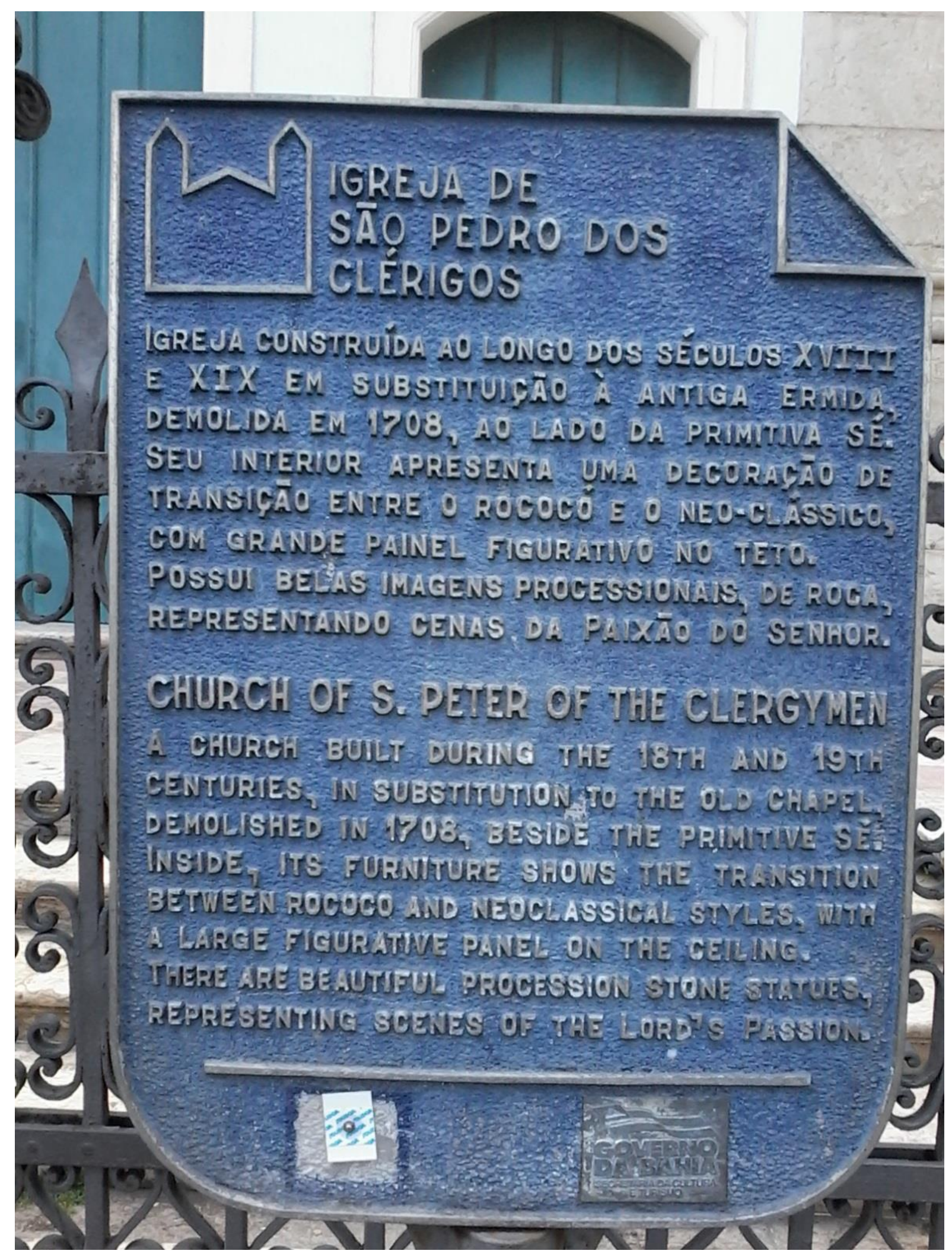

Figura 5.1.2.4 - Características da igreja de São Pedro dos Clérigos, praça do Terreiro de Jesus, centro histórico de Salvador - BA

(Imagem do autor em trabalho de campo, 2014) 
Foi o período do auge do estilo barroco na Bahia. Muitas dessas igrejas foram construídas com doações de senhores de engenho do Recôncavo Baiano e de comerciantes em ascensão em Salvador. Foi o período da consolidação das ordens religiosas na cidade, influenciando o seu entorno imediato e o Recôncavo. Construíram inúmeros prédios religiosos e civis, inclusive dois engenhos no Recôncavo pelos Beneditinos, como nos informa Vasconcelos (2002).

\subsubsection{O período entre 1763 e 1823 ( $3^{\circ}$ período de Vasconcelos)}

O terceiro período (1763/1823) é marcado inicialmente pela transferência da capital da colônia (Salvador) para o Rio de Janeiro e concluído com a independência e emancipação política brasileira, da condição de colônia de Portugal, para a condição de Império independente. Salvador continuava sendo até quase o final do período, a principal cidade da América Portuguesa e primeira praça comercial (VASCONCELOS, 2002).

Corroborando com as afirmações de Vasconcelos (2002), ainda no próspero século XVIII, Risério (2006), quando trata da produção do urbano, especialmente do patrimônio edificado em Salvador neste mesmo período, assevera que:

\footnotetext{
Além de prédios isolados, pontuando com destaque o espaço citadino, surgiram também ao longo do século XVIII, alguns conjuntos urbanos, são os produtos do urbanismo barroco na Bahia. Grupos de prédios residenciais e comerciais, construídos de acordo com um projeto comum. Como seria no cais da farinha e no cais das amarras, ambos no bairro da Praia. Eram conjuntos de quadras, formados por edifícios que tinham o mesmo número de andares e o mesmo acabamento externo, fazendo com que o observador tivesse a impressão de estar vendo um único prédio em cada quadra. E cada conjunto aparecia como uma obra que se impunha no espaço urbano, como uma espécie de "quebra mar" de ordem e elegância (RISÉRIO, 2006, s/p.).
}

A Figura 5.1.3.1 a seguir, nos dá uma dimensão da descrição supracitada e da paisagem urbana de Salvador no século XIX, mas ainda com grande parte da sua tessitura urbana do século anterior. 


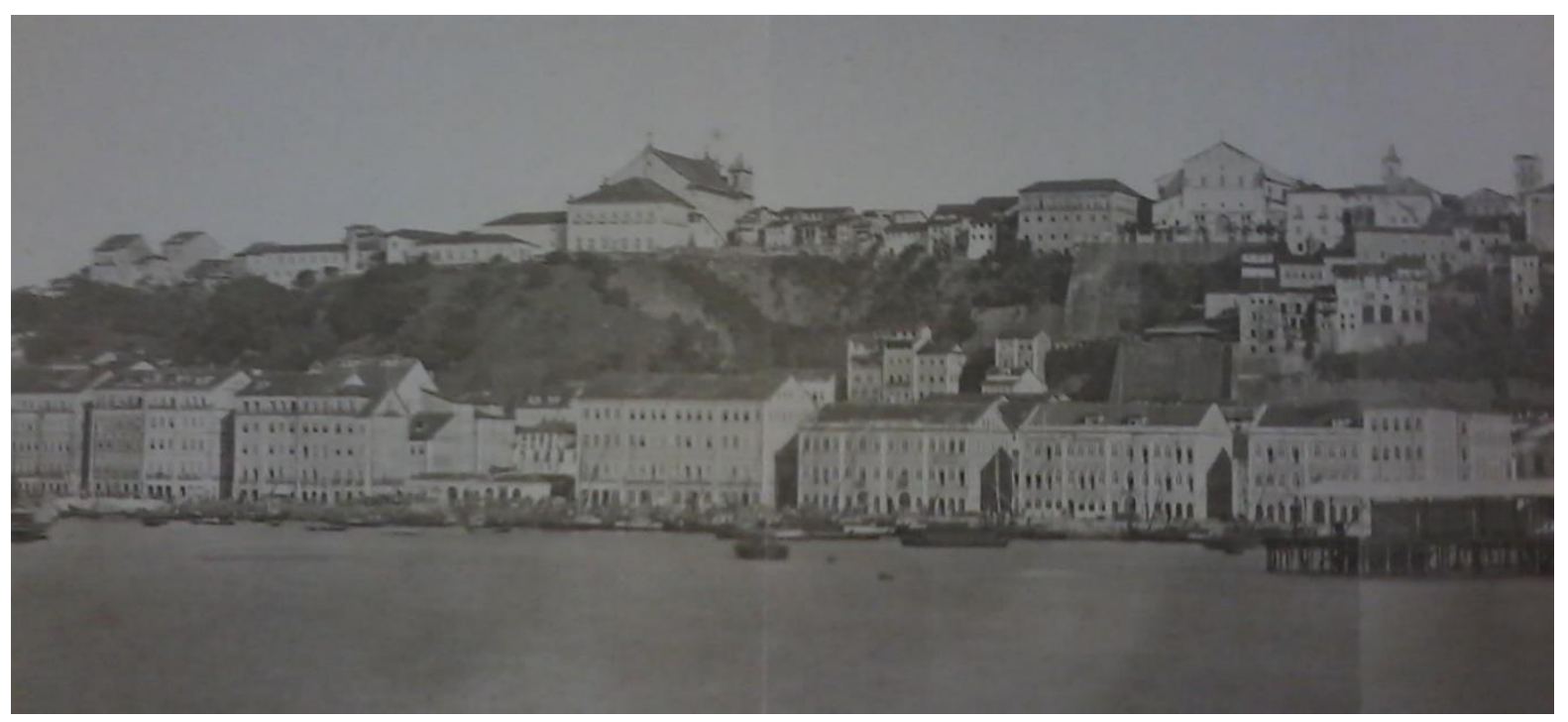

Figura 5.1.3.1 - Vista da cidade de Salvador a partir da Baía de Todos os Santos no século XIX (FERREZ, 1988)

Este período também coincidiu com o final do curto, porém próspero ciclo do ouro na região das Minas Gerais. Assim o escoamento da produção mineral da região das minas foi estrategicamente transferido do porto da primeira capital do país, para o litoral fluminense.

As capitanias do nordeste não acompanharam o desenvolvimento das novas estruturas produtivas da mesma forma que as do sudeste, principalmente no que tange a aplicação de novas técnicas e tecnologias ao campo e, consequentemente suas vilas e cidades perderam a importância e destaque no cenário nacional. Além disso, a visão empreendedora e menos tradicional dos produtores rurais do Sudeste fez com que aquela região prosperasse mais rapidamente do que o Nordeste, onde ainda permanecia uma visão tradicionalista e arcaica, oriunda dos antigos senhores de engenho da região, desde os tempos coloniais.

No Atlas de Representações Literárias de Regiões Brasileiras (IBGE, 2006), encontramos uma descrição apontando que, com o café, surgiu no final do Século XVIII um novo gênero de vida no Brasil que marcou os momentos finais do período colonial. Inserido noutro contexto político-econômico-mundial, a cafeicultura representou um retorno à economia agrária. Promoveu grandes transformações nas várias esferas da vida brasileira em âmbito interno, à medida que se conjugava com as instituições vigentes. Os autores consideram esta cultura, como uma "civilização do café", vinculada “[...] à independência política, ao Império brasileiro, a formação de um ideário nacional e, posteriormente ao regime republicano" (IBGE, 2006). 
Daí surgirem ainda no século XVIII, ao longo do trajeto entre o interior de Minas Gerais e o litoral da província fluminense, núcleos de povoamento nos territórios daquela região da colônia, que iriam se transformar em importantes vilas e, posteriormente cidades prósperas, ao longo daquele período.

Além de toda essa atmosfera política e socioeconômica, a vida de relações na área das minas e, posteriormente em todo Sudeste brasileiro, prosperou com foco na riqueza da produção mineral, especialmente do ouro e, mais tarde, da cultura do café naquela região.

Após as considerações incluídas no próximo tópico, retomaremos a contextualização de mais dois períodos estipulados na periodização de Vasconcelos (2002). O período entre 1850 e 1889; e o outro entre 1889 e1944, este último, como já explicamos na introdução deste trabalho, ultrapassa o recorte estipulado para a pesquisa, mas julgamos importante, já que buscamos um diálogo em que, o passado serve de expiação para o entendimento de períodos posteriores.

Destacamos o período a seguir (1823 a 1849), pois nele está incluído o ano em que se consolidou a Independência do Brasil, na Bahia. Este evento teve grande importância para o entendimento das relações entre os agentes sociais da cidade do Salvador e as vilas portuárias do Recôncavo Baiano, principalmente Cachoeira, São Francisco do Conde, Santo Amaro, Maragogipe e Jaguaripe. Nessa época, São Felix e Nazaré ainda não haviam se emancipado. Portanto, cabe aqui o destaque, pois a estrutura de rede existente e a estrutura urbana das referidas cidades, foi fundamental na estratégia de organização das batalhas entre os autóctones e os portugueses.

\subsection{O PERÍODO ENTRE 1823 E 1849 (4 PERÍODO DE VASCONCELOS)}

Após a independência esse período foi marcado por grande instabilidade política, relacionada às questões de centralidade do Império e a autonomia das províncias. Foi um período de intensa ação do Estado como agente mantenedor da unidade nacional, apesar das instabilidades regionais.

A Igreja Católica agora estava subalterna ao Estado brasileiro, não tendo mais o mesmo papel do período colonial, perdendo espaço político e territorial com o confisco dos 
bens de algumas ordens regulares de clero português. Entretanto, muitas ordens ainda detinham propriedades urbanas e rurais. Segundo Vasconcelos (2002),

Em 1823, os Beneditinos ainda possuíam 93 prédios em Salvador, além de fazendas no Recôncavo [...] Em 1847, temos um balanço do patrimônio das ordens regulares, conforme o relatório do presidente da Província, Magalhães: a referida ordem dos Beneditinos possuía sete engenhos de açúcar e recebia quatro contos de aluguéis urbanos; os Carmelitas eram 46 religiosos e tinham 15 contos de réis de rendimentos de foros, prédios urbanos e produtos agrícolas [...] (VASCONCELOS, 2002, p. 183-184).

Os fatos apontados acima nos dão pistas que podem revelar a concomitância temporal e as similaridades na produção material do patrimônio na cidade do Salvador e nas cidades do Recôncavo Baiano. As igrejas monumentais erigidas nos séculos XVIII e XIX nas cidades de Jaguaripe, Cachoeira, São Francisco do Conde, Santo Amaro, Maragogipe, Nazaré e São Felix são um exemplo desse processo que estamos denominando de produção simultânea nas cidades dessa região.

A sinalização para institucionalização das matrizes culturais genuinamente brasileiras, através da identificação de suas formas materiais e imateriais foi enaltecida no Império. Teve início após a independência, por uma busca de identidade e cultura própria do território. Tal processo foi encabeçado pelo próprio imperador D. Pedro II.

Ao longo desse período, D. Pedro II buscou a criação de uma identidade nacional que ultrapassasse as diferenças regionais - utilizando-se de uma simbologia autóctone, através do uso da imagem do índio brasileiro e do branco europeu aqui nascido.

É ainda neste período que vão ser criados o Instituto Histórico e Geográfico Brasileiro e a Academia Imperial de Belas Artes no Rio de Janeiro (SCHWARCZ, 2011). Portanto, temos um movimento intelectual e político na busca de nossa cultura e identidade próprias e, consequentemente, a afirmação dos nossos símbolos de nacionalidade, que perpassa pela identificação de símbolos nacionais, dentre estes os de natureza material, inclusive os monumentos arquitetônicos das nossas cidades coloniais.

Entretanto, o que de fato ocorreu foi o predomínio do sentimento de nacionalidade focado na capital do Império. Tal constatação se baseou no fato de ali serem construídas as infraestruturas necessárias para a organização institucional do aparelho de Estado, de onde partiriam os ideais de consolidação da nossa identidade. 
Este período (1823 a 1845) nos chama a atenção e nos interessa principalmente pelo evento da Independência do Brasil, na Bahia, que culminou no 2 de julho de 1823, fato que destacamos no próximo subtópico, pois tem relação mais direta entre Salvador e cinco das sete cidades históricas portuárias do Recôncavo baiano que estamos pesquisando. É o que veremos a seguir.

\subsubsection{A interação entre a cidade de Salvador e as vilas portuárias do Recôncavo Baiano, na consolidação da independência do Brasil na Bahia, e o patrimônio edificado como testemunho}

Na introdução do seu livro sobre o ano da Independência do Brasil, Gomes (2010, p. 24), afirma que constatou em suas pesquisas que "[...] a história da Independência tem sido contada excessivamente pela perspectiva das margens do Ipiranga". O referido autor critica este fato, demonstrando que esta visão direciona o foco apenas para a região sudeste, “[...] como se o restante do país não existisse ou todos os demais brasileiros fossem coadjuvantes de acontecimentos limitados à região compreendida pelas províncias de São Paulo, Rio de Janeiro e Minas Gerais [...]”. Concordamos com a visão do autor que, com base em viagens de pesquisa pelo Brasil constatou que "[...] O processo de separação de Portugal envolveu todo o Brasil e custou muito sangue e sacrifício às regiões Norte e Nordeste, onde milhares de pessoas pegaram em armas e morreram na Guerra da Independência [...]” (GOMES, 2010, p. 24).

Nossa intenção em trazer para a análise o evento da Independência da Bahia, é a de chamar a atenção para a questão simbólica atrelada ao patrimônio edificado, relacionado àquele evento. Alguns edifícios utilizados como uma espécie de "aparelho" do movimento (residências, igrejas, conventos, casas de câmara e cadeia), serviu como pontos de encontros e de reuniões, onde foram articuladas e deliberadas importantes decisões relacionadas ao movimento. Muitos dos referidos edifícios permanecem na paisagem urbana das cidades pesquisadas.

$\mathrm{Na}$ Bahia não foi diferente e as cidades portuárias do Recôncavo Baiano, especialmente Cachoeira, Santo Amaro, Maragogipe, Jaguaripe e São Francisco do Conde tiveram grande importância no processo de consolidação da independência do Brasil entre os 
anos de 1822 e 1823. A articulação entre elas foi fundamental nos últimos combates contra as tropas portuguesas no Recôncavo e, finalmente em Salvador.

Segundo o historiador Tavares (2008),

[...] é possível encontrar uma sequência de preparativos na Bahia para o reconhecimento da autoridade do príncipe dom. Pedro, já então aclamado no Rio de Janeiro Defensor Perpétuo e Constitucional do Brasil. Realizou-se em 21 de junho uma reunião secreta de proprietários, lavradores e militares. Em 24 de junho concentraram-se soldados e oficiais milicianos armados sob o comando dos grandes proprietários e coronéis de milícias [...] no sítio de Belém, povoado pouco acima da vila de Cachoeira (TAVARES, 2008, p. 236).

A sequência de eventos acima apontada por Tavares (2008) se deu resumidamente da seguinte forma:

1. Em 25 de junho de 1822, a Câmara de Cachoeira pediu uma reunião urgente como a presidida pelo juiz de fora Antônio de Cerqueira Lima, do Capitão-Mor José Antônio Fiuza e vereadores, quando foram indagados: “[...] do povo. E tropa... se eram contentes que se aclamasse a S.A.R Sr. D. Pedro de Alcântara, por Regente e Perpétuo defensor e protector do Reino do Brasil” (TAVARES, 2008, p. 236). A resposta foi afirmativa e daí, o procurador da vila, "[...] jogou o estandarte da Câmara para os mais de quatrocentos homens armados que se encontravam em frente ao prédio" (TAVARES, 2008, p. 237).

2. Nesse mesmo dia o povo se revoltou e se insurgiu contra uma canhoneira lusa, fundeada em frente a vila para policiá-la e disparou contra a população. “[...] Quase ao mesmo tempo, alguns portugueses atiraram de suas casas nos brasileiros que passavam nas ruas. No dia seguinte, formou-se a primeira Junta Interina, Conciliatória e de Defesa [...]”, que adotou as decisões de governo, tais como:

[...] enviar mensageiros às vilas e povoações para informar-lhes a aclamação do príncipe e as hostilidades portuguesas já declaradas pela escuna canhoneira. Também solicitava que organizassem homens e armas para deter os tiros da canhoneira e dos portugueses isolados em suas residências (TAVARES, 2008, p. 237).

A reação foi imediata e, à custa de muita luta e derramamento de sangue, os cachoeiranos tomaram heroicamente a canhoneira. Este evento é tido como o início do momento definitivo no processo efetivo de lutas pela emancipação política do Brasil em relação a Portugal, e de Cachoeira como a vila pioneira deste movimento (CEI, 1994). 
Segundo o historiador acima referido,

A 26 de junho reuniu-se a Câmara da vila de Maragogipe e decidiu: "No Reino do Brazil deve residir um único Centro de Poder Executivo na Pessoa do Príncipe Real". No dia 29 chegou a Cachoeira uma delegação das vilas de São Francisco do Conde e de Santo Amaro [...] Propuseram que a Junta ampliasse suas atribuições e se transformasse em governo militar e civil legítimo para todas as vilas do Recôncavo. Nesse mesmo dia as vilas de São Francisco do Conde e de Santo Amaro aclamaram o príncipe dom Pedro como Regente Constitucional do Brasil [...]

No passo seguinte, em agosto, incisiva representação das Vilas de São Francisco do Conde e Santo Amaro pediu o estabelecimento de um governo geral, não só para o recôncavo e comarca da Bahia, mas para toda a Província [...] (TAVARES, 2008, p. 238).

O governo foi estabelecido composto por representantes das vilas da seguinte forma: de Santo Amaro (presidente); Cachoeira (secretário); São Francisco do Conde (desembargador); Jaguaripe (capitão); Maragogipe (capitão - mor). Além dessas, outras vilas, além do Recôncavo Baiano foram incorporadas. São elas: Inhambupe, Pedra Branca, Abrantes, Itapicuru, Valença Água Fria Jacobina, Marau, Rio de Contas, Camamu, Santarém e Cairú (TAVARES, 2008, p. 238-239).

Podemos perceber pela assertiva acima que naquela época já havia uma considerável articulação inter-regional entre as vilas do Recôncavo e outras do Litoral Norte, Litoral Sul e sertão da Província da Bahia.

Ainda segundo Tavares,

Esse Conselho Interino exerceu enérgica e constante ação política, militar e administrativa desde sua instalação. Procurou manter-se governo ao longo da campanha militar para expulsar o Exército português da cidade do Salvador. Nos primeiros dias de sua existência, dirigiu-se às Câmaras e exigiu votos de fidelidade e obediência, organizou batalhões, reuniu e distribuiu armas e munições, assim se comportando até que o coronel de milícias Joaquim Pires de Carvalho e Albuquerque de Ávila Pereira entregou o comando das forças milicianas e de voluntários que comandava ao general francês Pedro Labatut, enviado pelo governo do príncipe dom Pedro no comando do exército pacificador que continuaria a guerra de novembro de 1822 a 2 de julho de 1823. Foi com o Exército de milicianos e voluntários que o Conselho Interino sustentou as posições de defesa estabelecidas na ilha de Itaparica e nos pontos do Funil, São Roque, Encarnação, Iguape, Capanema, Saubara e ponta de Nossa Senhora (TAVARES, 2008, p. 239).

Como se pode perceber pelo exposto acima, uma grande rede de vilas e povoados já estava formada no início do século XIX, estabelecendo com Salvador uma conexão intensa e 
complementar. Tanto do ponto de vista das relações político - administrativas, como também do ponto de vista dos fluxos, incluindo neste último não só mercadorias e suprimentos, mas também ideias, informações, aspirações e cultura material. Essa última, presente no patrimônio da paisagem urbana das cidades que compunham a referida rede.

Conhecida pelos baianos como independência da Bahia, mas que na verdade, como apontado anteriormente, o 2 de julho de 1823 foi a consolidação da Independência do Brasil. Fato até hoje negligenciado pela maioria dos brasileiros. Para os Baianos essa data tem profunda representação simbólica de patriotismo e civismo e é comemorada até os nossos dias em vários municípios baianos, especialmente aqueles que tiveram participação efetiva no processo, com desfile cívico e militar.

Em Cachoeira, no dia 25 de junho, a sede do governo da Bahia é transferida para aquela cidade e há desfile cívico e militar, resgatando de forma simbólica o importante papel desempenhado pelos agentes políticos, militares e civis naquela vila.

Em Salvador, no dia 2 de julho há uma grande festa em algumas artérias importantes da cidade, com "parada" militar e desfile cívico, quando vários segmentos da sociedade civil organizada manifestam seu descontentamento ou contestamento contemporâneo. O cortejo apresenta elementos que simbolizam a cultura brasileira e busca reproduzir a tomada de Salvador e expulsão definitiva dos portugueses.

O "2 de julho de 1823" foi um marco definitivo da libertação brasileira da opressão portuguesa. Além do significado político de emancipação definitiva do Brasil da condição de colônia de Portugal para a condição de Império independente. Significou também um profundo marco em relação à questão do verdadeiro sentido de nacionalidade que permeava o sentimento dos aqui nascidos. Foi um momento ímpar para o processo de integração e de sentimento de pertença ao território.

Em pesquisa de campo, encontramos a exposição "Rota da Independência", que ocorreu no Centro Histórico de Salvador, ao longo do mês de julho de 2013. A referida exposição nos chamou a atenção para o papel dos negros no processo de independência da Bahia. Além disso, foram expostos painéis fotográficos com imagens da paisagem urbana atual das cidades do Recôncavo Baiano que tiveram participação na logística das lutas pela independência do Brasil, na Bahia. Nos referidos painéis podemos ver os conjuntos urbanos e monumentos isolados das cidades de Cachoeira, Santo Amaro, Maragogipe, São Francisco do Conde e São Felix, que de alguma forma tornaram-se simbólicos para a memória da resistência e da articulação entre as então vilas da região. 
A descrição dos painéis dessa exposição nos ajudam na percepção do patrimônio, no sentido de visualizarmos, ainda que de forma indireta, os edifícios que ainda permanecem na paisagem urbana daquelas cidades. Eles nos ajudam também a obter uma visão de conjunto dos monumentos das mesmas.

Na Figura 5.2.1.1 a seguir, temos as informações sobre os objetivos da exposição, um mapa de localização da área e uma breve descrição sobre a participação da população negra no evento da independência da Bahia, que reproduzimos em seguida:

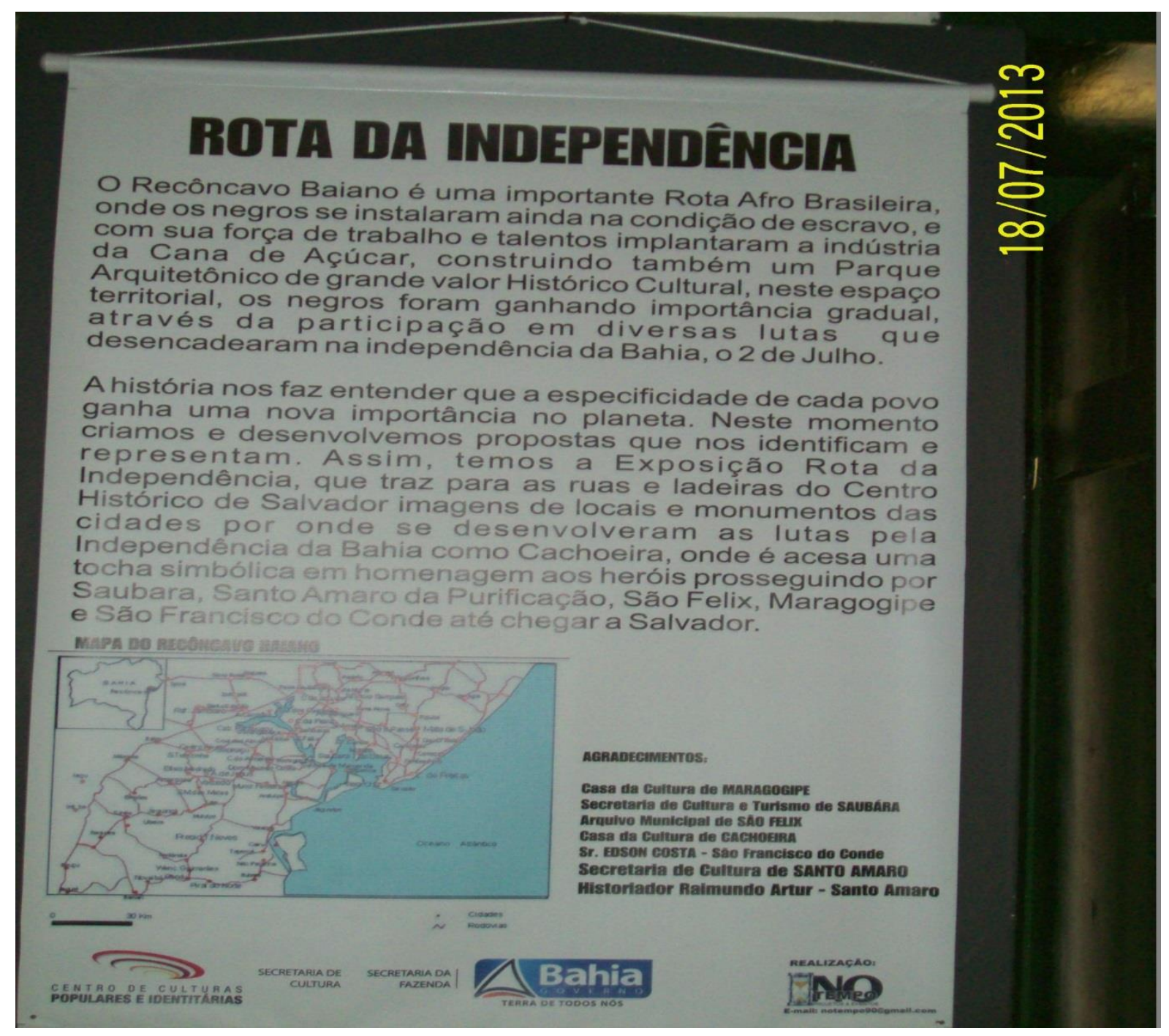

Figura 5.2.1.1 - Exposição Rota da Independência, centro histórico de Salvador - BA (Imagem do autor, 2013) 


\section{Rota da Independência}

O Recôncavo Baiano é uma importante Rota Afro Brasileira, onde os negros se instalaram ainda na condição de escravo, e com sua força de trabalho e talentos implantaram a indústria da cana de açúcar, construindo também um Parque Arquitetônico de grande valor Histórico Cultural, neste espaço territorial os negros foram ganhando importância gradual, através da participação em diversas lutas, que desencadearam na independência da Bahia, o 2 de julho.

A história nos faz entender que as especificidades de cada povo ganham uma nova importância no planeta. Neste momento criamos e desenvolvemos propostas que nos identificam e representam. Assim, temos a exposição Rota da Independência, que traz para as ruas e ladeiras do centro histórico de Salvador imagens dos locais e monumentos das cidades por onde se desenvolveram as lutas pela Independência da Bahia como Cachoeira, onde é acesa uma tocha simbólica em homenagem aos heróis, prosseguindo por Saubara, Santo Amaro da Purificação, São Felix, Maragogipe e São Francisco do Conde, até chegar a Salvador (EXPOSIÇÃO ROTA DOS DESCOBRIMENTOS, 2013).

Nos chama a atenção na Figura 5.2.1.1 a descrição que enaltece o papel do negro no processo de construção do "Parque Arquitetônico de grande valor histórico", revelando o valor do trabalho de uma grande parcela da população que vivia na condição de escravos. $\mathrm{Ou}$ seja, podemos inferir daí que o conteúdo da forma urbana não é apenas aquilo que desponta ao nosso olhar. A forma pura. Isto é, a forma urbana é também um dado que nos revela o conteúdo. Como afirma Santos (1992), as formas não são apenas um dado passivo, mas um dado ativo também, quando buscamos interpretá-lo à luz da história e da formação socioespacial.

A exposição acima mencionada foi uma iniciativa do Centro de Culturas Populares e Identitárias, órgão vinculado à Secretaria da Cultura do estado da Bahia e teve apoio da Secretaria da Fazenda do estado Bahia.

É interessante perceber que até os nossos dias esse evento (o 2 de julho) é um marco identitário muito significativo para os baianos de todas as classes sociais e etnias. No desfile que acontece em Salvador no dia 2 de julho, feriado estadual, o maior destaque é para os carros alegóricos que transportam as figuras do Caboclo e da Cabocla, representantes maiores do povo baiano naquelas batalhas.

A referida exposição é um indicador que nos chama a atenção para o fato de que o evento da independência da Bahia está marcado na memória e nos territórios das então vilas envolvidas no processo.

Segundo Gomes (2010), 
Nenhum estado brasileiro comemora a Independência do Brasil com tanto entusiasmo quanto a Bahia. As diferenças começam pelo calendário. $\mathrm{O}$ feriado de sete de setembro, marcado nas outras regiões por desfiles militares e escolares aos quais o povo raramente comparece, é ignorado pela maioria dos baianos. A verdadeira festa acontece no dia 2 de julho, data da expulsão das tropas portuguesas de Salvador em 1823. E só perde em grandiosidade para o carnaval. [...] Em todo o percurso, os moradores enfeitam suas casas, estendem faixas pelas ruas e reúnem os amigos para celebrar. As alegorias misturam elementos de festa cívica, Carnaval e sincretismo religioso. O carro principal mostra o Caboclo, símbolo do sentimento nativista, matando uma serpente, representação da tirania portuguesa em 1822 [...] (GOMES, 2010, p. 195-196, grifo nosso).

A descrição acima nos dá a dimensão da grandiosidade e importância do evento do "Dois de Julho" para os baianos, principalmente para o povo de Salvador e do Recôncavo. Se trata de um marco no processo de auto reconhecimento da relação sociedade/espaço na Bahia, cuja conexão entre agentes sociais de territórios adjacentes foi fundamental para o objetivo final e para consolidação de uma identidade regional. Essa conexão só foi possível pelo fato de já haver estabelecida uma conexão de rede urbana desde o século XVIII naquela área, Guardadas as devidas proporções para o que era considerado urbano naquela época (ANDRADE, 2013).

A seguir continuaremos descrevendo os painéis fotográficos da exposição mencionada anteriormente, para que possamos ter uma ideia do conjunto arquitetônico e de alguns monumentos isolados das cidades acima referidas. Trazemos isso para que possamos perceber as similaridades do conjunto urbano na escala local e daí termos uma ideia na escala regional, especialmente no que se refere à forma urbana.

Continuando a descrição dos painéis acima referidos, a Figura 5.2.1.2, a seguir, mostra os monumentos principais da cidade de Santo Amaro, onde aconteceram fatos relevantes na ocasião da independência. 


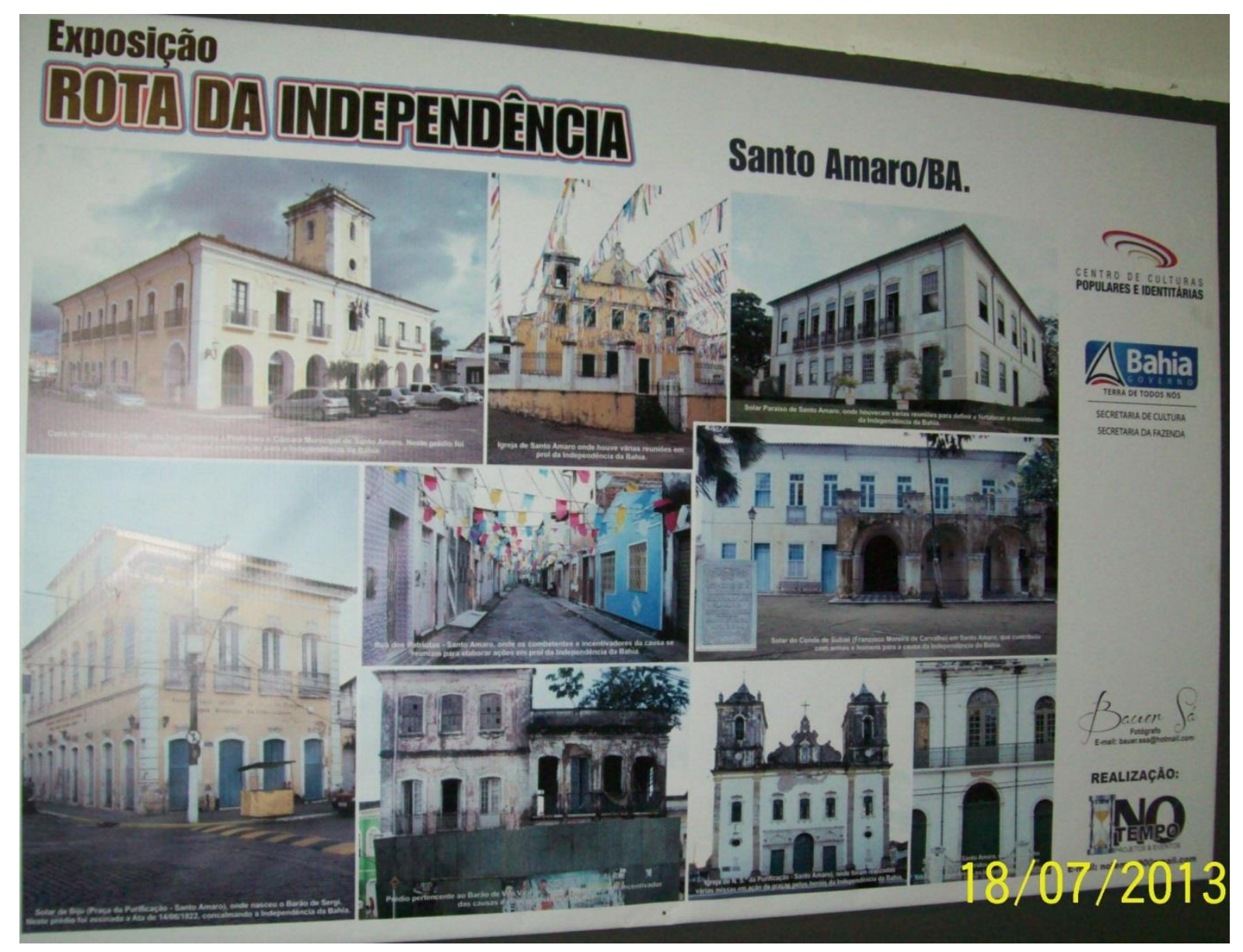

Figura 5.2.1.2 - Cidade de Santo Amaro - BA e arredores na exposição Rota da Independência (Imagem do autor, 2013)

Abaixo descreveremos as informações deste painel, com base nas informações das legendas de cada foto:

1. Primeira foto à esquerda da parte superior do painel: Casa de Câmara e Cadeia, onde atualmente funciona a prefeitura. Naquele prédio foi assinada a $1^{\mathrm{a}}$ ata de convocação para a independência da Bahia;

2. Segunda foto da esquerda para direita da parte superior do painel: Igreja de Santo Amaro, onde aconteceram várias reuniões em prol da independência da Bahia;

3. Terceira foto da esquerda para direita da parte superior do painel: Solar Paraíso de Santo Amaro, onde houve várias reuniões para definir e fortalecer o movimento de independência da Bahia;

4. Primeira foto da esquerda para a direita, logo abaixo da Casa de Câmara e Cadeia: Solar do Biju (Praça da Purificação), onde nasceu o Barão de Sergi. Neste prédio foi assinada a Ata 14 de junho de 1822, conclamando a independência da Bahia; 
5. Foto bem ao centro do painel: Rua dos Patriotas, onde os combatentes e incentivadores da causa se reuniam para elaborar ações em prol da independência da Bahia;

6. Última foto à direita da segunda fileira: Solar Conde de Subaé (Francisco Moreira de Carvalho), que contribuiu com homens e armas para a independência da Bahia;

7. Segunda foto da esquerda para a direita da última fileira da parte inferior do painel: prédio pertencente ao Barão de Vila Viçosa, grande incentivador das causas da independência da Bahia;

8. Penúltima foto da esquerda para a direita da última fileira da parte inferior do painel: Igreja de Nossa Senhora da Purificação, onde foram realizadas várias missas de ação de graças pelos heróis da independência da Bahia;

$\mathrm{Na}$ última foto da esquerda na fileira inferior do referido painel, não foi possível identificar os caracteres da legenda.

A Figura 5.2.1.3 mostra o painel fotográfico da cidade de Cachoeira.

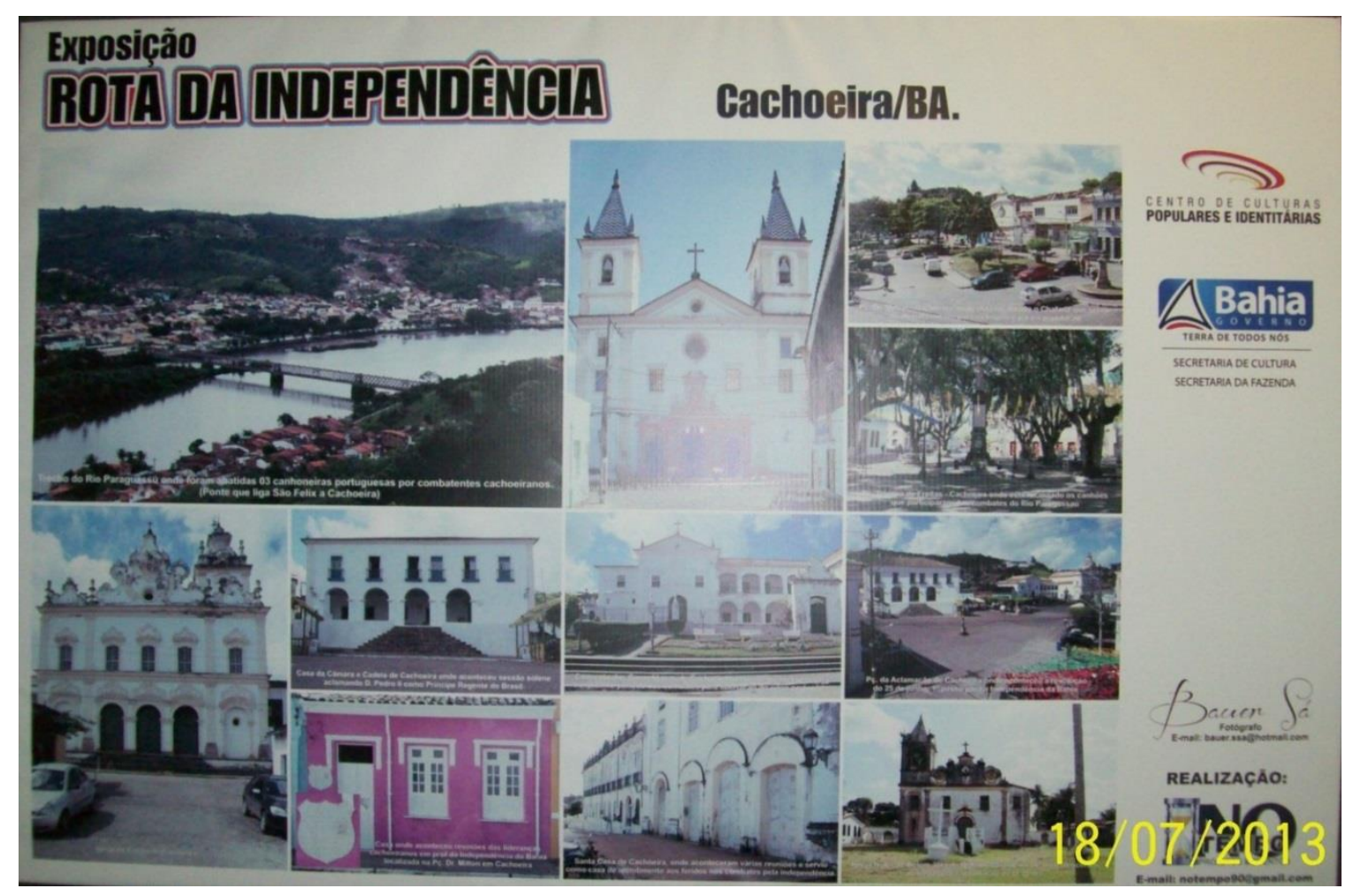

Figura 5.2.1.3 - Cidade de Cachoeira - BA na exposição Rota da Independência (Imagem do autor, 2013)

As legendas das imagens apresentadas no painel da cidade de Cachoeira nos dão as seguintes informações: 
1. Primeira foto do canto superior do painel: trecho do rio Paraguaçu, onde foram abatidas três canhoneiras portuguesas por combatentes cachoeiranos. Ponte que liga São Felix a Cachoeira;

2. A segunda foto da esquerda para a direita na fileira superior: Igreja Matriz de Nossa Senhora do Rosário de Cachoeira;

3. A terceira foto do canto superior direito: Praça Dr. Milton, onde está localizado o Chafariz que serviu de abastecimento para as tropas e para a população;

4. A quarta foto, logo abaixo da foto acima: Praça Teixeira de Freitas, onde estão localizados os canhões que participaram dos combates do Rio Paraguaçu;

5. Primeira foto do canto inferior esquerdo: Igreja de Nossa Senhora do Carmo;

6. Ao lado da foto acima se encontram duas fotos: A primeira é Casa de Câmara e Cadeia, onde aconteceu a sessão solene, aclamando D. Pedro II, como Príncipe Regente do Brasil. Logo abaixo desta está a foto de uma casa em cor lilás. Na referida casa aconteceram reuniões das lideranças cachoeiranas em prol da independência da Bahia. Localizada na Praça Dr. Milton;

7. Terceira foto da esquerda para a direita, na fileira do meio: Convento da Ordem Terceira do Carmo. Não conseguimos visualizar a descrição da legenda, mas no inventário do IPAC (BAHIA, 1982, p. 40) consta de que nesse convento, entre 1817/1823, “[...] sendo poucos os religiosos, é instalado, no térreo do convento, quartel do Bat. da Inf. Miliciana e, depois, das tropas libertadoras".

8. Foto em seguida a do Convento, terceira de cima para baixo do canto direito: Praça da Aclamação de Cachoeira, onde aconteceu a revolução de 25 de junho, $1^{\circ}$ passo para a independência da Bahia;

9. Penúltima foto da esquerda para a direita da fileira inferior: Santa Casa de Cachoeira, onde aconteceram várias reuniões e serviu como casa de atendimento aos feridos nos combates pela independência;

10. A foto do canto inferior direito: Igreja de Nossa Senhora de Belém.

A última foto do painel acima se refere ao atual distrito de Belém, onde também aconteceram reuniões em prol da independência, mas está fora do nosso recorte espacial para esta pesquisa.

O próximo painel é referente à cidade de Maragogipe, Figura 5.2.1.4, a seguir. 


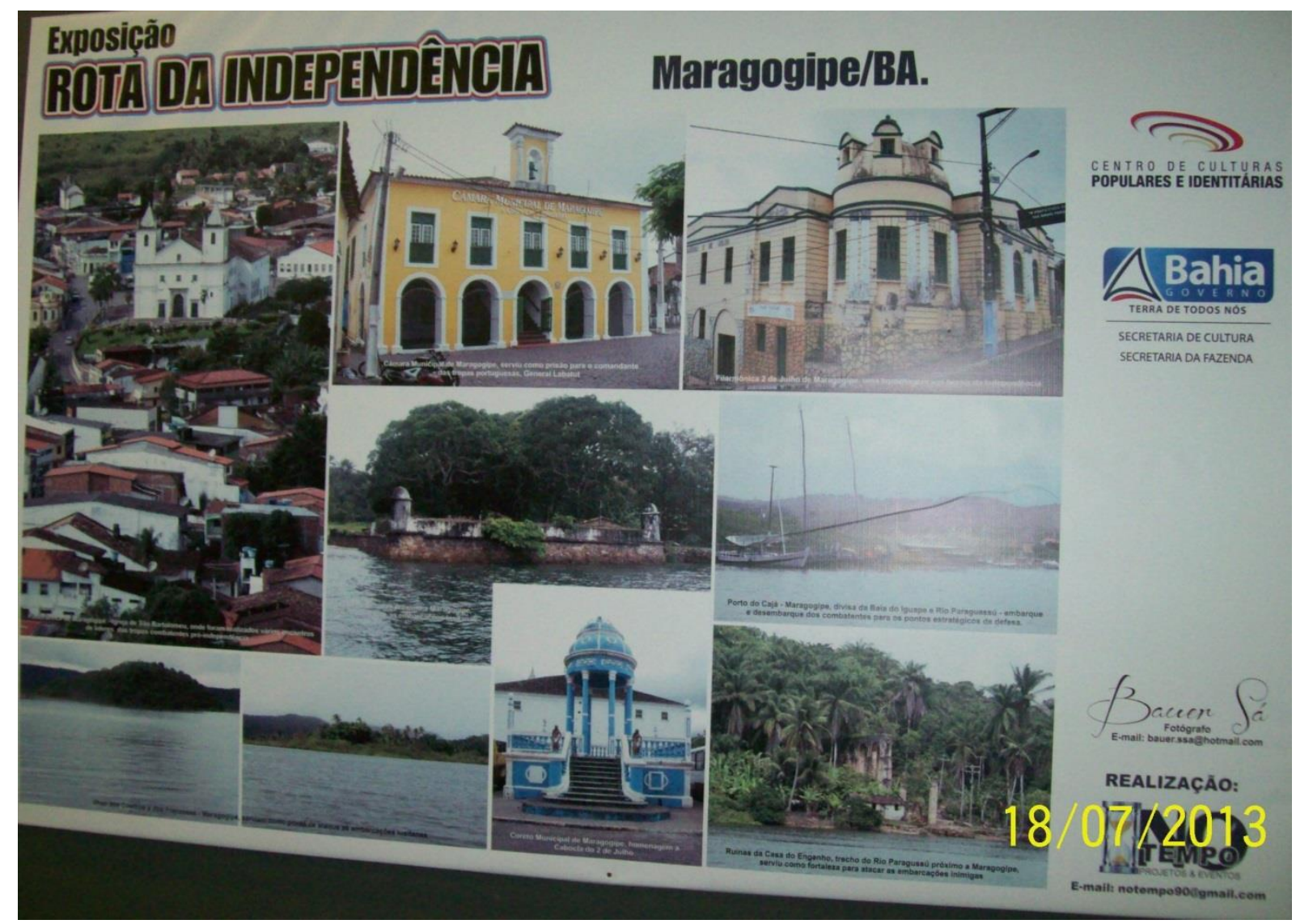

Figura 5.2.1.4 - Cidade de Maragogipe - BA e arredores na exposição Rota da Independência (Imagem do autor, 2013)

No painel acima destacamos as fotos que se referem aos monumentos na área urbana de Maragogipe, cujas legendas informam o seguinte:

1. Primeira foto, no canto superior direito: foto panorâmica da cidade, com destaque para a Igreja Matriz de São Bartolomeu, onde foram realizados vários encontros de líderes das tropas combatentes pró-independência;

2. Segunda foto da esquerda para a direita da fileira superior: Casa de Câmara e Cadeia, onde foi preso o comandante das tropas portuguesas;

3. Terceira foto no canto superior direito: casa onde funciona a Filarmônica 2 de Julho de Maragogipe, uma homenagem aos heróis da Independência;

4. A última foto da esquerda para a direita da fileira do meio: Porto do Cajá, divisa da baía do Iguape e Rio Paraguaçú. Local de embarque e desembarque dos combatentes para os pontos estratégicos de defesa; 
5. A penúltima foto da fileira inferior: Coreto Municipal de Maragogipe, homenagem a Cabôclado 2 de Julho.

As demais fotos do referido painel são registros de imagens do rio Paraguaçú e da Baía de Iguape, no mesmo rio.

No painel de fotos de São Francisco do Conde, Figura 5.2.1.5, encontramos as seguintes imagens:

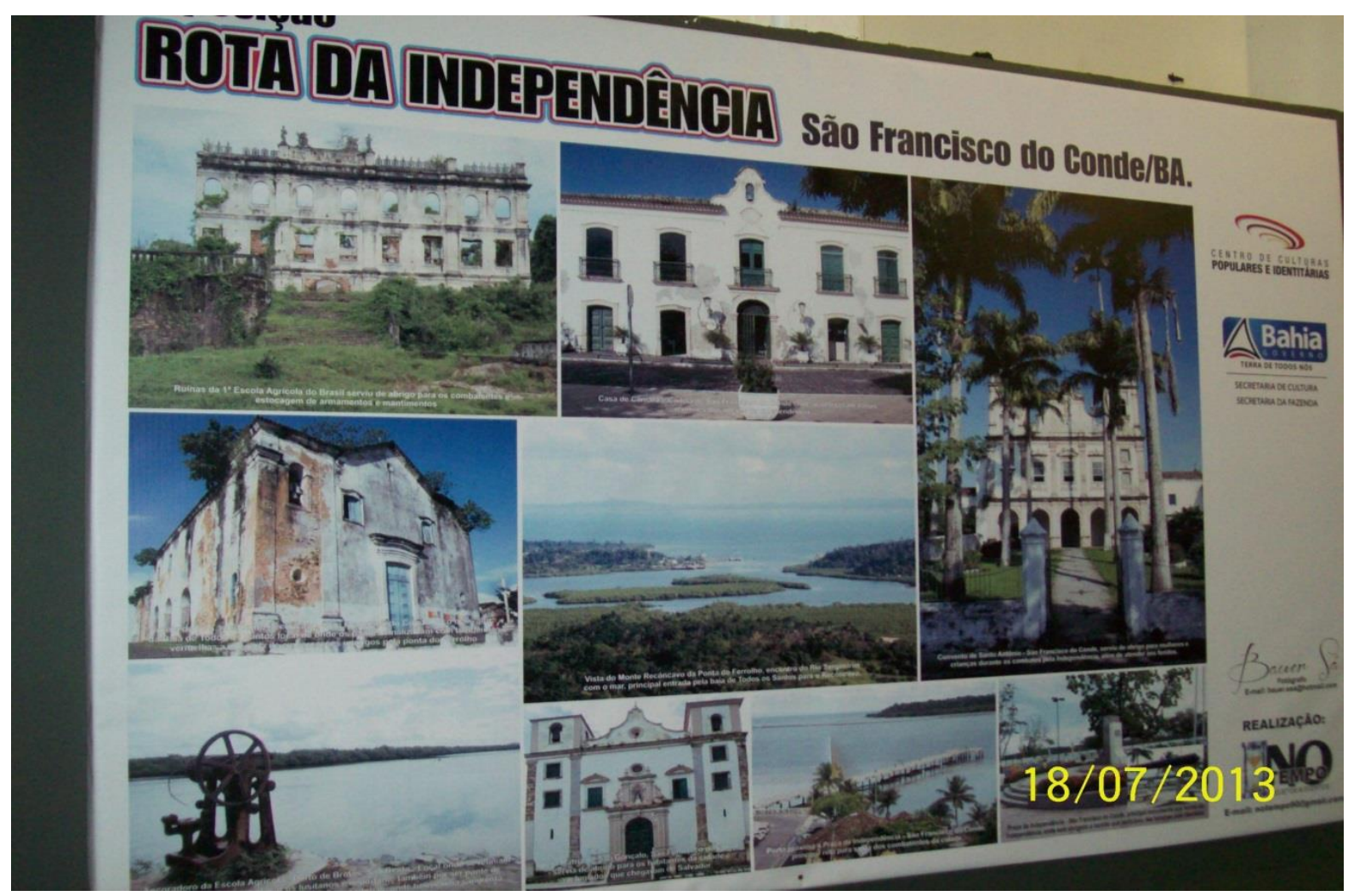

Figura 5.2.1.5 - Cidade de São Francisco do Conde - BA e arredores na exposição Rota da Independência (Imagem do autor, 2013)

Neste painel, além das imagens que consideramos mais importantes para o nosso trabalho, aquelas que retratam o patrimônio na zona urbana, registramos também uma imagem da zona rural, que julgamos importantes no processo de articulação entre os territórios e monumentos rurais e urbanos, no processo da independência. O painel informa o seguinte: 
1. A primeira foto da esquerda para a direita na parte superior do painel: ruínas da primeira Escola Agrícola do Brasil, que serviu de abrigo para os combatentes e de armazém para estocagem de armamentos e mantimentos;

2. A segunda foto da esquerda para a direita, na parte superior do painel: Casa de Câmara e Cadeia onde aconteceram várias reuniões dos líderes da independência da Bahia;

3. A foto do canto superior direito do painel: Convento de Santo Antônio, que serviu de abrigo para mulheres e crianças durante os combates pela independência, além de atender seus feridos;

4. A foto do centro do painel: vista do Monte Recôncavo da Ponta do Ferrolho, encontro do rio Sergimirin com o mar, principal entrada da Baía de Todos os Santos para o Recôncavo.

5. Primeira foto da esquerda para a direita da fileira inferior do painel: Igreja Matriz de São Gonçalo serviu de abrigo para os habitantes da cidade e desabrigados que chegavam da cidade do Salvador;

6. Segunda foto da esquerda para a direita da fileira inferior do painel: porto próximo a Praça da Independência, principal rota para a saída dos combatentes;

7. Foto do canto inferior do painel: Praça da Independência, principal monumento aos heróis da independência, onde está abrigado o canhão que foi utilizado nas batalhas.

No próximo painel, referente a cidade de São Felix, Figura 5.2.1.6, destacamos os monumentos mais significativos: 


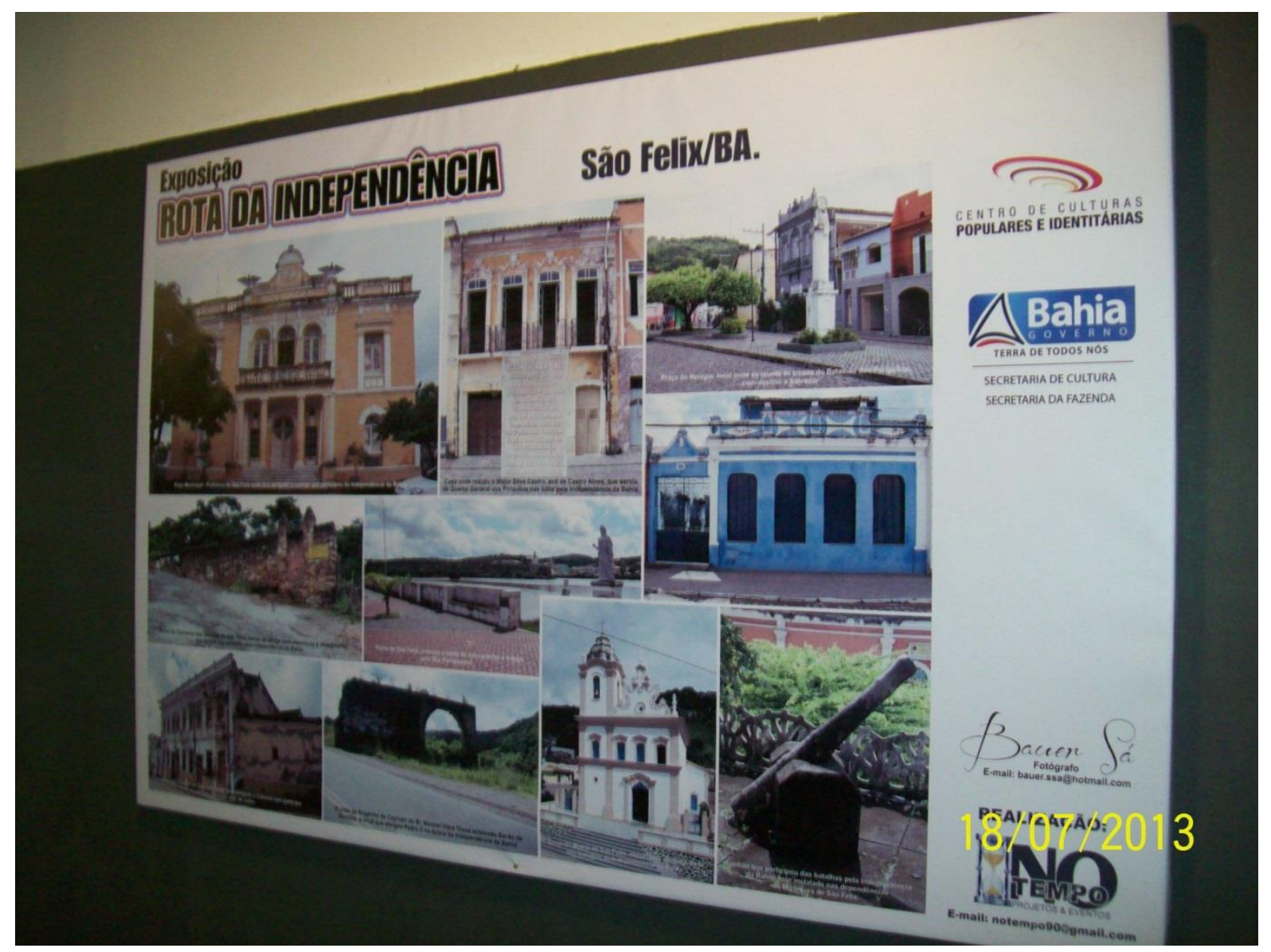

Figura 5.2.1.6 - Cidade de São Felix - BA e arredores na exposição Rota da Independência (Imagem do autor, 2013)

As legendas do painel, figura 5.2.1.6, nos informam o seguinte sobre os monumentos:

1. Primeira foto da esquerda para a direita do painel: Paço Municipal, Prefeitura de São Felix.

2. Segunda foto da esquerda para a direita na fileira superior do painel: casa onde residiu o Major Silva Castro, avô de Castro Alves, que serviu de Quartel General dos Periquitos nas lutas pela independência da Bahia;

3. Terceira foto do canto superior direito do painel: Praça do Relógio, onde se reuniam as tropas do Batalhão dos Periquitos com destino a cidade do Salvador;

4. Segunda foto da esquerda para a direita na parte inferior do painel: ruínas do Engenho de Capivari do Sr. Manuel Vieira Tosca, aclamado Barão de Moritiba e local que abrigou D. Pedro II na época da independência da Bahia;

5. Penúltima foto da parte inferior do painel: Igreja Matriz de São Felix, ponto de apoio em prol da independência da Bahia; 
6. Última foto do canto inferior do painel: canhão que participou das últimas batalhas pela independência da Bahia, atualmente instalado nas dependências da Prefeitura de São Felix.

Após a descrição das imagens dos painéis acima e do contexto regional analisado, não restam dúvidas sobre a rede que essas cidades formaram desde o século XVIII, como foi detectado por Andrade (2013). Portanto, o evento da Independência do Brasil, na Bahia, foi um marco importante de consolidação desta rede, pois houve uma maior intensidade nas relações entre aquelas vilas e a capital do Império que se formava, num sentido político e de solidariedade, além de um profundo sentido de unidade regional.

A questão do uso do patrimônio urbano para além das funções para as quais foram concebidos no período da Independência da Bahia mostra a sua importância na relação entre a sociedade e o uso do território. Igrejas, conventos, Casas de Câmara e Cadeia, sobrados, Casas de Misericórdia, Chafarizes, enfim, diversos tipos de equipamentos urbanos utilizados na logística de guerra nas vilas que participaram mais efetivamente do processo, nos dão uma ideia, segundo a qual, em todas elas havia um padrão similar destes equipamentos. Isso foi percebido, principalmente na análise dos painéis da exposição "Rota da Independência", acima descritos.

Tendo em vista o exposto, podemos considerar as sete cidades históricas portuárias no contexto regional do Recôncavo Baiano, como um conjunto que forma uma região simbólica, na perspectiva de Corrêa (2012, p. 138-139). Ou seja, lugares onde acontecem manifestações espaciais da cultura. Simbólicos porque “[...] são lugares que estão impregnados de significados políticos, religiosos, étnicos ou associados ao passado". Fato que os torna “[...] dotados de uma singularidade simbólica, distintos qualitativamente dos demais lugares caracterizados por uma diferenciação quantitativa" (CORRÊA, 2012, p. 139). No caso das cidades em tela, cada uma tem seu legado simbólico, que se complementam e se constituem num legado simbólico em escala regional.

Para Corrêa uma cidade histórica é um possível exemplo de lugar simbólico, inserida em uma dada rede urbana regional. Para este autor,

[...] Um bairro, uma praça ou rua, ou mesmo um prédio, são exemplos possíveis de lugares simbólicos inseridos no complexo espaço urbano, diferenciado em termos econômicos e sociais. Há, na realidade, escalas espaciais em que os lugares simbólicos podem ser apreendidos (CORRÊA, 2012, p. 138-139). 
É no sentido simbólico apontado acima e numa escala regional, que no próximo tópico retomamos a periodização de Vasconcelos (2002), para análise das transformações e permanências da cidade do Salvador, buscando sempre contextualizá-la com o processo de produção do patrimônio urbano das cidades portuárias do Recôncavo Baiano.

\subsection{O PERÍODO ENTRE 1850 E 1889 (5² PERÍODO DE VASCONCELOS)}

Para Vasconcelos (2009, p. 149), 1850 é um exemplo de “[...] momento de ruptura e início de um 'período denso' da história de Salvador". Porém, estamos considerando a influência direta que esta cidade exerceu sobre as demais cidades históricas portuárias do Recôncavo Baiano.

Vasconcelos (2009) faz uma síntese de eventos importantes que se sucederam após 1850 na cidade do Salvador:

[...] Externamente o governo da Inglaterra, líder político e tecnológico mundial, ampliou sua pressão contra o tráfico de escravos. Internamente os principais agentes tomaram posições diferenciadas. O estado Imperial tomou medidas sérias contra o tráfico, com o decreto de 1850 e a utilização da marinha, ao tempo que elaborou normas em outros campos (Lei de Terras, Código Comercial) no mesmo ano, e favoreceu a modernização das províncias (início da ferrovia na Bahia em 1853). Os grandes comerciantes e traficantes de escravos baianos, diante da impossibilidade de continuar o tráfico, tinham as seguintes opções: (1) comprar terras agrícolas segundo a nova lei; (2) investir na modernização da produção agrícola (144 engenhos a vapor na Bahia, em 1855); (3) comprar terras ou imóveis urbanos; (4) investir em infraestrutura urbana (primeiras linhas de diligências em Salvador em 1851); (5) investir no transporte marítimo (a companhia Santa Cruz, do traficante de escravos Pedroso de Albuquerque é fundada em 1852); (6) investir em bancos e seguradoras (o Banco da Bahia, fundado em 1858 , teve entre seus quatro fundadores o traficante de escravos Pereira Marinho); (7) investir em fábricas (têxteis ou outras); (8) ajudar obras assistenciais (o referido Pereira Marinho tem seu busto defronte do Asilo Santa Isabel, da Ordem Terceira do São Francisco). Quanto aos senhores de engenho, em plena crise (em 1850 a Bahia deixa de ser o primeiro produtor brasileiro de açúcar), sofrem a concorrência da beterraba europeia, as consequências da epidemia de febre amarela (1849 - 1850), e veem os preços dos escravos aumentar com o fim do tráfico, e têm poucas alternativas além da venda de escravos para o sul do Brasil (em 18531.622 escravos vendidos), no momento em que o café passa a ser o principal produto brasileiro. Esse ano decisivo inicia assim um 'período denso' do 
ponto de vista de transformações espaciais de Salvador [...] (VASCONCELOS, 2009, p. 150).

Incluímos nesse período de ruptura as novas estruturas políticas, administrativas, socioeconômicas, técnicas e culturais, que também influenciaram diretamente as cidades portuárias do Recôncavo Baiano.

As transformações apontadas acima não se limitaram apenas ao contexto da cidade do Salvador, mas também às vilas portuárias que formavam uma densa rede com a capital. Sustentava-se através da relação de intercâmbio de mercadorias e pessoas nesse processo. Mattoso (1988, p. 7) assevera que, “[...] Ainda durante todo o século XIX, Salvador urbs princeps é herdeira plena e soberba das riquezas do Recôncavo, do Agreste e dos vastos Sertões que se estendem para além do vale do São Francisco".

Mattoso (1988) comenta sobre uma Salvador cujo crescimento e importância no contexto regional, estiveram diretamente associados ao comércio e a exportação de produtos de toda a província da Bahia, especialmente com o conjunto das cidades portuárias do Recôncavo, além de outras províncias vizinhas. Entretanto, no século XIX apresentava contrastes entre a opulência de sua paisagem urbana e a realidade econômica em decadência. Vejamos o que afirma a referida pesquisadora:

A cidade que outrora comandava o comércio de toda a província e das províncias vizinhas de Sergipe, Alagoas, Piauí e Minas Gerais vê sua influência reduzir-se drasticamente. Involução fatal, inteiramente oculta pela opulência ostentatória das fotografias, que cantam os telhados, as árvores e as águas. Tomadas de uma janela da cidade alta, elas privilegiam os sobrados opulentos dos comerciantes da cidade baixa. Podem também fixar em suas chapas milagrosas as maravilhas das novas estradas de ferro e imortalizar pontes em construções ou estações copiadas das gares inglesas e francesas. A realidade baiana é bem outra, pois, se é verdade que as comunicações ferroviárias tiveram um desenvolvimento precoce na província, essa política se fez sem continuidade. Aranha preguiçosa, Salvador não soube tecer sua teia de estradas e ferrovias. Mesmo sua frota de navios mercantes tornava-se pouco a pouco obsoleta (MATTOSO, 1998, p. 8).

A descrição acima nos remete a uma ideia de estagnação econômica, especialmente em relação ao papel que Salvador desempenhava ao longo do século XIX, que paulatinamente se estendeu para as cidades do Recôncavo. Tal fato se deu dentre outros fatores, devido à “"[...] perda de liderança baiana na produção do açúcar, coincidindo com a passagem do café como primeiro produto brasileiro" (VASCONCELOS, 2002, p. 209). 
Considerando o período adotado para a pesquisa, se faz necessário apontar que a consolidação do eixo econômico em torno do café no final do século XIX no Sudeste do Brasil, além do desenvolvimento de técnicas aplicadas ao território, especialmente nas províncias do Rio de Janeiro, São Paulo e Minas Gerais, tiveram consequências diretas para a cidade do Salvador. Segundo Sampaio (2005, p. 17) “[...] Salvador foi o porto mais movimentado do país, até pelo menos 1873 , quando perdeu a liderança para o centro-sul cafeeiro".

A seguir veremos uma foto da cidade do Salvador, Figura 5.3.1, onde temos uma ideia de parte da Cidade Baixa. Provavelmente é uma das fotos sobre a qual Mattoso (1988) se refere anteriormente, quando menciona que as mesmas foram feitas a partir do ângulo de uma janela da Cidade Alta, que privilegiou os "[...] sobrados opulentos dos comerciantes da Cidade Baixa” (MATTOSO, 1988, p. 8).

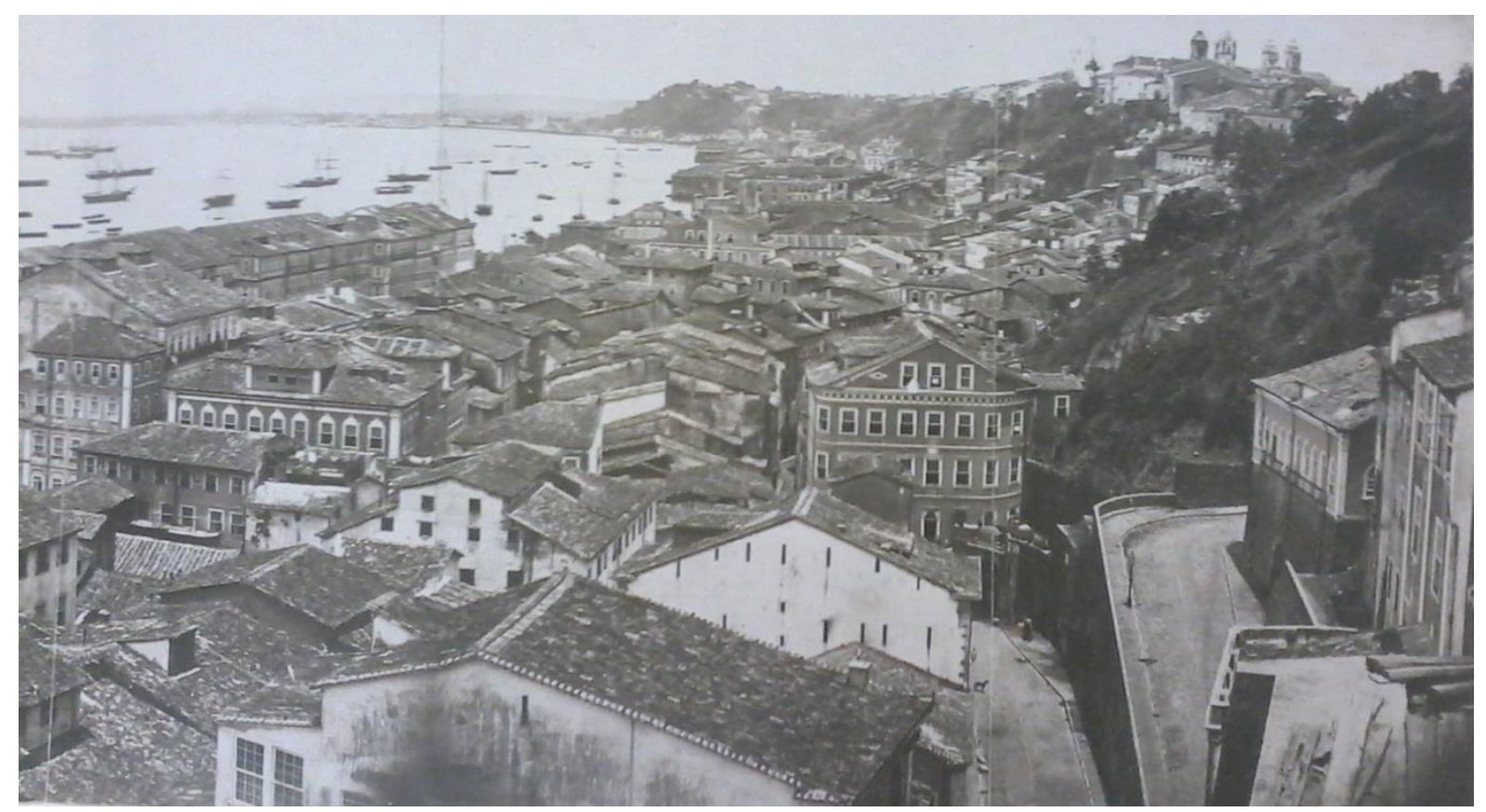

Figura 5.3.1 - Vista panorâmica da cidade baixa em Salvador - BA (FERREZ, 1988)

Além da questão relacionada ao que se vê numa fotografia e o que a cidade apresentava em sua realidade cotidiana, Mattoso (1988) faz inferências importantíssimas sobre a conjuntura de opulência material, registrada na materialidade do território da cidade 
do Salvador, mas também sobre a conjuntura de desgaste que se abatia sobre a dinâmica daquela cidade, principalmente sobre a realidade de sua população mais carente.

Em outro trecho do mesmo texto acima referido Mattoso (1988) afirma que:

[...] No entanto é preciso se dar ao trabalho de deixar esse conjunto arquitetônico da cidade baixa, como também o do outro centro administrativo, o da cidade alta, construído em torno da Praça da Sé e da Praça Tomé de Souza e parar na praia da Barra, com suas casas de pescadores, subir a colina onde se ergue a Igreja de Santo Antônio, e, com os fotógrafos, seguir pela costa até o Bonfim, para assim apreender os dois mundos que constituem a verdadeira Bahia do século XIX. Um desses mundos vive ainda de suas riquezas passadas, habita os palácios e ou as casas senhoriais, circula entre o porto e os edifícios que abrigam as autoridades administrativas, judiciárias ou religiosas. Mas o outro mundo, tão próximo, tão imbricado no primeiro é o da vida quotidiana ao pé das águas e da terra, onde de 80 a $90 \%$ da população é de pessoas pobres que habita Salvador [...] (MATTOSO, 1988, p. 9)

Outro aspecto relevante da descrição anteriormente citada está relacionado aos aspectos urbanos da cidade de Salvador e de sua atmosfera cotidiana, revelado nos contrastes entre a opulência do patrimônio material e a pobreza de sua população.

A referida autora afirma ainda que a cidade vai triplicar sua população entre 1800 e 1890, o que acabou refletindo em sua paisagem urbana, com o aparecimento de novos bairros de ocupação intensa ocupação (MATTOSO, 1988). Podemos inferir que esse aumento de população se deveu ao grande número de migrantes oriundos de várias cidades do Recôncavo Baiano e não só.

Vasconcelos (2002), com base na análise do livro do Tombo das irmandades nos informa que o patrimônio das ordens leigas de Salvador em 1853 totalizava 400 imóveis (sem incluir a Misericórdia). A maioria localizada na área central da cidade. Adicionando o patrimônio das ordens regulares, somam-se mais 260 imóveis no período.

Segundo Mattoso (1988), Salvador do século XIX aparentava um dinamismo que escondia "fraquezas fatais". Não houve um desenvolvimento industrial, além da indústria açucareira, acarretando uma riqueza concentrada, um consumo e até ostentação por parte de uma ínfima parcela de consumidores, especialmente seus mercadores.

Para Vasconcelos (2002), o final deste período foi marcado por uma franca modernização de Salvador, após o tráfico de escravos em 1850, “[...] com investimentos realizados em bancos, seguradoras, indústrias e, sobretudo, nos transportes marítimos e urbanos" (VASCONCELOS, 2002, p. 256). 
Percebemos até aqui que Salvador foi marcada pelo contraste. De um lado, a riqueza e opulência de uma classe de proprietários de terras e comerciantes. Do outro, uma grande massa de trabalhadores livres e também de escravos que se constituía a maioria de sua população. A paisagem urbana, portanto, no seu aspecto puramente relacionado à materialidade construída no território, expressa apenas um aspecto da realidade e de sua história. A opulência e a monumentalidade das classes mais abastadas. É provável que esse contraste também acontecia com as cidades históricas portuárias do Recôncavo Baiano.

Para o arquiteto Fernando Peixoto (A Tarde, 2015, p. 3) essa configuração urbana suscita a ideia de "memória arquitetônica". Segundo o mesmo:

O que a população sente como histórico em Salvador é construção. A Baíade Todos-os-Santos é linda, mas sozinha não é cartão postal. Qualquer coisa que você pensa como identidade histórica até o século XIX é arquitetônico: Ladeira da Montanha, Cidade Alta, Farol da Barra (PEIXOTO, A tarde, $29 / 03 / 2015$, p. 3).

Para nós essa "memória arquitetônica" faz parte do que estamos denominando de "narrativa espacial regional" que suscita do uso do território, moldando a sua paisagem como um texto, escrito pelo próprio processo de produção e organização socioespacial e, em última análise, na configuração do território, quando pensado como conjunto urbano de suas cidades históricas em sua dimensão regional.

\subsection{BREVES CONSIDERAÇÕES SOBRE O PERÍODO ENTRE 1889 E MEADOS DO SÉCULO XX}

Avançando o recorte temporal por nós estipulado, cabe uma referência ao período entre 1889 e 1944, (6º período de Vasconcelos (2002)), o qual foi marcado no contexto nacional, inicialmente pela proclamação da República e está dividido entre República Velha (1889/1930) e o período iniciado com a revolução de 1930. O subperíodo da "República Velha" é caracterizado pelo domínio das elites agrárias tradicionais paulistas e mineiras. O segundo subperíodo, "[...] resultou no domínio das elites urbanas e industriais, sobretudo as de São Paulo" (VASCONCELOS, 2002, p. 259). 
Corroborando com o que afirmou Mattoso (1988) anteriormente, Vasconcelos (2002, p. 259) também admite que a industrialização na Bahia se consolidou após a descoberta do petróleo “[...] e com as novas condições de desenvolvimento após a Segunda Guerra Mundial". Para o referido autor, “[...] a Bahia tem uma temporalidade própria, diferente da nacional" (VASCONCELOS, 2002, p. 306). Fato que implica numa análise diferenciada, já que nesse período há um contexto de crise na produção açucareira ${ }^{7}$, e de tentativa de implantação industrial por parte do governo do estado da Bahia, com recursos da exportação do cacau, produzidos no Sul do estado.

É o período que, segundo Vasconcelos (2002, p. 306) coincide com o ideário modernista, com intervenções urbanas de grande porte em Salvador. Essas reformas vão gerar uma arquitetura institucional de estado que continuará influenciando as cidades do Recôncavo. É a época dos Paços Municipais, dos prédios de padrão único dos Correios e Telégrafos e de escolas públicas. Todos típicos do período getulista.

Ainda tomando como exemplo e referência numa escala nacional, Getúlio Vargas instituiu o modernismo como a marca do Estado Novo, com a construção do Ministério da Educação e Saúde, no Rio de Janeiro, e numerosas escolas neste estilo por todo o Brasil (AZEVEDO, 2010).

No que concerne às políticas de Estado e à questão da identidade nacional, adentrando no período republicano, Ouro Preto foi a primeira cidade classificada como monumento nacional. Esta cidade foi objeto de políticas de preservação desde a década de 1930, reforçando a ideia de marco de referência material da cultura e identidade nacional. Foi o exemplo mais contundente dos mecanismos que regem as políticas do patrimônio, implementados tradicionalmente pelos estados, visando uma identidade nacional. Para Castriota (2009), tais políticas privilegiam certos aspectos em detrimentos de outros, numa dialética lembrar-esquecer. Ou seja, para se criar uma memória nacional, “[...] iluminam-se certos momentos da história, enquanto outros permanecem na obscuridade" (CASTRIOTA, 2009, p. 131). Ou seja, naquela época, as cidades históricas do Recôncavo Baiano, tão importantes quanto as cidades mineiras, não foram alvo de aplicação dessas políticas.

\footnotetext{
${ }^{7}$ Sobre essa questão e suas reverberações no contexto do Recôncavo Baiano veja-se: BRITO, Cristóvão de Cássio da Trindade. A Petrobras e a gestão do território no Recôncavo Baiano. Salvador: EDUFBA, 2008.
} 
Para nós, a periodização de Vasconcelos (2002) nos interessa até o referido período, para termos noção da importância de considerar o patrimônio urbano de períodos anteriores, nas concepções de salvaguarda do patrimônio na Primeira República.

Após a contextualização dos períodos estipulados por esse autor para a análise da cidade do Salvador e, da nossa contextualização e associação da referida periodização a dimensão regional do Recôncavo Baiano, reafirmamos a ideia da forte influência que a capital exerceu sobre aquela região.

Tratando da atmosfera urbana e social de Salvador em meados do século XX, Carybé, artista plástico argentino, radicado nesta cidade, descreve com riqueza de detalhes o ambiente da Rampa do Mercado. Naquele local havia uma grande movimentação de mercadorias proveniente de várias localidades do Recôncavo. Diz ele:

[...] E tem a Rampa do Mercado. Para onde convergem todas as velas do Recôncavo. De manhãzinha, olhando da Cidade Alta, percebem-se os rebanhos de velas emproadas para a Rampa, vêm do rumo de Cachoeira, de Suape, de São Roque, da Gamboa, de Nazaré das Farinhas, de Itaparica, Mar Grande ou da Ponta de Areia, agrupados e serenos, levados pelo vento que Nossas Senhora da Viração tenramente assopra.

[...] E começam a sair dos saveiros balaios de quiabos, de mangas, porcos, mantas de toucinho, latas de dendê, feixes de lenha, cajus, mudanças, cerâmica e um mundo imprevisível de coisas; tudo é desembarcado na cabeça dos carregadores, verdadeiros equilibristas que passam de um saveiro a outro com agilidade de gatos, não importa se levam três sacos de farinha ou um galo de briga, a elegância é a mesma. No desembarcar cachos de banana ou feixes de lenha, jogam a carga, que é aparada por outro, e por outro até que é arrumada no cais. Cá de fora é um formigar de gente comprando e vendendo de tudo, garoupinhas rubras, perus e laranjas. Siri mole, ostras catadas ou terríveis balaios de goiamuns se mexe-mexendo na lama de mangue. Alho, cebola e pimenta de cheiro. Lulas e camarões, azeite dourado e coentro que, tudo misturado, virará xinxim, frigideiras, moqueca, caruru, enfim a deliciosa cozinha baiana [...] (CARYBÉ, 2014, s/p).

A narrativa de Carybé nos possibilita imaginar a dimensão e a densidade das relações entre Salvador e o Recôncavo Baiano, numa perspectiva do cotidiano do desembarque das mercadorias oriundas daquela região na capital baiana. É possível perceber uma diversidade de produtos que vai muito além dos tradicionais produtos de exportação como o açúcar, o tabaco e a mandioca. Na verdade sempre foi muito mais do que isso. Havia um grande mercado interno e diversificado de alimentos e outros produtos da vida cotidiana entre as vilas da região e entre essas com a cidade do Salvador. Na Figura 5.4.1 a seguir, podemos ter uma 
ideia da atmosfera social daquele lugar, dessa vez sob a perspectiva de uma narrativa através do desenho de Carybé (2014).

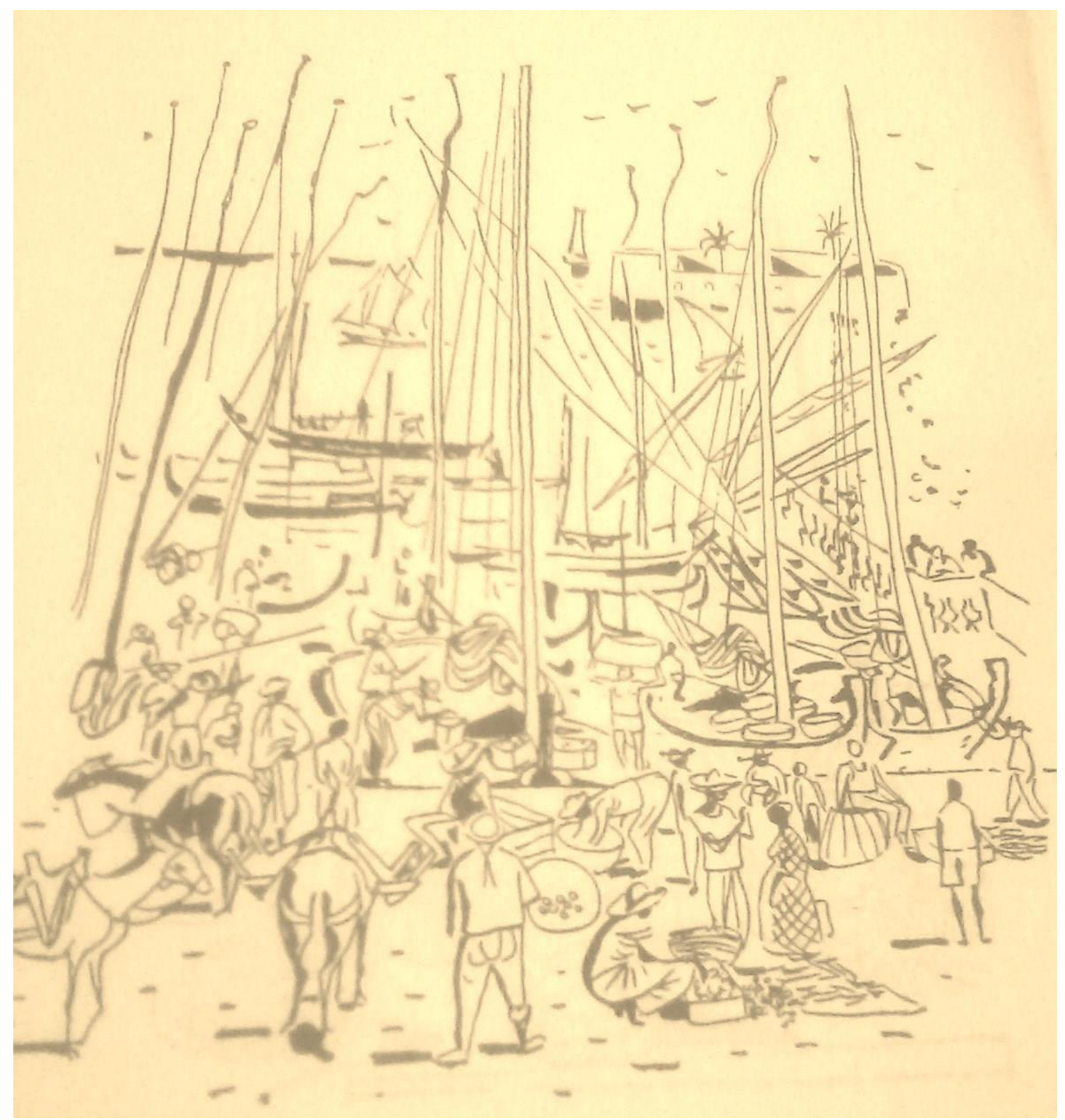

Figura 5.4.1 - Ambiente da rampa do mercado em Salvador - BA na coleção "As sete portas da Bahia"

(CARYBÉ, 2014)

Ainda falando sobre o comércio de variedades de produtos oriundos do Recôncavo, dessa vez na Feira de Água de Meninos, na cidade do Salvador, em meados do século XX, Carybé (2014), mais uma vez nos traz uma narrativa explicativa sobre a atmosfera social da 
cidade e, especificamente daquela importante feira. Vejamos o que diz o texto desse artista plástico que fez do cotidiano da cidade do Salvador, uma de suas maiores inspirações:

[...] Fica lá em baixo, junto ao mar, num amontoado inverossímil de barracas, divididas por becos, ruelas e passadiços, formigando de gente, de saveiros, de jegues, frutas, legumes, jabá, cestas e tamancos, camarão seco e raladores de coco, fifós, cana e farinha de guerra.

Cerâmica de todo o recôncavo. De todos os feitios e para todos os usos.

[...] Mercam-se ali panelas de alumínio, bacias, canecos e bules. Banha de jibóia para reumatismo, canela de ema para a asma e folhas, cascas e paus para curar de tudo [...]

Na principal rua, a rua que atravessa a feira, mal se pode passar de tanto povo, carroças, caminhões, jegues encangalhados, vendedores, camelôs, balaios [...] ali o marcado humano é inesgotável, as mulheres do carimã peneirando a puba $[\ldots]$

Há montanhas de cachos de banana, de laranja, de pinhas, de limas e canade-açúcar, pois é aí que se abastecem os vendedores ambulantes, os hotéis, restaurantes e as famílias pobres. Hercúleos carregadores descarregam os saveiros, entram na água até o umbigo e voltam carregados com tijolos, carvão, balaios imensos de jiló, porcos, capoeiras de galinha d'angola ou feixes de caibros[...]

Em Água de Meninos se concentra a produção do Recôncavo. Chegam as mercadorias de Santo Amaro, Nazaré das Farinhas, Cachoeira, São Francisco do Conde e outras cidades, estivadas na barriga chata dos saveiros, que esperam banzos, adernados, que os livrem desse peso todo[...] (CARYBÉ, 2014, s/p).

A descrição acima reforça mais uma vez o que a historiografia afirma sobre a intensa conexão que sempre houve entre a cidade do Salvador e o Recôncavo Baiano, especialmente entre suas vilas portuárias. Na Figura 5.4.2 a seguir, podemos ter a ideia do ambiente daquela feira, mais uma vez sob o olhar sensível do artista plástico Carybé. 


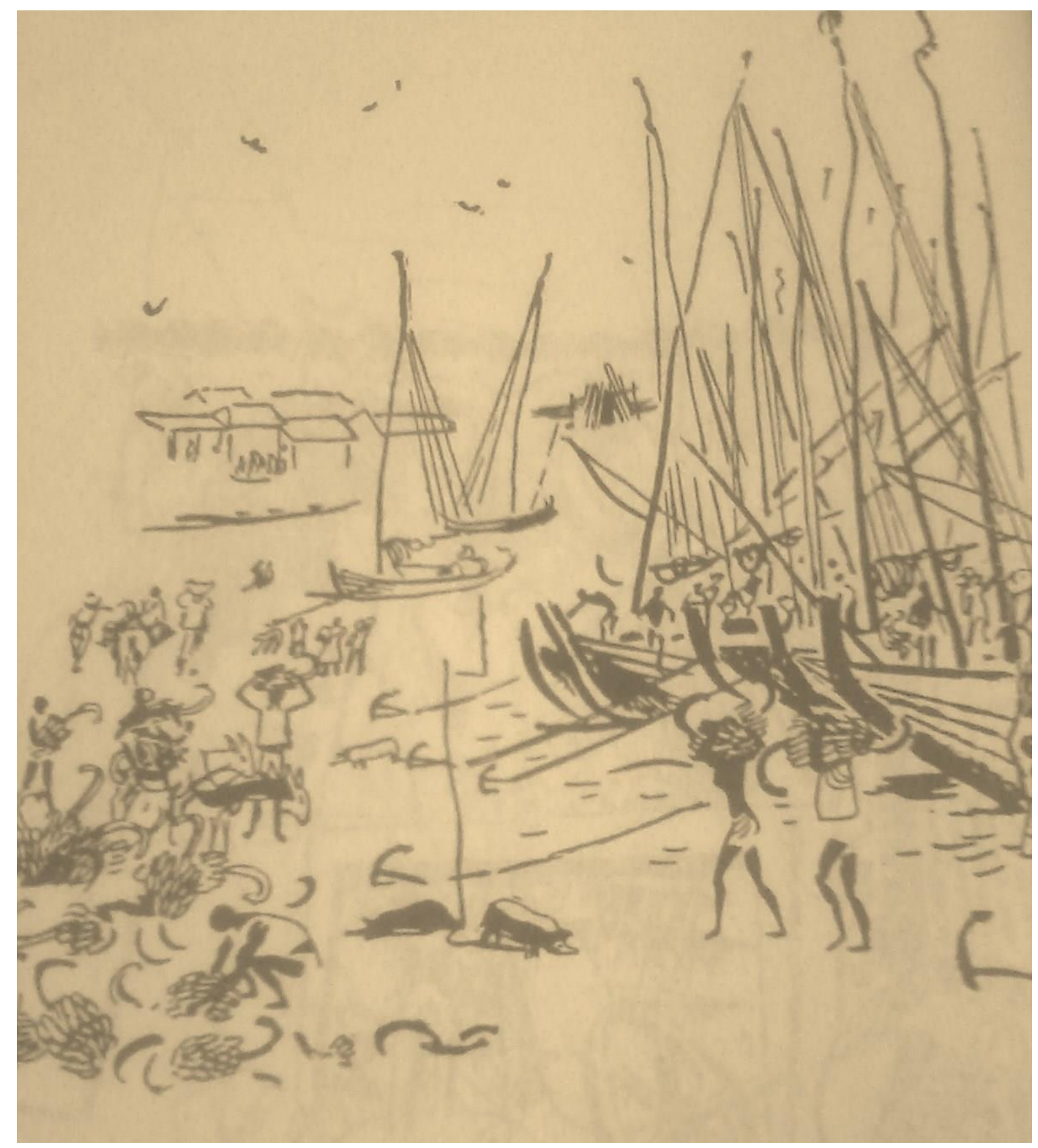

Figura 5.4.2 - Desenho retratando a Feira de Água de Meninos em Salvador - BA na coleção "As sete portas da Bahia"

(CARYBÉ, 2014)

Percebemos nos desenhos e nas descrições de Carybé, uma forte intensidade e variedade de trocas de mercadorias, num ambiente extremamente dinâmico, onde a presença dos Saveiros provenientes do Recôncavo, ancorados no cais da Rampa do Mercado e na feira de Água de Meninos, na cidade do Salvador, são a marca presente nas imagens. O ambiente 
descrito e desenhado nos dá uma ideia de uma intensa vida de relações entre a cidade do Salvador e as cidades portuárias do Recôncavo Baiano.

Conhecida pela densidade cultural e simbólica na formação do que poderíamos chamar de civilização da cidade do Salvador e seu entorno junto à Baía de Todos os Santos, o Recôncavo, segundo Risério (2004), é um "espaço coeso e essencialmente tradicional“, que ao longo do século XX, até a década de 1950 - quando ainda na baía predominavam os saveiros, e na Bahia, o "terno branco e, a vegetação exuberante" - possuía uma sociedade extremamente complexa sob o ponto de vista sociocultural.

Ainda segundo o autor supracitado, numa alusão à relação entre a cidade do Salvador e o Recôncavo,

[...] a partir da década de 1960, tudo muda. Surgem estradas e distritos industriais. [...] A cidade da Bahia (Salvador) explode para todos os lados. [...] Salvador se volta para o litoral norte, divorciando-se do Recôncavo Histórico" (RISÉRIO, 2004, p. 455).

Percebe-se pelas palavras deste estudioso, o quanto a capital baiana era ligada e dependia do seu Recôncavo. Até os nossos dias ainda persistem ligações e grande trânsito de capital financeiro e social entre essas partes, via Baía de Todos os Santos ${ }^{8}$.

Apesar do surgimento de novas rodovias e o crescimento econômico de Salvador, houve uma mudança na dinâmica da economia regional. O Recôncavo, que antes se tornava centro polarizador e dinamizador devido a importância de suas cidades portuárias no contexto da economia regional, transforma-se em um espaço simbólico com marcas históricas e culturais, mas ainda com municípios cuja economia ainda é incipiente na atualidade. Fato que está expresso nas condições do seu patrimônio urbano histórico e atual. É o caso das cidades de Jaguaripe, Nazaré, Maragogipe, São Felix e Santo Amaro.

\footnotetext{
${ }^{8}$ Sobre a importância da Baia de Todos os Santos como patrimônio natural e para a economia no cenário regional, nacional e internacional, Athayde (2015), informa que, foi definido pela marinha brasileira o conceito de Amazônia Azul. Tal conceito refere-se aos 4,5 milhões de Km2, polígono formado por 8,5 mil Km da costa brasileira, abrangendo 17 estados e mais de 400 municípios; e mais de 200 milhas marítimas $(370 \mathrm{Km})$ de largura do mar territorial, definidas internacionalmente pela Convenção das Nações Unidas sobre os Direitos do Mar (CNUDM), ratificada por 156 países, como Zona Econômica Exclusiva (ZEE). São muitos os recursos naturais e econômicos a serem explorados na referida zona, tais como "os ativos da lâmina d'água, do solo oceânico e do subsolo (província mineral e as reservas do pré-sal" (Athayde, 2015, p. 66). O referido articulista, que é Diretor da Associação Comercial da Bahia, nos informa o seguinte: "Fundada em 1811 e sediada às margens da Baía de Todos os Santos (BTS), a Associação Comercial da Bahia - ACB, ciente da influência que a BTS (70\% do PIB da Bahia) exerce sobre a economia do Estado, articula com a Marinha do Brasil trazer para a BTS a inteligência dos debates nacionais e decisões sobre a Amazônia Azul. Posicionada no centro da costa brasileira e berço da civilização nacional, a maior baía tropical do mundo foi declarada pela ACB, através de Carta da BTS, assinada por empresários, acadêmicos e sociedade civil organizada, como sede natural da Amazônia Azul". (ATHAYDE. Baía de Todos os Santos, sede da Amazônia Azul. Revista [B+] ed. 28. Salvador: Editora Sopa de Letras. Fev./Mar. 2015, p. 66).
} 
A cidade de São Francisco do Conde tem sua economia impulsionada pela presença da Petrobras no município do qual é a sede, com a Refinaria Landulfo Alves instalada no distrito de Mataripe, desde os anos de 1960. Trata-se de um município, com um dos maiores PIBs do Brasil. Portanto tem maiores condições de salvaguarda do seu patrimônio urbano.

Quanto à cidade de Cachoeira, por ter sido considerada Patrimônio Histórico Nacional pelo IPHAN, desde a década de 1980, e ali ter sido implantado um dos campus da Universidade Federal do Recôncavo da Bahia (UFRB), além do turismo étnico e cultural, a cidade vem passando por uma grande transformação que está visível em sua paisagem urbana, com a preservação de grande parte do seu patrimônio urbano.

Mesmo tendo em vista que a cidade de Salvador não seja o foco principal da nossa pesquisa, ressaltamos uma observação do arquiteto Fernando Peixoto sobre a realidade atual da relação da sociedade soteropolitana e o patrimônio urbano/edificado na referida cidade. Peixoto (2015) afirma o seguinte:

Quando você pensa em Viena, vêm à mente valsa e música clássica. Se você
pensa no Rio, a paisagem, a geografia, o Pão de Açúcar, Copacabana,
Ipanema é o que vem a sua mente.
Mas se você pensa em Salvador, a memória é arquitetônica. Mesmo sem
considerar nível social ou cultural, a imagem mental e comum da nossa
história é de coisas construídas: Pelourinho, Forte São Marcelo, igrejas,
Elevador Lacerda e por aí vai.
De repente, e por alguma razão, a partir de grande parte do século XX essa
memória arquitetônica desapareceu, e nossa tradição e identidade se
transferiram para a música. Mesmo os poucos exemplos de boa arquitetura
nesse período têm sido sistematicamente destruídos e degradados com total
indiferença de todos.
[...] É muito curioso e estúpido achar que sem presente há futuro. Não é a
beleza arquitetônica, nem mesmo a solução funcional perfeita, que tornam
uma obra um valor a preservar, mas sim, sua representatividade de uma
época (PEIXOTO, 2015, p. 95).

Na citação acima a ideia de "imagem mental" que o autor se refere para a cidade do Salvador, no nosso entendimento, também pode ser aplicado ao conjunto urbano do Recôncavo Baiano, como já foi possível demonstrar anteriormente, especialmente quando nos reportamos ao evento da Independência do Brasil na Bahia. Naquela altura mencionamos o papel dos monumentos na memória histórica e da representatividade do patrimônio edificado na logística do evento do 2 de Julho na região. Ou seja, a sua grande representatividade simbólica de uma época. 
No nosso entendimento e corroborando com a assertiva do autor supracitado, a imagem da foto a seguir, Figura 5.4.3, nos dá a dimensão exata no sentido do apelo à "memória arquitetônica", a "imagem mental das coisas construídas", que o mesmo se refere, principalmente quando se trata do turismo cultural na atualidade.

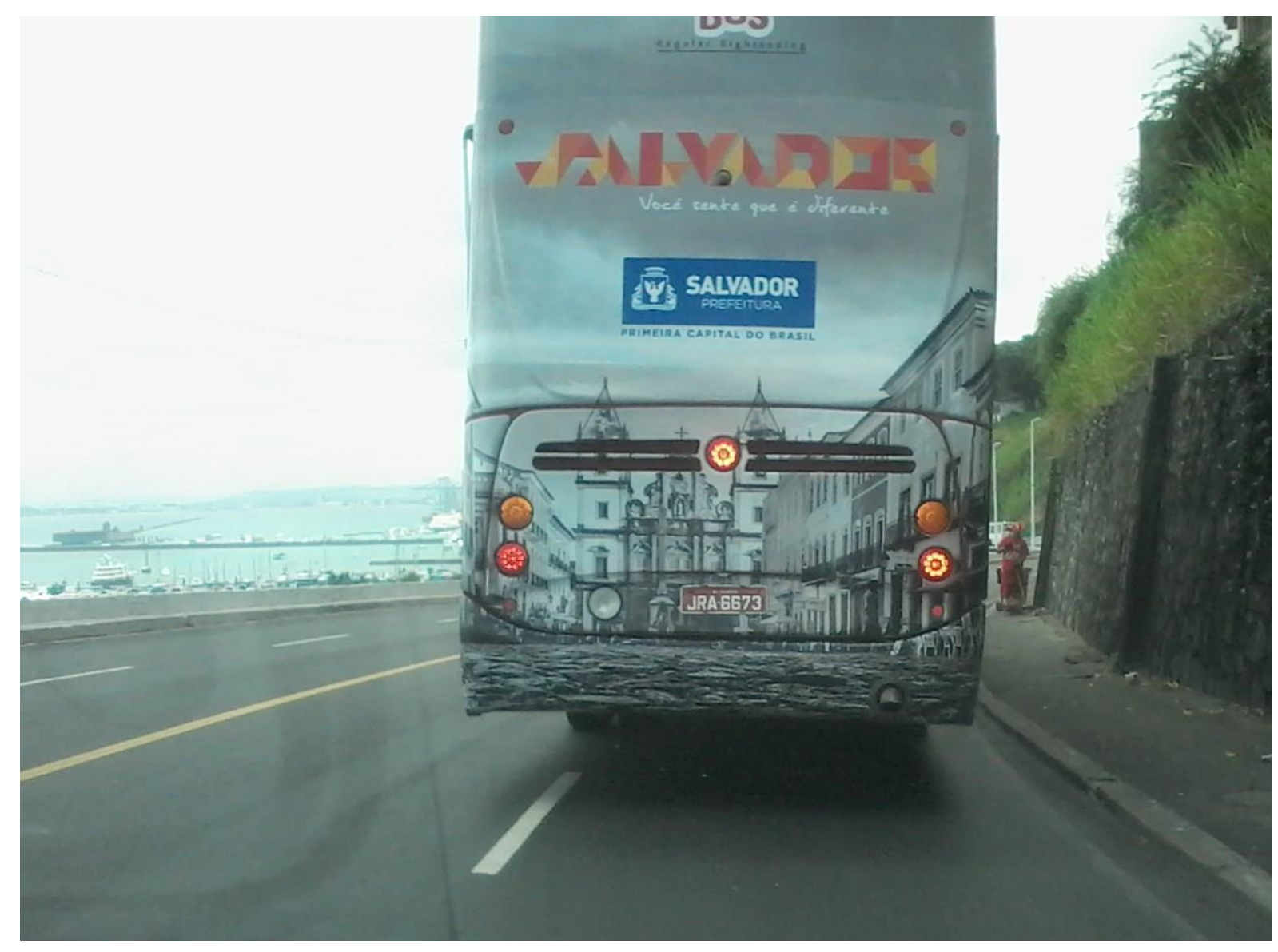

Figura 5.4.3 - Ônibus de linha especial para turistas na cidade de Salvador, trafegando entre a cidade alta e baixa, com foto da igreja e do cruzeiro de São Francisco

(Imagem do autor, 2015)

Consideramos, por outro lado, que outras imagens mentais que não apenas as do patrimônio edificado fazem parte da memória e da identidade do povo de Salvador e de seu Recôncavo. Assim como de um visitante mais atento. O patrimônio de natureza imaterial, incluídas suas mais diversas manifestações culturais em vários níveis de relação entre a sociedade e o espaço, é diverso e também fica na memória fazendo parte do imaginário local, assim como sua paisagem natural e urbana, como podem ser vistas na Figura 5.4.3. 
Manifestações do patrimônio imaterial do Recôncavo Baiano e da cidade do Salvador foram salvaguardadas e oficialmente consideradas pelas instâncias do Governo estadual e federal, como fundamentais para a identidade da região, “[...] mediada e catalisada pelo samba de roda e, em geral, pelas manifestações culturais de matriz africana, tais como a capoeira e o candomblé” (CARVALHO; SILVA, 2015).

No caso desta pesquisa, tratamos da cultura material como as marcas, permanências históricas da dimensão urbana, na forma de seu patrimônio edificado (monumentos isolados e conjuntos urbanísticos) das cidades pesquisadas, associadas a possíveis relações com a cidade do Salvador. É o que analisaremos mais pormenorizadamente no próximo capítulo. 


\section{6 - A CONCEPÇÃO DE URBANISMO E O PATRIMÔNIO DAS CIDADES PORTUÁRIAS DO RECÔNCAVO BAIANO: A NARRATIVA ESPACIAL REGIONAL}

Iniciamos nossa análise mais específica do patrimônio urbano/edificado das cidades em tela, partindo dos monumentos isolados que fizeram parte do núcleo de ocupação histórica das vilas em questão. Em alguns momentos reportarmo-nos, como já fizemos anteriormente, a períodos históricos anteriores, quando a cidade do Salvador foi referenciada nos dando o suporte espaciotemporal em escala regional, pelos motivos já apontados ao longo dos capítulos anteriores desta tese.

Concordamos com Morais (2013), quando o mesmo afirma que:

[...] Como toda perspectiva parcial, a análise geográfica esclarece mediações, que em alguns contextos históricos particulares podem constituir os mais importantes elementos de uma explicação. Sendo a relação sociedade-espaço um processo universal, as formas de sua manifestação histórica servem também como fortes indicadores na definição das particularizações no estudo da história (MORAIS, 2013, p. 7).

Na compreensão do autor, o estudo da espacialidade da vida social dentro de uma totalidade multidimensional perpassa por uma "visão específica do fluir histórico" (MORAIS, 2013). Esse "fluir histórico" acontece e se desenrola nos lugares. Por isso, a pesquisa e a investigação necessitam de um recorte, de uma periodização, para haver uma relação entre tempo e espaço no processo de análise das relações entre sociedade e natureza. Por isso a nossa opção pelo campo da Geografia Histórica, como já apontado anteriormente, os modelos estritamente econômicos na Geografia brasileira que priorizam uma análise sob uma perspectiva da produção agrícola. Entretanto, estes também não podem ser desprezados.

Tendo em vista o importante papel do clero junto à administração local que representava a Coroa portuguesa na colônia, no processo de produção e organização socioespacial dos primeiros núcleos de povoamento no Brasil e no Recôncavo Baiano, primeiramente fizemos uma análise do papel das Igrejas de uma maneira geral na região, incluindo a cidade do Salvador. Posteriormente, analisamos mais pormenorizadamente as 
Igrejas Matrizes e Casas de Câmara e Cadeia no contexto da descrição e análise histórica de cada uma delas nas cidades que são o foco principal da pesquisa.

Isso se fez necessário devido a uma busca por tipologias e estilos de suas construções e daí percebermos suas diferenças, similaridades e concomitância temporal, inclusive as influências destas com algumas igrejas da cidade do Salvador e vice-versa. Ou seja, estamos admitindo que houvesse também a influência originada de algumas vilas do Recôncavo no sentido da capital e não só da capital para o Recôncavo, como sempre pareceu mais provável. É o que buscaremos descobrir a seguir.

É fato que as vilas de Cachoeira, Maragogipe, São Francisco do Conde e Santo Amaro passaram por um período de esplendor econômico no século XVIII, a ponto de terem contribuído em 1727, para o casamento dos príncipes reais e para a reconstrução de Lisboa, após o terremoto de 1755 (ANDRADE, 2013). Isso nos dá uma dimensão da importância dessas vilas no contexto regional e sua conexão em escala internacional via a cidade do Salvador.

Portanto, os fatos apontados acima nos permitem prever uma possível influência nas construções da época, já que tais vilas tinham condições econômicas suficientes para erguer algumas igrejas antes mesmo que a capital, desde o século XVIII. O que não quer dizer que chegaram a ser mais promissoras do que a cidade do Salvador.

Estamos diante do maior conjunto de cidades de origem portuguesa do mundo, fora daquele país. Milton Santos em 1959, já afirmava que no Recôncavo Baiano se formou a primeira e mais importante rede de cidades da América Latina, na época, sendo a cidade do Salvador a capital econômica daquela região (SANTOS, 2008).

Os grandes sobrados do século XIX são outra marca registrada da paisagem urbana das cidades históricas dessa região, especialmente no centro histórico das mesmas. Em vários desses exemplares pode-se perceber a monumentalidade de suas construções, com fachadas exuberantes.

As sete cidades que são o foco deste trabalho se originaram de vilas que foram emancipadas à condição de cidades no século XIX e XX, porém seus núcleos de povoamento originais são muito mais antigos. Remontam aos séculos XVI e XVII.

Retomando o século XVI, tanto em Portugal como no Brasil, são encontradas as primeiras praças urbanas regulares, construídas daquelas originárias, "das de raiz", como afirma Teixeira (2012), inseridas em novas malhas urbanas planejadas. Para Teixeira (2012, p. 117), “[...] Tratava-se de espaços de origem religiosa, associados a igrejas e a conventos 
que, a par de sua função religiosa, logo foram apropriadas para outras funções urbanas [...]”. A cidade de Angra, nos Açores, em Portugal e o Terreiro de Jesus, na cidade do Salvador, no Brasil são exemplos desse tipo de espaço.

Segundo Claval (2004),

A cidade portuguesa é um centro religioso. Como por toda a Europa Ocidental, atrai muitos conventos, o que remonta ao aparecimento das ordens mendicantes, dominicanos, carmelitas e franciscanos. A tendência reforça-se na época da Contra-Reforma, quando surgem as ordens missionárias, as ordens docentes, e as ordens de vocação criativa. Uma grande parte do espaço urbano pertence-lhes (CLAVAL, 2004, p. 128).

Em muitas dessas praças de origem portuguesa quinhentista ocorreu um longo processo de transformação na forma e na função ao longo dos séculos subsequentes. Nesse processo, segundo Teixeira (2012),

[...] a construção das praças novas estava associada à edificação de novos equipamentos civis e religiosos, em um programa coordenado de equipamento e modernização arquitetônica, de ordem e de embelezamento urbano. Casas de câmara, misericórdias e igrejas matrizes passaram a constituir as principais referências desses novos espaços urbanos. Todas as praças tinham pelo menos um, por vezes dois, desses equipamentos. Tais transformações urbanas já eram expressão dos novos ideais renascentistas. [...] (TEIXEIRA, 2012, p. 116).

Assim sendo, ao longo dos séculos XVII e XVIII irá consolidar-se um processo de estruturação de praças modernas, de rigor geométrico que lhe estava subjacente, perceptível na regularidade dos traçados. Segundo (TEIXEIRA, 2012, p. 117), “[...] no século XVII observam-se os primeiros exemplos de praças geradoras de traçados urbanos”. Ainda segundo o referido autor:

[...] A cidade construía-se de raiz, de acordo com um plano predefinido em que os principais elementos estruturantes não eram já a topografia do terreno ou a localização privilegiada de edifícios notáveis, mas uma praça regular, localizada centralmente, a partir da qual se estruturava a malha urbana, segundo uma matriz ortogonal, como em São Luís do Maranhão (TEXEIRA, 2012, p. 119).

A estruturação da cidade portuguesa acima apontada foi transferida para as cidades em suas colônias no século XVIII, onde se percebe que “[...] a praça torna-se um elemento 
fundamental de qualquer novo traçado urbano, sendo pensada de raiz como o centro da cidade, em termos simbólicos, funcionais e formais" (TEIXEIRA, 2012, p. 119). É o que percebemos no traçado da cidade do Salvador, que é considerada por Teixeira (2012, p. 135), como “[...] um dos melhores exemplos da síntese de diferentes modelos do urbanismo português, ilustrando algumas de suas principais características morfológicas".

As características acima mencionadas ratificam o que Abreu (2005) nos informa sobre a questão do planejamento estratégico do Estado português no processo de organização territorial e urbana da colônia, no sentido de sua importante e efetiva participação como agente idealizador. Ou seja, as vilas e cidades brasileiras naquela época não foram "obra do acaso e da imprevidência”, como apontaram alguns estudos, mas estiveram sujeitas "[...] a um projeto de política territorial muito mais abrangente do que aquele que é geralmente admitido" (ABREU, 2005, p. 151).

Abreu (2005), em prefácio da obra de Vasconcelos (2002), afirma que é nas cidades onde se observa em primeiro lugar e mais nitidamente, como processos sociais que procedem de relações escalares diversas (global, nacional, regional e local) se justapõem, se combinam ou se repelem num mesmo lugar. A dialética entre determinação e contingência vem em segundo lugar no processo de observação que a cidade oferece ao pesquisador. Segundo ele, o referido processo dialético gera sínteses socio espaciais que são, ao mesmo tempo, gerais, particulares e singulares.

Mais significativo para nós é o fato de ser nas cidades o locus da incorporação das heranças de tempos anteriores, muitas vezes registradas no seu patrimônio material. É o local privilegiado para a percepção da mudança social. Local onde o embate entre transformação e resistência se expressa mais vigorosamente. Portanto, “[...] as cidades constituem um laboratório permanente de riquezas (e de surpresas) analíticas" (ABREU, 2002, p. 8).

No caso específico da nossa pesquisa, tratamos do que Abreu (2002) considera como resto do "estoque de materialidades históricas" e dos "vestígios materiais do passado". Nosso foco está nas cidades históricas portuárias do Recôncavo Baiano, onde paisagens culturais/urbanas - traduzidas no patrimônio histórico de natureza material, especialmente os conjuntos arquitetônicos e monumentos - se destacam em determinadas localidades das cidades pesquisadas.

Para Corrêa (2012, p. 43), “[...] os agentes sociais da produção do espaço estão inseridos na temporalidade e espacialidade de cada formação socioespacial capitalista", seja ela de uma rede urbana ou na dimensão intraurbana. “[...] A produção do espaço é 
consequência da ação de agentes sociais concretos, históricos, dotados de interesses, estratégias e práticas espaciais próprias" (CORRÊA, 2012, p.43). No caso da cidade capitalista, “[...] este espaço é caracterizado pelo conjunto dos diferentes usos, definindo áreas de funcionalidades distintas, formando um tecido simultaneamente fragmentado e articulado" (CORRÊA, 2004, p. 8-9).

A ação entre os diferentes agentes que influenciam e determinam a configuração dos territórios, resultam em paisagens, onde se caracteriza a hegemonia de alguns deles. Isto é, espaços que se diferenciam pelo maior ou menor grau de interferência desses agentes, principalmente o poder público.

Entende-se como agente social público, o Estado, na forma de interventor do espaço geográfico, através de políticas públicas de âmbito municipal, estadual e federal, determinando estratégias de apropriação dos espaços, tanto sob sua própria administração, como por parte dos agentes privados, induzidos por ações e programas elaborados pelo poder público ou subsidiados por este.

$\mathrm{O}$ agente social privado se constitui do pequeno, médio e grande empresário, atuando no espaço da cidade, beneficiando-se ou não da ação do Estado, através de prerrogativas relacionadas à regulação do acesso aos espaços destinados ao fim a que se propõem as empresas.

Segundo Abreu (2003), o estudo das cidades hoje revela locais de intersecção de processos sociais que têm origem em diversas escalas espaciais e que, segundo o mesmo, "[...] alguns desses processos são mundializados e que só podem ser compreendidos a partir de sua correta inserção numa escala global de interpretação" (ABREU, 2003, p. 97).

Na Figura 6.1, a seguir, temos a imagem ${ }^{9}$ da Praça Municipal de Salvador no século XIX, que nos dá uma ideia do exposto acima.

\footnotetext{
${ }^{9}$ A tela onde é retratada a imagem da figura 6.1 fez parte de uma exposição em homenagem ao centenário de nascimento do artista plástico, arquiteto e urbanista baiano Diógenes Rebouças, que executava suas obras com base em fotografias, gravuras e depoimentos, recriando nas telas os principais logradouros de Salvador no século XIX.
} 


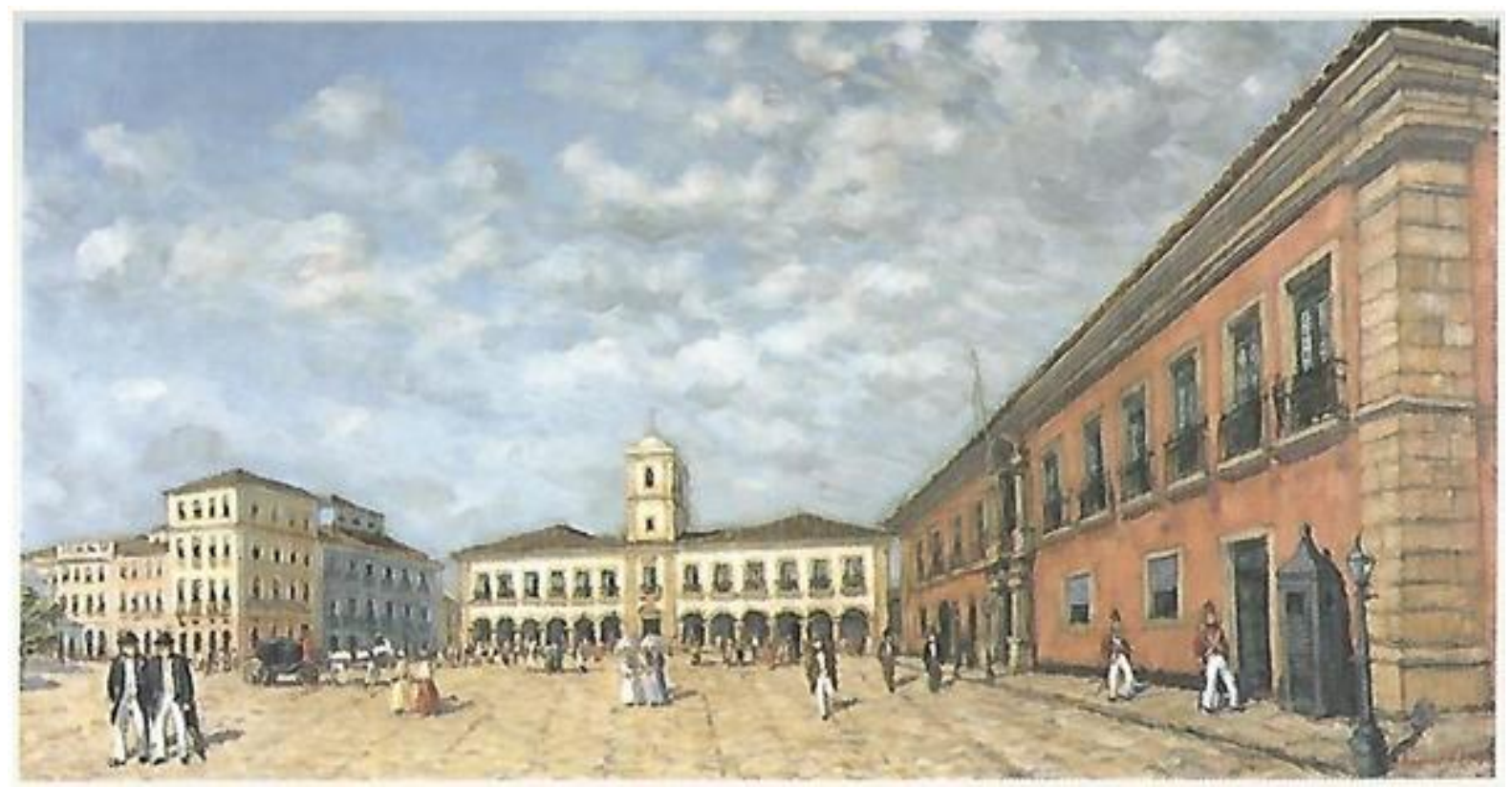

Figura 6.1 - Tela retratando a atual praça municipal de Salvador - BA no século XIX, prospecto da Exposição Diógenes Rebouças 1914 - 2014

(MAB, 2014)

Percebe-se na imagem a típica praça de origem portuguesa, transposta para terras brasileiras, onde Salvador, como primeira capital desde 1549, era uma das maiores expoentes do estilo lusitano. Aqui cabe inferirmos que, guardadas as devidas proporções de morfologia do terreno, as cidades portuárias do Recôncavo Baiano, seguiram a mesma lógica de organização espacial ao longo do período colonial. Muitas delas copiaram o padrão da capital, quando da instalação das praças, onde funcionariam suas Casas de Câmara e Cadeia, cujos edifícios também eram do mesmo estilo do da capital.

Dentre alguns aspectos das cidades do Recôncavo Baiano no período colonial, Azevedo (2010), faz referência às políticas urbanas que contemplavam a questão cultural que ao fim e ao cabo, refletia na forma física de suas construções, especialmente os prédios públicos. Como exemplo, o referido autor cita o modelo do Paço Municipal de Salvador, com galerias e torre sineira, reproduzido como um símbolo do poder municipal em Santo Amaro e em Maragogipe (AZEVEDO, 2010, p. 93).

Ratificando o que foi dito acima e a nossa percepção de uma influência direta de estilo de época nas construções da Região do Recôncavo, além da similaridade de formas entre alguns prédios da cidade do Salvador e de algumas cidades daquela região, Mello (1983), comentando sobre o estilo barroco nas construções do Brasil Colônia, nos informa que: 
Não é possível deixar de relacionar pelo menos algumas construções civis e oficiais que também fazem parte do panorama barroco do Nordeste, entre os quais o imponente conjunto do Engenho Freguezia, no Recôncavo Baiano, bem como as Casas de Câmara e Cadeia de Cachoeira e de Maragogipe, além de algumas residências senhoriais de Salvador que, sem a imponência de seus equivalentes na América Espanhola, são belos exemplos de arquitetura civil, como o Solar do Unhão (atual Museu de Arte Popular), o Solar do Saldanha e o Palácio do Conde dos Arcos (ou Paço dos Arcos) (MELLO, 1983, p. 95).

Para Teixeira (2012), a estruturação das cidades portuguesas em malhas urbanas sensivelmente regulares, de base ortogonal, foi adotada porque era a forma mais lógica e mais eficiente de construir cidades num novo território. Fato que facilitava as operações de divisão da terra, de aforamento, de estabelecimento de infraestrutura e de construção. O referido autor assevera também que a ortogonalidade desse urbanismo de traçados regulares correspondia aos ideais de racionalidade renascentista da época da fundação dessas cidades. É o caso da construção da cidade do Salvador, após sua fundação no século XVI (1549), que nos dois séculos subsequentes, corresponderam a uma nova fase do processo de organização do seu centro urbano. Para esse autor, a construção da cidade do Salvador correspondeu a uma nova fase do processo de colonização do Brasil, centralizado pela Coroa (TEIXEIRA, 2012, p. 137). Fato que nos leva a crer sobre sua importância também como um centro gerador das novas ideias e concepções urbanísticas, que terminavam por se espalhar por sua área de influência regional.

A seguir temos duas imagens que ilustram o que foi dito acima. A primeira, Figura 6.2 , corresponde a uma das principais praças do centro da cidade de Braga, no norte de Portugal, e a segunda, Figura 6.3, corresponde a uma das praças mais importantes da cidade do Salvador. É evidente a semelhança entre elas, demonstrando o mesmo padrão urbanístico e arquitetônico das mesmas. 


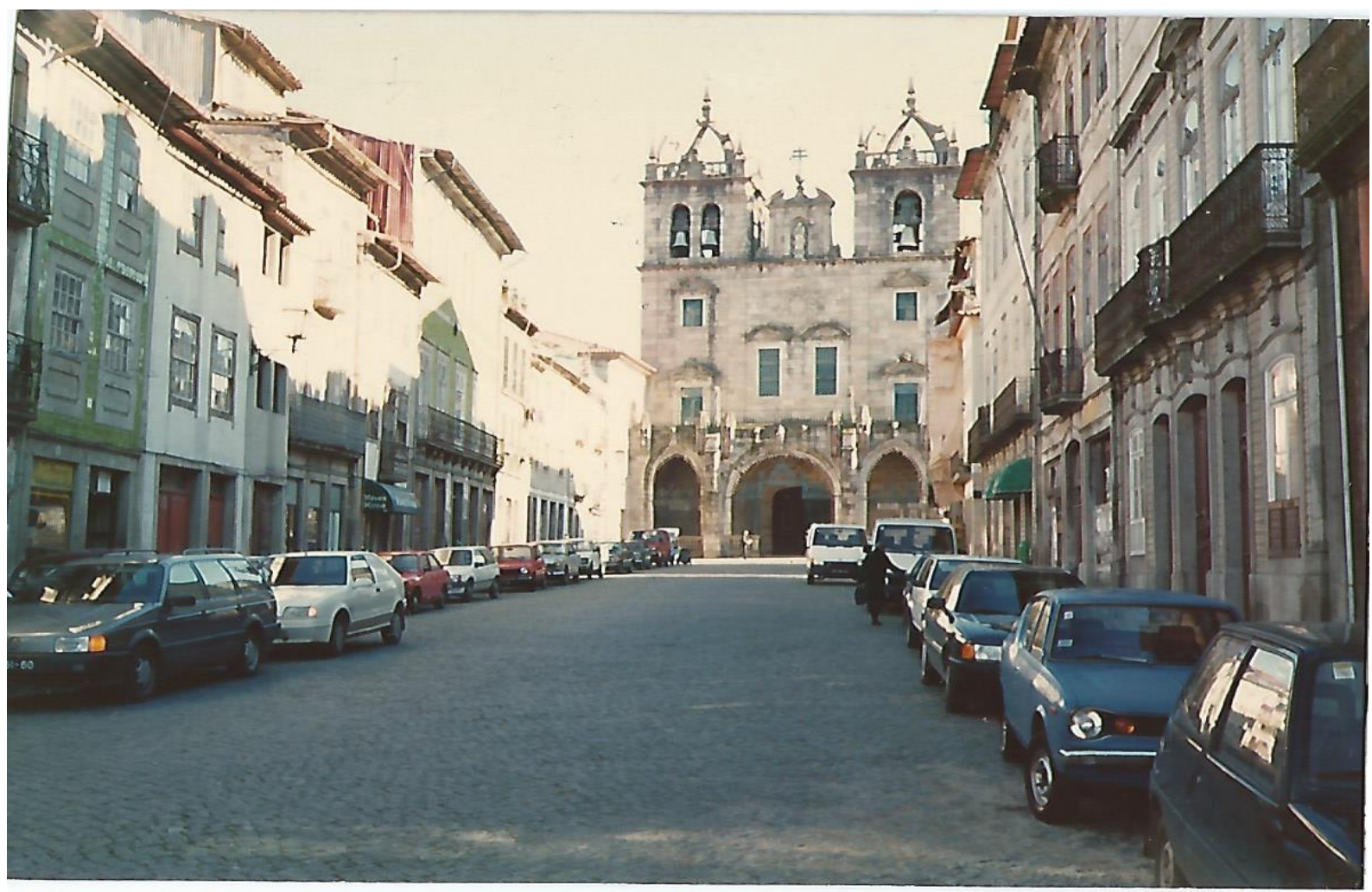

Figura 6.2 - Centro da cidade de Braga, Portugal, vendo-se ao fundo a catedral da cidade (Imagem do autor, década de 1990)

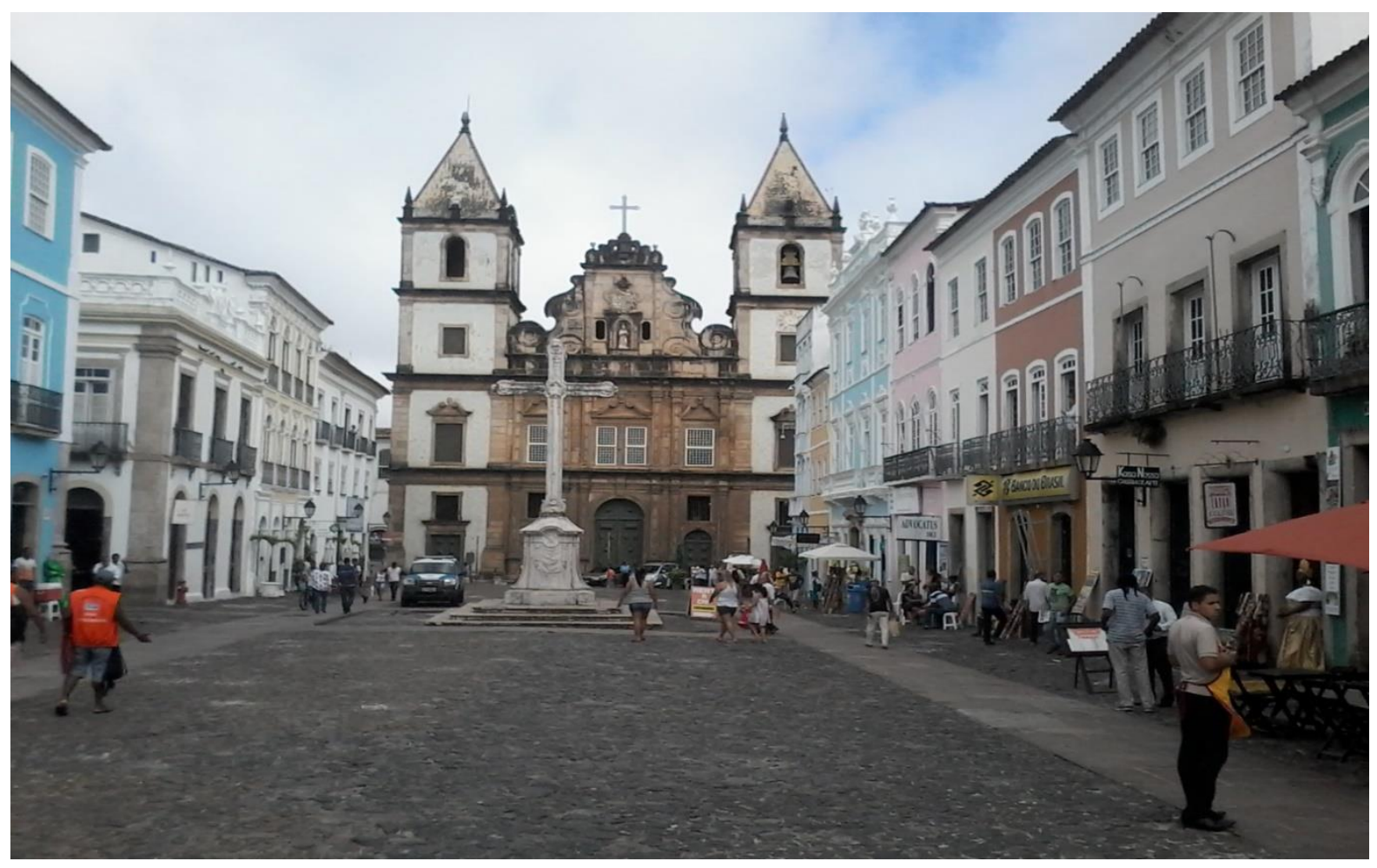

Figura 6.3 - Largo de São Francisco em Salvador - BA (Imagem do autor em trabalho de campo, 2014) 
Ainda discorrendo sobre estrutura urbana da cidade do Salvador, Teixeira (2012), chama a atenção para o fato de que, ao longo dos séculos XVII e XVIII, um novo conceito de urbanismo se estabelecia na colônia. Ou seja, o elemento dominante e gerador da malha urbana é a praça e não, como no século XVI, os edifícios singulares e ruas que os articulavam entre si. Essa nova tendência, segundo este autor, “[...] irá dominar a teoria e a prática urbanística portuguesa" (TEIXEIRA, 2012, p. 148). Segundo o autor, esses novos conceitos, desenvolvidos em múltiplas situações, “[...] irão expressar-se plenamente nos traçados urbanos setecentistas - joaninos e pombalinos - construídos quer no Brasil, quer em Portugal” (TEIXEIRA, 2012, p. 148).

Para Azevedo (2010), no caso do Brasil e referindo-se a Salvador, especificamente,

\begin{abstract}
Os construtores, mestres de obras, pedreiros e carpinteiros, faziam construções correntes, a casa, a oficina, a loja sem projeto, seguindo tipologias padronizadas e normatizadas, a começar pelo tamanho do lote e a altura das edificações. Nós tivemos isso em Salvador. De um lado, elementos emergentes, como torres bulbosas e cúpulas de igrejas e conventos, fortes e edifícios públicos, projetados por arquitetos religiosos ou militares e, por entre eles, um casario apócrifo com ruas onduladas de sobrados de uma porta e duas janelas, mas com diversidade de detalhes e cores, como o Pelourinho, o Maciel, o Carmo, o Pilar e Itapajipe (AZEVEDO, 2010, p. 90).
\end{abstract}

A assertiva acima nos oferece algumas pistas sobre a organização do espaço urbano da cidade do Salvador, Figura 6.4 a seguir. Segundo o mesmo autor acima referido, D. João VI decretou o neoclássico como estilo dos edifícios públicos após sua chegada em 1808, dentre outras deliberações, inclusive a vinda da Missão Francesa (AZEVEDO, 2010). 


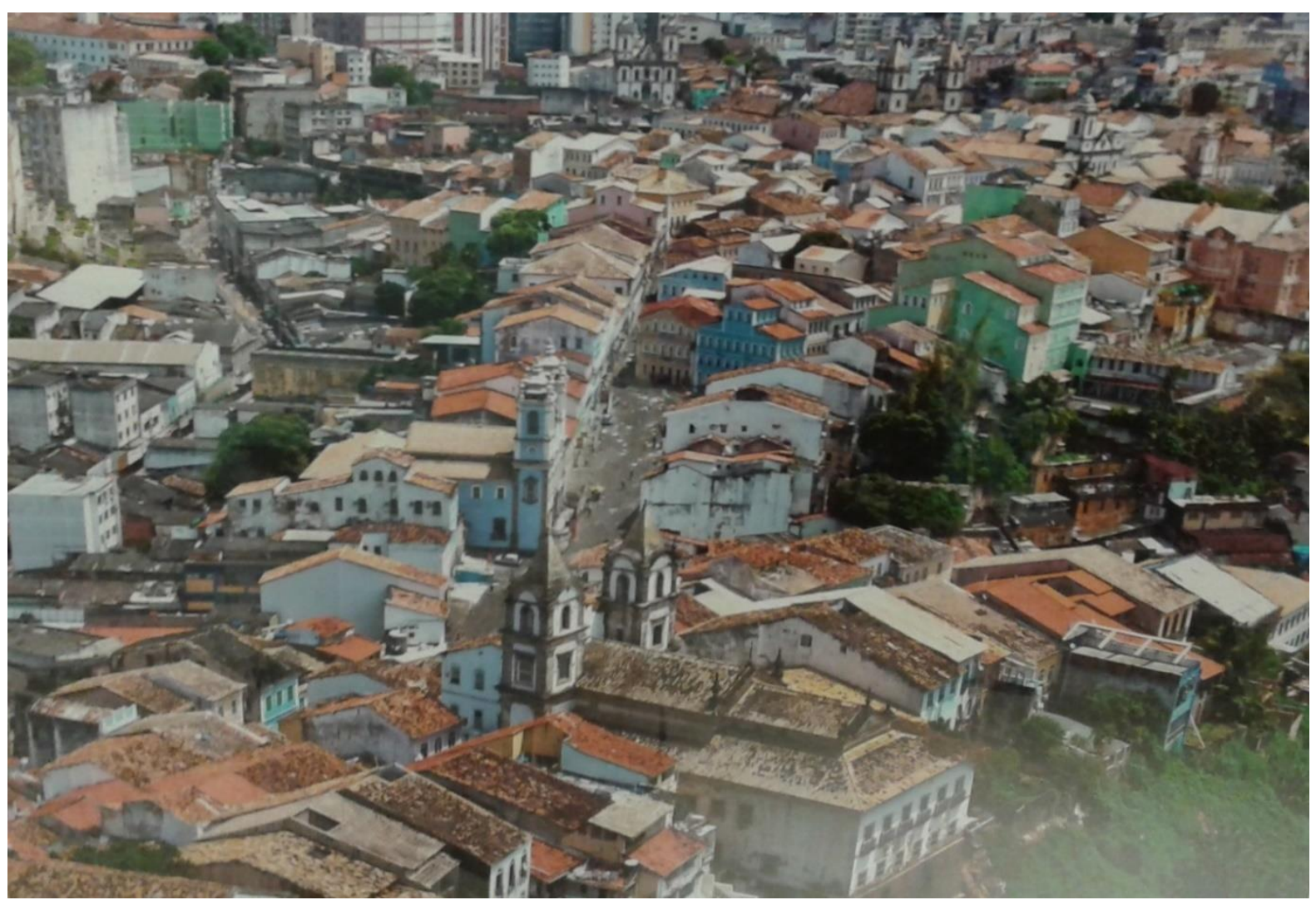

Figura 6.4 - Vista panorâmica do centro antigo da cidade de Salvador - BA na atualidade, onde vê a área do Pelourinho ao centro

(GAMA, 2015)

Teixeira (2012), comentando sobre as praças de origem portuguesa, assevera que:

Do ponto de vista funcional, as praças podem ter diversas origens: praças com funções de mercado, que muitas vezes se iniciaram em campos e terreiros extramuros e posteriormente se transformaram em praças urbanas; praças com funções religiosas, que tiveram sua origem em adros de igreja ou terreiros de conventos; praças com funções militares, como os campos adjacentes às torres de mensagem medievais e as praças de armas seiscentistas; praças com funções políticas e administrativas, em que se incluem as praças ao poder municipal onde se localizavam a Casa de Câmara e o pelourinho ou, nas cidades coloniais, as praças onde se localizava o palácio do governador. (TEIXEIRA, 2012, p. 100).

A descrição acima contempla as cidades por nós pesquisadas, onde as casas de Câmara e Cadeia, assim como os Paços Municipais, são exemplos de equipamentos localizados em praças até hoje importantes e de onde se estruturou a malha urbana das mesmas. Na Figura 6.5 a seguir, apresentamos uma imagem esquemática com o núcleo de ocupação histórica e a 
localização das Casas de Câmara e Cadeia e Igrejas Matrizes, onde podemos perceber a similaridade de organização do espaço em cinco das sete vilas por nós pesquisadas.

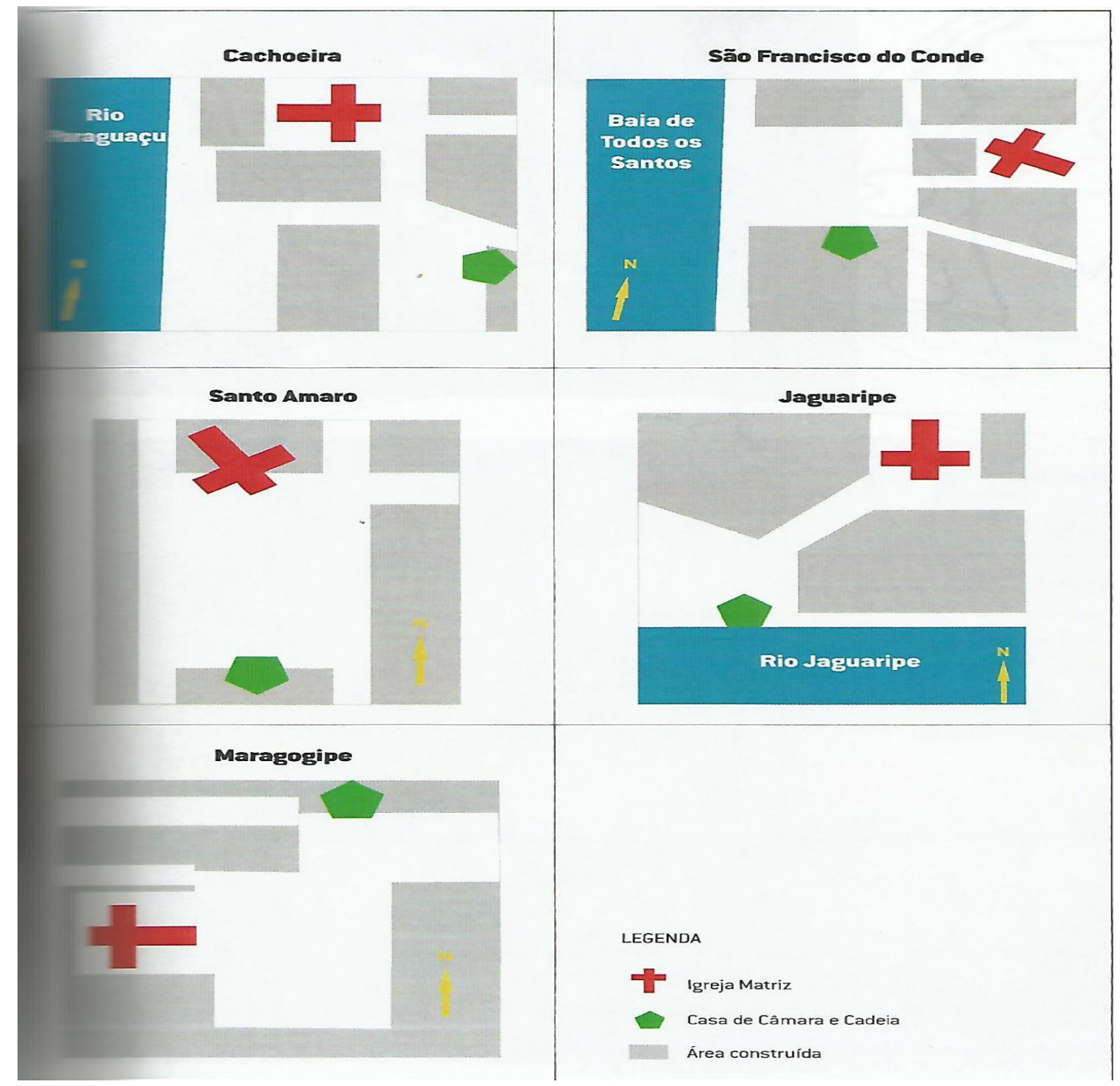

Figura 6.5 - Esquema de localização do núcleo de ocupação histórica de cinco vilas do Recôncavo Baiano (ANDRADE, 2013, p. 269)

No esquema da Figura 6.5 acima podemos perceber outra característica importante da tradição urbana portuguesa apontada por Teixeira (2012), no que se refere à multiplicidade de praças dentro de um mesmo núcleo urbano. Comumente se encontram nas cidades de origem portuguesa, diferentes praças para diferentes funções. Ainda segundo este pesquisador 
português, “[...] essa característica que encontramos em cidades de vários períodos, é formalizada nos traçados urbanos planejados setecentistas, em que frequentemente existem duas praças: uma associada ao poder político e outra, ao poder religioso" (TEIXEIRA, 2012, p. 100).

Para Magnavita (2013), o conceito de Patrimônio sempre esteve ligado à questão das três formas de pensar e criar: arte, ciência e filosofia, na maioria das vezes sob a perspectiva do poder do Estado. Nesse sentido, segundo este autor, “[...] O conceito de Patrimônio é relacionado com o 'aparelho' de Estado, e isso constitui uma 'máquina de guerra". Ainda segundo o mesmo, "[...] o conceito de Patrimônio é relacionado com a formação profissional da Arquitetura e por fim, com o conceito de Ética, enquanto 'visão de mundo' em sua dimensão política" (MAGNAVITA, 2013, p. 204). Entretanto cabe relativizar a ideia do referido autor, no sentido da associação do conceito de patrimônio apenas à arquitetura ao longo do século XX. Se é fato que foi assim, o século XXI mostra - e esta tese é a prova disto, entre outros fatores - que o patrimônio hoje é campo de antropólogos, sociólogos, geógrafos, turismólogos etc..

A dimensão política acima referida está na gênese das cidades históricas brasileiras, que por sua vez são oriundas de concepções do urbanismo português. Além desta, acrescentamos a dimensão religiosa, que também é política, quando se trata da relação entre a Igreja e o Estado no período colonial brasileiro.

O próprio estilo Barroco foi considerado como a arte da Contra - Reforma, tendo no seu bojo um forte apelo ideológico e político, principalmente na Europa, com suas ramificações em suas colônias. As igrejas setecentistas da Bahia são um grande exemplo de apelo ao fiel, através das fortes e densas imagens em escultura e pintura no interior e na monumentalidade de seus edifícios. A pintura em perspectiva, a densidade de detalhes, o contraste, o brilho do ouro etc..

A seguir veremos alguns exemplos de igrejas e seu papel de forma mais geral na produção e organização do espaço geográfico das cidades do Recôncavo Baiano. 


\subsection{MONUMENTOS ISOLADOS: AS IGREJAS}

O papel da Igreja Católica com todas as suas funções exercidas através de seus atores foi de extrema importância como agente de produção e organização do espaço, onde surgiram os primeiros núcleos de povoamento do país. Muitos destes se transformaram em importantes centros urbanos nas mais diversas regiões do Brasil. O Recôncavo Baiano foi uma dessas regiões. Ali se formou uma rede de cidades históricas que até os nossos dias se impõem na paisagem urbano-regional, especialmente pela monumentalidade e grande número de edifícios eclesiásticos espalhados pelos seus centros urbanos.

Andrade (2013) faz uma síntese do papel da Igreja na produção do espaço no Recôncavo Baiano, inferindo sobre suas variadas e fundamentais funções no processo de instalação e dinâmica da rede urbana regional. São elas:

[...] ação concreta de produção e organização do espaço urbano; ocupação e divisão administrativa do território; associação com a Coroa na regulação do uso do espaço e controle social; estabelecimento de centralidades e consequente atração de fluxos regulares (missas e circulação de religiosos) e eventuais (procissões e festas); assumiu, também, o papel de instrumento de agrupamento social com uniformidade étnica, econômica, laborial e de gênero; produziu unidades materiais (conventos, hospitais, seminários, igrejas e capelas), que se transformaram em centros de ocupação, e também assumiu funções empreendedoras como proprietária de terras rurais e urbanas, lavouras e engenhos, além de escravos (ANDRADE, 2013, p. 172).

Podemos perceber pela descrição acima que a instalação de Capelas e Freguesias foi o primeiro passo administrativo dado pela Coroa portuguesa em associação com a Igreja, para a posterior instalação das vilas, concomitante à instalação de todo o seu aparato político, administrativo e militar.

O Clero, associado aos mais altos representantes da Corte na colônia foi fundamental para o processo de domínio territorial e imposição da cultura portuguesa nas suas mais diversas dimensões civilizatórias, de base eurocêntrica, aplicadas ao novo território. Foi fundamental para o êxito daquela operação de sobreposição de culturas. Tanto na dimensão da cultura imaterial - a imposição da língua, por exemplo - como na dimensão material, através do posicionamento dos templos católicos nos territórios. 
Pesquisando o conteúdo dos textos das Constituições Primeiras do Arcebispado da Bahia de 1707, Andrade (2013, p. 174) descobriu pistas interessantes sobre diversos aspectos do papel da Igreja Católica no Brasil Colônia. Dentre eles destacamos a centralidade das Igrejas Matrizes que eram construídas nas então sedes de freguesias, exercendo forte centralidade sobre aqueles territórios eclesiásticos. O referido autor nos apresenta ainda uma fiel interpretação extraída dos referidos textos, que muito interessa ao nosso estudo. Ele faz as seguintes observações, aplicadas às cinco vilas setecentistas do Recôncavo Baiano (Jaguaripe, Cachoeira, São Francisco do Conde, Maragogipe e Santo Amaro), associando-as às instruções daquele documento eclesiástico:

Esse pequeno recorte do texto (CONSTITUIÇÕES...., L.4, Tit. 17, 1707) apresenta diversas nuanças acerca da posição dos edifícios religiosos, de modo especial a Matriz, e o controle do espaço construído no meio urbano [...] A observação das matrizes [...] revela que determinações como localização em cumeadas, abertura voltada para o nascente, adro ao seu redor (sem encontro com outras paredes) e a ocupação em parte central do sítio foram seguidas parcialmente, sendo, entretanto, decisivas na orientação do destino material dessas vilas. Da mesma forma, o tamanho e a suntuosidade das ditas igrejas tanto refletem a importância desse agente como dão indícios da concentração demográfica daquelas localidades [...] (ANDRADE, 2013, p. 175, grifo nosso).

Este fato é perceptível até os nossos dias nas cidades históricas brasileiras. Dos mais simples edifícios que abrigam as Capelas Jesuíticas, passando pelas igrejas convencionais, conventos, mosteiros, até as mais suntuosas Catedrais e Igrejas Matrizes. Todos esses equipamentos situam-se em pontos estratégicos para a ordenação do território, fato que demonstra sua importância no processo de urbanização de várias regiões. Foi o caso das cidades históricas do Recôncavo Baiano.

Em obra que trata do desenvolvimento da arquitetura religiosa no Brasil, desde fins do século XVI até o princípio do século XIX, no que concerne ao estilo dos templos, Bazin (1956, p. 168), considera que a Bahia talvez seja a melhor região para sentir a continuidade entre a arte do século XVII e a do século XVIII. Este autor faz alusão aos edifícios (templos) da cidade do Salvador e de algumas cidades do Recôncavo, indicando similaridades entre estes, a partir de influências entre edifícios oriundas de ambas as partes. Segundo o autor, apesar de a Bahia ter perdido prestígio político e econômico com a transferência da capital da colônia para o Rio de Janeiro em 1763, 
[...] conservou o privilégio de ser a sede do arcebispado e de numerosas cabeças de ordem religiosas; é a capital religiosa do Brasil e nela a densidade de construções religiosas é a mais forte do país; esta arte se estende às margens do Recôncavo, admirável baía onde desemboca o grande estuário do rio Paraguçú, perto do qual permanece, retirado, o gracioso e antigo vilarejo de Cachoeira (BAZIN, 1956, p. 27).

É importante salientar que, segundo Bazin (1956, p. 6), ao tempo em que escreveu sua obra, considerou que o Brasil tem lugar de destaque no "[...] desenvolvimento da arte monástica na civilização ocidental” entre os séculos XVII e XVIII. Portanto, é possível perceber ao longo destes dois séculos e início do século XIX, uma evolução que passa pelo maneirismo, barroco, rococó e neoclássico.

A imagem ${ }^{10}$ da Figura 6.1.1, reproduz a paisagem do centro histórico da cidade do Salvador, no século XIX e nos dá uma dimensão da presença da igreja na paisagem urbana da cidade naquele século.

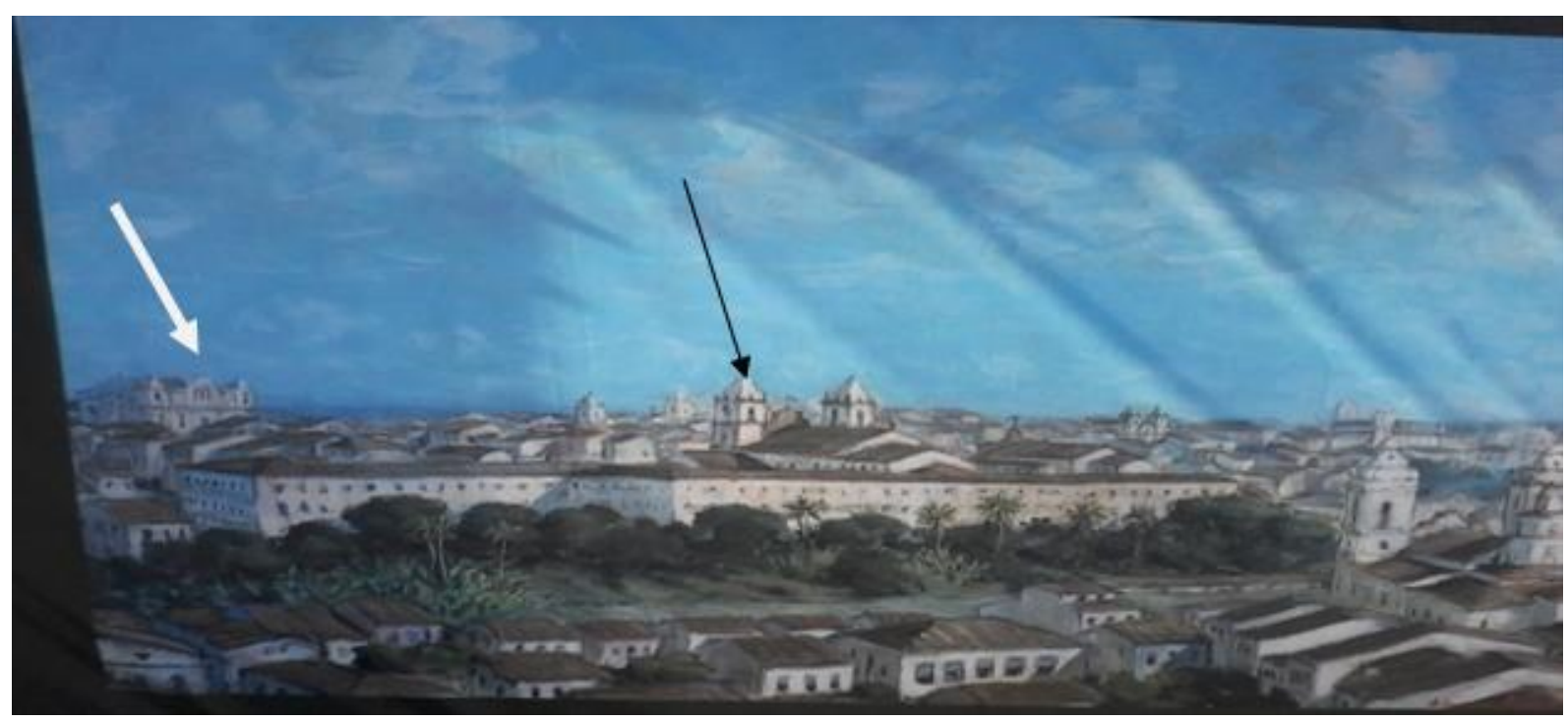

Figura 6.1.1 - Centro da cidade de Salvador - BA no século XIX (REBOUÇAS, 2014, modificado)

É possível perceber na imagem algumas importantes e significativas igrejas e suas torres. Destacamos a Catedral Basílica de frente (seta branca) e os fundos da Igreja de São Francisco (seta preta).

\footnotetext{
${ }^{10}$ A imagem é uma foto da plotagem de uma tela de Diógenes Rebouças em exposição na área externa do Farol da Barra, Salvador, Junho de 2014.
} 
Vejamos o que diz Bazin, sobre uma importante capela setecentista de Cachoeira e Igreja Matriz na mesma localidade, além de outras espalhadas por Salvador:

O estado da arquitetura do primeiro quartel do século XVIII nos é mostrado em Cachoeira, pela capela da Ordem Terceira do Carmo (mais ou menos 1702) e pela matriz do Rosário; em Salvador, por toda uma série de fachadas: a da Igreja da Boa Viagem, a de São Francisco (terminada em 1723), aquela destruída da antiga catedral e as das igrejas dos carmelitas e da capela de São Miguel (BAZIN, 1956, p. 168-169).

Em outro trecho da descrição de Bazin (1956, p. 169), encontramos uma informação curiosa, dessa vez fazendo referência à igreja de São Francisco, em Salvador, como uma “evolução do tipo de Cachoeira e Maragogipe", nos dando a entender que as duas últimas foram instaladas antes da primeira. Mais adiante o referido autor nos informa que "[...] a nobre fachada de São Francisco foi copiada, como vimos, por volta de 1725, de outro convento franciscano da Bahia, na vila de São Francisco" (BAZIN, 1956, p. 170). A vila que o autor se refere é a atual cidade de São Francisco do Conde.

Ainda sobre a similaridade de padrão arquitetônico religioso barroco na Bahia, Bazin (1956) nos informa que no segundo terço do século XVIII, são empreendidos diversos templos religiosos. E que, “[...] sendo o principal elemento das igrejas, as fachadas se mantém fiéis ao princípio cuja gênese nos é mostrada em Maragogipe [...]” (BAZIN, 1956, p. 171).

Segundo Bazin (1956, p. 171) a igreja de Nossa Senhora da Penha, “[...] construída a partir de 1741, como capela da residência de verão dos arcebispos, tem um frontão semelhante ao da igreja do seminário de Belém da Cachoeira”. Fica claro nessa descrição, mais uma referência sobre a semelhança de padrões, acrescentando-se o fato de que a segunda igreja mencionada (a de Belém de Cachoeira) foi construída entre 1726 e 1732. Portanto, antes daquela construída na cidade do Salvador em 1741. Ou seja, nove anos depois. Por isso a Igreja de Nossa Senhora da Penha, em Salvador, ter sofrido a influência do padrão da de Belém de Cachoeira.

Como já vimos, o Recôncavo Baiano em direta conexão com a primeira capital da Colônia, foi a primeira região a formar uma densa rede de vilas ainda no século XVIII, estruturando-se na forma urbana e no conteúdo social desde então, sendo a Igreja um dos principais agentes nesse processo, tanto do ponto de vista da produção e organização espacial urbana, como da perspectiva da estruturação social. 
No próximo tópico fizemos também uma descrição das principais características das igrejas matrizes das sete cidades pesquisadas, com base no inventário do IPAC (BAHIA, 1982a; 1982b) e com os mesmos objetivos apontados no final do tópico anterior.

\subsubsection{As igrejas matrizes}

Em Jaguaripe, a Matriz de Nossa Senhora da Ajuda, Figura 6.1.1.1, está localizada no cume da maior elevação existente na zona urbana, de onde se domina a cidade e estuário do rio Jaguaripe. Segundo os dados tipológicos do IPAC, a igreja é do início do século XVIII. Apresenta planta típica das igrejas daquele século, herança jesuítica de tradição lusobrasileira. A fachada, do início do século XIX, é do tipo rococó. A sacristia é conservada como no século XVIII. Existem ali dois altares: um do mesmo tipo do de Monte Serrat, e outro, rococó tardio, com talha do mesmo estilo da Igreja de Nossa Senhora do Pilar, na cidade do Salvador (BAHIA, 1982, p. 170).

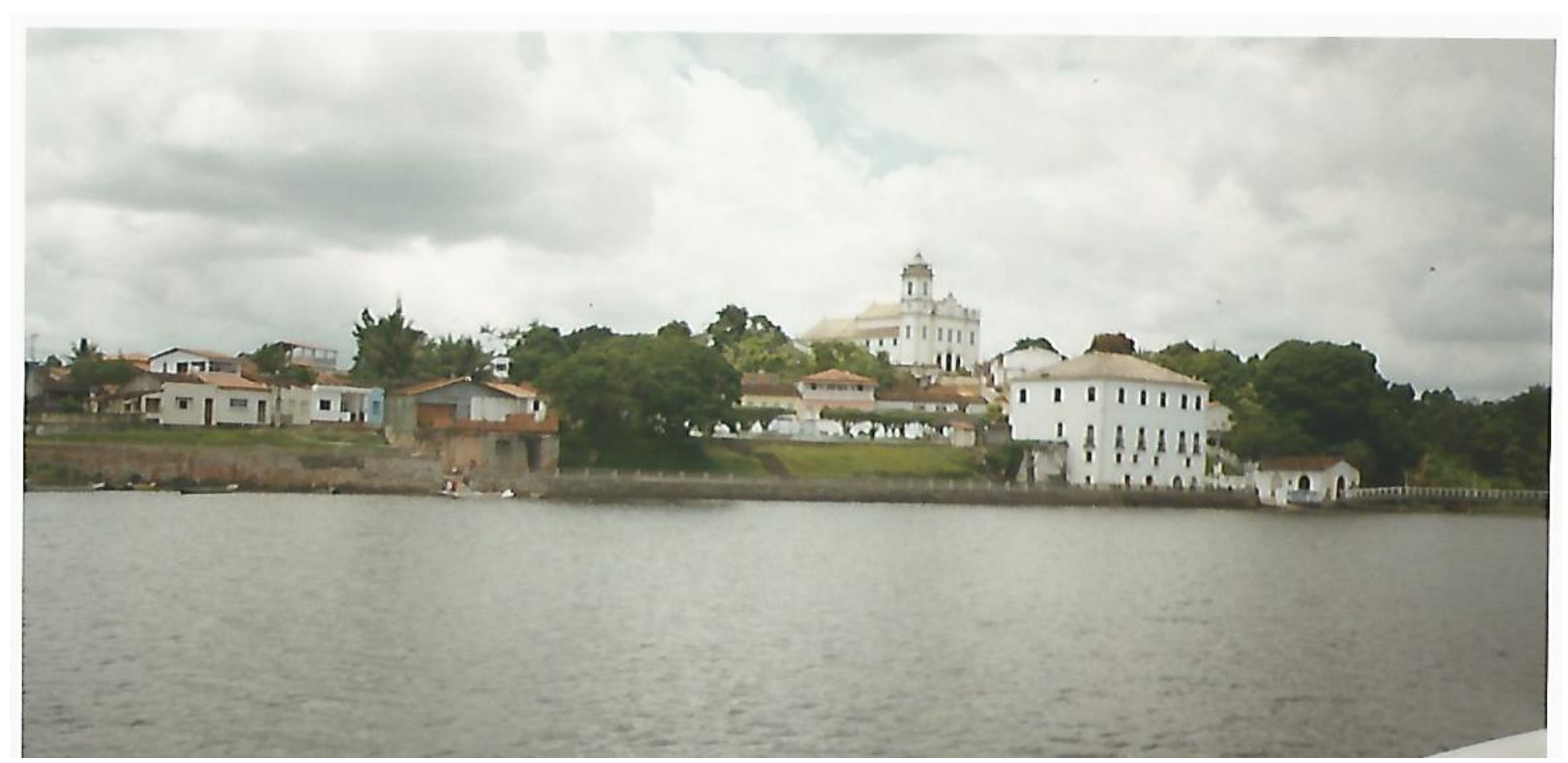

Figura 6.1.1.1 - Igreja Nossa Senhora da Ajuda em Jaguaripe - BA, no alto, ao fundo, a partir do rio Jaguaripe

(Acervo do autor, década de 2010) 
A descrição acima faz alusão à semelhança entre a sacristia da Matriz de Jaguaripe, com a de duas igrejas da cidade do Salvador, fato que demonstra a conexão do clero em diferentes territórios, mantendo os estilos padrões de suas construções.

No inventário do IPAC consta que a Matriz de Nossa Senhora do Rosário, em Cachoeira, Figura 6.1.1.2, é da primeira metade do século XVIII, mas fiel à tradição clássica do século anterior. Forma uma pequena quadra compreendida entre a Rua Ana Nery e a Praça 13 de Maio. Sua fachada principal está voltada para a Rua Ana Nery e coincide com o eixo da Rua Comendador Assis, o que lhe proporciona uma boa perspectiva (BAHIA, 1982).

No caso da descrição acima, chamamos a atenção para o que Teixeira (2012), apontava anteriormente, quando indica em seu estudo que no século XVI, ainda se privilegiava as localidades onde seriam instalados os edifícios e daí viriam as praças, como foi o caso a partir dos séculos XVII e XVIII. Ou seja, as praças ou ruas vão surgir de um edifício simbólico pré-existente. 


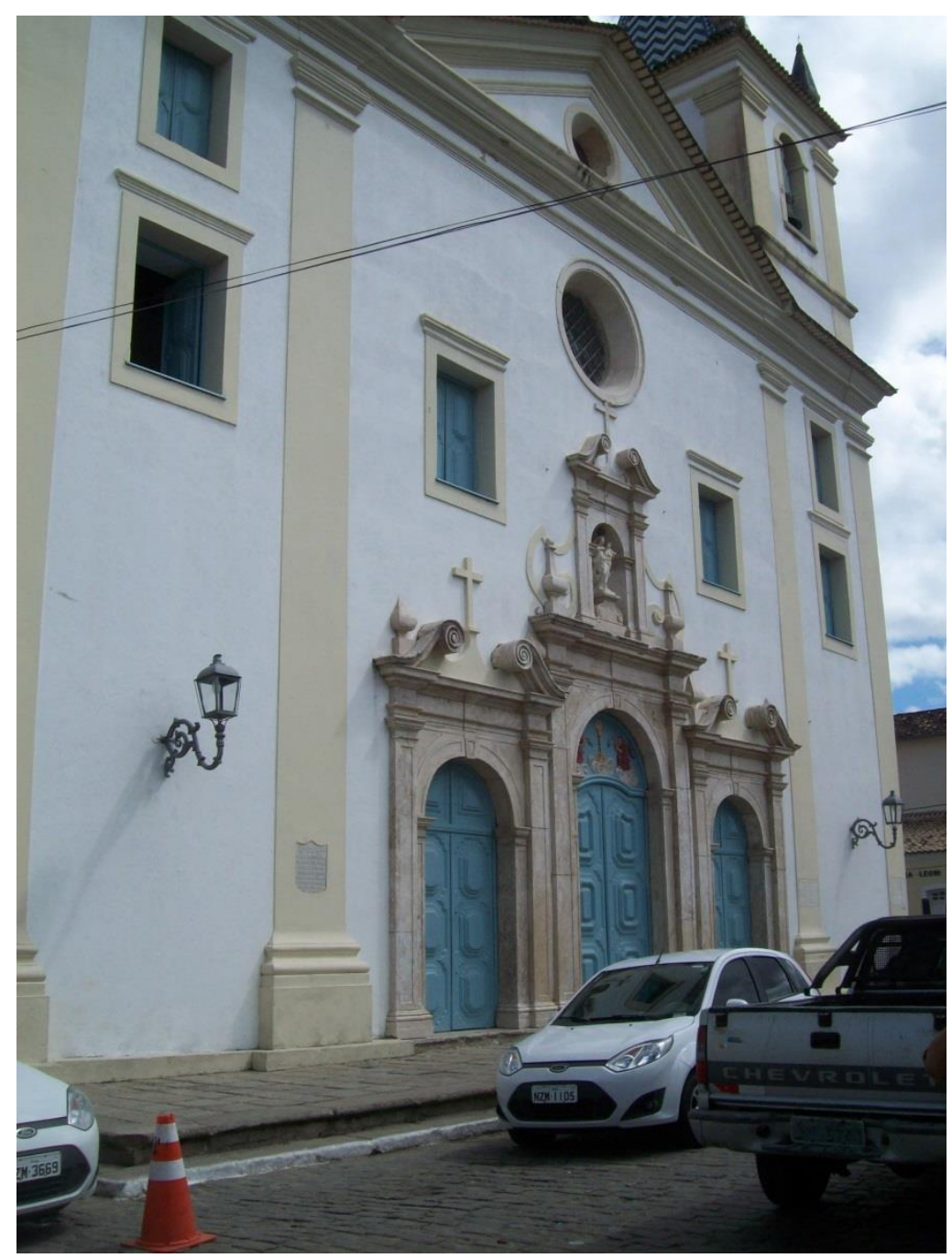

Figura 6.1.1.2 - Igreja matriz de Nossa Senhora do Rosário em Cachoeira - BA

(Foto do autor em trabalho de campo, junho 2012)

Da torre da igreja se avista quase toda a cidade de Cachoeira e parte de São Felix, situada na margem direita do rio Paraguaçú. O frontispício se inspira diretamente nas igrejas de São Bartolomeu, na cidade de Maragogipe, e Santo Antônio da Barra, na cidade do Salvador. Os azulejos do revestimento da torre são encontrados também em Belém (atualmente distrito de Cachoeira); na Boa Viagem e na Santa Casa de Misericórdia, na cidade do Salvador; e no convento de Santo Antônio, na cidade de São Francisco do Conde. Segundo o inventário do IPAC (BAHIA, 1982), as portadas e outros elementos dessas igrejas em peças de lioz, eram comuns no século XVIII. As igrejas do Pilar e da Conceição na cidade do Salvador, são exemplos do uso do referido material em Salvador. Ainda segundo o inventário, 
Os azulejos do interior da matriz de Cachoeira foram classificados como dos mais importantes existentes no país e de qualidade semelhante aos melhores que se produziam em Lisboa em 1750 (3). A pintura do forro da nave é tipo ilusionista italiano, difundida na Bahia na segunda metade do século XVIII e que teve como principal expressão José Joaquim da Rocha (BAHIA, 1982, p. 48).

A descrição acima nos remete à reflexão sobre a importância da cidade de Cachoeira no cenário regional do século XVIII, tendo em vista as indicações do alto padrão dos materiais utilizados, especialmente na decoração de sua igreja matriz. Além disso, a semelhança apontada com outras igrejas da cidade do Salvador e de outras vilas do Recôncavo nos permite salientar a existência de uma forte conexão, através de uma rede urbana regional, como já apontada anteriormente. Tal rede, nos seus pontos nodais, a influência de métodos construtivos e artísticos chegavam concomitantemente. Fato que permitiu a semelhança dos estilos artísticos, inclusive da confecção de determinadas obras de pintura do interior dos templos, executada por um mesmo artista.

Encontramos no portal da Matriz de Cachoeira uma lápide, Figura 6.1.1.3, que expressa com seus dizeres a importância daquela vila na época da Independência do Brasil, na Bahia, como já foi mencionada anteriormente neste trabalho. Tal fato reflete o significado daquele patrimônio para os cachoeiranos e para o povo baiano. São detalhes muito significativos no que diz respeito à relação sociedade - território, sob uma perspectiva simbólica e identitária.

Os escritos da lápide dizem o seguinte: 


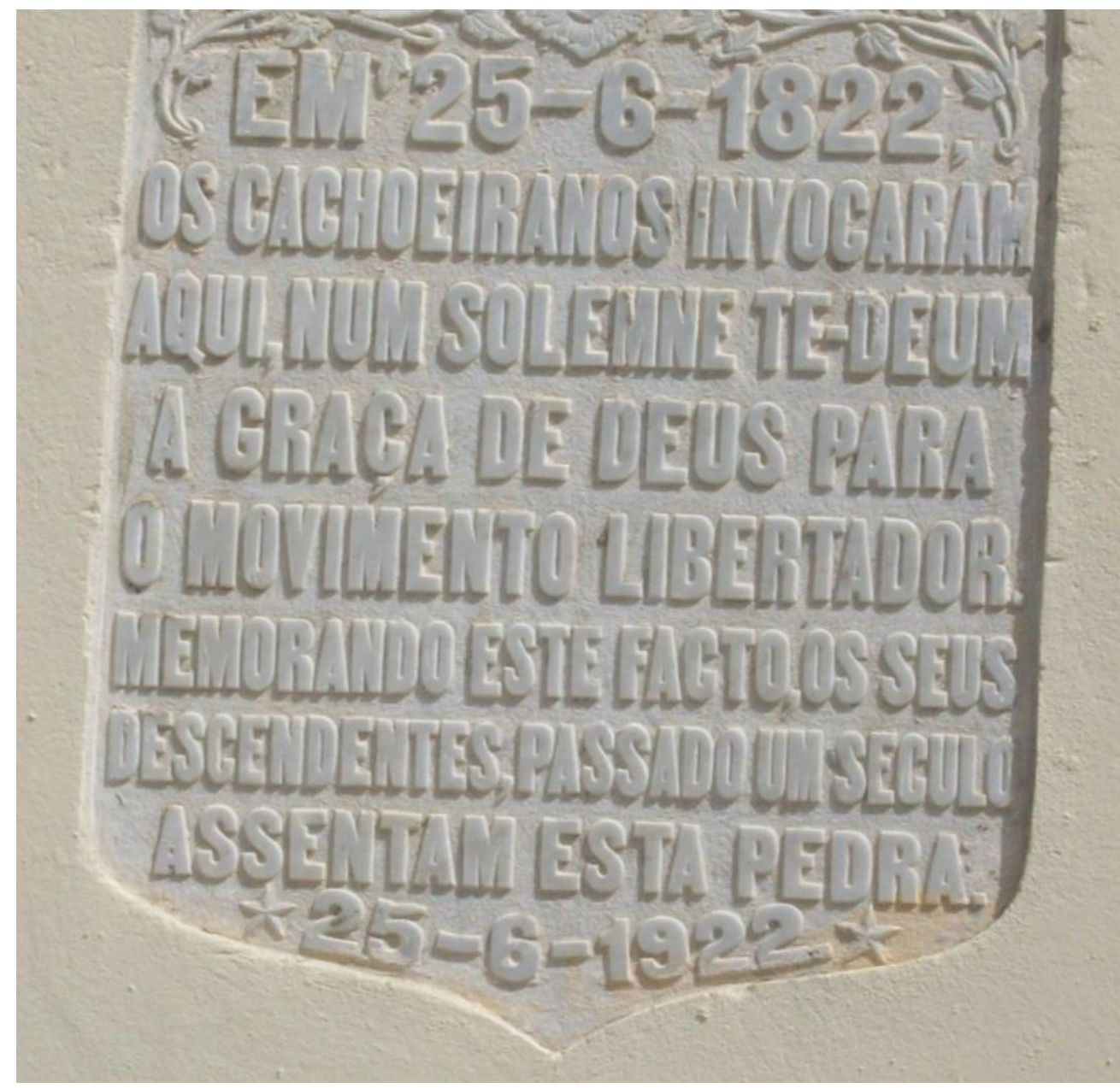

Figura 6.1.1.3 - Lápide localizada na parede da igreja matriz de Cachoeira-BA

(Imagem do autor, 2012)

Sobre a Igreja Matriz de São Gonçalo na cidade de São Francisco do Conde, Figura 6.1.1.4, o inventário do IPAC diz o seguinte:

Esta matriz, reconstruída no início do século XVIII, conserva elementos da capela de meados do século anterior, de uma só sacristia. A reconstrução deve ter consistido no aumento do pé direito da nave e capela - mor, na criação de corredores laterais, tribunas e consistórios, como era moda nas matrizes do início do século XVIII. Esta afirmativa baseia-se na diferença entre as janelas da parte primitiva e das partes ampliadas. A fachada é típica de capelas do século XVII, pois ainda não incorporou as três portas de acesso, comuns nas matrizes do século seguinte [...] Esta igreja conserva um elemento arcaico, a capela lateral, resíduo do falso transepto da tradição jesuítica luso-brasileira, encontrada também em outras matrizes como as de Maragogipe, Ipitanga e Santo Amaro da Purificação (BAHIA, 1982, p. 170, grifo nosso). 


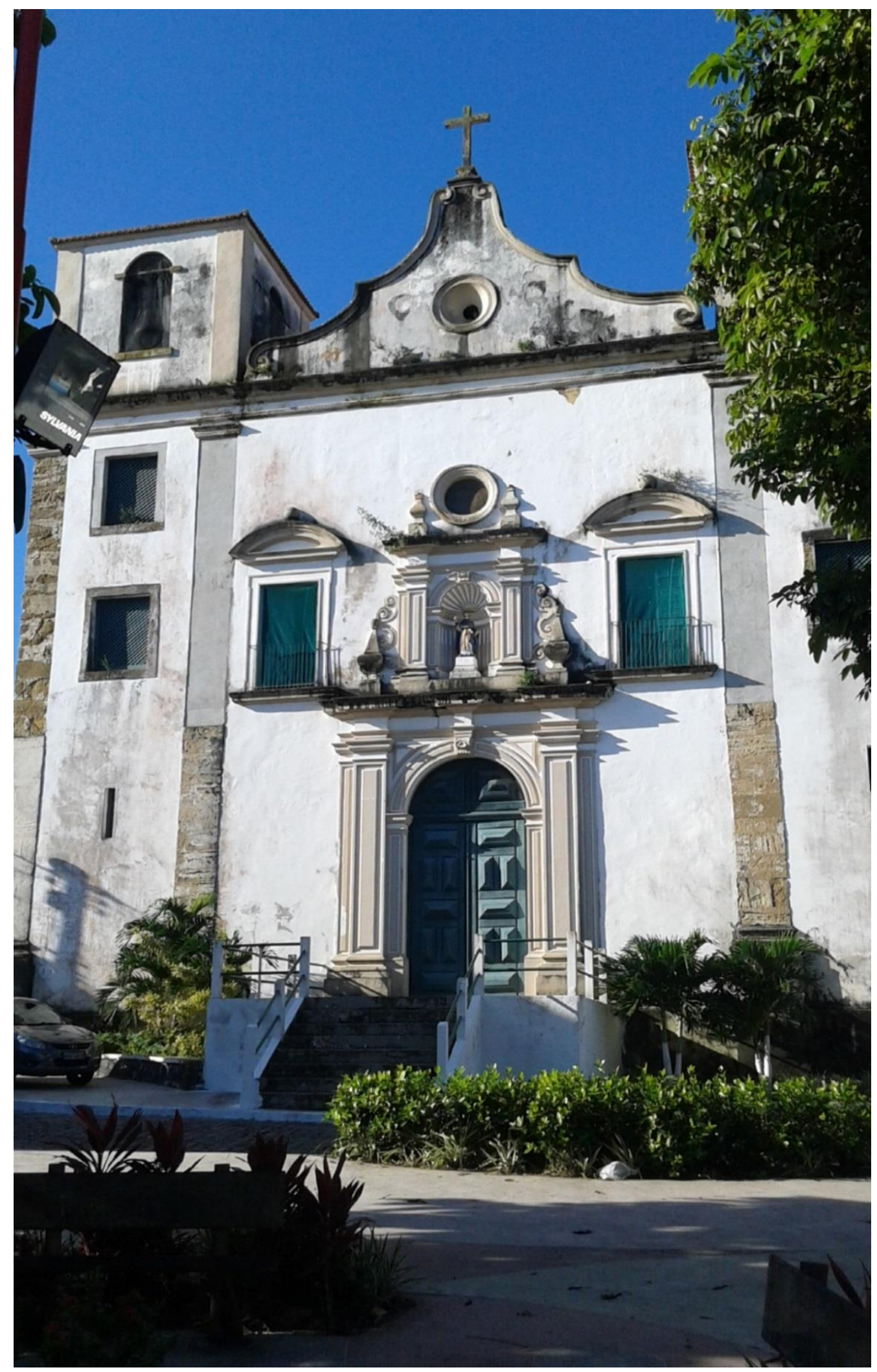

Figura 6.1.1.4 - Igreja matriz de São Gonçalo em São Francisco do Conde - BA (Imagem do autor em trabalho de campo, 2015) 
Uma expressão em especial nos chamou a atenção na descrição acima: [...] como era moda nas matrizes do início do século XVIII [...]. Tal expressão nos indica que naquela época todas as vilas seguiam um padrão pré-determinado nas suas construções eclesiásticas desde o século XVII. Ainda segundo o inventário, a matriz de São Francisco do Conde localiza-se numa colina de vinte metros de altura, com sua fachada principal voltada para a Baía de Todos os Santos e de costas para a cidade.

A Matriz de São Bartolomeu em Maragogipe, Figura 6.1.1.5, ocupa o ponto mais alto da colina sobre a qual se desenvolveu a cidade de Maragogipe.

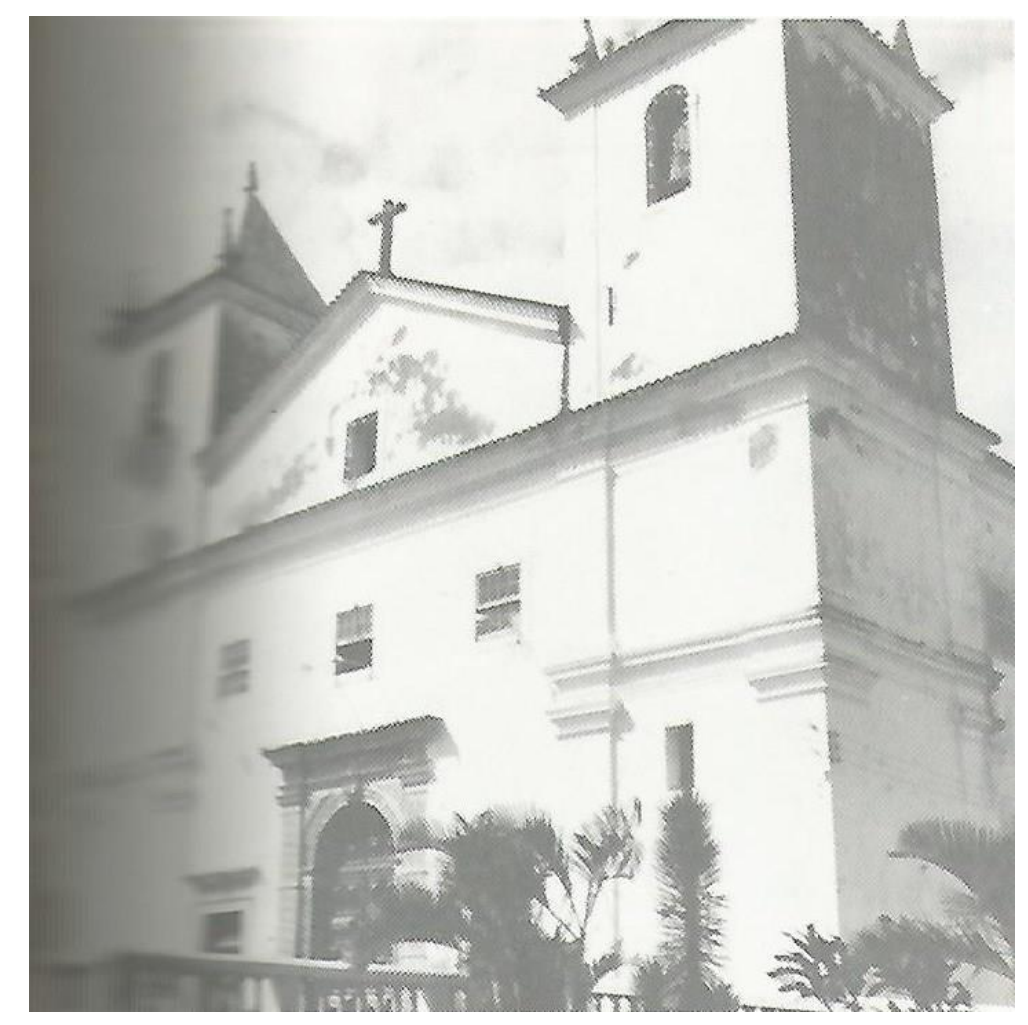

Figura 6.1.1.5 - Igreja matriz de São Bartolomeu em Maragogipe - BA

(BAHIA, 1982, p. 193)

Segundo a descrição do inventário do IPAC,

Trata-se de um dos mais importantes templos baianos, que se antecipou e serviu de modelo às igrejas de corredores laterais e fachadas com duas torres, difundidas no século seguinte, especialmente entre as matrizes e sedes de irmandades [...] Seu frontispício, com corpo central tipo templo, ladeada por duas torres com terminação piramidal serviu de modelo, conjuntamente com a de S. Antônio da Barra, a muitas igrejas baianas do início do século seguinte, como São Francisco, de Salvador, e Rosário de Cachoeira. Este tipo de terminação surgiu primeiro em Cairu e foi em seguida adotado em 
Maragogipe. Sua portada é do mesmo tipo da que existiu na antiga Sé de Salvador e que se conserva em São Dâmaso, S. Casa de Misericórdia, Sta. Tereza e Casa de Gregório de Matos, em Salvador, e em São Brás, em S. Amaro (BAHIA, 1982, p. 194).

Na descrição acima percebemos mais uma vez que houve influências no sentido da origem dos estilos de alguns edifícios. Ou seja, alguma nuance de detalhes no estilo de alguns templos, poderiam ser oriundos de diferentes localidades da região e, por motivos diversos, tais como poder econômico local, serem erigidos primeiramente e influenciar outros edifícios noutras localidades, antes mesmo de seus congêneres na capital. A Matriz de São Bartolomeu, na cidade de Maragogipe, expressa toda uma monumentalidade típica de uma vila que exercia grande influência estratégica no processo de povoamento e catequização no século XVII e XVIII, como de poder econômico ligado à produção e exportação de produtos típicos da região, como já foi visto na descrição da cidade.

A Matriz de Nossa Senhora da Purificação, Figura 6.1.1.6, segundo descrição do IPAC (BAHIA, 1982, p. 102), “[...] Seria portanto uma igreja na linha das matrizes de Maragogipe e Santo Amaro de Ipitanga, do final do século XVII, com um falso transepto, reminiscência da tradição jesuítica luso-brasileira [...]”.

Ainda segundo o mesmo inventário,

Como sua construção demorou quase um século, a igreja foi se adaptando aos modismos de cada época e acabou se convertendo em uma igreja do tipo comum no século XVIII. Suas fachadas testemunham o lento desenvolvimento das obras incluindo desde janelas com conversadeiras (BAHIA, 1982, p. 102).

Percebemos pela descrição acima que, ao longo do tempo de construção das igrejas, muitas adaptações eram feitas, copiadas de prédios mais antigos ou em estágio mais avançado no processo de construção. Ou seja, quando se fala em adaptação aos "modismos de cada época", presume-se que existia uma dinâmica troca de informações e ideias, que são reveladas no próprio território, através da leitura do seu patrimônio edificado. 


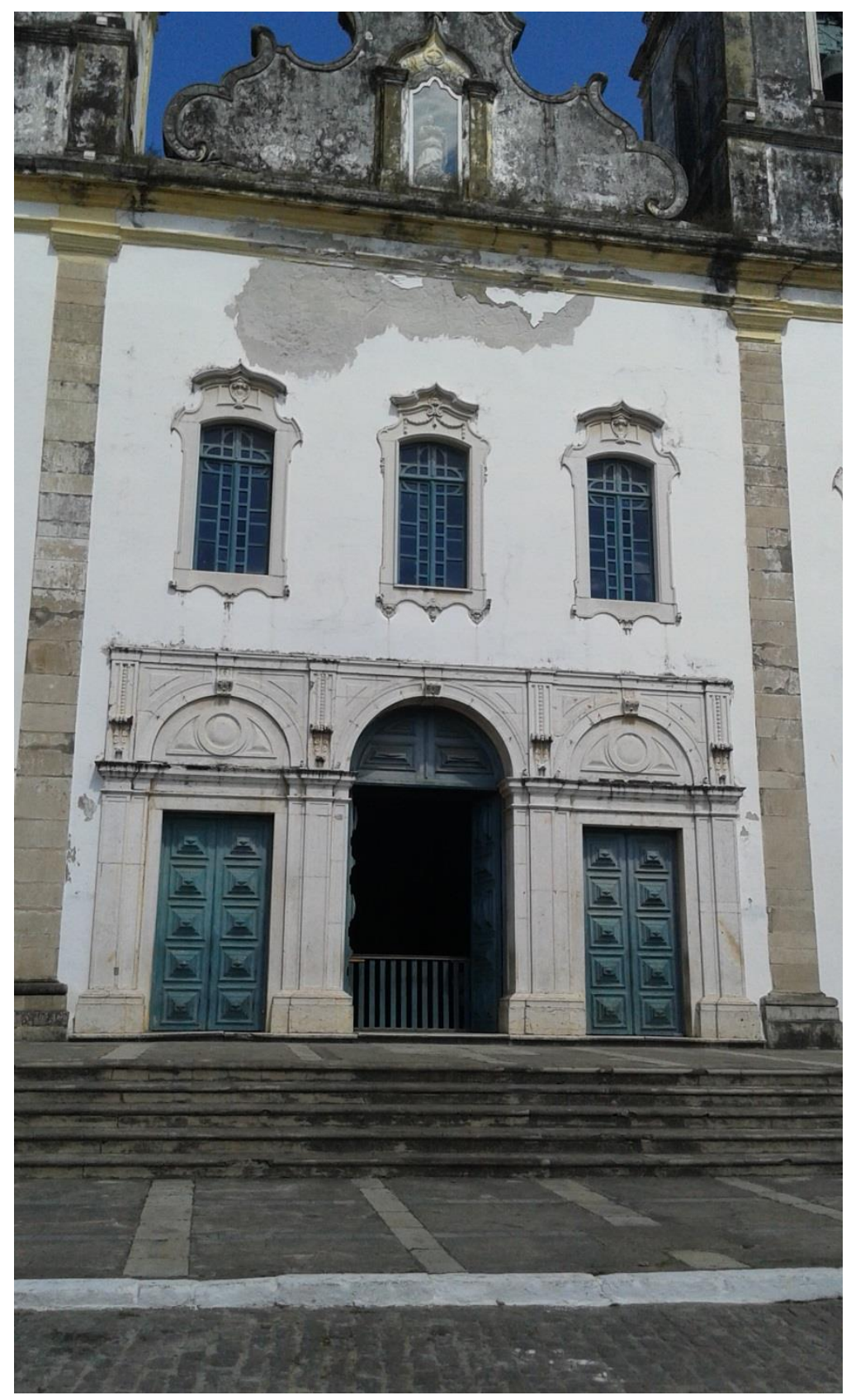

Figura 6.1.1.6 - Igreja matriz de Nossa Senhora da Purificação em Santo Amaro - BA

(Imagem do autor em trabalho de campo, 2015)

Segundo o inventário do IPAC, a Igreja Matriz de Nazaré, Figura 6.1.1.7, foi iniciada no segundo quartel do século XVIII e concluída oitenta anos mais tarde, seguindo a planta típica das matrizes e igrejas de irmandades do século XVIII (BAHIA, 1982, p. 248). Segundo a fonte supracitada “[...] A torre em bulbo, revestida de embrechados, foi construída no final do século XVIII e reflete a tendência do período". 


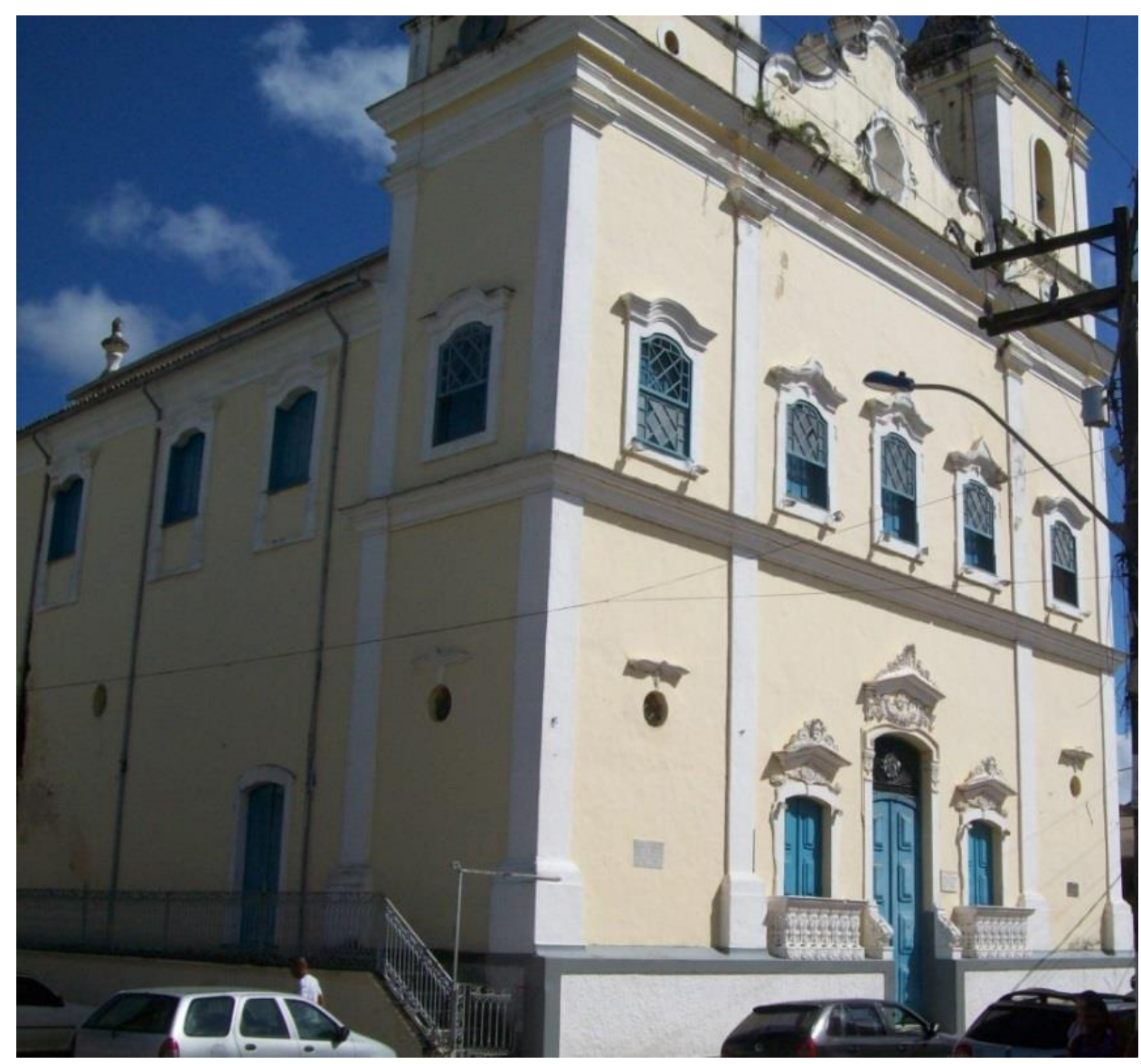

Figura 6.1.1.7 - Igreja matriz de Nossa Senhora em Nazaré - BA (Imagem do autor em trabalho de campo, 2012)

$\mathrm{Na}$ descrição percebemos que existiu uma tendência de estilo das igrejas em determinados períodos na região, fato que reforça certa homogeneidade de formas, entretanto, é possível perceber, por outro lado, algumas diferenciações de estilos entre elas nas cidades em tela, devido ao longo tempo de construção das mesmas. Ou seja, a depender das peculiaridades das condições econômicas e estruturais dos territórios, alguns desses monumentos poderiam apresentar maior ou menor riqueza de detalhes ou transição entre estilos de época, a exemplo de diferentes aspectos do barroco e neoclássico. Podemos perceber isso na continuação da descrição da referida Matriz da cidade de Nazaré:

[...] A igreja em estudo não apresenta, porém, a sacristia transversal, observada em muitos templos da mesma época e gênero. As duas grandes capelas laterais são herança do falso transsepto da tradição jesuítica lusobrasileira, enquanto a sub-divisão da fachada por pilastras e friso é uma reminiscência de velho esquema maneirista. [...] Os altares são neoclássicos, de meados do século passado (séc. XIX), com fundo branco predominando sobre a talha dourada (BAHIA, 1982, p. 248, grifo nosso). 
A concomitância temporal na construção (das igrejas) e na implantação do acervo artístico (interior e exterior) dos edifícios ao longo do século XVIII nos indica que esse processo teve continuidade em períodos posteriores, porém com variações locais.

É possível perceber também que, devido às condições técnicas de construção e engenharia da época, houve uma diferenciação de estilos entre a parte externa e a decoração interna dos templos, muitos deles refletindo diversos períodos de época, numa mesma igreja e influências de outras, da capital ou do Recôncavo.

Vejamos o que diz o inventário sobre a Matriz Deus Menino, na cidade de São Felix:

Edifício do final do século XVIII que apresenta uma planta muito comum nas matrizes da época: um corpo central, constituído por nave e capela-mor flanqueadas por corredores laterais e sacristias, superpostas por galerias de tribunas e consistórios. Neste caso, porém, só um corredor foi concluído. Provavelmente deste século $(\boldsymbol{X X})$, são as grandes aberturas comunicando a capela-mor com as sacristias e consistórios. Sua fachada é tipicamente rococó, com um frontão flamejante, que denota influência direta do Carmo de Cachoeira, e uma torre bulbosa revestida de embrechados, com tocheiros nos cantos, na mesma linha da torre da Igreja de N. Sra. da Conceição do Boqueirão, em Salvador. Muito interessante era o forro "Art-Decó" da nave, já destruído (BAHIA, 1982, p. 336, grifo nosso).

Mais uma vez é possível perceber na descrição do Inventário do IPAC, a questão do padrão comum entre as referidas igrejas matrizes, além das influências de que cada uma delas recebia de outras igrejas da região, como é caso acima. Além disso, percebe-se também algumas peculiaridades, fruto, provavelmente, da influência que seus mestres construtores e artistas, sofreram ao longo do período de sua construção e realização de suas obras, como já visto anteriormente. 


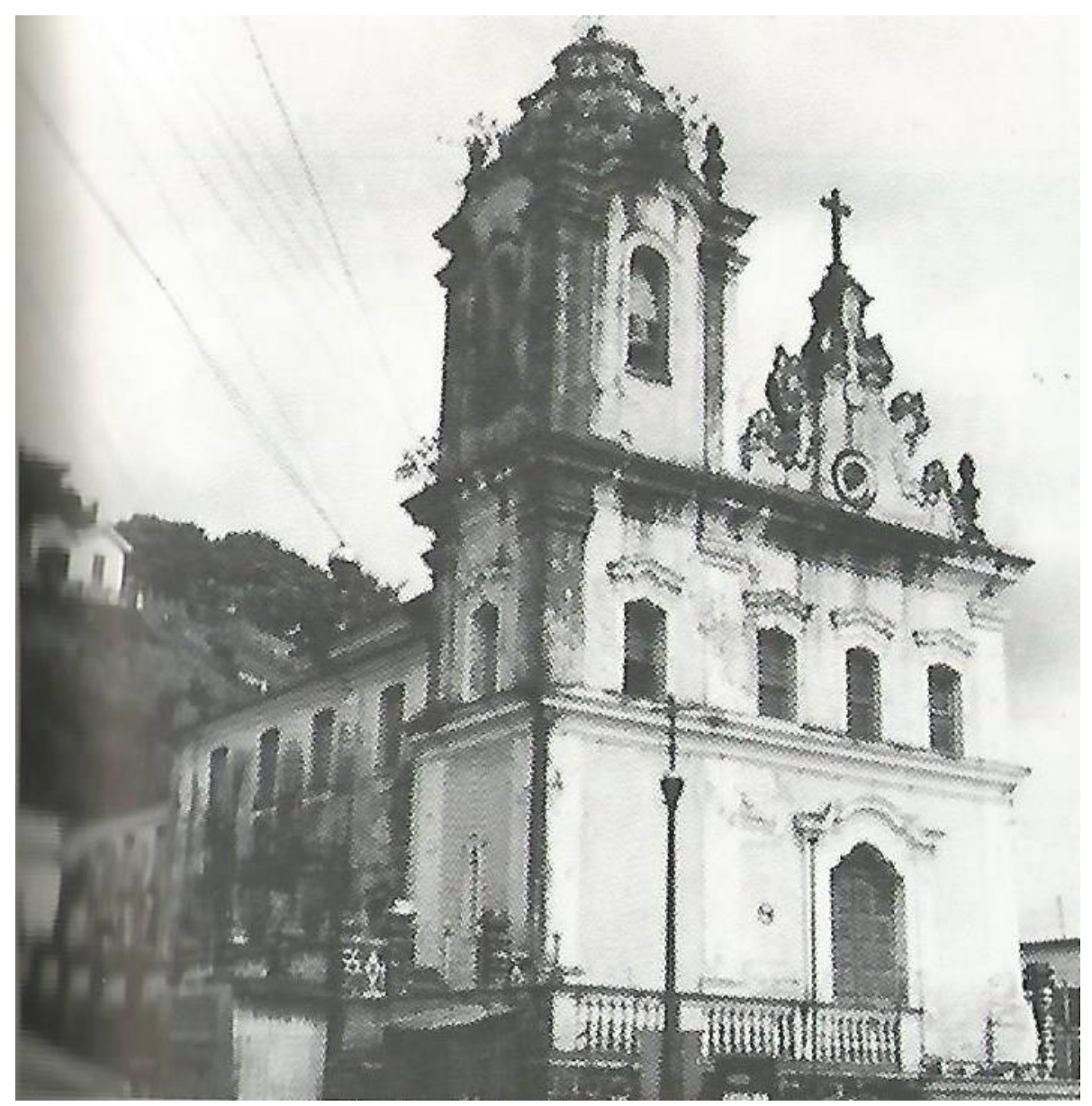

Figura 6.1.1.8 - Igreja matriz de Deus Menino em São Felix - BA (BAHIA, 1982, p. 335)

Após análise das descrições do inventário do IPAC e das fotos das igrejas matrizes, percebemos que a mais evidente característica comum às mesmas é a monumentalidade de seus prédios. Característica típica do período de suas construções, entre os séculos XVII e XVIII, no auge do ciclo do ouro na Colônia, coincidindo também com o auge do Barroco e suas derivações no Brasil. Período que denota uma intensa dinâmica socioespacial, socioeconômica, política e cultural, que culminaria ao longo do século XIX na produção de um considerável patrimônio urbano/edificado, com maior número de construções residenciais, melhoramentos dos portos e atracadouros e na construção de uma malha ferroviária com suas respectivas estações.

No próximo tópico, ainda sobre a produção do patrimônio, com seus monumentos mais significativos no período que antecedeu a 1823, continuaremos nossa análise, tendo como foco os edifícios de função administrativa. As Casas de Câmara e Cadeia e Paços Municipais das cidades em tela. 


\subsubsection{Monumentos isolados: As Casas de Câmara e Cadeia}

Das sete cidades pesquisadas, em cinco delas foi apontada pelo documento do IPAC (BAHIA, 1982) e por nós, em trabalho de campo, a existência de casas de Câmara e Cadeia, erguidas anteriormente ao período entre 1823 e 1945. Dentre elas estão a de Jaguaripe, Cachoeira, São Francisco do Conde, Santo Amaro e Maragogipe. Em Nazaré e São Felix não existiu este tipo de edifício. No caso da cidade de Nazaré foi apontado e confirmado em trabalho de campo a existência de Paço Municipal erguido em meados do século XIX. O referido inventário não menciona nenhum tipo deste equipamento (Casa de Câmara e Cadeia) na cidade de São Felix, mas constatamos a existência do mesmo em trabalho de campo.

Casa de Câmara e Cadeia de Jaguaripe, Figura 6.1.2.1, é uma das mais antigas do estado, assim como a instalação da vila, como visto anteriormente.

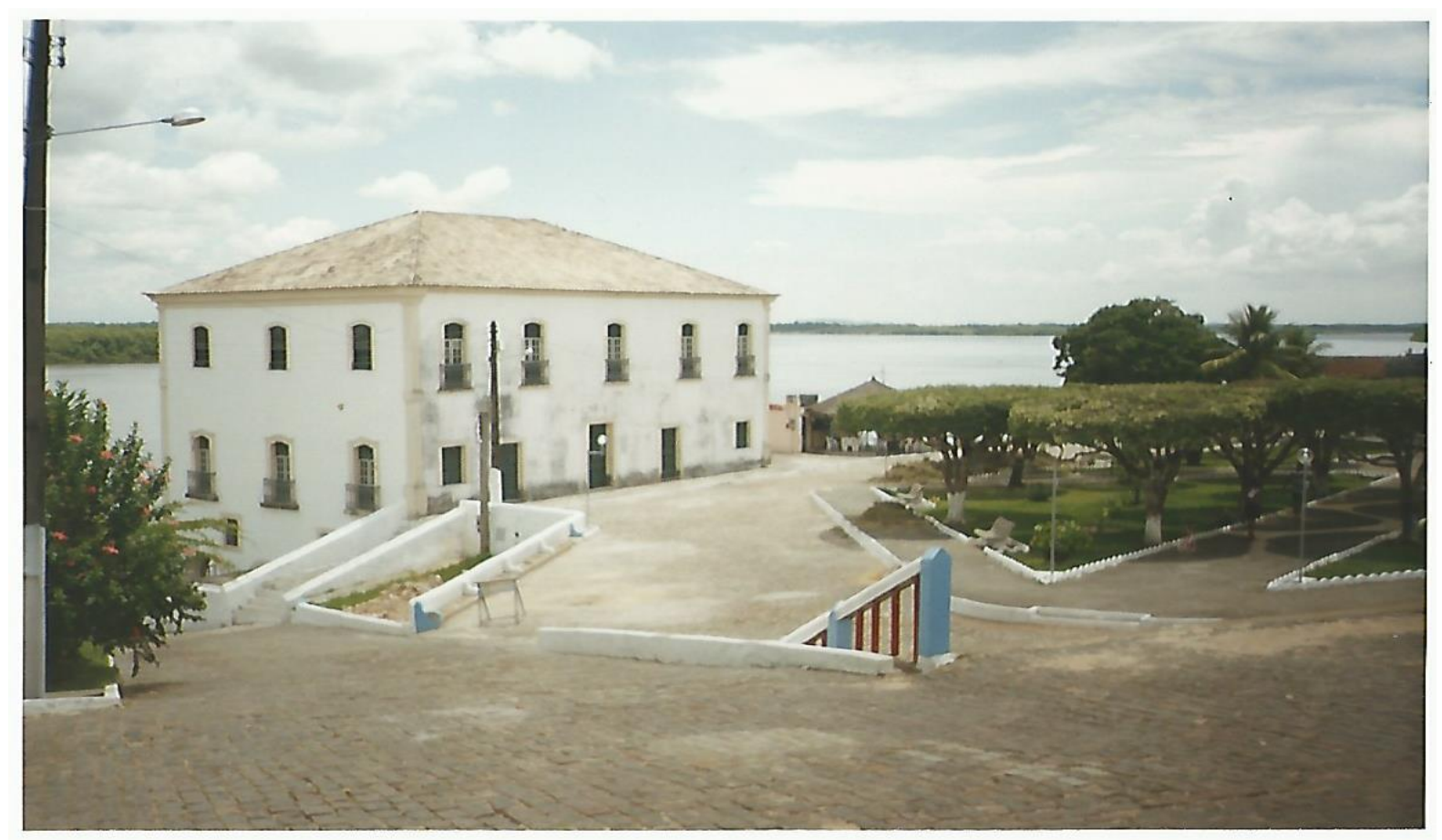

Figura 6.1.2.1 - Casa de Câmara e Cadeia de Jaguaripe - BA (Imagem do autor, primeira década dos anos 2000) 
No inventário do IPAC encontramos a seguinte descrição sobre a mesma:

“[...] construída segundo planta retangular sem pátio interno nem torre sineira. Na verdade, sua volumetria e planta não diferem muito da arquitetura residencial do século XVII. Apresenta, porém, em forma embrionária, e por influência da Casa de Câmara de Salvador, um elemento que viria a se difundir, no séc. XVIII, em edifícios semelhantes do Recôncavo: a arcaria (BAHIA, 1982, p. 168).

O Inventário do IPAC (BAHIA, 1982) é bastante sucinto quanto à descrição da Casa de Câmara e Cadeia da cidade de São Francisco do Conde, Figura 6.1.2.2 a seguir.

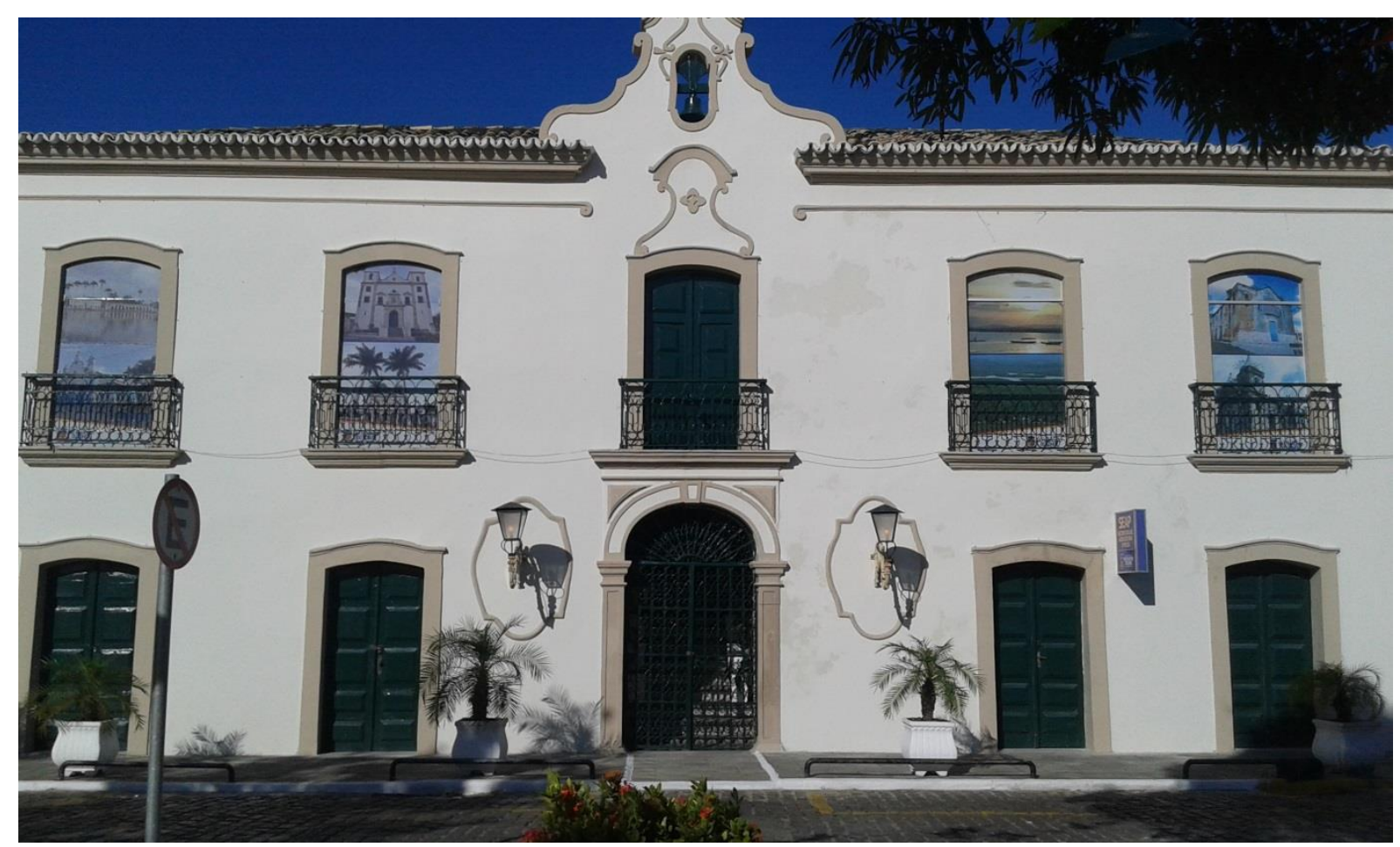

Figura 6.1.2.2 - Casa de Câmara e Cadeia de São Francisco do Conde (Imagem do autor em trabalho de campo, 2015)

O referido inventário não informa precisamente a data de conclusão do edifício, apenas menciona que "[...] foi terminada, provavelmente em meados do século XVIII, embora sua fachada nordeste pareça ser anterior” (BAHIA, 1982, p. 172). Encontramos, entretanto, mais referências às semelhanças com o edifício de Salvador. Assim menciona o documento: 
[...] O edifício foi reformado no terceiro quartel do século passado (século XIX). Sua planta primitiva era retangular com um pequeno pátio central. Esta disposição foi também adotada nas Casas de Câmara e Cadeia de Salvador e Santo Amaro, mas difere destas por não possuir pórtico e torre central. Volumetricamente a Casa de Câmara e Cadeia de São Francisco do Conde se assemelha mais às de Jaguaripe e Rio de Contas [...] (BAHIA, 1982, p. 172, grifo nosso)

Percebemos pela descrição acima que os padrões de semelhança ultrapassavam por vezes a dimensão regional do Recôncavo, atingindo até o interior, quando se menciona a cidade de Rio de Contas.

Segundo o documento do IPAC (BAHIA, 1982) na descrição sobre o edifício de Santo Amaro, inaugurado em 1769, o mesmo fora construído "à imagem e semelhança" do Paço Municipal de Salvador, que, por sua vez, havia sido reformado na segunda metade do século XVI. Neste mesmo documento de pesquisa, registrou-se também que "[...] semelhante atitude foi também adotada pela cidade de Maragogipe, ao construir sua sede municipal" (BAHIA, 1982, p. 104).

$\mathrm{Na}$ descrição sobre o equipamento da cidade de Maragogipe encontramos também referências com a Casa de Câmara e Cadeia da cidade de Salvador. Segundo o inventário do IPAC (BAHIA, 1982), a de Maragogipe, Figura 6.1.2.3, é, “[...] depois da de Salvador, a mais graciosa e bem proporcionada Casa de Câmara e Cadeia da Bahia" (BAHIA, 1982, p. 196). Ainda segundo o referido documento, o edifício é da terceira década do século XVIII, “[...] seguindo a tradição inaugurada em Salvador, em meados do século anterior, apresenta um pórtico arqueado, onde se realizava a feira semanal" (BAHIA, 1982, p. 196). Continuando a descrição, o documento informa o seguinte:

[...] Solução semelhante fora adotada, pouco antes em Cachoeira e, trinta anos mais tarde em Santo Amaro. Não se trata, porém, de uma miniatura da Casa de Câmara e Cadeia de Salvador, como ocorre em Santo Amaro. A Sede Municipal de Maragogipe não possui pátio interno, e sua sineira é do tipo "espadanha". No final do século XVIII foi adaptado à mesma um relógio, retirado durante a restauração do edifício. Na mesma oportunidade foram eliminadas também as grades do século passado dos balcões. Cadeia especial para pessoas ilustres, no sobrado, é encontrada também na Casa de Câmara e Cadeia de Cachoeira (BAHIA, 1982, p. 196). 


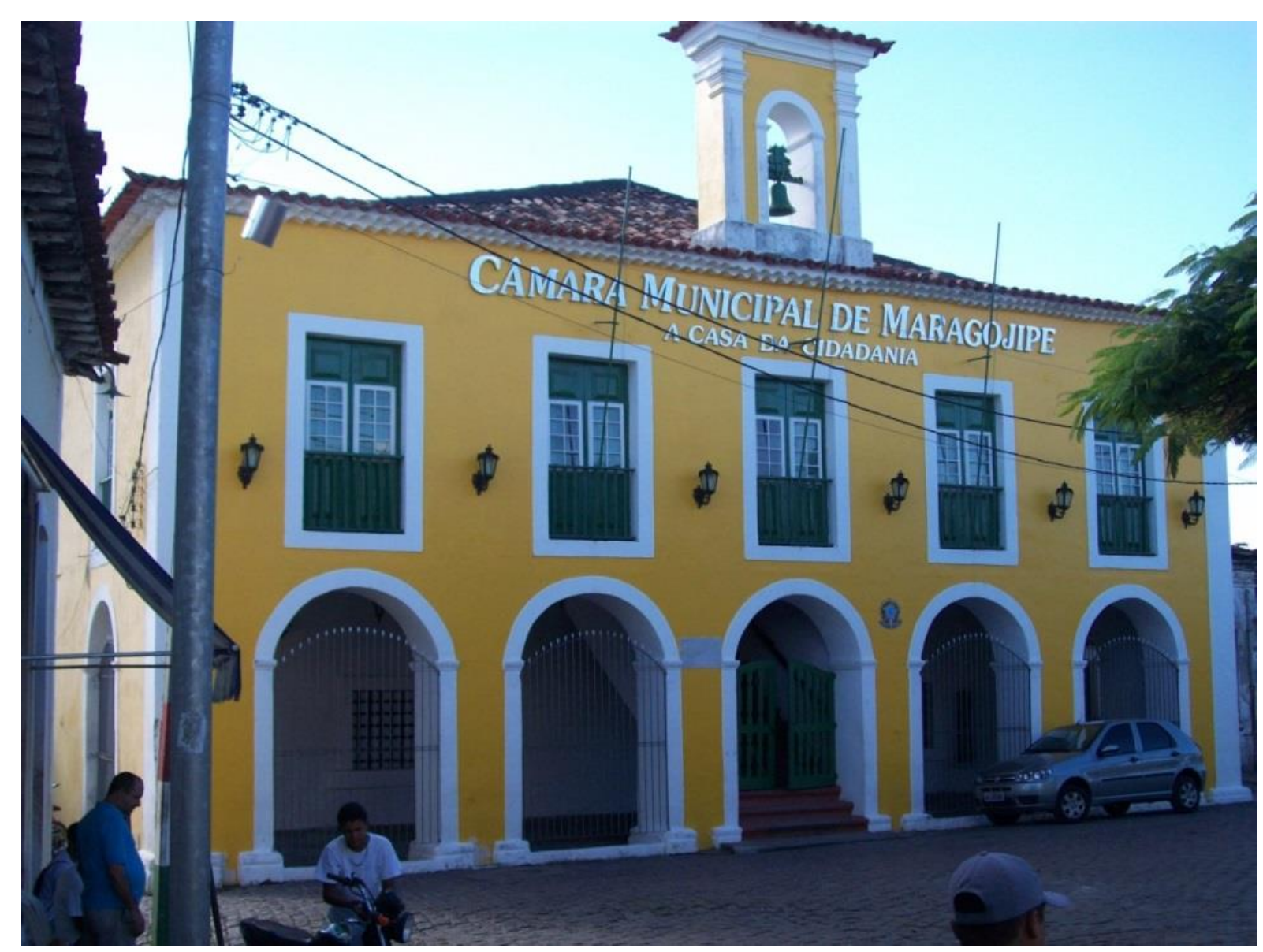

Figura 6.1.2.3 - Casa de Câmara e Cadeia de Maragogipe - BA (Imagem do autor, 2012)

Apesar de alguma distância temporal entre as construções desses equipamentos nas cidades em tela, percebemos através das descrições e fotos do IPAC, e também pelas fotos tiradas em campo, que existiu uma semelhança do padrão construtivo desses edifícios. Existia o que nos parece, uma necessidade de acompanhar os padrões da capital e assim demostrar também o poder local desses municípios, através da mesma simbologia usada na cidade mais importante da época. A semelhança apontada entre os edifícios construídos em Jaguaripe, Cachoeira, São Francisco do Conde, Maragogipe e Santo Amaro, com o edifício construído na cidade do Salvador, aparece em todas as descrições referentes a essas cidades. Era uma espécie de padrão construtivo, o que supõe também uma subordinação da região ao mando da capital.

A descrição sobre este equipamento urbano na cidade de Cachoeira, Figura 6.1.2.4, é contundente e comprova mais uma vez nossa afirmativa. 


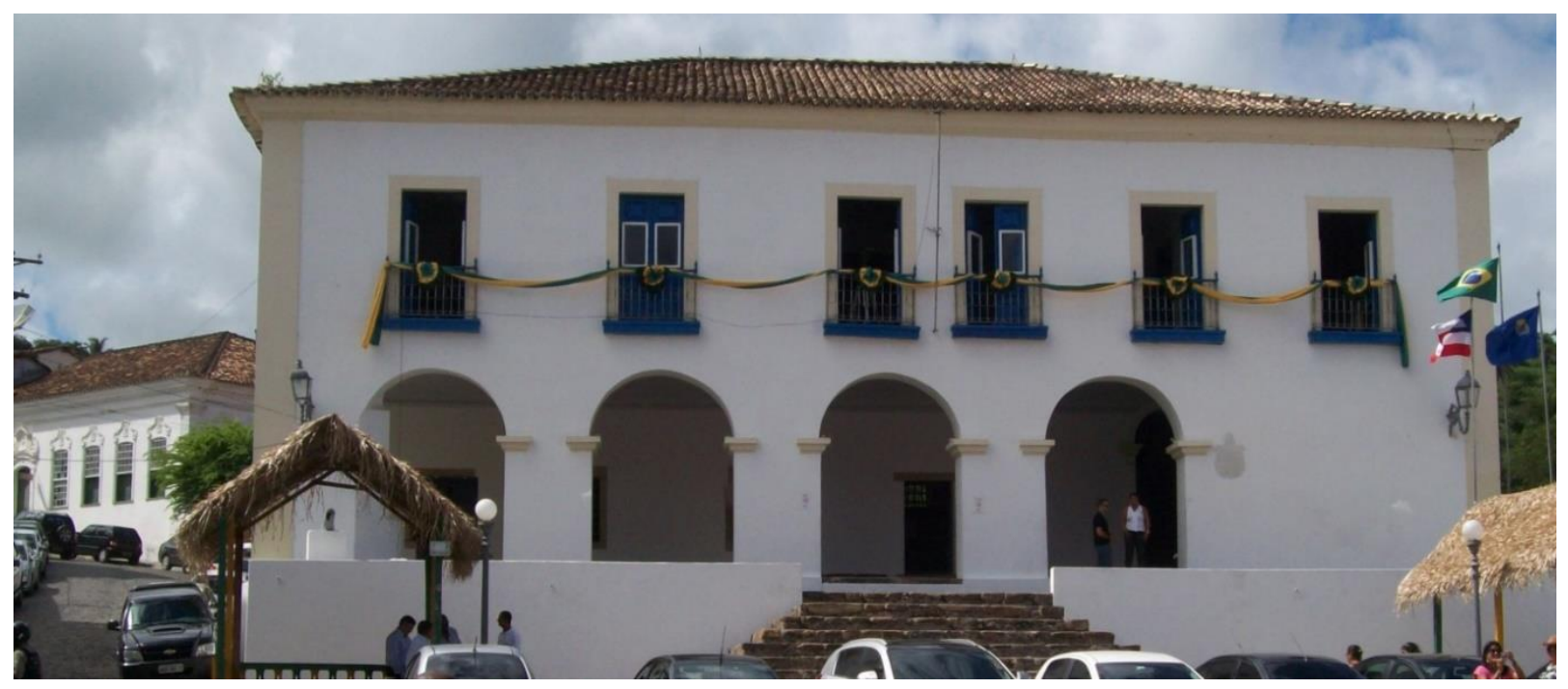

Figura 6.1.2.4 - Casa de Câmara e Cadeia de Cachoeira - BA (Imagem do autor, 2013)

Assim descreve o documento acima citado:

Casa de Câmara e Cadeia dos primeiros anos do século XVIII, com elementos característicos desta tipologia no Recôncavo. Algumas destas casas de Câmara e Cadeia, como as de Cachoeira, Maragogipe e Santo Amaro, foram diretamente influenciadas por Salvador, edificada em 1660, que apresenta também uma galeria em arcaria. Em 1698, a Casa de Câmara e Cadeia de Salvador recebeu uma torre que foi assimilada por outras sedes municipais do Recôncavo. Não existe documentação escrita que comprove a presença deste elemento em Cachoeira, mas um desenho que ilustra a monografia de Joaquim de Amorim Castro, reproduzida porSmith - "Some Viewsof Colonial Bahia", in Belas Artes. Lisboa S. (1), 1948 - sugere que existiu uma torre na esquina direita do edifício. A interrupção dos arcos naquela parte da fachada e a existência em planta baixa de um pequeno cômodo naquele ângulo reforça a hipótese que este edifício teria possuído torre. A presença de celas para presos qualificados no pavimento nobre foi notada, também, em Maragogipe (BAHIA, 1982, p. 44).

Constatamos que todos os edifícios onde funcionaram esses equipamentos urbanos de função política e administrativa foram construídos entre o final do século XVII e meados do século XVIII. A maior distância temporal entre essas construções está entre a que foi inaugurada em Jaguaripe, a primeira entre elas (1697) e a de Santo Amaro (1769), Figura 6.1.2.5, a última construída neste padrão. Portanto uma distância de 72 anos, fato que não implicou numa grande mudança de padrão construtivo e estilo arquitetônico de época, como constatamos adiante. 


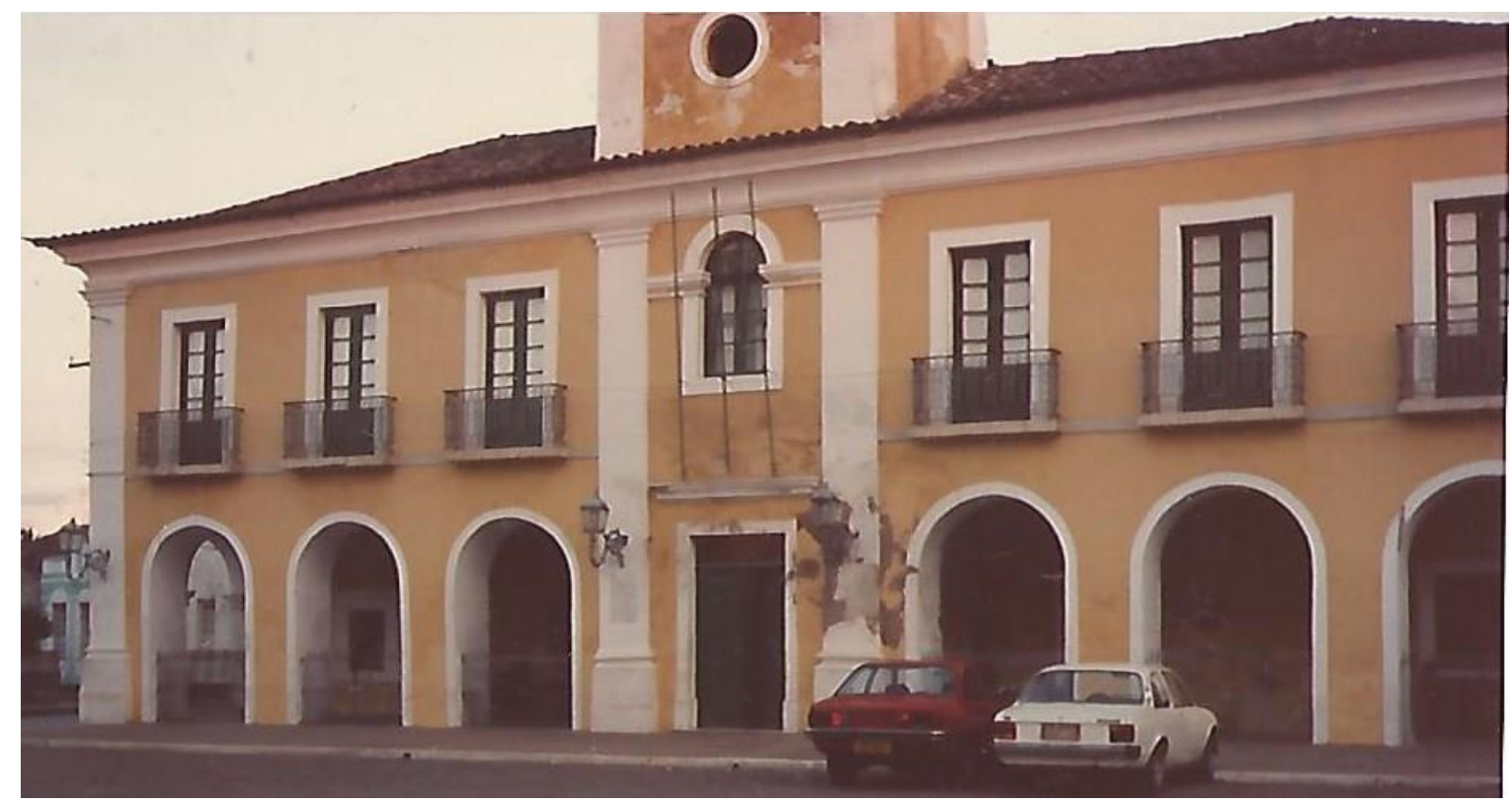

Figura 6.1.2.5 - Casa de Câmara e Cadeia de Santo Amaro - BA (Imagem do autor, década de 1990).

No caso da cidade de Nazaré, por ser uma cidade emancipada mais tardiamente do que as outras vistas anteriormente, o edifício construído para servir como sua sede municipal, Figura 6.1.2.6, apresenta estilo diferenciado. Segundo o IPAC (BAHIA, 1982) foi construído no último terço do século XIX.

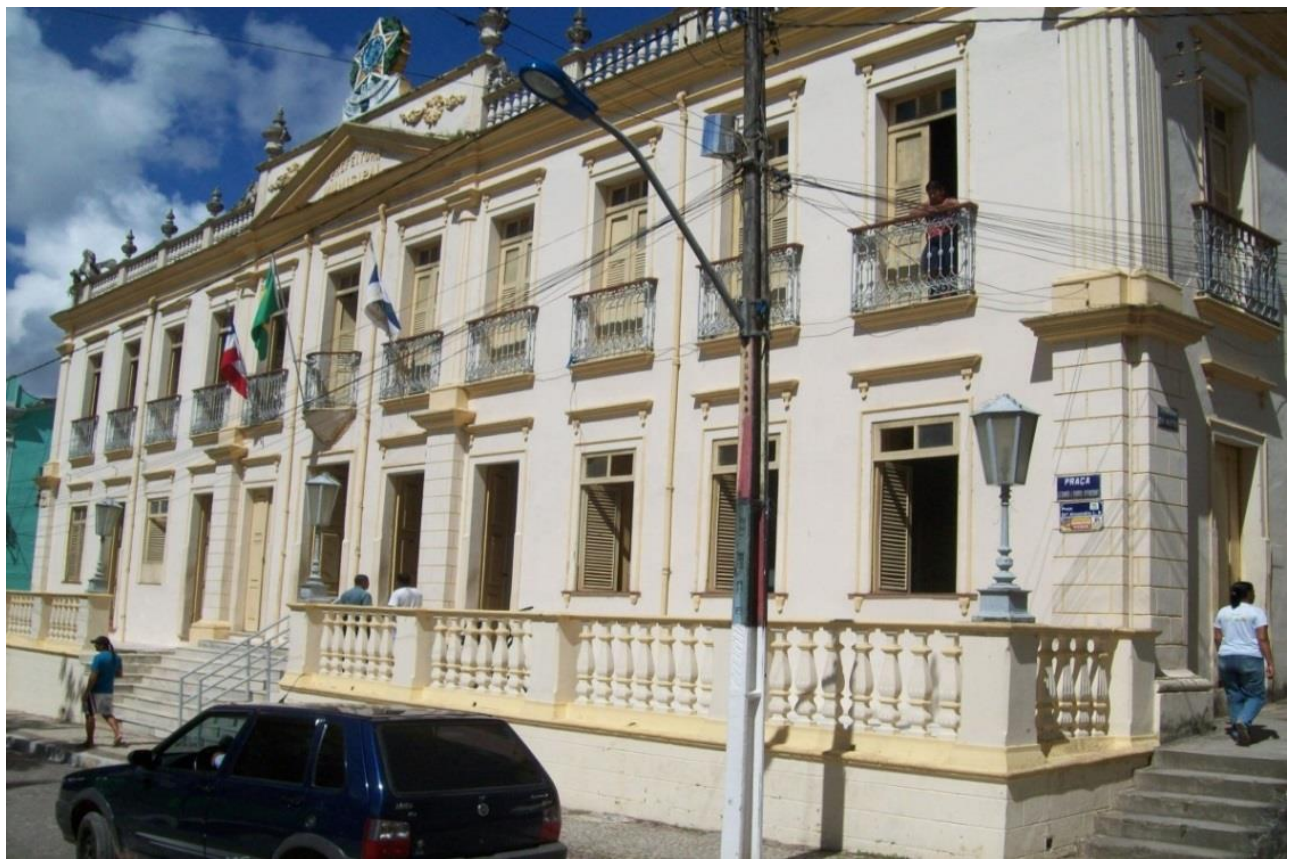

Figura 6.1.2.6 - Paço Municipal de Nazaré - BA (Imagem do autor, 2012) 
Segundo o referido documento:

[...] Mesmo sendo construído no final do Império, segue o velho esquema das casas de Câmara e Cadeia do período colonial, embora o tratamento seja outro: neoclássico. Este estilo foi introduzido no país ainda no tempo de D. João VI pela Missão Francesa e difundido pela Imperial Academia de Belas Artes. O Neo-Clássico foi estilo oficial da corte adotado em todos os edifícios públicos durante o Império e, até mesmo, $1^{\text {a }}$ República. A reforma por qual passou o edifício, em 1904, não lhe mudou o estilo se não o aperfeiçoou com balaustradas, jarros, grifos e escudos em concreto. Este quadro só foi modificado com a revolução de 1930, que, em seu afã de modernização, foi buscar no "International Style" a sua expressão, com obras como o Ministério da Educação e Cultura no Rio de Janeiro e o Bairro da Pampulha, em Belo Horizonte [...] (BAHIA, 1982, p. 270).

Na descrição acima podemos obter importantes informações acerca dos movimentos culturais que influenciaram diretamente o estilo das construções, especialmente aquelas destinadas à representação do poder público, desde a colônia, passando pelo Império, até chegar a Primeira República. Percebe-se claramente o que os arquitetos denominam por “arquitetura institucional". Alguns exemplos dessa arquitetura são encontrados em várias regiões do Brasil. A exemplo das sedes do poder municipal, como visto na Figura 6.1.2.6; nos prédios dos Correios e Telégrafos; estações ferroviárias etc..

Na cidade de São Felix não foi registrado a existência de Casa de Câmara e Cadeia, já que a vila foi ali instalada muito posteriormente às outras, no final do século XIX (1890). Entretanto encontramos um belo exemplar do Paço Municipal de São Felix, Figura 6.1.2.7 a seguir. 


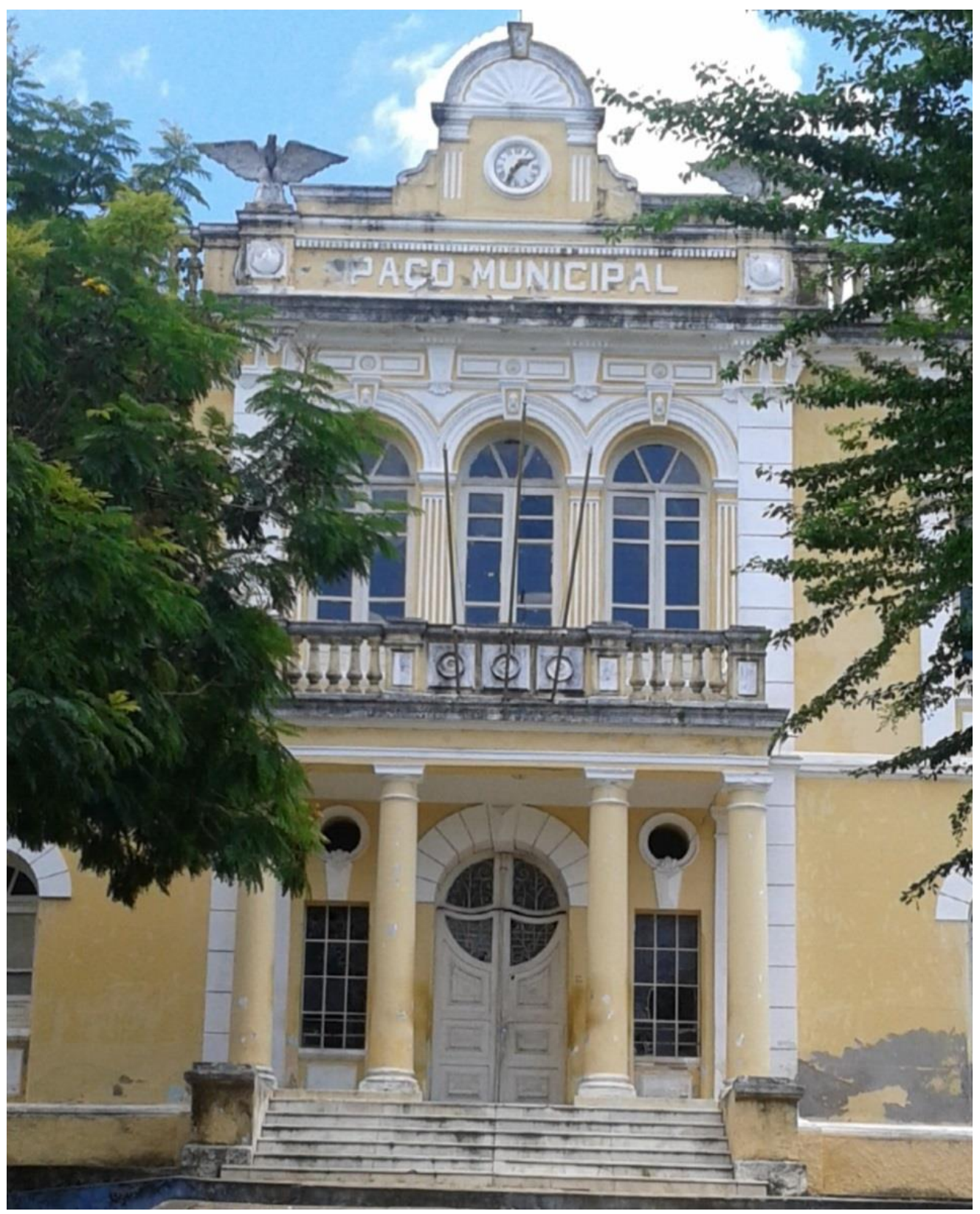

Figura 6.1.2.7 - Paço Municipal de São Felix - BA (Imagem do autor em trabalho de campo, 2015)

O prédio do Paço Municipal de São Felix não está registrado no inventário do IPAC (BAHIA, 1982), constando apenas uma foto da praça onde o mesmo se encontra, fato que consideramos gravíssimo, tendo em vista a exuberância e monumentalidade do edifício, cujas características se destacam na paisagem urbana da cidade.

Para Andrade (2013, p. 286), as orientações pombalinas de meados do século XVIII, não tiveram muita repercussão no Recôncavo, que já estava ocupado economicamente e já 
possuía várias conexões entre as cinco vilas “[...] estrategicamente distribuídas na região e nenhuma mais fundada até os Oitocentos". As próximas vilas instaladas, complementando a rede urbana que ia se adensando demograficamente ao longo do século XIX foi a de Nazaré, por Decreto Imperial em 1832; e a de São Felix, instalada logo após a proclamação da República, em 1890 (BAHIA, 1982).

Portanto, estão registrados naquela região os traços materias da configuração territorial urbana e regional dos três períodos da história brasileira: Brasil Colônia, Brasil Império e Brasil República.

Fica clara a importância de analisarmos os monumentos isolados que se destacam na paisagem urbana das cidades estudadas em períodos que antecedem o recorte temporal da pesquisa, pois aqueles edifícios ajudam a contar a história da produção e organização dos territórios que vieram a se configurar nas atuais cidades do Recôncavo Baiano e caracterizar o fato urbano no século XVIII e XIX.

Nesse sentido a "fala" do território pela produção e organização do espaço, sendo o patrimônio edificado um dos elementos principais da narrativa espacial, se faz contundente. Vimos até aqui duas categorias de edifícios que demonstram certa concomitância temporal e similaridade de padrão regional, mas com suas peculiaridades locais, como foi o caso das Igrejas Matrizes e Casas de Câmara e Cadeia das cinco vilas mencionadas. Entretanto, mesmo as vilas de Nazaré e São Felix terem sido emancipadas à condição de vila bem posteriormente, 1831 e 1899, respectivamente, ambas possuíam suas igrejas Matrizes de grande monumentalidade, desde o século XVIII. Por outro lado, os seus edifícios públicoadministrativos já revelam outra característica bem diferente das cinco primeiras. Estamos aqui nos referindo aos Paços Municipais.

No próximo tópico veremos como as sete cidades portuárias do Recôncavo Baiano se originaram e o papel que cada uma delas exerceu no contexto regional do Recôncavo Baiano, identificando as pistas que revelam a produção simultânea dos territórios. Destacamos mais uma vez o fato de que, como já visto anteriormente, não podemos compreender a história de cada uma delas, desvinculando-as da história regional, incluindo nesta escala a cidade do Salvador.

Fizemos uma análise sobre os conjuntos urbanísticos, contextualizando a produção e organização espacial das cidades. Nesse sentido buscamos encontrar as similaridades das formas e a concomitância temporal entre elas. É o que trataremos a seguir. 


\subsection{A CONSTITUIÇÃO DO FATO URBANO: A NARRATIVA ESPACIAL REGIONAL}

Já vimos anteriormente que as histórias das sete cidades portuárias do Recôncavo Baiano se confundem com a própria história da região, e do Brasil. Elas pertenceram a primeira e segunda geração no processo de formação de uma civilização urbana. De uma maneira geral estavam associadas a um espaço geográfico intimamente ligado aos aspectos econômicos, sociais e culturais que evoluíram sob as influências da tradição da economia e de suas respectivas atividades acessórias. Assim como sofreram influências de uma cultura material e até mesmo no sentido de assimilação de outra civilização, no sentido técnico, especialmente na estrutura e na forma urbana.

Yázigi (2003, p. 107), ao tratar do barroco no Brasil, considera que a constituição do fato urbano foi uma consequência da economia agroexportadora, que criou "[...] mais que modestas cidades nos dois primeiros séculos. Foi preciso ouro, muito ouro garimpado para que algum excedente sofisticasse a civilização no fato urbano". Portanto, como vimos anteriormente, a consolidação de uma civilização urbana no Brasil, antecede o século XIX. Para esse autor:

[...] Foram as cidades mineiras e do Nordeste, paramentadas de barroco, iniciadas em artes plásticas, música, literatura; dotadas de arquitetura mais elaborada... Mas Portugal, impedindo contatos do Brasil com o exterior (mas contrariados por nosso vigor barroco [...] e proibindo manufaturas, cerceou outras possibilidades que produzissem maior densidade civilizatória. Isso só seria iniciado com a transferência da Corte para o Rio de Janeiro. Foi esse o acaso que criou o grande marco (YÁZIGI, 2003, p. 107).

A questão da materialidade cultural no fato urbano no Recõncavo, no que diz respeito e estrutura de algumas cidades, demonstra que a cidade do Salvador e o seu hinterland, o Recôncavo Baiano, no final dos setecentos, já possuíam nuanças do que se poderia conceituar como urbano. Andrade (2013, p. 66), nos chama a atenção para o fato de que, “[...] o estudo sobre a história do urbano e das cidades é um desses temas que recorrentemente oferece a 'armadilha' da anacronia [...]”. Ou seja, para esse autor, “[...] é um pressuposto fundamental para a aplicação do conceito de 'urbano' em tempos mais recuados, não confundir ou utilizar os mesmos critérios de hoje, para uma dinâmica, vivida outrora" (ANDRADE, 2013, p. 66). 
No que diz respeito à realidade do fato urbano - atentando-se para a questão de que deve-se distinguir entre cidade e urbano -, guardadas as devidas proporções para a época, a visão de Andrade (2013) para o Brasil colonial, no entendimento deste conceito (de urbano) em relação às vilas e cidades da época, após análise de vasta documentação nacional e, também do Arquivo Histórico Ultramarino em Portugal, sustenta a argumentação sobre a existência da “[...] estrutura das formações urbanas e suas interconexões no Recôncavo Baiano setecentista" (ANDRADE, 2013, p. 75). Segundo as próprias palavras deste autor:

Esse conjunto de documentos apresenta, com riqueza de detalhes, a emergência de uma nucleação urbana formalmente instaurada no Recôncavo Baiano setecentista. A última vila fundada na região, ainda no início do século XVIII, fechava um ciclo de atos políticos que dava status urbano e estabelecia poderes formais em cinco unidades do entorno da Baía de Todos os Santos (Jaguaripe, Cachoeira, São Francisco do Conde, Maragogipe e Santo Amaro) que, com Salvador, configuravam uma incipiente rede urbana regional (ANDRADE, 2013, p. 84).

Dentre outros argumentos utilizados por Andrade (2013) para justificar a assertiva acima e, que vem ao encontro da nossa perspectiva de pesquisa, é o seguinte:

Nas vilas e cidades também se concentravam os maiores conjuntos edificados regionais, e nessas formações estavam construídos edifícios religiosos, civis e públicos que demarcavam uma suntuosidade só encontrada, em conjunto, no urbano. Ainda que se considere a existência de vilas paupérrimas, levando-se em consideração o seu entorno regional, era nelas que estavam localizadas as principais construções (ANDRADE, 2013, p. 84).

Assim como o autor acima citado, e levando em conta a história do Recôncavo Baiano e suas cidades portuárias no período colonial, consideramos também o urbano, além da estrutura e da forma, “[...] como uma unidade nodal de rede onde se estabeleciam formalmente os agentes de controle do vasto território (termo e ou sertões)" (ANDRADE, 2013, p. 67), sem, contudo, desprezá-las completamente.

Estamos levando em conta também a morfologia urbana, sua tessitura, no sentido da produção de sua cultura material, expressada no seu patrimônio edificado. Mas, concordamos com o referido autor, quando afirma, com base em Renata Malcher Araújo, que é necessário ter a clareza no estudo da cidade, especialmente, no período colonial. Isto é, se faz necessário ter a clareza de que, “[...] mais do que traçar as formações urbanas como forma ou desenho, é 
fundamental entendê-las como pontos articuladores [...] de uma rede colonial que impõe um novo pensar e agir por vasto território" (ARAÚJO apud ANDRADE, 2013, p. 67).

Após a independência e até meados do século XX, em relação às cidades históricas portuárias do Recôncavo Baiano, é fato que se falar de cidade nos remete a outra "sensação", além de considerar as cidades apenas como "nós" de rede. A memória é mais local e de construção, ou seja, a imagem é de opulência, densidade e monumentalidade da sua tessitura urbana. A paisagem em si mesma é mais urbana. Culturalmente urbana.

Adiante faremos uma breve descrição de cada uma dessas cidades, com base em pesquisa bibliográfica, principalmente, na obra do IPAC (BAHIA, 1982), anteriormente mencionada, para possibilitar posteriormente, a partir do mesmo documento, a eleição de alguns monumentos e conjuntos urbanos que podem ser utilizados para subsidiar nossa tese. Isto é, acreditamos que existiu uma concomitância temporal na construção do patrimônio edificado e conjuntos urbanísticos nas cidades históricas portuárias do Recôncavo Baiano, que nos leva a crer na existência de uma narrativa espacial comum a elas. Esse processo, portanto, contribui para reafirmarmos que, a partir da leitura da paisagem urbana cujo texto é o patrimônio edificado, existe uma rede urbana coesa e de peculiar similaridade na forma e uma simultaneidade temporal na sua produção espacial, que reforça o sentido de região. É o que estamos denominando de produção simultânea dos territórios. Ou uma produção simultânea das paisagens urbanas das cidades em tela.

Começaremos pelos primeiros municípios e núcleos urbanos que deram origem às primeiras vilas da região e cujo desmembramento dos territórios originou as demais, numa ordem temporal e espacial resultante das relações socioeconômicas da época, como veremos a seguir.

Após pesquisa bibliográfica em várias fontes, não restam dúvidas sobre as três primeiras vilas que foram instaladas no Recôncavo Baiano (Jaguaripe, Cachoeira e São Francisco do Conde), entretanto, há controvérsias em relação à cronologia das datas de suas instalações, embora com diferenças temporais mínimas, que indicam que a ordem para criação das mesmas originou-se de um mesmo documento régio. Viana (1893, p. 548), afirma sobre a criação das três primeiras vilas do Recôncavo entre 1697 e 1698, na seguinte ordem: Jaguaripe em dezembro de 1697; Cachoeira em janeiro de 1698 e São Francisco da Barra de Sergipe do Conde, atual São Francisco do Conde em fevereiro de 1698. No Inventário do IPAC (BAHIA, 1982), confirmamos os mesmos meses e anos de criação das referidas vilas. 
Sobre as demais vilas em foco não há controvérsias quanto ao ano de criação das mesmas, segundo pesquisa em fontes primárias e secundárias, tais como o Inventário do IPAC (BAHIA, 1982) e Andrade (2013), as datas são as seguintes: Maragogipe (1724); Santo Amaro (1727), Nazaré (1831), e São Felix (1889). Essa última já na República.

Continuando com a compreensão da paisagem urbana como a narrativa do território usado, daqui em diante daremos destaque aos conjuntos urbanos que foram erigidos no período entre 1823 e 1945. É importante ressaltar que a definição de um recorte temporal não exclui a possibilidade de ultrapassarmos tais limites, tendo em vista que a produção e organização dos territórios das cidades em tela foram muito dinâmicas e que, muitos dos padrões urbanísticos e arquitetônicos predominantes na paisagem urbana num determinado período, remonta a períodos anteriores. Tal fato ajuda a compreender a organização do espaço no período adotado para a pesquisa.

Buscamos numa perspectiva panorâmica, analisar através de iconografia e das plantas dos centros históricos delimitados pelo IPAC (BAHIA, 1982) à época do inventário, encontrar a concomitância temporal e similaridade de formas e estilos arquitetônicos entre eles no período acima citado. Destacamos os prédios residenciais (sobrados), identificados e caracterizados no referido documento, assim como fotos obtidas em pesquisa de campo.

Segundo notas do referido documento acima mencionado, o neoclássico se difundiu através dos edifícios públicos, pois era o estilo oficial do Império. Mesmo no século XX, continuou sendo a "arquitetura do poder", pelo menos até a década de 1930, quando a Arquitetura Moderna passou a influenciar a criação de novos padrões e estilos arquitetônicos pelos revolucionários de 1930. (BAHIA, 1982, p. 310).

É notória a predominância de grande número de construções do século XIX em todas as plantas das sete cidades pesquisadas. Tendo em vista que as referidas plantas foram elaboradas inicialmente entre o final da década de 1970 e início da década de 1980, muitos daqueles imóveis sofreram a ação do tempo, no sentido da depredação, abandono ou mesmo tornando-se ruína. Sem falar da descaracterização parcial ou total dos imóveis, através de reformas, mesmo daqueles que entraram na lista do inventário do IPAC à época. Isso quer dizer que, nem todos os imóveis contabilizados nas plantas dos centros históricos foram caracterizados no inventário.

Ou seja, só em Santo Amaro, na delimitação e descrição da planta do centro histórico, o documento aponta 631 edifícios. Entretanto, foram escolhidos alguns deles e enquadrados nas sete categorias de edificações a seguir: 
1 “edifícios de elevado valor monumental", a exemplo das Casas de Câmara e Cadeia, as igrejas Matrizes dentre outros templos católicos, como conventos e outras igrejas do século XVIII;

2 "sobrados de relevante interesse arquitetônico", tais como sobrados do período de transição do século XVIII para o século XIX; sobrados urbanos dos primeiros anos do século XIX, que adotam a planta comum em todo o período colonial e imperial;

3 "edifícios de relevante interesse arquitetônico", tais como casas urbanas do início do século XIX, as Santas Casas de Misericórdia, edifícios hospitalares de meados do século XIX, sobrados neoclássicos de meados do século XIX, sobrados ecléticos do final do século XIX; sobrados neoclássicos do final do século XIX;

4 "edifícios de valor principalmente ambiental", como sobrados urbanos do final do século XIX;

5 "arquitetura de valor menor principalmente ambiental"; como sobrados de utilização mista, residencial e comercial de meados do século XIX, sobrados neoclássicos da segunda metade do século XIX;

6 "construção de relevante interesse arquitetônico", como um chalé dos últimos anos do século XIX, com elementos pré-fabricados de ferro fundido.

Faz-se necessário ressaltar que não é nosso objetivo, uma investigação das condições desses imóveis, mas apresentar uma visão analítica. Ou seja, na perspectiva da produção e organização espacial dos territórios em foco no século XIX, buscando entender suas transformações e permanências.

Portanto, não se trata de um trabalho em arquitetura e urbanismo, mas buscamos subsidiar uma intervenção no sentido da preservação do patrimônio urbano/edificado (histórico arquitetônico) nessas localidades e numa escala regional. Interessa-nos o registro já obtido pelo IPAC, para daí darmos sustentação a nossa tese, mesmo no atual estágio em que se encontram alguns prédios, como já foi feito em relação a alguns monumentos isolados (igrejas matrizes, casas de câmara e cadeia e paços municipais), em épocas anteriores.

Foi constatado inclusive em trabalho de campo, que muitos edifícios inventariados, já entraram em total estado de arruinamento na atualidade em todas as cidades pesquisadas. Fato que, de certa forma empobrece o conjunto, mas não tira o efeito da nossa proposta de uma 
narrativa espacial regional comum em todas elas, especialmente quando se trata do patrimônio urbano/edificado no século XIX.

Iniciaremos nossa descrição e análise pelas plantas anteriormente referidas, que serviram como amostra visual do número de edifícios e daremos maior destaque aos prédios contruídos no século XIX. Na legenda de cada uma das plantas dos centros históricos é indicada a época das construções inventariadas, divididas por séculos, da seguinte forma: século XVII (verde); século XVIII (azul); século XIX (cinza) e século XX (vermelho). Na planta do IPAC (BAHIA, 1982), a qual foi a base para a nossa pesquisa, existia uma categoria que eram os prédios do século XIX, transformados no século XX. Esta categoria foi por nós incluída na legenda como pertencentes ao século XIX.

As plantas serviram para que possamos ter uma ideia de conjunto dos edifícios em vários períodos, facilitando o entendimento da questão da simultaneidade e concomitância temporal na ereção dos mesmos. É o que veremos adiante, paralela à história de cada cidade e apontando a produção de seu patrimônio edificado, através das referidas plantas e de fotografias da época do inventário e atuais.

\subsubsection{Jaguaripe}

Desde o século XVI, a localidade onde hoje se encontra a cidade de Jaguaripe já era observada com o intuito de instalar engenhos de açúcar e extrair madeira. A vila de Nossa Senhora da Ajuda de Jaguaripe foi a primeira a ser instalada no Recôncavo. A extração de madeira foi o primeiro atrativo para a ocupação e posterior povoamento desta região, que foi integrada rapidamente à economia de subsistência dirigida para a produção de farinha de mandioca (BAHIA, 1982).

Andrade (2013, p. 119) em estudo sobre a rede de vilas já existente no Recôncavo Baiano no século XVIII, com base em cartografia de época, encontrada no Arquivo Histórico Ultramarino de Lisboa, Portugal, menciona o “[...] intricado sistema fluviomarítimo que cortava a região do entorno de Jaguaripe ao final dos setecentos".

$\mathrm{O}$ referido autor atesta também a evidência de intenso tráfego entre Jaguaripe e as diversas freguesias e povoados da região, devido à "densidade da malha hídrica", 
possibilitando a ocupação local e a navegação "a mar aberto para Salvador" (ANDRADE, 2013).

A farinha produzida no município de Jaguaripe era enviada para a cidade do Salvador e outros núcleos urbanos do Recôncavo, empenhados exclusivamente na produção do açúcar. Praticamente, toda a faixa litorânea, entre os rios Paraguaçu e Jaguaripe, tinha esta função durante a colônia.

É importante salientar que a cadeia produtiva manufatureira do açúcar envolvia toda uma dinâmica de suporte bastante complexa. A madeira, por exemplo, era um insumo importante, pois além de servir como material nas construções dos engenhos e dos artefatos para o fabrico do açúcar servia também para a construção das rodas d'água que movimentavam as prensas de moagem de cana; era usada nas estruturas de telhados das casas grandes, senzalas e galpões de armazenamento; servia como combustível nos fornos de cozimento do melaço; e na construção naval.

Outro insumo importante da cadeia produtiva do açúcar em todos os municípios do Recôncavo foi a criação do gado. Estamos nos referindo a uma proporção bem menor do que aquela que viria a ser instalada no sertão. Nos municípios aqui tratados, a criação era apenas para o provimento e produção de leite e carne para consumo interno do engenho, especialmente o charque, utilizado na alimentação; e do couro, para confecção de artefatos de armazenamento de materiais. Mais tarde, a produção de víveres, especialmente, a farinha de mandioca foi uma especialidade daquele município (BAHIA, 1982).

No final do século XVI a colonização do Vale do Jaguaripe se restringia a alguns engenhos e pequenas propriedades agrícolas. No início do século seguinte surgiu o Arraial de Nossa Senhora da Ajuda, que em 1631 é elevado à freguesia, que por sua vez foi elevada à condição de vila em 1697. Em 1759, a Freguesia possuía cerca de 718 fogos e 5.016 almas ${ }^{11}$. O seu termo compreendia os atuais municípios de Nazaré, emancipado em 1831, e que, por sua vez foi desmembrado em Aratuípe, Laje (1905) e Muniz Ferreira (1962); e Santo Antônio de Jesus, emancipado em 1880 e que deu origem a São Miguel das Matas (1891).

Por volta de meados do século XIX, Jaguaripe, Figura 6.2.1.1, recebeu a visita de D. Pedro II que estimou sua população urbana em 2000 habitantes. Foi descrito naquela época, 1888, como uma vila "em perfeita decadência, quase deserta" (BAHIA, 1982, p. 161). Nessa

\footnotetext{
${ }^{11}$ Segundo Holanda (1986) Freguesia significa povoação, sob o aspecto eclesiástico (p.810); Alma: pessoa, indivíduo (p.88). O referido menciona o significado de "fogos" no sentido do texto, mas fica evidente que se trata de uma palavra que se relaciona à habitação.
} 
época, Nazaré ia crescendo sua importância no contexto regional e Jaguaripe passou a ter transporte hidroviário regular a vapor para a capital a partir de 1852. A vila foi elevada à condição de cidade em 1899. Devido à contínua decadência do município, Jaguaripe foi extinto em julho de 1931, e seu território, foi anexado ao de Aratuípe. Foi novamente restaurado em agosto do mesmo ano, devido aos protestos de sua população (BAHIA, 1982).

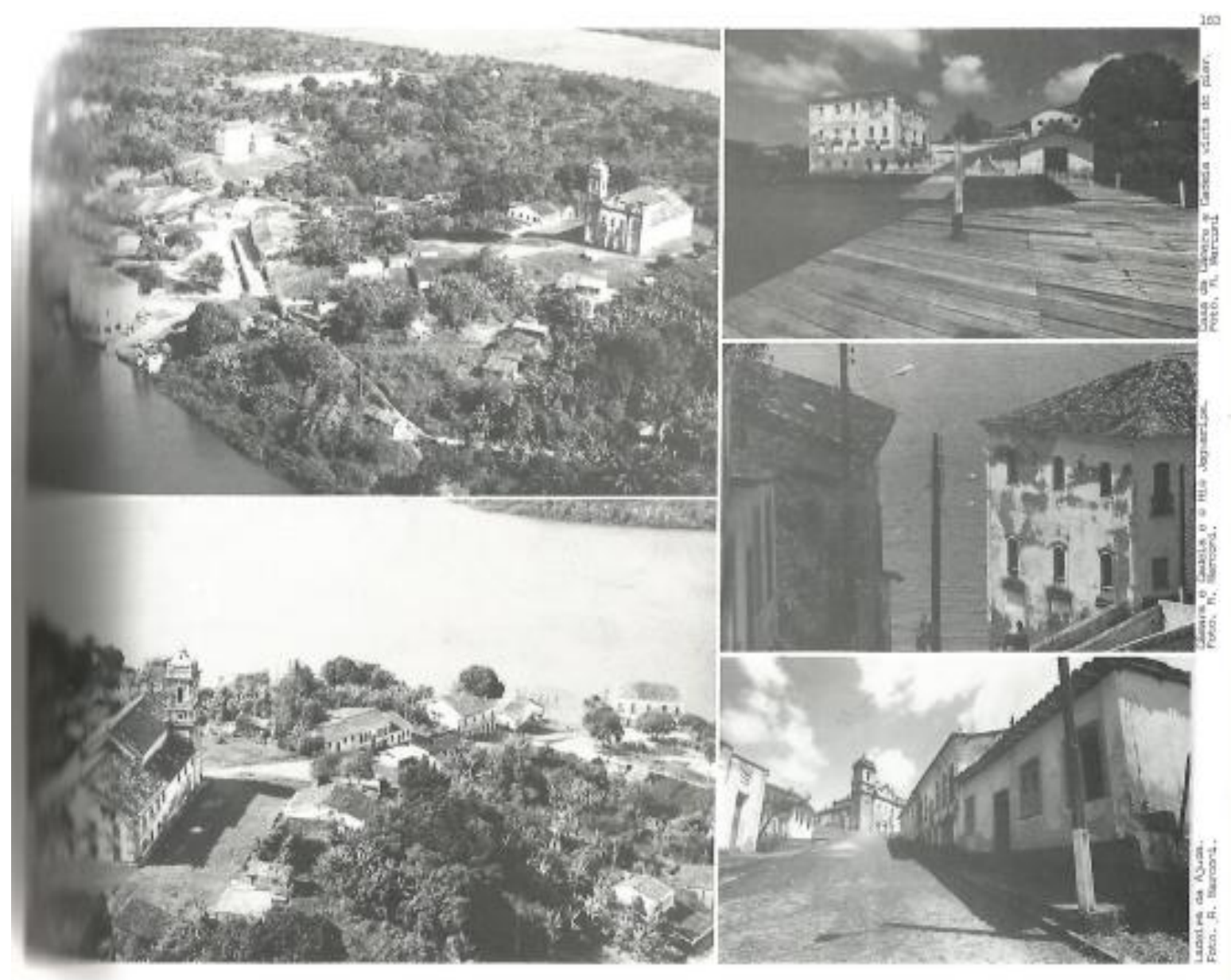

Figura 6.2.1.1 - Painel fotográfico da cidade de Jaguaripe (BAHIA, 1982, p. 163)

Jaguaripe foi perdendo a função portuária. Diminuindo seu prestígio com o aumento desta mesma função desempenhada pela cidade de Nazaré, pois estava melhor situada, no limite da navegação do rio Jaguaripe. Pertence ao subgrupo das cidades portuárias que serviam de apoio a rotas marítimo - fluviais mais longas.

Ainda com base em pesquisa documental no Arquivo Histórico Ultramarino de Lisboa, Portugal, Andrade (2013, p. 120) nos informa sobre registros de época que 
focalizavam a “[...] especialização produtiva da região, em relação à farinha de mandioca e ao volume de mercadorias que circulavam, via Jaguaripe, para a cidade de Salvador e seu Recôncavo, além de produtos que permanecem para as trocas na região”.

A cidade de Maragogipe desempenhava função semelhante no rio Paraguaçú e São Francisco do Conde, próximo à foz do rio Subaé também desempenhavam esta função auxiliar da navegação de longo curso à época. Estas povoações tiveram um desenvolvimento menor que os núcleos urbanos localizados no limite da navegação destes mesmos rios, como Nazaré, Cachoeira e Santo Amaro. Estas três últimas, por sua vez, conectadas ao interior da Bahia por ferrovias, a partir de meados do século XIX (BAHIA, 1982).

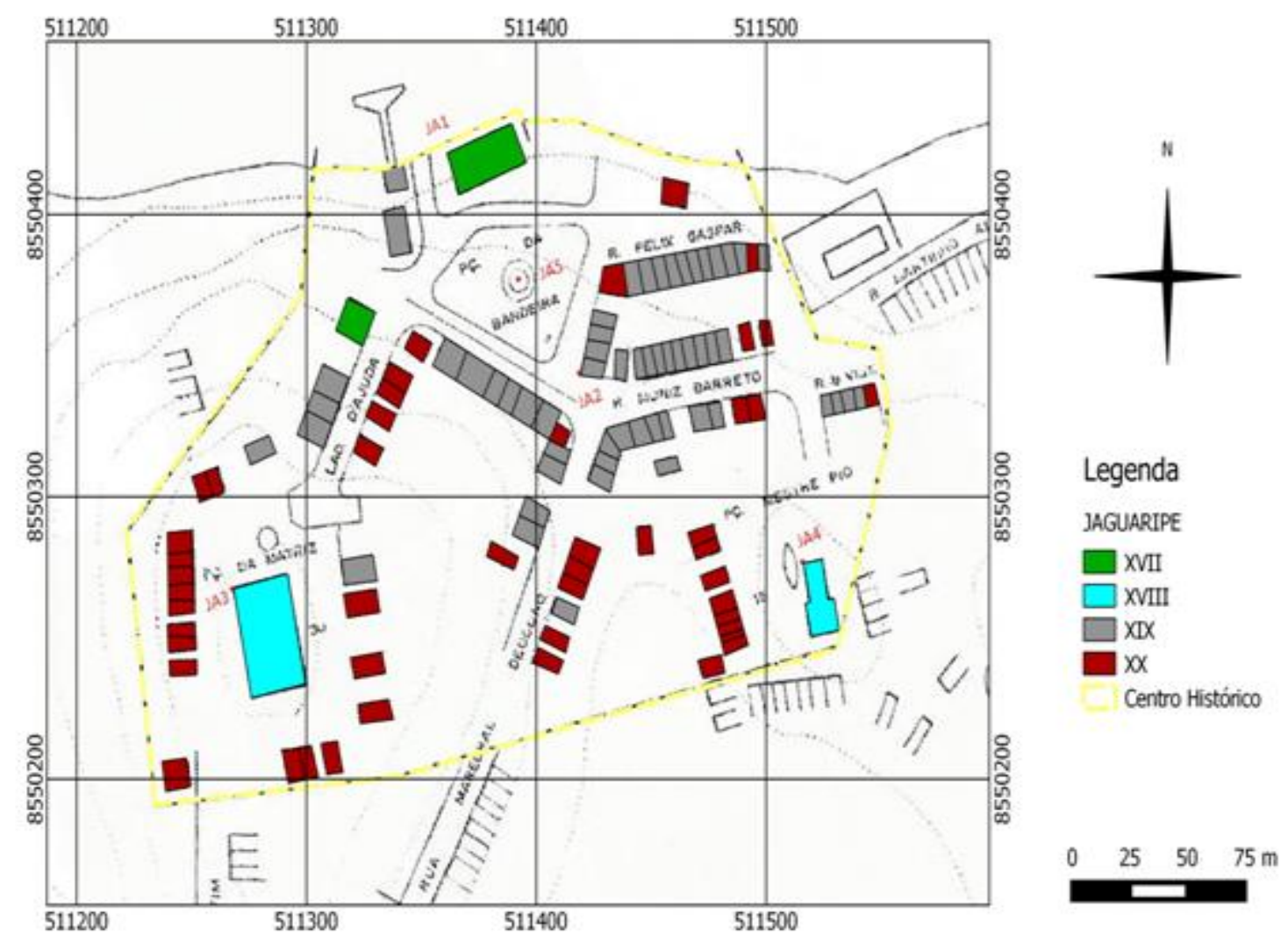

Figura 6.2.1.2 - Centro histórico da cidade de Jaguaripe (modificado pelo autor e pelo geógrafo Marcus Fábio (UnB) - Base cartográfica IPAC, 1982)

O IPAC (BAHIA, 1982) assim descreve a planta acima, Figura 6.2.1.2: 
colina da Ajuda até as águas do Jaguaripe. Delimitou-se apenas a zona $\mathrm{GP}^{12}$ $1^{13}$, devendo as demais serem definidas oportunamente. O acervo arquitetônico do Centro Histórico é constituído por 112 imóveis, em sua quase totalidade casas térreas. Apenas 3\% dos edifícios estão em estado satisfatório. Cerca de $83 \%$ em estado medíocre; e 14\%, ruim [...] Os edifícios de relevante interesse arquitetônico, em número de cinco, são originários do século XVII e XVIII (BAHIA, 1982, grifo nosso).

Pela descrição acima e observando a planta do centro histórico da referida cidade, se percebe que se trata de uma área bem menor em relação as demais cidades pesquisadas, revelando um ostracismo econômico, que por sua vez se revela no território, já que esta cidade sofreu os impactos da implantação da rede ferroviária que ia até Nazaré, na margem do mesmo rio. Ou seja, como já foi visto anteriormente, a cidade de Jaguaripe, perdeu muito da sua importância regional, devido a sua própria localização geográfica, tendo um dos fatores principais, a falência do meio de transporte hidroviário.

Percebe-se na Figura 6.2.1.3, que a Casa de Câmara e Cadeia de Jaguaripe e a Igreja Matriz da cidade se destacam na paisagem urbana pela sua monumentalidade, numa clara evidência da influência dos agentes políticos, administrativos e religiosos naquela localidade.

\footnotetext{
${ }^{12}$ Segundo o inventário do IPAC, a sigla GP indica Grau de Proteção: como somatório de todos os valores artísticos, históricos e ambientais de cada unidade imobiliária considerada. A rigor um só monumento poderá compreender distintos Graus de Proteção, a depender da possível existência de partes de diferentes valores. Por exemplo, partes contrastantes classificáveis como GP-4 coexistem com partes GP-1 ou GP-2. O G4, proteção de referência, aplica-se apenas a enxertos espúrios que deverão ser eliminados (BAHIA, 1982a; 1982b).

${ }^{13}$ Segundo o inventário do IPAC, GP1 significa a Proteção Direta: monumentos que devem ser conservados integralmente; GP2 - Proteção direta: monumentos que sofreram sucessivas transformações, muitas vezes impróprias, e só algumas partes justificam a proteção, enquanto o resto do edifício pode ser modificado, sob o controle da autoridade competente (BAHIA, 1982a; 1982b).
} 


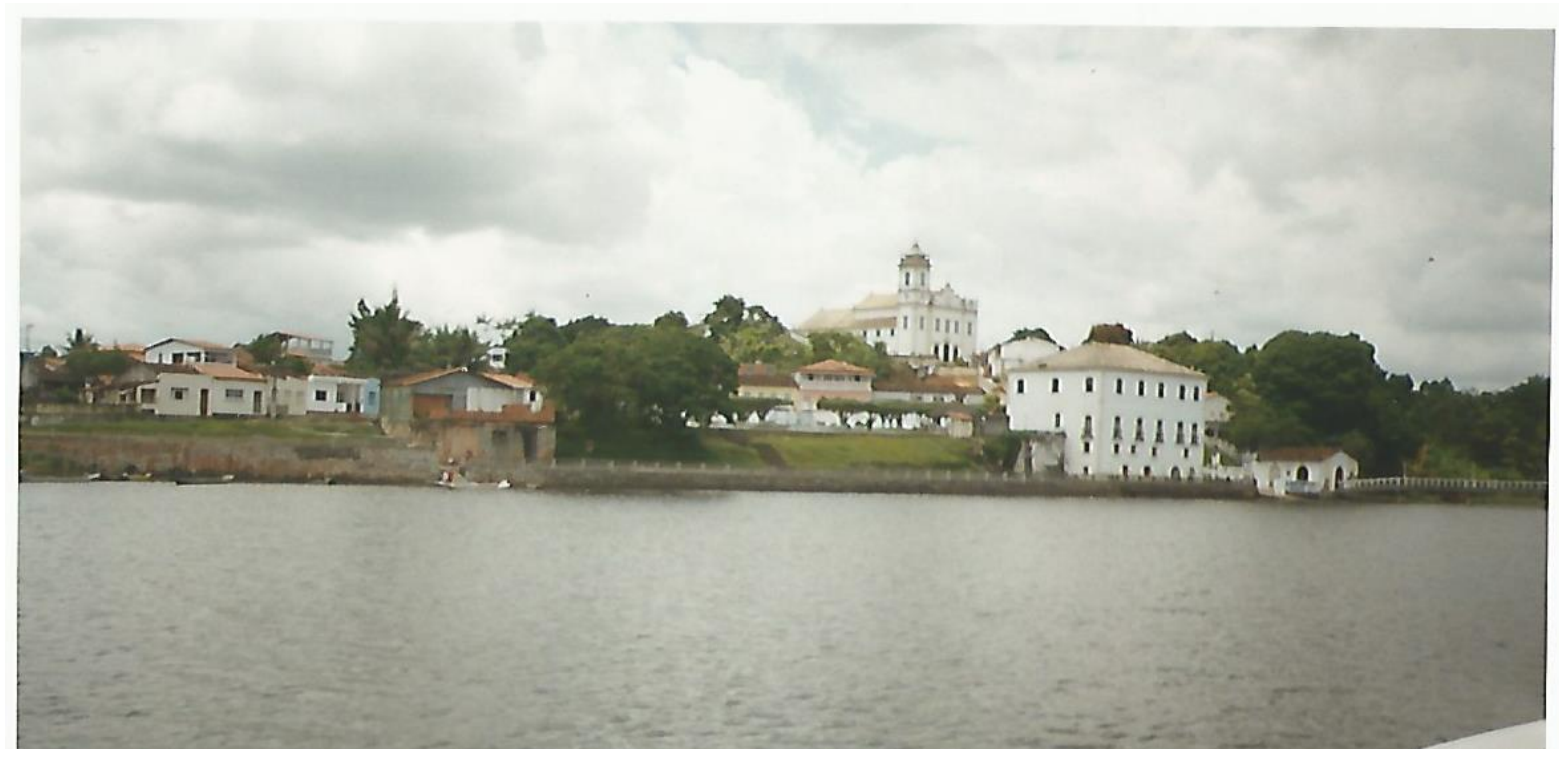

Figura 6.2.1.3 - Vista da cidade de Jaguaripe a partir do rio do mesmo nome (Imagem do autor, primeira década dos anos 2000)

Ainda segundo a mesma descrição do referido inventário:

[...] Como São Francisco do Conde, a sede do poder religioso está no alto e do civil, junto ao embarcadouro. Sua trama de ruas é irregular, com algumas ruas seguindo as curvas de nível e outras, as linhas de maior declive. A pobreza de sua gente se reflete no casario térreo da cidade. Só a arquitetura do poder é assobradada, como as casas de Câmara e Cadeia, e do Ouvidor; e a Matriz. A cidade sonolenta, que só é desperta com o apito do vapor da Baiana (nome popular dado à antiga Companhia de Navegação Baiana), tem uma moldura paisagística coerente: planície sedimentar tranquila, cortada pelas águas plácidas dos rios Jaguaripe e da Dona [...] (BAHIA, 1982, p. 162, grifo nosso).

A cidade de Jaguaripe está localizada numa faixa de terra entre a margem direita do rio Jaguaripe e a margem esquerda do seu maior afluente, o Rio da Dona ou Caípe. O porto da cidade fica sobre o Jaguaripe e é capaz de receber embarcações de médio calado. Dista 43km em linha reta de Salvador, no rumo O.S.O. e foi articulada pela mesma por linha regular da antiga Cia. de Navegação Baiana. Atualmente se articula via ferry boat Salvador - Bom Despacho prosseguindo pela BA - 001 (84km) (BAHIA, 1982). 


\subsubsection{Cachoeira}

A cidade de Cachoeira, Figura 6.2.2.1, como pode ser visto ao longo deste trabalho, foi a cidade que mais se destacou no cenário regional do Recôncavo Baiano, principalmente devido a sua localização geográfica, no último trecho navegável do rio Paraguaçú, um dos mais importantes rios da Bahia e importante via de acesso ao interior do estado.

Em 1674 foi criada a Freguesia de Nossa Senhora do Rosário do Porto da Cachoeira, desmembrada de Santiago do Iguape. A vila foi criada por Carta Régia em 1663 e instalada em 1698. É a segunda do Recôncavo. Sua elevação à cidade só aconteceu em 1837 (BAHIA, 1982).

Tavares (2008) afirma que a vila de Nossa Senhora do Rosário da Cachoeira data de 1693, e originou-se do povoado à margem esquerda do rio Paraguaçu. Ganhou muita importância no século XVIII devido a sua condição de centro comercial de uma região que incluía o rio Iguape e era passagem para vilas e povoados dos sertões do rio São Francisco (TAVARES, 2008, p. 157).

Percebemos acima uma imprecisão quanto a data de criação da vila, mas tal fato não influencia no contexto da nossa pesquisa, haja vista que essas não descaracterizam a unidade do período, pois a diferença de tempo é curta, fato que não afeta o contexto da pesquisa.

Diferentemente da cidade de Jaguaripe, Cachoeira prosperou. Desenvolveu-se à margem esquerda do rio Paraguaçú, sobre um terraço fluvial entre o cais e a encosta do vale. Seu sítio urbano é mais espaçoso do que o da cidade de São Felix, na margem oposta. A cidade era periodicamente alagada pelas águas do rio Paraguaçú nos eventos de enchente. Algumas dessas enchentes ficaram famosas e se incluem no período da nossa pesquisa: 1839, 1861, 1875, 1882, 1893 (BAHIA, 1982).

Segundo Spix; Martius (1916, p. 35), no início do século XIX, Cachoeira era “[...] sem dúvida a mais rica, populosa e uma das mais agradáveis vilas de todo o Brasil. Numerosas vendas e armazéns cheios de vários artigos europeus revelam o alto grau de movimentação de seu comércio". A produção açucareira foi desde os primórdios de sua origem no século XVI, até início do século XIX, a atividade predominante. Originada de um engenho de açúcar, essa vila prosperou e os engenhos se multiplicaram ao longo desse período no município. Entretanto, a atividade comercial também teve papel importante para o desenvolvimento da vila. A sua situação privilegiada entre duas regiões econômicas complementares, o Recôncavo 
e o Sertão, além de se encontrar no limite navegável do rio Paraguaçu, foram dois fatores preponderantes que a destacou no contexto da região, enquanto Brasil Colônia, Império e República (BAHIA, 1982).

Ao longo do século XVIII a vila viveu grande apogeu, quando era alto o preço do açúcar e também do ouro proveniente do Rio de Contas. Na primeira metade do século XIX, o fumo dos tabuleiros vizinhos e os diamantes de Mucugê e Lençóis se tornaram produtos frequentes na pauta de exportação do seu porto. Nesse período Cachoeira viveu sua fase áurea (BAHIA, 1982).

Andrade (2013, p. 242) após estudo que analisou farta documentação cartográfica do século XVIII, além de documentação eclesiástica da mesma época, concluiu que naquele século se formou uma incipiente rede urbana regional, com centralidade em Cachoeira e articulações com as outras formações urbanas do Recôncavo Baiano. E que a referida rede “[...] ligava as vilas do Recôncavo da Baía de Todos os Santos e a cidade do Salvador a partir de uma malha fluviomarítima e terrestre (caminhos internos)". O referido autor também assinala que nessa rede destacavam-se "[...] as formações urbanas que se localizavam nos pontos finais da navegação fluvial dos mais caudalosos rios da região, dentre elas a vila de Cachoeira no último trecho navegável do rio Paraguaçúu” (ANDRADE, 2013, p. 242).

As outras formações urbanas supramencionadas eram as vilas portuárias de Jaguaripe, São Francisco do Conde, Maragogipe e Santo Amaro. Mais tarde, no século XIX, mais duas se destacaram naquele mesmo cenário regional. As vilas de Nazaré e São Felix, emancipadas à condição de cidade na segunda metade desse mesmo século.

O estudo supracitado nos revela a articulação que essas vilas mantinham na primeira metade do século XIX, iniciada um século antes, como foi visto anteriormente por Andrade (2013) e pelos relatos de Orbiginy (1976). Esse processo continuou de forma cada vez mais fluida, através das infraestruturas implantadas no território em períodos posteriores, resultando numa conexão cada vez mais veloz e intensa, especialmente a partir da segunda metade do século XIX. Como já relatado anteriormente, a referida vila foi importante como liderança política durante as lutas da Independência, se tornando Sede da Junta Governativa e, posteriormente, Governo Provisório (BAHIA, 1982).

O pesquisador francês, Alcide D’Orbigny, em viagem ao Brasil no início do século XIX, menciona Cachoeira algumas vezes. A primeira quando ainda viajava pelo sertão da Bahia, nas imediações de Juazeiro. Ele assinala que “[...] os lugares vizinhos daquela parte do curso do São Francisco recebem, quase todas, as suas mercadorias por terra, da vila de 
Cachoeira" (ORBIGNY, 1976, p. 98). A segunda, quando passa a descrever a sua chegada àquela cidade do Recôncavo Baiano:

Foi assim que chegamos à cidade de Cachoeira, situada no sopé de uma cadeia de colinas, à margem do rio Paraguaçu. Alguns prédios mais importantes do que os das localidades do interior já anunciam a proximidade do litoral e comunicações fáceis e seguras com a grande cidade da Bahia (ORBIGNY, 1976, p. 100).

A descrição acima nos é muito cara, pois nos faz refletir sobre a discussão das narrativas espaciais que mencionamos anteriormente neste trabalho. Percebe-se que Orbigny faz uma leitura e interpretação da vila de Cachoeira, através dos seus edifícios e do que eles representavam. A sua narrativa, a partir do que estamos considerando como outra narrativa posta no território. Ou seja, aquela que surge do próprio espaço.

Continuando a sua descrição, o autor escreve o seguinte:

Em frente a Cachoeira fica Porto Feliz, localidade bem povoada e com bastante movimento, que não passa de uma parte da cidade.

Cachoeira é rica e florescente. Tem uma igreja dedicada a Nossa Senhora do Rosário, um convento de carmelitas, um hospital denominado São João de Deus, um chafariz e duas pontes de pedra sobre os ribeirões Piranga e Caquende, cursos de água de pouca extensão, que servem para mover alguns engenhos de açúcar.

Porto Feliz também tem duas Igrejas. As casas de uma e outra margem, do rio são feitas de pedra e as ruas são calçadas.

O Paraguaçu, que serve de via de comunicação, não é navegável acima de Cachoeira[...]

De Cachoeira à Bahia, a viagem é agradável, atravessando terras cultivadas e fartas de recursos. Com o refluxo da maré, poucas horas são suficientes para o trajeto. A 15 de abril, chegamos à Bahia (ORBIGNY, 1976, p. 100).

Na ilustração abaixo, Figura 6.2.2.1, o autor nos dá uma ideia de sua visão da cidade de Cachoeira naquela época. 


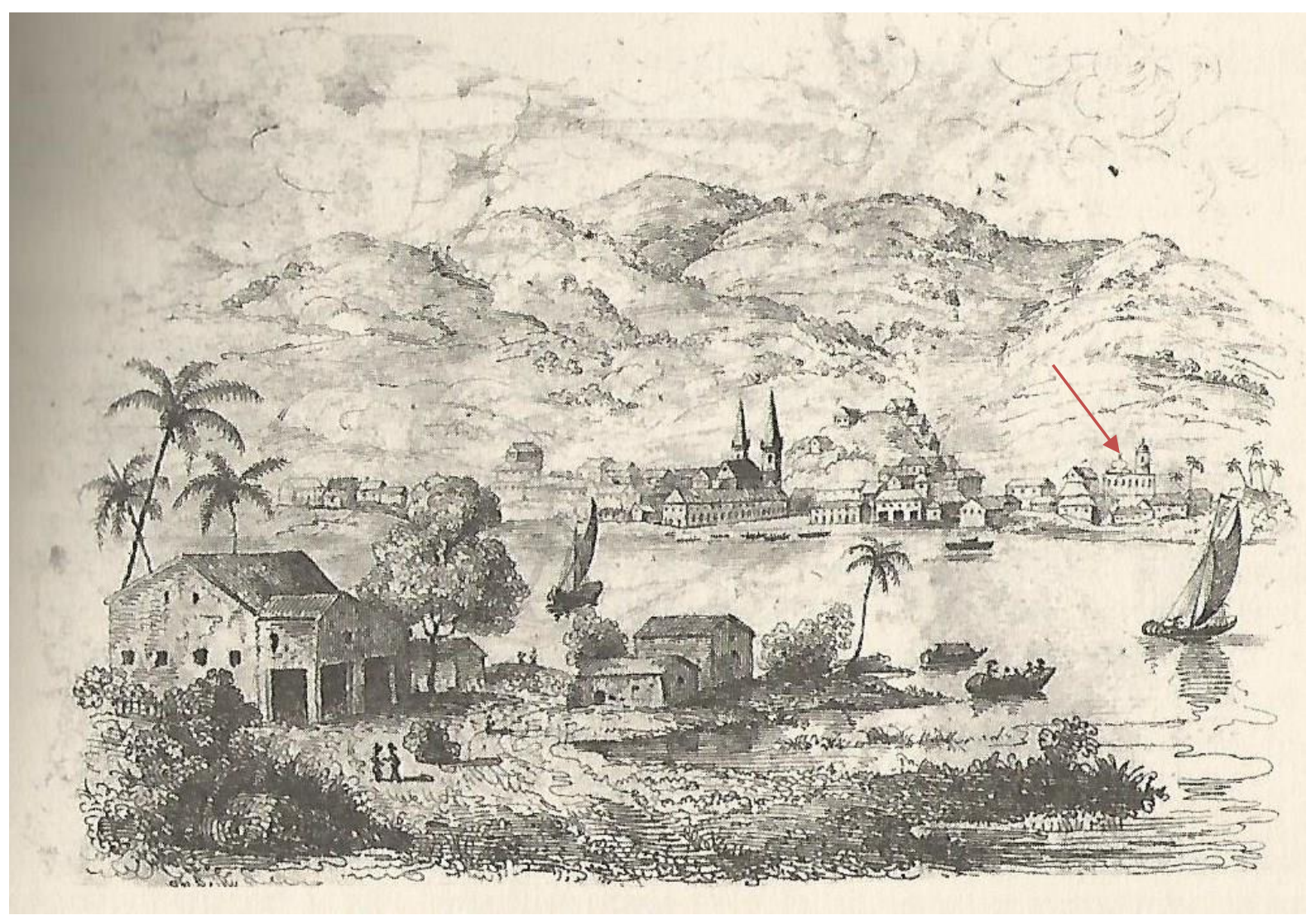

Figura 6.2.2.1 - Ilustração da vila de Cachoeira - BA na primeira metade do século XIX (ORBIGNY, 1976, p. 101, modificado (grifo nosso, seta em cor vermelha))

Pela descrição e também pela ilustração de Orbigny (1976), é possível perceber elementos da paisagem urbana de Cachoeira que evidenciam sua importância no contexto regional, como o atual conhecido conjunto da igreja e convento do Carmo, além da igreja do Rosário. Indicamos com a seta o referido conjunto, com base na localização e estrutura do edifício. Fica clara a presença desse agente (Igreja) na organização do espaço urbano daquela localidade. É possível perceber também que o ângulo, através do qual o observador executou o desenho, foi a partir da atual cidade de São Felix, na época chamada de Porto Feliz.

Orbigny (1976), após alguns dias na cidade de Cachoeira, continua sua viagem rumo ao seu próximo destino: Região das Minas. Vejamos a última descrição deste viajante sobre a região:

Depois de passar uma estada de uma semana na Bahia, parti, em companhia de alguns comerciantes que iam fazer uma viagem de negócios à região das Minas. Tendo navegado, de novo, pelo Paraguaçu, vimos, sucessivamente, Maragogipe, com suas plantações de cana-de-açúcar e, depois, Cachoeira, já 
visitada antes, rico entreposto que conta com 1.000 casas e 10.000 habitantes.

Em Cachoeira, tem-se que abandonar o rio, que deixa de ser navegável, e começa a viagem a cavalo. Em dois dias de jornada, chega-se, através de uma região bem povoada e bem cultivada, à aldeia de Tapera (ORBIGNY, 1976, p. 109).

Mais uma vez percebe-se nos relatos de Orbigny (1976), a intensidade da atmosfera da vida no Recôncavo Baiano naquela época. Não descobrimos qual a fonte que o autor utilizou para os dados sobre o número de casas e habitantes que observou na cidade de Cachoeira, mas acreditamos em duas hipóteses prováveis. A primeira é a de que o mesmo fez uma estimativa visual. A segunda, diz respeito à possibilidade de ele ter tido acesso às informações descritas por outros viajantes. Saint-Hilaire, por exemplo, já havia feito viagens pelo Brasil na mesma época, como afirmou Vivaldi Moreira na contracapa do livro editado da obra de Obginy em 1976, a qual nos referenciamos; Spix; Martius (1916), que afirmaram ter a vila no início daquele mesmo século, exatamente as mesmas quantidades apontadas por Oribgny (1976) (cerca de 1000 casas e mais de 10.000 habitantes) (ANDRADE, 2013). Entretanto, mesmo sem a fonte exata deste dado, fica evidente a intensidade da dinâmica entre aquela vila e outras regiões da Bahia e do Brasil. Além disso, nota-se também a importância da referida vila e de outras como Maragogipe, na mesma região, como entreposto comercial e ponto de apoio para os viajantes que iam de Salvador para os sertões e vice-versa.

Cachoeira era local de convergência da Estrada Real do Gado, que ligava a zona de criação oriunda da região do Rio São Francisco; e da zona da Estrada de Minas, que ligava São Felix à Chapada Diamantina, Minas Gerais e Goiás. Era um ponto obrigatório de transbordo das vias fluvial e terrestre e, portanto, se transformou em empório de uma vasta e rica região. Por isso a atividade comercial intensa de importação e exportação de produtos variados entre o interior do próprio Recôncavo e deste para Salvador, especialmente açúcar, ouro, dentre outros, movimentava freneticamente sua vida urbana e sua zona portuária (BAHIA, 1982).

Na feira da vila e posterior cidade de Cachoeira se encontravam gêneros alimentícios provenientes de Minas Gerais; além de algodão, couros e gado de outras regiões do sertão. Os portugueses tradicionalmente exerciam a atividade comercial. Porém, quando a produção de fumo começou a prosperar, a partir de meados do século XIX, surgem no cenário os alemães e brasileiros, entretanto, nessa mesma época o município enfrenta uma forte recessão com a perda de $25 \%$ da população local, devido uma epidemia de cólera em 1855, que matou 3000 
pessoas na cidade e 8.500 na Comarca. Além desse fato, se somaram as perdas decorrentes da Guerra do Paraguai (1865-70). Essa situação só iria melhorar a partir dos últimos quinze anos daquele mesmo século e início do século XX, com a valorização do fumo e a realização de grandes obras públicas de infraestrutura, como a ponte D. Pedro II (1882-85) e a Hidrelétrica de Bananeiras (1907-20) (BAHIA, 1982).

Com a construção da ponte D. Pedro II, paradoxalmente, a vila perdeu seu status privilegiado de ponto de transbordo e centro distribuidor, conhecida também como empório do sertão. Além disso, no segundo quartel do século XX, a reestruturação do sistema viário estadual enfraqueceu suas funções portuárias e de conexão ferroviária, principalmente com a conclusão da rodovia Salvador-Feira (1924-28) e interligação das ferrovias baianas (BAHIA, 1982).

Mais uma vez, a partir dos anos de 1930, Cachoeira volta a perder quase um terço de sua população em decorrência da crise da agroindústria fumageira, fato que a levou a um ostracismo econômico que ficou refletido na sua paisagem urbana, quando grande parte do seu patrimônio edificado entrou em estado de decadência, devido à falta de manutenção, que por sua vez, era consequência da decadência econômica de muitas famílias da região e da cidade (BAHIA, 1982).

Segundo o IPAC:

[...] A falta de áreas planas obriga a cidade a conquistar terrenos de encosta, na $1^{\mathrm{a}}$ metade do século XIX e a aterrar a margem do rio, na $2^{\mathrm{a}}$ metade com a construção do cais, como o da Manga (1858) e do Alambique (1897). No auge do seu crescimento, em meados do século XIX possuía 1051 casas, 233 sobrados e perto de 150 casebres de palha. Depois de um século de estagnação, Cachoeira retoma, lentamente, o crescimento, através do afavelamento da encosta do vale (BAHIA, 1982, p. 30). 


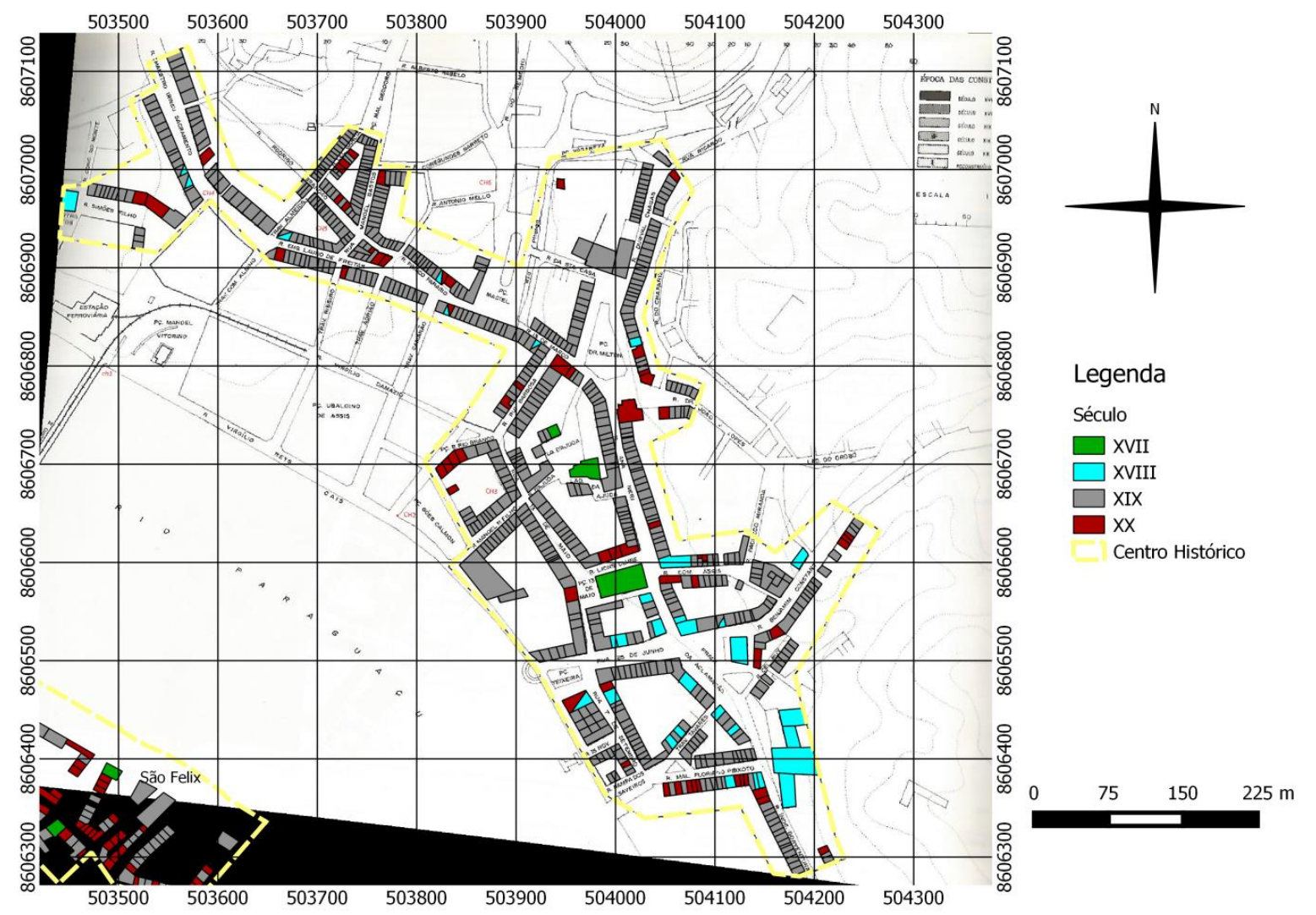

Figura 6.2.2.2 - Centro histórico da cidade de Cachoeira - BA

(BAHIA, 1982, modificado pelo autor e pelo geógrafo Marcus Fábio (UnB) - Base cartográfica do IPAC)

Na sequência de fotos a seguir, Figura 6.2.2.3, podemos visualizar, através da paisagem urbana e alguns aspectos do conjunto urbano da cidade de Cachoeira na década de 1970. É possível visualizar também aspectos do rio Paraguaçú, inclusive algumas ruas alagadas, quando da época das cheias do referido rio, antes da construção da barragem de Pedra do Cavalo, inaugurada em 1985.

Apesar de seu tombamento, muitos dos seus edifícios ainda continuavam em estado precário, especialmente à época do inventário do IPAC, que assim caracterizou a zona delimitada do seu centro histórico: a zona GP- 1 (grau de proteção-1), delimitada na planta acima, figura 6.2.2.2, tem área de 20,13 ha, onde estão compreendidas 29 ruas, 8 praças e 668 imóveis. Destes, 35 foram inventariados e tiveram suas tipologias caracterizadas segundo as categorias anteriormente mencionadas. Quanto ao estado de conservação dos edifícios 86\% estava em condição medíocre; 9\%, satisfatória, e 5\% ruim (BAHIA, 1982, p. 30). 


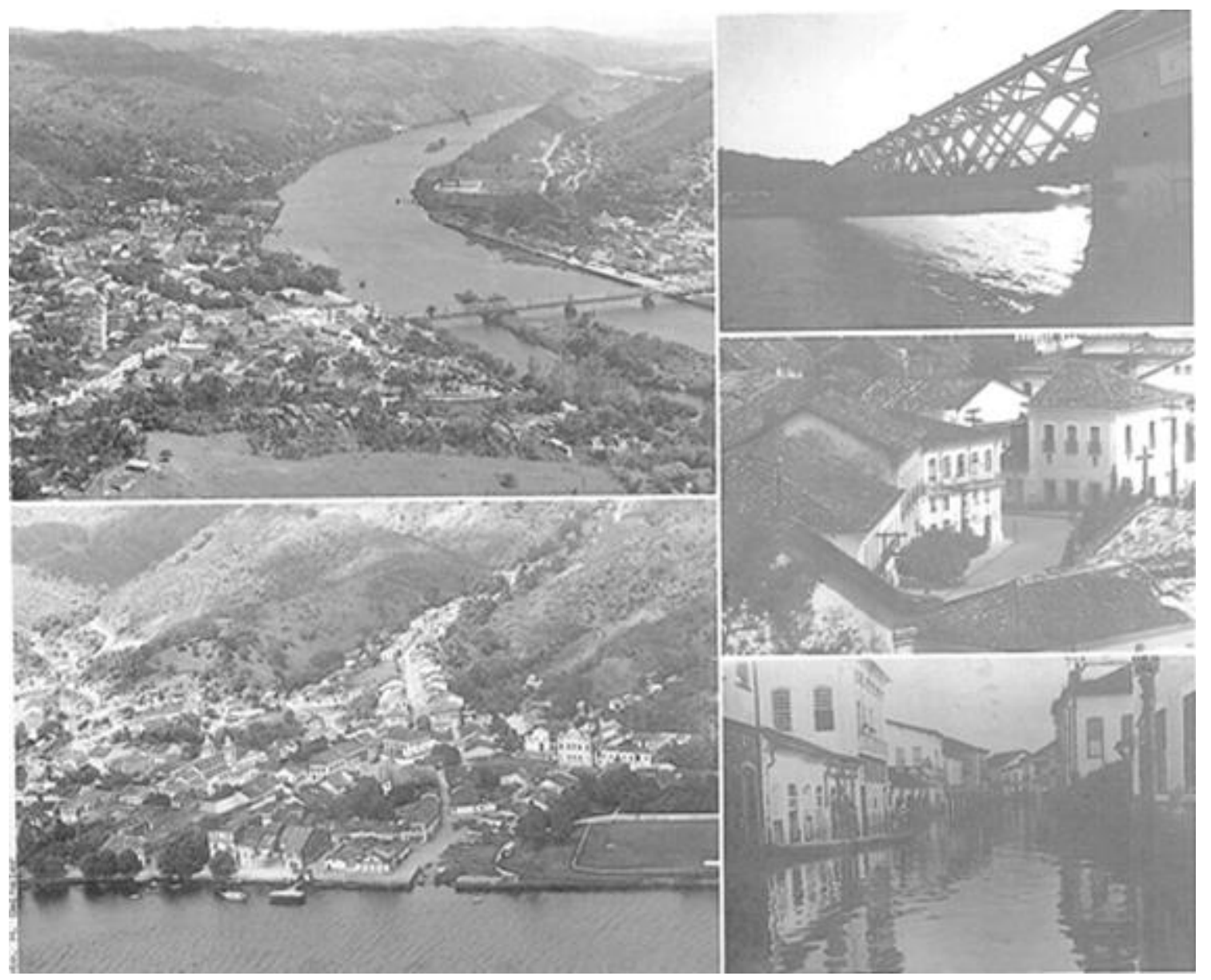

Figura 6.2.2.3 - Cidade de Cachoeira - BA, década de 1970 (BAHIA, 1982, p. 31)

Na foto seguinte, Figura 6.2.2.4, podemos ter uma visão panorâmica de parte do centro histórico de cidade de Cachoeira numa foto atual, obtida numa exposição sobre Salvador e o Recôncavo Baiano, num shopping da cidade. Isso revela o quanto ainda está presente na memória de alguns artistas baianos a relação entre Salvador e o seu Recôncavo. 


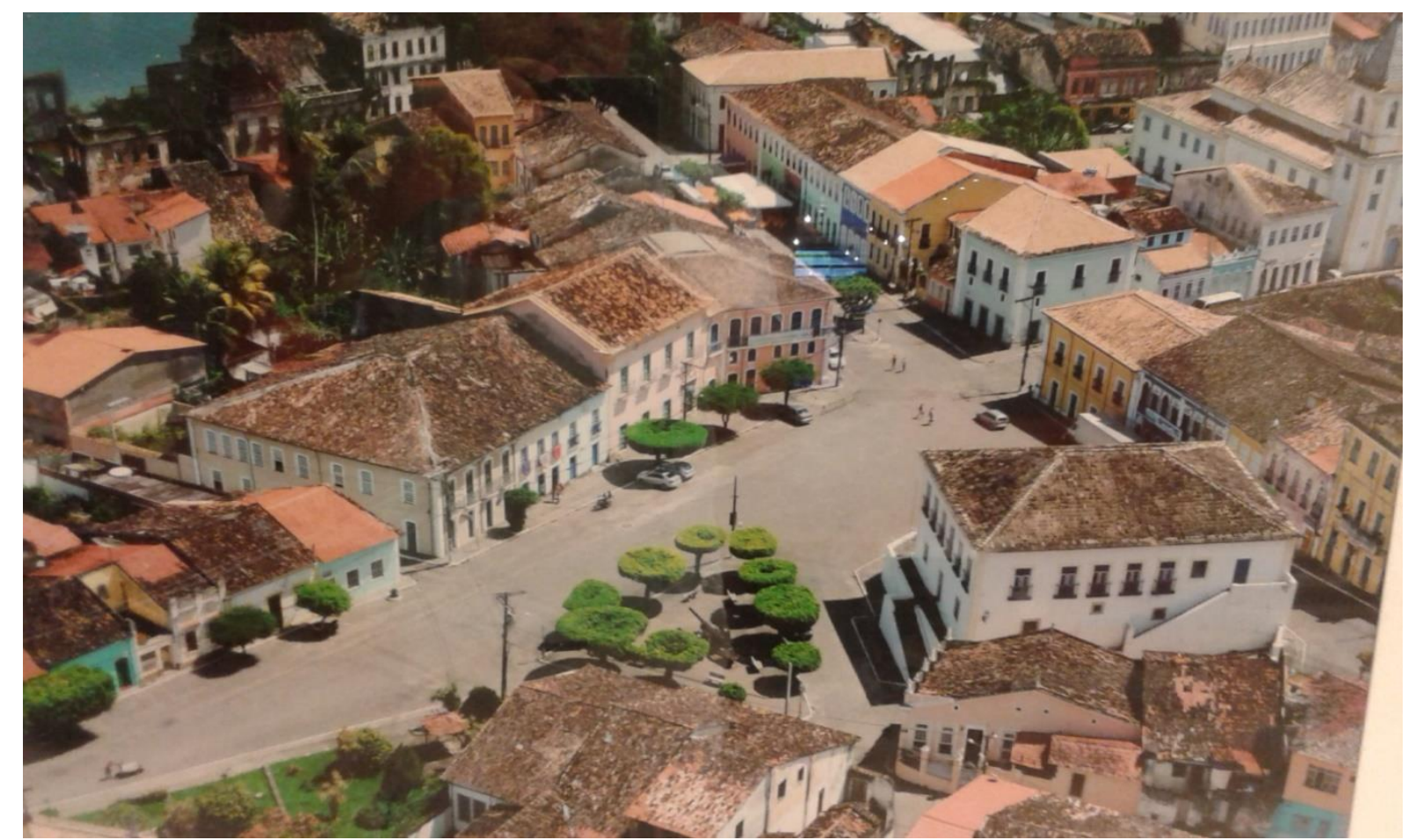

Figura 6.2.2.4 - Vista panorâmica da cidade de Cachoeira - BA na atualidade, exposição "Quem ama a Bahia" - Salvador e o Recôncavo Baiano

(GAMA, 2015)

\subsubsection{São Francisco do Conde}

Segundo o estudo do IPAC (BAHIA, 1982), a extensão inicial do município de São Francisco do Conde compreendia os atuais municípios de Santo Amaro, Amélia Rodrigues, Jacuípe, Terra Nova, Teodoro Sampaio, São Sebastião do Passé e Catu. Nestas terras desenvolveu-se uma próspera agroindústria açucareira a partir de 1563, além de ter sido centro pesqueiro, especialmente de camarões, que secos eram enviados para a capital e outros núcleos do Recôncavo. Produzia também cachaça em larga escala. A vila foi instalada em novembro de 1698, logo após a instalação das vilas de Jaguaripe, em dezembro de 1697 e Cachoeira, em janeiro de 1698. Nesse município existiam em 1757 cerca de 40 engenhos, distribuídos da seguinte forma: 14 na freguesia de São Gonçalo (sede), 15 na de Nossa Senhora do Monte e 10 na de Nossa Senhora do Socorro (Mataripe). A elevação da vila a condição de cidade se deu tardiamente, em março de 1938. A povoação da cidade, nascida em torno do convento de Santo Antônio se debruçou sobre as encostas do promontório até o pequeno porto (BAHIA, 1982). 
Segundo Tavares (2008) a primeira vila instalada no Recôncavo Baiano foi a de São Francisco da Barra do Rio de Sergipe do Conde, atual São Francisco do Conde. Segundo o mesmo, semelhante a outras vilas, essa também se originou da feira semanal armada em torno da primitiva capela do engenho. Na segunda metade do século XVIII (1759), a referida vila possuía 325 casas e 2.724 habitantes. Totalizava então catorze engenhos principais (TAVARES, 2008, p. 157).

Percebe-se aqui mais uma vez a imprecisão entre as fontes acima citadas, quanto a ordem de criação das vilas de Jaguaripe, São Francisco do Conde e Cachoeira, como já assinalado anteriormente.

Vilhena (1969) sinalizou que em 1802 a vila entrou em decadência devido à perda da área que corresponde ao município de Santo Amaro em 1725. Esse processo foi agravado com os desmembramentos de 1868 (Vila de Santana do Catu), 1926 (São Sebastião do Passé) e 1945 (Madre de Deus) e após as sucessivas crises da economia açucareira (SEI, 2001). A recuperação econômica do município só se deu a partir de 1947 com o início da produção de petróleo e inauguração, em 1950, da Refinaria Landulfo Alves.

A descrição do inventário do IPAC, quanto a situação do centro histórico da cidade de São Francisco do Conde e a análise da sua respectiva planta, Figura 6.2.3.1, diz o seguinte:

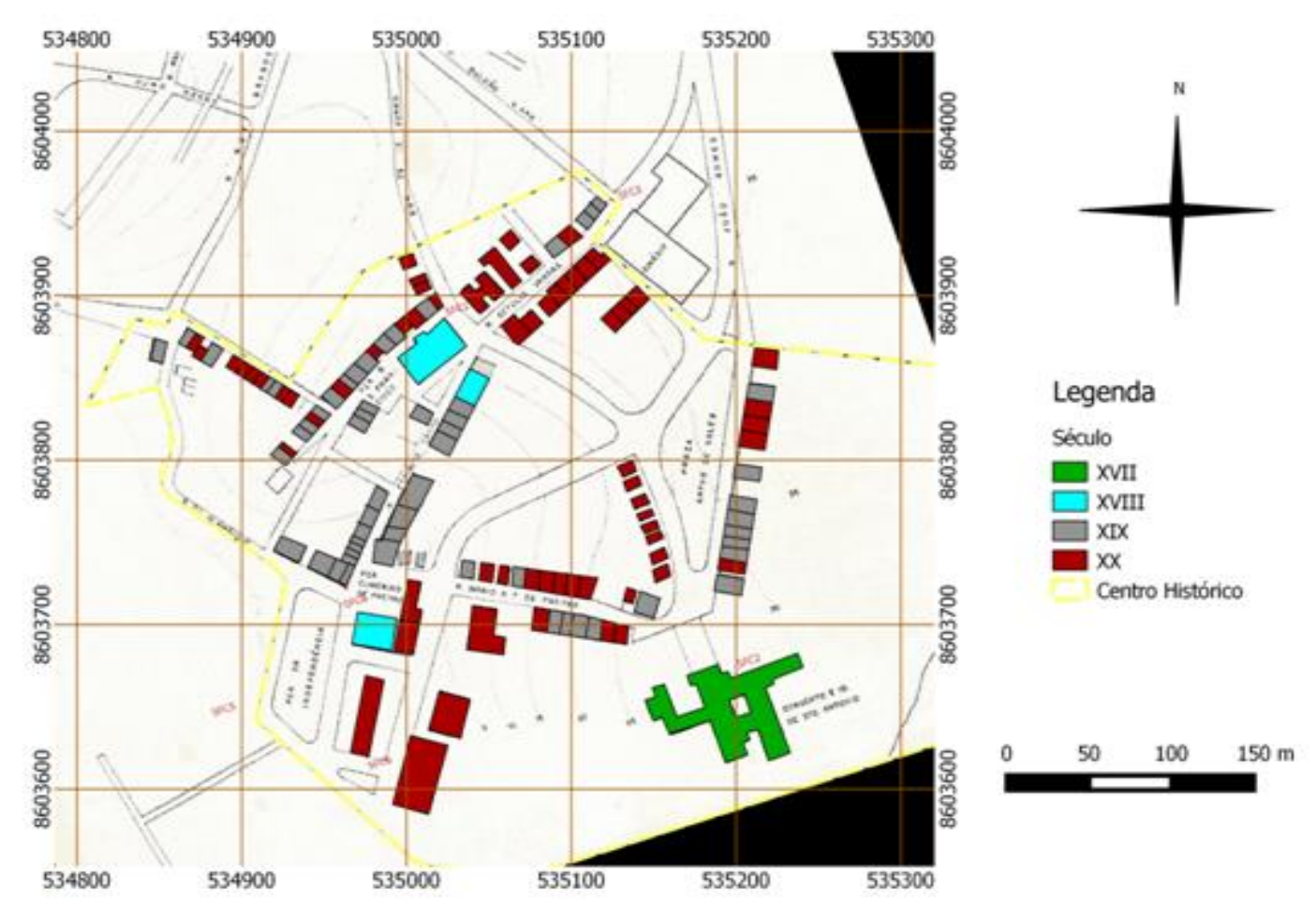

Figura 6.2.3.1 - Centro histórico da cidade de São Francisco do Conde - BA (modificado pelo autor e pelo geógrafo Marcus Fábio (UnB) - Base cartográfica IPAC, 1982) 
A povoação de S. Francisco do Conde, nascida em torno ao convento, se derramou pelas encostas do promontório até o pequeno porto. Sua tipologia é simples, isto é, mononuclear e razoavelmente homogênea, como "formae urbis". Seu sítio é acidentado e sua trama de ruas irregular. O "entorno" natural da cidade é constituído pelas águas da Baía de Todos os Santos, que contornam em três lados, e por colinas verdejantes, na praça norte. Nesta conjugação de sítio natural privilegiado com a obra excepcional do homem está o maior interesse do conjunto. Seu centro histórico, que está delimitado em planta anexa, mede 13,57 há e foi classificado com grau de proteção dois (GP-2), devido a numerosa substituição de casas. Seu traçado urbano é primitivo, originário do século XVII. Nesta área estão compreendidas: 15 ruas, 4 praças, a roça do convento franciscano, ribeira que contorna a cidade e 134 edifícios [...] O espaço público mais importante é a praça Arthur Salles, onde está localizado também o monumento mais expressivo do conjunto: o Convento de Santo Antônio. Destacam-se ainda dentre os edifícios relevantes, a Matriz de S. Gonçalo, a Casa de Câmara e Cadeia e três imóveis de arquitetura civil, inventariados a seguir. Seu casario é constituído por casas térreas de parede-meia, em sua maioria do século XIX e XX (IPAC, BAHIA, 1982, p. 162).

Abaixo, foto da cidade na década de 1970, Figura 6.2.3.2:

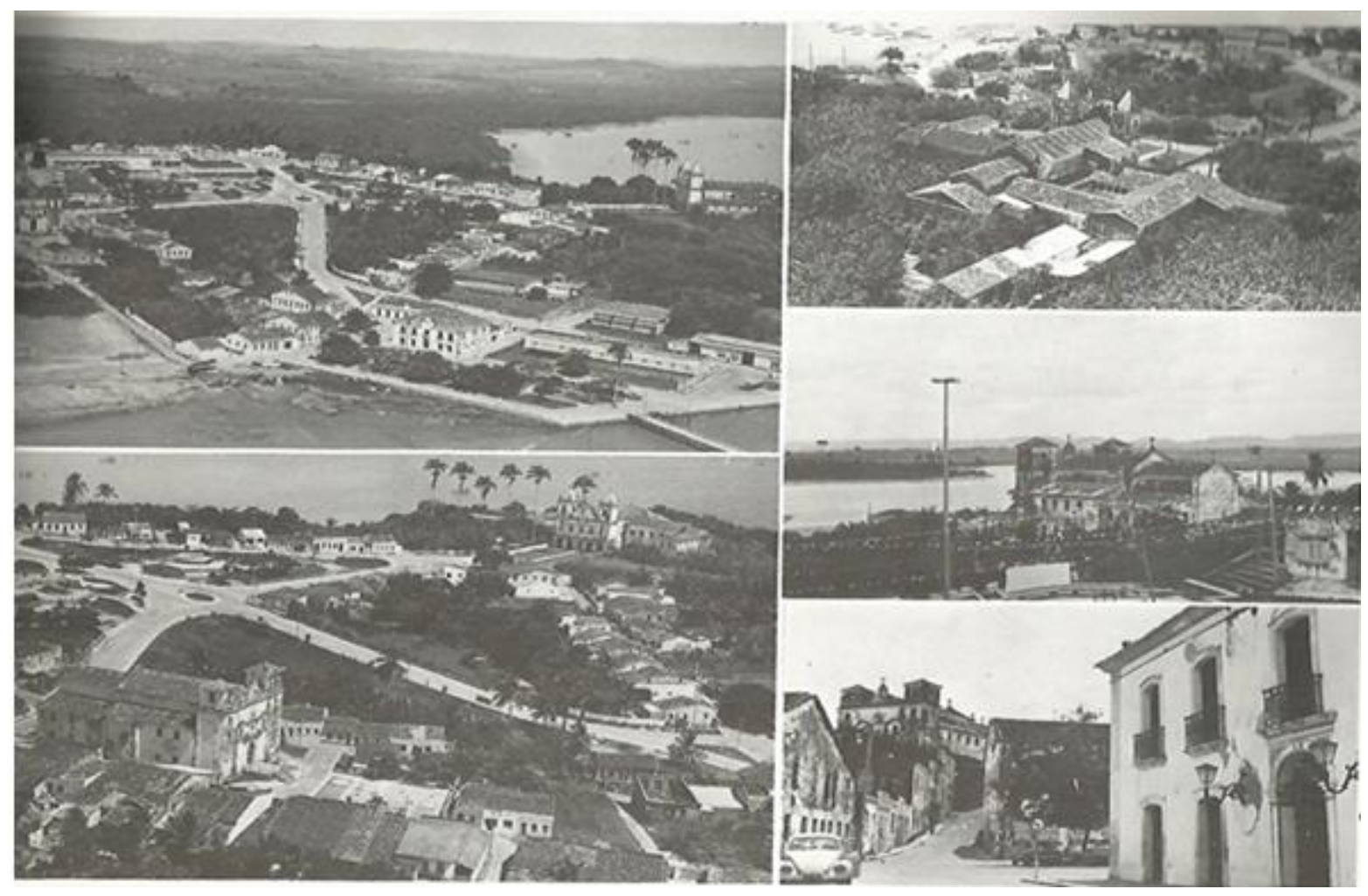

Figura 6.2.3.2 - Cidade de São Francisco do Conde - BA, década de 1970

(BAHIA, 1982, p. 163) 


\subsubsection{Maragogipe}

A vila de São Bartolomeu de Maragogipe fazia parte da capitania do Paraguaçu ou do Recôncavo, confirmada a dom José da Costa em 1730. Possuía 4.500 habitantes em 1759 e já se destacava na produção de fumo e farinha de mandioca.

As terras do município de Maragogipe foram desmembradas do município de Jaguaripe, a vila foi criada em 1724 e elevada à condição de cidade em 1850. Está situada sobre uma colina, a $18 \mathrm{~m}$ do nível do mar, numa península que aflora do terraço sedimentar existente na base da falha geológica do mesmo nome, no ponto em que o rio Guaí desagua no Lagamar do Iguape. O núcleo inicial da cidade teria sido construído na borda do lagamar, mas em meados do século XVII, com a construção da Igreja Matriz de São Bartolomeu, no topo da colina, criou-se um novo centro, consolidado oitenta anos mais tarde, com a construção da Casa de Câmara e Cadeia (BAHIA, 1982). A Figura 6.2.4.1 mostra um painel com algumas imagens panorâmicas da referida cidade na década de 1970.
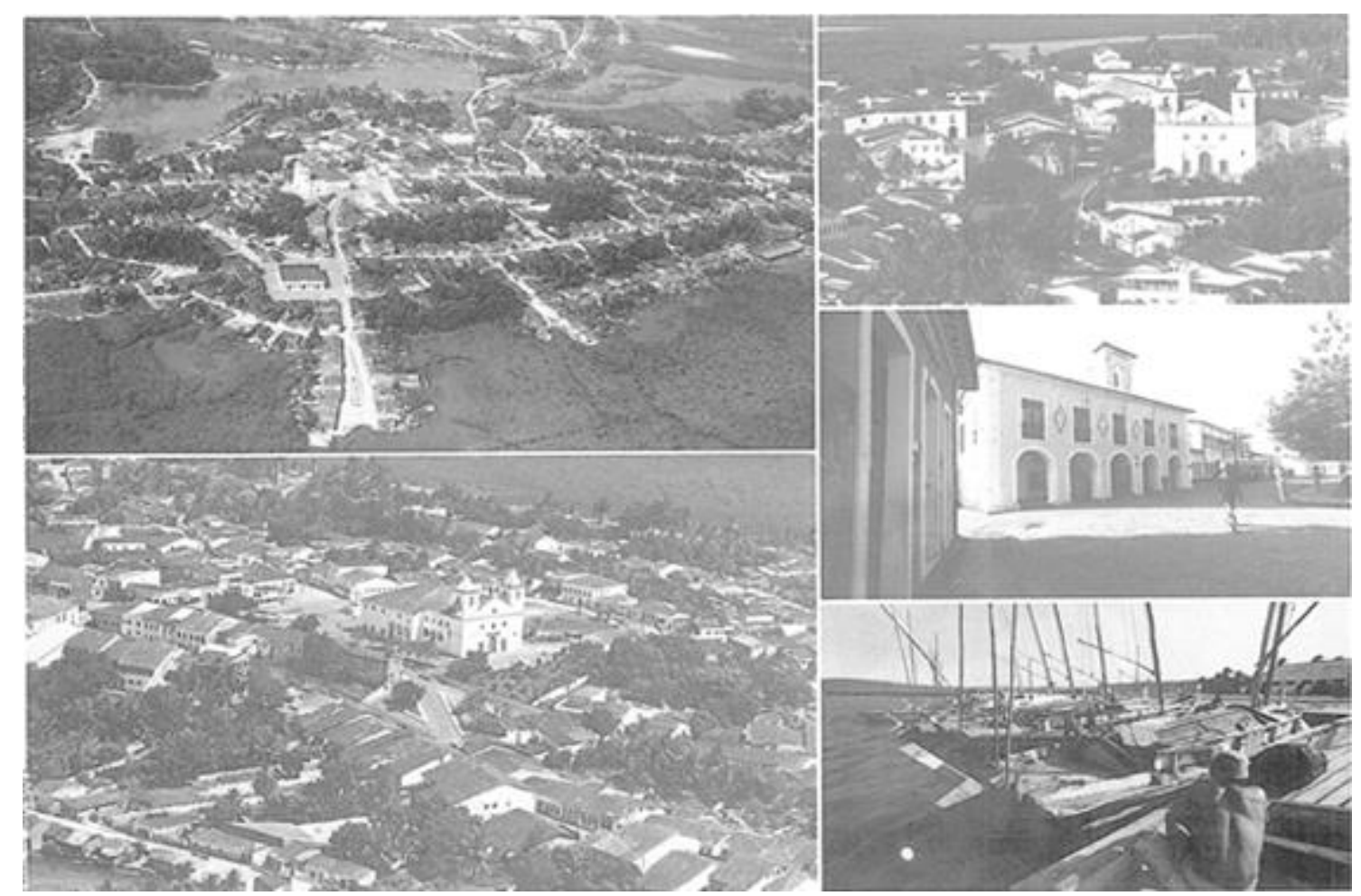

Figura 6.2.4.1 - Cidade de Maragogipe, década de 1970 (BAHIA, 1982, p. 189) 
A cidade está rodeada por mangues e dois rios navegáveis, o Paraguaçu e o Guaí, além de outros rios menores que banham suas terras, fato que contribuiu durante o século XIX para sua expansão e desenvolvimento, em consequência da importância da cultura do fumo na economia baiana. Maragogipe se desenvolveu como porto de apoio à rota marítimo-fluvial que terminava em Cachoeira. Papel semelhante desempenhado por Jaguaripe em relação a Nazaré. Razões defensivas ao longo dos dois primeiros séculos de colonização fizeram com que fosse escolhido o sítio acima citado, para a fundação do povoado, assim como outros núcleos pesquisados e anteriormente descritos (BAHIA, 1982).

Spix; Martius (1916, p. 38) em viagem rumo a um engenho as margens do rio Paraguaçú, na primeira metade do século XIX, descrevem a vila de Maragogipe como um "rico burgo situado no fundo desta baía", que "[...] contribui bastante para o comércio forte com a Capital, existindo em seus férteis arredores muitos engenhos de açúcar”.

Dentre as melhorias em infraestrutura implantadas no município, está a abertura da estrada carroçável, ligando a sede do mesmo à cidade de São Felix em 1807; a criação das cadeiras de primeiras letras e de latim; o estabelecimento de linha regular de navio a vapor para Salvador em 1839; e a instalação de fábricas de charuto ainda neste mesmo século (BAHIA, 1982).

Dentre as fábricas instaladas no século XIX, destacam-se a Dannemann e Suerdieck, instaladas no mesmo prédio, numa das principais praças da cidade, Figura 6.2.4.2. 


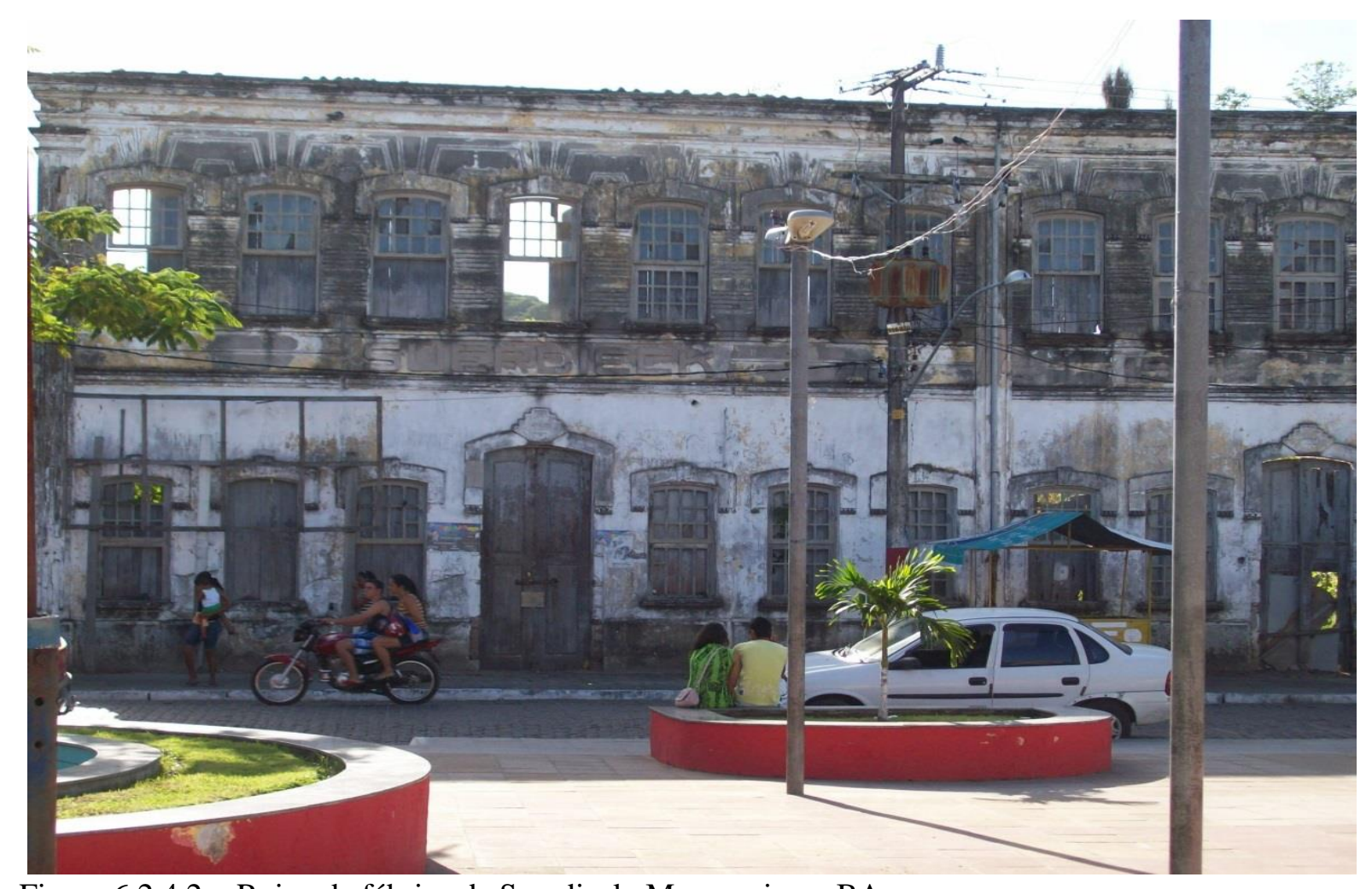

Figura 6.2.4.2 - Ruina da fábrica da Suerdieck, Maragogipe - BA (Imagem do autor em trabalho de campo, 2014)

Podemos perceber pela imagem da foto que a localização da fábrica de charutos SUERDIECK, antiga fábrica da DANNEMANN, junto a antiga casa de Câmara e Cadeia da cidade demonstra sua importância no cenário econômico e na paisagem urbana da cidade na época áurea da indústria fumageira de Maragogipe. Atualmente se encontra em ruínas, restando apenas a fachada do prédio da última década do século XIX.

Os dados cronológicos do inventário do IPAC apontam as seguintes características:

1872 - Geraldo Dannemann se estabelece em São Felix como exportador de fumo e abre, mais tarde, filiais em seis localidades vizinhas. Dannemann foi, duas vezes, intendente e, uma vez, prefeito de São Felix, tendo promovido sua elevação à categoria de cidade (1). Em 1888, sua fábrica era citada ao lado da "Fragância" de José F. de Simas e "Juventude" de José Cardoso como uma das três mais importantes de São Felix (2).

1892/95 - Datas inscritas nas portadas dos imóveis indicam o período em que os edifícios originais foram interligados e convertidos em fábrica de charutos.

1942 - Com a entrada do Brasil na II Grande Guerra e pertencendo a firma a descendentes de alemães, é decretada sua intervenção, primeiro pelo Governo da Bahia e depois pela União, através do Banco do Brasil (1) 
1948 - Tendo a firma se tornado insolvente pela má administração durante a interventoria, seus imóveis são leiloados para o pagamento de obrigações trabalhistas $(1,3)$.

1954 - O imóvel é adquirido pela Suerdieck S/A, que no ano seguinte instala no edifício o departamento de fabricação de caixas de charutos (3) (BAHIA, 1982).

Os dados acima nos dão a dimensão do quanto pode ser reveladora a pesquisa num prédio histórico de uma determinada cidade: a própria dimensão física, no sentido da sua monumentalidade, revela o grau de dinâmica de uma determinada economia de época, influenciada por um determinado produto; as verticalidades e horizontalidades que podem interferir numa cidade ou região, a partir de um fato externo, como foi o caso das consequências das duas Grandes Guerras Mudiais, trazendo seus efeitos locais e regionais, como apontado anteriormente por Nardir (2013) na cultura do fumo no Recôncavo Baiano.

Quanto à planta do centro histórico de Maragogipe, segundo o inventário do IPAC (BAHIA, 1982), Figura 6.2.4.3, os dizeres e dados são os seguintes:

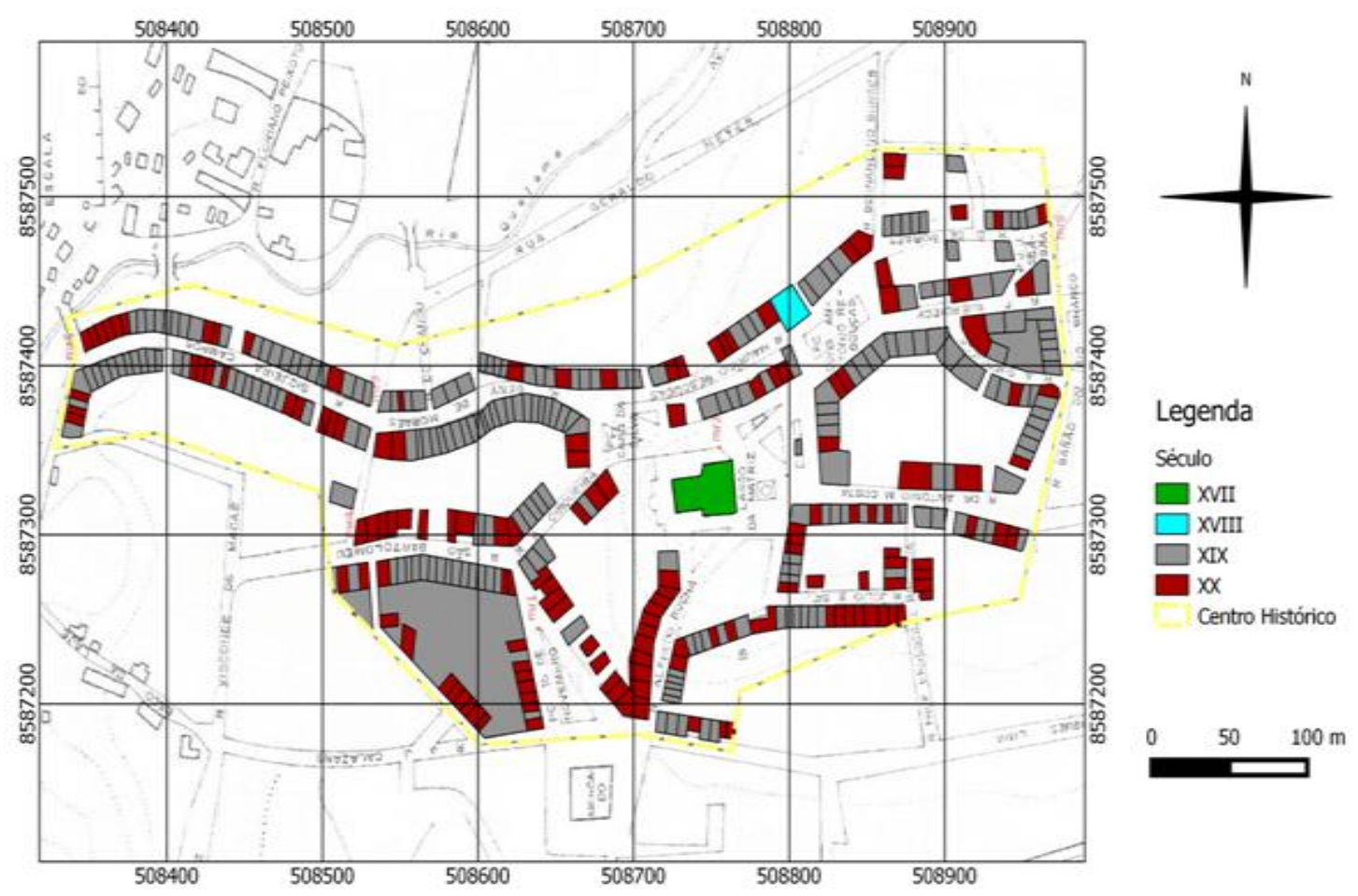

Figura 6.2.4.3 - Centro histórico da cidade de Maragogipe - BA (modificado pelo autor e pelo geógrafo Marcus Fábio (UnB) - Base cartográfica do IPAC, 1982) 
Delimitamos em planta anexa a zona de preservação integral (GP-1), que possiu uma área de 12ha. As demais zonas devem ser definidas oportunamente, mas toda a península deve ser preservada. Dentro da zona (GP-1) estão compreendidas 15 ruas, 5 praças e algumas encostas arborizadas. Nesta área estão localizados 382 imóveis, onde vivem 1.385 pessoas. A Matriz de São Bartolomeu, situada no topo da colina, emerge como grande destaque do casario do centro histórico, constituído de sobrados e casas originárias do século XIX. Destacam-se, ainda, a Casa de Câmara e Cadeia e alguns sobrados, [...] (BAHIA, 1982, p. 188).

Sobre a igreja Matriz de São Bartolomeu e a Casa de Câmara, já falamos anteriormente. Sobre o casario mencionado destacamos o sobrado azul, Figura 6.2.4.4:

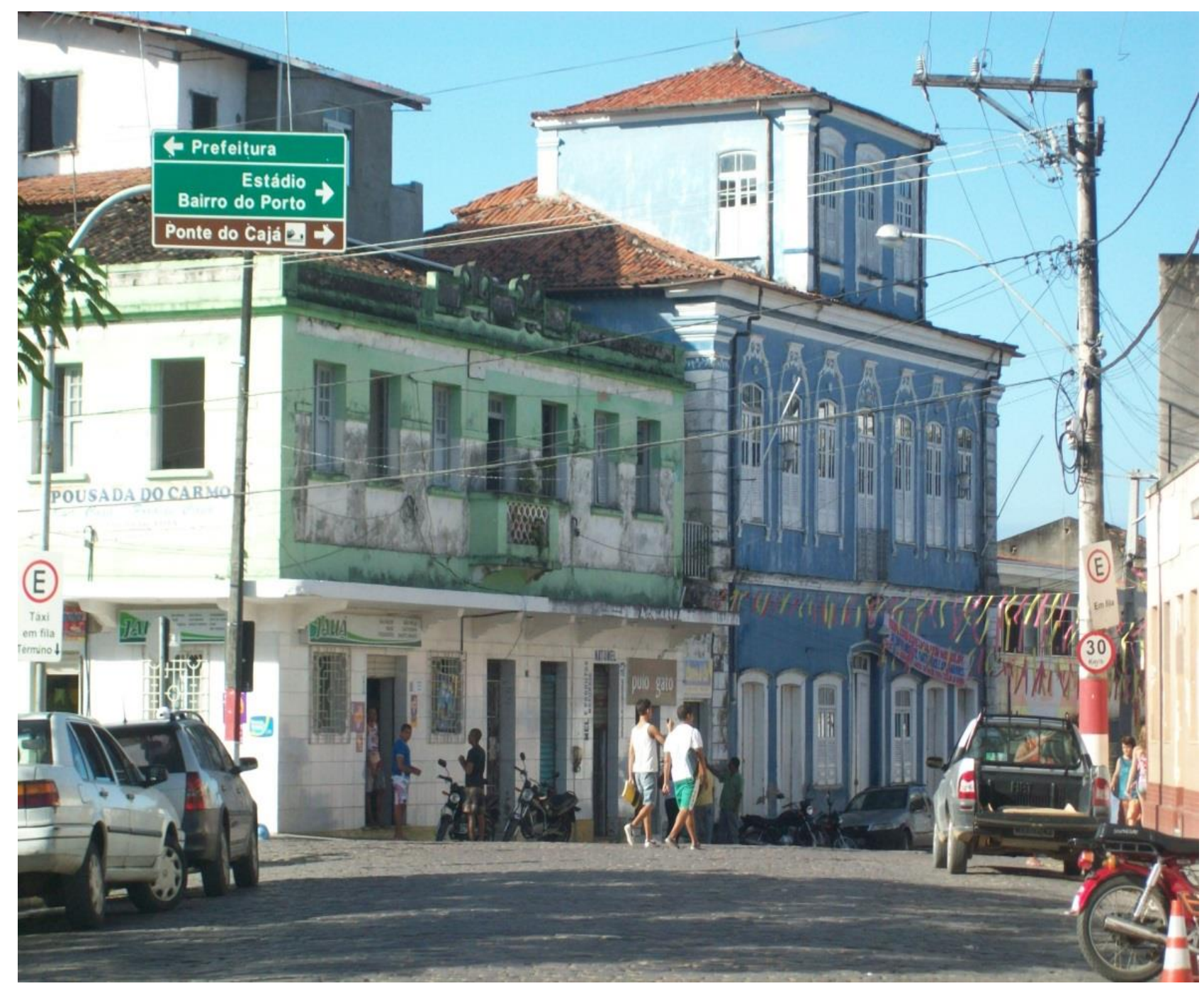

Figura 6.2.4.4 - Casario no centro histórico de Maragogipe - BA (Imagem do autor em trabalho de campo, 2013) 
O sobrado azul da foto, Figura 6.2.4.4, se destaca na paisagem urbana do centro histórico de Maragogipe e está caracterizado pelo inventário do IPAC, com as seguintes características tipológicas:

Sobrado com sótão-mirante, provavelmente do início do século XIX. Este elemento, de origem medieval, foi introduzido na Bahia no início do século XVIII em conventos de freiras, tendo-se difundido, pouco depois, em casas nobres de Salvador, como os solares Boa Vista e Barão do Rio Real e na casa à rua do Saldanha $n^{\circ} 25$. No interior sua popularização se deu no século XIX, especialmente em S. Amaro, Cachoeira, S. Felix, Nazaré e Maragogipe [...] (IPAC, BAHIA, 1982).

Da descrição acima podemos tirar algumas conclusões: 1- o modelo característico de padrão de uma narrativa espacial onde a forma exibia o conteúdo socioeconômico local e regional; 2- a ideia de moda de época e padrões de construções que denotam uma rede de ideias, absorvidas por construtores de diferentes áreas.

\subsubsection{Santo Amaro}

Segundo Tavares (2008), a vila de Nossa Senhora da Purificação foi criada em 1724, por Vasco Fernandes César de Menezes, governador-geral. O município de Santo Amaro foi estabelecido em 1727 e a vila foi emancipada à condição de cidade em 1837. Seu território foi emancipado do de São Francisco do Conde. Sua povoação data da segunda metade do século XVII e tem sua origem na capela beneditina homônima (BAHIA, 1982).

A cidade está situada no interior do Recôncavo, na zona de sedimentação cretácea da fossa tectônica que forma a Baía de Todos os Santos, se expandindo em terraços do rio Subaé, cuja navegação é feita por pequenas embarcações até a altura de Santo Amaro. A cidade, Figura 6.2.5.1, se desenvolveu como porto fluvial e entreposto regional do comércio (BAHIA, 1982). 


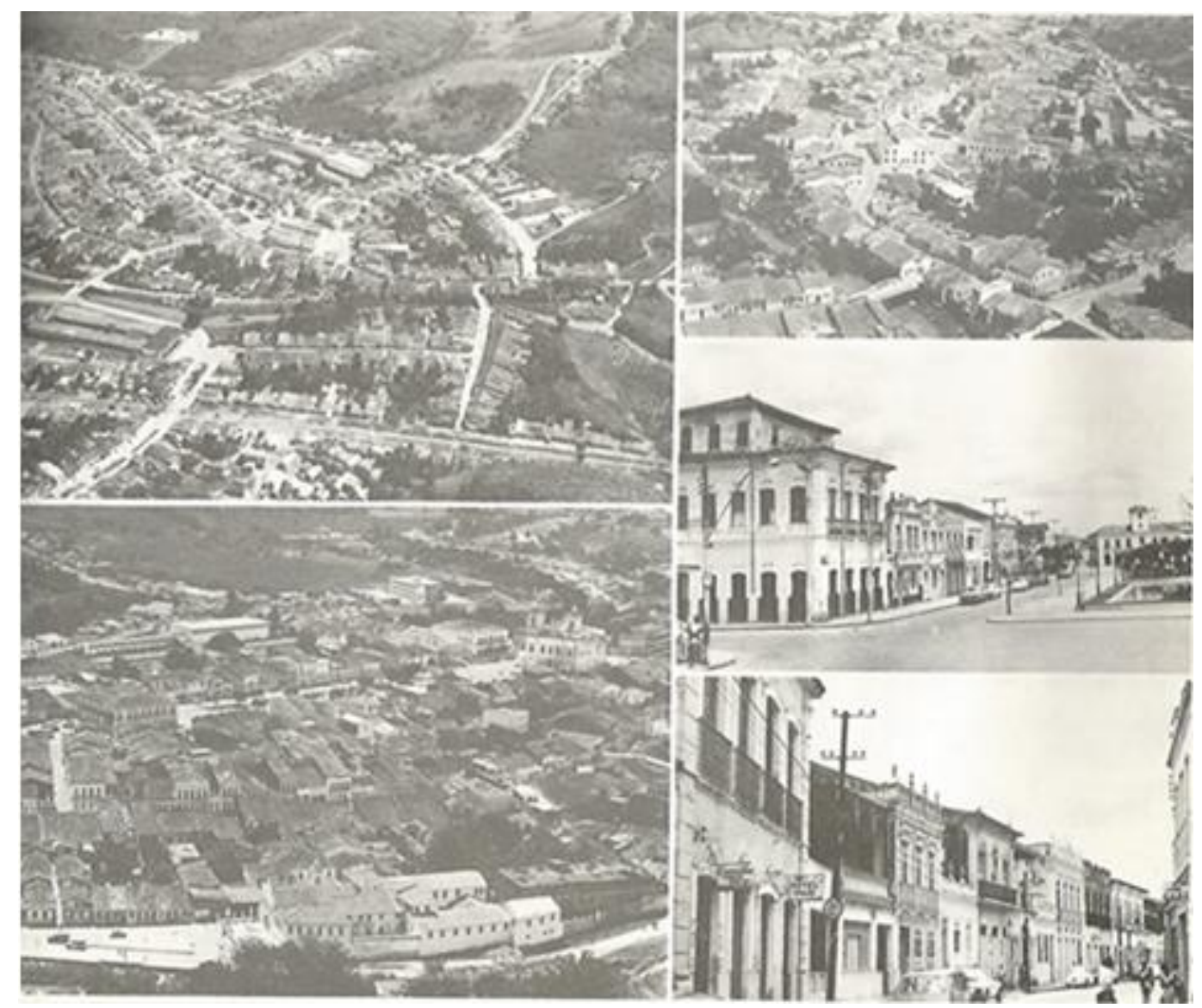

Figura 6.2.5.1 - Cidade de Santo Amaro - BA, década de 1970

(BAHIA, 1982, p. 97)

Em 1847 foi estabelecida a navegação regular a vapor entre a cidade e a capital. Em 1855, Santo Amaro foi acometida por uma epidemia de choleramorbus, proveniente de Cachoeira. Estima-se que metade da população urbana morreu. A cidade teve papel destacado em movimentos emancipacionistas como a Revolução dos Alfaiates, Sabinada e lutas pela Independência. Quando da Guerra do Paraguai a cidade enviou três batalhões de Voluntários da Pátria, num total de 1.290 homens, além de vultuosos recursos financeiros (BAHIA, 1982).

Desde o século XVI até finais dos anos de 1970, a economia de Santo Amaro esteve primordialmente associada a cultura da cana. Em 1757, segundo a Relação do Vigário José Nogueira da Silva, existiam 61 engenhos no município. Em 1870, ainda sobravam 31.

Com um porto situado dentro do continente, em plena zona de solos de massapê, Santo Amaro arrebatou de São Francisco do Conde a condição de entreposto regional e passou a ser o porto açucareiro por excelência do Recôncavo. Villhena (1969) observou que em 1802, duas estradas terminavam em Santo Amaro. Uma na direção norte, que adentrava os sertões até o 
Maranhão, e outra que em direção sul, proveniente de Minas Gerais. O município produzia também fumo e algodão (BAHIA, 1982).
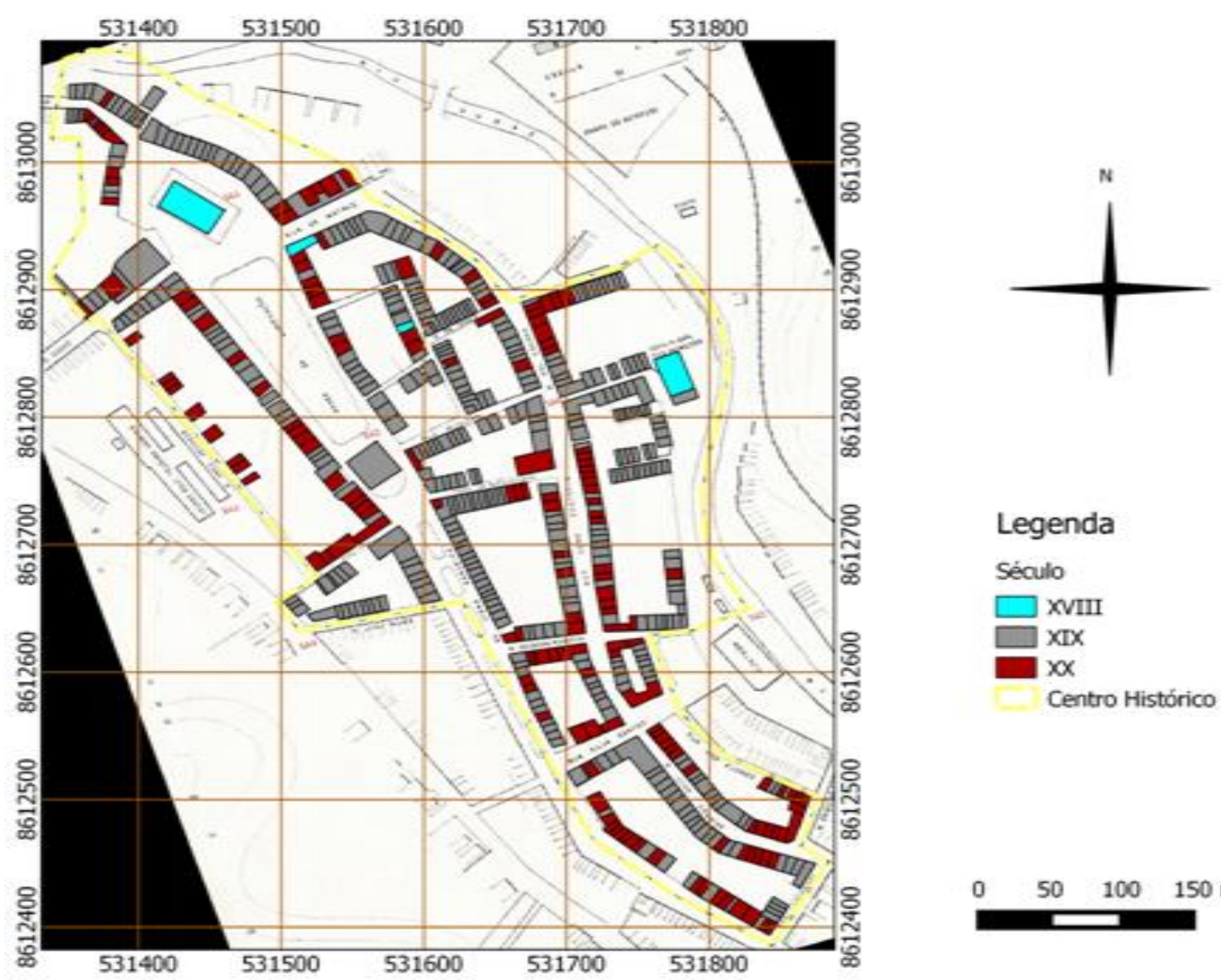

Figura 6.2.5.2 - Centro histórico da cidade de Santo Amaro - BA

(BAHIA, 1982, modificado pelo autor e pelo geógrafo Marcus Fábio (UnB) - Base cartográfica do IPAC)

A planta do centro histórico da cidade de Santo Amaro, Figura 6.2.5.2, nos dá uma dimensão da extensão daquela área, demonstrando uma grande dinâmica no século XIX, devido ao grande número de sobrados e casarões históricos, como ainda atualmente pode ser vista na foto a seguir, Figura 6.2.5.3. 


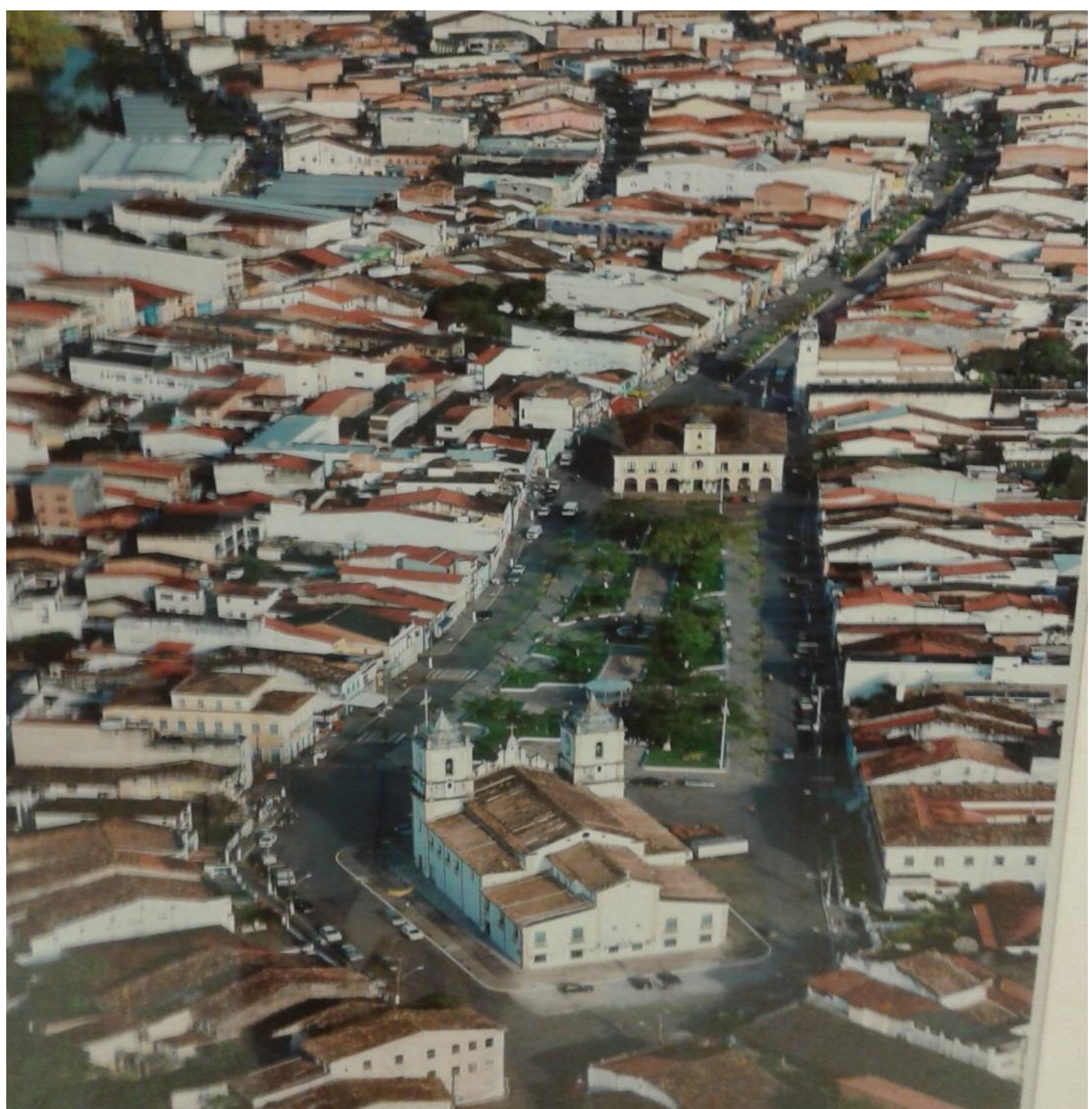

Figura 6.2.5.3 - Vista panorâmica da cidade de Santo Amaro - BA na atualidade (GAMA, 2015)

$\mathrm{Na}$ descrição da planta do centro histórico, Figura 6.2.5.2, o inventário do IPAC (BAHIA, 1982) diz o seguinte:

A povoação nascida em torno da capela de Santo Amaro, começou a se transferir a partir de 1700 , para o núcleo formado pela Pr. Nsra. da Purificação, onde estão localizadas a matriz e a Casa de Câmara e Cadeia (figura acima) [...] Sua tipologia é composta, porque formada de duas matrizes lineares separadas pelo rio. [...] O centro histórico delimitado em anexo, (acima) compreende 27 ruas, a Pr. De N. sra. da purificação, a ribeira direita do subaé e 631 edifícios. Delimitou-se apenas a zona GP-1 que mede 15,41 há, ficando as demais zonas para serem definidas oportunamente. O 
centro histórico apresenta traçado irregular, proveniente do século XVIII. Seu conjunto arquitetônico é formado por casas e sobrados de meados e final do século XIX. [...] Os edifícios relevantes, em número de 12, são do meado do século XVIII e início do seguinte [...] (BAHIA, 1982, p. 96, grifo nosso).

\subsubsection{Nazaré}

A vila de Nazaré foi estabelecida mais tarde em 1831 e elevada à condição de cidade em 1849 (BAHIA, 1982).

A dinâmica socioeconômica de Nazaré no contexto regional do Recôncavo Baiano sempre esteve atrelada à sua localização geográfica estratégica a beira do rio Jaguaripe, no ponto final do seu trecho navegável. A partir daí esta cidade se tornaria um sub centro regional importante junto à rede urbana do Recôncavo.

Segundo Adan (2012), Nazaré crescia,

[...] fruto da demanda contínua de cana-de-açúcar, fumo e gêneros alimentícios, através da consolidação de outros espaços regionais: a zona canavieira, a zona fumageira e a zona mandioqueira, tendo como centros as vilas de Santo Amaro, Cachoeira e Nazaré, respectivamente (ADAN, 2012, p. 52).

Todas as três cidades acima mencionadas localizam-se às margens de rios que desaguam na Baía de Todos os Santos. O Subaé, que corta a cidade de Santo Amaro, o Paraguaçú, que banha Cachoeira e o Jaguaripe, onde se situa a cidade de Nazaré no seu último ponto navegável. Todas essas vilas, desde o século XVIII, exerceram papel fundamental no processo de escoamento da produção oriunda de sub-regiões do Recôncavo e dos sertões da Bahia. Eram portos fluviais importantíssimos no contexto regional além Recôncavo e formaram uma dinâmica rede urbana.

Nazaré, que ficou conhecida como Nazaré das Farinhas, “[...] desenvolveu-se mais rapidamente do que Jaguaripe por ser o porto fluvial dos produtos da lavoura de subsistência de suas terras e das terras acima do rio Jaguaripe (rios da Dona e Jaguaripe)" (TAVARES, 2008, p. 157). As vilas de Jaguaripe e Nazaré também se tornaram conhecidas produtoras de farinha de mandioca. 
Para termos uma ideia da importância da rede urbana formada por essas vilas - que posteriormente, no século XIX, emanciparam-se para a condição de cidades -, e, em especial, de Nazaré, nos séculos XVIII e XIX, Adan (2012) chama a atenção de que:

[...] Esta última, sobretudo, merece atenção especial pela sua importância como centro dinamizador do processo de ocupação da região meridional do Recôncavo e do Vale do Jiquiriçá, constituindo-se como importante produtora e comercializadora de gêneros alimentícios destinados ao mercado de Salvador ainda nos finais do século XVIII, antes mesmo de se converter em vila, o que só veio a acontecer em 1831. A persistência na tradição oral de seu singular epíteto, Nazaré "das farinhas", é uma evidência da expressividade dessa atividade na região, e mesmo da sua importância para o abastecimento da capital. (ADAN, 2012, p. 52).

Graham (2013, p. 138), em obra que trata da história do abastecimento alimentar da cidade de Salvador, informa que $43 \%$ da farinha de mandioca consumida ali era fornecida pelos municípios de Jaguaripe e Nazaré. Segundo este autor “[...] embarcações que transportavam farinha de mandioca partiam sobretudo de áreas dos extremos sul e sudoeste do Recôncavo, onde o solo era relativamente arenoso e as plantas de mandioca se desenvolviam bem". Este pesquisador também nos revela que aos sábados, na "cidade comercial de Nazaré", cerca de 10 mil a 12 mil alqueires de farinha eram vendidos naquele dia da semana (GRAHAM, 2013, p. 138). Na Figura 6.2.6.1, podemos ter uma ideia do conjunto do patrimônio arquitetônico da cidade em tela. 


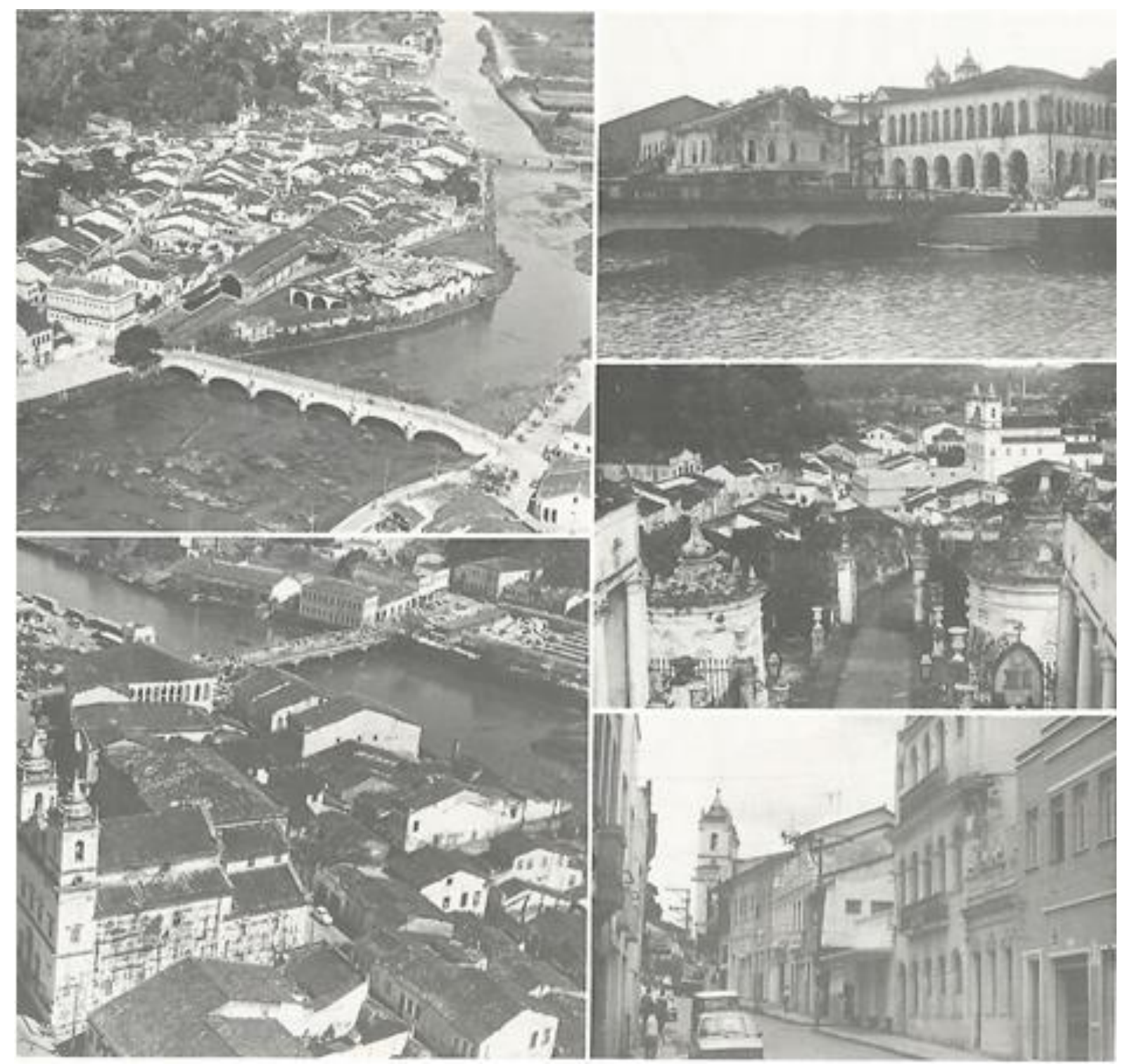

Figura 6.2.6.1 - Cidade de Nazaré - BA, década de 1970 (BAHIA, 1982, p. 243)

Na imagem da Figura 6.2.6.2, dá para ter uma ideia da intensa movimentação do porto de Nazaré em 1860, pelo elevado número de embarcações atracadas. Eram saveiros que faziam o transporte de pessoas e mercadorias para outros portos da região e, principalmente, para a cidade do Salvador. 


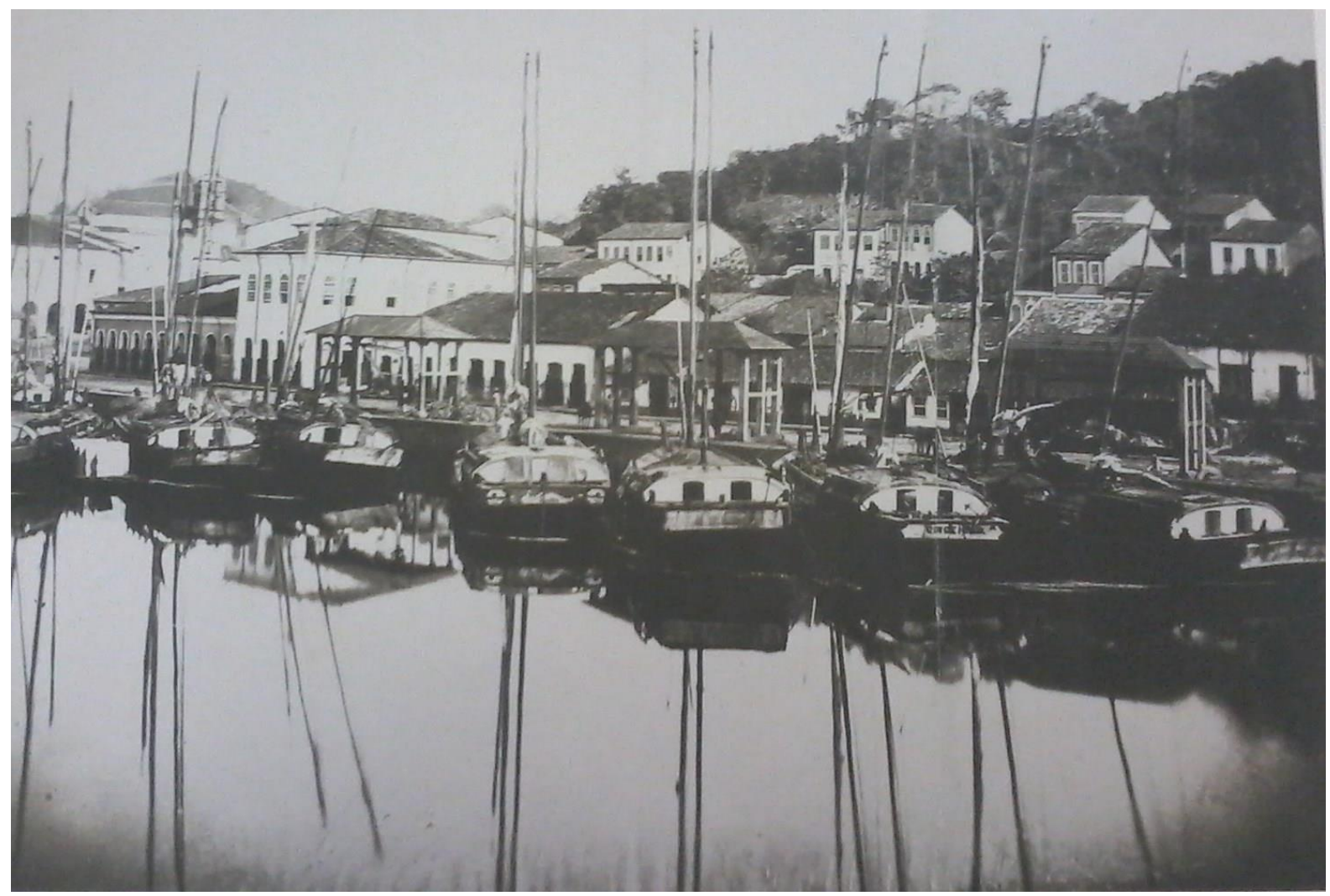

Figura 6.2.6.2 - Saveiros atracados no porto de Nazaré - BA, 1860 (FERREZ, 1988)

Adam (2012), com base em Sampaio (2008), comenta a questão do papel de Nazaré e sua centralidade na economia de abastecimento para o funcionamento do complexo regional do Recôncavo, articulado pela implantação da navegação a vapor e das ferrovias, ficando notório,

[...] o fato de essa municipalidade ter sido um dos pontos estruturantes do processo de construção das novas dinâmicas territoriais que emergiram na região a partir da segunda metade do século XIX, influenciadas, sobretudo, pela introdução das ferrovias e da navegação a vapor [...] (SAMPAIO, 2008, apud ADAM, 2012, p. 53).

Nesse contexto de aparelhamento técnico do território, a partir da implantação de meios de transportes mais rápidos e integrados. Assim,

[...] Nazaré via sua centralidade sub-regional crescer, a partir da segunda metade do século XIX, à medida que se constituía em ponto final da ferrovia Tram Road Nazareth, que percorria a região drenando em sua direção a produção realizada no Médio Rio de Contas e no Vale do Jiquiriçá. 
Paralelamente, era através do seu porto que tal produção era escoada para Salvador por meio dos paquetes a vapor que singravam o mar da baía, integrando essas regiões ao circuito produtivo do Recôncavo e cristalizando a influência das cidades portuárias sobre os territórios a seu redor (SAMPAIO, 2008, apud ADAN, 2012, p. 53).

Percebe-se na descrição acima que o autor fala de uma espécie de consolidação da influência das cidades portuárias sobre o seu entorno. Ou seja, cada cidade portuária, além de manter uma intensa relação entre elas, iam além disso, polarizando outras vilas no interior da região e suas respectivas freguesias, povoados etc.

Para Adan (2012), a evidência da importância da cidade de Nazaré ainda no cenário da Bahia oitocentista estava na concentração de instituições e serviços urbanos,

[...] entre os quais merece destaque a criação em 1831, da Irmandade da Santa Casa da Misericórdia de Nazaré, por iniciativa dos senhores pertencentes as mais abastadas famílias locais, compostas de proprietários de terras e comerciantes (TAVARES apud ADAN, 2012, p. 53).

O prédio que serviu de sede da referida Irmandade até 1888, atualmente ainda funciona como Hospital e permanece preservado. Tal fato evidencia a importância desse equipamento urbano para a cidade e para o seu entorno até os nossos dias. Na Figura 6.2.6.3 pode-se perceber a monumentalidade de sua obra em estilo neoclássico. 


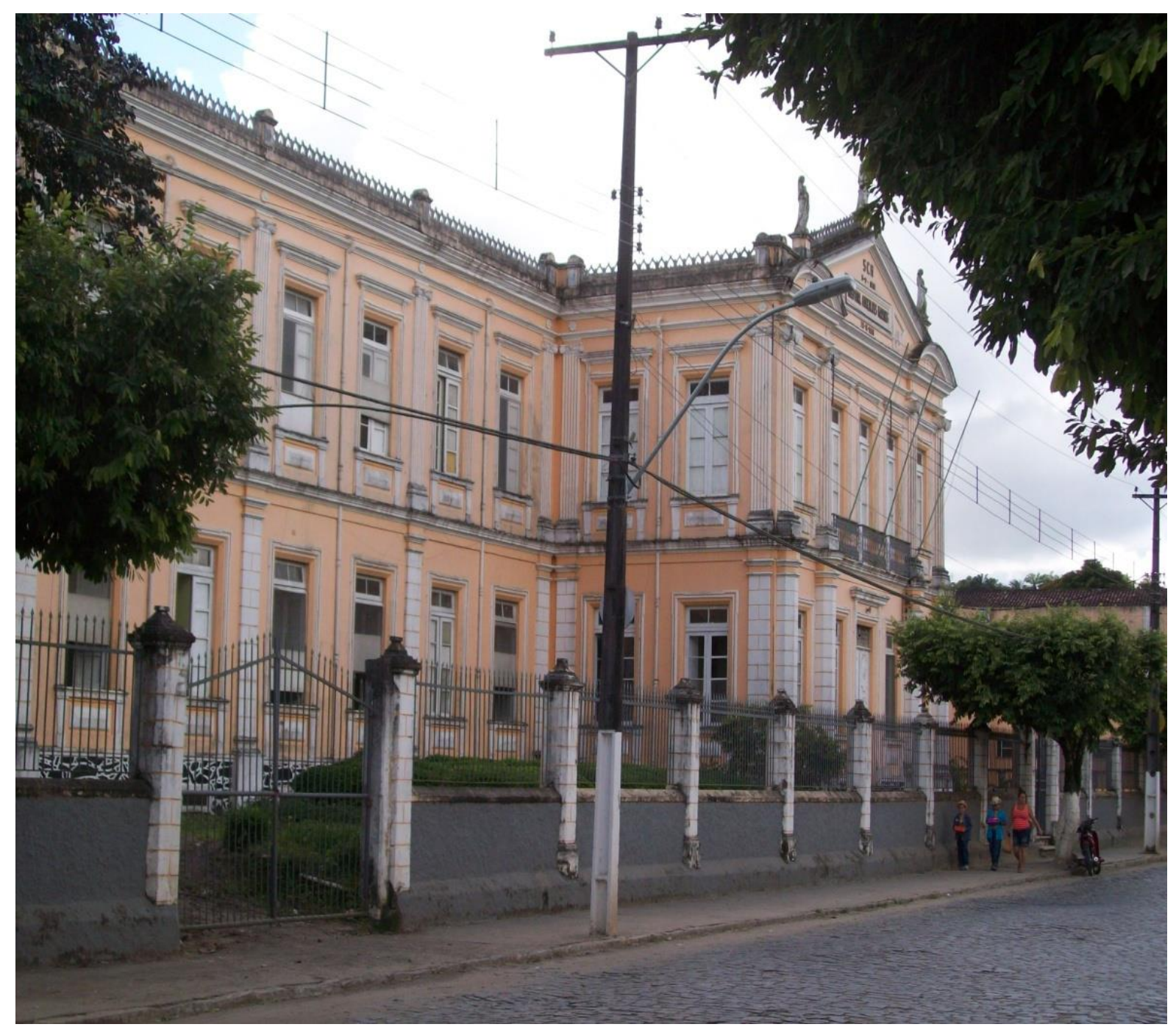

Figura 6.2.6.3 - Prédio onde funcionou a Santa Casa de Misericórdia de Nazaré - BA, atual Hospital Gonçalves Martins

(Imagem do autor em trabalho de campo, 2012)

Em texto publicado no Encontro Internacional ARQUIMEMÓRIA 4, sobre a preservação do patrimônio edificado, ocorrido na cidade do Salvador, Silva (2013) ${ }^{14}$ tratou do patrimônio edificado da cidade de Nazaré, buscando compreender sua organização espacial na sua paisagem urbana. A partir de uma contextualização do ambiente urbano o estudo analisou

\footnotetext{
${ }^{14}$ Ver detalhes em SILVA, Luís Cláudio Requião. PATRIMÔNIO EDIFICADO, PAISAGEM URBANA E A RELAÇÃO DE SIGNIFICADO COM A SOCIEDADE LOCAL NA CIDADE DE NAZARÉ-BA. In: Anais do Encontro Internacional ARQUIMEMÓRIA 4: A DIMENSÃO URBANA DO PATRIMÔNIO. 14 - 17 de maio, Salvador - BA, 2013.
} 
o patrimônio edificado da referida cidade, como resultado da produção e organização do espaço geográfico da mesma ${ }^{15}$.

A partir dos resultados dos referidos questionários aplicados em pesquisas de campo, verificou-se que, quanto à representação do patrimônio arquitetônico no contexto da cidade, $6,7 \%$ dos entrevistados o vê como luxo e riqueza; $13,9 \%$ como beleza; $21,8 \%$ como parte da identidade e pertencimento com o lugar; $56,3 \%$ como parte da história do lugar e 1,3 não responderam.

Como se pode perceber a maioria dos entrevistados identifica o patrimônio como algo representativo da história do lugar. Apesar desta identificação isso significa que, o patrimônio não é fator revelador exclusivo do sentido de pertencimento e identidade com o lugar. Outros fatores levam a isso, tais como laços de família, amigos, histórias pessoais etc. Ou seja, o objeto em foco - o patrimônio edificado - é algo que pertence à história da maioria dos entrevistados, mas não à sua própria história, principalmente para a população pobre.

Tendo em vista que 54,3\% dos entrevistados ganham menos que um salário mínimo e, na sua maioria, se declararam afrodescendentes, pode-se ainda inferir que a história de vida desta parcela da população está de alguma forma distante simbolicamente daquilo que a paisagem mais reflete. Isto é, a opulência e monumentalidade do seu patrimônio arquitetônico.

Quanto ao quesito relacionado à importância do patrimônio arquitetônico como representante desta cidade para a região, $85,4 \%$ dos entrevistados consideram que sim; 13,2\% não o consideram importante e $1,3 \%$ não responderam. Neste caso a opinião da grande maioria dos entrevistados demonstra que o patrimônio arquitetônico da cidade expressa a importância da mesma no contexto regional.

\footnotetext{
${ }^{15} \mathrm{O}$ texto tratou da questão da apropriação social na preservação do patrimônio na cidade. Consideramos pertinente abordá-lo nessa altura do texto, para articular o trabalho empírico aos conceitos até aqui mencionados. Com o objetivo específico de buscar identificar a representatividade e o significado do patrimônio para os entrevistados, teve como objetivo adicional, compreender em que medida o patrimônio edificado influenciou no processo de identidade da população com a cidade.

Foi organizada uma pesquisa e aplicados 151 questionários a pessoas residentes em diferentes bairros da cidade. O objetivo foi apreender, através de uma amostra casual, o grau de conhecimento dos questionados em relação ao seu patrimônio histórico edificado. Como o identificam em relação à cidade e o que representa para eles. Para complementar as informações, foram feitas entrevistas semiestruturadas com gestores públicos (Silva, 2013).

O questionário foi estruturado em quatro questões objetivas:

1 - O que representa o patrimônio arquitetônico no contexto da cidade?

2 - Qual a importância do patrimônio arquitetônico como representação desta cidade para a região?

3 - Você considera significativo/importante a preservação do patrimônio para o desenvolvimento da cidade?

4 - Você já ouviu falar em tombamento?
} 
No que se refere ao item conservação do patrimônio arquitetônico e sua influência para o desenvolvimento da cidade, $55 \%$ das respostas revelaram que a conservação do mesmo possui muita influência; 33,1\% acreditam que possui significado razoável; 9,9\% acham que não possui influência alguma e $2 \%$ não responderam. No que diz respeito a essa questão notase que parte significativa dos entrevistados considera a conservação do patrimônio arquitetônico como algo representativo para o desenvolvimento de Nazaré.

Com relação ao termo tombamento, $49 \%$ dos entrevistados nunca ouviram falar; 19,2\% já ouviu falar, mas não sabem o que significa; $29,8 \%$ já ouviu falar e sabe o significado e $2 \%$ não responderam. Neste caso, nota-se uma carência de informação acerca do referido assunto, o que nos faz supor uma falta significativa de políticas públicas voltadas para a questão da educação patrimonial para esta população.

A observação direta e as dimensões das questões inseridas nos questionários aplicados nos trabalhos de campo nas cidades pesquisadas e especificamente no caso de Nazaré, nos fez perceber também a imbricada relação entre patrimônio e o seu simbolismo na vida cotidiana urbana e da relação de sua população no uso do território. É provável que as conclusões retiradas a partir do estudo acima referido (caso de Nazaré) podem ser aplicadas as demais cidades pesquisadas.

Tendo em vista o exposto podemos inferir que a cidade de Nazaré se enquadra no rol das cidades históricas do Recôncavo que exerciam uma centralidade importante no contexto inter e intrarregional do território baiano. Uma localidade em que a densidade dos fluxos de mercadorias e pessoas, por meio de transporte hidroviário e ferroviário produziu um patrimônio edificado que, ao longo do tempo, marca sua paisagem urbana até os nossos dias.

$\mathrm{Na}$ cidade de Nazaré, segundo pesquisa do IPAC realizada em 1982, foram delimitadas a zona de preservação integral (GP-1), Figura 6.2.6.4. Dentro do que o referido estudo denominou de GP-1, foi delimitada uma área de 2,4 ha; estavam aí compreendidas sete ruas e duas praças. Ainda segundo levantamento realizado na pesquisa anteriormente citada, seu acervo arquitetônico era fundamentalmente do século XIX. Dos 92 imóveis que a compunham, $18 \%$ estavam em estado de conservação satisfatório; $64 \%$, em estado medíocre $18 \%$, ruim. Dentre os monumentos considerados mais relevantes estavam a Matriz de Nossa Senhora de Nazaré, o Paço Municipal, além de alguns sobrados inventariados à época (BAHIA, 1982, p. 242) 


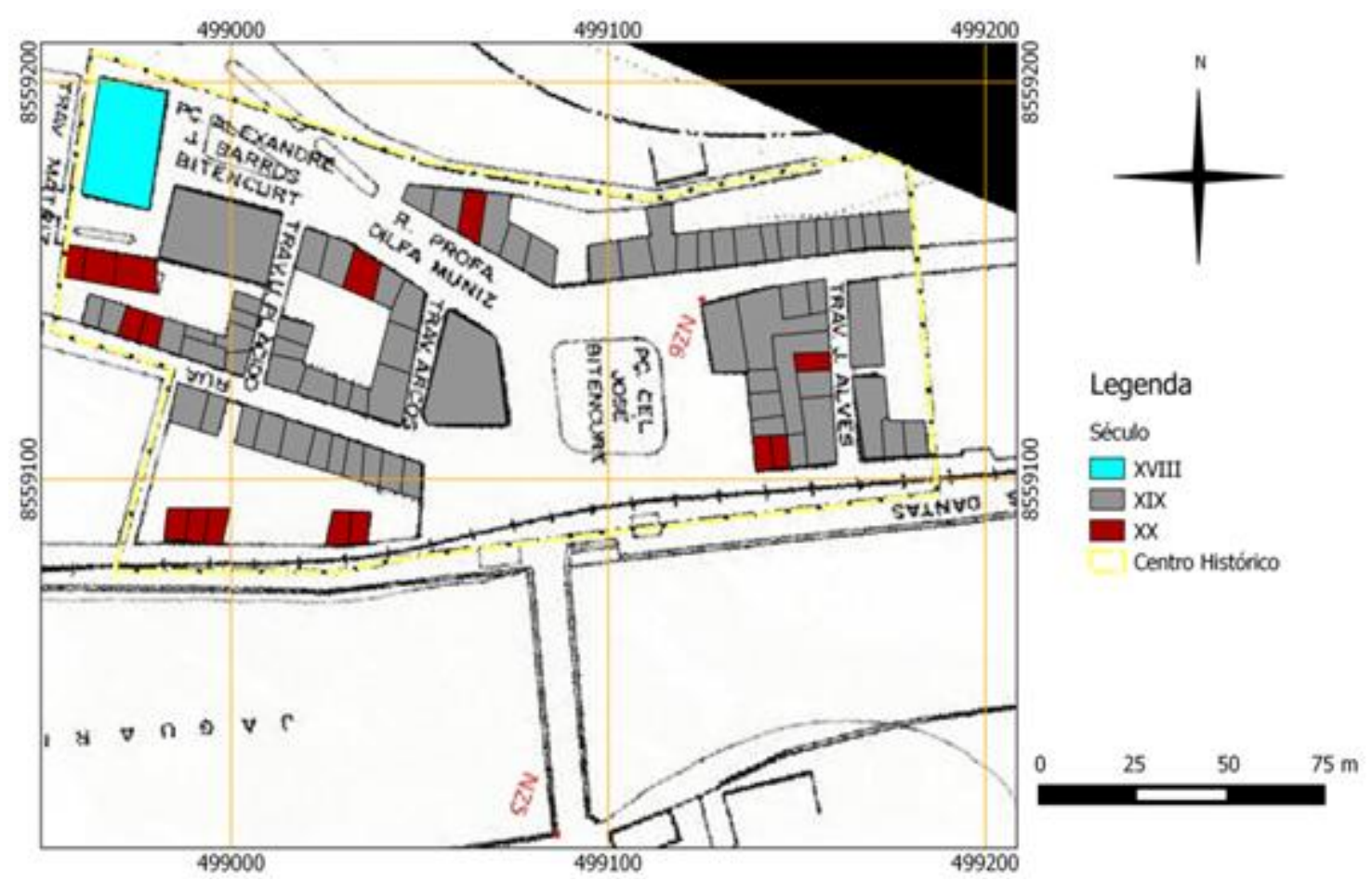

Figura 6.2.6.4 - Centro histórico da cidade de Nazaré - BA

(BAHIA, 1982, modificado pelo autor e pelo geógrafo Marcus Fábio (UnB) - Base cartográfica do IPAC)

\subsubsection{São Felix}

A Freguesia do Senhor Deus Menino de São Felix foi criada em 1857, por Resolução Provincial $n^{\circ}$ 613. O território que formou o município de São Felix foi desmembrado do município de Cachoeira pelo Ato Estadual de 23/XII/1889, pouco mais de um mês depois de proclamada a República. A vila de São Felix foi instalada em fevereiro de 1890 e em outubro do mesmo ano foi elevada à condição de cidade com o nome de São Felix do Paraguaçu (BAHIA, 1982).

De São Felix partia a Estrada das Minas, com destino a cidade de Rio de Contas e aos estados de Minas Gerais e Goiás. O porto de Cachoeira exerceu grande influência para que ali se fixasse o primitivo povoado, ainda no final do século XVI. Tal situação estratégica em relação à estrada e ao porto de Cachoeira, na margem oposta do rio Paraguaçu, tornaram São Felix uma vila dinâmica internamente e complementar à Cachoeira.

Spix; Martius (1916), em viagem pela Bahia, assim descreveram o povoado de São Felix, quando passaram por ali no início do século XIX: 
O porto de São Felix, na margem sul do Paraguassú, por assim dizer, uma parte da grande vila de Cachoeira, situada na margem oposta, e é para essa praça, como também para a da BAHIA, de grande importância como logar de expedição. Numerosas tropas de muares recebem as mercadorias europeias, vindas por via marítima, para transportá-las para o interior do IMPÉRIO. Reina ali a atividade de um porto terrestre, enquanto que na vila de Cachoeira, tudo lembra a proximidade do mar e do comércio marítimo. A vista deste logar, belamente edificado e animado de atividade européa, foi um verdadeiro prazer para nós, que passamos tão grande temporada no sertão. (SPIX; MARTIUS, 1916, p. 35).

A Estrada das Minas favorecia atividade comercial do povoado por onde transitavam tanto os produtos de exportação, como fumo, ouro e diamantes, quanto os manufaturados importados para o consumo interno da vasta região do Recôncavo. Portanto ali, se fez porto complementar ao de Cachoeira, e ponto de distribuição e comércio de produtos oriundos do Sertão e da capital e vice-versa. É durante o século XVIII e primeira metade do XIX, tal como ocorreu em Cachoeira, que a povoação vai experimentar seu maior desenvolvimento, como resultado da intensa atividade comercial (BAHIA, 1982).

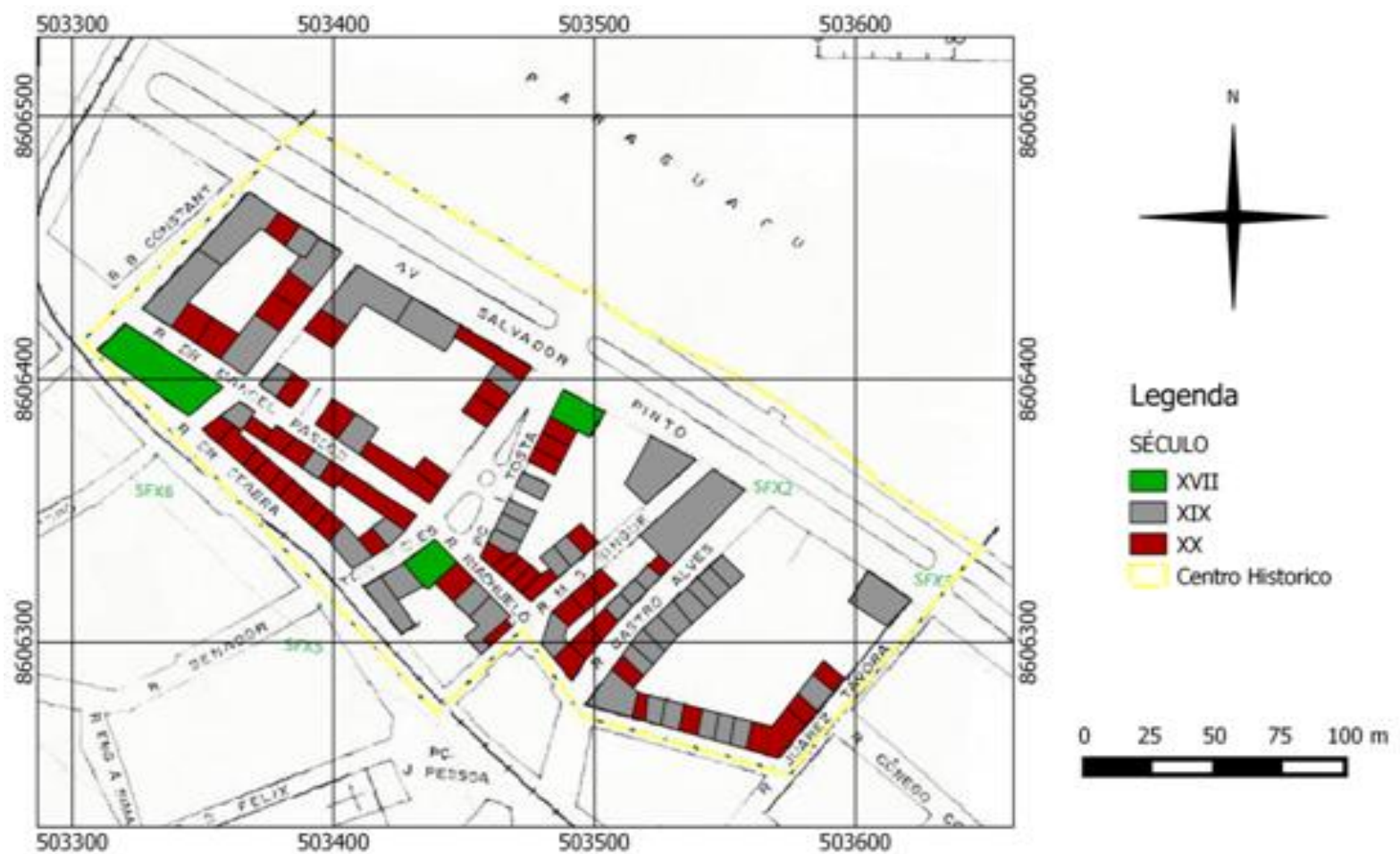

Figura 6.2.7.1 - Centro histórico da cidade de São Felix - BA

(BAHIA, 1982, modificado pelo autor e pelo geógrafo Marcus Fábio (UnB)) 
Sobre a caracterização da planta apresentada, Figura 6.2.7.1, o inventário do IPAC diz o seguinte:

[...] São Felix é uma cidade de tipologia simples, mononuclear, desenvolvida segundo uma matriz nuclear, paralela ao rio. Uma extremidade deste eixo se prolonga em direção a Maragogipe; e a outra, em direção a represa de Pedra do Cavalo, substituta da de Bananeiras. A linha férrea penetra neste eixo, dividindo a cidade em uma estreita parte plana, construída num terraço do rio , e outra, em pendente, com ruas subindo a encosta do vale. Seu centro histórico, classificado com o grau de proteção (GP-1), tem área de quatro há. Dentro desta zona estão compreendidas uma praça, onze ruas e parte da ribeira direita do Paraguaçu. Os 101 imóveis ali situados são na sua quase totalidade do século XIX [...] (BAHIA, 1982, p. 330).

Como podemos perceber, São Felix, Figura 6.2.7.2, se desenvolveu em função do porto de Cachoeira. Devido à natureza de suas terras, mais aptas ao plantio do fumo e às culturas de subsistência, especialmente a mandioca e se integrou ao chamado "Recôncavo de Subsistência" (BAHIA, 1982, p. 329). Entretanto, sua função de entreposto comercial foi muito importante como terminal tropeiro. 


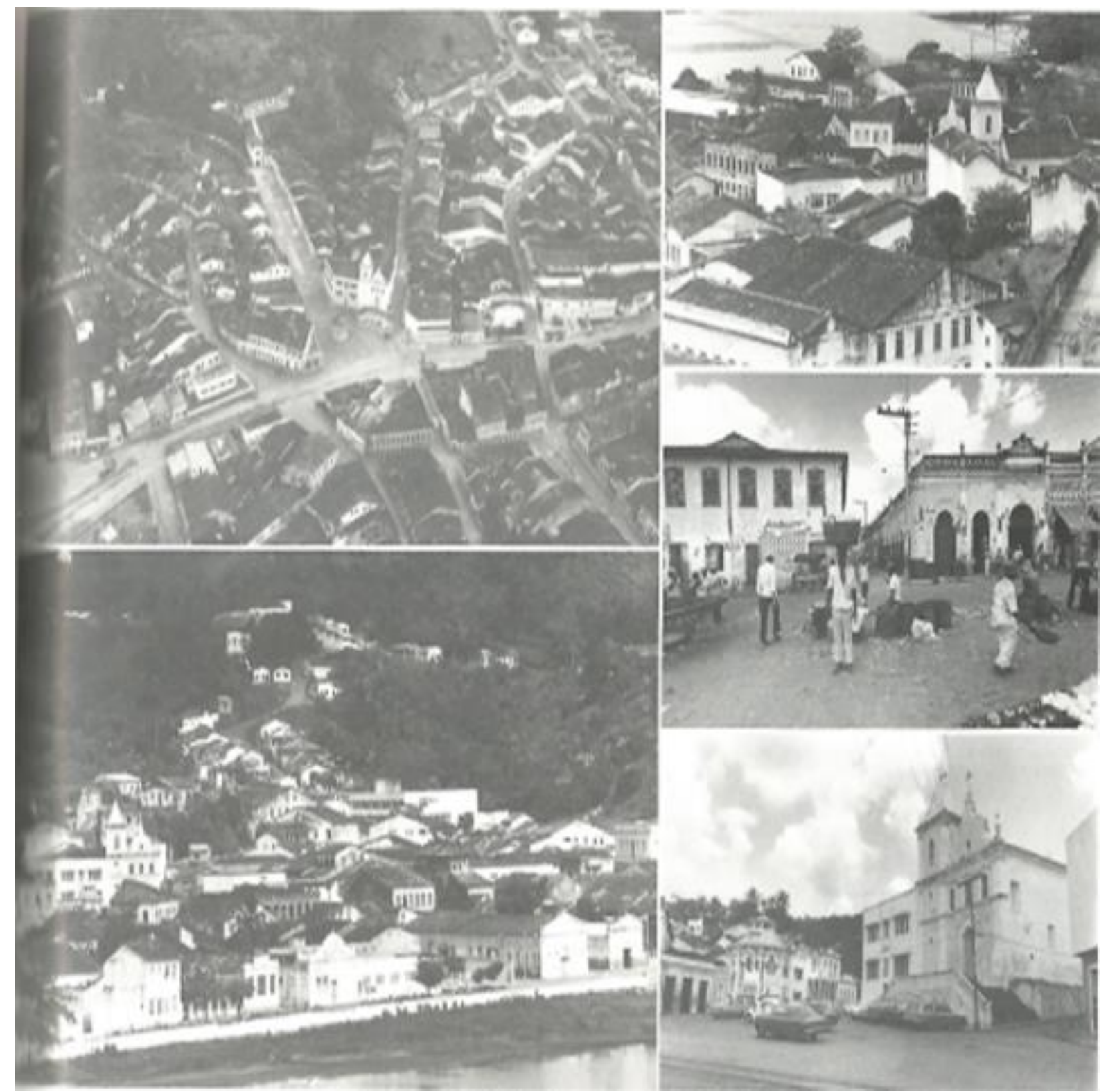

Figura 6.2.7.2 - Cidade de São Felix - BA, década de 1970 (BAHIA, 1982, p. 331)

No painel fotográfico, Figura 6.2.7.2, podemos ter uma ideia da movimentação no centro histórico de São Felix no início da década de 1980. O mercado municipal, a fábrica de charutos Dannermann, a margem do rio Paraguaçu.

Na foto da Figura 6.2.7.3, feita em nossos dias, podemos perceber que a cidade, ainda mantem alguns de seus edifícios históricos, dentre os quais se destaca a igreja Matriz de Deus Menino. 


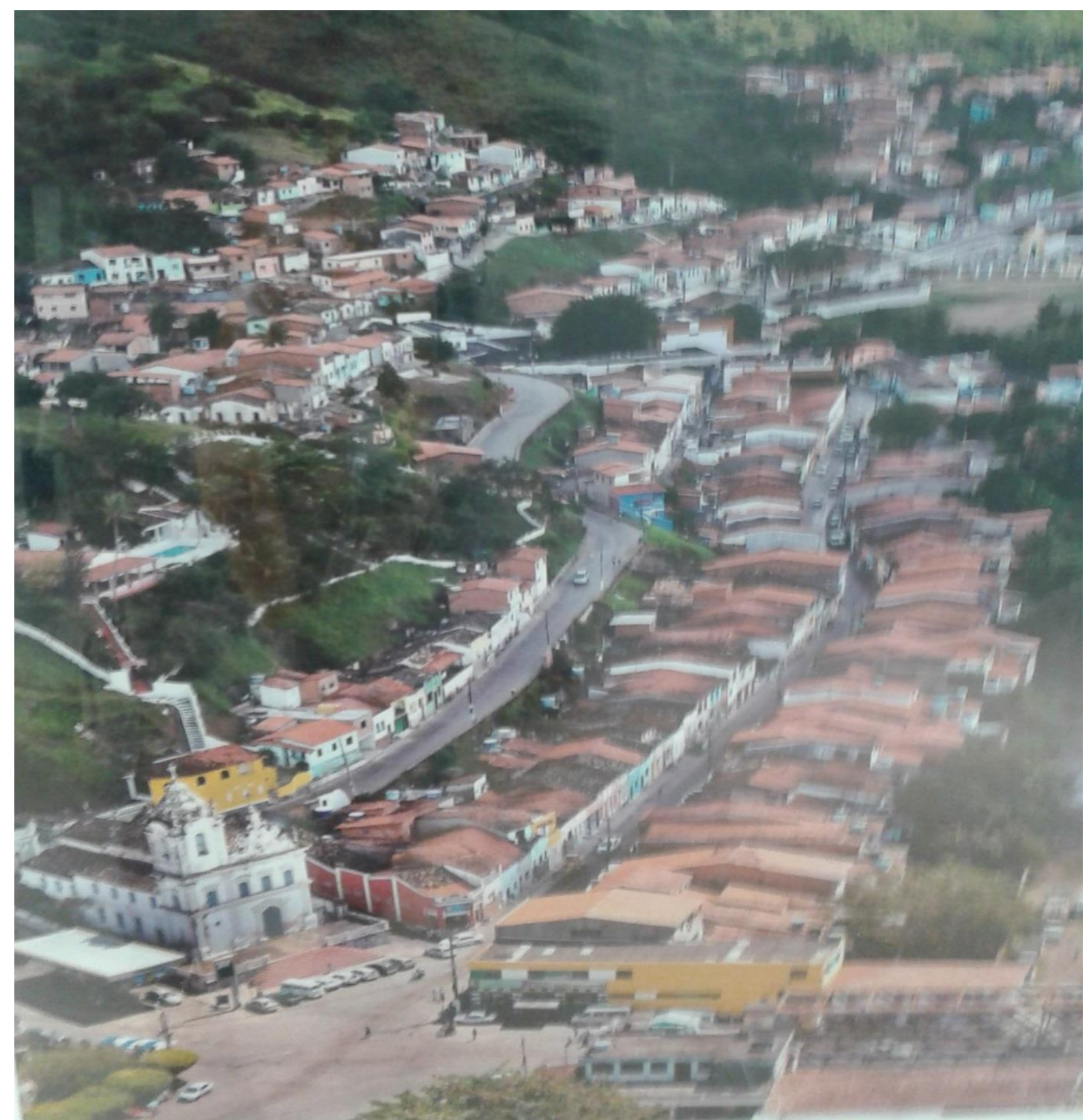

Figura 6.2.7.3 - Vista panorâmica de São Felix na exposição "Quem ama a Bahia", Salvador e o Recôncavo Baiano

(GAMA, 2015)

Buscando fazer um resumo analítico do que foi descrito e investigado na nossa pesquisa e tendo como base principal o Inventário de Proteção do Acervo Cultural da Bahia, IPAC (BAHIA, 1982), as fotos antigas e atuais e a bibliografia consultada, chegamos a algumas conclusões neste capítulo que discorreremos antes das considerações finais.

Ficou evidente que as cidades em tela constituíram uma rede urbana desde o século XVIII, exercendo um papel de centros interiores. Corroboramos com Andrade (2013), quando o mesmo aponta algumas características da referida rede naquele século. O referido autor, 
após detalhado estudo encontrou características próprias no traçado da rede urbana do Recôncavo Baiano, a qual apresenta alguma aproximação com o modelo dendrítico de rede proposto por Corrêa, com base no modelo clássico de Cristaller, quando do período colonial. O referido autor assevera que no referido modelo apontado “[...] há uma distribuição hierárquica rígida entre os centros de diferentes tamanhos (população, valor econômico e político)" (ANDRADE, 2013, p. 108).

Concordamos com a visão de Andrade (2013), para o qual é mais importante perceber a dinâmica que movimenta e comanda a dimensão espacial da referida rede, do que de "encaixá-la em um modelo específico". O referido autor caracteriza da seguinte forma a dinâmica espacial do Recôncavo Baiano no século XVIII, especificando suas principais nodalidades:

Dentre os elementos constituintes da rede, as vilas exerciam o papel de centros interiores. Ao seu redor, diversas povoações se estabeleciam e consolidavam centralidades da malha a que se integravam. Esses conjuntos, compostos pelas vilas e povoações diversas do seu entorno, formavam subregiões no Recôncavo Baiano, espaços com uma maior integração dentro da rede urbana regional e, normalmente, com algum nível de especialização da produção (ANDRADE, 2013, p. 110).

Portanto, o autor supracitado detectou como principais nodalidades e suas áreas de influência imediata da rede urbana do Recôncavo Baiano, quatro conjuntos, além daquele formado por Salvador/recôncavo oriental/ litoral atlântico norte / Ilha de Itaparica. São eles: Santo Amaro (vila) e São Francisco do Conde (vila); Cachoeira (vila), Belém (povoado), São Felix (porto da freguesia de São Pedro do Monte) e Muritiba (sede de freguesia); Maragogipe e Iguape (povoado); Jaguaripe e Nazaré das Farinhas (ANDRADE, 2013).

Entretanto à medida que nos distanciamos deste período (século XVIII), aumentam as peculiaridades das características da referida rede que mais a distanciam do que a aproximam da rigidez daquele modelo. Ou seja, no século XIX percebemos uma maior autonomia dos centros urbanos e redirecionamento de suas vidas de relações, imbricados aos mais diversos fatores endógenos e exógenos, tais como questões ao desenvolvimento de infraestrutura regional de transportes e vias de comunicação, assim como efeitos nas economias locais por fatores inerentes às mais diversas causas, desde conflitos internos e externos à região até a introdução de outros produtos de exportação e consequente mudança de direcionamento do eixo produtivo do país. A questão da cultura do café, por exemplo, no sul do país, como foi 
apontado neste trabalho e as oscilações de preços de produtos como o açúcar e o fumo (tabaco), causaram impactos importantes no conjunto da região nordeste do país e de suas sub-regiões, como foi o caso do Recôncavo Baiano.

Já abordamos anteriormente neste capítulo, e no anterior, sobre as dinâmicas específicas e integradas dessas nodalidades, quando falamos da região e das cidades portuárias especificamente. O estudo sobre a rede urbana do Recôncavo Baiano nos da uma ideia da coesão regional, para o qual uma visão da rede foi indispensável.

Essa ideia de rede e de coesão regional dos territórios nos aproxima das questões que mais nos interessam e norteiam este trabalho. Ou seja, a questão da concomitância temporal na produção do espaço urbano; da complementaridade entre eles e da similaridade do patrimônio urbano. Isto é o que buscamos comprovar, para daí sustentarmos a ideia, segundo a qual, houve uma produção simultânea dos territórios das sete cidades históricas portuárias do Recôncavo Baiano, produzindo uma narrativa espacial própria que denota um sentido de coesão regional e de identidade social.

Pelo número de imóveis inventariados pelo IPAC (BAHIA, 1982), e através da visualização das plantas de delimitação dos centros históricos das cidades em tela e de toda pesquisa bibliográfica anteriormente realizada, ficou evidente que as dinâmicas socioespaciais de cada uma delas tiveram rebatimentos no espaço geográfico e na configuração dos seus territórios urbanos.

Das sete cidades pesquisadas, houve uma verdadeira "explosão" de imóveis erigidos ao longo do século XIX em seis delas, exceto em Jaguaripe, onde o acervo arquitetônico do centro histórico era constituído por 112 imóveis, dos quais apenas cinco foram considerados como de "relevante interesse arquitetônico", originários do século XVII e XVIII (BAHIA, 1982). Este fato demonstra que nesta cidade, apesar de sede de um dos maiores municípios do estado na atualidade, não acompanhou o desenvolvimento das demais. Isso se deve à sua localização geográfica e às mudanças estruturais relacionadas à evolução dos meios de transporte, beneficiando outras localidades como Nazaré, situada em local estratégico, no último trecho navegável do rio Jaguaripe, em conexão com a malha ferroviária da época.

Cachoeira foi a cidade que mais prosperou, tendo o seu auge econômico no século XIX, quando a produção do seu patrimônio urbano/edificado. Atualmente é cidade que apresenta as melhores condições de preservação do seu patrimônio urbano/edificado, pois foi a primeira e única cidade da região integrada aos grandes projetos de preservação em escala nacional, através do IPHAN, considerada como Patrimônio Histórico Nacional. 
Todas as sete cidades pesquisadas apresentam similaridades de forma e concomitância temporal na ereção de sua tessitura urbana, com a grande maioria de seus edifícios erigidos no século XIX, como pode ser visto na descrição e análise das plantas dos centros históricos e das fotos anteriormente exibidas.

A atual situação do patrimônio edificado da maioria das cidades do Recôncavo Baiano impressiona e chama a atenção não só pela monumentalidade dos templos católicos, mas também pela arte e sutileza da construção civil e decoração interna de suas igrejas, com seus diversos estilos arquitetônicos de diferentes épocas (século XVIII, XIX e XX). Esses períodos incluem diversos estilos tais como o maneirista, barroco, rococó, neoclássico e eclético.

Chama a atenção também o péssimo estado de conservação, a degradação e o arruinamento da maioria dos prédios residenciais na paisagem urbana destas cidades, exceto Cachoeira. Desde a década de 1980, o inventário do IPAC, já sinalizava para este fato, quando da caracterização dos imóveis registrados nas plantas dos centros históricos e daqueles que foram inventariados e caracterizados em suas tipologias arquitetônicas.

Os fatos apontados acima revelam a carência de programas e projetos de grande envergadura, no sentido de incrementar na população uma cultura de reconhecimento e respeito ao seu ambiente de vivência. A degradação e arruinamento do casario histórico e alguns prédios eclesiásticos, salvo algumas exceções, são algumas das características atuais de suas paisagens urbanas. Fato que revela a falta de projetos relacionados à educação patrimonial nessas localidades.

Através de fotos atuais e de época e a contagem do número de prédios erigidos no século XIX buscamos remeter a ideia, segundo a qual ainda é possível identificar as peculiaridades, tais como as similaridades de formas; concomitância temporal na ereção dos edifícios que permanecem na paisagem urbana dessas cidades e que justificam novos modelos de intervenções, para a preservação da memória urbana da região do Recôncavo Baiano.

A narrativa espacial regional que se constrói na relação com a paisagem nela contida, o patrimônio urbano de natureza material, com seu acervo histórico arquitetônico, é uma realidade na memória e nas ações de alguns agentes sociais. A afirmação acima pode ser comprovada pelas exposições visitadas, e cujos alguns dos conteúdos iconográficos foram apresentados no corpo deste trabalho ${ }^{16}$.

\footnotetext{
${ }^{16}$ Foram quatro exposições visitadas na cidade de Salvador com os seguintes temas: 1 - "QUEM AMA A BAHIA”, SALVADOR E O RECONCAVO BAIANO: pelas lentes do fotografo Osmar Gama, exposição de fotografias num shopping da cidade em 2015; 2 - DIÓGENES REBOUÇAS 1914 - 2014, exposição sobre a obra
} 
É importante salientar a questão da relação entre a dinâmica econômica e a noção de progresso no processo de preservação da memória urbana, atrelada à conservação do patrimônio edificado. Neste sentido, determinados períodos de estagnação econômica seria, para além da decadência do cenário urbano, uma forma de sua preservação, ao retirar determinada cidade do centro da vida econômica, do progresso, então atrelado à noção de transformação. Todas as cidades pesquisadas passaram por diferentes períodos de dinamismo e estagnação que impactaram de maneira positiva e negativa, o seus conjuntos urbanísticos e arquitetônicos.

Exemplo emblemático sobre a questão acima mencionada é a presença da Petrobrás em São Francisco do Conde. A existência da mesma e o reflexo do PIB, não são sinais, de fato, de maior condição de salvaguarda. Constatamos pelo inventário do IPAC e em pesquisa de campo, que a referida cidade é a que menos conservou bens erigidos no recorte temporal da pesquisa e na atualidade.

Adiante teceremos mais alguns comentários no âmbito da conclusão deste trabalho, buscando dar sentido e demonstrando a viabilidade da nossa tese.

do artista do mesmo nome, no Museu de Arte da Bahia, situado numa das mais tradicionais artérias da cidade, em 2014, que mostrou a obra pictórica do referido artista, com ricas telas sobre a paisagem urbana de Salvador no século XIX; 3 - a exposição de Diógenes Rebouças, acima referida, também foi apresentada em forma de plotagem das mesmas telas, numa exposição ao ar livre, na área em frente ao Farol da Barra, monumento tradicional de Salvador, no âmbito da inauguração das obras de requalificação do bairro da Barra, um dos mais tradicionais da referida cidade. 4 - a exposição ROTA DA INDEPENDÊNCIA, no Cento Histórico da cidade, em 2013, quando retratou através de fotos o patrimônio e a paisagem urbana das cidades do Recôncavo Baiano no processo de Independência do Brasil, na Bahia. 


\section{7 - CONCLUSÃO}

$\mathrm{Na}$ atualidade as cidades em tela trazem inseridas em suas paisagens, heranças dos traços de sua formação socioeconômica e cultural. Algumas delas, enquanto são articuladas à dinâmica de uma sociedade globalizada, conseguem manter seus registros históricos valorizados e preservados. Outras, em áreas de economia tradicional e dependentes de fontes endógenas limitadas, encontram dificuldades para preservar sua cultura material. Em consequência, tende a ocorrer uma degradação mais intensa e acelerada do patrimônio urbano, na forma de seus conjuntos arquitetônicos e urbanísticos e monumentos isolados, comprometendo a estética de suas paisagens urbanas, além da memória e a identidade do seu povo.

Com representativa paisagem urbana, essas cidades são reveladoras de contextos e dinâmicas dos processos socioeconômicos nos períodos colonial, imperial e republicano da história brasileira. Trata-se de exemplo da convivência entre as transformações e as permanências de edificações de grande valor histórico e simbólico.

As paisagens de uma maneira geral e, especificamente, as paisagens urbanas em nossa concepção, são mosaicos de imagens, onde é possível captar diversas temporalidades e formas que se expressam no patrimônio cultural material. É o registro da temporalidade num mesmo lugar, que podem ou não ficar impressas na paisagem, através da materialidade construída em diferentes períodos. Umas são mais resistentes que outras e estão condicionadas pela dinâmica socioespacial do país e suas reverberações nas regiões e cidades que as compõem.

A paisagem não se explica por si só, ela necessita do conhecimento histórico e geográfico da formação socioespacial subjacente, e pode ser percebida na dimensão física, simbólica, política e ideológica. Portanto, ao se fazer a leitura da paisagem, associando-a a dimensão urbana, cultural e política do espaço geográfico, discutiu-se também o sentido do patrimônio. Portanto, o termo "paisagem" foi empregado como conceito estruturante; "paisagem cultural", como conceito mediador e "paisagem urbana" como categoria de análise, assim como o patrimônio urbano/edificado e território usado.

Diante do exposto é perceptível que a instalação dos edifícios mais representativos no processo de organização dos territórios, tais como as Igrejas Matrizes e Casas de Câmara e Cadeia das sete cidades históricas portuárias do Recôncavo Baiano, foram pré-concebidas. 
Em todos os lugares existem paisagens únicas e mutáveis, transformações e permanências, mas em alguns deles elas são mais resistentes ao tempo. É como se ele (o tempo) e também o espaço, permanecessem imutáveis aos olhos de quem observa suas formas.

No processo de observação das paisagens urbanas o sujeito tende a criar uma narrativa própria, a partir de outra pré-existente. Mesmo em se tratando de uma perspectiva para a análise e interpretação científica, baseada em documentos bibliográficos e iconográficos de registros de épocas pretéritas.

São duas narrativas que se cruzam. Uma é oriunda da "fala" do próprio território, sua dimensão cultural e, consequentemente, ideológica e política sob a qual aquele espaço foi concebido. Outra é a impressão de quem as percebe, impulsionada pelo conhecimento teórico e empírico do objeto. Uma leitura posterior à implantação da materialidade e às funções inerentes às mesmas ao longo do tempo.

Afirmamos isso com base na análise atual daquelas cidades onde foram implantadas as praças com funções políticas e administrativas, após a implantação das primeiras sedes de freguesias com funções religiosas em sítios próximos ou mesmo adjacentes.

Além disso, como foi visto no esquema de localização do núcleo de ocupação histórica de cinco vilas mais antigas (Jaguaripe, Cachoeira, São Francisco do Conde, Maragogipe e Santo Amaro), da figura 6.5, observa-se que as mesmas apresentam uma narrativa espacial comum, que denota em suas formas e funções, a estrutura social e política daquela época. As funções iniciais a que se propunham as Casas de Câmara e Cadeia e Igrejas Matrizes são o maior exemplo dessa intencionalidade. Assim, entendemos que daí surge a própria "fala" do território e as maneiras do seu uso. Isto é, as suas formas urbanas são a expressão da cultura material e simbólica de uma época, com suas variações de padrões em tempos longos.

A dinâmica socioeconômica no Brasil produziu cidades com uma urbanização muito semelhante, apesar das distâncias e das diferenças culturais de cada região. No caso do Recôncavo Baiano, o processo de produção e organização do espaço geográfico de suas cidades históricas, sua morfologia urbana, assim como sua estrutura social se deu de forma muito peculiar, devido à intensa integração sub-regional entre os seus centros urbanos, desde a época colonial.

A partir dos elementos estruturantes da produção e organização urbana portuguesa e sua influência nas cidades brasileiras, tomando como base empírica, o caso de Salvador, constatamos que nas cidades mais antigas do Recôncavo, especialmente aquelas localizadas 
no interior da Baía de Todos os Santos e às margens dos rios que nela desaguam, o processo de estruturação urbana não foi muito diferente. Isto é, por se tratar de cidades oriundas dos primeiros núcleos de povoamento do território brasileiro, as mesmas possuem também uma estruturação da malha urbana similar à de Salvador, que era a "cabeça" de seu hinterland e foi estruturada a partir de suas praças, em diferentes momentos de seu desenvolvimento.

É possível inferir que, tendo em vista a comprovada existência de uma rede urbana que se formou ao longo do século XVIII e que no final deste mesmo século o fenômeno urbano, apesar de incipiente, já era evidente, fica clara a influência entre as sete cidades em tela no que diz respeito à organização espacial, padrão construtivo e estilos arquitetônicos, que se mostram similares, além de erigidos num mesmo período. O que não quer dizer que os edifícios tenham sido construídos na mesma data.

Portanto, entendemos que - no final do século XVII e ao longo de todo o século XVIII - houve uma produção similar e concomitante dos territórios urbanos das cinco primeiras vilas instaladas no Recôncavo Baiano, especialmente no que diz respeito às instalações de prédios públicos com função política e administrativa (Casas de Câmara e Cadeia) e dos prédios com função religiosa/“civilizatória” (Igrejas Matrizes). Ou seja, aquilo que estamos chamando de produção simultânea dos territórios num determinado período histórico.

Além disso, é possível inferir também que, existiram influências de estilos que partiram de modelos oriundos do Recôncavo Baiano para Salvador, e não apenas o inverso. Como foi o caso da igreja de São Francisco, em Salvador, descrita por Bazin (1956, p.169), como uma "evolução do tipo de Cachoeira e Maragogipe", como já vimos anteriormente, inferindo que as duas últimas foram instaladas antes da primeira. E também sobre sua fachada, copiada de um outro convento franciscano da Bahia, existente na atual cidade de São Francisco do Conde.

Ainda sobre a similaridade de padrão arquitetônico religioso barroco na Bahia, Bazin (1956, p. 171) nos informa que no segundo terço do século XVIII, são empreendidos diversos templos religiosos. E que, “[...] sendo o principal elemento das igrejas, as fachadas se mantem fiéis ao princípio cuja gênese nos é mostrada em Maragogipe [...]”.

Portanto, podemos admitir que as influências de padrões arquitetônicos partissem também das importantes vilas do Recôncavo para Salvador, e não apenas o contrário. Ou seja, de Salvador para as vilas do Recôncavo. Fato que pode ilustrar uma possível concomitância temporal e troca de informações ao longo do processo de construção dos edifícios, tendo em 
vista o tempo de até 20 a 30 anos para ser concluída totalmente a construção de algumas igrejas, nessa época.

Como vimos, Nazaré e Jaguaripe prosperaram com a produção e comercialização da farinha de mandioca, enquanto que Santo Amaro e São Francisco do Conde, primeiramente tiveram associadas à produção e comercialização do açúcar e produtos derivados. Posteriormente, essas duas últimas passaram por diferentes fases na sua história comercial. Entretanto, todas elas devido à localização estratégica tiveram importância fundamental enquanto conjunto, criando uma rede de entrepostos comerciais, com intensa vida de relações intra e inter-regional, devido aos seus portos. A exceção foi Jaguaripe, que perdeu suas funções devido à situação estratégica de Nazaré.

Esses sistemas vão aos poucos se expressar na paisagem urbana das futuras cidades portuárias da região. Isto é, paulatinamente e concomitantemente, essas vilas e posteriormente cidades, vão dotando seus territórios de infraestrutura logística e de equipamentos urbanos, tais como atracadouros, portos, estaleiros, e, posteriormente, estações ferroviárias.

Além disso, a circulação, acumulação e reprodução do capital oriundo dos referidos sistemas produtivos vão produzir na paisagem urbana, um patrimônio cultural de natureza material bastante rico e diversificado. Referimo-nos aqui ao patrimônio edificado propriamente dito. Seja na forma de monumentos eclesiásticos, civis e institucionais isolados; seja na forma de conjuntos arquitetônicos e urbanísticos residenciais.

Tais atividades foram inerentes às necessidades de estruturação da vida de relações intraurbana, interurbana e, portanto, da produção e organização do espaço geográfico da região. Tudo isso é fruto da construção de infraestruturas necessárias ao funcionamento das atividades relacionadas a essa dinâmica socioespacial, principalmente nas escalas local e regional.

As permanências históricas do patrimônio na paisagem urbana atual das cidades em tela, assim como os documentos históricos de concepção de instalação dos monumentos pesquisados, nos dão pistas importantes para o entendimento da história da produção e organização do espaço urbano das mesmas. Estamos considerando que a paisagem expressa elementos da história do território, materializada em suas formas e que, no caso do Recôncavo Baiano houve uma produção simultânea do patrimônio das referidas cidades em tela.

As permanências de conjuntos arquitetônicos e urbanísticos inteiros, além dos monumentos isolados, no contexto do seu patrimônio urbano, sua paisagem é o registro de 
uma cultura material e simbólica da região, produzida num determinado período histórico. É a paisagem cultural/urbana que, por si só, expressa uma narrativa espacial própria.

Ficam evidentes pela descrição e pelas imagens obtidas, as semelhanças de padrões arquitetônicos entre as Casas de Câmara e Cadeia das cinco primeiras vilas instaladas no Recôncavo Baiano. Além disso, admite-se também que existiu uma grande influência de ideias, subsidiadas por condições socioeconômicas num mesmo nível; assim como condições políticas que permitiam um mesmo padrão de construções e de estilo arquitetônico.

Constatamos, portanto, que as paisagens urbanas dessas cidades revelam uma parte da sua história. A história que restou em suas permanências, materializadas nos territórios. São núcleos urbanos reveladores, principalmente, de sua relação com o mundo rural, cujo capital se reproduziu nos seus conjuntos urbanísticos, deixando para posteridade a monumentalidade de seus elementos mais significativos. Tanto do ponto de vista da materialidade de seus edifícios que mais resistiram ao tempo e as mazelas do progresso, como no sentido de sua revelação simbólica para a memória e identidade regional. Por outro lado, fica claro que a outra parte da história não pode ser contada apenas pelo que está apresentado pela materialidade do território.

Algumas das cidades pesquisadas, guardadas as devidas proporções de seus papeis como entrepostos no contexto regional prosperaram e, assim como Salvador, com o progresso, aumentaram a dimensão de suas malhas urbanas. Seus casarios e monumentos também aumentaram em número e na forma, como foi o caso de Cachoeira. Entretanto, o progresso nem sempre foi sinônimo de preservação. Muito pelo contrário! Outras sofreram mais intensamente com o processo de mudanças na dinâmica socioeconômica e socioespacial, ficando à margem do progresso regional.

Jaguaripe, por exemplo, é o caso mais evidente, quando a partir do século XIX, começa a perder importância com o surgimento de outro núcleo estrategicamente mais viável para o escoamento da produção regional, como foi o caso de Nazaré. Paradoxalmente, em alguns casos, a letargia da dinâmica econômica ou a falta dela, pode ter ajudado a manter o seu patrimônio, desgastado apenas pelo tempo e pela falta de manutenção de seus monumentos.

A produção e a organização espaciais dos territórios das cidades em tela revelam também as estratégias de suas concepções pelos agentes hegemônicos da época. Inicialmente a Coroa portuguesa, a Igreja e os grandes proprietários de terras. Posteriormente, os agentes urbanos, públicos e privados: o Estado na forma de seus prepostos administrativos e a 
sociedade de forma geral (comerciantes; profissionais liberais, trabalhadores cativos e libertos, sociedade civil organizada etc.). Estes agentes concretizaram a história geográfica dos territórios, com sua presença física e simbólica em cada uma daquelas cidades.

Consideramos que as cidades históricas portuárias do Recôncavo Baiano, foram tão importantes quanto as cidades históricas mineiras no processo de formação da nossa identidade nacional, visto seu acervo cultural de natureza material e imaterial que carregam como herança. Entretanto é visível a falta de manutenção e mesmo de arruinamento de grande parte dos prédios históricos das cidades baianas, especialmente, Jaguaripe, São Francisco do Conde, Maragogipe, Santo Amaro, Nazaré e São Felix. Ou seja, por enquanto só a cidade de Cachoeira sofreu intervenções significativas no âmbito da salvaguarda do seu conjunto urbanístico.

$\mathrm{Na}$ descrição geohistórica, socioeconômica e cultural das cidades pesquisadas, percebemos que foi no período do recorte temporal desta pesquisa, que a rede formada entre elas se consolidou de forma mais dinâmica, conectadas por uma maior fluidez dos fluxos de mercadorias e pessoas entre seus territórios, especialmente no que concerne à cadeia produtiva da indústria do açúcar e do fumo. É também nesta época que grande parte de seu patrimônio edificado foi erigido e as vilas, sedes dos municípios, elevadas à condição de cidades.

O crescimento da intensidade da dinâmica dos fluxos de rede e o maior volume de fixos se deram no século XIX, com o aparelhamento técnico do território, principalmente entre as primeiras cidades da região e o interior do país, especialmente o sertão, mas também com o litoral Sul da Capitania (posteriormente Província e Estado da Bahia). Ainda nessa escala (regional) a relação com Salvador era preponderante desde os primórdios de formação da referida rede, pois dali se expandiria para a escala internacional, com as exportações através do seu porto.

Assim, no século XIX, se consolida a produção simultânea dos territórios daquelas cidades, principalmente dos grandes conjuntos urbanísticos/arquitetônicos de grande valor artístico e estético em cada uma delas. Entretanto todos eles erigidos simultaneamente, com uma linguagem única, demostrada pelos padrões de seus conjuntos de casas, sobrados, arruamentos etc.

Portanto, dinâmica econômica, patrimônio urbano/edificado e paisagem se interrelacionam de forma dialética, pois são ao mesmo tempo causa e efeito das relações entre sociedade e espaço, reproduzindo no patrimônio material e imaterial relações sociais, culturais 
e de identidade ao longo do processo de consolidação da cultura regional e produção material de sua paisagem.

A existência de peculiaridades marcadas pelas similaridades das paisagens urbanas das cidades históricas portuárias do Recôncavo Baiano, expressas principalmente no patrimônio edificado, oriundo de diferentes momentos da história regional, confirma a ideia, segundo a qual, o patrimônio edificado é a síntese de variadas épocas, revelando o dinamismo socioeconômico de cada uma delas e aspectos culturais, políticos dessas sociedades.

Sendo assim, o que denominamos de narrativa espacial regional das cidades históricas portuárias do Recôncavo Baiano é fruto da concomitância temporal do processo de produção e organização espacial, além da complementaridade socioeconômica entre essas cidades. Processo revelado pelos conjuntos arquitetônicos e urbanísticos e monumentos isolados, que reforça a ideia de coesão cultural material e simbólica similar no processo de produção simultânea de seus territórios urbanos.

Guardadas as devidas peculiaridades sub-regionais entre diferentes pontos do Recôncavo Baiano no que tange à dinâmica socioeconômica, entendemos que o patrimônio edificado é a evidência mais contundente e expressiva da cultura material da região. Ou seja, uma paisagem cultural urbana que expressa uma narrativa espacial própria, a qual buscamos identificar, analisar e interpretar, gerando a nossa narrativa.

A partir dos resultados do trabalho de campo, confirmamos que, no período estudado, grande parte do patrimônio edificado dessas cidades foi erigida simultaneamente, revelando uma coesão do processo de produção e organização espacial, associado a um desenvolvimento socioeconômico regional em concomitância em cada localidade. Tal fato reforça inclusive o sentido de rede urbana.

Não obstante, constatarmos também que parte do que estamos considerando como uma narrativa comum entre estes centros históricos se perdeu ao longo do tempo e, na atualidade a descaracterização, o arruinamento decorrente da falta de manutenção dos prédios históricos, especialmente de caráter residencial em Salvador e seu Recôncavo, se perderam no tempo. Ou seja, houve uma perda de parte da cultura material em seis das sete cidades pesquisadas, especialmente, Maragogipe, Santo Amaro, São Felix, Nazaré, Jaguaripe e São Francisco do Conde.

Trabalhamos com a ideia de paisagem produzida como resultado do território usado. Por isso, utilizamos conceitos e categorias de análise da ciência geográfica que se 
complementam e ajudam a entender a composição de elementos que se inserem nos processos de produção das cidades e região analisadas.

Dessa forma, concluímos que foram identificadas nesses territórios, as peculiaridades materiais que denotam a concomitância temporal de sua produção material. O que nos leva a perceber a identidade regional daquela área e a produção simultânea dos territórios urbanos das cidades históricas portuárias da região do Recôncavo Baiano, resultando numa narrativa espacial regional própria.

Pesquisas em fontes do IPHAN revelam que a preservação do patrimônio e sítios históricos priorizou os monumentos de forma isolada e não os conjuntos urbanos como um todo.

No Brasil as intervenções do IPHAN desde a sua criação, na década de 1930, nas diversas regiões do país, especialmente na perspectiva de tombamentos isolados e registros fotográficos realizados por aquele órgão ao longo das décadas de 1960 e 1970, revelam que pouco foi feito no sentido de uma intervenção mais abrangente dos conjuntos urbanos.

Em artigo publicado no maior jornal de circulação do Norte e Nordeste do país, Lourenço Muller ${ }^{17}$, queixa-se da invisibilidade da cidade de Salvador no cenário nacional. Segundo o mesmo, sua importância é minimizada, quando toda a riqueza de patrimônio material e imaterial desta cidade, que possui o "provável" maior conjunto arquitetônico colonial das Américas, é sucumbida na sua importância pela maior rede de TV do país, que prefere o Rio de Janeiro, “[...] mostrado ao mundo como a cidade de mais visibilidade do Brasil [...]". Enquadramos esta posição, no sentido de que tal invisibilidade se estende para o conjunto das sete cidades portuárias do Recôncavo Baiano.

As cidades históricas portuárias do Recôncavo Baiano também foram negligenciadas do imaginário nacional, no que diz respeito à sua importância no contexto histórico de formação urbana do país. Mesmo na Bahia, onde tiveram importância fundamental, como apoio logístico e estratégico nas batalhas para a independência da província e, consequentemente, para a conclusão da independência do Brasil, não lograram o devido lugar na história do país.

Entretanto, no que se refere aos monumentos de caráter religioso e administrativos e, em alguns trechos das cidades, em alguns sobrados, ainda é possível identificar valores materiais de relevância histórica, fundamentais para consolidação de uma narrativa, na qual o

\footnotetext{
${ }^{17}$ MUELLER, Lourenço. O patrimônio invisível de Salvador. A TARDE, Salvador, 9/3/2014, p A2.
} 
próprio patrimônio se encarrega de expressar a produção e a organização espacial no recorte temporal a que se propôs a pesquisa.

Enfim, consideramos que os conceitos e categorias de análise da Geografia (paisagem, região e território) aqui articulada aos conceitos de patrimônio, cultura, identidade e memória, mesmo que alguns destes vistos de forma subliminar nos interstícios do estudo, são preponderantes para uma proposta mais abrangente e propositiva de salvaguarda de uma área numa escala regional, pelos diversos motivos expressos na pesquisa.

Sugerimos um movimento de salvaguarda num modelo integrado entre municípios, estado e União, numa visão de intervenção territorial em escala regional da paisagem cultural. Uma forma de consórcio entre os poderes executivos municipais, para que juntos possam ter mais força política e visibilidade perante possíveis ações por parte das demais instâncias de poder, através do IPAC e do IPHAN.

Acreditamos que ainda é possível reverter esse quadro atual de degradação da paisagem urbana das cidades em tela, desde que haja uma intervenção urgente por parte do poder público, no sentido da salvaguarda da região e das cidades em tela.

Finalmente, pretendemos que esta tese sirva como subsídio, dentre outras tantas já publicados sobre o Recôncavo, para pleitearmos, através do IPHAN, uma intervenção junto à UNESCO, no sentido de dar a Região o título de Patrimônio Mundial para a Paisagem Cultural. 


\section{REFERÊNCIAS BIBLIOGRÁFICAS}

ABREU, Maurício de. Sobre a memória das cidades. In: CARLOS, A. F. A.; SOUZA, M. L.; ESPÓSITO, M. E. B. (Orgs). A produção do espaço urbano: agentes e processos, escalas e desafios. São Paulo: Contexto, 2012. p. 19-39.

. Pensando a cidade no Brasil do passado. In: CASTRO, I. E.; GOMES, P. C. C.; CORRÊA, R. L. (Orgs). Brasil: questões atuais de reorganização do território. Rio de Janeiro: Bertrand Brasil, 2005. p. 145-184.

Cidades: Espacialidades e temporalidades. In: CARLOS, A. F. A.i; LEMOS, A. I. G. (Orgs). Dilemas urbanos: novas abordagens sobre a cidade. São Paulo: Contexto, 2003. p. 97- 98.

- Prefácio. In: VASCONCELOS, Pedro de Almeida. Salvador: transformações e permanências (1549 - 1999). Ilhéus: Editus, 2002.

ADAN. Caio Figueiredo Fernandes. A Dinâmica cultural contemporânea nos territórios de identidade do Recôncavo, do Vale do Jiquiriçá e do Baixo Sul. In: Panorama cultural da Bahia. Superintendência de Estudos Econômicos e Sociais da Bahia; Secretaria da Cultura Salvador. SEI, 2012.

ALMEIDA, Maria Geralda de. Paisagens culturais e patrimônio cultural: Contribuições introdutórias para reflexões. In: Maneiras de ler: geografia e cultura [recurso eletrônico] / HEIDRICH, A. L.; COSTA, B. P.; PIRES, C. L. Z. (Orgs). Porto Alegre: Imprensa Livre Compasso Lugar Cultura, 2013. 364 Kb ; PDF. p. 186-194.

ANDRADE, Adriano Bittencourt. O Modelo Espacial da Rede Urbana do Recôncavo Baiano Setecentista à luz da Cartografia Histórica. In: SIMPÓSIO BRASILEIRO DE CARTOGRAFIA HISTÓRICA. PASSADO PRESENTE NOS VELHOS MAPAS: 
CONHECIMENTO E PODER, 1., 2011, Paraty - RJ. Anais do simpósio brasileiro de cartografia histórica. 2011.

O outro lado da baía: a gênese de uma rede urbana colonial. Salvador: Edufba, 2013.

ATHAYDE, Eduardo. Baía de Todos os Santos, sede da Amazônia Azul. Revista [B+], Salvador. v. 28. p. 66. fev.-mar., 2015.

AZEVEDO, Paulo Ormindo de. A cidade como cultura. Jornal A Tarde, Salvador, BA. 15 jul., 2012. p. 2.

. Cultura e cidade. In.: Políticas Culturais para as cidades. RUBIN, A. A. C.; ROCHA, R. (Orgs). Salvador: Edufba. 2010. p. 90- 95.

BAHIA. Secretaria da Indústria e Comércio. IPAC-BA - inventário de proteção do acervo cultural; monumentos e sítios do Recôncavo, I parte. $2^{\mathrm{a}}$ edição. v. 2. Salvador, BA. 1982a.

BAHIA. Secretaria da Indústria e Comércio. IPAC-BA - inventário de proteção do acervo cultural; monumentos e sítios do Recôncavo, II parte. $1^{\text {a }}$ edição. v. 3 Salvador, BA. 1982b.

BARICKMAN, Bert Jude. Um contraponto baiano: açúcar, fumo, mandioca e escravidão no Recôncavo, 1780-1860. Rio de Janeiro: Civilização Brasileira, 2003.

BAZIN, Germain. A arquitetura religiosa barroca no Brasil: estudo histórico e morfológico. v. 1 Rio de Janeiro, 1956.

BERDOULAY, Vicent. Espaço e Cultura. In: Olhares geográficos: modos de ver e viver o espaço. CASTRO, I. E. de, GOMES, P. C. da C, CORRÊA, R. L. (Orgs). Rio de Janeiro: Bertrand Brasil, 2012. p. 100-113.

BERTRAND, Georges. Olhares cruzados, imagens enquadradas (Prefácio). In: STEINK, V. A.; REIS JUNIOR, D. F.; COSTA, E. B. (Orgs). Geografia e fotografia: apontamentos 
teóricos e metodológicos. Brasília: Laboratório de Geoiconografia e Multimídias - LAGIM, UnB, 2014. p. 6-9.

BRANDÃO, Maria de Azevedo. Recôncavo da Bahia - Sociedade e economia em transição. Salvador: Academia de letras da Bahia (ALB) - UFBA, 1997.

BRANDÃO, Maria de Azevedo; PEDRÃO, Fernando Cardoso. Projetos: complexo universitário de ciência e tecnologia. Economia e cultura, 2007.

BRITO, Cristóvão. A petrobras e a gestão do território no Recôncavo Baiano. Salvador: Edufba, 2008.

BONDUKI, Nabil. Intervenções urbanas na recuperação de centros históricos. Brasília: IPHAN - Programa Monumenta, 2010.

CAMARGO, José Carlos Godoy; REIS JUNIOR, Dante Flávio da C. A Filosofia (Neo) Positivista e a Geografia Quantitativa. In. VITTE, A. C. (Orgs). Contribuições à História e à Epistemologia da Geografia. Rio de Janeiro: Bertrand Brasil, 2005. p. 83-99.

CARYBÉ. A rampa do mercado. Jornal Correio da Bahia. Salvador: Coleção As sete portas da Bahia. Instituto Carybé. Pan ArtWorks / GBDG, Editorial Ltda. 2014.

A feira de Águas de Meninos. Jornal Correio da Bahia. Salvador: Coleção As Sete Portas da Bahia. Instituto Carybé. Pan ArtWorks/ GBDG, Editorial Ltda. 2014.

CASTRIOTA, Leonardo Barci. Patrimônio cultural: conceitos, políticas e instrumentos. São Paulo: Annablume, Belo Horizonte: IEDS, 2009.

CARLOS, Ana Fani Alessandri. O turismo e a produção do espaço. Revista Geografia \& Ensino, Belo Horizonte, v. 8, n. 1, p. 47-56, jan.-dez., 2002.

A (Re) Produção do Espaço Urbano. São Paulo: Editora da Universidade de São Paulo, 1994. 
CARVALHO, Caé Garcia; SILVA, Renata Oliveira. Samba de roda e identidade: um estudo comparativo da identidade regional mediada pelo samba do Recôncavo e no Portal do Sertão. In: SERPA, A. (Org). Territórios da Bahia: regionalização, cultura e identidade. Salvador: Edufba, 2015, p. 259-297.

CARVAlHO, Sonia Nahas de. Condicionantes e Possibilidades. Políticas do Planejamento Urbano. In: VITTE, C. C. S.; KEINERT, T. M. M. (Orgs). Qualidade de vida, planejamento e gestão urbana: discussões teórico-metodológicas. Rio de Janeiro: Bertrand Brasil, 2009.

CENTRO DE ESTATÍSTICA E INFORMAÇÕES. Informações Básicas dos Municípios Baianos: Recôncavo Sul. Salvador, BA, 1994.

Centro guarda patrimônio da fase do apogeu. A Tarde. Salvador, BA. 29 mar. 2015.

CERTAU, Michel. A escrita da história. Rio de Janeiro: Forense, 1982.

CLAVAL, Paul. A Construção do Brasil: uma grande potência em emergência. Coleção Economia e Política, Lisboa: Edittions Belin, Instituto Piaget, 2004.

CHOAY, Françoise. A alegoria do patrimônio. São Paulo: Estação Liberdade. UNESP, 2006.

CORRÊA, Roberto Lobato. Região e Organização Espacial. São Paulo: Editora Ática, 1986.

O Espaço Urbano, São Paulo: Editora Ática, 2004.

Sobre agentes sociais, escala e produção do espaço: um texto para discussão. In: CARloS, A. F. A.; SOUZA, M. L.; ESPÓSITO, M. E. B. (Orgs). A Produção do Espaço Urbano: agentes e processos, escalas e desafios. São Paulo: Contexto, 2012. p. 40-51. 
CORIOLANO, Luzia Neide Menezes Teixeira; SILVA, Sylvio Carlos Bandeira de Mello. Turismo e Geografia: abordagens críticas. Fortaleza: Editora UECE, 2005.

COSTA PINTO, Luiz de Aguiar. Recôncavo da Bahia: laboratório de uma experiência humana. Rio de Janeiro: CLACSO, 1958.

COSTA, Everaldo Batista da; SCARLATO, Francisco Capuano. Patrimônio da humanidade: universalismo de um apoderamento territorial soberano. In: COSTA, E. B. et. al. (Orgs). Valor patrimonial e turismo: limiar entre história, território e poder. São Paulo: Outras expressões, 2012.

Paisagem-Memória e Função Social da Fotografia. In: STEINK, V. A.; REIS JUNIOR, D. F.; COSTA, E. B. Geografia e fotografia: apontamentos teóricos e metodológicos. Brasília: Laboratório de Geoiconografia e Multimídias - LAGIM, UnB, 2014. p. 80-106.

DA GUIA, Alex. Redes de cidades no Brasil colônia e políticas de preservação do patrimônio cultural. In: Instituto de Pesquisa Econômica Aplicada (IPEA). Infraestrutura social e urbana no Brasil: subsídios para uma agenda de pesquisa e formulação de políticas públicas. Brasília: Ipea, 2010. p. 747-792.

DE MASI, Domenico. O futuro chegou. 1. ed. Rio de Janeiro: Casa da Palavra, 2014.

FALCÓN, Gustavo. A Face hegemônica da Bahia. In: Superintendência de Estudos Econômicos e Sociais da Bahia; Secretaria da Cultura. Panorama cultural da Bahia. Salvador: SEI, 2012. p. 21-40.

Baianos. Fotografias: Manu Dias; Texto: Gustavo Falcón. Lauro de Freitas, BA: Solisluna Editora, 2013.

FERREZ, Gilberto. Bahia: velhas fotografias, 1858 - 1900. Rio de Janeiro: Kosmos Ed.; Salvador: Banco da Bahia Investimentos S.A., 1988. 
FLORENCE, Afonso. O Fenômeno Urbano como Fenômeno Cultural. In: Políticas Culturais para as cidades. RUBIN, A. A. C.; ROCHA, R. (Orgs). Salvador: Edufba, 2010. p. $17-21$.

FRIDMAM, Fania. Breve história do debate sobre a cidade colonial brasileira. In: PINHEIRO, E. P.; GOMES, M. A. A. F. (Orgs). A cidade como história: os arquitetos e a historiografia da cidade e do urbanismo. Salvador: Edufba, 2004.

FURTADO, Celso. Formação econômica do Brasil. São Paulo: Editora Nacional, 1968.

GIL FILHO, Sylvio Fausto. Geografia cultural: estrutura e primado das representações. Rio de Janeiro: Espaço e Cultura, UERJ. n.19-20. p.51-59, jan.-dez., 2005. Disponível em: <http://www.nepec.com.br/faustogil_espaco_e_cultura_1920.pdf.> Acesso em: 24 out. 2011.

GOUlaRT, José Alípio. Tropas e Tropeiros na Formação do Brasil. Rio de Janeiro: Conquista, 1961.

GOMES, Paulo Cesar da Costa. Geografia e Modernidade. Rio de Janeiro: Bertrand Brasil, 1996.

GONÇALVES, Adelino. A dimensão urban(ística) do patrimônio. In: ENCONTRO INTERNACIONAL SOBRE PRESERVAÇÃO DO PATRIMÔNIO EDIFICADO. Arquimemória 4: a dimensão urbana do patrimônio, 2013, Salvador. Anais do IV Encontro Internacional sobre Preservação do Patrimônio Edificado. Salvador: IAB, 14-17 mai., 2013.

GRAÇA FILHO, Afonso de Alencastro. História Região \& Globalização. Belo Horizonte: Autêntica Editora, 2009.

GRAHAM, Richard. Alimentar a cidade: das vendedoras de rua à reforma liberal (Salvador, 1780-1860). São Paulo: Companhia das Letras, 2013. 
HAESBERT, Rogério; PEREIRA, Sérgio Nunes; RIBEIRO, Guilherme (Orgs). Rio de Janeiro: Bertrand Brasil, 2012.

HARVEY, David. Condição pós-moderna: uma pesquisa sobre as origens da mudança cultural. 12a ed. São Paulo: Ed. Loyola, 2003.

Espaços de Esperança. São Paulo: Ed. Loyola, 2004.

HENRIQUE, Wendel. Planejamento urbano e vida cotidiana em cidades e áreas patrimoniais. Terr@Plural. Ponta Grossa, v. 3, n. 2, p.187-195, jul./dez. 2009.

HOLANDA, Sérgio Buarque de. Novo dicionário Aurélio da Língua Portuguesa. $2^{\mathrm{a}}$ edição, revista e ampliada. Ed. Nova Fronteira, Rio de Janeiro, 1986.

INSTITUTO BRASILEIRO DE GEOGRAFIA E ESTATÍSTICA (IBGE). Atlas das Representações Literárias de Regiões Brasileiras: Sertões Brasileiros I. v. 2. Rio de Janeiro: IBGE, 2006.

LA BLACHE, Vidal de. Da interpretação geográfica das paisagens (1908). In: HAESBAERT, R.; PEREIRA, S. N.; RIBEIRO, G. (Orgs). Vidal, vidais: textos de geografia humana, regional e política. Rio de Janeiro: Bertrand Brasil, 2012.

LEFEBVRE, Henry. O direito à cidade. São Paulo: Centauro, 2001.

LENCIONE, Sandra. Região e Geografia. São Paulo: Editora da Universidade de São Paulo, 2003.

LINS, Eugênio. Patrimônio Cultural: questões para um debate. In: ROCHA, R.; RUBIN, A. A. C. (Orgs). Políticas Culturais para as cidades. Salvador: Edufba, 2010. p. 58-60.

LOIZOS, Peter. Vídeo, filme e fotografias como documentos de pesquisa. In: BAUER, M. W.; GASKELL, G. (Orgs). Pesquisa qualitativa com texto: imagem e som: um manual prático. Petrópolis: Vozes, 2008. 
LUCHIARI, Maria Tereza Duarte Paes. A (re) significação da paisagem no período contemporâneo. In: ROSENDAHL, Z.; CORRÊA, R. L. (Orgs). Paisagem, imaginário e espaço. Rio de Janeiro: EDUERJ, 2001.

A reinvenção do patrimônio arquitetônico no consumo das cidades. São Paulo: GEOUSP - Espaço e Tempo. n. 17, 2005. p. 95-105.

MAGNAVITA, Pasqualino Romano. Diferença versus Identidade nos processos culturais. In: RUBIN, A. A. C.; ROCHA, R. (Orgs). Políticas Culturais para as cidades. Salvador: Edufba, 2010. p. 67-73.

_. Patrimônio arquitetônico nas "sociedades de controle" novos conceitos e novo paradigma ético-estético. In: ENCONTRO INTERNACIONAL SOBRE PRESERVAÇÃO DO PATRIMÔNIO EDIFICADO. Arquimemória 4: a dimensão urbana do patrimônio, 4., 2013, Salvador. Anais do IV Encontro Internacional sobre Preservação do Patrimônio Edificado. Salvador: IAB, 14-17 mai., 2013.

MASSEY, Doreen. Pelo Espaço: uma nova política da espacialidade. Rio de Janeiro: Bertrand Brasil, 2009.

MATTOSO, Kátia. Introdução. In: FERREZ, G. Bahia: velhas fotografias, 1858 - 1900. Rio de Janeiro: Kosmos Ed.; Salvador: Banco da Bahia Investimentos S.A. 1988, p.7-10.

. Bahia, século XIX: uma província no império. Rio de Janeiro: Nova Fronteira S. A. 1992.

. A Opulência na província da Bahia. In: NOVAIS, F. A.; ALENCASTRO, L. F. (Orgs). História da vida privada no Brasil: Império 2. São Paulo: Companhia das Letras, 1997.

MELLO, Suzy de. Barroco. Coleção Primeiros Vôos. n. 17. Belo Horizonte: Ed. Brasiliense, 1983. 
MORAIS, Antônio Carlos Robert de. Bases da Formação Territorial do Brasil: o território colonial brasileiro no "longo” século XVI. São Paulo: Hucitec, 2000.

- Geografia Histórica do Brasil: capitalismo, território e periferia. São Paulo: Annablume, 2011.

MOREIRA, Igor. Para onde vai o pensamento geográfico?: por uma epistemologia crítica. São Paulo: Contexto, 2006.

O pensamento geográfico brasileiro: as matrizes da renovação. São Paulo: Contexto, 2009.

_. O pensamento geográfico brasileiro: as matrizes clássicas originárias. v. 1. São Paulo: Contexto, 2010.

_. O pensamento geográfico brasileiro: as matrizes brasileiras. v. 3. São Paulo: Contexto, 2010.

MOTTA, Lia. O Patrimônio Cultural Urbano à Luz do Diálogo entre História e Arquitetura. In: Revista do patrimônio histórico e artístico nacional. n. 34. Brasília: Instituto do Patrimônio Histórico e Artístico Nacional. 2011. p. 249-279.

MUELLER, Lourenço. O patrimônio invisível de Salvador. A Tarde, Salvador, BA. 9 mar. 2014. p.2.

NARDI, Jean-Baptiste. Análise da cadeia produtiva do tabaco na Bahia. Salvador: Arcádia, 2013.

ORBGINY, Alcide d' (1802-1857). Viagem pitoresca através do Brasil. Belo Horizonte: Ed. Itatiaia; São Paulo: Ed. da Universidade de São Paulo, 1976.

OLIVEIRA, F. M. K. P.; SILVA, M. Patrimônio Histórico Edificado e Memória Urbana em Irati/PR. UNICENTRO: Revista Eletrônica Lato Sensu. Ed. 4, 2008. Disponível em: 
<http://web03.unicentro.br/especializacao/Revista_Pos/P\%C3\%A1ginas/4\%20Edi\%C3\%A7 \%C3\%A3o/Humanas/PDF/10-Ed4_CH-Patrimo.pdf> Acesso em: 30 Jul. 2011.

OLIVEIRA, A. M. (Org.). Guia dos bens tombados. Rio de Janeiro: Expressão e Cultura, 1983.

OSEKI, Jorge Hagime; PELLEGRINO, Paulo Renato Mesquita. Paisagem, sociedade e ambiente. In: PHILIPPI JUNIOR, A. et. al. (Orgs). Curso de gestão ambiental. Barueri, SP: Manole, 2004.

PAES, Maria Tereza Duarte; OLIVEIRA, Melissa Ramos da Silva (Orgs). Geografia, turismo e patrimônio cultural. São Paulo: Annablume, 2010.

O olhar dos geógrafos sobre o patrimônio cultural e o turismo no Brasil. In: Seminário de Geografia, Turismo e Patrimônio Cultural, 3., 2010. Disponível em: <http://geografiaturismopatrimonio.wordpress.com/2010/05/15/portal-unicamp> Acesso em: 29 abr. 2011.

PEDRÃO, Fernando. Novos e velhos elementos da formação social do Recôncavo da Bahia de Todos os Santos. In: Revista do Centro de Artes, Humanidades e Letras. v.1. n.1. 2007. Cachoeira - BA: Universidade Federal do Recôncavo da Bahia.

PEIXOTO, Fernando. Triste Bahia. In: REVISTA [B+]. v.7. n.28. Salvador: Sopa de Letras Editora. fev./mar, 2015. p.95.

PELEGRINI, Sandra C. A. Cultura e natureza: os desafios das práticas preservacionistas na esfera do patrimônio cultural e ambiental. In: Revista Brasileira de História. São Paulo, v.26. n. 51. 2006. p. 115-140.

PESAVENTO Sandra Jatahy. História \& História Cultural. Belo Horizonte: Autêntica, 2008. 
PIRES, Hindenburgo Francisco. Reflexões sobre a contribuição da geografia histórica e da geohistória na renovação dos pensamentos geográfico e histórico no séc. XX. In: COLÓQUIO BRASILEIRO DE HISTÓRIA DO PENSAMENTO GEOGRÁFICO, 1., 2008, Uberlândia. Anais do I Colóquio Brasileiro de História do Pensamento Geográfico. Uberlândia: UFU, 2008. Disponível em: <http://br.monografias.com/trabalhos909/reflexoessobre-contribuicao/reflexoes-sobre-contribuicao.pdf>. Acesso em: 29 set. 2014.

PRADO JUNIOR, Caio. História Econômica do Brasil. São Paulo: Brasiliense, [1945] 2008.

RIBEIRO, Darcy. O Brasil como problema. Rio de Janeiro: Fundação Darcy Ribeiro; Brasília: Editora UnB, 2010.

RISÉRIO, Antônio. Uma História da Cidade da Bahia. São Paulo: Versal Editores, 2004.

Retratos de um tempo: exposição interativa com imagem e texto. Conceito e Criação: Floro Freire e Antônio Risério. Texto: Antônio Risério. Salvador: [s.n.]. Museu de Arte Moderna de Salvador - BA, mar. 2006.

RODRIGUES, Adyr Balastreri. Geografia do Turismo: novos desafios. In: TRIGO, L. G. G. et. al. (Orgs). Turismo. Como Aprender, como ensinar. São Paulo: Editora Senac, 2003. p.87-122.

RODRIGUES, Marly. Preservar e consumir: o patrimônio histórico e o turismo. In. FUNARI, P. P.; PINSKY, J. (Orgs). Turismo e patrimônio cultural. São Paulo: Contexto, 2005.

SAMPAIO, Consuelo Novais. 50 anos de urbanização: Salvador da Bahia no Século XIX. Rio de Janeiro: Versal, 2005.

SANTOS, Milton. A rede urbana do Recôncavo. Salvador: Laboratório de Geomorfologia e Estudos Regionais - UFBA, 1959. 
A rede urbana do Recôncavo. Salvador: Imprensa Oficial da Bahia e Universidade Federal da Bahia, 1960.

A Natureza do Espaço. Técnica e tempo. Razão e emoção. São Paulo: Hucitec, [1996], 2008b.

. Espaço e método. São Paulo: Nobel, 1985.

Metamorfoses do Espaço Habitado. São Paulo: Hucitec, 1988.

O Centro da Cidade do Salvador: estudo de geografia urbana. $2^{a}$ ed. São Paulo: Editora Universidade de São Paulo; Salvador: Edufba, 2008a.

_. Por uma Geografia Nova. São Paulo: Hucitec, [1978] 1980.

SANTOS, Milton; SILVEIRA, Maria Laura O Brasil: território e sociedade no início do século XXI. Rio de Janeiro: Record, 2001.

SANTOS, Júlia Monteiro Oliveira; SERPA, Ângelo. O Território do Recôncavo. In: SERPA, A. (Orgs). Territórios da Bahia: regionalização, cultura e identidade. p.75-98. Salvador: Edufba, 2015.

SCARLATO, Francisco Capuano; COSTA, Everaldo Batista da. Geografia e patrimônio urbano: questão metodológica. In: Espaço e Geografia. v.16. n.2. Brasília: Ed. UnB, 2013.

SCHWARTS, Stwart B. Segredos internos: engenhos e escravos na sociedade colonial, 1550-1835. São Paulo: Companhia das Letras, 1988.

SCHWARCS, Lilia Moritz. Nacionalidade e patrimônio: o segundo reinado brasileiro e seu modelo tropical exótico. In: Revista do Patrimônio Histórico e Artístico Nacional. n.34. Brasília: IPHAN, 2011.p. 337 - 359. 
SERPA, Ângelo. Territórios da Bahia: regionalização, cultura e identidade. Salvador: Edufba, 2015.

SIMIÃO, Maria Cristina Rocha. Preservação do patrimônio cultural em cidades. Belo Horizonte: Autêntica, 2006.

SILVA, Fernando Fernandes da. As Cidades Brasileiras e o Patrimônio Cultural da Humanidade. São Paulo: Edusp, 2003.

SILVA, Silvio Bandeira de Mello e.; SILVA, Bárbara Cristine Nentwig. Estudos sobre Globalização, Território e Bahia. Mestrado em Geografia, Departamento de Geografia. Salvador: UFBA, 2003.

SILVA, Bárbara-Christine N. et al. Atlas escolar da Bahia: espaço geo-histórico e cultural. 2 ed. João Pessoa: Grafset, 2004.

SILVA, Luís Cláudio Requião da. Os meios de hospedagem em Salvador: distribuição espacial ao longo de sua história. 2007. Dissertação (Mestrado em Geografia) - Instituto de Geociências da UFBA, Salvador, 2007.

_. Patrimônio edificado, paisagem urbana e a relação de significado com a sociedade local na cidade de Nazaré-BA. In: ENCONTRO INTERNACIONAL SOBRE PRESERVAÇÃO DO PATRIMÔNIO EDIFICADO, 4., 2013, Salvador. Anais do IV Encontro Internacional sobre Preservação do Patrimônio Edificado. ARQUIMEMÓRIA 4: a dimensão urbana do patrimônio. Salvador: IAB, 2013.

SILVEIRA, Maria Laura. A região e invenção da viabilidade do território. In: SOUZA, M. A. et. al. Território brasileiro: Usos e Abusos. Campinas: Edições Territorial, 2003.

SOUZA, A. M. (coordenação e pesquisa). Guia dos bens tombados: Bahia. Rio de Janeiro: Expressão e Cultura, 1983. 
SPIX, Johann Baptist Von; MARTIUS, Karl Friedrich Philipp Von. Através da Bahia. Bahia: Imprensa Oficial do Estado, 1916.

SUPERINTENDÊNCIA DE ESTUDOS ECONÔMICOS E SOCIAIS DA BAHIA (SEI). Evolução territorial e administrativa do Estado da Bahia: um breve histórico. Salvador: SEI, 2001.

TAVARES, Luís Henrique Dias. História da Bahia. São Paulo: Ed. da UNESP; Salvador: Edufba, 2008.

TEIXEIRA, Marli Geralda; ANDRADE, Maria José de Souza. Memória Histórica de São Gonçalo dos Campos. Edição comemorativa do $1^{\circ}$ Centenário do Município. São Gonçalo dos Campos - BA, 1984.

TEIXEIRA, Manuel C. A forma da cidade de origem portuguesa. São Paulo: Editora Unesp. Imprensa Oficial do Estado de São Paulo, 2012.

TONET, Ivo. Método científico: uma abordagem ontológica. São Paulo: Instituto Lukács, 2013.

TORRES, Lucia Helena dos Santos. Espaços urbanos em processo de representação: Praça Floriano Peixoto e Ilha dos Museus. 2008. Dissertação (Mestrado em Museologia e Patrimônio) - Universidade Federal do Estado do Rio de Janeiro - UFRJ; MAST, Rio de Janeiro, 2008.

UNESCO aprova título de Patrimônio Mundial para a Paisagem Cultural do Rio de Janeiro. Instituto do patrimônio histórico e artístico nacional. Disponível em: <http://portal.iphan.gov.br/portal/montarDetalheConteudo.do?id=16727\&sigla=Noticia\&retor no=detalheNoticia $>$. Acesso em 04 mar. 2015.

VASCONCELOS, Pedro de Almeida. Salvador: transformações e permanências (1549 1999). Ilhéus: Editus, 2002. 
. Questões metodológicas na geografia urbana histórica. GeoTextos. vol. 5. n. 2, p.147157. Dez., 2009.

. Geografia histórica: Campo disciplinar e questões de pesquisas. 2015 (inédito).

VIANNA, Francisco Vicente. Memória sobre o Estado da Bahia. Salvador: Typografia e Encadernação do Diário da Bahia, 1893.

VILHENA, Luis dos Santos. A Bahia no século XVIII. Salvador: Editora Itapuã, 1969.

YÁZIGI, Eduardo. Turismo - uma esperança condicional. São Paulo: Plêiade, 1998.

. A importância da paisagem. In: Turismo e paisagem. YÁZIGI, Eduardo (Org.). São Paulo: Contexto, 2002.

_. Civilização urbana, planejamento e turismo: discípulos do amanhecer. São Paulo; Contexto, 2003.

\section{EXPOSIÇÕES VISITADAS}

Exposição: “Quem ama a Bahia", Salvador e o Recôncavo Baiano: pelas lentes do fotógrafo Osmar Gama. Shopping Barra. Salvador - BA, 2015.

Exposição: Diógenes Rebouças 1914-2014. Museu de Arte da Bahia. Salvador - BA, 2014.

Exposição: Diógenes Rebouças 1914-2014. Plotagem de algumas telas do autor na área externa do Farol da Barra, Salvador - BA, 2014.

Exposição: Rota da Independência. Centro Histórico de Salvador - BA, 2013. 


\section{ANEXO 1}

\section{Quadro1 - EVOLUÇÃO TERRITORIAL E ADMINISTRATIVA DO ESTADO DA BAHIA: CAPITANIA BAHIA DE TODOS OS SANTOS I}

FONTE: SUPERINTENDÊNCIA DE ESTUDOS ECONÔMICOS E SOCIAIS DA BAHIA (SEI).

Evolução territorial e administrativa do Estado da Bahia: um breve histórico. Salvador: SEI, 2001. 


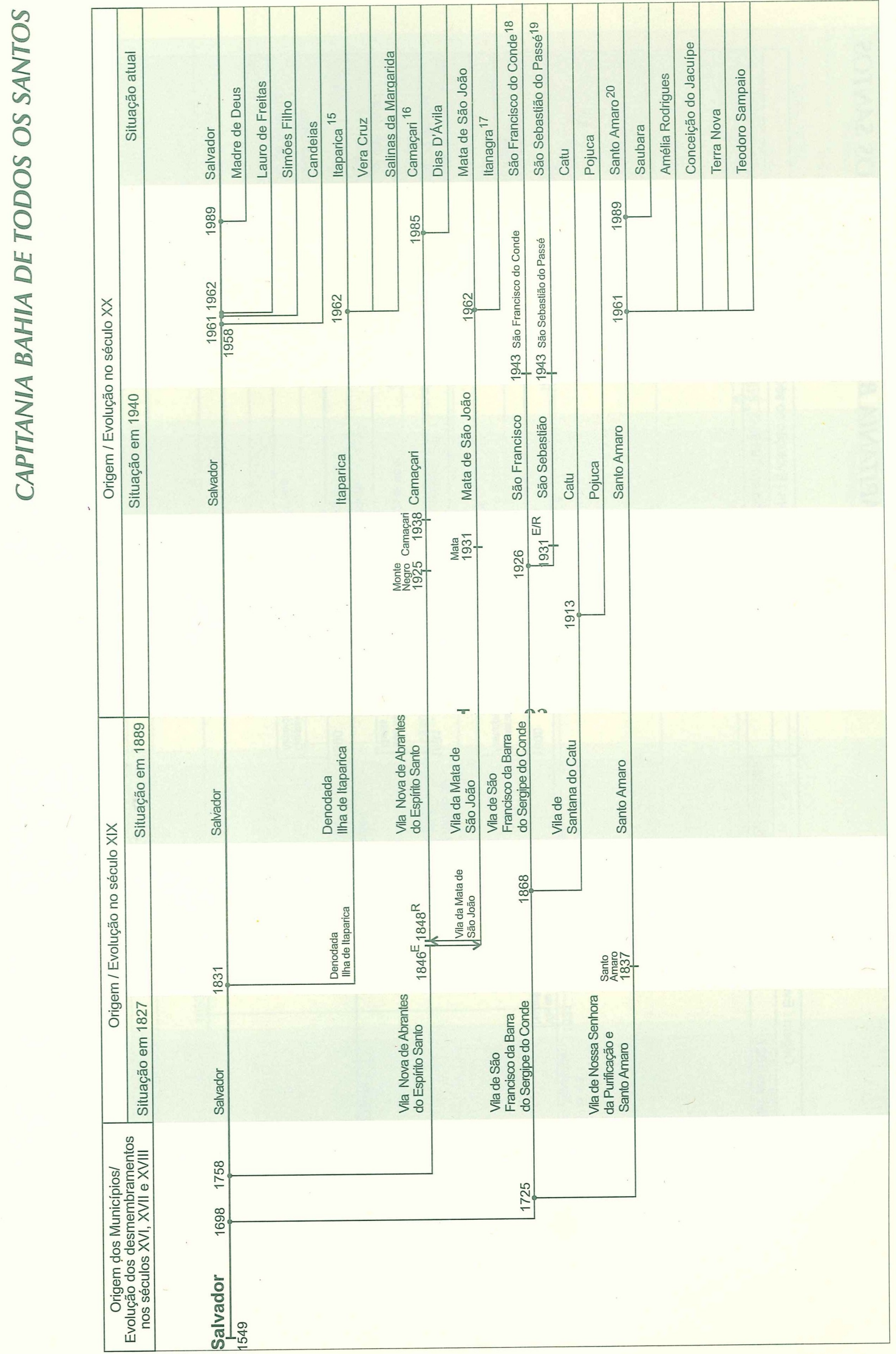




\section{ANEXO 2}

Quadro 2 - EVOLUÇÃO TERRITORIAL E ADMINISTRATIVA DO ESTADO DA BAHIA: CAPITANIA BAHIA DE TODOS OS SANTOS II

FONTE: SUPERINTENDÊNCIA DE ESTUDOS ECONÔMICOS E SOCIAIS DA BAHIA (SEI).

Evolução territorial e administrativa do Estado da Bahia: um breve histórico. Salvador: SEI, 2001. 

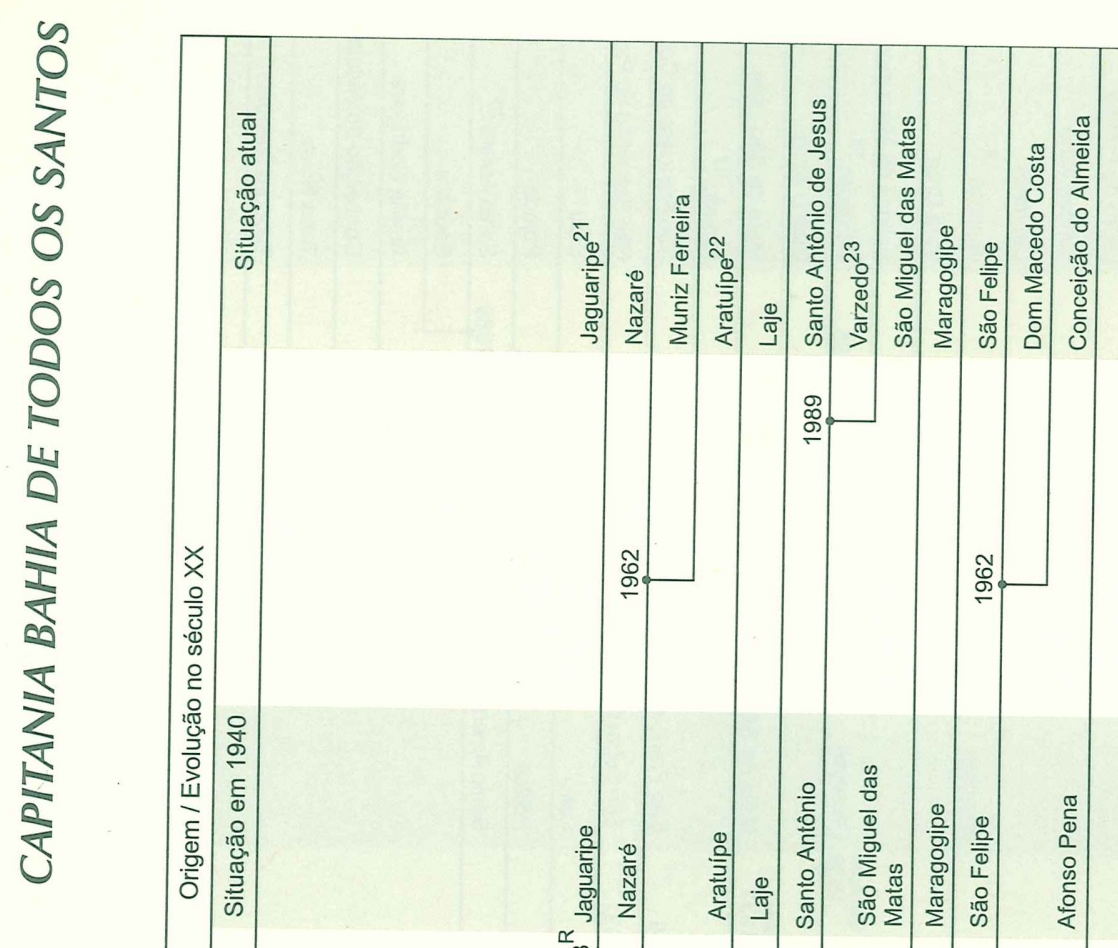

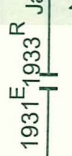

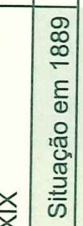

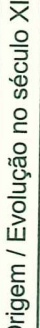

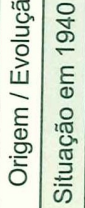
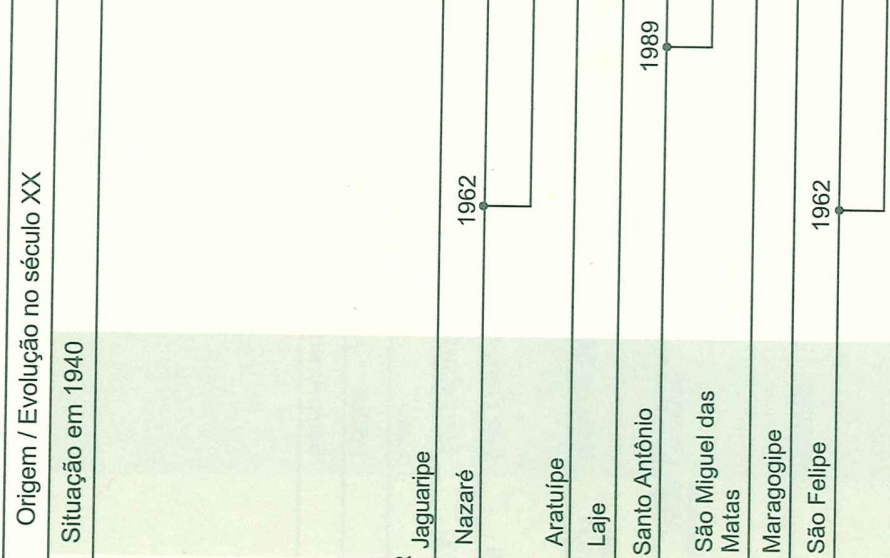

. In
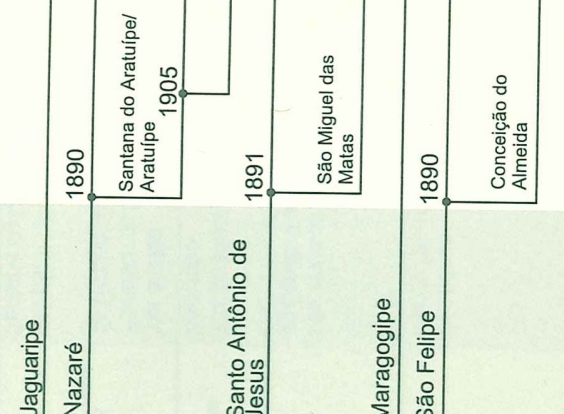


\section{ANEXO 3}

Quadro 3 - EVOLUÇÃO TERRITORIAL E ADMINISTRATIVA DO ESTADO DA BAHIA: CAPITANIA BAHIA DE TODOS OS SANTOS III

FONTE: SUPERINTENDÊNCIA DE ESTUDOS ECONÔMICOS E SOCIAIS DA BAHIA (SEI).

Evolução territorial e administrativa do Estado da Bahia: um breve histórico. Salvador: SEI, 2001. 


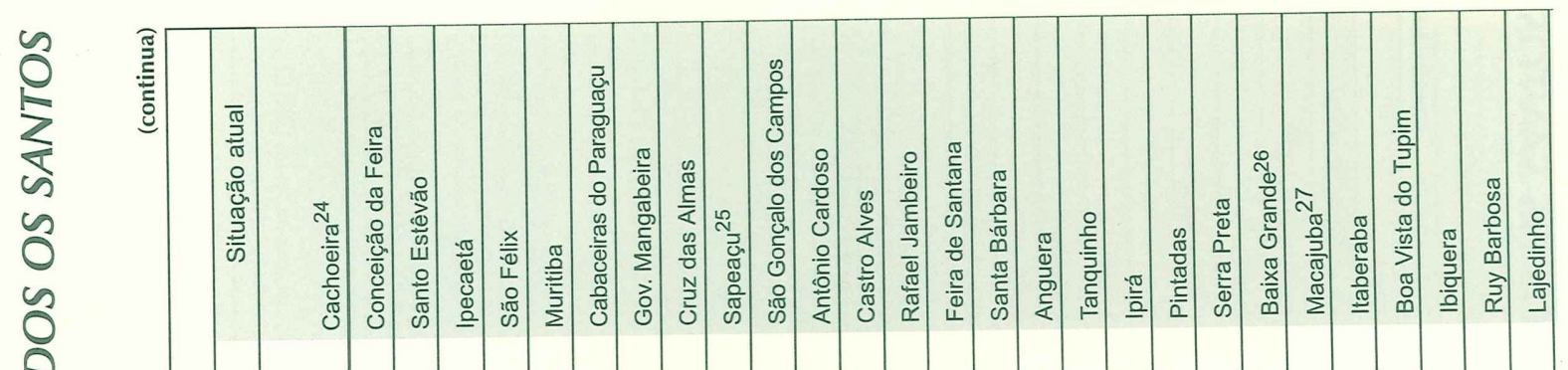

章
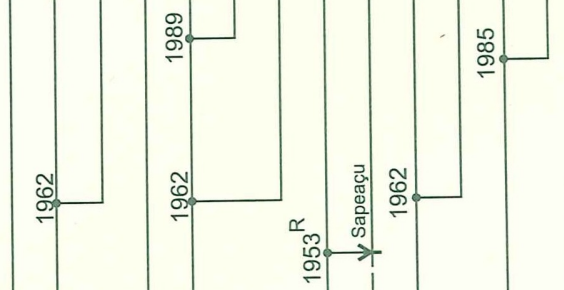
迥

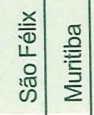
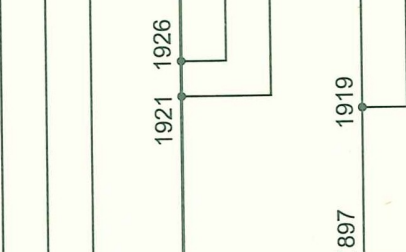

$\infty$
$\infty$
$\infty$
0

के

을

o

密

Ш⿱⺌兀

है

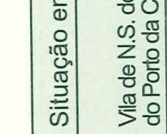

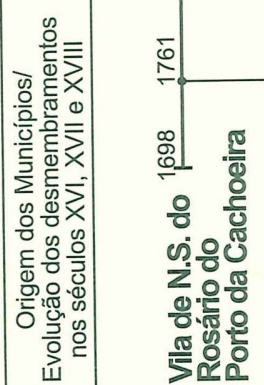
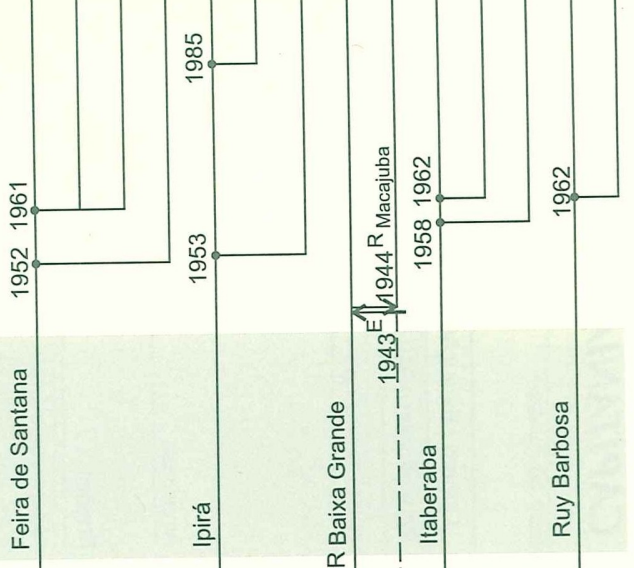

문

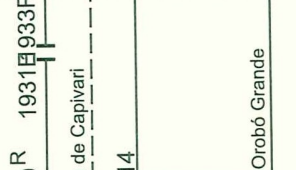

뜽

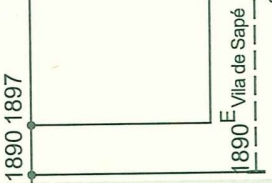

용

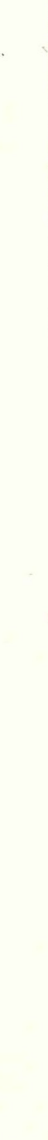




\section{ANEXO 4}

Quadro 4 - EVOLUÇÃO TERRITORIAL E ADMINISTRATIVA DO ESTADO DA BAHIA: CAPITANIA BAHIA DE TODOS OS SANTOS - IV (conclusão)

FONTE: SUPERINTENDÊNCIA DE ESTUDOS ECONÔMICOS E SOCIAIS DA BAHIA (SEI). Evolução territorial e administrativa do Estado da Bahia: um breve histórico. Salvador: SEI, 2001. 


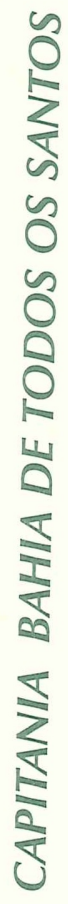

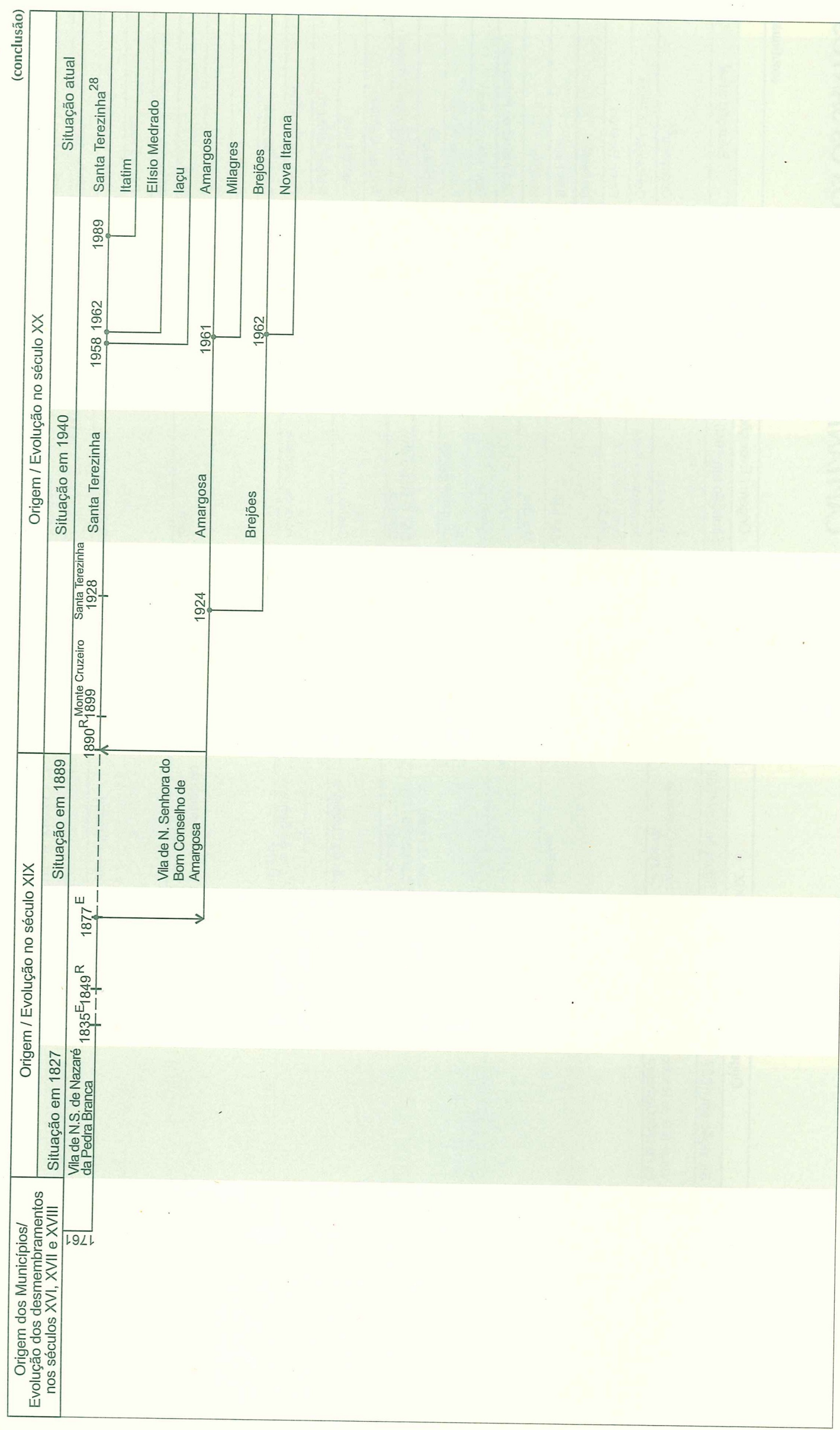




\section{ANEXO 5}

MAPA 1- DIVISÃO POLÍTICO-ADMINISTRATIVA DA BAHIA: Situação em 1827

FONTE: SUPERINTENDÊNCIA DE ESTUDOS ECONÔMICOS E SOCIAIS DA BAHIA (SEI).

Evolução territorial e administrativa do Estado da Bahia: um breve histórico. Salvador: SEI, 2001. 


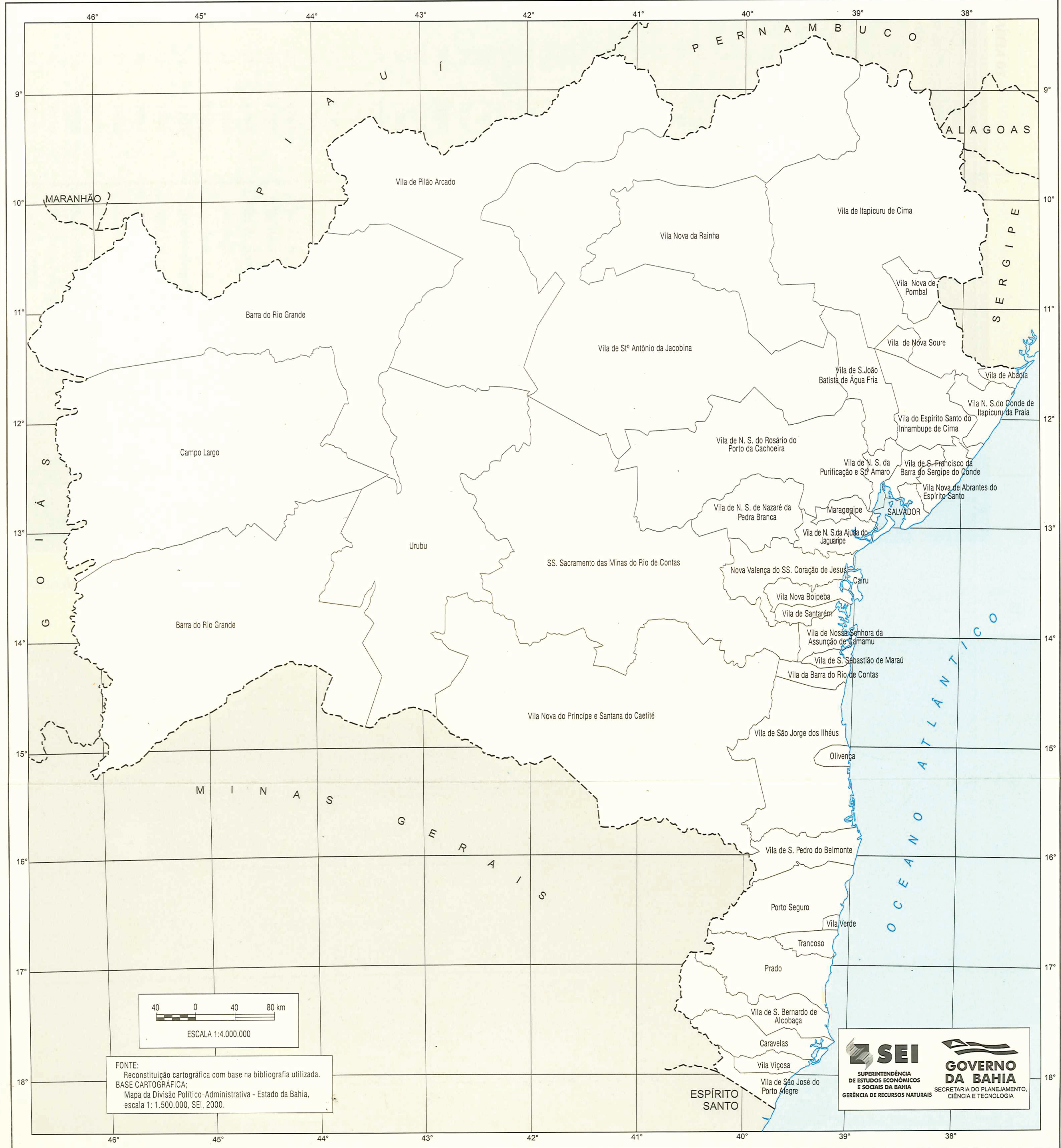




\section{ANEXO 6}

MAPA 2 - DIVISÃO POLÍTICO-ADMINISTRATIVA DA BAHIA: Situação em 1889

FONTE: SUPERINTENDÊNCIA DE ESTUDOS ECONÔMICOS E SOCIAIS DA BAHIA (SEI). Evolução territorial e administrativa do Estado da Bahia: um breve histórico. Salvador: SEI, 2001 


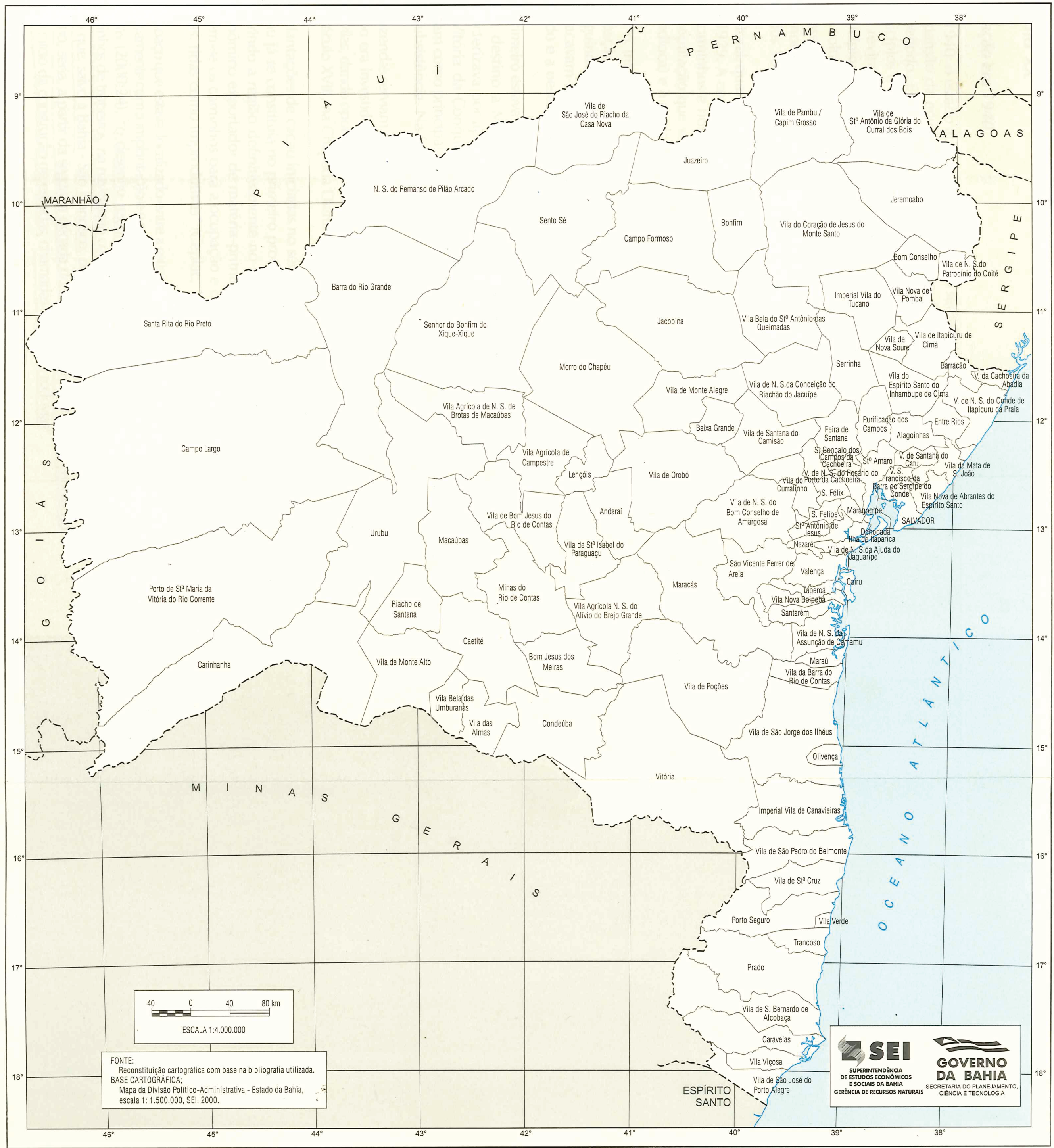




\section{ANEXO 7}

MAPA 3 - DIVISÃO POLÍTICO-ADMINISTRATIVA DA BAHIA: Situação em 1940

FONTE: SUPERINTENDÊNCIA DE ESTUDOS ECONÔMICOS E SOCIAIS DA BAHIA (SEI).

Evolução territorial e administrativa do Estado da Bahia: um breve histórico. Salvador: SEI, 2001. 


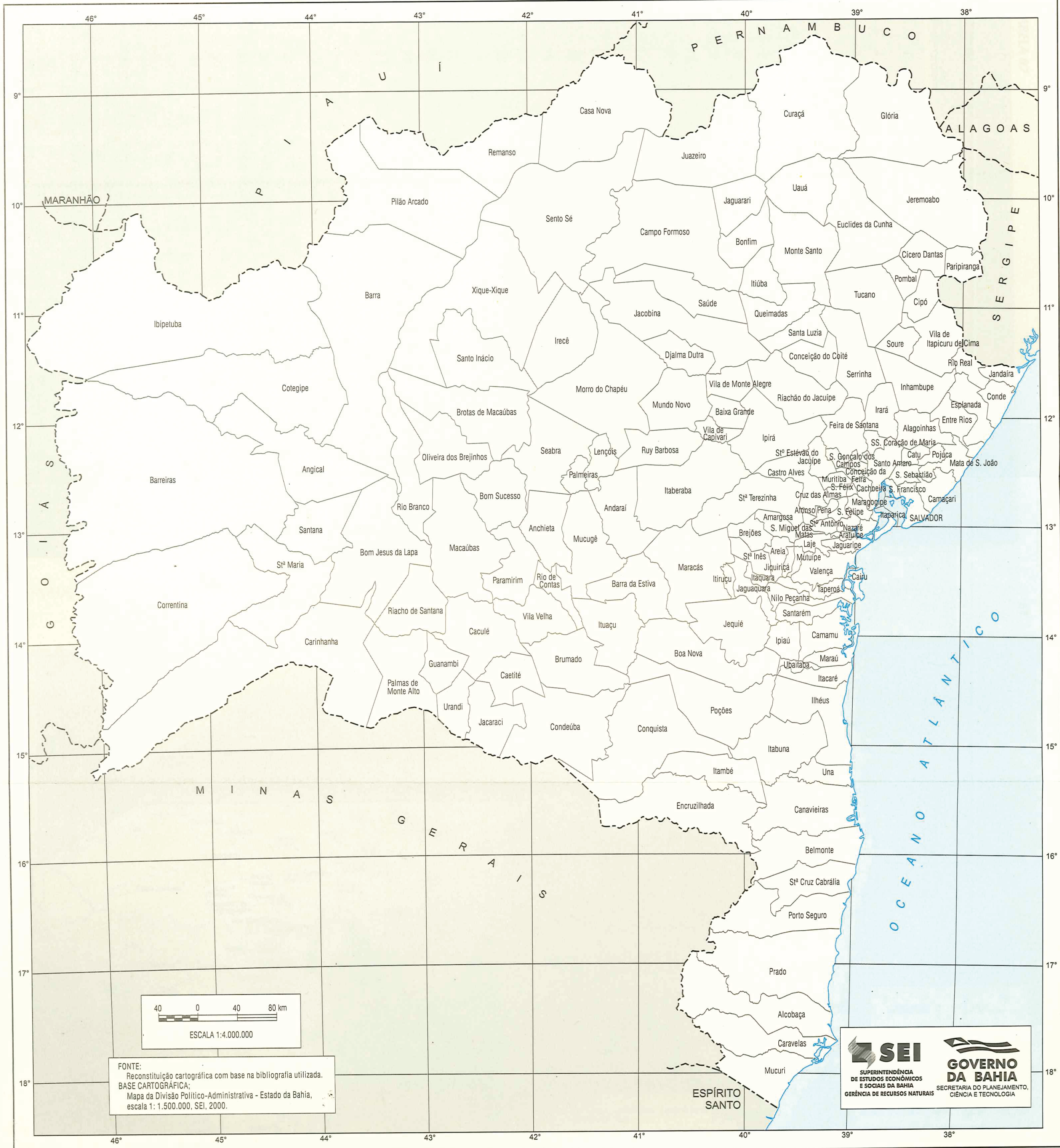




\section{ANEXO 8}

MAPA 4 - DIVISÃO POLÍTICO-ADMINISTRATIVA DA BAHIA: Situação em 2000

FONTE: SUPERINTENDÊNCIA DE ESTUDOS ECONÔMICOS E SOCIAIS DA BAHIA (SEI).

Evolução territorial e administrativa do Estado da Bahia: um breve histórico. Salvador: SEI, 2001. 


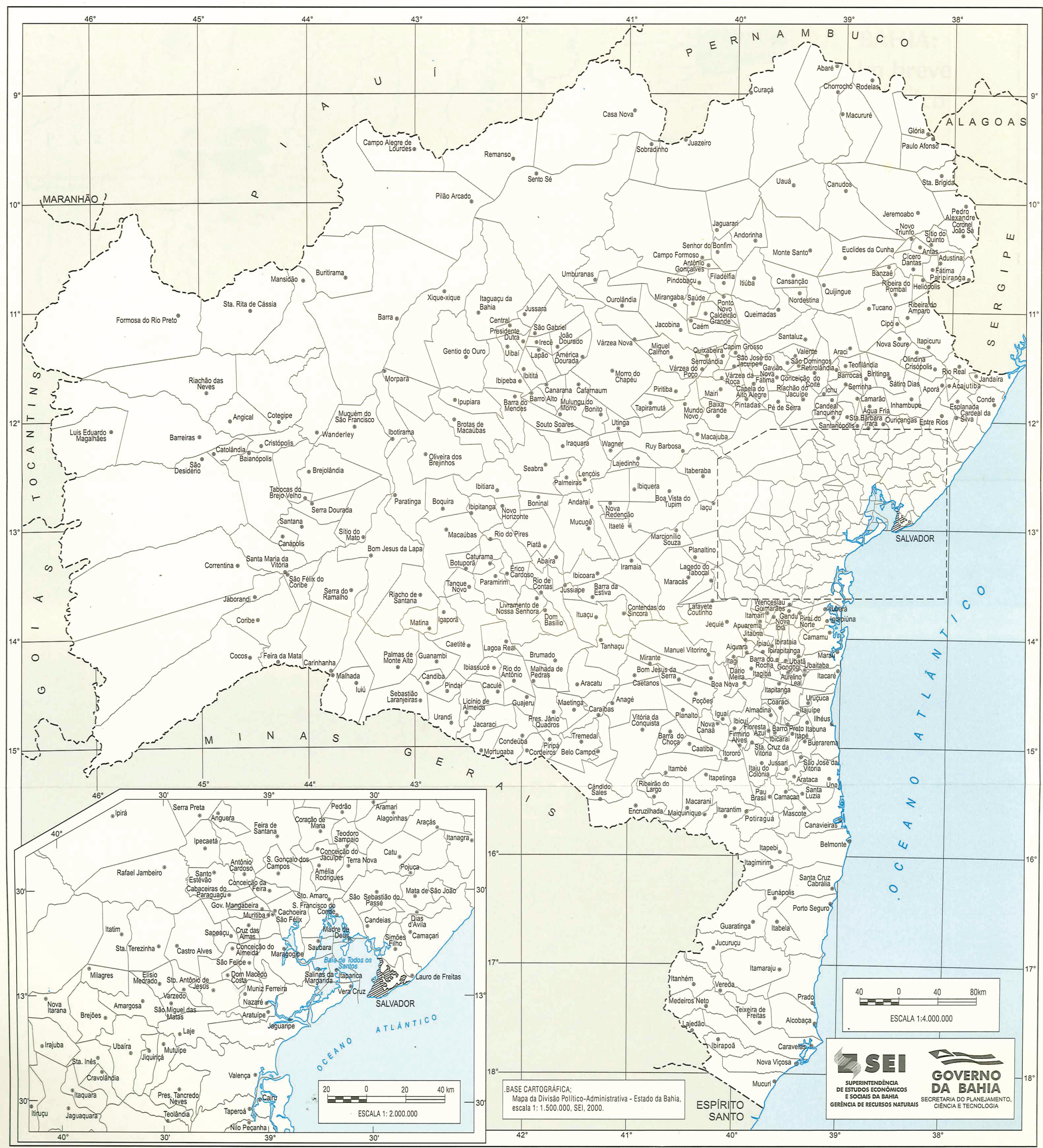




\section{ANEXO 9}

\section{PERFIL SOCIOECONÔMICO DO TERRITÓRIO DE IDENTIDADE RECÔNCAVO}

FONTE: SEI-SEPLAN-BA, com base no IBGE, 2011.

(1) Estimativa da população residente com data de referência em 01.07.2011 
Diretoria de Preservação do Patrimônio Cultural (DIPAT)

Coordenação de Articulação e Difusão (COAD)

Coordenação do Sistema de Informações do Patrimônio Cultural (COSIS)

Perfil Socioeconômico do Território de Identidade Recôncavo

\begin{tabular}{|c|c|c|c|c|c|c|}
\hline $\begin{array}{l}\text { Território de } \\
\text { Identidade }\end{array}$ & Município'1 & População & $\begin{array}{c}\text { Área } \\
\left(\mathrm{Km}^{2}\right)\end{array}$ & $\begin{array}{c}\text { Densidade } \\
\text { Demográfica } \\
\left(\mathrm{hab} / \mathrm{Km}^{2}\right)\end{array}$ & $\begin{array}{c}\text { PIB } \\
\text { (R\$ milhões) }\end{array}$ & $\begin{array}{l}\text { PIB Per } \\
\text { Capita } \\
(R \$ 1,00)\end{array}$ \\
\hline \multirow[t]{21}{*}{ Recôncavo } & TOTAL & 579.628 & $5.250,51$ & 110,39 & $14.615,87$ & $25.230,18$ \\
\hline & $\begin{array}{l}\text { Cabaceiras do } \\
\text { Paraguaçu }\end{array}$ & 17.456 & 213,55 & 81,74 & 58,25 & $3.136,83$ \\
\hline & Cachoeira & 32.150 & 398,47 & 80,68 & 193,70 & $5.733,96$ \\
\hline & Castro Alves & 25.482 & 762,98 & 33,40 & 110,34 & $4.417,47$ \\
\hline & $\begin{array}{l}\text { Conceição do } \\
\text { Almeida }\end{array}$ & 17.795 & 281,90 & 63,13 & 69,32 & $3.856,48$ \\
\hline & Cruz das Almas & 59.045 & 150,90 & 391,29 & 387,27 & $6.782,57$ \\
\hline & Dom Macedo Costa & 3.884 & 93,22 & 41,66 & 16,69 & $4.224,20$ \\
\hline & $\begin{array}{l}\text { Governador } \\
\text { Mangabeira }\end{array}$ & 19.872 & 94,36 & 210,60 & 92,90 & $4.495,06$ \\
\hline & Maragogipe & 42.967 & 436,07 & 98,53 & 178,41 & $4.061,97$ \\
\hline & Muniz Ferreira & 7.346 & 113,71 & 64,60 & 26,53 & $3.666,90$ \\
\hline & Muritiba & 28.921 & 110,56 & 261,59 & 128,21 & $4.619,38$ \\
\hline & Nazaré & 27.365 & 256,35 & 106,75 & 136,21 & $4.966,21$ \\
\hline & Santo Amaro & 57.890 & 518,26 & 111,70 & 307,41 & $5.265,04$ \\
\hline & $\begin{array}{l}\text { Santo Antônio de } \\
\text { Jesus }\end{array}$ & 92.048 & 259,21 & 355,11 & 835,16 & $9.408,31$ \\
\hline & São Felipe & 20.317 & 197,90 & 102,66 & 80,60 & $3.846,66$ \\
\hline & São Félix & 14.129 & 95,50 & 147,95 & 70,21 & $4.331,82$ \\
\hline & $\begin{array}{l}\text { São Francisco do } \\
\text { Conde }\end{array}$ & 33.713 & 266,63 & 126,44 & $11.437,50$ & $360.815,83$ \\
\hline & $\begin{array}{l}\text { São Sebastião do } \\
\text { Passé }\end{array}$ & 42.321 & 549,43 & 77,03 & 317,99 & $7.615,17$ \\
\hline & Sapeaçu & 16.602 & 125,58 & 132,20 & 70,58 & $4.130,58$ \\
\hline & Saubara & 11.278 & 158,93 & 70,96 & 58,81 & $5.055,57$ \\
\hline & Varzedo & 9.047 & 167,00 & 54,17 & 39,79 & $4.209,67$ \\
\hline
\end{tabular}

Fonte: SEI-SEPLAN-BA, com base no IBGE, 2011.

(1) Estimativas da população residente com data de referência em 01.07.2011. 


\section{ANEXO 10}

PERFIL SOCIOECONÔMICO DO TERRITÓRIO DE IDENTIDADE BAIXO SUL

FONTE: SEI-SEPLAN-BA, com base no IBGE, 2011.

(1) Estimativa da população residente com data de referência em 01.07.2011 
Diretoria de Preservação do Patrimônio Cultural (DIPAT)

Coordenação de Articulação e Difusão (COAD)

Coordenação do Sistema de Informações do Patrimônio Cultural (COSIS)

Perfil Socioeconômico do Território de Identidade Baixo Sul

\begin{tabular}{|c|c|c|c|c|c|c|}
\hline $\begin{array}{l}\text { Território de } \\
\text { Identidade }\end{array}$ & Município & População & $\begin{array}{l}\text { Área } \\
\left(\mathrm{Km}^{2}\right)\end{array}$ & $\begin{array}{c}\text { Densidade } \\
\text { Demográfica } \\
\text { (hab/Km²) }\end{array}$ & $\begin{array}{c}\text { PIB } \\
\text { (R\$ milhões) }\end{array}$ & $\begin{array}{l}\text { PIB Per } \\
\text { Capita } \\
(\mathrm{R} \$ 1,00)\end{array}$ \\
\hline \multirow[t]{16}{*}{ Baixo Sul } & TOTAL & 361.531 & $7.611,60$ & 47,50 & $2.109,33$ & $6.276,50$ \\
\hline & Aratuípe & 8.616 & 177,15 & 48,64 & 31,97 & $3.623,96$ \\
\hline & Cairu & 15.678 & 451,19 & 34,75 & 409,26 & $27.773,11$ \\
\hline & Camamu & 35.274 & 885,20 & 39,85 & 149,33 & $4.541,48$ \\
\hline & Gandu & 30.580 & 229,12 & 133,47 & 173,95 & $5.466,84$ \\
\hline & Ibirapitanga & 22.641 & 470,26 & 48,15 & 43,89 & $3.046,24$ \\
\hline & Igrapiúna & 13.183 & 512,84 & 25,71 & 137,95 & $10.397,48$ \\
\hline & Ituberá & 26.763 & 417,54 & 64,10 & 132,64 & $5.488,14$ \\
\hline & Jaguaripe & 16.701 & 891,35 & 18,74 & 60,39 & $3.463,78$ \\
\hline & Nilo Peçanha & 12.631 & 385,38 & 32,78 & 60,19 & $4.534,68$ \\
\hline & Piraí do Norte & 9.816 & 227,64 & 43,12 & 36,21 & $4.106,12$ \\
\hline & $\begin{array}{l}\text { Presidente Tancredo } \\
\text { Neves }\end{array}$ & 24.187 & 414,91 & 58,29 & 89,92 & $3.708,16$ \\
\hline & Taperoá & 18.964 & 408,58 & 46,41 & 80,99 & $4.177,25$ \\
\hline & Teolândia & 14.941 & 288,27 & 51,83 & 46,18 & $3.605,31$ \\
\hline & Valença & 89.509 & $1.190,38$ & 75,19 & 555,57 & $6.200,79$ \\
\hline & Wenceslau Guimarães & $22.047 \mid$ & 661,79 & 33,31 & 144,76 & $5.836,83$ \\
\hline
\end{tabular}

Fonte: SEI-SEPLAN-BA, com base no IBGE, 2011.

(1) Estimativas da população residente com data de referência em 01.07.2011. 